Texts And Studies 13

THIRd SERIES

NYNOIA AMEMOIIOI

EXEICINATICCEEHU

OTIMAJAGYEZHAQEC

OHRE AJTITICTEYET

KAIEXHAY AEN INAC

EKACTOCICTAIAIA

A

OTATHJMETEMOYEC

YMEININAENEMOIE

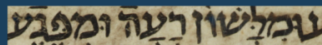
צח

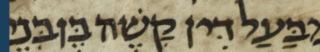

Commentaries, Catenae and Biblical Tradition

Papers from the Ninth Birmingham Colloquium on the Textual Criticism of the New Testament, in association with the COMPAUL project

Edited by

H. A. G. Houghton 


\section{Commentaries, Catenae and Biblical Tradition}

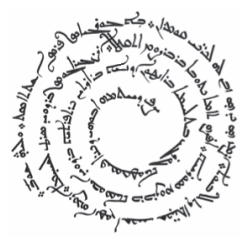




\section{Texts and Studies}

13

Series Editor

H. A. G. Houghton

Editorial Board

Jeff W. Childers

Viktor Golinets

Christina M. Kreinecker

Alison G. Salvesen

Peter J. Williams

Texts and Studies is a series of monographs devoted to the study of Biblical and Patristic texts. Maintaining the highest scholarly standards, the series includes critical editions, studies of primary sources, and analyses of textual traditions. 


\title{
Commentaries, Catenae and Biblical Tradition
}

Papers from the Ninth Birmingham Colloquium on the Textual Criticism of the New Testament, in association with the COMPAUL project

\author{
Edited by
}

H. A. G. Houghton

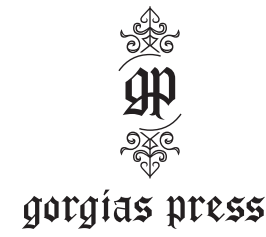

2016 
Gorgias Press LLC, 954 River Road, Piscataway, NJ, 08854, USA

www.gorgiaspress.com

Copyright C 2016 by Gorgias Press LLC

All rights reserved under International and Pan-American Copyright Conventions. No part of this publication may be reproduced, stored in a retrieval system or transmitted in any form or by any means, electronic, mechanical, photocopying, recording, scanning or otherwise without the prior written permission of Gorgias Press LLC.

2016
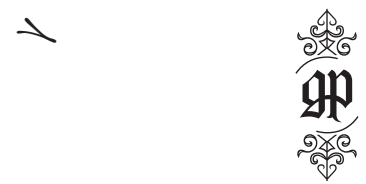

ISBN 978-1-4632-0576-8

ISSN 1935-6927

\section{Library of Congress Cataloging-in-Publication Data}

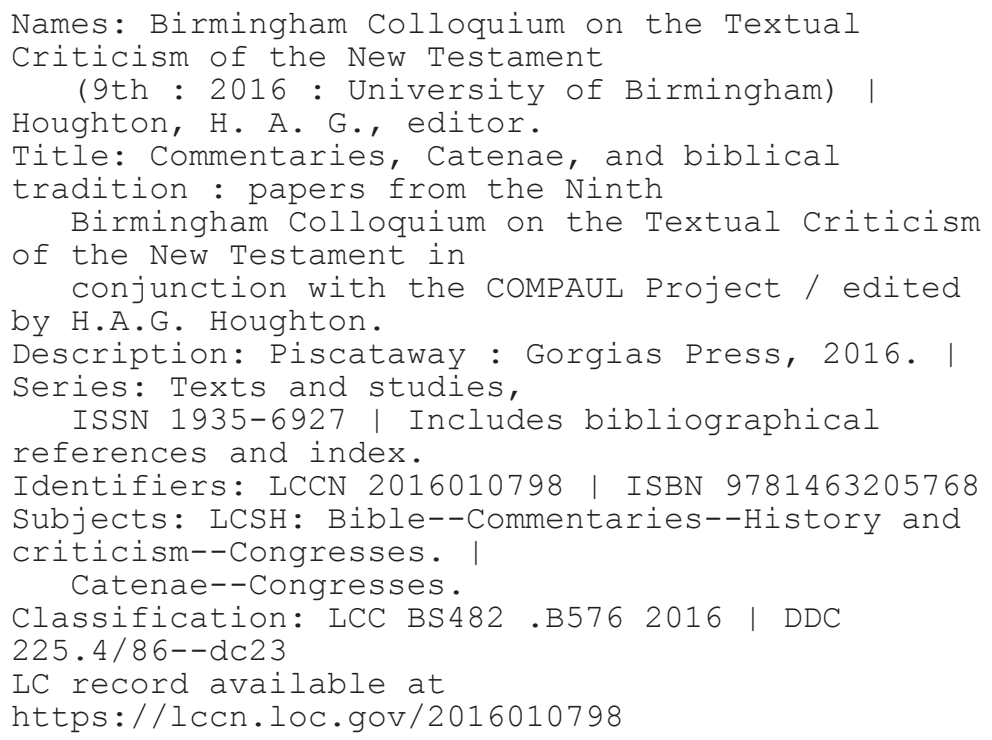

Printed in the United States of America 


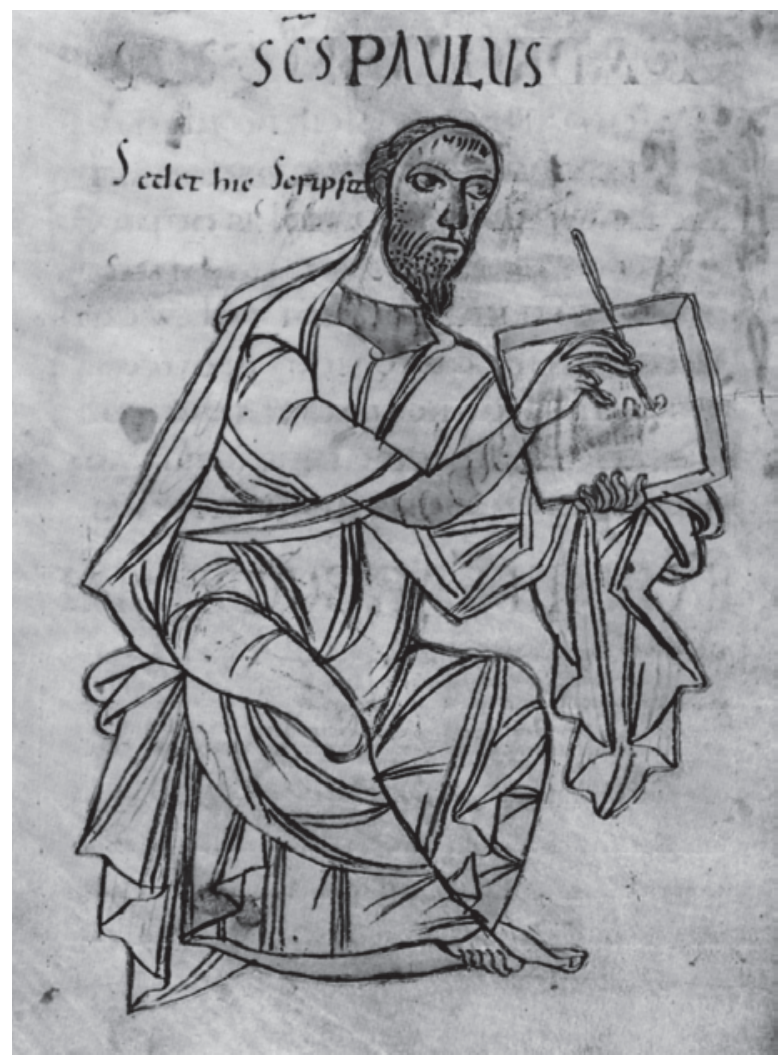

Stüttgart, Württembergische Landesbibliothek, HB II 54, f. 25v. By kind permission of the Württembergische Landesbibliothek.

The COMPAUL project has received funding from the the European Union Seventh Framework Programme (FP7/2007-2013) under grant agreement no. 283302 ('The Earliest Commentaries on Paul as Sources for the Biblical Text').
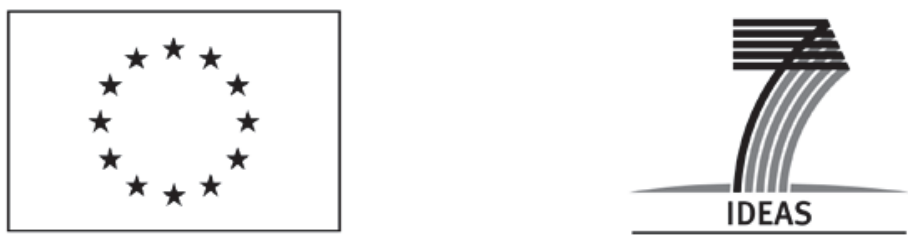



\section{TABLE OF CONTENTS}

List of Contributors ......................................................................................... vii

List of Abbreviations ....................................................................................

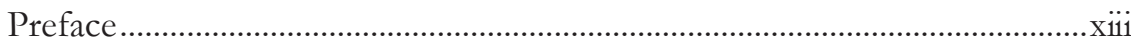

1 An Introduction to Greek New Testament Commentaries with a Preliminary Checklist of New Testament Catena Manuscripts. H.A.G. HOUGHTON \& D.C. PARKER ...................................................... 1

2 The Context of Commentary: Non-Biblical Commentary in the Early Christian Period.

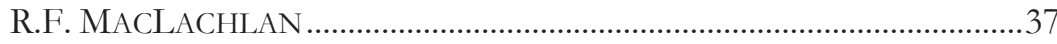

3 Biblical Catenae: Between Philology and History.

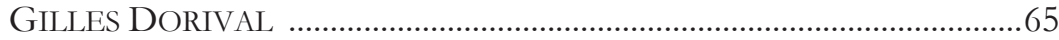

4 Catenae and the Art of Memory. WILLIAM LAMB

5 Parsing Paul: Layout and Sampling Divisions in Pauline Commentaries.

BRUCE MORRILL \& JOHN GRAM .

6 Resurrection Appearances in the Pauline Catenae.

THEODORA PANELLA

7 The Reception of Scripture and Exegetical Resources in the Scholia in Apocalypsin (GA 2351).

GARRICK V. ALLEN

8 Theodoret's Text of Romans. AGNÈs LORRAIN

9 Bethania, Bethara, or Bethabara: Fortunatianus of Aquileia and Origen's Commentary on John, with particular reference to John 1:28. LUKAS J. DORFBAUER

10 Ambrose the Appropriator: Borrowed Texts in a New Context in the Commentary on Luke.

SUSAN B. GRIFFITH 
11 Rufinus' Translation of Origen's Commentary on Romans.

CHRISTINA M. KREINECKER

12 The Transmission of Florus of Lyons' Expositio epistolarum beati Pauli apostoli. State of the Art and New Results.

SHARI BOODTS \& GERT PARTOENS

13 Biblical Quotations in the Gothic Commentary on the Gospel of John (Skeireins). CARLA FALLUOMINI

14 An Overview of Research on Bohairic Catena Manuscripts on the Gospels with a Grouping of Arabic and Ethiopic (Gə⿳亠二口) Sources and a Checklist of Manuscripts.

MATTHIAS SCHULZ .295

Index of Manuscripts

Index of Biblical Passages 341

Index of Subjects .345 


\section{LIST OF CONTRIBUTORS}

Garrick V. Allen is a Research Fellow at the Institut für Septuaginta und biblische Textforschung at the Kirchliche Hochschule Wuppertal/Bethel and a research associate of the School of Ancient Language, University of Pretoria, South Africa. His research focusses on the reuse of the Hebrew Bible in the Second Temple Period and the text of the New Testament. He recently edited The Book of Revelation: Currents in British Research on the Apocalypse (2015).

Shari Boodts is a Research Fellow of the Flemish Research Foundation, working at KU Leuven on an edition of the Commentary on Romans attributed to Helisachar in Paris, BnF, lat. 11574. She is a senior member of LECTIO, the Leuven Centre for the Study of the Transmission of Texts and Ideas in Antiquity, the Middle Ages and the Renaissance. Her doctoral research resulted in a new edition of Augustine's sermons on the New Testament epistles in the Corpus Christianorum series and she has published extensively on the transmission of patristic texts.

Lukas J. Dorfbauer has been a Research Fellow at the Corpus Scriptorum Ecclesiasticorum Latinorum (CSEL) since 2006, currently based at the University of Salzburg. He has published monographs on late antique Latin authors and an edition of pseudo-Augustinian texts, as well as numerous articles on Latin gospel commentaries. Following his rediscovery of the fourth-century Commentary on the Gospels by Fortunatianus of Aquileia, he is currently preparing an edition and companion volume to be published in the CSEL series.

Gilles Dorival is an Emeritus Professor at the University of Aix-Marseille, where he was co-founder of the Centre Paul-Albert Février for the study of ancient and mediaeval texts and documents from the Mediterranean. He is well-known for his longstanding research into Greek patristic and biblical texts, including a five-volume edition of the Catenae on the Psalms. He is also 
editor of La Bible d'Alexandrie, an annotated translation of the Septuagint into French.

Carla Falluomini is Associate Professor of Germanic Philology at the University of Perugia. She has published widely on the text and history of the Gothic Bible, including a monograph on The Gothic Version of the Gospels and Pauline Epistles (2015) and an edition of the palimpsest Codex Carolinus. A member of numerous advisory boards, she has also been a recipient of a research fellowship from the Humboldt foundation.

John Gram has spent many years as a Lutheran minister in Vancouver, as well as teaching at Lutheran Theological Seminary in Saskatoon. He is a long-time collaborator on the International Greek New Testament Project and a member of the Society of Biblical Literature (SBL).

Susan B. Griffith is a Research Fellow on the COMPAUL project at the University of Birmingham. She has taught Greek and Latin at a variety of levels from California to Croatia. Her doctoral thesis at the University of Oxford was on medical imagery in the sermons of Augustine, and she has served as co-convenor of the Oxford patristics seminar. She also worked with Jeremy Duff on the third edition of Elements of New Testament Greek.

H.A.G. Houghton is Reader in New Testament Textual Scholarship at the University of Birmingham and Principal Investigator of the COMPAUL project. He has co-organised the Birmingham Colloquia on the Textual Criticism of the New Testament since 2007. He is executive editor of the the Texts and Studies book series and a corresponding editor of the Vetus Latina Institute. His publications include monographs on the gospel text of Augustine and the Latin New Testament.

Christina M. Kreinecker is Assistant Professor of New Testament Studies at the University of Salzburg. She is a member of SNTS, SBL and an honorary fellow of the Institute for Textual Scholarship and Electronic Editing. From 2011-13, she was a research fellow on the COMPAUL project. Her publications include a papyrological commentary on 2 Thessalonians and a monograph on Coptic witnesses to the resurrection narrative.

William Lamb has been Vice-Principal and Tutor in New Testament Studies at Westcott House, Cambridge and an Affiliated Lecturer, Faculty of Divinity, University of Cambridge, since 2010. He has also taught at the 
University of Leeds, the University of Sheffield and the College of the Resurrection, Mirfield. His publications include a study and translation of the Catena in Marcum (2012) and Scripture: A Guide for the Perplexed (2013).

Agnès Lorrain, agrégée de Lettres classiques, is a Research Fellow on the European Research Council-funded ParaTexBib project at the University of Basle. She was recently awarded her doctorate at the University of ParisSorbonne for a new edition of Theodoret's Commentary on Romans. Her studies included a year at the École Biblique in Jerusalem. She spent the rest of her $\mathrm{PhD}$ in Tübingen.

R.F. MacLachlan is a Research Fellow on the COMPAUL project at the University of Birmingham. She previously worked on the Vetus Latina Iohannes project, producing a new edition of the Old Latin text of the Gospel of John. Her doctoral work in Classics at the University of Cambridge focussed on the Epitomes in Ancient Literary Culture.

Bruce Morrill is an Honorary Fellow of the Institute for Textual Scholarship and Electronic Editing at the University of Birmingham. He has been a member of the International Greek New Testament Project for many years and is currently working on the Editio Critica Maior of the Gospel according to John.

Theodora Panella is a doctoral student on the COMPAUL project at the University of Birmingham, working on an edition of the Oecumenian catena on Galatians. She is also the holder of an AHRC Midlands3Cities doctoral scholarship. While studying at the Aristotle University, Thessaloniki, she was an assistant on the edition of Photius' Lexicon. She is co-chair of the European Association of Biblical Studies unit on the textual criticism of the New Testament, the Old Testament and the Qur'an.

D.C. Parker is Edward Cadbury Professor of Theology at the University of Birmingham and Director of the Institute for Textual Scholarship and Electronic Editing. He is also executive editor of the Gospel according to John for the International Greek New Testament Project, an editor of the Nestle-Aland $2^{\text {th }}$ edition and UBS Greek New Testament $6^{\text {th }}$ edition, and consultant to the COMPAUL project. A Fellow of the British Academy and of the Society of Antiquaries of London, he was awarded the Order of the British Empire in the Queen's Birthday Honours List 2015. 
Gert Partoens is Associate Professor of Latin Literature at KU Leuven. He is vice-director of the Latin series of the Corpus Christianorum. He has published widely on the textual tradition of Augustine, including an edition of the sermons on the Pauline Epistles in the Corpus Christianorum series, and is currently also focussing on Bede and Florus of Lyons.

Matthias Schulz is a Research Fellow in the Evangelisch-Theologische Fakultät at the University of Vienna, where he is working on the Sahidic tradition of the Gospel according to John. Formerly he was a Research Associate at the the Institute for New Testament Textual Research, University of Münster, where he completed a master's thesis in Coptology on the Manichaean Psalm Book. 


\section{LIST OF ABBREVIATIONS}

$\begin{array}{ll}\text { ANTF } & \text { Arbeiten zur neutestamentlichen Textforschung } \\ \text { AGLB } & \text { Aus der Geschichte der lateinischen Bibel } \\ \text { BAC } & \text { The Bible in Ancient Christianity } \\ \text { BAV } & \text { Biblioteca Apostolica Vaticana } \\ \text { BM } & \text { Bibliothèque municipale } \\ \text { BML } & \text { Biblioteca Medicea Laurenziana } \\ \text { BnF } & \text { Bibliothèque nationale de France } \\ \text { BNM } & \text { Biblioteca Nazionale Marciana } \\ \text { BNU } & \text { Bibliothèque nationale et universitaire } \\ \text { BSB } & \text { Bayerische Staatsbibliothek } \\ \text { CCCM } & \text { Corpus Christianorum continuatio medievalis } \\ \text { CCSG } & \text { Corpus Christianorum series graeca } \\ \text { CCSL } & \text { Corpus Christianorum series latina } \\ \text { CPG } & \text { Clavis patrum graecorum } \\ \text { CPL } & \text { Clavis patrum latinorum } \\ \text { CSEL } & \text { Corpus Scriptorum Ecclesiasticorum Latinorum } \\ \text { CUA } & \text { Catholic University of America } \\ \text { CUP } & \text { Cambridge University Press } \\ \text { GA } & \text { Gregory-Aland (see also Liste) } \\ \text { GCS } & \text { Die griechischen christlichen Schriftsteller der ersten drei } \\ & \text { Jahrhunderte } \\ \text { IGNTP } & \text { International Greek New Testament Project } \\ \text { JBL } & \text { Journal of Biblical Literature } \\ \text { JECS } & \text { Journal of Early Christian Studies } \\ J T S & \text { Journal of Theological Studies } \\ \text { Liste } & \text { Kurt Aland, Kurzgefasste Liste der griechischen Handschriften des } \\ & \text { Neuen Testaments. Zweite neubearbeitete and ergänzte } \\ & \text { Auflage. ANTF 1. Berlin \& New York: de Gruyter, 1994. } \\ & \text { The most up-to-date version is found at: } \\ \text { LXX } & \text { http://ntvmr.uni-muenster.de/liste } \\ & \text { Septuagint } \\ & \end{array}$


E. Nestle, K. Aland et al., Novum Testamentum Graece, twenty-eighth edition. Stuttgart: Deutsche

Bibelgesellschaft, 2012.

NovT

NRSV

ns

NTAbh

NTS

NTTSD

NTVMR

OCA

ÖAW

ÖNB

os

OUP

$P G$

PL

PO

PTS

RevBén

RevBib

$S C$

SBPK

T\&S

TEG

TLG

TLL

TU

UBS

UP

VC

WUNT

$Z A C$

$Z N W$

Novum Testamentum

New Revised Standard Version

new series

Neutestamentliche Abhandlungen

New Testament Studies

New Testament Tools, Studies and Documents

New Testament Virtual Manuscript Room, hosted online

by the University of Münster at:

http://ntvmr.uni-muenster.de/

Orientalia Christiana Analecta

Österreichischen Akademie der Wissenschaften

Österreichischen Nationalbibliothek

old series

Oxford University Press

Patrologia Graeca [= Patrologiae cursus completus: Series graeca]. Edited by J.-P. Migne. 161 vols. Paris, 1857-1866. Patrologia Latina [= Patrologiae cursus completus: Series latina]. Edited by J.-P. Migne. 217 vols. Paris, 1841-1855.

Patrologia Orientalis

Patristische Texte und Studien

Revue bénédictine

Revue Biblique

Sources Chrétiennes

Staatsbibliothek Preußischer Kulturbesitz

Texts and Studies

Traditio Exegetica Graeca

Thesaurus Linguae Graecae, hosted online by the University of California, Irvine at www.tlg.uci.edu

Thesaurus Linguae Latinae

Texte und Untersuchungen zur Geschichte der

Altchristlichen Literatur

United Bible Societies

University Press

Vigiliae Christianae

Wissenschaftliche Untersuchungen zum Neuen Testament

Zeitscbrift für antikes Christentum

Zeitschrift für die neutestamentliche Wissenschaft 


\section{PREFACE}

\section{The COMPAUL Project}

In 2011, the European Research Council awarded Dr Hugh Houghton a Starting Grant to lead a five-year project investigating the earliest commentaries on Paul as sources for the biblical text. ${ }^{1}$ This project, known by its acronym COMPAUL, was intended to build on Dr Houghton's doctoral work analysing Augustine's gospel citations. ${ }^{2}$ The aim was to instigate a better understanding of commentaries and their contribution to the transmission of the New Testament in anticipation of two major editing projects: the Vetus Latina edition of the four principal letters of Paul and the Novum Testamentum Graecum Editio Critica Maior of all Pauline Epistles being planned by the IGNTP.

Greek commentaries, often in the form of catena manuscripts (exegetical compilations accompanying a continuous biblical text), are one of the more complex and less examined aspects of New Testament tradition. As for individual commentators, one extreme is represented by the extremely abundant textual history of the writings of John Chrysostom, the principal fourth-century Greek commentator on the Bible, with a corresponding lack of modern editions. The opposite is embodied in the meagre Greek fragments remaining of Origen's highly influential expositions of New Testament books. On the Latin side, the abundance of Pauline commentaries produced between the middle of the fourth century and the early fifth century not only inaugurate a distinctive Latin exegetical tradition but also constitute much of the evidence for the Old Latin versions of the Epistles, preceding the revision of their biblical text around

1 The project was funded by the European Union Seventh Framework Programme (FP7/2007-2013) under grant agreement no. 283302.

2 See further H.A.G. Houghton, Augustine's Text of John. Patristic Citations and Latin Gospel Manuscripts. Oxford: OUP, 2008, and H.A.G. Houghton, 'Augustine's Adoption of the Vulgate Gospels.' NTS 54.3 (2008) 450-64. 
the beginning of the fifth century which was later adopted as the Vulgate. Marius Victorinus, the anonymous author known as Ambrosiaster, Jerome, Augustine, Pelagius (and his revisors), the anonymous Budapest commentary, Rufinus' translation of Origen's Commentary on Romans and the anonymous Latin version of the Pauline commentary by Theodore of Mopsuestia are all of value in understanding the history and reception of the Pauline text as well as early translation practice.

The aim of the project was to combine the collection of biblical evidence which would subsequently be employed in the planned editions of the Pauline Epistles with a broader investigation of the field of commentaries as a whole and the detailed analysis of certain key or lesserknown witnesses. ${ }^{3}$ Particular attention was paid to the manuscript transmission of commentaries themselves as evidence for the reception of the Pauline text, the distinction of the source from its exegesis, and the coexistence of different textual traditions. Given the lack of existing scholarly resources pertaining to the text of the four principal Pauline Epistles (Romans, 1 \& 2 Corinthians and Galatians), members of the project team made fresh transcriptions of all the manuscript witnesses to these letters listed in the Vetus Latina Register. ${ }^{4}$ They also assembled the text of all the quotations of these four Epistles made by Greek authors up to the middle of the fifth century and Latin writers from the first eight centuries. These online databases will be made available for searching, reuse and integration into other platforms. The gathered data provides significant information about the use, diffusion and understanding of the Pauline corpus as well as the differing forms of the biblical text. The team endeavoured to analyse the internal structure of Latin commentaries and the consistency of their text of each verse using a specially-designed interface, known as the 'comcitation' tool; researchers also experimented with different ways of recording the organisation and relationship of the contents of Greek catena manuscripts in spreadsheets and electronic text encoding.

${ }^{3}$ For more on the project goals and background, see Christina M. Kreinecker, 'The Earliest Commentaries on Paul as Sources for the Biblical Text. A New Research Project at the Institute for Textual Scholarship and Electronic Editing at the University of Birmingham'. Early Christianity 3.3 (2012) 411-5.

${ }^{4}$ Roger Gryson, ed., Altlateinische Handschriften/Manuscrits Vieux-Latins. 1. Mss 1 275. (Vetus Latina 1/1A). Freiburg: Herder, 1999. The transcriptions are to be published online at the website www.epistulae.com and a printed collation of these and other significant Old Latin evidence is in preparation. 
Among the planned outputs of the COMPAUL project was an international conference on biblical commentaries and the publication of a collaborative work constituting the state of the art in their study and textual analysis. This is represented by the present volume; more details on its contents and the conference itself are given in separate sections below. Team members have presented the work of the project at a wide range of international conferences and academic gatherings, including the annual meetings of the Society of Biblical Literature and the Studiorum Novi Testamenti Societas, the Oxford International Patristics Conference, the British Patristics Conference and the Editio Critica Maior editorial meetings. In addition to this book and the electronic resources mentioned above, the project has generated numerous publications. These include a new analysis of the biblical text in Jerome's Commentary on Galatians, examinations of the text of several Old Latin manuscripts (including the anonymous Budapest Commentary on Paul), studies of the newly-rediscovered gospel commentary of Fortunatianus of Aquileia, an investigation of Origen's Pauline citations and a general introduction to the Latin New Testament. ${ }^{5}$

5 In chronological order: H.A.G. Houghton, 'The Biblical Text of Jerome's Commentary on Galatians'. JTS ns 65.1 (2014) 1-24; R.F. MacLachlan, 'A Reintroduction to the Budapest Anonymous Commentary on the Pauline Epistles' in Early Readers, Scholars and Editors of the New Testament, ed. H.A.G. Houghton. T\&S 3.11. Piscataway: Gorgias, 93-106; Matthew R. Steinfeld, 'Preliminary Investigations of Origen's Text of Galatians', in Early Readers, Scholars and Editors, 107-17; H.A.G. Houghton, 'A Longer Text of Paul: Romans to Galatians in Codex Wernigerodensis (VL 58)' in Studies on the Text of the New Testament and Early Christianity, ed. Daniel M. Gurtner, Juan Hernández Jr. and Paul Foster. NTTSD 50. Leiden: Brill, 2015, 329-44; H.A.G. Houghton, The Latin New Testament. A Guide to its Early History, Texts, and Manuscripts. Oxford: OUP, 2016; H.A.G. Houghton, 'The Gospel according to Mark in Two Latin Mixed-Text Manuscripts.' Revue Bénédictine 126.1 (2016) 16-58; H.A.G. Houghton, 'The Text of John in Fortunatianus of Aquileia's Commentary on the Gospels' in Studia Patristica LXXIV. Papers Presented at the Fifth British Patristics Conference. Leuven: Peeters, 2016. H.A.G. Houghton, 'The Gospel according to Luke in Vetus Latina 11A (Würzburg, Universitätsbibliothek M.p.th.f. 67)' in Traditio et Translatio. Studien zur lateinischen Bibel zu Ehren von Roger Gryson, ed. Thomas Johann Bauer. AGLB 40. Freiburg: Herder, 2016, 117-34; H.A.G. Houghton, 'The Divisions and Text of the Gospels in Fortunatianus' Commentary on the Gospels' in a companion volume to Fortunatianus' Commentary on the Gospels, ed. L.J. Dorfbauer. Berlin: de Gruyter, 2016. See also H.A.G. Houghton, 'The Use of the Latin Fathers for New Testament Textual Criticism', in The Text of the New Testament in Contemporary 
The project was based at the Institute for Textual Scholarship and Electronic Editing (ITSEE) in the School of Philosophy, Theology and Religion at the University of Birmingham. The core team members were Hugh Houghton (Principal Investigator); David Parker (Consultant); Rosalind MacLachlan, Christina Kreinecker, Catherine Smith, Susan Griffith and Amy Myshrall (Research Fellows); Theodora Panella amd Matthew Steinfeld (Doctoral Students). In addition, the following contributed to the collection of data: Jonathan Day, Robin Diver, Alan Taylor Farnes, Samuel Gibson, Rachel Kevern, Christopher Knibbs, Amanda Myers, Holly Ranger, Thomas Ruston, Georgia Tsatsani and Angeliki Voskou. In addition to our grateful acknowledgment of the generous funding of the European Research Council, we would also like to express our gratitude for the support of colleagues in both academic and administrative matters, including Helen Beebee, Helen Ingram, Sue Bowen, Caroline Marshall, and various members of the research finance, human resources, European funding, and Worklink teams at the University of Birmingham.

\section{Contents of the Present Volume}

This book offers an account of the state of the question regarding New Testament commentaries and catenae, combining broader surveys of different types of material with more detailed investigations of specific authors and works. Every chapter was originally delivered as a paper at the Ninth Birmingham Colloquium on the Textual Criticism of the New Testament and revised, in the light of discussion at the conference and further research, for inclusion in the present collection. While each contribution stands by itself, the book is arranged thematically and internal cross-references have been added where particular papers treat related topics. Although contributors were not asked to provide separate bibliographies, these have been included for two of the articles in which a catalogue of manuscripts is given, in order to enable the abbreviation of references to secondary literature.

Research. Essays on the Status Quaestionis, ed. B.D. Ehrman \& M.W. Holmes. 2nd edn. Leiden: Brill, 2012, 375-405; Christina M. Kreinecker, 'The Imitation Hypothesis. Pseudepigraphic remarks on 2Thess with help from documentary papyri' in Paul and Pseudepigraphy, ed. Stanley E. Porter and Gregory P. Fewster. Leiden: Brill, 2013, 197-219; H.A.G. Houghton and C.J. Smith, 'Digital Editing and the Greek New Testament' in The Ancient Worlds in A Digital Culture, ed. Claire Clivaz, Paul Dilley and David Hamidović. Leiden: Brill, 2016. Further publications related to the project are in preparation. 
The first four chapters provide overviews of commentary tradition. Expanding on introductory remarks at the Birmingham Colloquium and introducing research from the Editio Critica Maior of John and the COMPAUL projects, H.A.G. Houghton and D.C. Parker offer an introduction to Greek New Testament commentaries. They deal with questions of terminology, describe the layout of commentaries and catenae and briefly introduce the principal Greek commentators along with a summary of research on catenae. The checklist of manuscripts at the end of the chapter brings together the 526 representatives included in the Gregory-Aland Liste along with 100 additional witnesses in an attempt to lay the foundations for further study of New Testament catenae. R.F. MacLachlan explores the context of commentary in secular Graeco-Latin literature during the first Christian centuries. She describes commentaries on works of literature, Roman legal writings, and philosophical and scientific works: particular subjects include papyrus fragments treating Homer and Demosthenes, commentaries on Aristotle and the Hippocratic Corpus, and the prodigious output of Galen along with his reflections on writing commentary. Gilles Dorival traces the development of scholarship on catenae over almost five hundred years, beginning with the sixteenth century. Using the Catenae on Psalms, he seeks to reconstruct the origins of the catena tradition as well as outlining its subsequent reworkings. The differing concerns of philological and historical approaches still leave many questions unanswered, despite significant progress in the latter part of the twentieth century. William Lamb considers the catena as a literary genre within Byzantium, arguing that accusations of a lack of originality are unjust. The way in which florilegia are assembled, including the treatment of diverse theological positions, requires linguistic and doctrinal sensitivity. Attentiveness to the role of memory in the early medieval period also casts light on the compilers' aims and achievements.

The next four chapters explore aspects of Greek tradition in greater detail. Bruce Morrill and John Gram first enumerate the differing orders of the Pauline Epistles in Greek manuscripts as possible evidence for differing editions. They continue by looking at the layout of 107 catena manuscripts of Romans and the consistency which is displayed in the indication and numbering of divisions. This sample provides a significant collection of data, illustrating many more general features and trends. Theodora Panella focusses on just four verses of 1 Corinthians in order to investigate the relationship of the commentaries of Oecumenius, Theophylact and Zigabenus, as well as the Typus Parisinus catena. Although Chrysostom is the ultimate origin of many comments, she demonstrates how this was often mediated through one of the other commentaries, as 
well as identifying features typical of the individual catenists. Garrick V. Allen examines the scholia on Revelation attributed first to Origen and more recently to a previously unknown monk reliant on the lost commentary of Didymus of Alexandria. Allen concentrates on the exegetical practices of this commentary, demonstrating the sophisticated techniques employed by the author. He also considers the presentation of the scholia in the single surviving manuscript, which betrays evidence of a change in format during the transmission of the work. Based on her new edition of Theodoret's Commentary on Romans, Agnès Lorrain reflects on the difficulty of reconstructing the biblical text used by the commentator. Examples of alterations introduced at a later stage suggest that even the earliest surviving manuscripts may not represent the original form. What is more, the commentary is often so allusive that it could be used in support of multiple variants. Where readings can be reconstructed, the affiliation is, as expected, with the Byzantine text.

The following group of chapters turns to Latin tradition, although the first three contributions focus on its importance for the preservation of material from Origen. Lukas J. Dorfbauer, responsible for the recent rediscovery of Fortunatianus of Aquileia's Commentary on the Gospels, demonstrates how this work provides new evidence not only for the wellknown emendation proposed by Origen to the place name in John 1:28 but also for the often-overlooked orthography of this noun in the principal manuscript of Origen's Commentary on John. Other passages are also considered in which Fortunatianus may also be dependent on a Latin version of this commentary. Susan B. Griffith compares Ambrose's Commentary on Luke with Jerome's translation of Origen's Homilies on Luke and their surviving Greek fragments, as well as Hilary of Poitiers' Commentary on Matthew. While Ambrose and Jerome's dependence on Origen is evident from their overlap with the Greek fragments, other shared passages may represent Greek material which has otherwise been lost. Careful attention to Ambrose's compositional practices is needed before he can be used as evidence for his sources. Christina M. Kreinecker explains how Rufinus' translation of Origen's Commentary on Romans, too, is not a verbatim reproduction of its original but a creative reworking. Rufinus' treatment of the biblical text is of particular interest: the Old Latin version which he substitutes for Origen's lemmata is sometimes inconsistent with his translation of biblical quotations in the exegesis, prompting him to introduce text-critical observations.

Shari Boodts and Gert Partoens present evidence from a later form of Latin commentary, with a certain resemblance to Greek catenae: the exposition of the Pauline Epistles consisting solely of extracts from the 
works of Augustine, assembled by Florus of Lyons in the middle of the ninth century. Several of the manuscripts used by Florus have survived, bearing witness to his manner of working. However, despite the existence of a partial autograph, the textual tradition of the commentary presents problems which must be addressed before a critical edition can be undertaken. The indication of sources in certain manuscripts offers another parallel with catena tradition.

The final two chapters address textual traditions which, although valuable for the textual history of the New Testament, were not included in the scope of the COMPAUL project. Carla Falluomini introduces the only New Testament commentary to be preserved in Gothic. Known as Skeireins, it was produced some time between the fourth and sixth centuries and covers the first third of the Gospel according to John. The majority of its biblical citations are of verses which are not otherwise attested in Gothic; agreements and differences between other verses and Wulfila's translation suggest that the biblical text of the Skeireins may, in part, derive from a different source. An intriguing connection has also been proposed between this work and the Commentary on John by Theodore of Heraclea, only preserved in catenae. Finally, Matthias Schulz sets out the evidence for New Testament catenae in Coptic and related languages. The principal Bohairic catena manuscript of the Gospels is one of the earliest witnesses to a catena, copied in the late ninth century. Unpublished fragments survive from two others, while one of the Ethiopic catenae appears to be a translation from Bohairic. The next best-attested Ethiopic gospel catena derives from an Arabic catena assembled from Eastern and Western authorities by a priest of the East Syrian Church in the early eleventh century, which is also transmitted in its original language; a third Arabic catena, on Matthew, was composed a century or so later.

In sum, this volume with its particular focus on Greek tradition (as well as contributions on later commentaries and those in other languages) addresses many of the areas in the history and transmission of commentaries which have not so far been covered in the publications of the COMPAUL project. What is more, each chapter explores at least one of the specific areas highlighted by the project: the significance of commentaries for the text of the New Testament, the internal consistency of biblical quotations, the manuscript presentation and transmission of commentaries, and the reuse of earlier authors by later commentators. Most of the contributions are based on fresh investigation of primary sources and, in several cases, constitute significant advances which make possible future research and further developments in knowledge. The editor would like to express his thanks to all contributors, especially those not directly involved 
with the COMPAUL project, for their willingness to join in this collaborative volume and share the results of their original research. In addition, we are grateful to the Württembergische Landesbibliothek and the Bibliothèque nationale de France for permission to reproduce images of manuscripts in their collections.

\section{The Ninth Birmingham Colloquium}

As noted above, all the chapters in this book derive from presentations at the Ninth Birmingham Colloquium on the Textual Criticism of the New Testament. Founded by D.C. Parker and D.G.K. Taylor in 1997, these events have developed over the years into ever larger and more diverse gatherings of established textual scholars and doctoral researchers from across the world. The Ninth Colloquium was held in Birmingham on 2-4 March 2015, with the title 'The History and Text of New Testament Commentaries' and was attended by delegates from twelve countries. Generous funding from the European Research Council covered the expenses of several invited speakers: in addition to those who contributed to the present volume, these included Ronald E. Heine and Alexander Andrée, whose respective presentations on Origen's gospel commentaries and the Glossa ordinaria were already scheduled for publication elsewhere. ${ }^{6}$

Following the pattern of previous years, guests were accommodated at Woodbrooke Quaker Study Centre, where the famous textual scholar and editor J. Rendel Harris was once Director of Studies. The colloquium excursion was to the city of Worcester: despite the closure of the cathedral library for renovation, delegates were treated to guided tours of the cathedral and the bell tower which included the memorable experience of being in the bell chamber when the cathedral clock struck five. The speaker following the conference dinner in the University's Staff House was Gordon Campbell, Professor of Renaissance Studies at the University of Leicester and co-chair of the international advisory council to the Museum of the Bible in Washington DC, who spoke on plans for this museum which is scheduled to open in 2017. Among the many who contributed to the colloquium, the organisers would particularly like to thank Lisa Davies

${ }^{6}$ For Heine's contribution, see Ronald E. Heine and Karen Jo Torjesen, ed., The Oxford Handbook to Origen. Oxford: OUP, 2016; Andrée's presentation will appear in the journal Traditio under the title 'Peter Comestor's Lectures on the "Glossa Ordinaria" on the Gospel of John: The Bible and Theology in the Twelfth-Century Classroom.’ 
and Peter Chinn at Woodbrooke, Rebecca Fielder, Michael Brierley and Saskia Frisby at Worcester, Rachel Canty, Robin Reeve, Sue Bowen, Tim Pearson, Geoff Clinton and Sarah Edwards at the University of Birmingham and Jenny Rousell, Sue Kennedy and their team at Jenny's Kitchen. Members of the COMPAUL project team, especially Catherine Smith, worked exceptionally hard to enable the smooth running of the event.

This is the fourth volume of proceedings from the Birmingham Colloquium on the Textual Criticism of the New Testament to be published in the Gorgias Texts and Studies series. We would like to thank Dr Melonie Schmierer-Lee, Jeff Haines and George Kiraz of Gorgias Press for making this possible. The proceedings of the Sixth Colloquium, held in London jointly with the British Library, have now been published as Scot McKendrick, David Parker, Amy Myshrall and Cillian O'Hogan, ed., Codex Sinaiticus: New Perspectives on the Ancient Biblical Manuscript. London: British Library; Peabody MA: Hendrickson, 2015; other volumes are listed in the Gorgias catalogue. Finally, we would like to express our gratitude once again to the European Research Council for funding the open access publication of both this volume and the papers from the Eighth Colloquium online in the Gorgias Press Repository. ${ }^{7}$

H.A.G. Houghton

Birmingham, 29 February 2016

${ }^{7}$ H.A.G. Houghton, ed., Early Readers, Scholars and Editors of the New Testament. Papers from the Eighth Birmingham Colloquium on the Textual History of the New Testament. T\&S 3.11. Piscataway: Gorgias, 2014.

See http://gorgiaspress.com/bookshop/t-openaccess repository.aspx. 



\title{
1. AN INTRODUCTION TO GREEK NEW TESTAMENT COMMENTARIES WITH A Preliminary Checklist of NeW Testament CATENA MANUSCRIPTS
}

\author{
H.A.G. HOUGHTON \& D.C. PARKER ${ }^{1}$
}

Commentaries remain a relatively underexplored aspect of the textual tradition of the New Testament, even though they have been used by editors of the Greek New Testament for five hundred years. Erasmus' text of Revelation in his 1516 edition was dependent on a single manuscript, a copy of the Commentary on the Apocalypse of Andreas of Caesarea (GA 2814): it is said that the difficulties of locating the biblical text is one reason for his occasional retroversions of the Latin text into Greek. ${ }^{2}$ Thus the printed text has from the beginning made use of the commentary manuscript tradition.

While Erasmus' manuscript was from the twelfth century, early examples contribute in multiple ways to the study of the transmission of the Bible. Many commentaries include a full text of the biblical book under consideration, in addition to quotations made by the commentator during the course of their exposition. A commentary may thus offer evidence for the form of biblical text used at a particular time and place, as well as

1 The research leading to these results has received funding from the European Union Seventh Framework Programme (FP7/2007-2013) under grant agreement no. 283302 (COMPAUL). Houghton was primarily responsible for the body of this chapter, while Parker produced the accompanying Checklist. We would like to thank the participants at the Ninth Birmingham Colloquium and members of the ITSEE seminar on Greek commentaries in Autumn 2015, especially Theodora Panella, for their contributions reflected in this chapter.

2 See D.C. Parker, An Introduction to the New Testament Manuscripts and their Texts. Cambridge: CUP, 2008, 228. 
containing explicit observations on variant readings in manuscripts known to the author. The sections of exegesis also bear witness to the reception and interpretation of the biblical text, which may shed further light on its history. Central to the understanding of the creation and use of these works is an appreciation of the manuscripts in which they are transmitted. The present chapter seeks to offer an orientation to the different types of early Greek commentary on the New Testament including catenae, the terminology associated with this field of study, the recent history of scholarship, the manuscript tradition of these writings and their value for the biblical text.

\section{Commentaries, CatenaE AND the Liste}

From the outset, it is important to distinguish between commentaries by a single author and collections of exegetical extracts usually assembled from multiple sources. The latter are known as catenae, the Latin word for 'chains', although in the manuscripts themselves they are described as

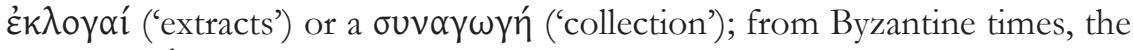

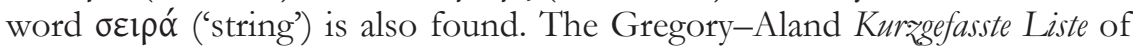
manuscripts of the Greek New Testament tends to exclude copies of singleauthor commentaries, although some are included (occasionally through an oversight) and the situation is different again in the case of Revelation. ${ }^{3}$ The majority of manuscripts identified in the Liste as commentaries (by means of a $\mathrm{K}$ in the list of contents) are actually catena manuscripts which include a more-or-less complete text of one or more biblical books. Although Dorival has suggested that catenae in the strict sense should only be used to

${ }^{3}$ Kurt Aland, Kuragefasste Liste der griechischen Handschriften des Neuen Testaments. $2^{\text {nd }}$ edn. ANTF 1. Berlin: de Gruyter, 1994. The most up-to-date version of this register is now found online, as part of the New Testament Virtual Manuscript Room: http://ntvmr.uni-muenster.de/liste. Entries in this list are preceded by GA. Examples of a single-author commentary erroneously included in the Liste (and now enclosed in square brackets) are GA 882 (Chrysostom's Homilies on John) and GA 2114 and 2402 (Maximus of the Peloponnese, Commentary on Revelation). However, at least five copies of Cyril of Alexandria's Commentary on John are still included (GA 849, 850, 1819, 1820 and 2129; see Parker, An Introduction to the New Testament Manuscripts, 41). Some collections of extracts derive from (or are ascribed to) a single author, despite their catena format, such as the catena of John of Damascus or Nicetas of Heraclea. For Revelation, which is normally accompanied by a commentary, see the section below on Early Greek Commentators on the New Testament. 
refer to collections in which source identifications are present for each extract and that later compilations based on catenae but which lack these indications are better described as commentaries, the present chapter uses catenae in its traditional, fuller sense. ${ }^{4}$

The most comprehensive investigation to date of New Testament commentary manuscripts is that of Hermann von Soden, in conjunction with his edition of the New Testament which appeared in 1902-13. ${ }^{5}$ Von Soden's scheme of sigla for manuscripts includes details of their textual affiliation, as well as an indication whether or not they were a commentary. ${ }^{6}$ The studies of the Epistles by Staab and the Gospels by Reuss have increased the number of known catena manuscripts, although both of these authors were reliant on catalogues representing only a selection of libraries. ${ }^{7}$ Moreover, many of their manuscripts were not added to the Liste, so that there is no single list based on a search of all repositories. The identification of further copies of the New Testament with catenae is therefore relatively common, such as the twelfth-century gospel manuscript in Oxford recently added to the Liste as GA $2879 .{ }^{8}$

The checklist attached to the present chapter represents an initial attempt to bring together a list of New Testament catena manuscripts from the principal published sources. Arranged by contents, it reveals both the variety in the contents of catenae and the significant proportion these manuscripts constitute in the overall total of witnesses for each book. Roughly one in ten Greek New Testament manuscripts included in the Liste is a catena: the present checklist contains a total of 526 witnesses which have been assigned Gregory-Aland numbers. If lectionaries and papyri are excluded, the proportion of catenae increases to one in six. In addition, the checklist identifies another 100 catena manuscripts which do not appear in the Liste. While not all of these are proposed as candidates for inclusion in

4 See the works of Dorival, in particular page 67 below, where he states that 'Oecumenius, Peter of Laodicea, Procopius of Gaza, Theophylact and others are not authors of catenae, but of commentaries totally or partially made from catenae'.

${ }^{5}$ Hermann von Soden, Die Schriften des Neuen Testaments in ibrer ältesten erreichbaren Textgestalt. Four vols. Göttingen: Vandenhoek \& Ruprecht, 1902-13.

6 For more on this system, see Parker, An Introduction to the New Testament Manuscripts, 38.

${ }^{7}$ For more information about Staab and Reuss, see the section below on the History of Research on New Testament Catenae.

${ }^{8}$ See A.J. Brown, 'The Gospel Commentary of Theophylact and a Neglected Manuscript in Oxford.' NovT 49 (2007) 185-96. 
the Liste, this initial enumeration demonstrates the significance of catena manuscripts and the need for a more comprehensive investigation of this tradition. ${ }^{9}$

\section{The Structure and Presentation of Commentaries}

In almost all New Testament commentaries, the biblical text to be expounded is quoted at the top of each section. This means that readers do not have to refer to a separate manuscript of the source under consideration and can locate passages relatively easily, as the commentary follows the sequence of the biblical text. This initial quotation is called the lemma. It may extend over several modern verses, or simply consist of a single phrase. In a number of commentaries, especially those delivered as sermons or homilies, the initial lemma is relatively long and shorter extracts are used to introduce subsections. In German, the initial lemma is designated the Hauptlemma, while the secondary, shorter lemma is known as the Nebenlemma. ${ }^{10}$ The lemma also serves to specify the text which is being expounded, in order to mitigate the differences between individual biblical manuscripts.

Where a lemma is not provided, the first occasion on which an author quotes their source in sequence, known as the running text, serves a similar function to the lemma, although it may not be as clearly distinguished from the subsequent commentary as lemmata, which are usually grammatically separate. During the course of the exposition, an author may quote from the text under consideration. These sequential citations may be given verbatim or adapted to fit the context or grammar of the commentary: apart from comments about the wording of the biblical text, there appears to have been little concern in antiquity to reproduce sources exactly, especially in a homiletic environment. Alterations to enable a verse to stand out of context, whether to remove unnecessary information

\footnotetext{
${ }^{9}$ Further discussion about the origins of catena manuscripts and the problems of classification they pose, along with an indication of their potential significance for the hisotry of the biblical text, is to be found in D.C. Parker, Textual Scholarship and the Making of the New Testament. Oxford: OUP, 2012, esp. 40-52. Parker even goes so far as to speculate that 'the true number of catena manuscripts lacking from the Liste may even be as many as those that have been included' (46).

${ }^{10}$ For an example from Origen's Commentary on Romans, see Caroline P. Hammond Bammel, 'Die Lemmata bei Origenes und Rufin', in Der Römerbrieftext des Rufin und seine Origenes-Übersetzung. AGLB 10. Freiburg: Herder, 1985, 173-203 (discussed on page 233 below).
} 
or extend the import of the dictum, have been described as flattening. ${ }^{11}$ Sometimes a commentator may paraphrase, or adjust the source to make a point. Equally, quotations may be adduced from elsewhere in the source text or from other biblical books. These non-sequential citations, comparable to biblical quotations in other genres of writing, are normally likely to have been drawn from memory. Nevertheless, the fact that they have been provided as illustrations means that they often share a word or concept with the text under consideration. ${ }^{12}$

Manuscripts of commentaries normally employ a system of indicating the structural features of the commentary. ${ }^{13}$ The most common way of marking a new section is by leaving a blank space within a line. The first line of a section may begin with ekthesis, the projection of the first word into the left margin by the width of a few characters, sometimes termed a 'hanging line'. When a section does not begin on a new line, the ekthesis may be applied to the first complete line of the section, with the projection sometimes coming in the middle of a word which began on the previous line. Quotations may be indicated by eisthesis, the indentation of each line by the width of one or two characters, usually beginning with the first complete line. In Christian texts, biblical quotations are frequently identified by the use of the diple, shaped like an arrow-head $(>)$. This critical symbol appears to have been developed by the textual scholars of Alexandria to indicate passages of interest in the text of Homer. Even though the first explicit reference to the use of diplai to indicate biblical quotations is in the seventh-century Latin grammarian Isidore of Seville, there are numerous earlier examples of diplai in Greek manuscripts: in a papyrus from Oxyrhynchus copied around 200 (P.Oxy.III 405) they are used to mark a quotation of Matthew 3:15-16 in a copy of Irenaeus' Against Heresies, while

11 See H.A.G. Houghton, "Flattening” in Latin Biblical Citations' in J. Baun, A. Cameron, M. Edwards and M. Vinzent, ed., Studia Patristica XLV. Papers from the Fifteenth International Patristics Conference. Leuven: Peeters, 2010, 271-6.

12 On the ancient practice of 'concordance exegesis', known in Hebrew as gezerah shewa, in which a biblical text may be elucidated by any other scriptural instance of the same word, see Frances M. Young, Biblical Exegesis and the Formation of Christian Culture. Cambridge: CUP, 1997, 92.

${ }^{13}$ For a comparative study of the manuscript presentation of early Latin commentaries on Paul, see H.A.G. Houghton, 'The Layout of Early Latin Commentaries on the Pauline Epistles and their Oldest Manuscripts', forthcoming in M. Vinzent, ed., Studia Patristica. Papers from the Seventeenth International Patristics Conference. Leuven: Peeters, 2017. 
they are commonly found alongside quotations from the Septuagint in fourth-century copies of the New Testament. ${ }^{14}$ In early manuscripts of commentaries, including the papyrus fragments of Origen and Didymus found in Tura in 1941, the principal lemma is accompanied by a double diple $(>>)$, while the secondary lemmata and other citations only have a single diple. ${ }^{15}$ Additional ways of indicating lemmata may include rubrication or the use of a different size of writing or script. For example, the Old Testament citations in Codex Claromontanus (GA 06) are written in red, while in some commentary manuscripts from the ninth century onwards the biblical lemmata continue to be written in majuscules while the rest of the commentary is in the more compact minuscule script: an example of this is given in Image 1.16

Different forms of presentation are found in other types of commentary from antiquity. ${ }^{17}$ It seems to have been more common for commentators on classical texts, whether poems, plays, speeches or philosophical or scientific treatises, to write a companion volume rather than incorporate the source text into their commentary. In manuscripts of works in verse, however, there was space for critical annotations, or scholia, to be added in the margins. These may come from a single commentary or a variety of sources and extend from single-word alternative readings to longer comments on the interpretation of the text. ${ }^{18} \mathrm{~A}$ number of formats may be found for philosophical commentaries, some of which may have had their origin as notes taken from lectures. These range from individual scholia to companion volumes and hybrid forms in

14 See the survey of Ulrich Schmid and Marcus Sigismund, 'Die Markierung von Zitaten in den Handschriften', in M. Karrer, S. Kreuzer \& M. Sigismund, ed., Von der Septuaginta zum Neuen Testament. ANTF 43. Berlin \& New York: de Gruyter, 2010, 75-152.

15 See further Caroline P. Hammond, 'A Product of a Fifth-Century Scriptorium Preserving Conventions used by Rufinus of Aquileia.' JTS ns 29.2 (1978) 366-91, especially 382-3, where it is noted that this practice was also adopted by Rufinus in his translation of Origen's Commentary on Romans.

16 New Testament manuscripts sometimes feature marginal indications of the source for the quotation, as is seen in Codex Sinaiticus (GA 01; e.g. Acts 2:34, 3:22, $3: 25,4: 25$ etc.).

${ }^{17}$ See further the chapter by MacLachlan in the present volume.

18 A number of examples of such manuscripts may be seen online in the Homer Multitext Project (http://www.homermultitext.org/). 


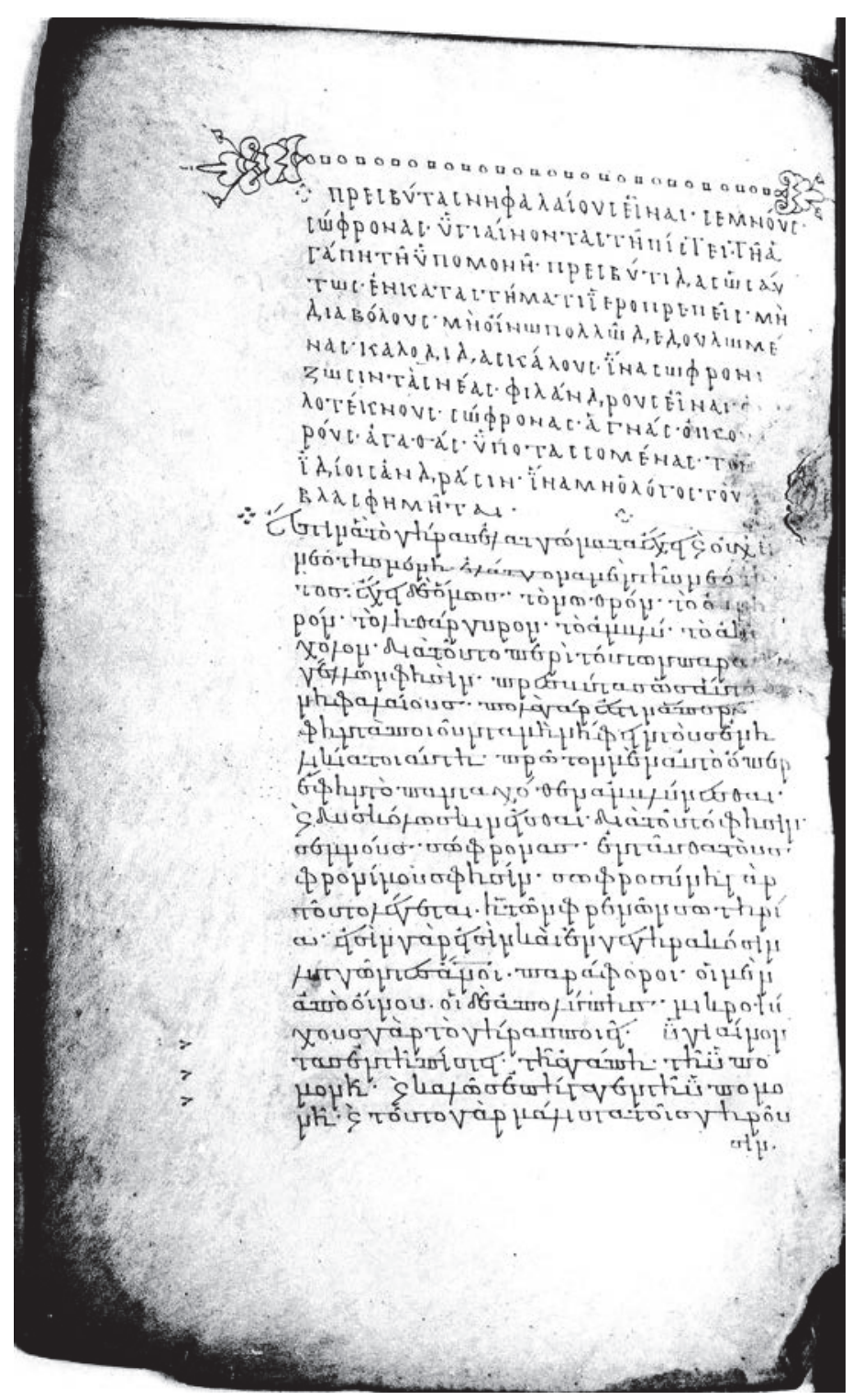

Image 1. Paris, BnF, grec 744, fol. 250v

A ninth-century copy of Chrysostom's commentary on 1 Timothy (in the form of homilies). The lemma at the top of the section is written in majuscule and the commentary in minuscule. A biblical quotation later in the commentary is indicated by a marginal diple alongside each line. 
which the commentary is written in a separate column alongside the source text. ${ }^{19}$

\section{The Structure and Presentation of Catenae}

The earliest manuscripts of biblical catenae may have had the source text and comments in parallel columns. ${ }^{20}$ There are two main formats for catena manuscripts of the New Testament. The earlier of these features the biblical text written continously in a rectangular space adjoining the central margin, with comments added in the other three margins, above, below and to the side (see Image 2). In German, this is known as a Randkatene, 'marginal catena', or a Rabmenkatene, 'frame catena'. As the former term may lead to confusion with discontinuous comments or scholia placed in the margin, we propose to adopt the latter term and call them frame catenae. ${ }^{21}$ Parallels have been drawn between this 'book within a book' presentation and the format of commentary on the Hebrew Scriptures in manuscripts of the Talmud, although there is no evidence for the influence of the latter on the former. Rather, the creation of codices with extra-wide margins for the addition of comments is likely to have been an independent development in a variety of traditions. Nevertheless, the production of copies in which the original format is preserved, presumably to maintain the integrity of the continuous biblical text, is striking. In fact, when the sections of commentary in frame catenae are particularly extensive, a single verse may be repeated several times in the space for biblical text on each page rather than strict continuity being maintained. ${ }^{22}$

19 See further the different types of commentary enumerated in Rodney M. Thomson, Catalogue of Medieval Manuscripts of Latin Commentaries on Aristotle in British Libraries. Volume II: Cambridge. Turnhout: Brepols, 2013, 18-19, and the contributions to Josef Lössl and John W. Watt, ed., Interpreting the Bible and Aristotle in Late Antiquity: the Alexandrian Commentary Tradition between Rome and Baghdad. Farnham: Ashgate, 2011.

20 See further Dorival on page 76 below.

21 Another advantage of this term is that the frames may be of different shapes and sizes: even catenae in which the biblical text is in one column and the commentary in another may be described within this category. On the chronological priority of frame catenae, see H. Lietzmann, Catenen. Mitteilungen über ibre Geschichte in handschriftlicher Überlieferung. Freiburg-im-Breisgau: Mohr, 1897, 912; Dorival suggests that this format may have originated as scholia in the margins of a biblical text (page 76).

22 An example of this is GA 050, in which blocks of text are omitted and 


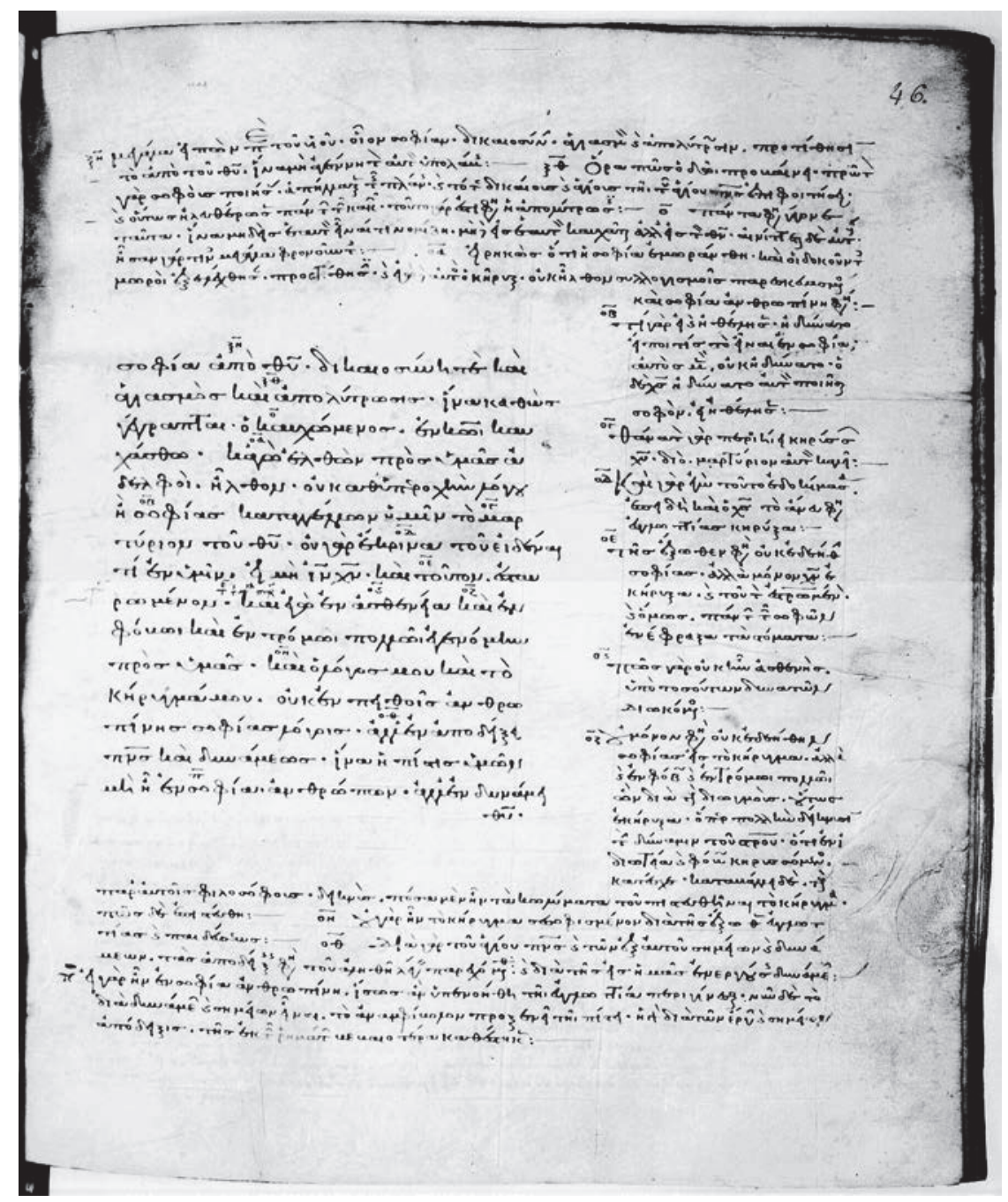

Image 2. Paris, BnF, grec 222, fol. 46r (GA 1932).

A frame catena on 1 Corinthians copied in the tenth or eleventh century. Each comment is identified by a number placed above the corresponding word in the biblical text and preceding the commentary: this is typical of Oecumenian tradition (see below).

repeated: see further U. B. Schmid, with W. J. Elliott and D. C. Parker, ed., The New Testament in Greek IV. The Gospel According to St John. Vol. II: The Majuscules. NTTSD 37. Brill: Leiden, 2007. 
The frame catena is the predominant form of New Testament catena until the end of the eleventh century. ${ }^{23}$

The alternative form of presenting catenae consists of lemmata followed by sections of exposition, as in single-author commentaries. These may be described as alternating catenae (designated in German by the unmarked term Katene). As the presentation is much less complicated, and the commentary easier to read, this seems to be a secondary development from the layout of frame catenae. The attestation of this form is also later: it only becomes popular in the New Testament tradition from the twelfth century onwards. An example of this format is shown in Image 3.

Within the commentary sections, the independence of each extract is usually preserved, although later catenists are more interventionist in their treatment of their sources. ${ }^{24}$ The original practice may be taken as an indication of the authority of the sources from which the comments were taken: in many manuscripts, the author is identified before each extract. This is often in the form of an abbreviation or monogram, such as a combination of $\omega$ and $\mathrm{P}$ for Origen ( $\omega \rho p \gamma \varepsilon ́ v \eta \varsigma$ ) or XP for Chrysostom

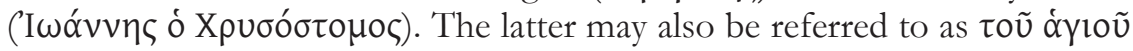

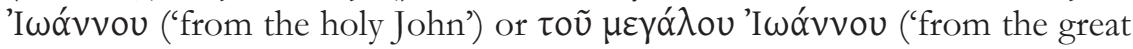
John'): names may be used for other authors, along with the indication $\tau$ ov

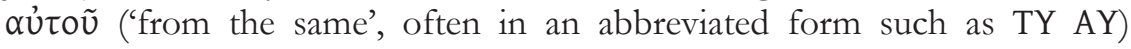
between passages from the same author. Nevertheless, the identification of each author is not always accurate and care must be taken when using catenae as evidence for works which do not survive in their entirety. In frame catenae, the sections of commentary may be connected to the biblical text either through a lemma in the margin consisting of the opening words of the section being expounded, or through a system of symbols above words in the source text. In some traditions, notably the Oecumenian catenae on the Pauline Epistles, numerals are placed above biblical words corresponding to each section of commentary (see Image 2). ${ }^{25}$ These begin afresh for each book, although in some cases additional comments have been added which interrupt the numerical sequence.

The biblical text in alternating catenae is normally distinguished by the same means as the lemmata in single-author commentaries, described

${ }^{23}$ Compare the tables in Morrill and Gram's chapter in the present volume (pages 110-3), confirming Dorival's observation on page 77.

${ }^{24}$ See the chapter by Panella in the present volume.

25 See further the tables of Morrill and Gram below, in which every catena in frame format includes these numbered divisions (page 111). 
above. The end of comments is often indicated by blank space or punctuation. One of the most common marks is a double-dot (dicolon) followed by a horizontal line (:-), as illustrated in Image 2.26 In some manuscripts, the lemma text is indicated in the margin with the word

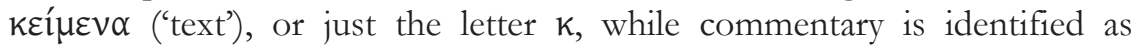

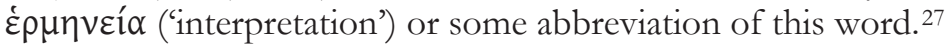

In frame catenae, the commentary is often written in smaller script in order to fit a greater amount of text on the page. This is the case in the late seventh-century Codex Zacynthius (GA 040), the earliest surviving catena manuscript, in which both Gospel text and exposition are written in majuscule script. ${ }^{28}$ Other frame catenae usually have the commentary in minuscule script, with frequent abbreviations. One counter-example is the ninth-century GA 1900, which has the biblical text in a large minuscule but the exposition in small majuscule script and leaves several lines of blank space at the end of certain sections. This suggests that the manuscript stands at a relatively early point in its tradition, because later copyists would have sought to eliminate the gaps. If the biblical text is written in majuscule characters, the manuscript may have been categorised among the majuscules in the Liste regardless of the presence of minuscule on the same page (e.g. GA 0141, 0142). ${ }^{29}$ This explains why catenae constitute practically all of the New Testament manuscripts classified as majuscule but copied in the tenth century or later. On the other hand, there are also catenae in which the biblical text is initially written in majuscules but later gives way to minuscules: these are usually classified among the latter in the Liste (e.g. GA 2351).

26 For more on punctuation, see E. G. Turner and P.J. Parsons, Greek Manuscripts of the Ancient World. $2^{\text {nd }}$ edn. London: Institute of Classical Studies, 1987, 8-9; we are grateful to Grant Edwards for drawing our attention to this.

27 E.g. GA 0150 and 2110; compare also the use of $\varepsilon \rho /$ in GA 2351 noted by Allen on pages 147 and 161-3 below.

28 On the dating and script of Codex Zacynthius, see D.C. Parker and J.N. Birdsall, 'The Date of Codex Zacynthius ( $\Xi$ ): a New Proposal.' JTS ns 55 (2004) 117-31.

29 There is, however, some inconsistency, including the example given by Panella on page 121 below: GA 0150 and 2110 are possibly written by the same scribe and identical in format, with majuscule lemmata and minuscule comments, but are assigned to different categories in the Liste. 


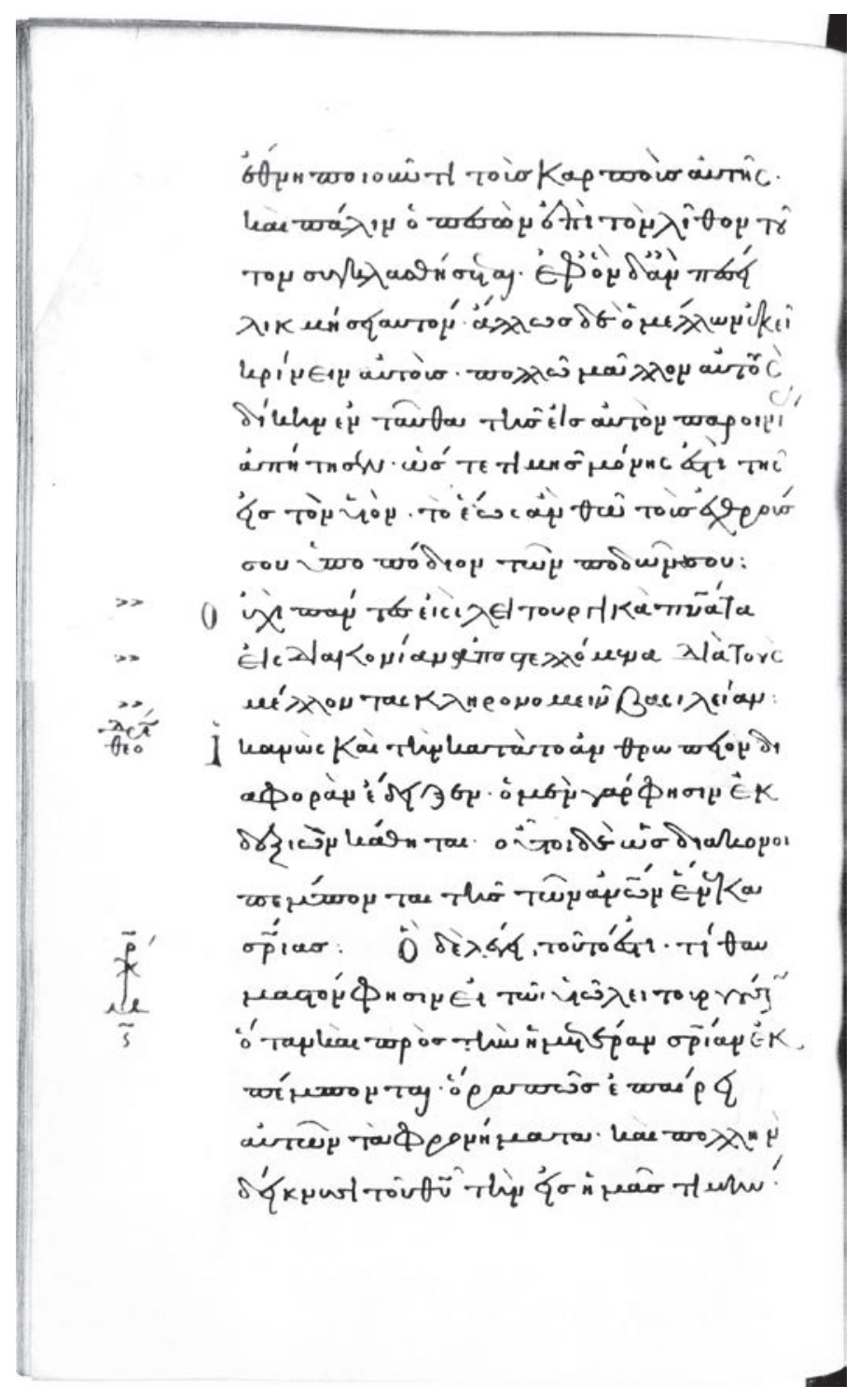

Image 3. Paris, BnF, grec 238, fol. 125v (GA 1938).

A lineated catena on Hebrews copied in the thirteenth century. The lemma, in the middle of the page, is indicated by double diplai in the margin; the first comment is marked as coming from Theodoret and the next from Chrysostom. Comments and the lemma are separated by a dicolon. 
There are a number of intermediate forms of commentary in New Testament manuscripts: although these do not correspond to the full catenae types, they also consist of extracts. The most common is a series described as 'Extracts from Chrysostom', which may occur either as a sequential text or in the margins like a frame catena. ${ }^{30}$ Biblical codices may also have occasional scholia in the margins, added initially by users but incorporated into later copies. The best-known examples of this are the members of the group of manuscripts known as Family 1, whose exemplar included marginal notes of alternative readings, and GA 1739 (known as the von der Goltz codex). ${ }^{31}$ The latter is a copy of the Pauline Epistles which reports differences from the text used by Origen for his Commentary on Romans.

\section{EARLy Greek Commentators ON THE NeW TESTAMENT}

The earliest New Testament commentaries are lost or only partially preserved. We know of a commentary on John by the Gnostic writer Heracleon, composed at some point in the second century, from reports in other authors. The most prolific early commentator was Origen, later condemned as a heretic, active in the early decades of the third century. Origen's exegetical works cover most of the New Testament, including multiple-volume commentaries on Matthew, John and Romans, homilies on Luke, Acts and Hebrews and, possibly, scholia on Revelation. ${ }^{32}$ These were

30 An example of the latter is GA 457, discussed by Panella in papers to the Fifth British Patristics Conference and the Society of Biblical Literature Annual Meeting in 2014.

${ }^{31}$ For Family 1, see Amy S. Anderson, The Textual Tradition of the Gospels: Family 1 in Matthew. NTTSD 32. Leiden: Brill, 2004, and Alison Welsby, A Textual Study of Family 1 in John. ANTF 45. Berlin \& New York: de Gruyter, 2013; the editio princeps of GA 1739 is Eduard von der Goltz, Eine textkritische Arbeit des zehnten bezw. sechsten Jahrbunderts. TU 17.4. Leipzig: Hinrichs, 1899.

32 Critical editions of Origen are as follows:

Matthew: Erich Klostermann, Origenes Werke X. Commentarius in Matthaeum I. GCS 40. Leipzig: Teubner, 1935; Ursula Treu, Origenes Werke XI. Commentarius in Matthaeum II. $2^{\text {nd }}$ edn. GCS 38. Leipzig: Teubner, 1976; Erich Klostermann, Origenes Werke XII. Commentarius in Matthaeum III.1. GCS 41.1. Leipzig: Teubner, 1941; Ursula Treu, Origenes Werke XII. Commentarius in Matthaeum III.2. 2 ${ }^{\text {nd }}$ edn. GCS 41.2. Leipzig: Teubner, 1968; R. Girod, Origène. Commentaire sur l'évangile selon Matthieu, vol. 1. SC 162. Paris: Cerf, 1970; see also Erich Klostermann and Ernst Benz, Zur Überlieferung der Matthäuserklarung des Origenes. TU 47.2. Leipzig: Hinrichs, 1931, and 
popular among Latin authors at the end of the fourth century: Jerome relied heavily on Origen for his commentaries on Matthew, Galatians, Ephesians, Titus and Philemon, while Rufinus of Aquileia produced an abbreviated translation of Origen's Commentary on Romans and Origen was also an influential source for Ambrose of Milan. ${ }^{33}$ Most of Origen's commentaries have not survived and portions are only known through translations or discoveries such as the Tura papyri. As a result, catena manuscripts can be valuable as a source of otherwise lost extracts from his writings. ${ }^{34}$

Didymus, sometimes known as Didymus the Blind or Didymus of Alexandria, where he lived in the fourth century, was a prolific exegete. Parts of his commentaries on books of the Old Testament were found among the Tura papyri, but nothing remains of his work on the New Testament apart from fragments in catenae and a Latin translation of his commentary on the Catholic Epistles. ${ }^{35}$ Cyril of Alexandria, patriarch in

Erich Klostermann, Nacblese zur Überlieferung der Matthäus-Erklarung des Origenes. TU 47.4. Leipzig: Hinrichs, 1932.

Luke: M. Rauer, Origenes Werke, vol. 9. 2nd ed. GCS 49. Berlin: Akademie, 1959.

John: E. Preuschen, Origenes Werke, vol. 4. GCS 10. Leipzig: Hinrichs, 1903; C. Blanc, Origène. Commentaire sur saint Jean. 5 vols. SC 120, 157, 222, 290, 385. Paris: Cerf, 1966-92.

Pauline Epistles: A. Ramsbotham, 'The Commentary of Origen on the Epistle to the Romans.' JTS os 13 (1912) 210-24, 357-68 \& 14 (1912) 10-22; J. Scherer, Le commentaire d'Origène sur Rom. III.5-V.7. Cairo: Institut Français d'Archéologie Orientale, 1957; C. Jenkins, 'Origen on I Corinthians.' JTS os 9 (1908) 232-47, 353-72, 500-14 \& 10 (1908) 29-51; J.A.F. Gregg, 'The Commentary of Origen upon the Epistle to the Ephesians.' JTS os 3 (1902): 234-44, 398-420, 554-76; these have recently been brought together by Francesco Pieri, Opere di Origene 14/4. Exegetica in Paulum Excerpta et Fragmenta. Rome: Città Nuova, 2009.

Revelation: C.H. Turner, 'Origen, Scholia in Apocalypsin.' JTS os 25 (1923): 115; Constantin Diobouniotis and Adolf Harnack, Der Scholien-Kommentar des Origenes zur Apokalypse Johannis. TU 38.3. Leipzig: Hinrichs, 1911.

${ }^{33}$ For Origen and Jerome, see Ronald E. Heine, The Commentaries of Origen and Jerome on St Paul's Epistle to the Ephesians. Oxford: OUP, 2002, and M.A. Schatkin, 'The Influence of Origen upon St. Jerome's Commentary on Galatians.' VC 24 (1970), 49-58. An edition of Rufinus' translation of Origen's Commentary on Romans and studies of their relationship have been published by Caroline Hammond Bammel: see also H. Chadwick, 'Rufinus and the Tura Papyrus of Origen's Commentary on Romans'. JTS ns 10 (1959) 10-42, and the chapter by Kreinecker in the present volume. For Ambrose, see the chapter by Griffith below.

${ }^{34}$ See also Griffith's discussion of the Homilies on Luke (pages 203-25 below).

35 See F. Zoepfl, Didymi Alexandrini in epistulas canonicas brevis enarratio. NTAbh 
the first half of the fifth century, wrote commentaries on several New Testament writings. Only the Commentary on John is substantially extant in Greek; a Syriac translation provides much of the evidence for the Commentary on Luke, while his expositions of Matthew, Acts and the Epistles only survive in fragments. ${ }^{36}$ Clement of Alexandria produced an exposition of the Acts of the Apostles and Catholic Epistles, although this only survives in a Latin translation. ${ }^{37}$

The most extensive Greek commentator of the fourth century was John Chrysostom, known as 'Golden Mouth' because of the quality of his preaching. His expositions of the Gospels, Acts and Epistles are transmitted in their entirety. Almost all of these take the form of sets of homilies delivered at the liturgy and recorded by stenographers. They appear to have a lengthy initial lemma quoted at the beginning of each sermon, followed by shorter lemmata structuring the exposition, although it is unclear how much this is owed to redactional activity: most of Chrysostom's works lack an adequate modern edition because of the abundance and complexity of their manuscript tradition. ${ }^{38}$ Chrysostom forms the basis for much of the exposition in catenae, adding another layer to his already complicated textual history.

4.1. Münster: Aschendorff, 1914, which also includes the Latin version attributed to Epiphanius Scholasticus, and Erich Klostermann, Über des Didymus von Alexandrien In epistolas canonicas enarratio. TU 28.2. Leipzig: Hinrichs, 1905.

${ }^{36} \mathrm{~J}$. Sickenberger, Fragmente der Homilien des Cyrill von Alexandrien zum Lukasevangelium. TU 34. Leipzig: Hinrichs, 1909; P.E. Pusey, Sancti patris nostri Cyrilli archiepiscopi Alexandrini in D. Joannis evangelium. 3 vols. Oxford: Clarendon, 1872. Pusey's third volume assembles Cyril's fragments on the Pauline Epistles. For Acts and the Catholic Epistles, see PG 74, cols 757-73 and 1008-24. Parker, An Introduction to the New Testament Manuscripts, 330, notes that manuscripts of Cyril's commentaries are included in the Kuragefasste Liste: the fragments of Cyril in catenae are assembled by Reuss for all three gospels: see note 75 below.

37 Edition in Otto Stählin and Ludwig Fruchtel, Clemens Alexandrinus III. Stromata Buch VII \& VIII. $2^{\text {nd }}$ edn. (GCS 17). Leipzig, 1970, 203-15.

38 The most recent edition remains $P G 57-62$, which often reprints an earlier edition. For an analysis of different families of text, see Maria Konstantinidou, 'Opting for a Biblical Text-Type: Scribal Interference in John Chrysostom's Homilies on the Letter to Titus' in Textual Variation: Theological and Social Tendencies? ed. H.A.G. Houghton and D.C. Parker. T\&S 3.5. Piscataway: Gorgias, 2008, 13348. The Codices Chrysostomici Graeci project to catalogue all known manuscripts of Chrysostom is a necessary precursor to editorial work on his text: seven volumes have been published by the CNRS in Paris from 1968 to 2011. 
The beginning of the fifth century saw the production of two commentaries on the Pauline corpus. That of Theodore of Mopsuestia only survives for the shorter epistles from Galatians onwards, in a Latin translation, although there are a few fragments of Greek. ${ }^{39}$ Theodore may also have written a commentary on John. ${ }^{40}$ By contrast, the Commentary on Paul by Theodoret of $\mathbf{C y r}$ is transmitted in its entirety. ${ }^{41}$

Other exegetes of the fourth and fifth centuries include Acacius of Caesarea, Apollinarius of Laodicea, Basil the Great, Cyril of Jerusalem, Diodore of Tarsus, Epiphanius of Salamis, Eusebius of Caesarea, Gennadius (patriarch of Constantinople), Gregory of Nyssa, Gregory of Nazianzus and Severian of Gabbala. Eusebius of Emesa, based near Antioch, had influential contacts with the Syriac Church and was also translated into Latin at an early stage. Even though these authors are not known to have written commentaries on New Testament books, their works are often cited in New Testament catenae. Fragments of works which are only preserved in this way have been collected by Staab (for the Pauline Epistles) and Reuss (Matthew, Luke and John). ${ }^{42}$ Staab's collection also includes two later authors from the ninth century, the patriarch Photius and his pupil Arethas, archbishop of Caesarea.

Commentaries on Revelation (the Apocalypse of John) offer an entirely different situation. This book appears to have taken some time to become accepted into the New Testament and circulates in manuscripts separately from the other canonical books, usually with a commentary. The earliest commentary is that of Oecumenius, also known as a compiler of Pauline catenae, who was active in the early sixth century. ${ }^{43}$ This is based on

39 The edition is H.B. Swete, Theodori Episcopi Mopsuesteni in epistolas B. Pauli Commentarii. The Latin Version with the Greek Fragments. 2 vols. Cambridge: CUP, 1880 \& 1882. Additional fragments have been identified since this edition (e.g. Cambridge MA, Harvard University Houghton Library, f MS Lat 433), and work is underway on an edition of a Syriac commentary heavily reliant on Theodore.

${ }^{40}$ See R. Devreesse, Essai sur Théodore de Mopsueste. Studi e Testi 141. Vatican City: BAV, 1948, which assembles fragments from catenae.

${ }^{41}$ Its text of Romans is discussed by Agnès Lorrain in the present volume, whose edition of the commentary on this Epistle replaces that of PG 82.

${ }^{42}$ See notes 72 and 75 below; these collections are also available in digital form in the corpus of the Thesaurus Linguae Graecae (www.tlg.uci.edu).

${ }^{43}$ M. de Groote, ed., Oecumenii Commentarius in Apocalpsin. TEG 8. Leuven: Peeters, 1999 replaces H.C. Hoskier, The Complete Commentary of Oecumenius on the Apocalypse. Ann Arbor: University of Michigan, 1928. 
the better of the two early text forms of Revelation, also found in Codex Alexandrinus (GA 02), Codex Ephraemi Rescriptus (GA 04) and several papyri. The most commonly-found commentary is that of Andreas of Caesarea, present in around one-third of the surviving manuscripts of Revelation. Even though the commentary was created in the latter part of the sixth century, drawing on Oecumenius, it is found along with its characteristic form of biblical text in numerous manuscripts copied a thousand years later. ${ }^{44}$ Arethas of Caesarea relied heavily on Andreas' commentary for his tenth-century exposition of Revelation. ${ }^{45}$

\section{TyPes of CaTENAE}

The beginnings of the catena tradition have been heavily debated. With the exception of the early Codex Zacynthius (dated by Birdsall and Parker to around 700), the oldest manuscripts to have survived date from the ninth century onwards. ${ }^{46}$ We are thus dependent on the analysis of the catena forms for reconstructing the growth of the tradition. Numerous reworkings, in the form of expansions and abbreviations, are attested in catena manuscripts. The origins are often associated with Procopius of Gaza, at the turn of the sixth century, who describes how he compiled extracts from multiple sources on the Old Testament:

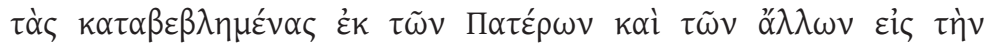

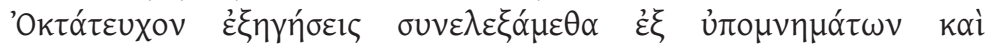

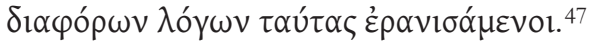

44 See Parker, An Introduction to the New Testament Manuscripts, 239. The commentary is edited in J. Schmid, Studien zur Geschichte des griechischen ApokalypseTextes, 1. Der Apokalypse-Kommentar des Andreas von Kaisareia. Münchener Theologische Studien 1. Munich: K. Zink, 1955. On Andreas' text, see Juan Hernández, 'The Relevance of Andrew of Caesarea for New Testament Textual Criticism.' JBL 130.1 (2011) 183-96, and the recent work of the Wuppertal Apocalypse Project, including Marcus Sigismund, Martin Karrer and Ulrich Schmid, eds, Studien zum Text der Apokalypse. ANTF 47. Berlin \& New York: de Gruyter, 2015.

45 There is no critical edition of this commentary, although fifteen manuscripts are listed in J. Schmid, 'Untersuchungen zur Geschichte des griechischen Apokalypsetextes.' Biblica 17 (1936) 273-93.

46 On Codex Zacynthius, see note 28 above.

47 Procopius' Commentary on Genesis, prologue (PG 87, col. 21.2-5). The compilations of extracts from Augustine in the fifth and sixth centuries offer a 
We gathered together expositions laid down by the Fathers and others on the Octateuch, collecting these from treatises and different works.

Catenae on the New Testament have different origins, which may go back even earlier. The oldest catena on Mark is attributed to the fifth-century Victor of Antioch. ${ }^{48}$ That on Luke is connected with Titus of Bostra, from several decades earlier, although it seems that the catena might have been extracted from his commentary. ${ }^{49}$ The earliest compilations on Matthew and John derive predominantly from the writings of John Chrysostom, putting them no earlier than the fifth century or the date of the latest author to be included in the commentary. Although certain witnesses to Matthew and Luke identify their catenae as the work of Peter of Laodicea, possibly active in the seventh or eighth century, this attribution is no longer accepted. ${ }^{50}$ Three subsequent catenists are known by name, whose work covers other books of the New Testament in addition to the Gospels. The earliest and most popular is Theophylact, archbishop of Ohrid in Bulgaria in the eleventh century. ${ }^{51}$ His contemporary Nicetas is usually identified as a bishop of Heraclea, although he is sometimes called Nicetas of Serrae. ${ }^{2}$ The third was a twelfth-century monk from Constantinople, Euthymius Zigabenus. ${ }^{53} \mathrm{~A}$

parallel development in Latin tradition at the same time (see H.A.G. Houghton, The Latin New Testament. A Guide to its History, Texts, and Manuscripts. Oxford: OUP, 2016, 59).

48 See further W.R.S. Lamb, The Catena in Marcum: A Byzantine Anthology of Early Commentary on Mark. Texts and Editions for New Testament Study 6. Leiden: Brill, 2012.

49 J. Sickenberger, Titus v. Bostra. Studien sur dessen Lukashomilien. TU 21.1. Leipzig: Hinrichs, 1901.

50 See G. Heinrici, Des Petrus von Laodicea Erklärung des Matthäusevangeliums. Beiträge zur Geschichte des Neuen Testaments 5. Leipzig, 1908, M. Rauer, Der dem Petrus von Laodicea zugeschriebene Lukaskommentar. NTAbh 8.2. Munich, 1920 and the observations at Parker, An Introduction to the New Testament Manuscripts, 331.

51 Theophylact's works are printed in PG 123-6, which reproduces the mid eighteenth-century edition of De Rossi.

52 An investigation of the catena on John associated with Nicetas has just been completed by Michael Clark at the University of Birmingham; for Luke, see Joseph Sickenberger, Die Lukaskatene des Niketas von Herakleia. TU 22.4. Leipzig: Hinrichs, 1902. Serrae is likely to be the modern city of Serres in Greece, although it is sometimes interpreted as a reference to the Byzantine term for catenae, $\sigma \varepsilon \tilde{\mathrm{l}} \rho \alpha \mathrm{l}$.

53 Zigabenus' gospel catena is printed in PG 129, reproducing the eighteenthcentury edition by C.F. Matthaei; Zigabenus' catena on the Pauline and Catholic 
fourteenth-century archbishop of Philadelphia, Macarius Chrysocephalus, was responsible for catenae on Matthew and Luke, which appear to be an expansion of Nicetas' catena. ${ }^{54}$

The earliest catenae on the Pauline Epistles are associated with the name of Oecumenius. For many years, this compiler was identified with the tenth-century bishop of Trikka but, as the catena is attested in manuscripts from the ninth-century onwards, the attribution was not accepted by scholars and the commentary was known as PseudoOecumenius. The discovery of a commentary on Revelation apparently by the same author enabled the connection of Oecumenius with an author active in Asia Minor around the end of the sixth century. This date which is much more consistent with the history and attestation of the catena and enables the pseudonymous label to be dropped. ${ }^{55}$ Many of the extracts in the Oecumenian tradition are taken from Chrysostom's commentaries on the Pauline Epistles. This is also true of the early eighth-century catena on Paul attributed to John of Damascus. ${ }^{56}$ There is then a gap of three centuries or so before the Pauline catenae of Theophylact, Nicetas and Zigabenus.

Five catenae are identified for the Catholic Epistles. ${ }^{57}$ An early form was used as the basis for a compilation attributed to Andreas the Presbyter. Another is identified as (Pseudo)-Oecumenius, and the latest is the work of Theophylact. Little work has been done on catenae on the Acts of the Apostles. In Revelation, as noted above, the commentaries of Oecumenius and Andreas of Caesarea hold pride of place, followed later by

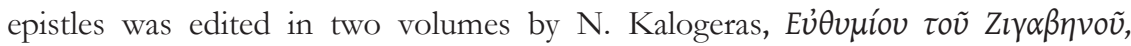

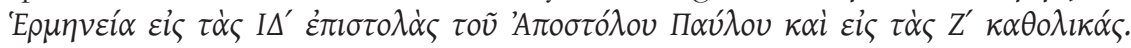

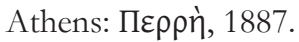

${ }^{54}$ Matthew is known from a single manuscript, the sixteenth-century Oxford, Bodleian Library, Barocci 156. Luke is more widely attested. Lamb, The Catena in Marcum, 30 notes that Macarius' sobriquet derives from the gold leaf used for the headings under which his extracts were arranged.

${ }^{55}$ See F. Diekamp, 'Mittheilungen über den neuaufgefundenen Commentar des Oekumenius zur Apokalypse.' Sitzungsberichte der Preußischen Akademie der Wissenschaften zu Berlin (Pbil.-bist. Klasse) 43 (1901) 1046-56, and John Suggit, trans., Oecumenius, Commentary on the Apocalyse. Washington DC: Catholic University of America Press, 2006.

${ }^{56}$ The most recent edition remains PG 95, col. 441-1033.

${ }^{57}$ See Parker, An Introduction to the New Testament Manuscripts, 305 and the survey by Staab detailed in note 71 below. 
Arethas. There is also a tradition of scholia, some of which may derive from Origen's lost exposition of this book. ${ }^{58}$

It is worth noting that most of the differing types of catenae are found in both formats, as alternating catena and frame catenae. In addition, catena manuscripts which contain more than one section of the New Testament are not always consistent in the affiliation of their commentary in different biblical books. For example, GA 1424 contains a commentary based on Chrysostom in the Gospels and one from Theodoret and other authors in the Pauline Epistles. ${ }^{59}$ Finally, as has already been mentioned above with regard to Peter of Laodicea, the titles in catenae manuscripts are often misleading and should not be taken as a firm attribution.

There are examples of catenae manuscripts with integrated lectionary apparatus (e.g. GA 0141) and others with the Eusebian apparatus. These examples raise significant questions with regard to the use of such manuscripts. One witness consists of a series of extracts from a catena based on the gospel readings for five feasts in the liturgical calendar. ${ }^{60} \mathrm{In}$ addition, catena manuscripts of the Pauline Epistles may contain some or all of the Euthalian apparatus of prologues, chapter divisions and so on. ${ }^{61}$

\section{History OF RESEARCH ON NEW TESTAMENT CATENAE ${ }^{62}$}

The earliest assembly of catena material was that of John Anthony Cramer, published in eight volumes between 1838 and $1844 .{ }^{63}$ This consists of the transcription of each biblical book from a single manuscript, with variant readings from one or two other witnesses. Cramer was already familiar with the attribution of the catena on Mark to Victor of Antioch and that on

58 See Diobouniotis and Harnack, Der Scholien-Kommentar des Origenes zur Apokalypse Johannis and Allen's chapter below (pages 141-63).

${ }^{59}$ See Parker, An Introduction to the New Testament Manuscripts, 78.

${ }^{60}$ Milan, Bibl. Ambros., D.25.inf (920); although only five feasts are included,

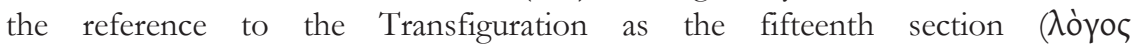
$\pi \varepsilon \nu \tau \varepsilon \kappa \alpha 1 \delta \varepsilon ́ k \alpha \tau O \zeta)$ suggests that this derives from a larger collection. The second half of this manuscript is an autograph Latin translation of the Greek catena extracts.

${ }^{61}$ See the observation by Morrill and Gram on page 103 below.

${ }^{62}$ For more on this subject, see the contributions of Gilles Dorival and William Lamb to the present volume.

63 J.A. Cramer, Catenae Graecorum Patrum in Novum Testamentum, 8 vols, Oxford: OUP, 1844. In addition to scanned copies, the text of this work is now available online in XML format at http://opengreekandlatin.github.io/catenae-dev/. 
Luke to Titus of Bostra. His principal witness for all four gospels is the eleventh-century Paris, BnF, Coislin gr. 23 (P; GA 39). In Matthew and John he adds information from the tenth-century Oxford, Bodleian Library, Auct. T.1.4 (B; GA 709), while in Mark and Luke he compares the Paris manuscript with the twelfth-century Oxford, Bodleian Library, Laud. Gr. 33 (L; GA 50). Eight manuscripts are used for the Pauline Epistles. Romans is edited from Oxford, Bodleian Library, Auct. E.2.20, with lacuna suppled from a manuscript which Cramer identifies as no. 23 in the Royal Library of Munich (now BSB Gr. 412; GA 1909). ${ }^{64}$ For both letters to the Corinthians, Cramer uses Paris, BnF, grec 227 (GA 1937), which he compared with Oxford, Bodleian Library, Auct. T.1.7 and Roe 16 (GA 1908). ${ }^{65}$ For the rest of Paul, he prints the text of Paris, BnF, Coislin grec 204 (GA 1910); for Hebrews he also uses Paris, BnF, grec 238 (GA 1938) and grec 224A (GA 1964). The catenae on Acts and the Catholic Epistles, which he describes as based on Chrysostom, are printed from Oxford, New College, MS 58 (GA 2818), with variants from Paris, BnF, Coislin gr. 25 (GA 307). For Jude, Cramer used Oxford, Bodleian Library, Rawlinson G. 157.66 For Revelation, he prints a single work which he identifies as the commentary of Oecumenius and Arethas, from Oxford, Bodleian Library, Barocci 3 (GA 314) and Paris, BnF, Coislin gr. 224 (GA 250). While the choice of manuscripts is somewhat random and there is little in the way of analysis, the transcriptions in Cramer's volumes are useful as a point of reference.

Around a century and a half later, Paul Wendland and Leopold Cohn realised the importance of creating a catalogue of catenae manuscripts and their contents as a prelude to a more scientific study. ${ }^{67}$ The first attempt was the Catenarum Graecarum Catalogus published by Georg Karo and Hans Lietzmann in 1902 (often known as Karo-Lietzmann). ${ }^{68}$ This builds on

${ }^{64}$ Karo and Lietzmann (see below) identify the Oxford manuscript as 'Bodl. Misc. 48'.

${ }^{65}$ Cramer describes the manuscript as Reg. 227, but this appears to be a mistake; grec 227 was previously Reg. 1892.

${ }^{66}$ This manuscript is not in the Liste; Karo and Lietzmann (see below) identify it as as 'Bodl. Misc. 169'.

${ }^{67}$ Paul Wendland, Neu entdeckte Fragmente Pbilo's nebst einer Untersucbung über die ursprüngliche Gestalt der Schrift de Sacrificiis Abelis et Caini, Berlin: Georg Reimer, 1891; L. Cohn, 'Zur indirekten Überlieferung Philo's und der älteren Kirchenväter. Nebst einem Nachtrage von P. Wendland.' Jabrbüch für Protestantische Theologie 18 (1892) $475-92$.

${ }^{68}$ Georg Karo and Johannes (Hans) Lietzmann, Catenarum Graecarum Catalogus. 
Cramer, identifying multiple types of catenae and providing lists of the authors cited and the opening and closing words of each extract. There are six types of catena identified in Matthew, Luke and John, and nine in the Pauline Epistles. Mark and Acts are described as single traditions (attributed to Victor of Antioch and Andreas the Presbyter respectively); information on the Catholic Epistles is limited, and Revelation is not included. The manuscripts used by Cramer are supplemented with a number of additional witnesses, many from libraries in Florence, Moscow, Milan, Rome and the Vatican. Nevertheless, despite the useful indices of authors and manuscripts, the coverage is by no means exhaustive. Lietzmann also inaugurated a series of Catenenstudien, but only two volumes appeared in this and they met with a lukewarm reception. ${ }^{69}$ Other scholars were also active in the field at the same time. Heinrici edited a catena on Matthew, upholding its attribution to Peter of Laodicea, while Sickenberger followed up his edition of Nicetas' catena in Luke and the commentary of Titus of Bostra with surveys of the same gospel in other writers. ${ }^{70}$

A thorough account of catenae on the Epistles was produced by Karl Staab a few decades later. First of all, he published an essay on the Catholic Epistles. ${ }^{71}$ This was followed by two volumes on Paul, the first identifying and analysing the different types of catena and the second assembling the full text of each extract by author in order to reconstruct exegetical works which were no longer transmitted in their entirety. ${ }^{72} \mathrm{Staab}$ is responsible for

(Nachrichten von der Königl. Gesellschaft der Wissenschaften, philol.-hist. Klasse). Göttingen: Lüder Horstmann, 1902; see also H. Lietzmann, Catenen. Mitteilungen über ihre Geschichte in handschriftlicher Überlieferung, Freiburg-im-Breisgau: Mohr-Siebeck, 1897.

${ }^{69}$ O. Lang, Die Catene des Vaticanus gr. 762 zum Ersten Korintherbrief analysiert. Catenenstudien 1. Leipzig: Hinrichs, 1909; O. Hoppmann, Die Catene des Vaticanus gr. 1802 zu den Proverbien. Catenenstudien 2. Leipzig: Hinrichs, 1912.

${ }^{70}$ G. Heinrici, Des Petrus von Laodicea Erklärung des Matthäusevangeliums. Beiträge zur Geschichte des Neuen Testaments 5. Leipzig, 1908; J. Sickenberger, Aus römischen Handschriften über die Lukas Katene des Niketas. Roma, 1898; J. Sickenberger, Titus v. Bostra. Studien sur dessen Lukashomilien. TU 21.1. Leipzig: Hinrichs, 1901; J. Sickenberger, Die Lukaskatene des Niketas von Herakleia untersucht. TU 22.4. Leipzig: Hinrichs, 1902; J. Sickenberger, Fragmente der Homilien des Cyrill von Alexandrien zum Lukas Evangelium. TU 34.1. Leipzig: Hinrichs, 1909.

71 K. Staab, 'Die griechischen Katenenkommentare zur den katholischen Briefe.' Biblica 5 (1924) 296-353.

${ }^{72}$ K. Staab, Die Pauluskatenen nach den handschriftlichen Quellen untersucht, Rome: Pontifical Biblical Institute, 1926; K. Staab, Pauluskommentare aus der griechischen 
the names by which each of the six types of Pauline catena are known. Three are identified by the library of their principal witness: Typus Vaticanus is based on Vatican gr. 762 (GA 1915), Typus Monacensis is based on Munich, BSB, Gr. 412 (GA 1909) and Typus Parisinus derives from Paris, BnF, Coislin gr. 204 (GA 1910; Image 4). The other three are identified by author: Nicetas, Pseudo-Oecumenius and Theodoret. The Oecumenian tradition consists of five subtypes, a-e, including two expansions and one set of extracts. There are four manuscripts which do not correspond with any of the six principal types. ${ }^{73}$ Staab offers an analysis of each of the types and their character, along with extensive descriptions of the key manuscripts and comments on their biblical text. He also gives an indication of the total number of extracts for each Epistle, divided by author: some extracts are attributed to more than one source (Doppellemmata). In the second volume, these are assembled for eleven authors, eight from the fourth or fifth century (Didymus of Alexandria, Eusebius of Emesa, Acacius of Caesarea, Apollinarius of Laodicea, Diodore of Tarsus, Theodore of Mopsuestia, Severian of Gabbala and Gennadius of Constantinople) along with Photius, Arethas and Oecumenius (whom he identifies as Oecumenius of Trikka).

A similar approach was taken for the Gospels by Staab's pupil Joseph Reuss. His initial survey divided the catenae on Matthew into five types (A$\mathrm{D}$ and Macarius Chrysocephalus), Mark into two recensions, and John into seven types (A-F and Macarius Chrysocephalus), along with various subtypes, several individual manuscripts, and chapters on the commentaries of Theophylact and Euthymius Zigabenus; Nicetas of Heraclea is represented by Type $\mathrm{C}$ in Matthew and Type $\mathrm{E}$ in John. ${ }^{74}$ In three subsequent volumes Reuss assembled the extracts for Matthew, John and Luke by authors whose works are otherwise not transmitted: Apollinaris of Laodicea, Theodore of Heraclea, Cyril of Alexandria and Photius appear in all three gospels; Theophilus of Alexandria is cited in Matthew and John, and Theodore of Mopsuestia in Matthew and Luke; Matthew names a further, unidentified, Theodore; John also features Didymus and Ammonius of Alexandria; Luke has extensive extracts by an anonymous

Kirche. Aus Katenenhandschriften gesammelt und herausgegeben. NTAbh 15. Münster: Aschendorff, 1933 (reprinted 1984).

73 Athos, Pantokrator 28 (GA 1900), Vatican, Vat. gr. 1650 (GA 623), Paris, BnF gr. 226 (GA 1936) and Coislin gr. 208 (not in the Liste).

${ }^{74}$ Joseph Reuss, Matthäus-, Markus,, und Johannes-Katenen nach den handscbriftlichen Quellen untersucht. NTAbh 18.4-5. Münster: Aschendorff, 1941. 


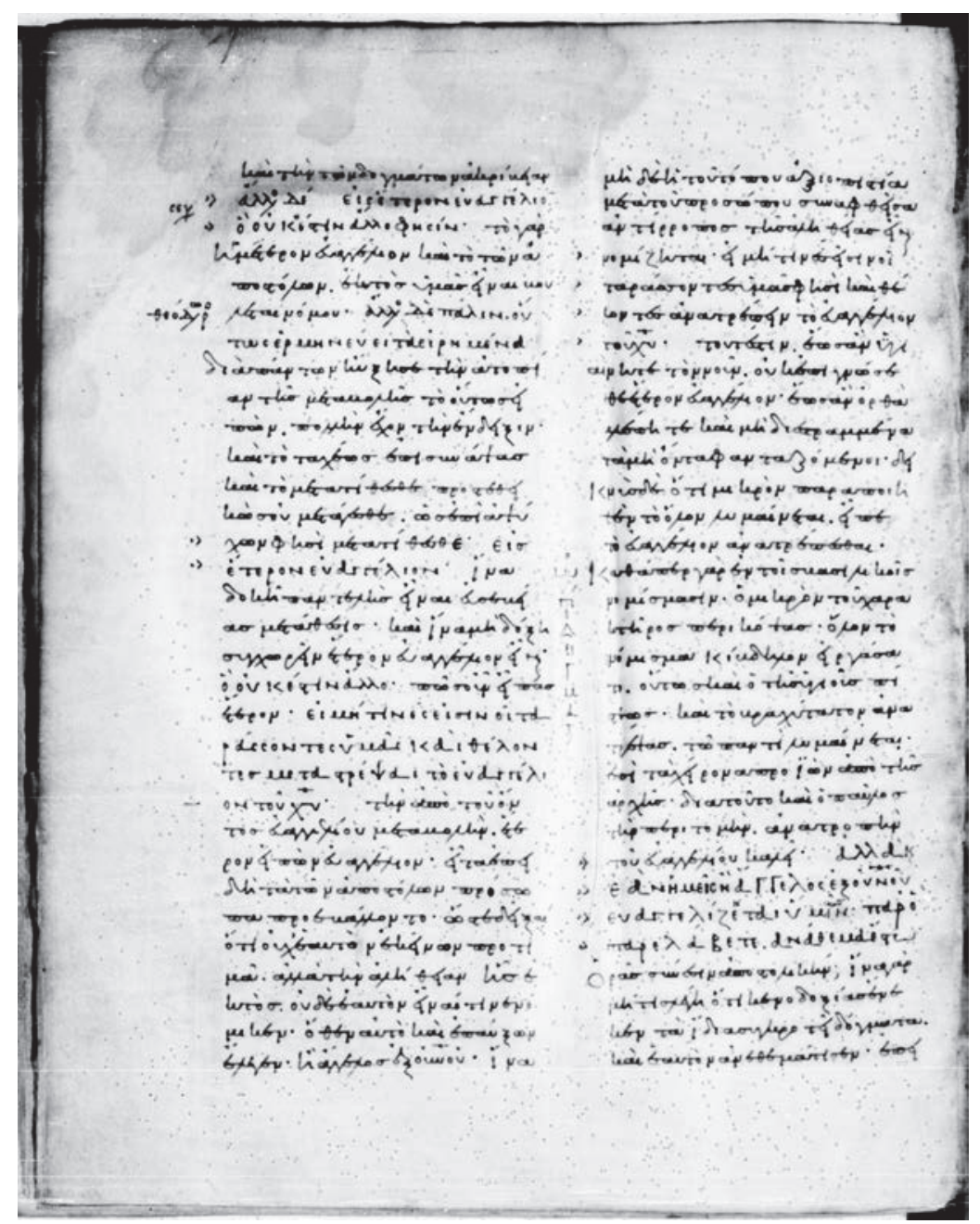

Image 4. Paris, BnF, Coislin grec 204, fol. 7v

The Typus Parisinus catena, copied in the eleventh or twelfth century. The biblical lemmata are written in a slightly larger script, including some majuscule letter forms, and sometimes indicated by double diplai. Another biblical quotation is indicated by single diplai. In the left margin, there are indications of the authors Severian of Gabbala and Theodore of Mopsuestia. 
author from Jerusalem covering the first chapter only. ${ }^{75}$ Like Staab, Reuss includes details of the folio in each manuscript on which an extract occurs and a critical apparatus of textual variation. The introductions to each of the later volumes offer further precisions to Reuss's initial classifications, including the introduction of a new type ( $\mathrm{E}$ in Matthew, $\mathrm{G}$ in John) based on an important eleventh-century witness, Athos, Lavra, B 113 (GA 1507). ${ }^{76}$ The Lucan catena tradition is divided into six types (A-F), of which Type $\mathrm{C}$ is Nicetas and Types D-F are only transmitted in single manuscripts; Type E is the oldest, as found in Codex Zacynthius. The lack of compilation of extracts for Mark is compensated by Lamb's recent study and translation of the Catena in Marcum. ${ }^{77}$

\section{Catenae and Commentaries as Witnesses to the Biblical TEXT}

Many catena manuscripts are classified as witnesses to the direct tradition of the Greek New Testament, numbered as majuscules or minuscules in the Liste based on the script used for the biblical text. Nevertheless, there are some differences between catenae and other members of these categories. Catenae tend to be much later than other majuscules because of the artificial preservation of this script to distinguish the source from the commentary. In alternating catenae, even if the whole book is quoted, the biblical text is not continuous but separated by the intervening sections of commentary. There are also alternating catena manuscripts in which the biblical text is not given in full, but abbreviated. Examples of this include manuscripts which omit numerous verses (e.g. GA 1942 of the Pauline letters), or just give the opening and closing text of each extract. In addition, biblical quotations may be more heavily abbreviated by copyists than the commentary text, if they were seen to function simply as a aidemémoire. In frame catenae, the biblical text does follow continuously from one page to the next. As mentioned above, however, verses may be

75 Joseph Reuss, Matthäus-Kommentare aus der griecbischen Kirche. TU 61. Berlin: Akademie, 1957; Joseph Reuss, Johannes-Kommentare aus der griechischen Kirche. TU 89. Berlin: Akademie, 1966; Joseph Reuss, Lukaskommentare aus der griechischen Kirche. TU 130. Berlin: Akademie, 1984.

${ }^{76}$ See J. Reuss, 'Die Evangelienkatenen im Cod. Athon. gr. Lawra B 113.' ZNW 42 (1949) 217-28.

${ }^{77}$ Lamb, The Catena in Marcum; concerns about the textual accuracy of this volume were presented by Joseph Verheyden at the Seventeenth International Patristics Conference (Oxford, 2015). 
repeated when the accompanying portions of commentary are particularly extensive. Sometimes, this introduces variation in the biblical text, comparable to the appearance of the same verse in more than one extract in a lectionary.

The biblical text in catena manuscripts may be diagnostic of their affiliation. For examples, there are readings which are unique to witnesses which present the catena of Nicetas on the Gospel according to John. ${ }^{78}$ Nevertheless, the unity of commentary and biblical text should not be assumed: it is possible that catenae were copied into manuscripts with a different form of biblical text. One interesting recent finding is that a number of the forms of text which are particularly influential in the textual history of the Catholic Epistles are found in catena manuscripts. ${ }^{79}$ The proximity of the continuous text to biblical quotations in the commentary might result in influence one way or the other, although few examples of this have been convincingly identified. In alternating catenae, there is the possibility that a quotation of the biblical text in one of the extracts could be misidentified as a part of the continuous text. ${ }^{80}$ Repetitions of biblical verses in the margins of frame commentaries, which may divide groups of comments, could derive from a separate textual tradition to that of the continuous text, and must therefore be studied separately (e.g. GA 1900). The text of any quotation of the verse under consideration transmitted within an extract is of interest, in terms of its relationship both to the biblical text associated with the catena and also the direct tradition of that author (where this exists).

The lemmata in biblical commentaries have to be carefully assessed. If they are extensive, it is possible to use them in the same manner as the biblical text in alternating catenae to reconstruct a more-or-less complete form of the book which is being expounded. However, this is not necessarily the text used by the commentator: as in the catenae, it could have been replaced or adjusted by later editors. Comparing the lemmata with repetitions of the biblical text in the body of the commentary offers a means of determining whether or not the lemmata have been substituted.

${ }^{78}$ Examples were presented by Michael Clark at the Society of Biblical Literature Annual Meeting in Atlanta, 2015.

79 This was demonstrated by Klaus Wachtel in a paper presented at the Ninth Birmingham Colloquium which, unfortunately, was not available for inclusion in the present volume.

${ }^{80}$ Compare the problems faced by Erasmus in his use of a commentary manuscript of Revelation, described at the beginning of this chapter. 
Quotations in the exegetical sections are normally not as clearly indicated as the lemma and are sometimes grammatically incorporated into the commentary, which means that they are less likely to have been altered by an editor seeking to update the continuous text to another form. Nonetheless, even these quotations may have been reworked or harmonised to a differing text in the lemma during copying and the commentator themselves may not always have been consistent. ${ }^{81}$

Not all commentaries have lemmata and in some cases (particularly commentaries initially delivered as homilies) biblical references may have been added at a later stage. The reconstruction of the source of their continuous biblical text must therefore proceed from the basis of the first quotation of each verse in the context of its exegesis, comparing this with the other citations and allowing for the possibility of authorial freedom or later adjustment. As noted above, quotations adduced by the commentator as illustrations are generally not as valuable as the sequential citations in the exegetical sections, because the majority of these are likely to be made from memory. Once all of the biblical references have been assembled from a commentary and, where possible, its manuscript tradition, comparison with direct biblical tradition can also offer an indication of the likelihood that the transmitted text is authorial. The lack of modern critical editions of early Greek commentaries, however, means that at present we have little idea of the variation in the biblical text in the manuscript tradition. ${ }^{82}$ If different forms of text are present in manuscripts of commentaries, this is of interest for the history of the work's transmission, the sensitivity of users to variations in the canonical text and the sort of texts which were introduced into the tradition.

\section{CONCLUSION}

Approaching Greek New Testament commentaries and catenae requires considerable background knowledge and familiarity with a number of sources. Although the present overview is necessarily superficial in many

${ }^{81}$ Compare Konstantinidou, 'Opting for a Text-Type'. An example of this in Latin tradition is given in H.A.G. Houghton, 'The Biblical Text of Jerome's Commentary on Galatians'. JTS ns 65.1 (2014) 1-24.

82 In R.L. Mullen et al., ed., The Gospel According to John in the Byzantine Tradition, Stuttgart: Deutsche Bibelgesellschaft, 2007, two sources were used for the quotations of Chrysostom's Homilies on John, a doctoral dissertation by S.D. Patton based on Montfaucon's edition and the manuscript Sinai, gr. 369-70. Numerous differences between these are reported in the critical apparatus. 
places, we hope that it will encourage and be of assistance to future research. The establishment of consistent terminology, in particular, is a necessary stage to ensure parity between studies. In addition, the failure of later studies to take full account of what has gone before has led to surprising gaps in the listing of manuscripts. This is shown by the absence of numerous catena manuscripts from the Liste. The need for a comprehensive catalogue and a scientific approach to identifying different types of catenae remains as pressing now as it was at the end of the nineteenth century, despite the significant contributions of Staab and Reuss. It is hoped that the following Checklist goes some way to making a start on this. The advent of substantial electronic corpora (such as the Thesaurus Linguae Graecae), the increased understanding of the textual history of the New Testament in the first millennium provided by the Editio Critica Maior, the ever-increasing number of digitised manuscripts available online and the use of databases and other software to hold together large amounts of information means that researchers are in a stronger position than ever before to address the challenges and puzzles posed by these fascinating manuscripts, their murky origins and their complicated textual traditions.

\section{A Preliminary Checklist of New Testament Catena MANUSCRIPTS}

This undoubtedly faulty and partial list has been compiled from a number of sources, each itself compiled with a different end in view. It began as a spreadsheet listing catena manuscripts of the Gospel of John, recording the different catena types to which different reseachers have assigned them. The foundation for this was the Liste, whose goal is to record all manuscripts with the potential to be included as Greek witnesses in a critical edition of the New Testament. ${ }^{83}$ To this were added entries for manuscripts not included in the Liste, from the publications of Reuss. ${ }^{84}$ Reuss' goal was to record catena manuscripts and to analyse catena types. Thus manuscripts not containing gospel text and so of no interest to the Liste may have been included by Reuss because they contain a catena. He at

${ }^{83}$ Unfortunately the data with regard to catenae in the online version of the Liste (see note 3 above) is not yet clean enough for one to be able to use it to search for them. This list was made by the traditional method of reading the printed volume.

84 See notes 74 and 75 above. 
least sometimes records the absence of biblical text in this earlier publication.

This Johannine list was subsequently expanded to include the other Gospels, using the same sources as before with the addition of the list of manuscripts of Nicetas of Heraclea compiled by Zamagni. ${ }^{85}$ The contents of individual manuscripts were checked using the online Pinakes catalogue. ${ }^{86}$

A separate list of all Pauline catena manuscripts was compiled as part of the COMPAUL Project, working from the Liste and the researches of Staab. ${ }^{87}$ To this a few other entries were added. Finally, a third list of manuscripts of Acts and the Catholic Epistles was made, again from the Liste and other work by Staab. ${ }^{88}$ The decision was taken to exclude the Apocalypse from this survey, as it constitutes a separate case (see above), although its presence is noted where manuscripts contain that book as well as at least one other. Finally, the three spreadsheets were amalgamated into one and the following data abstracted from it. ${ }^{89}$

It will be noted that a significant number of witnesses in this list lack a Gregory-Aland number. The causes for this are hard to ascertain. Both Gregory and von Soden recorded information about catena types, the latter even using it as part of his numbering system. Karo and Lietzmann, in their

85 C. Zamagni, 'New Perspectives on Eusebius' Questions and Answers on the Gospels - The Manuscripts', in Eusebius of Caesarea: Traditions and Innovations, ed. Aaron Johnson and Jeremy Scott. Cambridge MA and London: Center for Hellenic Studies, 2013, 239-61.

86 http://pinakes.irht.cnrs.fr. A few items in Zamagni's list appear slightly inaccurate (compare the comments of Schulz on page 310 below), although whether Pinakes or Zamagni is at fault remains to be determined. Item 1 (Athos, Vatopedi, 457) is described in Pinakes as containing a selection of writings, with no mention of Nicetas. Item 4 (Athos, Dionysiou, 377) is described in Pinakes as containing the works of Johannes Argyropoulus. Item 18 (Munich, BSB, Gr. 146) is described in Pinakes as Homiliae variae and Item 19 does not match the Pinakes entry either. Item 34 ('Venice, BNM Gr. 331') may be a doublet of Item 35 (Gr. Z. 494 (Coll. 331). Items 5 and 15 are the same manuscript according to the Liste (and item 15 is now with other Taphou manuscripts in the National Library in Athens and not in Istanbul).

87 Staab, Die Pauluskatenen.

88 Staab, 'Die griechischen Katenenkommentare'.

${ }^{89}$ Further work to be undertaken will include consideration of the manuscripts studied in Sickenberger, Titus von Bostra. 
pioneering study, record the Gregory number for every manuscript they cite, and the vast majority now have a Gregory-Aland number. ${ }^{90}$ Reuss and Staab, however, did not refer to Gregory numbers but only used library shelfmarks. Whether this led to a separation between New Testament manuscript studies and work on the catenae is no more than speculation. But it is the case that there is no reference to either of these writers in the additions to Gregory published by Kurt Aland in 1950 and $1953 .{ }^{91}$ Whether they were overlooked, or their significance was not recognised, or even they were examined and no manuscript deemed suitable for inclusion in the list, may be impossible to determine.

In the following list, the common English abbreviations for biblical books are used. Manuscripts with a Gregory-Aland number are cited first and are separated from each other by a space. This is followed after a fullstop by manuscripts without a Gregory-Aland number, which are cited by library and shelf number and are separated from each other by a semicolon. A listing of manuscripts by Gregory-Aland number is found in the Index of Manuscripts at the back of the present volume.

\section{Manuscripts containing books from more than one section of the New Testament}

Three catena manuscripts contain the entire New Testament:

$131^{92} 1424^{93} 1678$

One manuscript contains all but the Catholic Letters:

886

Two manuscripts contain books from the Gospels, Acts and Paul:

1371 (Mk Lk Jn Acts and Romans) 1980 (Mt Lk Jn Acts and Paul)

One manuscript contains the Gospels, Acts and Catholic Letters:

Vatican, BAV, Vat. gr. 1767

One manuscript contains the five Johannine writings:

743

${ }^{90}$ Karo and Lietzmann, 'Catenarum graecarum catalogus'.

${ }^{91}$ For information on additions to Gregory, see J.K. Elliott, A Bibliography of Greek. New Testament Manuscripts. Third Edition. Supplements to Novum Testamentum 160. Leiden: Brill, 2015.

92 Recorded in Liste as not containing Revelation.

93 There is no commentary on Revelation. 
Four manuscripts contain parts of the Gospels and Catholic Letters:

197 (Mt Mk Jas) 832 (Mt Lk Jn Cath). Vienna, ÖNB, Theol. Gr. 301

(Mt Lk Jn Jas 1-2Pt); Theol. Gr. 324 (all eleven writings)

Eight manuscripts contain parts of the Gospels and Paul:

858891 (both complete) 1267 (Jn Rom-Col) 1330 (Gospels

Rom/1Cor) 1506 (Gospels Rom-1Cor 4.15) 2482 (Gospels Heb).

Paris, BnF, Suppl. Gr. 71 (Gospels Hebrews); Paris, BnF, Gr. 702 (Mt

Lk Jn Paul)

Fourteen manuscripts contain parts of all of the New Testament apart from the Gospels:

$\begin{array}{lllllllllllll}82 & 91 & 250 & 254 & 314 & 42494 & 468 & 617 & 627 & 911 & 1862 & 1888 & 2431\end{array}$ 2776

Twenty-nine manuscripts contain some or all of Acts, the Catholic Letters and Paul:

01805601429495101103327454455463605606607608619621

$\begin{array}{llllllllllll}623 & 641 & 1162 & 1277 & 1360 & 1523 & 1524 & 1845 & 1871 & 2239 & 2242 & 2733 .\end{array}$

Patmos, Ioannou, 263

One manuscript contains Acts, the Catholic Letters and Revelation:

1859

Seven manuscripts contain Acts and the Catholic Letters:

3074536101066184218952818

Five manuscripts contain Acts and some or all of Paul:

441 2576. Florence, BML, Plutei VIII.19; Milan, Bibl. Ambros., F. 104 sup; Vatican, BAV, Vat. gr. 875

One manuscript contains the Catholic Letters, Paul (only Romans) and Revelation:

1769

Seven manuscripts contain Paul and the Catholic Letters:

4426229181840212521972318

One manuscript contains the Catholic Letters and Revelation:

2186

There are eighty-five manuscripts in this first category.

94 There is no commentary on Revelation.

95 In the printed Liste the contents are given as Acts, Paul and Revelation. But the Revelation commentary is older, and is now treated as a separate manuscript with the number GA 2917. 


\section{Manuscripts containing one or more books from a single section of the New Testament}

The bulk of the catena manuscripts comprises those containing only individual units of the New Testament.

\subsection{Manuscripts of the Gospels}

The Gospels form the greatest number, with 193 containing all four:

0330551219202425343637394048506377100108127129

137138143148151154168186194195196210215222233237

238240244253259299301303305329332353370373374377

379391392428549556569591599600649684719723727728

729730731732733740741744746747749754771772773800

807809814817818820833834835854855856861863878881

885888889890949951964978989102110291078108011301137

1160116411781182123012521253126112621263126512661268

1293130213031304131213131327133613731387139214191422

1423150715331534153515361570161616771684181420972100

2101210721092148218822032206221122142317234623812395

2414245224532458247025172539257826042637264627202735

2812 2887. Budapest, UB, VIIIc; Paris, BnF, Coislin Gr. 71; Gr. 233;

Gr. 703; Rome, Bibl. Angelica, Gr. 703; Vatican, BAV, Vat. Gr. 665;

Vat. Gr. 757; Vat. Gr. 1692; Vat. Gr. 1741; Venice, BNM, Gr. I.34; Vienna, ÖNB, Theol. Gr. $117 .{ }^{96}$

There are 195 manuscripts containing a catena on one or more Gospels, with the following permutations:

Matthew, Mark and Luke (six manuscripts):

30072215272285 2607. Milan, Bibl. Ambros. 538

Matthew, Mark and John (two manuscripts):

8362583

Matthew, Luke and John (thirteen manuscripts):

7342202 2768. Oxford, Bodley, Auct. T. 1.4 (Misc. 182); Paris, BnF

Gr. 193; Gr. 231; Gr. 701; Gr. 704; Suppl. Gr. 1300; Vatican, BAV,

96 Reuss lists Vatican, BAV, Pal. Gr. 363 as containing Theophylact, but Pinakes gives different contents, so I have not included this MS. 
Archivio di S. Pietro B 59; Barb. Gr. 562; Vat. Gr. 1753; Venice, BNM, Gr. 687

Matthew and Mark (thirteen manuscripts):

411361463043345905968479701374220725792755

Matthew and Luke (seven manuscripts):

2437351027 2838. Milan, Bibl. Ambros., D.25.inf (920); Paris, BnF,

Suppl. Gr. 28; Vatican, BAV, Vat. Gr. 1610 foll 360-388

Matthew and John (eighteen manuscripts):

3063334237367708199941043141215161613 2490. Oxford, Bodley, Auct. E.2.2 (Misc. 30); Paris, BnF, Gr. 199; Gr. 200; Gr. 700; Vatican, BAV, Barb. Gr. 444; Vienna, ÖNB, Theol. Gr. 251

Mark, Luke and John (two manuscripts):

239841

Mark and Luke (seven manuscripts):

42772111121337 1537. Vatican, BAV, Ottob. Gr. 113; Vat. Gr. 384

Mark and John (one manuscript):

2106

Luke and John (sixteen manuscripts):

951393163575898578841256136614112184 2185. Berlin, Staatsbibl., Phillipps 1419; Florence, BML, Gr. VIII.24; Vatican, BAV, Ottob. Gr. 237; Vat. Gr. 547

Matthew only (twenty-nine manuscripts):

31031135436673773875182284289310281156125413321631

21902450257725812597 2770. Florence, BML, Gr. VIII.29; Oxford, Bodley, Barocc. 156; Paris, BnF, Suppl. Gr. 272; Vatican, BAV, Vat. Gr. 724; Vat. Gr. 1190 foll. 799-819; Vat. Gr. 1437; Vat. Gr. 1915; Vienna, ÖNB, Theol. Gr. 209

Mark only (nine manuscripts):

89424812538 2738. Munich, BSB, Gr. 99; Paris, BnF Gr. 206; Gr. 939; Suppl. Gr. 40; Suppl. Gr. 94

Luke only (thirty-four manuscripts):

040313320362381426434598739840846848853859868879 101611771255126414371821182221112187 2593. Brussels, BRA, I I.8232-33; London, Lambeth Palace, 763, fol. 63-79v; Milan, Bibl. Ambros., O.245 sup (608); Munich, BSB, Gr. 33; Oxford, Bodley, Barocc. 211; Schleussingen, Hennerg. Gymn., 3; St Petersburg, NLR, Duh. Akad. 370, fol. 41-2; Vatican, BAV, Pal. Gr. 273

John only (thirty-eight manuscripts):

050014187249315317318397430742821849850862865869 874882883887993118412711370170718191820210321292192 
248025732575 2763. Milan, Bibl. Ambros., A 282 inf (951); C 255 inf (895); Patmos, Ioannou, 757; Vatican, BAV, Vat. Gr. 1804

The total number of manuscripts containing only Gospels is 388 .

\subsection{Manuscripts of the Apostolos}

Catena manuscripts containing only Acts are rare. The Liste only contains: 4371764.

There are six of the Catholic Letters only:

640 (Jas 1.1-23) 1844 (1 J-Jd) 2130 (Jas-3 Jn) 2741 (1 Pet 4.17-5.7).

Oxford, Bodley, Rawl. G.157 (Misc. 169); Rome, Bibl. Vallicelliana, 78 (F 9)

Finally, the letters of Paul. The eighty-five (more or less) complete manuscripts are:

075015001511798190019051906190719081911191419161917

1919192019211922192319241927192919301932193319341939

1941194319451947195019511952196119621963196919701971

1972197319771978198119821984198519861987199119921995

1996199719981999200020072008201120122102210521102183

21892205224826592690273928172889 2899. Kiev, National

Library, Ф.1,137, Ff 1-2; L’viv, Bibl., ZN 827; Oxford, Bodley, Auct. T

1.7 (Misc. 185); Paris, BnF, Coislin Gr. 208.1; Gr. 228; Gr. 2875;

Vatican, BAV, Vat. gr. 763; Vatican Vat. gr. 764; Vat. gr. 873; Vat. gr.

9, fol. 301-04; Venice, BNM, gr. Z. 155 (coll. 610)

The following twenty-nine manuscripts contain more than one letter:

1772181718781879191019131915192519351942194619531964

1968197419761988199319942001200220132092210421282257

2572 2668. Florence, Bib. Naz., Panciat. 157

For single letters, Romans is most common, with the following nine catenae covering the whole letter:

1909192819792006203822402698 2888; Vatican, BAV, Barb. gr. 546

Five more manuscripts are incomplete:

19361949 1967. Oxford, Bodley, Auct. E.II.20 (Misc. 48); Grabe 22 (1 fol.) 
1926 contains 1 and 2 Corinthians; 19371 Corinthians only and Athos, Vatopedi, 12 has 2 Corinthians. Short sections of 1 Corinthians are found in 2764 and in Munich, BSB, Gr. 571, f. 80 and of 2 Corinthians in 098. Galatians is in 2574 and 2596, 2 Timothy in 2820 and Hebrews in 1818, 1983 and Athos, Vatopedi, 38, with the incomplete copies 1938 and 2890. Finally, 19652090 and 2639 contain excerpts from a few letters.

\section{Summary}

388 manuscripts contain only Gospels. Two contain only Acts. Six contain only the Catholic Letters. 145 contain only Paul. The total number in the second category is 541. The total number of entries in this checklist is 626 . Of these, 100 lack a Gregory-Aland number. It is highly unlikely that all should be assigned one, but at this stage a maximalist approach is required. Further research should deal with four principal tasks:

(1) to ensure that all catena manuscripts in libraries which have been catalogued have been identified;

(2) to study the biblical content of each manuscript, its textual character and significance where it is present, and offer a clarification of the criteria for including such manuscripts in the Liste;

(3) to study the catena types, testing the schemata devised by earlier writers and establishing the type to which uncategorised manuscripts belong, as well as recording the excerpts and their sources;

(4) to explore the origin, context and use of the manuscripts.

As catenae, this class of manuscripts has supplied a wealth of patristic evidence from otherwise lost works and, as biblical manuscripts, some of them have proved significant in the study of the history of the text and the construction of an initial text. A thorough examination may provide further advances in these areas of study. 



\title{
2. THE CONTEXT OF COMMENTARY: NON-BIBLICAL COMMENTARY IN THE EARLY CHRISTIAN PERIOD
}

\author{
R.F. MACLACHLAN ${ }^{1}$
}

Commentaries from the ancient world have not traditionally attracted much attention from classicists and, where there has been interest, it has more often been in the text commented upon. The discipline's tendency to focus on 'original' works from choice periods has not favoured these secondary works which almost inevitably are not from those periods and have tended to be 'mined' for occasional nuggets of detail about the ancient world and snippets of other, earlier and otherwise lost works.

More recent years have, however, seen an increased interest in works which respond to and refashion 'classical' material, such as compilatory works like Pliny's Natural History and Athenaeus' Deipnosophistae, and also in antiquarian and technical writings such as Vitruvius on architecture and Varro on farming. These have been particularly explored as literature reflecting the Graeco-Roman imperial world of the Roman Empire and their ambitions of competitive comprehensiveness and responsive refashioning have been better appreciated as creative and critical processes. This trend has seen more work on commentaries as works in their own right. Volumes such as Most's Commentaries-Kommentare and Gibson and Kraus' The Classical Commentary explore what a commentary is from the perspective of how and why commentaries were produced and used and how they work within their reading culture. ${ }^{2}$ They cover not just

${ }^{1}$ The research leading to these results has received funding from the European Union Seventh Framework Programme (FP7/2007-2013) under grant agreement no. 283302 (COMPAUL).

${ }^{2}$ Glenn W. Most, Commentaries-Kommentare. Göttingen: Vandenhoeck \& 
commentaries from the Graeco-Roman world but also commentaries on classical works from other periods and cultures and, indeed, modern commentary practice on ancient works including digital expressions.

Both these recent volumes begin with editorial reflections on the nature of commentaries. In his introduction, Glenn Most picks out certain typical commonalities that tend to be shared by works considered commentaries, namely: that the content of the commentary relates closely, explicitly and directly to extensive sections, at least, of another earlier text; that the commentary is thereby structured according to the text it comments upon; that the commentary is by default secondary to the text it comments upon, which is usually an authority-text, and is, at least to an extent, driven by that work's agenda and interests; that the commentary generally aims to explain and clarify the work it comments upon often with a pedagogic intention. ${ }^{3}$ Christina Kraus's introductory article focusses on the relationship between author and reader created by commentaries. ${ }^{4}$ Beyond the basic sense of what a commentary is and what it sets out to do-comment on an existing text-it becomes very difficult to specify what is and is not a commentary, especially when formal features need not be present and the principles involved can extend beyond them. While 'commentary' can be viewed as a form which is genre-like in its own right, especially when one looks at groups of related commentaries which have been consciously produced in a tradition, when it interacts with the works being commented upon and their differing genres and contexts similar techniques and even aims can result in varied results.

There was certainly no lack of commentaries in the ancient world. Eleanor Dickey's book, Ancient Greek Scholarship: A Guide to Finding, Reading, and Understanding Scholia, Commentaries, Lexica, and Grammatical Treatises, from Their Beginnings to The Byzantine Period makes finding and accessing the remnants of this secondary material much easier today. ${ }^{5}$ It also demonstrates the range of works upon which commentaries were available-literary texts, philosophical texts, medical texts, grammatical texts, technical texts, etc. - and also that the surviving material is but a

Ruprecht, 1999; Roy K. Gibson \& Christina Shuttleworth Kraus, The Classical Commentary: Histories, Practices, Theory. Leiden: Brill, 2002.

${ }^{3}$ Glenn W. Most, 'Preface' in Commentaries-Kommentare, ed. Most, v-xv.

${ }^{4}$ Christina Shuttleworth Kraus, 'Introduction: Reading Commentaries/ Commentaries as Reading' in The Classical Commentary, ed. Gibson \& Kraus, 1-27.

${ }^{5}$ Eleanor Dickey, Ancient Greek Scholarship. A Guide to Finding, Reading and Understanding Scholia, Commentaries, Lexica, and Grammatical Treatises, from Their Beginnings to the Byzantine Period. Oxford: OUP, 2007. 
fraction of what originally existed. A barrier to the exploration of commentaries as works in their own right is that much of the commentary material from the ancient world, especially the material on literary texts, does not survive in its original form but has been winnowed down and refashioned into the scholia tradition found in later manuscripts. While fascinating in their turn, the scholia usually provide an adapted and often indirect representation of material which once came from commentaries. ${ }^{6}$ Though sometimes the scholia contain extensive material taken from particular commentary works by named authors, such as the commentaries on Horace one finds reassembled in nineteenth-century editions from the scholia, the format of the material has certainly changed. ${ }^{7}$

\section{Commentaries Among THe Greek Literary PAPYRI}

Texts preserved on papyrus offer an opportunity to look at commentaries from the ancient world in the physical form in which readers from the period would have encountered them. Looking at the artefacts also raises questions about how they were actually used. Material from commentaries and similar secondary works features regularly among finds of literary papyri. ${ }^{8}$ Trying to identify a fragment as from a commentary, rather than something else, proves to be revealing in terms of how one goes about it and about the range of materials that can be found. Studies of these papyrus fragments highlight issues involved in identifying a commentary and also expose some problems in doing so. ${ }^{9}$ Most papyrus fragments do not

6 The Homer Multitext Project, http://www.homermultitext.org, offers an excellent place to start exploring this material. See also Fausto Montana, 'The Making of Greek Scholiastic Corpora', in From Scholars to Scholia. Chapters in the History of Ancient Greek Scholarship, ed. Franco Montanari and Lara Pagani. Berlin, New York: de Gruyter, 2011, 105-62.

${ }^{7}$ These include F. Hauthal, ed., Acronis et Porphyrionis commentarii in Q. Horatium Flaccum. 2 vols. Berlin: Springer, 1864; W. Meyer, ed., Pomponii Porphyrionis commentarii in Q. Horatium Flaccum. Leipzig: Teubner, 1874, both of which are available on www.archive.org.

${ }^{8}$ Cf. the tables in George W. Houston, 'Papyrological Evidence for Book Collections and Libraries in the Roman Empire', in Ancient Literacies. The Culture of Reading in Greece and Rome, ed. Wiliam A. Johnson and Holt N. Parker. Oxford: OUP, 2009, 233-67.

${ }^{9}$ Cf. Tiziano Dorandi, 'Le Commentaire Dans La Tradition Papyrologique: Quelques Cas Controversés', in Le Commentaire Entre Tradition Et Innovation, ed. Marie-Odile Goulet-Cazé. Paris: Libraire Philosophique J. Vrin, 2000, pp. 15-28. 
identify themselves as being from a commentary, leaving it to today's scholars to make that identification. This necessitates some definition of a 'commentary' to allow material to be differentiated and excluded.

One approach is to look for formal characteristics which might indicate a commentary: namely, lemmata, with some form of 'text articulation' dividing the lemma text from the text of the commentary, such as spacing, lines in ekthesis, paragraphoi or similar marks at the beginning and end of text-sections, and the use of diplai or similar marks in the margin to indicate the locations of lemmata. ${ }^{10}$ Another is to look for the use of exegetical terminology, references to other scholars and approaches such as glosses in the commented text. The problem is that neither of these sorts of indication may be deployed, never mind consistently, in a commentary or belong solely to commentaries. As an extreme example perhaps, the discussion of the Twelve Tables in Book 3 of Cicero's dialogue De Legibus, in which the speaker proceeds legal clause by legal clause through the text, has been spotted as reading very like a lemmatised commentary, highlighting the potential deployment of commentary forms and techniques in works which are not commentaries. ${ }^{11}$

\section{Commentaries on Homer}

The works of Homer, particularly the Iliad, formed the foundation of ancient literary education, so it is not surprising to find commentary material on them well represented among the papyri. John Lundon's survey of Homeric commentaries on papyrus finds a temporal range of fragments extending from the third century BCE to the fourth century $\mathrm{CE}$ with a peak in the second century $\mathrm{CE}$, reflecting the general patterns of papyrus survival. ${ }^{12}$ They are found across a range of locations, though Oxyrhynchus seems to be an especially rich source perhaps due to links with the relatively nearby Alexandria and its scholarly community. The Iliad's predominance over the Odyssey reflects the general trend in the papyri too. ${ }^{13}$

${ }^{10}$ For more on these markings, see pages 5-6 above.

${ }^{11}$ Cf. R. G. Lewis, Asconius. Commentaries on Speeches of Cicero. Oxford: Clarendon Press, 2006.

12 John Lundon, 'Homeric Commentaries on Papyrus: A Survey', in Ancient Scholarship and Grammar, ed. Matthaios Stephanos, Franco Montanari, and Antonios Rengakos. Berlin: de Gruyter, 2011, 159-80.

${ }^{13}$ Lundon, 'Homeric Commentaries on Papyrus', 160-1. 
Lundon begins by dealing with material which past editors have identified as from a commentary but which should probably be discounted, often because of poor preservation-one marginal diple or a single lemma does not a commentary make-or because the pattern of lemmata in them might better fit a treatise discussing the passage rather than a lemmatised commentary. ${ }^{14}$ This difficulty of distinguishing a commentary from a treatise discussing a work becomes acute especially when commentaries can have selective, discontinuous lemmata rather than including the whole text. A fragment (P.Mich. inv. $3688=$ Erbse Pap. XIV) containing discussion and lemma from both the Iliad and Callimachus has been variously identified as from a commentary on each work quoting from the other, but could be from an treatise. ${ }^{15}$ The different levels of presentation, from formal bookhand texts to scrubby notes, also creates problems; at the lower levels, especially, it may not be clear what the item is aiming to be. There is also the issue of distinguishing commentaries proper from a range of secondary materials on the Homeric texts, such as glossaries, lexica, paraphrases, summaries, mythographic commentaries, which explain the stories alluded to in the epics in the order in which they are encountered in the work, and treatises on the work. This may, of course, be a problem with our modern definitions.

The earliest commentary proper which Lundon discusses, P.Lille inv. $83+134+93 b+93 a+114 t+114 o+87$, dating from the third century BCE, is nicely lemmatised but the comment mainly consists of paraphrase and glosses, which are also well represented in the material without lemmata. Other commentaries are more sophisticated and apply a range of exegetical techniques to their Homeric material, but even these can vary in their form. P.Wash.Univ. II 63 = Erbse Pap. VIIa (second century BCE) and P.Oxy.VIII 1086 = Pap. II Erbse (first century BCE) both have verse-byverse lemmata; the latter prefaces some lemmata with Aristarchan editorial symbols. ${ }^{16}$ On the other hand, P.Oxy. II 221 = Erbse Pap. XII (second century $\mathrm{CE}$ ), one of the most extensive and learned examples, has lemma varying from single words to groups of verses, thus perhaps presenting a difference in approach between the lemma guiding the reader to their place in the text and the lemma providing the text discussed in each section of commentary.

\footnotetext{
14 Lundon, 'Homeric Commentaries on Papyrus', 161-6.

15 Lundon, 'Homeric Commentaries on Papyrus', 166.

${ }^{16}$ Lundon, 'Homeric Commentaries on Papyrus', 173.
} 


\section{Commentaries on Demosthenes}

Papyrus P.Berol. 9780, dating from the second century CE, contains a substantial fifteen-column fragment of a commentary on Demosthenes' Pbilippics. ${ }^{17}$ The papyrus uses indentation and punctuation marks/diplai in the text to mark lemmata and is equipped with column headings that seem to relate to the content of the commentary rather than the work of Demosthenes; it is unclear whether these are in the same hand or later additions. ${ }^{18}$ This piece has generated much discussion because at its end it is

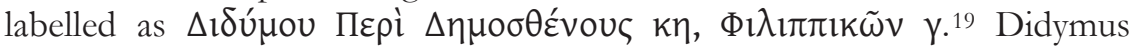
Chalcentrus was active in the first century BCE in both Alexandria and Rome, where he knew Varro, the Roman antiquarian. He became notorious for the volume of works he had 'digested', as is attested by his 'bronze guts' nickname and some rather snooty comments by Seneca and the Suda which claims he wrote over 3,500 books. Though that claim is probably hyperbolic, he was certainly prolific and is known to have worked on a large expanse of Greek prose and verse literature, including producing commentaries on lyric poetry, especially Pindar, on drama, especially Sophocles and Aristophanes, and the Attic orators, including Demosthenes. He is frequently mentioned in the scholia tradition and has been identified by modern scholarship as a potentially key conduit of Alexandrian scholarship into Roman elite circles and onwards into the scholia tradition for which he provides a likely source of 'quality' material. ${ }^{20}$

P.Berol. 9780 has, however, generated much discussion because it has been something of a disappointment: although the commentary is fairly sophisticated, it is does not quite reach the hoped-for Alexandrian scholarly heights. There is also the complication that, though its title clearly identifies Didymus, it does not actually say that it is a commentary. A title Пвpi $\Delta \eta \mu o \sigma \theta \dot{v}$ vous could accommodate a range of things from an original treatise to a secondary work such as a commentary. This has led to a two-

17 Cf. Phillip Harding, Didymos on Demosthenes. Introduction, Text, Translation, and Commentary. Oxford: Clarendon Press, 2006, 8-9; he favours 'the higher date of late-second or even third century after Christ'. Craig A. Gibson, Interpreting a Classic. Demosthenes and His Ancient Commentators. Berkeley, Los Angeles, London: University of California Press, 2002, 77, gives early second century.

18 Cf. Harding, Didymos on Demosthenes, 5.

19 Cf. the discussions in Harding, Didymos on Demosthenes, 4-20; Gibson, Interpreting a Classic, 77-136; Dorandi, 'Le Commentaire Dans La Tradition Papyrologique', 21-4. There are plates of the papyrus in Harding's edition.

${ }^{20}$ Cf. Gibson, Interpreting a Classic, 51-71; Harding, Didymos on Demosthenes, 1-4. 
fold discussion about the nature of the work of Didymus and how this papyrus might relate to it. Examination of the papyrus furthermore shows that it is not a professional scribal copy but an informal copy riddled with errors and inconsistencies. It has therefore been suggested that the papyrus may not be a simple copy of Didymus' work but some sort of adaption or abbreviation by a later user. The latest editor, Phillip Harding, concludes that it is 'a copy (most likely not a direct one) of an original work by Didymus that was entitled On Demosthenes. It was probably made by a student (under supervision)'. ${ }^{21}$

Whether or not the papyrus is true Didymus, the debate over P.Berol. 9780 draws attention to difficulties in identifying and interpreting commentary material on papyrus from the ancient world, and especially to the issue of how were they identified in the ancient world itself. The question of what an ancient commentary is in ancient terms is vexed. There were certainly no 'rules' about how to refer to a work. The term bypomnema (vंró $\mu \nu \eta \mu \alpha)$ can be used for the sort of lemmatised commentary we are concerned with, as opposed to an independent treatise which is a suggramma $(\sigma u ́ \gamma \gamma \rho \alpha \mu \mu \alpha){ }^{22}$ Yet this terminology is variably and imprecisely used: bypomnema can apply to a range of items from informal private notes to finished works not dissimilar to what might be expected to be suggrammata. The term bypomnema can also be equated with the Latin commentaria, though again not all works described as commentaria are what we would call commentaries. ${ }^{23}$ Julius Caesar's Commentaria is the classic example of this. It is debatable whether modern terminology is more transparent.

Another papyrus fragment of the late first century CE from a commentary on Demosthenes, P.Stras.inv. 84 ( Pack $\left.^{2} 310\right)$, also focusses on explaining the historical background to the speeches. The surviving portion proceeds through its passage of Demosthenes in order but, instead of textual lemmata, it gives references introduced by ö $\tau$ paraphrasing the

21 Harding, Didymos on Demosthenes, 41; Gibson, Interpreting a Classic, seems to treat it as more simply by Didymus; Dorandi, 'Le Commentaire Dans La Tradition Papyrologique', 24, concludes that it is impossible to tell.

22 Cf. Dorandi, 'Le Commentaire Dans La Tradition Papyrologique', passim; Herwig Maehler, 'L'évolution matérielle de l'bypomnèma jusqu'à la Basse Époque', in Le Commentaire Entre Tradition Et Innovation, 29-36; Dickey, Ancient Greek Scholarship, $129-30$, is also useful on book titles.

23 This is demonstrated by Jens Erik Skydsgaard, Varro the Scholar. Studies in the First Book of Varro's De Re Rustica. Copenhagen: Einar Munksgaard, 1968, 107-11. 
sentences under discussion from Demosthenes' speech. ${ }^{24}$ It has been suggested that this piece too does not represent a commentary in its original form but a later reader's adaptation. ${ }^{25}$ This new work could still have functioned for its maker as a historical commentary, focussed on the content of the work rather than its wording, when used alongside a separate text of Demosthenes. These items on papyrus exemplify the malleability of commentary material and its tendency to be continually recast and 'mashed up' by active and interventionist readers. What this means is that anyone encountering 'a commentary' in the ancient world may indeed have met with a range of material in a variety of forms, but with an expectation that they would remake that material into whatever form they wanted.

\section{LITERARY COMMENTARIES IN LATIN TRADITION}

Homer and Demosthenes provided, as it were, the prose and verse 'core texts' of the Greek educational system. On the Latin side, Jerome notably comments on the use of commentaries on a range of literature as a standard part of elite rhetorical education. These included commentaries produced by his own teacher, Donatus, on Virgil and Terence. ${ }^{26}$ This provides a comfortable model for us of how commentaries are generated and used within a seemingly quite familiar pedagogic context; comfortable because it allows us, in studying those same texts with the same material, to be being educated by the commentary in what must be the same way. This may not however be the whole story. Pedagogic intention, while at the heart of what commentaries are for, need not restrict them to passively conveying information. ${ }^{27}$

\section{Cicero and Virgil}

Like the commentaries on Demosthenes, Q. Asconius Pedianus' commentary on Cicero's speeches is another commentary focussed on

24 Gibson, Interpreting a Classic, 175-7; Harding, Didymos on Demosthenes, 33.

25 Cf. Dorandi, 'Le Commentaire Dans La Tradition Papyrologique', 24.

26 Jerome, Contra Rufinus 1.16: Puto quod puer legeris Aspri in Vergillium ac Sallustium commentarios, Vulcatii in orationes Ciceronis, Victorini in dialogos eius, et in Terentii comoedias praeceptoris mei Donati, aeque in Vergilium, et aliorum in alios, Plautus nidelicet, Lucretium, Flaccum, Persium atque Lucanum.

27 Ineke Sluiter, 'Commentaries and the Didactic Tradition', in Commentaries Kommentare, 173-206, explores how the pedagogical motivation of commentaries saturates their presentation. 
explaining the historical context and procedural background, this time of Latin speeches. The commentary, written around the middle of the first century CE on internal evidence, is explicitly written for the education of Asconius' sons. It too, however, survives incompletely, in the form of Renaissance transcriptions of a manuscript that is now lost. It has noncontinuous lemmata that pick out the historical details Asconius is interested in commenting upon rather than giving the continuous text of the speech, and, as well as these lemmata, is equipped with headings which seem to be intended to help the reader find the next lemma and section for comment within the text. ${ }^{28}$ These headings, for example circa vers. a primo [...] or circa vers. LXXX, to give the first two such references in the text as we have it, appear to indicate the location of the lemmata in relation to the beginning or end of the actual roll of the text, making this commentary very much designed to be read physically alongside a copy, indeed perhaps a particular copy, of the text it expounds. ${ }^{29}$

Though Asconius' first-century commentary on Cicero's speeches is written in a period not that long after Cicero's lifetime during which Cicero's literary reputation was subject to debate, Asconius' own attitude towards Cicero is quite reverential and defensive. ${ }^{30}$ Among Asconius' nowlost works was also a reply to critics of Virgil. ${ }^{31}$ The earliest surviving commentary on Virgil's poetry by Servius comes from the late fourth century, by which point Virgil's works had become classics and cornerstones of literary education. ${ }^{32}$ James Zetzel's study of textual variants in the Latin scholia tradition explores traces that early commentators on Virgil's Aeneid, writing in the generations immediately after Virgil, had not

28 These are included in Lewis, Asconius. Commentaries on Speeches of Cicero, but not in the edition of Simon Squires, Asconius' Commentaries on Five Speeches of Cicero. Bristol: Bristol Classical Press, 1990, aimed at a school audience. On Asconius's commentary, cf. Caroline Bishop, 'Roman Plato or Roman Demosthenes? The Bifurcation of Cicero in Ancient Scholarship', in Brill's Companion to the Reception of Cicero, ed. William H. F. Altman. Leiden: Brill, 2015, as well as the introduction to Lewis's edition.

${ }^{29}$ Lewis, Asconius. Commentaries on Speeches of Cicero, xvi.

30 Bishop, 'Roman Plato or Roman Demosthenes?', 293-4.

31 Lewis, Asconius. Commentaries on Speeches of Cicero, xii.

32 Cf. Charles Murgia, 'The Truth About Vergil's Commentators', in Romane Memento. Vergil in the Fourth Century, ed. Roger Rees. London: Duckworth, 2004, 189-200, on the nature of these later commentaries on Virgil and signs that they could sometimes take a more critical approach. 
always adopted such a reverential attitude towards the work. ${ }^{33}$ Virgil's infamous, and of course unexecuted, instructions, that the Aeneid be burnt at his death because it was not fully finished, helped open the field for suggestions how the work might have been corrected and 'improved', ranging from minor variant readings to radical restructuring. Zetzel notes that the variant readings from these suggestions seem not to have influenced the text as transmitted. ${ }^{34}$ Nevertheless, it opens the possibility for commentaries to be a venue for more than passive explanation of a text.

\section{Legal Commentaries}

One area where commentaries played a significant role is the law. ${ }^{35}$ The Justinian Digest of 533 consists of extracts from juristic writings of earlier centuries; many of these are from commentaries, both on law codes, especially the provisions of the archaic Republican Twelve Tables which were seen as the foundation of Roman law, and on legal treatises. The introductory constitutions promulgating the Justinian law codes (Const. Deo auctore \$12, reiterated Const. Tanta \$21) however contain an injunction against writing commentaries on these law codes:

nullis iuris peritis in posterum audentibus commentarios illi adplicare et uerbositate sua supra dicti codicis compendium confundere: quemadmodum et in antiquioribus temporibus factum est, cum per contrarias interpretantium sententias totum ius paene conturbatum est. (Const. Tanta \12).

What this injunction intended to achieve is difficult to interpret; the law schools and the production of commentary on the law code certainly continued. ${ }^{36}$ It has been suggested, however, that it was not so much a

33 James E. G. Zetzel, Latin Textual Criticism in Antiquity, reprint by The Ayer Company, Salem, 1984 (original ed. New York: Arno Press, 1981), chap. 3.

34 Zetzel, Latin Textual Criticism, 53.

35 The Biographies of Jurists of the Empire (27BC-284AD), one of the online materials accompanying Paul Du Plessis, Borkowski's Textbook on Roman Law, $5^{\text {th }}$ edn, Oxford: OUP, 2015, lists the major jurists of this period and their known works, including commentaries. It is available online at:

http://global.oup.com/uk/orc/law/roman/borkowski5e/resources/biographi es/jurists/.

36 See further Hans Julius Wolff, Roman Law. An Historical Introduction. Norman: University of Oklahoma Press, 1951, 180-2; Tammo Wallinga, 'The Reception of Justinian's Prohibition of Commentaries', Revue internationale des droits de l'antiquité, 59 (2012) 375-86; Willem Zwalve, 'Text and Commentary: The Legal Middle Ages 
complete ban on writing any commentaries on the new law codes, but was rather designed to deter commentary being used in place of the law code and perhaps to discourage the addition of further commentary into the text of the law code. This fits with other measures set out in these constitutions to establish the Justinian lawcode as the sole source of the law and to maintain the integrity of its text. The 'ban on commentary' can be seen as trying to set up the new law code as the authoritative text to be commented upon rather than as material to be reused in the composition of future commentaries. Whatever the interpretation of the Justinian injunction, it attests to a vigorous tradition of legal commentary which was potentially significant for the evolution of the commentary and scholia forms. ${ }^{37}$

\section{Commentaries on Aristotle}

Philosophy, and particularly commentaries on Aristotle by the Aristotelian School and later on Plato and Aristotle by Neo-Platonist philosophers, is another area with a rich supply of surviving commentaries produced in a self-conscious tradition where it is easier to interpret how they might have been used and experienced by their readers. ${ }^{38}$ 'Ancient Commentators on Aristotle' is a major ongoing collaborative project, led by Richard Sorajbi and based in the Department of Philosophy at King's College London, to produce English translations of the Commentaria in Aristotelem Graeca ( $C A G)$, the extensive corpus of commentaries on Aristotle surviving in Greek published from 1882-1909, along with related materials and fragments not yet rediscovered when $C A G$ was produced; so far over one hundred volumes of translation of the works of eighteen authors have been published. ${ }^{39}$ The commentaries concerned fall into three groups: a group by

and the Roman Law Tradition: Justinian's Const. Omnem and Its Medieval Commentators', in Neo-Latin Commentaries and the Management of Knowledge in the Late Middle Ages and the Early Modern Period (1400-1700), ed. Karl Enenkel and Henk Nellen. Leuven: Leuven UP, 2013, 349-81.

${ }^{37}$ Cf. Lewis, Asconius. Commentaries on Speeches of Cicero, xv, and also the discussion of where the form of scholia manuscripts originated in Montana, 'The Making of Greek Scholiastic Corpora'.

38 Cf. William A. Johnson, Readers and Reading Culture in the High Roman Empire. A Study of Elite Communities. Oxford: OUP, 2010.

39 Cf. the General Editor's Introduction to the series setting out its scope, first published in Christian Wildberg, Philoponus against Aristotle on the Eternity of the World, (London: Bloomsbury, 1987) and reprinted as an appendix to some subsequent volumes. The Ancient Commentators on Aristotle website also gives further information, including brief details of the leading commentators 
Aristotelian commentators up to the fourth century CE; the largest group by Neoplatonists up to the sixth century CE, with surviving material mainly from the fifth and sixth centuries; finally, a group from a much later Byzantine period.

The tradition of writing extensive commentaries on Aristotle's 'esoteric' works began in the first century BCE following the revival of interest in the works of Aristotle. The commentaries themselves were created within philosophical schools as material for the exposition of Aristotle's work to select groups of advanced students. Hence the commentaries grew out of the teaching practice of the school; the Categories seems to have been a key text and certainly attracts the most commentary. ${ }^{40}$ In essence they record the lectures of the head of a school, often teaching with reference to the works of their predecessors too, especially their own teacher. ${ }^{41}$ These commentaries were thus produced in a setting alongside the works they commented upon; indeed the point of studying Aristotle in a philosophical school was to access and study these texts. I do not presume to treat all of these commentators here, but will instead focus briefly on one influential member of the tradition from the second century CE, Alexander of Aphrodisias, and also observe a couple of commentators who do something slightly different from the norm which he helped to establish.

Alexander of Aphrodisias was a Peripatetic philosopher in the late second and early third century CE, who became head of a school at Athens where he held an imperial chair. Not much else is known about his life. He was a prolific commentator on most of Aristotle's major works and a good portion of his work survives in Greek or Arabic translation. ${ }^{42} \mathrm{He}$ is also

(www.ancientcommentators.org.uk); it recommends the entries in the online Stanford Encyclopaedia of Philosophy, starting from the general entry at http://plato.stanford.edu/entries/aristotle-commentators/. On commentators on Aristotle, cf. Miira Tuominen, The Ancient Commentators on Plato and Aristotle. Berkeley, Los Angeles: California UP, 2009; Silvia Fazzo, 'Aristotelianism as a Commentary Tradition', in Philosophy, Science and Exegesis in Greek, Arabic and Latin Commentaries, ed. Peter Adamson, Han Baltussen, and M. W. F. Stone. London: Institute of Classical Studies, 2004, 1-19.

${ }^{40}$ Cf. Andrea Falcon, 'Commentators on Aristotle', in The Stanford Encyclopedia of Pbilosophy, ed. Edward N. Zalta, 2013.

(http://plato.stanford.edu/archives/fall 2013/entries/aristotle-commentators/).

${ }^{41}$ Cf. Falcon, 'Commentators on Aristotle'; H. Gregory Snyder, Teachers and Texts in the Ancient World: Philosophers, Jews and Christians. London, New York: Routledge, 2000, part 1, has much on this philosophical teaching set-up.

${ }^{42}$ Surviving commentaries on Prior Analytics (Book 1), Topics, Meteorology, and On 
significant as a model for later commentators. ${ }^{43}$ Among the works in a thirteenth-century prayer book, now famous as the Archimedes Palimpsest following the most notable works revealed beneath its surface text by recent digital imaging, is a section of a hitherto unknown commentary on Aristotle's Categories which may be Alexander's otherwise lost commentary on this work. ${ }^{44}$

Alexander's commentaries stem from his teaching of Aristotle's works and are formal lemmatised commentaries. The preface discusses Aristotle's title, scope and subject matter, in a pattern that later became formalised within the tradition. ${ }^{45}$ The commentary itself proceeds through the text not always line by line but also by selecting passages in succession to discuss; the lemmata are not continuous but rather identify the passage under discussion for a class studying with the text. 46 The scope of the commentary then varies according to what Alexander is interested in-some passages are discussed at length, others are almost passed over — and can contain lengthy digressions. ${ }^{47}$ Thus, while Alexander's commentary on Metaphysics 4 goes through the text almost line by line, the commentary on Metaphysics 1, for example, devotes over half its length to just two chapters in which Aristotle discusses Plato. ${ }^{48}$ Elsewhere too, Alexander's explanations of Aristotle also go beyond explaining the text and meaning of Aristotle's work into presenting Alexander's own thinking and discussing developments in Peripatetic thought after Aristotle, on which his work is a valuable historical

Sense Perception and the start of the Metaphysics: see Falcon, 'Commentators on Aristotle'.

43 Tuominen, The Ancient Commentators on Plato and Aristotle, 20-3.

${ }^{44}$ R.W. Sharples, 'The New Commentary on Aristotle's Categories in the Archimedes Palimpsest', in The Archimedes Palimpsest. http://archimedespalimpsest.org/about/scholarship/commentary-aristotle.php (2007).

45 Cf. Jaap Mansfeld, Prolegomena: Questions to Be Settled before the Study of an Author, or a Text. Leiden: Brill, 1994.

46 Cf. Kraus, 'Introduction', 10-16, on the effects of different lemmatisation approaches on the reader's experience.

${ }^{47}$ Cf. Dorothea Frede, 'Alexander of Aphrodisias', in The Stanford Encyclopedia of Philosophy, ed. by Edward N. Zalta.

http://plato.stanford.edu/archives/sum2013/entries/alexander-aphrodisias. (2013) on Alexander as a commentator.

48 Arthur Madigan, Alexander of Aphrodisias: On Aristotle Metaphysics 4. London: Duckworth, 1993, 4; William E. Dooley, Alexander of Aphrodisias: On Aristotle Metaphysics 1. London: Bloomsbury, 1989, 1. 
source. While formally retaining the format of a commentary, at times Alexander's work therefore moves beyond what we might expect of commentary focussed on a particular work of Aristotle to become a vehicle for his own output orientated around his reading of Aristotle's work.

Alexander's commentary is, however, concerned where required with philological issues such as divergent readings and textual problems. His comments on these, including evidence from earlier commentaries, show he had access to textual traditions no longer represented in manuscripts surviving today. David Bloch's discussion of the value of Alexander's commentary on On Perception as a source for the text of Aristotle, however, considers that, with the exception of Alexander's direct attestations of textual variants, 'even though Alexander seems to be a excellent textual witness, the commentary can rarely be considered solid, textual evidence on a par with manuscript readings'. ${ }^{49}$ The partial lemmata in particular, though Bloch concludes that they do go back to Alexander, seem particularly susceptible to later intervention. ${ }^{50}$ Defining and identifying where Alexander is quoting Aristotle within his commentary text is often tricky; this is also true of the use of paraphrases, especially to support readings not preserved in manuscripts. ${ }^{51}$ Deciding what text of Aristotle to use and when to indicate quotations in their translations also presents challenges for the translators of the 'Ancient Commentators on Aristotle' series. ${ }^{52}$

A later member of the Peripatetic commentary tradition who was explicitly influenced by Alexander's works was Themistius, a fourth-century imperial administrator and political figure who also ran his own philosophical school from c. 345-55 CE. Out of a desire not to try to compete with Alexander's work, Themistius turned to a different strategy for his work on Aristotle. ${ }^{53}$ Todd, the editor for the 'Ancient Commentators on Aristotle' project of Themistius' treatment of Aristotles' Physics 1-3 explains:

${ }^{49}$ David Bloch, 'Alexander of Aphrodisias as a Textual Witness: The Commentary on the De Sensu', Cabiers de l'Institut du Moyen-Age Grec Et Latin, 74 (2003) 21-38.

${ }^{50}$ Bloch, 'Alexander of Aphrodisias as a Textual Witness', 23-27.

${ }^{51}$ Bloch, 'Alexander of Aphrodisias as a Textual Witness', 28-32.

52 Cf. comments in Mueller, On Aristotle Prior Analytics 1.23-31, 1-2; Madigan, On Aristotle Metaphysics 4, 4.

${ }^{53}$ Cf. Tuominen, The Ancient Commentators on Plato and Aristotle, 21-2. 
The first three books of the Physics elicit a paraphrase in which overall the length of the original is doubled with the Themistian response typically being not a simple summary or epitome but a definition of the sense of the Aristotelian original expressed in an authorial voice that mostly purports to be that of Aristotle himself offering, as it were, an alternative and usually more expansive version of himself. ${ }^{54}$

Another later member of the tradition, Dexippus, a fourth-century pupil of Iamblichus and then follower of Porphyry, produced a commentary on Aristotle's Categories which is in question and answer format, cast as a dialogue between Dexippus and his pupil Seleucus. ${ }^{55}$ Neither of these forms of commentary contain textual lemmata but both correspond to the pattern of working systematically through the text of Aristotle alongside a philosophical teacher and text. Indeed, both authors can be seen as in a way trying to embody and dramatise the experience of that teaching in works which challenge and expand our sense of what form commentaries could take.

\section{SCIENTIFIC COMMENTARIES}

Scientific commentaries represent an area of difference between ancient and modern practice. ${ }^{56}$ Modern scientists do not write commentaries, let alone multi-volume commentaries on distant predecessors; Richard Dawkins may be interested in Darwinism but this is unlikely to find expression in line-byline analysis of On the Origin of Species. This was not the case in the ancient world, from which there survives a range of commentaries on technical works in fields such as mathematics, astronomy, music, medicine and grammar. They are aimed at specialist audiences and often written in particularly difficult technical Greek. ${ }^{57}$

54 Robert B. Todd, Themistius: On Aristotle Physics 1-3. London: Bloomsbury, 2014, 1; cf. Tuominen, The Ancient Commentators on Plato and Aristotle, 25-7.

55 Cf. John Dillon, Dexippus on Aristotle Categories. London: Duckworth, 1990.

56 Cf. Heinrich von Staden, "A Woman Does Not Become Ambidextrous': Galen and the Culture of Scientific Commentary', in The Classical Commentary: Histories, Practices, Theory, 109-39, especially 124-6.

57 Cf. Jaap Mansfeld, Prolegomena Mathematica from Apollonius of Perga to Late Neoplatonism. Leiden: Brill, 1998; Dickey, Ancient Greek Scholarship. 


\section{Hipparchus on Aratus}

In fact, our earliest intact self-standing commentary from the ancient world is a scientific commentary on a work which poses a challenge to the division of writing in the ancient world into literary versus technical. An epic didactic poem written around the beginning of the third century BCE, Aratus of Soli's Phaenomena became one of the most popular literary works in antiquity and was translated into Latin by various Roman writers, including Cicero; it is also the poetic work cited in the speech given to Paul at Acts 17:28. ${ }^{58}$ It is not surprising therefore that there is evidence for a rich and varied range of commentary and other secondary materials connected with this text. ${ }^{59}$ The poem has two parts, describing the rising and setting of the constellations and meteorology respectively. The first part is based upon an astronomical work by Eudoxus of Cnidus, as is clear from the commentary on the works of Aratus and Eudoxus by Hipparchus of Nicaea, who was active in the late second century BCE.

Hipparchus was one of the period's foremost astronomers and mathematicians and author of several major works in the field, though only this commentary now survives. ${ }^{60} \mathrm{In}$ it, he sets out to correct and update the astronomical information in Aratus' works. To do this he quotes extensively from Eudoxus' work to show where the errors and inaccuracies in Aratus' astronomy originated. In the process, he also takes issue with a slightly earlier commentator on Aratus, Attalus of Rhodes, who took a more defensive stance towards the astronomical errors in the work. ${ }^{61}$ Hipparchus' commentary is thus not so much explanatory as critical of the work it comments upon. It has a distinctly polemical edge too, as part of an ongoing discourse with his professional rivals in their specialist field. ${ }^{62}$

58 On Aratus, see Emma Gee, Aratus and the Astronomical Tradition. Oxford: OUP, 2013.

${ }^{59}$ Dickey, Ancient Greek Scholarship, 56-60.

${ }^{60}$ On Hipparchus as a mathematician, cf. C.M. Linton, From Eudoxus to Einstein: A History of Mathematical Astronomy. Cambridge: CUP, 2004, 51-60.

${ }^{61}$ Cf. Caroline Bishop, 'Hipparchus among the Detractors?', in Classical Commentaries. Explorations in a Scholarly Genre, ed. Christina S. Kraus and Christopher Stray. Oxford: OUP, 2015, 379-96; Dickey, Ancient Greek Scholarship, 56; Serafina Cuomo, Ancient Mathematics. London, New York: Routledge, 2001, 82; Liba Taub, Ancient Meteorology. London, New York: Routledge, 2003, 47; also von Staden, 'A Woman Does Not Become Ambidextrous', 129, on the work's prefatory remarks.

62 Cf. Alexander Jones, 'Uses and Users of Astronomical Commentaries in Antiquity', in Commentaries-Kommentare, 147-72, on later astronomical 
One way of approaching these scientific commentaries is to define them as commentaries of a different sort to commentaries on literary works. ${ }^{63}$ When it comes to looking at models for biblical commentary, however, they may be equally relevant. Indeed, Japp Mansfeld's study of prefatory practices sets Origen's commentaries clearly within these technical/scientific/philosophical traditions of commentary. ${ }^{64}$ They introduce a further range of approaches and attitudes that a commentary could take towards both the text it commented upon and its readers.

\section{Commentaries and the Hippocratic Corpus}

The earliest surviving complete medical work is Apollonius of Citium's work on Hippocrates' On Joints. This first-century BCE work is today preserved solely in a famous early tenth-century codex now in the Laurentian Library (Florence, BML, Pluteo 74.7). ${ }^{65}$ According to epigrams in the manuscript, it was originally produced for the doctor Nicetas, possibly in the imperial scriptorium, who had collected together an array of medical texts. The manuscript is notable for its gorgeous, if slightly gruesome, multi-coloured illustrations of bone-setting techniques; these potentially go back to Apollonius' work since his text indicates that it contained some form of illustrations or diagrams. Though the work quotes extensively from the Hippocratic work it focusses upon and considers closely extended passages taken roughly in the order of Hippocrates' work, it is perhaps better considered as an independent treatise on the surgical topic of joints as dealt with in the work of Hippocrates. It does not present itself explicitly as a commentary and is not systematically lemmatised; indeed in places it rearranges and abbreviates the material from On Joints and adds material from other Hippocratic works. ${ }^{66}$ Again, the perhaps artificial boundary between a commentary and a treatise focused on another

commentaries.

${ }^{63}$ John T. Vallance, 'Galen, Proclus and the Non-Submissive Commentary', in Commentaries-Kommentare, 223-43, discusses these 'non-submissive' commentaries with reference to Galen and Proclus.

${ }^{64}$ Mansfeld, Prolegomena: Questions to Be Settled, 10-20.

65 See the description of this manuscript in the online exhibition at http://www.bml.firenze.sbn.it/laformadelibro/sezioni ing/scheda28.htm, including two images.

${ }^{66}$ Cf. Paul Potter, 'Apollonius and Galen on 'Joints", in Galen Und Das Hellenistische Erbe, ed. Jutta Kollesch and Diethard Nickel. Stuttgart: Franz Steiner Verlag, 1993, 117-24. 
work is highlighted and the potential for a 'commentary mode' to be used in works not formally commentaries.

What Apollonius' work does attest is the lively tradition of centring medical science around the discussion of a group of medical works characteristically written in Ionic Greek and dating from the sixth to the fourth centuries BCE that had become associated with the physician Hippocrates of Cos and his circle. ${ }^{67}$ This 'Hippocratic Corpus', a diverse and sometimes contradictory collection of textbooks, lectures, case studies, treatises and philosophical essays on various medical topics, certainly provided plenty of opportunity for explanation, interpretation and attempted clarification. The assembly of the corpus itself seems to owe something to third-century BCE editorial activity in Alexandria, which was noted as a centre for medical scholarship as well as for its library. Apollonius' work, however, represents a rare example of an earlier medical writer who is not known only through the medium of Galen of Pergamum whose prodigious output largely subsumed earlier medical writings.

\section{GALEN}

The most prolific commentator in the second century was Galen of Pergamum. Many of his commentaries have been preserved, including a large number on medical themes. ${ }^{68}$ Galen's incessant drive to promote and prove his expertise in all his chosen fields often impels him to demonstrate and explain what he is doing, including as an author and commentator. His works and what he says about them are therefore highly useful in exploring

${ }^{67}$ On the Hippocratic Corpus, cf. Elizabeth M. Craik, The 'Hippocratic' Corpus and Context, (London and New York: Routledge, 2015), which provides a useful summary of each work, as well as an introduction to the corpus.

${ }^{68}$ There has been much written on Galen. A good starting-point is offered by Vivian Nutton, Ancient Medicine, 2nd edn. London and New York: Routledge, 2013, chapters 15 and 16, and Simon Swain, Hellenism and Empire. Language, Classicism, and Power in the Greek World AD 50-250. Oxford: Clarendon Press, 1996, chapter 11. Susan P. Mattern, The Prince of Medicine. Galen in the Roman Empire. Oxford: OUP 2013 is a recent, more popular, biography of Galen. On Galen as a commentator, see Rebecca Flemming, 'Commentary', in The Cambridge Companion to Galen, ed. R.J. Hankinson (Cambridge: CUP, 2008), 323-54, and Mansfeld, Prolegomena: Questions to Be Settled, chapter 4; as a commentator on Hippocrates in particular, cf. D. Manetti and A. Roselli, 'Galeno Commentatore di Ippocrate', $A N R W$, II 37.2 (1994), and Wesley D. Smith, The Hippocratic Tradition. Ithaca, London: Cornell University Press, 1979, esp. 123-76. 
commentaries and what they were used for. Furthermore, Galen's 'autobibliographic' works, On My Own Books and On the Order of My Own Books, provide valuable context for his commentaries within his works and his career as Galen himself perceived it. ${ }^{69}$ Produced late in his life and driven by a concern to conserve and control his written legacy, these works, as their titles suggest, set out to catalogue his œuvre and instruct the reader how he wanted it to be approached; in this process, they also often explain the circumstances in which he came to produce his works. As such, they present a valuable opportunity to see what the production of commentaries might have contributed to an ancient author's career. This material does need to be regarded with some caution since it is very much Galen on Galen - the 'authorised' biopic, as it were, rather than the fly-on-the-wall documentary-and probably presents a schematised and perhaps consciously shaped account of his life and work. And, of course, one should be careful in taking Galen as a 'typical example', though his attitudes and approaches to commentary are likely to be pretty conventional and in step with his literary cultural background.

\section{Galen's Medical Writings}

In his autobibliographies Galen presents himself producing a range of commentaries during his career for different audiences and agendas. Foremost among these were lemmatised commentaries on the Hippocratic corpus, on which Galen anchored his own approach to medicine. He describes several phases in their production: firstly, there are works ostensibly for his own personal use; then works written for others, both a general audience and personalised productions for particular friends and

69 Text: Johann Marquardt, Iwan von Müller, and Georg Helmreich, Claudii Galeni Pergameni Scripta Minora. Vol. 2. Leipzig: B. G. Teubner, 1891, compared with Véronique Boudon-Millot, Galien, Tome I: Introduction Générale, Sur l'ordre de ses Propres Livres, Sur ses Propres Livres, Que l'Excellent Médecin est aussi philosophe. Paris: Belles Lettres, 2007; trans. P. N. Singer, Galen, Selected Works. Oxford: OUP, 1997. Both works are in K XIX = volume 19 of Karl Gottlob Kühn, 'Claudii Galeni Opera Omnia’, in Medicorum Graecorum Opera Quae Exstant. Leipzig: C. Cnobloch, 1821-33, which is still used as the standard reference edition. On these works, cf. Vivian Nutton, 'Galen and Medical Autobiography', Proceedings of the Cambridge Philological Society, 198 ns 18 (1972) and Mansfeld, Prolegomena: Questions to Be Settled, chapter 4 (whence the term 'autobibliographic'). 
associates; finally he contemplates a comprehensive set of formal commentaries on the whole corpus. ${ }^{70}$

At a critical point of the section in On My Own Works where Galen records his Hippocratic commentaries, some editors supply an oủ $\delta \dot{v} v$ which makes Galen say that he did not actually compose commentaries as an early stage of his career, but instead produced notes on medical topics in relation to the Hippocratic corpus. ${ }^{71}$ The way he explains this suggests that writing commentaries was something he was expected to have done: indeed, he seems to be trying to suggest that his topical notes might be considered the equivalent of commentaries. Whatever the nature of his own early works, Galen explains that, though he was familiar with earlier commentaries written 'on each word' of Hippocrates, he himself had written without close reference to these and instead focussed on giving his own interpretation. He claims that it was only when he encountered someone else giving a particularly poor interpretation of one of the Aphorisms that he was prompted to write his own commentaries for general circulation rather than

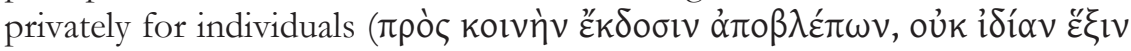

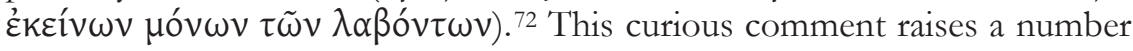
of questions about Galen's practice, but it does demonstrate that writing commentaries and using those of others could be a regular part of an active academic reading process. Despite Galen's division of commentaries into these two types, he refers to both with the term hypomnemata.

A move from presenting his own interpretations to producing commentaries that also take account of others' scholarship fits with some observable developments in Galen's commentaries. His commentary on Epidemics III makes notably more reference to other medical writers compared with the preceding commentary on Epidemics I, as well as having prefatory material explicitly re-establishing his methodological approach: Galen again claims this is responding to requests from his friends. ${ }^{73} \mathrm{~A}$ more

70 On how Galen classifies his commentaries, cf. Mansfeld, Prolegomena: Questions to Be Settled, chapter 4.

${ }^{71} \mathrm{~K}$ XIX.33.15-37.10. The oủ $\delta$ Év-variant is in K XIX.33.18; the most recent discussion of this was in a paper presented by P. N. Singer, 'Galen on Hippocrates on the Elements: Behind and Beyond the Commentary', at the $15^{e}$ Colloque Hippocratique. The Hippocratic Corpus and its Commentators: East and West (University of Manchester, 2015).

72 K XIX.35.8-11.

73 Presented in Jacques Jouanna, 'Galien commentateur de commentaires: À propos d'Épidémies I et III d'Hippocrate', at the $15^{e}$ Colloque Hippocratique. The 
critical interpretation of why he 'raised his game' as a commentator over the course of his career has however been suggested by Wesley D. Smith in his study of the Hippocratic tradition: the development in Galen's practice may have been due to pressure to compete with contemporary rivals who engaged with the complexities of the Hippocratic corpus and its text more than he had hitherto. ${ }^{74}$ Galen, who proclaimed himself an expert follower of Hippocrates, become obliged to demonstrate expertise in the Hippocratic tradition as well as in medicine.

Later, in On the Order of My Own Books, Galen professes an ambition to complete a comprehensive set of commentaries on Hippocrates if he lives long enough. ${ }^{75}$ While he contends that reading his other major works will sufficiently acquaint readers with Hippocrates, he also recommends other resources readers could seek out if he fails to complete his own commentaries. These are primarily the commentaries of Galen's own teachers, Pelops and Numisianus, whose works he comments were difficult to find, plus those by Sabinus and Rufus of Ephesus, both medical writers Galen praises elsewhere. He also warns against using certain commentaries, although his focus here is on the nature of the commentator's interpretation of Hippocrates rather than the intrinsic qualities of the commentary such as whether it is comprehensive, well-written or otherwise suitable for the reader. Galen concludes his section on Hippocratic commentaries with an assurance that those familiar with his works will, of course, be able to judge others' commentaries for themselves.

Galen also seems to list among his works in On My Own Books commentaries on other earlier medical writers with whom he disagrees: the sections of works 'against' Erasistratus and the Methodists both include commentaries. ${ }^{76}$ It is likely these were produced in a more combative mode than his commentaries on Hippocrates and were perhaps prompted by disputes with contemporary followers of other schools of medical thought. Certainly his work On Erasistratus' Anatomy prompted by a personal rivalry

Hippocratic Corpus and its Commentators: East and West (University of Manchester, 2015).

${ }^{74}$ Smith, The Hippocratic Tradition, especially 122-4; see also Flemming, 'Commentary', 333-4, who is more generous to Galen.

${ }^{75} \mathrm{~K}$ XIX.57.1-58.12, but note the text now restored to the lacuna at the start of this passage in the Boudon-Millot edition.

${ }^{76}$ K XIX.37.11-38.6 \& K XIX.38.12-38.20. Flemming, 'Commentaries', 3256 , discusses these and the difficulties caused by Galen's loose use of the term bypomnemata in establishing whether these works are commentaries. 
with his cantankerous elderly contemporary Martialius was, he says, written

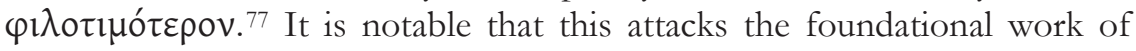
Erasistratus instead of addressing Martialius' own writings. Galen seems to have produced epitomes of his other rivals that meant summarising their works in his own words rather than commentaries which would have included their texts as lemmata. For example, On My Own Books mentions epitomes of works by Lycus and Marinus, his predecessors and rivals in the field of anatomy, and not commentaries. ${ }^{78}$

\section{Galen's Philosophical Works}

Galen also had philosophical ambitions. One of the driving forces of his career was the desire to establish medicine on a philosophical footing and elevate it to the status of philosophy, an approach exemplified by his work The Best Doctor Is Also A Philosopher. ${ }^{79}$ As in medicine, he preferred to take his own eclectic approach rather than identify with a single school, although he has an inclination towards Aristotle and Plato and a decided dislike of Epicureanism. His autobibliographies record his writings on a range of subjects: On My Own Books has sections for works on moral philosophy, Plato, Aristotle and other Aristotelians, the Stoics, and the Epicureans. His commentaries on Plato, Aristotle and Theophrastus reflect not only Galen's interests, but also, as Rebecca Flemming points out, the wider trends of production within philosophical schools: Aristotelian and Platonic philosophers produced written commentaries, while Stoics and Epicureans tended not to. ${ }^{80}$ Some of Galen's philosophical work seems to have been known to his near contemporary Alexander of Aphrodisias. ${ }^{81}$

77 K XIX.13.7-14.6.

${ }^{78}$ K XIX.25.9-34.5, but note the text now restored to the lacuna in BoudonMillot's edition at the start of this passage, which covers the description of the epitome of Lycus.

79 On Galen as a philosopher, cf. chapters in R. J. Hankinson, The Cambridge Companion to Galen. Cambridge: CUP, 2008, and in Christopher Gill, Tim Whitmarsh, and John Wilkins, Galen and the World of Knowledge. Cambridge: CUP, 2009, especially Philip J. van der Eijk, “Aristotle! What a Thing for You to Say!' Galen's Engagement with Aristotle and Aristotelians', 261-81.

80 Flemming, 'Commentaries', 326-9.

81 Ibid. 326; cf. Vivian Nutton, 'Galen in the Eyes of His Contemporaries', Bulletin of the History of Medicine 58 (1984) 315-24. Fragments in Arabic survive from a work by Alexander against Galen, cf. Frede, 'Alexander of Aphrodisias'. 
In On My Own Books Galen recalls that he had written a large number of works on logical proof for his personal use, including commentaries on Aristotle in particular, that had been destroyed by a major fire at Rome in 191 CE. ${ }^{82}$ This devastated a large area of the city including important imperial libraries and the secure warehouse which Galen rented near the Temple of Peace and where, at the time of the fire, much of his library happened to be in storage, including his own copies of many of his works. The recently rediscovered work $O n$ the Avoidance of Grief explains how Galen coped philosophically with this disaster and has greatly increased our knowledge of this episode. ${ }^{83}$ It includes the information that specially copied, personally corrected and carefully punctuated texts of various philosophers were lost, several of which had been the subject of works by Galen, including various commentaries on Aristotle and one on a work of

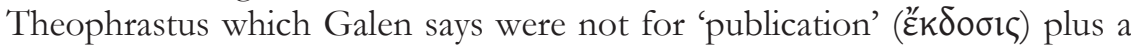
commentary on a work by one Eudemus written 'for friends'. ${ }^{84}$ Unlike Galen's mature Hippocratic commentaries, these works seem to have been passed out of circulation relatively rapidly. ${ }^{85}$ Galen also wrote commentaries and other secondary works on works of Plato: fragments from the four volumes of hypomnemata composed On the Medical Material in the Timaeus of Plato do survive, albeit focussing on one aspect of the text rather than the whole. These are set out in a formal lemmatised form. ${ }^{86}$

Galen is an outside contender for authorship of the commentary fragment on Aristotle's Categories in the Archimedes Palimpsest. ${ }^{87}$ On My Own Books records that he wrote a commentary on this work for a friend whom he ordered to share it only with those who had already read the Categories with a teacher, or at least made a start with some other commentaries, such as those of Adrastus and Aspasius'. ${ }^{88}$ This fits with the

82 K XIX.41.12-42.7.

83 Text: Véronique Boudon-Millot and Jacques Jouanna, Galien, Tome IV: Ne Pas Se Chagriner. Paris: Les Belles Lettres, 2010; translation: Vivian Nutton, 'Avoiding Distress', in Galen. Psychological Writings, ed. P. N. Singer. Cambridge: CUP, 2014), 43-106. Both feature introductions to this work and Galen's lost library.

${ }^{84}$ K XIX.42.8-42.12.

85 Flemming, 'Commentaries', 328.

86 H. O. Schröder, Galeni in Platonis Timaeum Commentarii Fragmenta. Leipzig: Teubner, 1934. cf. Flemming, 'Commentaries', 327.

87 Sharples, 'The New Commentary on Aristotle's Categories'.

${ }^{88}$ K XIX.42.12-43.1, trans. Singer. Adrastus' and Aspasius' commentaries on the Categories do not survive. 
picture of philosophical commentaries being created and used in a teaching context, though it also suggests that studying with suitable commentaries could be a substitute for studying with a teacher. It also gives the impression that commentaries could be tailored to different levels of student knowledge and engagement with the text being read, and that multiple commentaries might be employed as progress was made in the study of a work. Galen positions his own commentary as intended for more advanced study, following in the hierarchy of reading what were possibly standard commentaries by earlier Aristotelians.

\section{Galen's Prefaces}

The account of how the commentary on the Categories came to be written 'for a friend' also highlights a prefatory convention used by Galen and many other writers to account for how they came to compose their works. ${ }^{89}$ Galen appears to be more concerned with presenting himself as an intellectual figure than explaining the motivations for his works and career. ${ }^{90}$ The very concept of Galen's autobibliographies supposes a wider audience for his works than his immediate circle, but the narratives he provides leave it unclear how a wider audience could come to read his works, including commentaries. ${ }^{91}$ One cannot help but feel a gap between Galen's accounts of the casual and sometimes accidental ways his works were disseminated, even ones not intended to be so, and how those many works which did survive must have circulated widely enough to make their way through the vagaries of textual transmission. Galen follows the account of his commentary on the Categories with a particularly choice anecdote about more personal hypomnemata produced during his own childhood studies on the Stoic Chrysippus which, he says, came to be in general circulation because a household servant in Pergamum had handed them out to someone who came to his family home seeking for Galen's juvenilia. ${ }^{22}$

Galen's major commentaries themselves, nevertheless, often address their own methodology and come equipped with informative prefaces. The

89 Cf. Jason König, 'Conventions of Prefatory Self-Presentation in Galen's $O n$ the Order of My Own Books', in Galen and the World of Knowledge, 35-58.

90 Cf. especially Heinrich von Staden, 'Staging the Past, Staging Oneself: Galen on Hellenistic Exegetical Traditions', in Galen and the World of Knowledge, 132-56, and Mansfeld, Prolegomena: Questions to Be Settled, chapter 5.

91 Cf. Johnson, Readers and Reading Culture, esp. 85-91, on the 'publication' and reading of Galen's works.

${ }^{92}$ K XIX.43.1-43.8. 
preface to Epidemics III, for example, also discusses Galen's Hippocratic commentaries and sets out the works on which he has written commentaries. Even though the order of writing is slightly different from that in On My Own Books, the commentaries are again divided into two groups: the first group written for himself, the second for his friends and others interested in medicine. ${ }^{93}$ From these prefaces the aims of Galen's

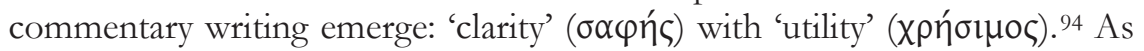
the first line of his commentary on On Fractures explains: 'that which is unclear in the text is to be made clear. ${ }^{95}$

Heinrich von Staden's analysis of Galen's comment on Hippocrates, Aphorisms 7.43, illustrates the stages of a typical Galenic commentary with reagrd to a statement whose meaning remains obscure: ГUvทे $\alpha \mu \varphi 1 \delta \varepsilon^{\prime} \xi 10 \zeta$ ov̉

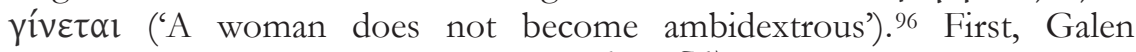
establishes his text and considers what $\alpha \mu \varphi \imath \delta_{\varepsilon}^{\prime} \xi 10 \varsigma$ might mean by looking for other instances of the term; second, he attempts an expanded explanatory retelling of the text; third, he looks for clarification elsewhere in Hippocrates' work; fourth, he considers the explanations of this statement offered by others which he (naturally) finds unconvincing; and then, finally, he tries, not entirely convincingly in this case, to offer his own explanation - to do with what side of the womb embryos of different gender develop - in accordance with his own medical theories. Yet, though certain aspects of this approach may not comparable to contemporary commentary practices, von Staden also shows how what Galen actually does in detail is not always quite what we might expect.

The preface to In Hippocratis librum de officina medici commentarii III may have particular resonance for the present volume since it is concerned with the use of commentaries, including as sources for the Hippocratic text upon which it comments. ${ }^{97}$ The preface starts by exploring typical concerns with

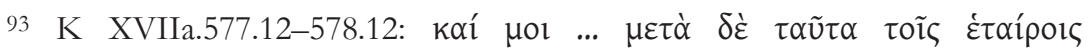

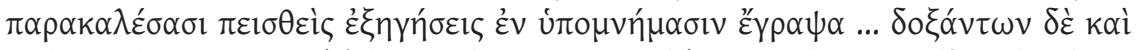

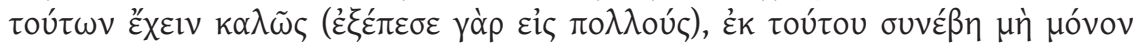

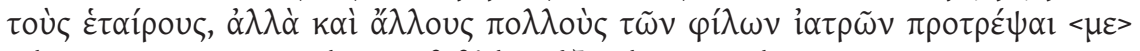

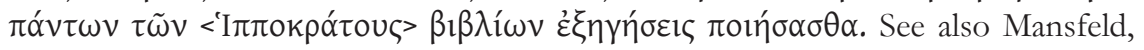
Prolegomena: Questions to Be Settled, 133-4.

${ }^{94}$ Observed by Flemming, 'Commentaries', 336-40.

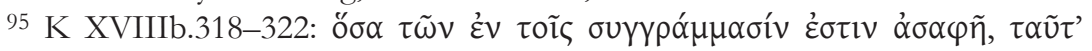

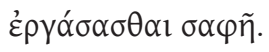

${ }^{96}$ von Staden, 'A Woman Does Not Become Ambidextrous', 109-24.

${ }^{97}$ Text: Galenus, In Hippocratis librum de officina medici commentarii iii, in Kühn, vol. 
the text of Hippocrates, including establishing the work's title, subject and scope. ${ }^{98}$. The title of Hippocrates' work, $k \alpha \tau$ ' in $\tau \rho \varepsilon \tilde{o} o v$, is compared with the longer title $\pi \varepsilon \rho i \tau \tilde{\omega} \nu \kappa \alpha \tau^{\prime}$ in $\tau \rho \varepsilon \tilde{i}$ V used for similar works by other writers and found in some copies, though most have the shorter title; Galen's concern seems at least to be partly whether this is the most appropriate title for the work rather than the most authentic. ${ }^{99}$

The preface also talks about the oldest texts available: these are said to be three hundred years old and written on books, papyrus rolls and possibly even the bark of trees ( $\dot{\varepsilon} v \delta 1 \alpha \varphi$ óporৎ $\varphi \imath \lambda u ́ p \alpha ı)$ ). ${ }^{100}$ Galen himself, however, has also investigated the earliest exegesis with a view to finding the genuine text from 'the majority and the most trustworthy' and claims to have found, to his surprise, that their evidence agreed well with the earliest textual sources. ${ }^{101} \mathrm{He}$ therefore criticises in typically polemical fashion recent editions of the work for introducing 'innovations' in the Hippocratic text; these are works produced c.120 CE by Dioscorides and Artemidorus Capito in the generation before Galen. ${ }^{102}$ In the present work, in the interests of brevity, rather than discussing all previous hypomnemata, which here seems almost to mean 'textual readings recorded by a commentator', Galen will, however, discuss only the oldest, plus the ones with fewest additions, though primarily the ones agreed upon by the earliest commentators; these are the earliest Hellenistic writers on the Hippocratic corpus, Zeuxis and Heraclides of Tarentum, Bacchius and Asclepiades. ${ }^{103}$

This consultation of commentaries and manuscripts to establish the text they comment upon is fascinating. It presents Galen at his most

18.2. The preface is K XVIIIb.629.1-632.12. On this preface cf. Mansfeld, Prolegomena: Questions to Be Settled, 145-6, and von Staden, 'A Woman Does Not Become Ambidextrous', 147, 153-5.

98 Cf. Mansfeld, Prolegomena: Questions to Be Settled, esp. chapter 1.

${ }^{99}$ K XVIIIb.629.1-8.

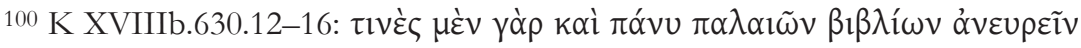

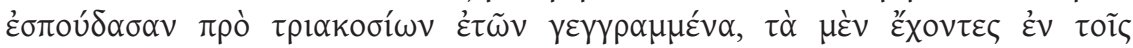

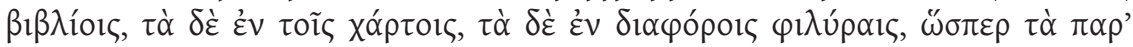

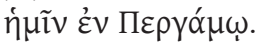

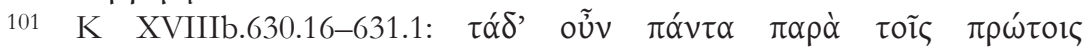

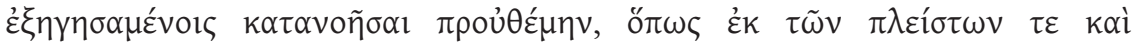

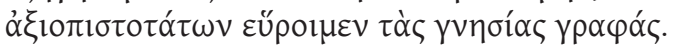

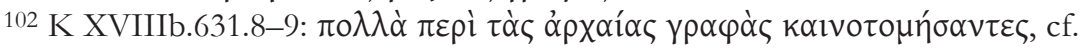
Nutton, Ancient Medicine, 213, on these Hadrianic editors of Galen.

103 K XVIIIb.631.11-14. On these Hellenistic editors and commentators, cf. von Staden, 'A Woman Does Not Become Ambidextrous', esp. 152-5. 
methodologically aware in dealing with a Hippocratic text written hundreds of years previously. Though one suspects his motivation may in practice actually turn out to be more to expose 'deficiencies' in rivals' texts and exploit this in bolstering his own reading and subsequent interpretation of the text rather simply determining what Hippocrates wrote, his awareness of the potential value of earlier commentaries and editions for the text is nevertheless striking. It raises questions about whether lemmata in a commentary were read as more significant textual evidence than just a convenient way of co-ordinating comment with text, even though Galen's focus is on the more explicit attestations of textual variants by earlier writers. For modern scholarship, the lemmata of Galen's commentaries themselves are significant sources for the Hippocratic texts on which they comment.

Yet the preface In Hippocratis librum de officina medici concludes, in fact, by dismissing this text-critical introduction and offering instead a brief and straightforward statement of the title, scope and traditional place of this introductory within the œuvre of Hippocrates. ${ }^{104}$ Having shown off his skills as a philological commentator, Galen, as it were, recants this ostentatiously learned approach in favour of something more utilitarian and hence more suitable for a commentary where practical concerns perhaps ought to outweigh discussion of more textual matters. ${ }^{105}$ There is a tension between the drive to impress as a commentator by addressing matters of other interest to him, but not of medical significance, and the pressure for the work to be useful. Different models of commentary on a practical, technical text are here in conflict. ${ }^{106}$

\section{CONCLUSION}

When the first readers of commentaries on biblical texts came to open their new commentaries they may have had quite a range of expectations based upon their experiences of commentaries on other ancient works. It seems reasonable that they would have encountered such material before. They could have been familiar with commentary material of quite diverse forms across a huge range of works produced with different aims and audiences in

104 K XVIIIb.632.1-3.

105 K XVIIIb.630.3-6.

106 This conflict is also found in the commentary on Epidemics III in the extended discussion of the mysterious characters which were found at the end of the various case-studies in some of the earliest manuscripts. These were mentioned by Jouanna in his paper 'Galien commentateur de commentaires' (see note 73). 
mind and setting out different levels and types of detail. In addition, it is likely that they may well also have been thinking about what they in turn were going to do with this commentary, and perhaps they were already equipped with pen and papyrus ready to make of it their own commentary in whatever way they chose. 


\section{Biblical Catenae: \\ BETWEEN PHILOLOGY AND HISTORY}

\section{GILLES DORIVAL}

\section{Catenae as a Field for Philologists}

In Chapter Ten of the third part of his famous Histoire critique du Vieux Testament, Richard Simon deals with the Greek and the Latin catenae. ${ }^{1} \mathrm{He}$ asserts:

Les Grecs ont un grand nombre de ces sortes de recueils sur la plupart des livres de la Bible, et l'on en trouve beaucoup dans les bibliothèques qui n'ont point été encore imprimés. Il ne serait même pas nécessaire de publier ces compilations entières, puisque nous avons les auteurs d'où elles ont été prises; mais il serait à désirer qu'on donnât seulement au public ce qui s'y trouve de singulier et qui n'a point été encore publié. Nous devons faire le même jugement des recueils auxquels les Latins ont donné le nom de Catena. Ces sortes d'ouvrages étaient fort utiles avant qu'on eut, par le moyen de l'impression, les commentaires des Pères et des autres auteurs sur la Bible. Il est bien plus à propos de lire les explications des Pères dans eux-mêmes que dans les livres de ceux qui en ont fait les extraits; outre que ces recueils contiennent une infinité de choses inutiles.

The Greeks have a large number of these types of anthologies on most of the biblical books, and many are found in libraries which have still not yet been printed. It would not even be necessary to publish these entire compilations, since we have the authors from which they have been extracted; yet it would be desirable to provide to the public just that which is unique and has not yet been published. We must make the same decision concerning the anthologies to which the Latins have

\footnotetext{
${ }^{1}$ Richard Simon, Histoire critique du Vieux Testament. Paris (Amsterdam: Elzevir), 1680 .
} 
given the name Catena. This type of work was extremely useful before printed copies of the Fathers and other writers on the Bible were available. It is much more relevant to read the Fathers' explanations in their own works than in the books of those who made extracts from them: moreover, these anthologies contain an infinity of useless material.

According to Richard Simon, it is therefore not necessary to publish the biblical catenae themselves: they are only a kind of mine from which one can extract patristic nuggets. Fortunately, his opinion did not prevail completely: there are editions of the Greek catenae since the end of the sixteenth century. Yet Simon's idea was in the air since the beginning of printing, as these editions are few and as there was never an overall editorial project. During the Renaissance, only Latin translations of Greek catenae were published: in 1546, in Florence, Franciscus Zephyrus (Zeffi) edited a catena on the Pentateuch; in 1546-1550, in Paris, Aloysius Lippomanus (Lippomano), a catena on Genesis and Exodus; in 1553, in Venice, Christophorus Serrarigus, a catena on Matthew; in 1569, in Venice, Daniele Barbaro, a catena on Psalms 1-50; in 1585, in Lyons, Paulus Comitolus, Nicetas' catena on Job, the author of which, in his eyes, was Olympiodorus; in 1589, in Rome, Antonius Agellius (Ajello), the catena on Lamentations; in 1614, in Antwerp, Theodorus Peltanus, a catena on Proverbs. But one should notice that some of the Greek catenae that these translations are supposed to represent have not been found among the collections of Greek manuscripts: for instance, Barbaro's and Lippomanus' translations are compilations made from various sources. In other words, some of the translators did not want to render a real Greek manuscript into Latin but had the philological project of creating a partly new compilation according to the model of the Greek and Latin catenae.

Between the beginning of the printing era and the end of the eighteenth century, only about a dozen Greek catenae were published. In 1565, in Padua, Antonio Carafa published a catena on Odes. In 1617, in Leiden, Johannes Meursius printed the so-called Eusebius and Polychronius catenae on the Song of Songs. In 1623, in Lyons, Michele Ghisleri published the catena on Jeremiah, Baruch and Lamentations sometimes attributed to John Droungarios. In 1630, in Antwerp, Balthasar Cordier published a catena on John. In 1637, Nicetas' catena on Job was edited in London by Patricius Junius (Young). In 1643-6, some catenae on Psalms were edited in Antwerp by Balthasar Cordier. In 1647 and 1648, in Toulouse, two catenae on Matthew were published by Balthasar Cordier and Pierre Poussines (Possinus). In 1672, in Rome, a catena on Mark was 
published by Pierre Poussines. The edition of the catena on the Octateuch and Kingdoms (the four books of Kings and Samuel) is more recent: it was produced in 1772-3, in Leipzig, by the Hieromonk Nikephoros Theotokis. In order to appreciate this rather short list, one must notice that, in my opinion, catenae always offer authors' names (or author lemmata); a compilation without names is not a catena, but a commentary, even if its sources are patristic fragments of various authors. For instance, Oecumenius, Peter of Laodicea, Procopius of Gaza, Theophylact and others are not authors of catenae, but of commentaries totally or partially made from catenae.

During this period and the nineteenth century, biblical catenae were seen in the same way as Richard Simon had described them: mines which allowed the publication of new fragments of patristic authors. For instance, they were used for editing Origen's works by Charles and Charles-Vincent Delarue (1733-59) and by the collaborators of the series Die griechischen christlichen Schriftsteller der ersten drei Jabrbunderte (1899-1955). During the first half of the nineteenth century, in Milan and Rome, Angelo Mai used many catenae in his editorial works and, a generation later, Jean-Baptiste Pitra did the same. In contrast, new publications of catenae are few. The enormous edition of many New Testament catenae by John Anthony Cramer in eight volumes (1838-44) should not create an illusion; one can quote only five editions: the Catena prima abbreviata on Matthew was published by Angelo Mai in 1834 and, in 1837, the same philologist gave the Catena prima abbreviata on John and, partially, Nicetas' catena on Luke; in 1860, in Pest (now Budapest), Samuel Markfi published the Catena prima aucta on Matthew; in 1887, in Athens, Nikephoros Kalogeras published PseudoAndreas' Catena on the Catholic Epistles, already edited by Cramer. One must emphasize the fact that, during this period, there was no new edition of Old Testament catenae.

Nonetheless, in 1897, in his book Catenen, which can be considered as the first philological study of biblical catenae, Hans Lietzmann recommends that scholars do not publish authors' fragments, but the collections themselves in full. ${ }^{2}$ In fact, his advice was not followed before the last third of the twentieth century: Marguerite Harl published the Palestinian Catena on Psalm 118 in 1972; Christos Krikonis, Nicetas' Catena on Luke in 1973; Sandro Leanza and Antonio Labate, four Catenae on Ecclesiastes in 1978, 1983, 1989 and 1992; Françoise Petit, the Catena on Genesis in 1992-6 and

2 H. Lietzmann, Catenen. Mitteilungen uber ibre Geschichte und handschriftliche Ueberlieferung, mit einem Beitrag von H. Usener. Freiburg im Breisgau: Mohr, 1897. 
the Catena on Exodus in 1999-2001; U. and D. Hagedorn, the Catena $\Gamma$ on Job in 1994-2004; Jean-Marie Auwers, Procopius' Catena on the Song of Songs in 2011.3 Why this gap between such relevant advice and its actual realization? Hans Lietzmann himself did not produce any edition, but, in association with Georg Karo, a catalogue of the manuscripts of Greek catenae, published in 1902.4 In this catalogue, which follows the order of the biblical books, the manuscripts were described and classified by types; for instance, there are twenty-seven types of catenae on the Psalms, which is the most complex case. In 1914, Alfred Rahlfs established a more complete catalogue of the manuscripts of the biblical catenae for the Old Testament. ${ }^{5}$ Philological instrumenta studiorum were thus considered a greater priority than editions. This was shown, in 1926, by Karl Staab's study of the catenae on Paul and, in 1941, by Joseph Reuss' book on the catenae on Matthew, Mark and John. ${ }^{6}$

3 M. Harl, La chaîne palestinienne sur le psaume 118 (Origène, Eusèbe, Didyme, Apollinaire, Athanase, Théodoret). Sources chrétiennes 189/190. Paris: Cerf, 1972; Christos

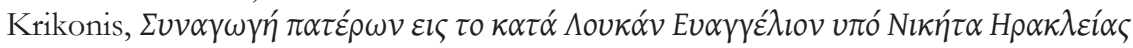

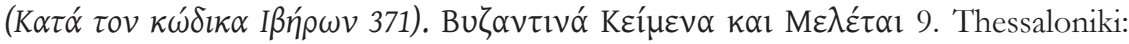
Centre for Byzantine Studies, 1973; S. Leanza, Procopii Gazaei Catena in Ecclesiasten necnon Pseudochrysostomi Commentarius in eundem Ecclesiasten. CCSG 4. Turnhout/Leuven: Brepols, 1978; S. Leanza, Un nuovo testimone della catena sull'Ecclesiaste di Procopio di Gaza: il Cod. Vindob. Theol. Gr. 147. CCSG 4 supplementum. Turnhout/Leuven: Brepols, 1983; A. Labate, 'La catena sull'Ecclesiaste del cod. Barb. Gr. 388.' Augustinianum 19 (1989) 33-339; A. Labate, Catena Hauniensis in Ecclesiasten in qua saepe exegesis servatur Dionyssi Alexandrini nunc primum edita. CCSG 24. Turnhout/Leuven: Brepols, 1992; F. Petit, La chaîne sur la Genèse. Edition intégrale. Traditio Exegetica Graeca 1-4. Leuven: Peeters, 1992-6; F. Petit, La chaîne sur l'Exode. Edition intégrale. Traditio Exegetica Graeca 9-11, Leuven/Paris/Sterling: Peeters, 1999--2001; D. Hagedorn \& U. Hagedorn, Die älteren griechischen Katenen zum Buch Hiob. PTS 40, 48, 53, 59. Berlin: de Gruyter, 1994-2004; J.-M. Auwers, Procopii Gazaei, Epitome in Canticum canticorum. CCSG 67. Turnhout: Brepols, 2011.

${ }^{4}$ G. Karo, J. Lietzmann, Catenarum graecarum Catalogus. Nachrichten von der Gesellschaft der Wissenschaften zu Göttingen philologisch-historische Klasse (1902). 1-66, 299-350, 559-620.

5 A. Rahlfs, Verzeichnis der griechischen Handschriften des Alten Testaments. Berlin: Weidmann, 1914.

6 K. Staab, Die Pauluskatenen nach den handschriftliche Quellen untersucht. Rome: Pontifical Biblical Institute, 1926; J. Reuss, 'Matthäus-, Markus- und Johannes-Katenen nach den handschriftlichen Quellen untersucht.' Neutestamentliche Abhandlungen 
Nonetheless, in this philological ocean, the historical dimension was not completely absent. As a rule, Procopius of Gaza, who died c. 530, was

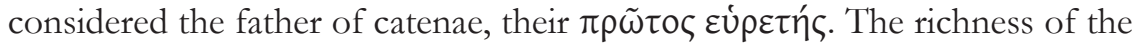
works of Nicetas of Heraclea, who wrote during the twelfth century, was known. The first scholar to introduce historical considerations into the philological approach was Michael Faulhaber. In 1899, he tried to situate chronologically the different catenae on the Prophets. ${ }^{7}$ In 1909, one year before he was appointed bishop of Speyer and eight years before he became archbishop of Munich, the same scholar asserted that the catena on the Song of Songs which alternates Gregory of Nyssa and Nilus of Ancyra goes back to the fifth century, as well as the catenae on Psalms and on the Twelve Prophets, which excerpt Hesychius and Theodoret: those catenae were prior to Procopius. ${ }^{8}$ His argument was that these compilations compare Alexandrian and Antiochean exegesis. In 1928, Robert Devreesse agreed with this view. ${ }^{9}$ The implicit argument is that the simple form of the two-author catenae is anterior to the complex form of the catenae with numerous authors. For the moment, our concern is not to discuss this opinion (which is false), but to show that historical reflections were not absent among the philologists. In doing so, they put life into the arid philological field.

In my own works on the catenae on Psalms, I have tried to emphasise this historical approach, showing that the catenae are not isolated documents, but are linked together and have a history and a geography. ${ }^{10}$ The aim is to situate them in time and space, but that is not easy, even in the cases of Procopius and Nicetas: we know the places, but not the precise dates. When one reads Maurice Geerard's admirable Clavis Patrum Graecorum, it is striking that the authors are examined not in alphabetical

XVIII, 4-5 (1941) 8-117.

7 M. Faulhaber, Die propheten-Catenen nach römischen Handschriften. Freiburg im Breisgau: Herder, 1899.

${ }^{8}$ M. Faulhaber, 'Katenen und Katenenforschung.' Biblische Zeitschrift 18 (1909) 383-95. See also M. Faulhaber, Hohelied, Proverbien- und Prediger-Catenen, Vienna: von Mayer, 1902.

${ }^{9}$ R. Devreesse, 'Chaînes exégétiques grecques.' Dictionnaire de la Bible, Supplément I. Paris: Letouzey \& Ané, 1928, col. 1084-1233.

${ }^{10}$ Details of these publications are given in the notes below; most recently, see G. Dorival, 'L'intérêt pour les chaines exégétiques grecques dans l'Europe de la Renaissance' in L'bumanisme italien de la Renaissance et l'Europe, ed. T. Picquet, L. Faggion, P. Gandoulphe. Aix-en-Provence: Publications de l'Université de Provence, 2010, 121-6. 
order but according to their position in time. ${ }^{11}$ Yet the same does not occur in the case of catenae, which are examined book by book and type by type. The scholars' task is to remedy this situation and to introduce some history and geography into the philological approach to the catenae. I would like to illustrate the need for this by coming back to my own researches. That is not immodesty, I hope, but a manner to put life into this paper.

\section{Personal Reflections on the Study of Catenae}

I began working on catenae at the end of 1967, as I was studying Aquila's vocabulary for a Master's degree at Paris-Sorbonne University. Marguerite Harl asked young students, including myself, to transcribe and translate with her the so-called Palestinian catena on Psalm 118 (119 MT). Some forty years before, in 1928, Robert Devreesse had published his famous paper on the catenae, in which he drew attention to that catena. ${ }^{12}$ In 1956, Marcel Richard, who was the Head of the Greek Department of the Institut de Recherche et d'Histoire des Textes (IRHT) in the Centre National de la Recherche Scientifique (CNRS), had described this catena and its manuscripts and had shown that it was the oldest and the best of all the catenae on the Psalms; he suggested a Palestinian origin for it. ${ }^{13}$

Marguerite Harl was a specialist on Origen, well-known for her book Origène et la fonction révélatrice du verbe incarné published in 1958. ${ }^{14}$ In Psalm 118, the Palestinian catena had about one hundred and seventy Origenian fragments, some of which were unpublished. Actually, Marguerite Harl had been convinced to undertake the edition by the great biblical scholar Dominique Barthélemy, who had collected in Fribourg (Switzerland) the microfilms of all the catenae on Psalms in order to publish a new edition of Origen's Hexapla. He was assisted by Adrian Schenker, who was to publish two important books on the catenae on Psalms in 1975 and $1982 .{ }^{15}$ Our

11 M. Geerard, Clavis Patrum Graecorum. 5 vol. Turnhout: Brepols, 1974-83; Supplementum, Turnhout: Brepols, 1998.

12 Devreese, 'Chaînes exégétiques grecques'.

13 M. Richard, 'Les premières chaînes sur le psautier.' Bulletin d'information de l'Institut de Recherche et d'Histoire des Textes 5 (1956) 87-98.

14 Marguerite Harl, Origène et la fonction révélatrice du Verbe incarné. Collection Patristica Sorbonensia 2. Paris: Éditions du Seuil, 1958.

15 A. Schenker, Hexaplarische Psalmenbruchstüke. Die hexaplarischen Psalmenfragmente der Handschriften Vaticanus graecus 752 und Canonicianus graecus 62. Fribourg/ Göttingen: Vandenhoek \& Ruprecht, 1975; A. Schenker, Psalmen in den Hexapla. Erste kritische und vollständige Ausgabe der hexaplarische Fragmente auf dem Rande der 
collaboration continued for four years, during which Marguerite Harl had long working sessions with Ekkehard Mühlenberg, from Göttingen University, who was preparing the edition of the fragments of Apollinarius and Didymus on Psalms. ${ }^{16}$ She also contacted Marie-Josèphe Rondeau, who was studying patristic commentaries on the Psalter and their prosopological hermeneutics. ${ }^{17}$ But she could neither meet René Cadiou, the editor of Vindobonensis th. gr. 8 in 1936, who was retired, nor Robert Devreesse, who was a solitary scholar preparing alone his work on the ancient Greek commentators on the Psalms, many pages of were devoted to Origen. ${ }^{18}$ The edition of the Palestinian Catena on Psalm 118 was published in 1972 in the Sources chrétiennes series by Marguerite Harl and myself; but I must confess that Marguerite Harl had done 90 per cent of the work and perhaps more. ${ }^{19}$

Be that as it may, two years before, in 1970, I had undertaken a PhD; Marguerite Harl was my tutor; the subject was the catenae on Psalm 118, with the subtitle 'Studies on the affiliations of the catenae and publication of unpublished fragments'. ${ }^{20} \mathrm{My} \mathrm{PhD}$ defence took place at the beginning of 1975. The thesis remains unpublished. Meanwhile, I had given my conclusions on Origen in the catenae on the occasion of the first Origen Conference, at Montserrat in September 1973. ${ }^{21}$ In my PhD, I edited and translated 163 Origen scholia on the Psalms which are present in the Vindobonensis th. gr. 8, instead of the 68 fragments edited by R. Cadiou in 1936. Some years ago, I gave that unpublished $\mathrm{PhD}$ to the German team which is preparing in Berlin the edition of Origen's works on Psalms.

Handschrift Ottobonianus graecus 398 zu den Ps. 24-52. Studi e Testi 295. Vatican City: BAV, 1982.

16 E. Mühlenberg, Psalmenkommentare aus der Katenenüberlieferung. PTS 15-16. Berlin/New York: de Gruyter, 1975, 1977; E. Mühlenberg, Untersucbungen zu den Psalmenkatenen. PTS 19. Berlin/New York: de Gruyter, 1978.

17 M-J. Rondeau, Les commentaires patristiques du psantier (IIIe -Ve siècles). Vol I Les travaux des Pères grecs et latins sur le Psautier. Recherches et bilan I. Rome: Institutum Studiorum Orientalium, 1982.

18 R. Cadiou, Commentaire inédit des psaumes. Etude sur les textes d'Origène contenus dans le manuscrit Vindobonensis 8. Paris: Les Belles Lettres, 1936; R. Devreesse, Les anciens commentateurs grecs des psaumes. Studi e Testi 264. Vatican City: BAV, 1970.

${ }^{19}$ Harl, La chaine palestinienne sur le psaume 118.

${ }^{20}$ G. Dorival, 'Les chaînes exégétiques grecques sur le psaume 118. Recherches sur les filiations des chaînes exégétiques grecques sur les psaumes et publication de fragments inédits.' (Typewritten PhD), Paris, 1974.

${ }^{21}$ G. Dorival, 'Origène dans les chainnes sur les psaumes: deux séries inédites de fragments.' Origeniana, Bari, Quaderni di Vetera Christianorum 12 (1975) 199-213. 
After my PhD, I undertook a French Doctorat ès lettres, a degree that has no equivalent in English-speaking countries, but is comparable to the German Habilitation. Marguerite Harl was my tutor again; the research was about all catenae and all Psalms, but I selected nineteen of them, making up 20 per cent of the psalter. I worked for about ten years, during which I visited many libraries and read the microfilms kept in Fribourg as well as in the Greek Department of the Institut de Recherche et d'Histoire des Textes in Paris. The result was an enormous work of about 2,500 pages. Its defence took place at the beginning of 1984, the year during which the Doctorat ìs lettres was abolished and replaced by the so-called Habilitation à diriger des recherches (HDR). Thanks to Maurice Geerard, the author of the Clavis Patrum Graecorum, Emmanuel Peeters accepted my work in one of his series: four volumes were published between 1986 and 1995.22 Because of my new research on the Septuagint and biblical traditions, the last volume is not yet published. I hope it will be soon.

\section{The Historical Beginning of the Catenae}

Let me sum up the results of my researches. Biblical catenae appeared in Judaea-Palestine at the beginning of the sixth century. Their $\pi \rho \tilde{\omega} \tau o \zeta$

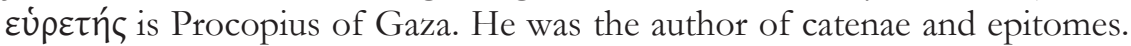
Several problems remain with these. The Monacensis gr. 358 and the Athous Koutloum. 10 offer a compilation on the Octateuch and Kingdoms, called an

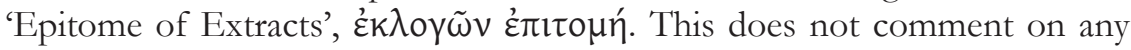
books from Ruth onwards. At its beginning, Procopius explains that he has abbreviated a previous work, which was a catena made by himself from patristic commentaries and homilies. Its title was probably Ei $\tau$ ìv

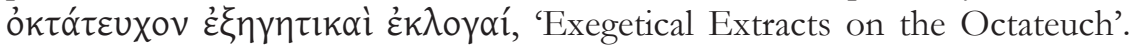
The 'Epitome of Extracts' does not present author lemmata: readers may feel that they are reading a unique text written by a single author. The catena is lost; the 'Epitome of Extracts' had only been published up to Genesis 18:3 in PG 87a, until the complete edition by Katrin Metzler in 2015.23 From folio 448, the Monacensis offers Procopius' scholia on Paralipomena (Chronicles), which remain unedited. Another epitome, on Isaiah, looks like the epitome on the Octateuch: it is without author

22 G. Dorival, Les chaînes exégétiques grecques sur les Psaumes. Contribution à l'étude d'une forme littéraire. 4 vol., Leuven: Peeters, 1986-95.

${ }^{23}$ K. Metzler, Prokop von Gaza Eclogarum in Libros Historicos Veteris Testamenti Epitome. Teil 1: Der Genesiskommentar. Berlin/Munich/Boston: de Gruyter, 2015. 
lemmata. In contrast, three epitomes on the Song of Songs, Proverbs and Ecclesiastes offer many author lemmata. In the Epitome on the Song of Songs, among these lemmata, there is the name Прокoríou. The presence of this is surprising and has not been explained in a satisfactory manner for the moment. In 1979, Pierre Nautin suggested that Procopius was the author of the two epitomes without lemmata, but not of the three epitomes with lemmata. ${ }^{24}$ The question is still open. Be that as it may, these three epitomes were written soon after Procopius, as is shown by the authors they quote.

Were there catenae before Procopius? Three issues have to be examined. First, is the catena on the Octateuch and Kingdoms, which is the source of Procopius' Epitome on the Octateuch and Kingdoms, from an author prior to Procopius? In 1979, Pierre Nautin established that the author of that catena was Procopius himself and that there was no other ancient catena on these biblical books.

Secondly, are there ancient catenae prior to Procopius' catenae? In the 1900s, Michael Faulhaber and others proposed the differentiation of two kinds of catenae: the multiple-author catenae and the two- or three-author catenae. ${ }^{25}$ In Faulhaber's opinion, there were four two-author catenae: on the Twelve Prophets, the catena which quotes Hesychius and Theodoret of Cyr; on Jeremiah, the catena which quotes Theodoret and Pseudo-John Chrysostom; on the Song of the Songs, the catena that quotes Gregory of Nyssa; on Psalms, the catena which quotes Hesychius and Theodoret. To these catenae, Robert Devreesse has added, on Psalms, the catena that quotes Athanasius and Hesychius; but there are also, on Psalms, the catena which quotes Origen and Theodoret (Vindobonensis th. gr. 8), the Catena that quotes Hesychius and Theodoret (Canonicianus gr. 62 and Scorialensis $\Psi$ I 2) and the catena that quotes Euthymius Zigabenus and Theodoret (Vallicellianus D. 35). According to Michael Faulhaber, the three-author catenae were the two Catenae trium Patrum, on the Song of Songs, which quotes Gregory of Nyssa, Nilus of Ancyra and Maximus the Confessor, and on Ecclesiastes, which quotes Gregory of Nyssa, Pseudo-Gregory of Nazianzus and Maximus; Robert Devreesse has added, on Psalms, the catena which quotes Athanasius, Basil of Caesarea and Theodore of Mopsuestia. Actually, this catena quotes four authors, Athanasius, Basil, John Chrysostom and Theodore of Mopsuestia. As for the two Catenae trium Patrum, they are late, as they quote Maximus (who died in 662) and they

24 P. Nautin, O. Guéraud, Origène, Sur la Pâque. Paris: Beauchesne, 1979.

${ }^{25}$ For the works of Faulhaber, see notes 7 and 8 above. 
were written by the same author. ${ }^{26}$ So, there is only one three-author catena, which must be considered as an enrichment of the two-author catenae or a simplification of the multiple-author catenae. Perhaps these catenae should be differentiated into two kinds, but this demonstration of this point is rather complicated.

How old are the two-author catenae? Michael Faulhaber situated them during the fifth century, Günther Zuntz during the eighth century. ${ }^{27}$ But the catena which quotes Euthymius Zigabenus and Theodoret is not prior to the end of the eleventh century or the beginning of the twelfth century. Is this an argument in favour of a late date for the two-author catenae? Actually, these offer, in one codex, a text which normally occupies two manuscripts. They allow the comparison of two ancient commentaries (for instance, Gregory of Nyssa and Nilus of Ancyra) or an ancient commentary and a recent one (Theodoret and Euthymius). Maybe such editions were written in scholarly circles which wanted to return to the Fathers. As a matter of fact, the Byzantine humanism of the ninth and tenth centuries had three characteristics: a return to the Classics, a return to artistic models of the end of Antiquity and a return to the Fathers. This humanist trend went on during the eleventh and twelfth centuries. Maybe the two-author catenae were written between the ninth and the twelfth centuries.

Let us return to the multiple-author catenae. Are some of them older than Procopius? In 1902, Michael Faulhaber estimated that Procopius' Epitome on the Song of Songs was dependent on a Urkatene, which was also the source of the so-called Eusebius Catena. ${ }^{28}$ For him, the date of that Urkatene was the first part of the fifth century. In my opinion, Procopius was the author of the Urkatene and the Epitome as well. The same phenomenon is attested in the case of Proverbs. But I should say that, in 2011, Jean-Marie Auwers mentioned my opinion without explicitly approving it. ${ }^{29}$ The issue remains open.

Thirdly, in the case of the biblical books that Procopius did not comment on, are there catenae prior to Procopius or contemporaneous with him? The catena on the Twelve Prophets in the Taurinensis B. N. B 12

26 See further S. Lucà, Anonymus in Ecclesiasten Commentarius qui dicitur Catena Trium Patrum. CCSG 11. Turnhout/Leuven: Brepols, 1983.

27 G. Zuntz, 'Die Aristophanes-Scholien des Papyri.' Byzantion 13 (1938) 63190; 14 (1939) 545-614.

28 Faulhaber, Hohelied-, Proverbien- und Prediger-Catenen.

29 J.-M. Auwers, L'interprétation du Cantique des cantiques à travers les chaînes exégétiques grecques. Turnhout: Brepols, 2011. 
offers at the end of Malachi a subscription with the date of 535; but this subscription is just after the biblical text and not after the text of the catenae: it probably comes from a manuscript that contained the biblical text alone without the catena. Were there catenae on the New Testament at the beginning of the sixth century? That was the opinion of Joseph Sickenberger in 1901 for Luke, and of Joseph Reuss in 1941 for Matthew and John. ${ }^{30}$ Even so, this was assumed rather than demonstrated by them: as a matter of fact, the basic author quoted by their catenae is John Chrysostom, and not a Palestinian author such as Origen or Eusebius; furthermore Chrysostom is characteristic of the Constantinopolitan period of the catenae. One could argue in favour of the sixth century on the basis of Codex Zacynthius: the older stratum of this palimpsest, written in uncial letters, offers fragments of Luke 1:1-11:33 and, on the external margins, a catena quoting Origen, Eusebius, Titus of Bostra, Basil, Isidore of Pelusium, Cyril of Alexandria, Severus of Antioch, Victor of Antioch and John Chrysostom. Codex Zacynthius is probably posterior to 538, the year of Severus' death. But was it written during the sixth century, as it is often said? David Parker has suggested on palaeographical grounds that it was produced during the seventh century. ${ }^{31}$ The first New Testament catenae date from this period. Moreover, it is likely that the authors of the catenae had begun their project with the Old Testament, as it was considered to be obscure and an outline of the New Testament, whereas the New Testament is clear and is seen as explaining the Old Testament.

As for Procopius, one last issue must be examined: is the Palestinian catena prior or posterior to him? It is certain that he is not the author of that catena, as the ancient data do not attribute to Procopius any work on Psalms. As a matter of fact, all the authors quoted by the Palestinian catena are prior to 460, except for one fragment attributed to Severus of Antioch on Psalm 50:7; this fragment is taken from Against Julian's Additions, which was written between 520 and 527. Therefore, the Palestinian catena cannot be prior to 528, the year during which Procopius died, and probably not prior to 538, the year of Severus' death, as it is likely that an author would not be introduced into a catena before his death. Nonetheless, according to Marcel Richard, Severus' fragment and the fragments of Gregory of Nazianzus on Psalms 2, 21 and 48 were added to the primitive Palestinian

30 J. Sickenberger, Titus von Bostra. Studien zu dessen Lukashomelien. TU nf. 6.1. Leipzig: J. C. Hinrichs, 1901; Reuss, Matthäus-, Markus- und Iohannes-Katenen.

31 D. C. Parker \& J. N. Birdsall, 'The Date of Codex Zacynthius: A New Proposal.' JTS ns 55 (2004) 117-31. 
catena. But there is no Greek manuscript without the above-mentioned fragments. Moreover, the fragments of Gregory on Psalm 21 and of Severus on Psalm 50 can be read in the rewritten form of the catena (Parisinus gr. 139): this means that it is highly likely that these fragments were in the primitive Palestinian catena.

\section{Catenae on Psalms: Historical and Geographical BENCHMARKS}

The first Palestinian catena is the catena that Marcel Richard called the Palestinian catena. The word 'first' means that, in my opinion, there are other Palestinian catenae. Procopius' catenae were composed according to

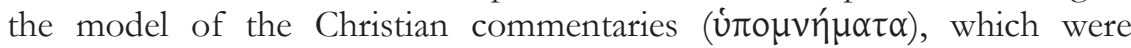
written as a rule on a full page. According to Procopius' model, the first Palestinian catena was composed about 540, maybe in Caesarea Maritima. The quoted authors are Apollinarius, Didymus, Eusebius, Origen and, as complementary authors, Basil of Caesarea, Cyril of Alexandria, John Chrysostom and Theodoret. Some years later, the second Palestinian catena was composed. It is an abbreviated as well as an enriched edition of the first catena; the fragments of the authors of that catena are abbreviated and there are new fragments of the same authors; on the other hand, there is a new author, Hesychius. The third Palestinian catena combines the rewriting of the first Palestinian catena with the second Palestinian catena, at a date which is not certain.

During this first Palestinian stage, there were also what I have called the Scholia-Catenae. Their origin is found in the scriptural Scholia, which have been known since Origen. Unlike the commentaries, the explanations are intermittent; often, they are short, but some of them are more developed. The Scholia were written in one column that was parallel to the other column reserved for the biblical text. This layout contrasts with the Procopius' full-page model. How did the Scholia-Catenae appear? As the Scholia were intermittent, the copists filled in the vacua with scholia from other authors and, later, with fragments belonging to commentaries or homilies. The first Scholia-Catenae date back to the sixth century. Some of them are not prior to the tenth century. They were composed first in Palestine, then throughout the Byzantine Empire. The two-column layout has survived, but, as a rule, it was replaced by the marginal layout: the biblical text was written on the inner margin and the fragments, on the three other margins, that is on the top, the outer side and the bottom. The history of the Scholia-Catenae is too complex to be described here. 
The combining of Procopius' model and the model of the ScholiaCatenae produced what I have called the mixed Palestinian catenae. The layout of these catenae is either that of Procopius or the marginal model. Altogether, fourteen catenae on Psalms at most were created during this first stage.

The second and final stage took place in Constantinople and its dependencies. Its beginning goes back to 650-700. Six characteristics can be described:

1. Increase of the number of catenae. This concerns both the Old Testament and the New Testament also; around forty catenae on Psalms were composed.

2. Change of layout. Until the eleventh century, the marginal model is predominant; from the twelfth century, the full-page model prevails.

3. New authors are quoted, such as Diodore of Tarsus and Theodore of Mopsuestia, but also Byzantine authors, such as Euthymius Zigabenus. Also, new works are quoted: not only commentaries, homilies and scholia on the Psalms, but commentaries, homilies and scholia that quote the Psalms here and there as well as fragments of patristic and Byzantine works where verses of Psalms are quoted.

4. New models appear. The first one consists of the systematic use of John Chrysostom's and Theodoret's works. The second one combines the complete commentaries of two authors such as Thedoretus and Euthymius Zigabenus. The third model is a mix of Procopius' model with the first Constantinopolitan model; it is highly productive: some thirty catenae of that kind were created; among them, there are seven primary catenae that do not use a previous catena among their sources; the others are secondary catenae. Two of the primary catenae deserve a few words: Nicetas' catena is the only catena on Psalms whose author we know and thirty manuscripts present it; in other words, it is the most widely circulated Catena that we know. The Coislinianus 12 quotes Athanasius, Basil of Caesarea, John Chrysostom and Theodore of Mopsuestia; as it has recourse to Photius' corpus of John Chrysostom's homilies on Psalms and as there are three marginal notes written by Photius, Robert Devreesse suggested in 1928 (but not in his later works), that the author of this catena 
was the patriarch Photius; in fact, the catena has only used Photius' corpus.

5. The above-mentioned secondary catenae are very numerous, about twenty-five in total. One can distinguish between child catenae and complex catenae. The former have recourse to only one primary catena with which they mix one or several interpretations; these are thirteen in number. The latter combine at least two primary catenae; five of them are stable, because the combination is the same throughout the Psalter; the six others are variable catenae; that is to say the order of the primary catenae changes in the course of the Psalter or the primary catenae are different through the Psalter.

6. New kinds of catenae appear. The fragmentary catenae select their Psalms and their verses; in the juxtaposed catenae, the sources are not combined but only juxtaposed.

Biblical catenae have had a literary posterity, which, as a rule, scholars do not mention. Made from commentaries, homilies and scholia, catenae themselves are converted into commentaries, homilies or scholia. For instance, Peter of Laodicea wrote his Commentary on Psalms (and other biblical books) thanks to patristic authors and catenae. In this work, dating back to 920, he systematically eliminated author lemmata. Much more must be done for a better knowledge of this literary phenomenon.

\section{Philology Rather Than History?}

The paradigm that I have proposed in the case of the Psalms is rather complex: two stages, the first one in Palestine during the beginning of the sixth century, with three models; the second one in Constantinople from the beginning of the seventh century until the end of Byzantium, with three models also. This complexity is not surprising as there are many different catenae on Psalms, which were written over almost a millenium. Things are less complex in the case of the New Testament, because this corpus is not concerned with the first stage of catenae, in Palestine. Is the same paradigm applicable to both? Either way, some additions and adjustments can be given.

First, where did Procopius get the idea of biblical catenae? The name

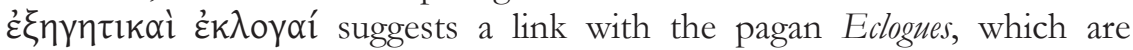
collections of chosen quotations, such as John Stobaeus' Anthology. Such eclogues are thematically organized, however, which is not the case in catenae. The latter follow the order of the scriptural text, as do the 
Christian commentaries and homilies. The pagan equivalent of this is the scholia on Homer, which follow the order of the Homeric text. Actually, patristic extracts and Homeric scholia are very similar. In her PhD in 2006, Mathilde Sütterlin-Aussedat rightly stressed this point. ${ }^{32}$

Second, there is the issue of the authors of the catenae. As we have seen, very few can be mentioned by name: Procopius of Gaza in Palestine and Nicetas of Heraclea in Constantinople, but neither Photius nor Peter of Laodicea, who is a commentator. Thanks to Bernard Flusin, another possible name has been known since 2006: John Mesarites, who wrote a Psalter in 1203 for the emperor Alexios IV Angelos; this psalter probably offered a catena or a commentary on the margins of the manuscript, but we do not know whether John was the author of the catena or the commentary or only a copyist. ${ }^{33}$ However, the psalter was destroyed by the Crusaders. Some other names are attested: in the case of the Twelve Prophets, Philotheos; in the case of Isaiah, Nicholas IV Mouzalon (c. 1070-1152); in the case of the Song of Songs, Proverbs and Ecclesiastes, Polychronios; as a matter of fact, the lemma 'Polychronios' is also present before fragments of the catena on Proverbs-in other words, the author of the catenae quotes himself! This is a disturbing fact, which shows that perhaps Polychronios is not the author of the catenae but only a commentator. Nevertheless, one name can be suppressed: Eusebius is not the author of a catena on the Song of Songs. Is John Droungarios the author of catenae on Isaiah, Jeremiah, Ezekiel and Daniel? His name is given only in the prologue of the catena on Isaiah and only by one manuscript, the Parisinus gr. 159, which is a direct descendant of the Chisianus R VIII 54 and the Vaticanus gr. 1153. As a matter of fact, these ancestors do not offer the name 'John Droungarios', so the authorship may be questionable. Some catenae on the New Testament are attributed to other authors, such as Oecumenius, Olympiodorus and Andreas. Surely the scholars who are working on these catenae will tell us what we are to think about these attributions. All in all, catenae attributions remain obscure, as a rule. That means that we shall continue to name them based on their manuscripts or with descriptive epithets, for instance the catena of the Coislinianus 12 or the ChrysostomicoTheodoretian catena whose main sources are John Chrysostom and

32 M. Aussedat, Les chaînes exégétiques grecques sur le livre de Jérémie (chap. 1-4). Présentation, texte critique, traduction française, commentaire. Unpublished $\mathrm{PhD}$. Paris, 2006.

33 B. Flusin, 'Un lettré byzantine au XII ${ }^{\mathrm{e}}$ siècle: Jean Mésaritès' in Lire et écrire à Byzance, ed. B. Mondrain. Paris: Collège de France-CNRS, 2006, 67-83. 
Theodoret. Nevertheless, it sometimes happens that a geographical epithet can be used, as in the case of the Palestinian catena. But, in my opinion, there are three Palestinian catenae which means that the geographical epithet is not such a good solution for the naming of the catenae. So, philology, in other words manuscripts and descriptive epithets, takes precedence over history, that is proper names and geographical naming.

Thirdly, there is the issue of the Monophysite catenae. In 1956, Marcel Richard suggested that one of the sources of Parisinus gr. 139 was a Catena on Psalms offering fragments of Athanasius, Basil, Cyril, Hesychius, John Chrysostom and Severus of Antioch. ${ }^{34}$ As a matter of fact, Severus did not comment on the Psalms; as Marcel Richard said, 'only a zealous Monophysite could pick up in his works all the allusions to the Psalms'. The catenae therefore had a Monophysite origin and were written in Egypt between Severus' death (538) and the final defeat of the Monophysites (639). In 1986, I proposed calling that catena the second Palestinian catena; it is not identical to Richard's catena, as it provides the so-called Monophysite fragments as well as fragments coming from the first Palestinian catena and fragments from Theodoret. Moreover, I was sceptical about the Monophysite origin of the catena, because Severus' fragments are few, unlike those of Hesychius; as a matter of fact, Hesychius is a Palestinian, which advocates a Palestinian origin. The only argument in favour of the Monophysite origin is that Severus' author lemmata sometimes offer the epithet 'Saint', but this could have been added by a copyist.

The issue was re-examined by Laurence Vianès in 1997 and by Mathilde Sütterlin-Aussedat in 2006, in their PhDs; the former has edited and translated Pseudo-John Droungarios' Catena on Ezekiel (chapters 36-48 only); the latter, the catena of the same author on Jeremiah (chapters 1-4 only). ${ }^{35}$ Laurence Vianès does not hesitate to speak about the Monophysite catena on Ezekiel, in which Severus is called 'Saint'. She suggests that the catena was written either in one of the Enaton monasteries, near Alexandria, between 574 and 639, or in Constantinople, in the vicinity of Theodora, between 538 and 565 . If she is right, the beginning of the second stage of catenae is a little earlier than the years $650-700$, contrary to my opinion. Other catenae could be Monophysite, such as Pseudo-Andrew's

34 Richard, 'Les premières chaînes sur le psautier'.

35 L. Vianès, La chaîne monophysite sur Ezéchiel 36-48. Unpublished PhD. Paris, 1996; Aussedat, Les chaînes exégétiques grecques sur le livre de Jérémie (chap. 1-4). 
catena on Acts which features an author lemma 'Saint Severus', but not the catenae on the Octateuch and Kingdoms, from which this lemma is lacking, even if there is the lemma 'Severus archbishop of Antioch'. As for Mathilde Aussedat, she notes that the catena on Jeremiah gives the epithet 'Saint' to John Chrysostom, Theophilus of Alexandria, Cyril of Alexandria and Severus. From a Monophysite point of view, the presence of Cyril and Severus is expected, but the presence of John Chrysostom and Theophilus is very surprising. The Monophysite hypothesis does not explain all the features of the catena on Jeremiah. So, the historical approach of the catenae once again has to be relativized in favour of the philological one. History remains the ideal; philology, the harsh reality. 



\title{
4. CATEnae AND THE ART Of MeMory
}

\author{
WILLIAM LAMB
}

\section{INTRODUCTION}

The compilation of catenae was one of the distinctive contributions of the Byzantine world to the development of biblical commentary. ${ }^{1}$ Found in hundreds of manuscripts and drawing on an established tradition of writing scholia and comments in the margin or between the lines of a text, these extensive anthologies present the biblical text embedded within a 'chain' or 'catena' of the writings of a diverse range of commentators from the first six centuries of the common era. That these texts can appear in radically different forms underlines the fact that the manuscript tradition is often chaotic and unpredictable. No two copies are ever exactly the same.

This presents the scholar with a number of challenges. Confronted by such a varied manuscript tradition, it is perhaps no surprise that the study of catenae is sometimes regarded as 'a bewildering task'. ${ }^{2}$ New Testament critics have been industrious in assessing the authenticity of the biblical texts offered in these manuscripts, but they have been more cautious about embarking on further research of the marginalia. The consequence is that the study of the New Testament catenae remains very much in its infancy. And yet, the material contained within catenae presents a wealth of evidence about the ways in which Byzantine scholars engaged with the writings of the New Testament.

Byzantine scholarship is often dismissed as unworthy of our attention, and this judgment, combined with the practical difficulty of making sense

\footnotetext{
1 The word 'catena' corresponds to the later Byzantine form $\sigma \varepsilon \iota \rho \alpha$ ('chain'), but

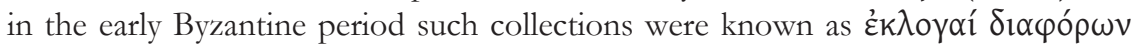
$\varepsilon \dot{\rho} \mu \eta \varepsilon \cup \tau \tilde{\omega} v$.

2 Charles Kannengiesser, ed., Handbook of Patristic Exegesis: The Bible in Ancient Christianity. Leiden: Brill, 2006. Quotation from page 978.
} 
of the manuscript tradition, has tended to distract scholars from a more sustained engagement with catenae. This dismissive attitude is partly due to an abiding suspicion of anthologies. Both Manlio Simonetti and Frances Young have argued that the development of Christian commentary in antiquity was heavily influenced by Greek conventions of literary and philosophical exegesis. ${ }^{3}$ And yet, given that training in rhetoric was only available to a tiny elite within the ancient world, it is sometimes difficult to assess just how pervasive these conventions were. Teresa Morgan suggests that the anthology was a genre which transcended the literature of high and popular culture. ${ }^{4}$ But the use of anthologies could be a mixed blessing. Robert Kaster points out that the compilation of anthologies carried with it inherent pedagogical weaknesses in offering little in the way of systematic knowledge but 'only a memory of disjointed but edifying vignettes'. ${ }^{5}$ The sense of fragmentation that accompanied the compilation of anthologies could sometimes be debilitating. Indeed, Françoise Petit has noted the 'astonishing eclecticism' of the compilers of catenae in their selection of sources from Philo of Alexandria to Severus of Antioch. ${ }^{6}$ Extracts from the writings of John Chrysostom sit side by side with a selection of passages drawn from the writings of Origen, Cyril, Gregory of Nyssa, Basil,

3 Manlio Simonetti, Biblical Interpretation in the Early Church: An Historical Introduction to Patristic Exegesis. Edinburgh: T. \& T. Clark, 1994, 4; Frances Young, Biblical Exegesis and the Formation of Christian Culture. Cambridge: CUP, 1997, 169-76.

${ }^{4}$ Teresa Morgan, Literate Education in the Hellenistic and Roman Worlds. Cambridge: CUP, 1998, 122.

${ }^{5}$ Robert Kaster, Guardians of Language: The Grammarian and Society in Late Antiquity. Berkeley: California UP, 1988, 12. In his classic travel book Eothen, Alexander Kinglake offers a similar perspective on the perils of a fragmented, narrow schooling in his lament over his own schooldays: 'thin meagre Latin (the same for everybody), with small shreds, and patches of Greek, is thrown like a pauper's pall over all your early lore; instead of sweet knowledge, vile, monkish, doggrell grammars, and graduses, Dictionaries, and Lexicons, and horrible odds and ends of dead languages are given you for your portion, and down you fall, from Roman story to a three inch scrap of 'Scriptores Romani,'- - from Greek poetry, down, down to the cold rations of 'Poetae Graeci,' cut up by commentators, and served out by schoolmasters!' (Alexander Kinglake, Eothen. First published in 1896; London: Century, 1982, 31).

${ }^{6}$ Françoise Petit, 'Les «chaînes» exégétiques grecques sur la Genèse et l'Exode. Programme d'exploration et d'édition', in Studia Patristica XII, ed. E.A. Livingstone. Berlin: Akademie, 1975, 46. 
Didymus, Theodore, Theodoret, Apollinarius and Severus. In catenae, we sometimes find a range of opinions about the interpretation of a particular passage. We find Alexandrian and Antiochene voices set side by side. In his study of Procopius of Gaza, the fifth-century teacher often credited with the creation of this particular genre of biblical commentary, Bas ter Haar Romeny notes that the choice of sources offer some insight into 'the kind of exegesis Procopius and his predecessors were interested in'. ${ }^{7} \mathrm{He}$ asserts that Procopius' choice of 'Antiochene' exegetes alongside 'Alexandrians' suggests that 'the different schools of exegesis were treated equally, and that doctrinal issues played no role'. ${ }^{8}$

Robert Browning remarks on the patterns of education in the Byzantine world, which he describes in terms of 'an age of uncreative erudition, of sterile good taste'. ${ }^{9}$ The intellectual climate 'all conspired to turn the young away from a dangerously critical attitude, and towards an elegant, learned and sterile mandarinism'. ${ }^{10}$ Similarly, in Biblical Interpretation in the Early Church, Manlio Simonetti speaks of the 'progressive sterility' of catenae, which was a consequence of the fact that their compilers were so fearful of straying into the doctrinal controversies of previous centuries. ${ }^{11}$ Commenting on the brevity of one of Theodoret's commentaries, Simonetti suggested that 'perhaps this is symptomatic of a certain weariness among the Christian community for exegetical works of large dimensions-a foretaste of that demand for anthologies and easily readable manuals which is characteristic of literary and cultural decline in general'. ${ }^{12}$ One is left with

7 Bas ter Haar Romeny, 'Procopius of Gaza and his Library,' in From Rome to Constantinople: Studies in Honour of Averil Cameron, ed. H. Amirav and B. ter Haar Romeny. Leuven: Peeters, 2007, 189.

8 ter Haar Romeny reinforces this perspective of 'doctrinal neutrality' when he offers the following comment: 'The catenists and Procopius were mostly interested in the solution of problems and questions posed by the text: ... There is hardly room for the philosophical, spiritual, and doctrinal here. As Petit remarks, on the basis of the Catena on the Octateuch one would not suspect that the majority of the exegetes quoted were involved in the Trinitarian and Christological debates of their era.' (ter Haar Romeny, 'Procopius of Gaza and his Library', 189).

9 Robert Browning, 'Enlightenment and Repression in Byzantium in the Eleventh and 'Twelfth Centuries' in Studies in Byzantine History, Literature and Education. London: Variorum, 1977, 5.

10 Browning, 'Enlightenment and Repression', 17.

11 Simonetti, Biblical Interpretation in the Early Church, 111.

12 Simonetti, Biblical Interpretation in the Early Church, 76. 
the unmistakable impression that the 'literary encyclopaedism' characteristic of catenae provides further evidence of the intellectual indolence of the Byzantine world. ${ }^{13}$ In all this, we hear echoing strains of Edward Gibbon's sharp criticism:

The Greeks of Constantinople ... held in their lifeless hands the riches of their fathers, without inheriting the spirit which had created and improved that sacred patrimony: they read, they praised, they compiled, but their languid souls seemed alike incapable of thought and action. In the revolution of ten centuries, not a single discovery was made to exalt the dignity or promote the happiness of mankind. Not a single idea has been added to the speculative systems of antiquity, and a succession of patient disciples became in their turn the dogmatic teachers of the next servile generation. ${ }^{14}$

Undeniably, this perspective has coloured our understanding of New Testament catenae. Yet I want to argue that this critique is not always helpful. While it is undeniable that there were aspects of the literary culture of the Byzantine world which were formalistic and flat, it is still worth considering whether every literary artefact has to offer a spark of tantalising originality in order to display the intellectual virtuosity of its author. Such an expectation can sometimes be rather wide of the mark. As Richard and Mary Rouse suggested some years ago:

The common, everyday handbooks of the later Middle Ages, ubiquitous works existing in hundreds of copies, have for the most part been bypassed by modern scholarship because they do not stand out as original thought or great literature. It is natural and generally more fruitful to single out the creative genius, to concentrate on the intellectual high points. ... Yet, obviously, we do not come to know the ordinary world of the literate populace of the thirteenth and fourteenth centuries only through a study of its extraordinary figures. Conversely, we cannot properly know the exceptional figures of late medieval thought and letters without some knowledge of the tools with which they worked, the manuals and reference books that constituted an

13 This helpful phrase comes from page 39 of Romilly J.H. Jenkins, 'The Hellenistic Origins of Byzantine Literature', Dumbarton Oaks Papers 17 (1963) 3752.

14 Edward Gibbon, The History of the Decline and Fall of the Roman Empire. Vol. 10. Dublin: White, 1788, 141. 
integral part of their training and comprised ever after a portion of their intellectual equipment. ${ }^{15}$

If a catena is basically an exegetical handbook, then in studying such a text, we need to think carefully about its purpose and its subsequent use. But the inference of all this should be clear: to expect a catena to present insights of sparkling originality in the interpretation of scripture is perhaps to invite disappointment. We cannot expect a common, everyday classroom textbook to stand out as great literature.

Nevertheless, some reflection on what exactly the compilers of catenae were attempting to do in drawing together an anthology of the writings of a varied and disparate group of commentators may yet prove fruitful. While there may be some wisdom in lowering our expectations, there may yet be more to these anthologies than a sterile and uncreative repetition of extracts from earlier authorities. Provoked in part by the work of Mary Carruthers and others, I will suggest that we might begin to challenge some of the prevailing assumptions made about anthologies by reflecting on the role of memory in the medieval imagination. When considered in the context of the development of artificial memory devices, we may recognise that catenae were not simply depositories of random information. Their compilation may have also played a part in the development of commentary and the craft of thought.

\section{THE ART OF MEMORY}

In the year 855, Photius, the Patriarch of Constantinople and one of the most learned men of his age, published the Bibliotheca, an extended review of almost three hundred different books, all of which he professed to have read. The Bibliotheca presents a striking example of the literary encyclopaedism characteristic of Byzantine literature. More importantly, it offers an important insight into the origins of catenae. Photius provides the following summary of the exegetical scholia of Procopius of Gaza:

I read the exegetical scholia of Procopius the Sophist On the Octatench of the Old Testament, as well as On 1-2 Kings and also On 1-2 Chronicles. This commentator is detailed and extensive, but he does not waste time in

15 Richard and Mary Rouse, Preachers, Florilegia and Sermons. Studies on the Manipulus florum of Thomas of Ireland. Toronto: Pontifical Institute for Medieval Studies, 1979, ix. 
unnecessary and irrelevant digressions; instead he records repeatedly differences of opinion on the same questions (Photius, Bibliotheca 206). ${ }^{16}$

Nigel Wilson has noted that 'the circumstances in which Photius wrote the Bibliotheca have been a topic for speculation and argument for a very long time'. ${ }^{17}$ The letter of dedication to his brother Tarasius at the beginning of the book suggests that Photius wrote it during a diplomatic mission to the Arab government in Baghdad. Some scholars, however, have suggested that this is problematic: where did he get hold of these books? No suitable library of almost three hundred books was available in Baghdad. And yet Photius himself seems to suggest that the contents of this book were preserved in his memory. Wilson suggests that regardless of the perennial debate about where exactly Photius wrote the book, we may still need to take his claim to have a remarkable memory seriously.

Wilson's comments provoke some reflection on the art of memory. They also call to mind an interesting parallel in a description of the life of Thomas Aquinas, recorded by a contemporary soon after his death:

His memory was extremely rich and retentive: whatever he had once read and grasped he never forgot; it was as if knowledge were ever increasing in his soul as page is added to page in the writing of a book. Consider, for example, that admirable compilation of Patristic texts on the four Gospels which he made for Pope Urban [the Catena aurea or 'Golden Chain'] and which, for the most part, he seems to have put together from texts that he had read and committed to memory from time to time while staying in various religious houses. ${ }^{18}$

Aquinas was noted for his prodigious memory (and it is perhaps worth noting as an aside that no-one suggests that Thomas' compilation of a catena was evidence of intellectual indolence). Compiled around the year 1263, the Catena aurea draws on a combination of Greek and Latin authorities and betrays some dependence on Greek catenae. In The Book of Memory, Mary Carruthers notes the fact that Aquinas appears to have memorised huge

16 The translation is adapted and revised from Photius, The Bibliotheca: a selection translated with notes by N.G. Wilson. London: Duckworth, 1994, 185.

17 Nigel Wilson, 'The Composition of Photius' Bibliotheca.' Greek, Roman, and Byzantine Studies 9.4 (1968) 451.

18 'The Life of St Thomas Aquinas' by Bernardo Gui, quoted by Mary Carruthers, The Book of Memory: A Study of Memory in Medieval Culture. Cambridge: CUP, 2008, 3. 
swathes of patristic commentary in order to compile his catena. In her study of the importance of memory in medieval culture and the memory techniques which medieval thinkers developed, she argues that two characteristics of the Catena aurea were consistent with some of these techniques: first, the inclusion of the names of the authors before their testimony was an aid to memorial retention, and secondly, the authorities were 'chained, or hooked, together by a particular Biblical phrase. Thus the commentary entirely follows the sequence of the main text, each chapter division of the Gospel book forming a division of the Catena, and each verse (actually its unnumbered phrases and clauses) quoted separately with a string of relevant comments following it'. ${ }^{19}$ Although it is very difficult to reconstruct the origins of catenae in the East, we may see similar memory techniques at work given the way in which the names of the authors are recorded and passages are chained together in order to follow the sequence of the main text.

Intriguingly, Carruthers also notes the comment of Marie-Dominique Chenu that the Catena aurea constitutes a 'concatenation of patristic texts cleverly coordinated into a running commentary'. ${ }^{20}$ This reminds us that the enterprise of compiling an anthology is not arbitrary. Memory is selective. While catenae may be characterised in terms of an 'astonishing eclecticism', their use of both Alexandrian and Antiochene voices should not lead us to imagine that the selection of these texts was completely haphazard and chaotic, nor should it lead us to conclude that these texts are characterised by a 'doctrinal neutrality'. Just as Chenu could see that Aquinas drew together and co-ordinated patristic texts into a running commentary, we can see a similar pattern elsewhere in the compilation of catenae.

\section{The Lord's Supper in the Catena in Marcum}

A consideration of the scholia on the institution of the Lord's Supper, Mark 14:22-4, in the Catena in Marcum may serve to illustrate the point. The manuscript tradition presents a sequence of seven anonymised scholia, drawn from a number of different authorities, including John Chrysostom, Apollinarius of Laodicea, Theodore of Mopsuestia, and Cyril of Alexandria. The range of authorities cited draws on both 'Antiochene' and 'Alexandrian' sources, and yet the argument presented betrays clear doctrinal commitments in terms of the compiler's understanding of both

19 Carruthers, The Book of Memory, 6.

20 Carruthers' translation of Marie-Dominique Chenu, Introduction à l'étude de St. Thomas d'Aquin. Paris: Vrin, 1974, 279-80, quoted in The Book of Memory, 6. 
the eucharist and Christology, questions which had been the source of considerable disagreement in the course of the Nestorian controversy.

The comments on Mark 14:22-4 unfold in the light of three distinct but related exegetical questions: was Judas present at the institution of the Lord's supper? Did Judas receive the body and blood of Christ? And how do the answers to these questions inform the Church's understanding of the effect of participating in the eucharist? The first passage is drawn from John Chrysostom's Homilies on Matthew. ${ }^{21}$ Given that Jesus has foretold Judas' act of betrayal in the previous passage (Mark 14:17-18), Chrysostom is concerned to address the way in which Judas was affected by partaking in the divine mysteries. He notes that according to Mark 'the betrayer was unaffected, and having been admitted to the most holy table, he did not change'.22 Clearly, this presented Chrysostom with something of a conundrum: if Judas had received these tokens of the body and blood of Jesus Christ, why were they not a means of grace and transformation for him? Chrysostom uses a common device in Christian apologetic by drawing on the witness of one of the other Gospels in order to complement the lack of detail presented in Mark. His response serves as an intriguing illustration of the way in which the relationship between the Gospels was often perceived in complementary rather than contradictory terms. ${ }^{23}$ He notes that Luke says that it was only afterwards that 'Satan entered him' (Luke 22:3). For Chrysostom, this is sufficient assurance that Mark is 'not suggesting that the body has no effect'. By contrast, Apollinarius draws on the witness of the Fourth Gospel to suggest that 'Judas went out beforehand' (John 13:27-30). ${ }^{24}$ He neatly sidesteps the issue presented by Chrysostom by insisting that the betrayer 'would not have received the token of communion for salvation'. In Apollinarius' view, the Lord had borne many things, but this was one thing 'he would not tolerate'. The passage continues with a reflection on the way in which Jesus handed on instructions to the disciples for performing the mystery of the new covenant: in receiving the tokens of the body and blood of Christ, they

${ }^{21}$ Chrysostom, Homiliae in Matthaeum 82.1 (PG 58.737.35-48).

22 William Lamb, The Catena in Marcum. A Byzantine Anthology of Early Commentary on Mark. Leiden: Brill, 2012, 421.

23 For further elaboration of this point, see Francis Watson, Gospel Writing: $A$ Canonical Perspective. Grand Rapids: Eerdmans, 2013.

24 Apollinarius, Fragmenta in Matthaeum Fr. 133.1-3 (Joseph Reuss, MatthäusKommentare aus der griechischen Kirche. Berlin: Akademie Verlag, 1957, 46). 
were participating in the reality of the Passion, which 'came to pass for both the common salvation of all people and for the forgiveness of their sins'. ${ }^{25}$

In 'Eucharist and Christology in the Nestorian Controversy', Henry Chadwick pointed out that there was an intimate connection in the theology of Cyril of Alexandria between his treatment of the eucharist and his understanding of the person of Jesus Christ. ${ }^{26}$ Indeed, he suggests that 'the real nerve-centre of Cyril's objection to Antiochene doctrine' was not simply Christological, but a nexus of issues 'relating to the doctrines of the and the atonement'. ${ }^{27}$ In the Catena in Marcum, the scholia which follow reveal some of the significant differences between Theodore of Mopsuestia and Cyril of Alexandria on their understanding of the eucharist, differences which reflect in turn their respective understandings of Christology. The catena presents a brief extract identified by Joseph Reuss as a fragment of Theodore's commentary on Matthew. ${ }^{28}$ In this passage, Theodore downplays questions about the exact substance of the elements, but instructs his readers simply 'to believe that these things are those things' ${ }^{29}$ The comment is tantalisingly brief and does not afford any detailed insight into Theodore's perspective. Given his caution, however, about asserting that the divine and human natures were substantially united to one another on the grounds that this would compromise the fullness of Christ's humanity, we might infer that there is a corresponding reticence about describing the exact substance of the elements in the eucharist. ${ }^{30}$ And yet, in

${ }^{25}$ Lamb, The Catena in Marcum, 421-2.

${ }^{26}$ Henry Chadwick, 'Eucharist and Christology in the Nestorian Controversy', JTS ns 2.2 (1951) 145-64.

27 Chadwick, 'Eucharist and Christology', 153. For further discussion of these questions, see also Ellen Concannon, 'The Eucharist as Source of St Cyril of Alexandria's Christology', Pro Ecclesia 18.3 (2009) 318-36; John McGuckin, Saint Cyril of Alexandria and the Christological Controversy. Leiden: Brill, 2004, 187-8; Thomas Weinandy and Daniel Keating, ed., The Theology of St Cyril of Alexandria: A Critical Appreciation. London: Routledge, 2003; Lawrence Welch, Christology and Eucharist in the Early Thought of Cyril of Alexandria San Francisco: Catholic Scholars Press, 1994.

${ }^{28}$ Theodore of Mopsuestia, Fragmenta in Matthaeum Fr. 106.3-5 (Reuss, Matthäus-Kommentare, 134).

${ }^{29}$ Lamb, The Catena in Marcum, 422 n. 67.

${ }^{30}$ For a discussion of Theodore's understanding of the eucharist and a summary of recent scholarship, see Frederick McLeod, "The Christological Ramifications of Theodore of Mopsuestia's Understanding of Baptism and the Eucharist', JECS 10.1 (2002) 37-75. 
spite of the reticence attributed to Theodore, the compiler of the Catena in Marcum continues with two extended extracts from Cyril of Alexandria.

Cyril recognised that the language used to describe the identity of Jesus Christ needed to demonstrate the profound intimacy of the connection between the two realities of his divinity and humanity. Cyril's own language is often difficult to understand, as he frequently resorts to paradox in order to encapsulate the mystery. As John McGuckin points out, phrases like 'suffering impassibly' may appear nonsensical or meaningless, but to draw such a conclusion neglects the fact that Cyril was seeking to state "both sides of the paradox with equal force and absolute seriousness of intent, refusing to minimise either reality'. ${ }^{31}$ The reason why this is so important for Cyril is that the incarnation describes the extraordinary transformation of human nature. The appropriation and transformation of human nature in the incarnation is an intimation of the Word's 'appropriation of human nature at large'. ${ }^{32}$ The separation between God and humanity is overcome and the union between God and humanity is restored. For Cyril, 'Christology is the paradigm of all salvation'. ${ }^{33}$ The believer's participation in Christ comes into particular focus in the celebration of the eucharist:

The theme which is recurrent throughout Cyril's exegetical and polemical writings is that in the eucharist we receive the flesh of Christ, the selfsame body that he took of Mary. Christ said: This is my body.

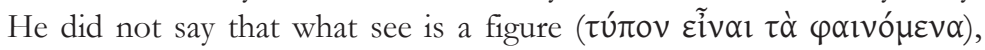
but rather that the elements are truly transformed into the flesh and blood of Christ so that by partaking we receive the lifegiving and sanctifying power of Christ. ${ }^{34}$

We should not be surprised that Cyril's understanding of Christology should lead him to hold as high a view of the Word's saving presence in the eucharist as his view of the Word's presence in the incarnate Christ. When we look at the extracts from Cyril's writings selected in the Catena in Marcum, this point is made with considerable force. The first passage is an extract from Cyril of Alexandria's commentary on Luke:

For the life-giving Word of God, having united himself to his own flesh in a way which he only knows, declares the flesh to be 'life-giving': for

31 McGuckin, Saint Cyril of Alexandria and the Christological Controversy, 185.

32 McGuckin, Saint Cyril of Alexandria and the Christological Controversy, 187.

${ }^{33}$ McGuckin, Saint Cyril of Alexandria and the Christological Controversy, 187.

34 Chadwick, 'Eucharist and Christology', 153. 
he himself said, 'Truly I say to you, whoever believes in me has eternal life. I am the bread of life: and whoever eats this bread will live for eternity. And the bread that I will give is my flesh, [given] for the life of the world. Truly I say to you, if you do not eat the flesh of the Son of Man, and drink his blood, you have no life in yourselves' (John 6:51-3). Surely then when we do this, we have life in ourselves, having been made one with him and abiding in him: and also having him in ourselves. ${ }^{35}$

The following passage, from Cyril's commentary on Matthew, emphasises that through participation in the eucharist, the believer receives the 'lifegiving blessing' of salvation: ${ }^{36}$

For it was necessary for him through the Holy Spirit to be in us divinely, and to be intimately united, as it were, with our bodies through his holy body and through his precious blood: which indeed also we have held [in our hands] in the form of bread and wine as a life-giving blessing: and in order that we may not be struck with fear by seeing both the flesh and the blood set forth on the holy tables of churches, he submits as God to our weaknesses and he sends the power of life into the Eucharistic elements, and he transforms them into the energy of his own body in order that we may hold them for the purpose of participation [in the life of God] which is life-giving.

For Chadwick, the key phrase 'his own body' affirms that 'every eucharist is a reincarnation of the Logos who is there $\pi \alpha \alpha^{\prime} \lambda v \mathcal{\varepsilon} v \sigma \omega \dot{\mu} \mu \alpha \tau$, and whose $i \delta i ́ \alpha$ $\sigma \alpha ́ \alpha \xi$ is given to the communicant'. ${ }^{37}$ Clearly, such a perspective throws into sharp relief the questions about whether Judas was present for this sacred meal or not.

This brief sequence of six scholia presents the reader with a variety of different opinions. Nevertheless, the catenist did not simply conserve material uncritically. These comments relate to and inform one another, and they have been heavily edited. The question about Judas' presence at the Lord's Supper presents an opportunity for further reflection about the effects of participating in the holy mysteries. As Chenu recognised in his

${ }^{35}$ Lamb, The Catena in Marcum, 422. The passage can also be found in Cyril of Alexandria, Commentarii in Lucam (in catenis) (PG 73.909.25-39).

36 Cyril, Commentarii in Matthaeum Fr. 289.12-22 (Reuss, Matthäus-Kommentare, 255).

${ }^{37}$ Chadwick, 'Eucharist and Christology', 155. 
reading of the Catena aurea, the compiler of the Catena in Marcum is also selecting a range of different elements in order to create a running commentary which betrays a distinctive point of view. The material is drawn together in such a way as to reinforce and underline Cyril of Alexandria's perspective. This does not appear to be an exercise in 'doctrinal neutrality'.

There is a sense in which modern commentators may have underestimated the creativity involved in this process. As Mary Carruthers points out, we sometimes conclude from the emphasis on 'memory' and 'recollection' in medieval accounts of religious meditation or literary composition that "medieval people had no concept at all of "creativity" in our sense and were devoted to a more of less slavish reiteration of other people's creations'. ${ }^{38}$ We imagine that the mental faculties of 'observation' and 'imagination' are the essential elements in the process of composition. Memory has no place here. And yet Carruthers argues that memory, with the ordering and sequencing of information, is an essential stage in the process of composition. Memory is, in her words, 'a construction machine for invention'. ${ }^{39}$

\section{The Distorting Mirror of THE Scholiastic Tradition}

The fact that these disparate sources have been moulded into a running commentary should also alert us to what Nigel Wilson has described as the 'distorting mirror of the scholiastic tradition'. ${ }^{40}$ In The Ancient Critic at Work, René Nünlist notes the way in which Greek scholia have often been ignored in discussions about the development of literary criticism in the ancient world. He argues that their study has also suffered from 'an overemphasis on Quellenforschung', which causes scholars to expend an enormous amount of energy in attributing the individual scholium to a particular source without actually pausing to consider 'the literary phenomenon under discussion and its potential complexities'. ${ }^{41}$ One might make similar observations about the study of catenae. In his authoritative essay on the

38 Mary Carruthers, The Craft of Thought: Meditation, Rhetoric and the Making of Images, 400-1200. Cambridge: CUP, 1998, 70.

${ }^{39}$ Carruthers, The Craft of Thought, 81.

40 Nigel Wilson, 'Scholiasts and Commentators', Greek, Roman, and Byzantine Studies 47 (2007) 39-70; quotation from 68.

41 Rene Nünlist, The Ancient Critic at Work: Terms and Concepts of Literary Criticism in Greek Scholia. Cambridge: CUP, 2009, 4. 
exegetical traditions surrounding the emergence of catenae, Robert Devreesse noted the dominance of source-critical approaches to the study of catenae: 'The Berlin Academy, when it decided to restore the corpus of works of the Greek Fathers of the first three centuries, recognised clearly that going through the catenae was an essential preliminary task'. ${ }^{42}$ The work of Joseph Reuss provides ample evidence of this kind of approach. His research was focussed principally on the catenae on the Gospels. In the light of his analysis of the manuscript tradition, he published more substantial volumes reconstituting the 'lost' commentaries of early Christian theologians in separate volumes on Matthew, Luke, and John. ${ }^{43}$ Reuss' work represents a remarkable achievement principally because the attribution of various scholia to their original authors is not as straightforward as it might at first appear: just as scribes may be mistaken about the identity of the catenist, occasionally they are also mistaken about the identity of the author of an original scholium.

Indeed, the compilers of a catena were not averse to altering or abbreviating its content: for example, a large proportion of the material from John Chrysostom's homilies on Matthew has been adapted and changed in the Catena in Marcum. ${ }^{44}$ Inevitably, this is a consequence of the need to adapt the material in order to follow the contours of Mark's narrative. It does indicate, however, that we need to be cautious about relying too heavily on the evidence of catenae in order to reconstitute 'lost' commentaries. To paraphrase Gibbon, Byzantine scholars were not simply 'content to admire and copy the oracles of antiquity'. They adapted them for their own purposes. For this reason, we should be wary of simply using catenae as a farm for sources. As Devreesse argued forcefully, 'one should study a collection for what it is, without worrying about what it could yield'. ${ }^{45}$

42 Robert Devreesse, 'Chaînes exégétiques grecques.' Dictionnaire de la Bible, Supplément I. Paris: Letouzey \& Ané, 1928, col. 1084-1233; quotation from 1099.

${ }^{43}$ Joseph Reuss, Matthäus-, Markus-, und Johannes-Katenen nach den handschriftlichen Quellen untersucht. NTAbh 18.4-5. Münster: Aschendorff, 1941; Joseph Reuss, Matthäus-Kommentare aus der griechischen Kirche. TU 61. Berlin: Akademie, 1957; Joseph Reuss, Johannes-Kommentare aus der griechischen Kirche. TU 89. Berlin: Akademie, 1966; Joseph Reuss, Lukaskommentare aus der griechischen Kirche. TU 130. Berlin: Akademie, 1984.

44 Cf. Lamb, The Catena in Marcum, 43-4.

45 Devreesse, 'Chaînes exégétiques grecques', 1098. 


\section{THE DEFICIENCIES OF MEMORY}

While such observations should cause us to pause and think about the kind of methods and approaches we adopt in making sense of catenae as literature, the account of Thomas Aquinas' extraordinary feat in remembering the disparate elements of the Catena aurea should also challenge us to reflect on the origins and compilation of these distinctive texts. They appear to have been created for those who were not blessed with a similar capacity for remembering the writings of the fathers. Indeed, Mary and Richard Rouse have argued that the production of anthologies and concordances and the creation of 'artificial devices' was a direct consequence of 'the insufficiency of memory as a finding device', and became crucial with the growth and development of schools, particularly cathedral schools. ${ }^{46}$ There 'the time for instruction was limited, in comparison with the lifelong immersion in prayerful reading that distinguished monastic learning. ${ }^{47}$ They suggest that 'the major collections of the twelfth century-the Gloss, the Decretum, the Sentences-were in effect "finding devices" in themselves. For example, one did not need to search all the literature, both patristic and canonical, on a given question of law, because Gratian had already done the job.' 48

Again, similar observations can be made about the production of catenae, particularly if we consider the career of one of the most prolific compilers of catenae of the eleventh century, Nicetas of Heraclea.

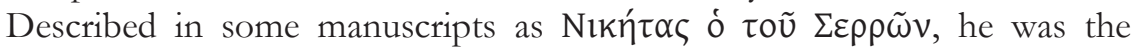
nephew of Stephanos, Bishop of Serrae in Macedonia. Nicetas became a teacher in the Patriarchal School, which was established from the end of the eleventh century. Nicetas began his career as 'proximos' (deputy head) of the school of Chalkoprateia, and by the 1080s was 'deacon and teacher of the Great Church' in Constantinople. Browning notes that one of the most significant innovations in the eleventh century was the development of a triad of teachers 'at the head of the Patriarchal School - the teachers of the Psalter, the Apostle and the Gospel'. ${ }^{49}$ It is perhaps no accident that Nicetas produced catenae on the Psalms, the Pauline Epistles, and each of the

46 Richard and Mary Rouse, Authentic Witnesses: Approaches to Medieval Texts and Manuscripts. Notre Dame: Notre Dame UP, 1991, 196.

${ }^{47}$ Rouse and Rouse, Authentic Witnesses, 196.

48 Rouse and Rouse, Authentic Witnesses, 196.

49 Browning, 'Enlightenment and Repression', 15. 
canonical Gospels. ${ }^{50}$ This suggests that he compiled his catenae principally as a resource for teaching in the Patriarchal School. Note, however, the judgement of Browning in his study of this School, who describes Nicetas as 'a conscientious compiler and an ingenious versifier, rather than an original mind'. 51

\section{MEMORY AND THE ORIGINAL MIND}

This brings us neatly back to the question of 'originality'. In her study of the Glossa ordinaria, Lesley Smith points out that 'the Gloss was used by different people in different ways, at different times and in different places. There is not a single "purpose" we can assign to the Gloss, one thing that it was "for"; rather, part of the Gloss's continuing success was that it proved itself adaptable to the needs of various users in various contexts." 52 Similarly, catenae may have offered a range of practical uses in the class room. Some teachers and older students may have read out portions from the Fathers verbatim to provide the most basic Bible lectures for beginners. Others may have found in catenae a convenient crib to lend a few authoritative witnesses to a sermon or treatise. Alternatively, it may have served to present a lot of past commentary in order for it to be put aside so that the class could take it for granted and move on to a new perspective. Just as catenae laid out 'differences of opinion on the same questions' (Photius, Bibliotheca 206) and presented a kind of staged conversation about the exegesis of the biblical text, they may also have played a key role in enabling commentators to remember the contours of established debate and to stimulate further reflection on the density of meaning within the text.

In Authentic Witnesses: Approaches to Medieval Manuscripts and Texts, Mary and Richard Rouse note that 'a formal florilegium ... is not an idiosyncratic notebook of random jottings, but a consciously created selection of excerpts, made for a purpose, and often surviving in more than one copy to confirm the fact that-however much it may fall short of one's preconceived standards — this is a piece of literature' ${ }^{53}$ One could make a

${ }^{50} \mathrm{He}$ also produced catenae on Job and on the four Major Prophets.

51 Robert Browning, 'The Patriarchal School at Constantinople in the Twelfth Century' in Studies in Byzantine History, Literature and Education. London: Variorum, $1977,17$.

52 Lesley Smith, The Glossa Ordinaria: the Making of a Medieval Bible Commentary. Leiden: Brill, 2009, 193.

${ }^{53}$ Rouse and Rouse, Authentic Witnesses, 6. 
very similar observation about the production of catenae. While catenae may not furnish us with insights of startling originality, we need to recognise that these anthologies are far from random. The compilers have drawn on a range of comments in order to create their own running commentary. If we start thinking of a catena as an artificial memory device, then the selection of these disparate and eclectic sources may not be quite as idiosyncratic as they at first appear. In reflecting on the development of catenae in this way, we may begin to put aside our prejudices about 'originality' and, eschewing the temptation simply to dismember a catena in order to reconstruct a number of lost sources, we may begin to recognise that a catena is a piece of literature which is in itself worthy of our attention. 


\title{
5. Parsing Paul: Layout and Sampling Divisions In PAUline CommentaRies
}

\author{
BRUCE MORRILL \& JOHN GRAM
}

\section{INTRODUCTION}

After several decades of working exclusively on the Gospels, for the last few years the International Greek New Testament Project (IGNTP) has been making preparations for the Editio Critica Maior volumes of the Pauline Letters. As well as preparing for individual letters, we are also interested in the edition of the Pauline corpus; several IGNTP committee members, including Ulrich Schmid and Michael Holmes, have addressed this in recent years, pointing out the effect of the history of the collection on the textual tradition of individual letters. ${ }^{1}$ In this paper, we would like to share some of the various data pertaining to the collection and transmission of the corpus gathered as we prepare for this work, particularly regarding the textual content and format. Similarly, just as there is an edition of the Pauline corpus, there are also editions of commentaries. We will focus on material that overlaps those editions.

\section{CONTENTS OF THE EDITION}

The first question about an edition is: what are its contents? The development of the New Testament Virtual Manuscript Room (NTVMR) at the Institut für neutestamentliche Textforschung (INTF), Münster, has

1 Ulrich B. Schmid, 'Marcion and the Textual History of Romans: Editorial Activity and Early Editions of the New Testament', in Studia Patristica LIV. Biblical Quotations in Patristic Texts, ed. Laurence Mellerin \& H.A.G. Houghton, Leuven: Peeters, 2013, 99-113; Michael W. Holmes, 'Creation, Transmission, Collection: Reflections on the Textual History of the Pauline Corpus', a paper presented at the General Meeting of the Studiorum Novi Testamenti Societas, 2014. 
given us the opportunity systematically to gather the contents and order of the letters in the Greek manuscripts. ${ }^{2}$ While scanning and checking photographs, we have built a database of these characteristics. ${ }^{3}$

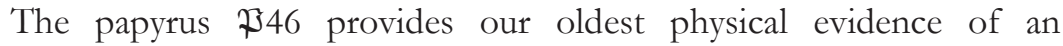
extensive collection. Of the fourteen letters that have strong candidacy for being part of the early editions of the Pauline corpus, it is well known that 346 has nine, lacking 2 Thess, 1 \& 2 Timothy, Titus, and Philemon. The missing portion of $¥ 46$ probably had additional letters, but it is unlikely to have had all five of these. The order of the letters present is also unusual:

P46: Rom, Heb, 1-2 Cor, Eph, Gal, Php, Col, 1 Thess

The surviving manuscripts do not give us much evidence for a corpus other than the fourteen letters. The large majority of the manuscripts have one of the following two orders:

Order 1: Rom, 1-2 Cor, Gal, Eph, Php, Col, 1-2 Thess, 1-2 Tim, Titus, $\mathrm{Phm}, \mathrm{Heb}$

Order 2: Rom, 1-2 Cor, Gal, Eph, Php, Col, 1-2 Thess, Heb, 1-2 Tim, Titus, Phm

The difference between these two is solely in the placing of Hebrews. Only a few of the oldest manuscripts give clear evidence of the order or number of letters included. There are 35 papyri containing parts of the Pauline letters, but 29 of these are fragments of a single letter which lack an indication as to whether they were part of a collection or not. Similarly, 39 of the 71 majuscules have only portions of a single letter.

Of the 6 papyri with multiple letters, only $\$ 46$ gives a real sense of order. $¥ 361$ and $¥ 99$ have fragments of seven and four letters respectively,

2 http://ntvmr.uni-muenster.de. The NTVMR is the creation of the INTF; the IGNTP contributes scans of manuscripts primarily through the Institute for Textual Scholarship and Electronic Editing (ITSEE), University of Birmingham. The creation of such a list is anticipated in David Trobisch, Die Entstebung der Paulusbriefsammlung. Freiburg: Schweiz, 1989, 14.

3 At this time, we have been able to see 567 of the some 828 catalogued Greek manuscripts with Pauline content. Trobisch, Die Entstehung der Paulusbriefsammlung, 14-62, summarizes the manuscript, versional, and citation evidence, including every manuscript reported to have a different content or order, but was not able to see all the manuscripts. See also David Trobisch, Paul's Letter Collection: Tracing the Origins. Minneapolis: Fortress, 1994, 1-27. 


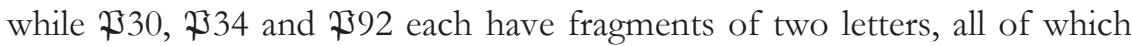
could support Order 1 or 2 , or other orders.

The evidence from the majuscule manuscripts is similarly sparse. There are ten majuscules that have all fourteen of the Pauline letters. Four of these have Order 1, four have Order 2, and the remaining two, GA 06 (the bilingual Codex Claromontanus) and 0319, have Order 3:

Order 3: Rom, 1-2 Cor, Gal, Eph, Col, Php, 1-2 Thess, 1-2 Tim, Titus, $\mathrm{Phm}, \mathrm{Heb}$

There are three other majuscules that are incomplete but which may support the complete collection: GA 03 (Codex Vaticanus) ends in the middle of Hebrews, with this letter in the Order 2 position; GA 0151 corresponds to Order 2 but ends after 1 Timothy; GA 075 has Order 1 except that it lacks Romans at the beginning.

Two majuscules, the bilinguals GA 010 and 012 , present a collection of thirteen letters in Greek, which does not include Hebrews. ${ }^{4}$ They therefore do not distinguish between Order 1 or 2. An additional sixteen incomplete majuscules have extensive lacunae or reordered pages with the result that that the original content or order of the letters cannot be determined. GA 025 may be complete but we have not been able to see it.

A large proportion of the minuscules are complete and thus give more certain results. Of the 722 minuscules containing Pauline material, we have been able to investigate 462 in their entirety. The majority of these, 317, are complete in Order 1, while 42 minuscules are complete in Order 2. There are four other orders represented by a single manuscript, as follows: ${ }^{5}$

GA 5: Rom, 1-2 Cor, Gal, Eph, Col, Php, 1-2 Thess, Heb, 1-2 Tim, Titus, $\mathrm{Phm}$

GA 33: 1-2 Cor, Gal, Eph, Php, Col, 1-2 Thess, Heb, 1-2 Tim, Titus, $\mathrm{Phm}$, Rom

GA 1241: 1-2 Cor, Gal, 1-2 Thess, 1-2 Tim, Titus, Phm, Heb, Rom, Eph, Php, Col

GA 1311: Rom, 1-2 Cor, Gal, Eph, Php, Col, 1-2 Thess, 1-2 Tim, Titus, Heb, Phm

\footnotetext{
${ }^{4}$ Hebrews is present, in Latin only, as the fourteenth letter in GA 010.

5 Trobisch, Die Entstehung der Paulusbriefsammlung, 15-16, notes that GA 1241 is written in multiple hands. He also notes (14) that GA 794 has Hebrews twice, after both 2 Thess and Phm; we have been unable to see this manuscript.
} 
An additional ten orders are found in commentary manuscripts, each represented by one or more minuscules. These orders are grouped by commentator:

Theodoret (GA 606):

Rom, 1-2 Cor, Gal, Eph, Heb, Php, Col, 1-2 Thess, 1-2 Tim, Titus, Phm

Chrysostom (GA 1840, 2690, 2739), Andreas (GA 1678), Zigabenus (GA 2008):

Rom, 1-2 Cor, Gal, Eph, Col, Phm, 1-2 Thess, Php, Heb, 1-2 Tim, Titus

\section{Theophylact}

GA 2000:

Rom, 1-2 Cor, Heb, Gal, Eph, Php, Col, 1-2 Thess, 1-2 Tim, Titus, Phm

GA 1977:

Rom, Heb, 1-2 Cor, Gal, Eph, Php, Col, 1-2 Thess, 1-2 Tim, Titus, Phm

GA 1930, 1978, 1992, 2248:

Rom, 1-2 Cor, Heb, Gal, Eph, Col, Php, 1-2 Thess, 1-2 Tim, Titus, Phm

GA 1947:

Rom, 1-2 Cor, Gal, Eph, Php, Col, Heb, 1-2 Tim, 1-2 Thess, Titus, Phm

GA 455, 1961, 2576:

Rom, Heb, Col, 1-2 Thess, Titus, 1-2 Cor, 1-2 Tim, Eph, Phm, Gal, Php

GA 103:

Rom, Heb, Col, 1-2 Thess, Php, 1-2 Tim, Titus, Phm, Eph, Gal, 1-2 Cor

GA 2482:

Heb, Eph, Col, Rom, 1-2 Tim, 1-2 Cor, Gal, 1-2 Thess, Php, Titus, Phm

GA 720:

Gal, Eph, Php, Col, 1-2 Thess, 1-2 Tim, Titus, Phm, Heb, Rom, 1-2 Cor

Manuscripts of Oecumenius' commentary present both Orders 1 and 2 . Similarly, Chrysostom commentaries present both Orders 1 and 2, plus the order shown above. Theodoret commentaries present Order 2 or the order shown above, while Theophylact commentaries present Order 1 and, in the case of GA 2105, Order 3, in addition to the many other orders shown above.

Seventy-five minuscules are incomplete or have been rebound so that the order cannot be determined. It is evident that most of these are portions of Order 1 or 2 , and none of them clearly attests to a different order. Some of the incomplete collections are due to lacunae, but others are 
difficult to tell. For example, there are two minuscules which only have one letter, perhaps intentionally: GA 1979, a commentary on Romans, and GA 2574, a commentary on Galatians. GA 2257 seems to be a commentary intentionally only on Romans and 1-2 Timothy.

\section{READER'S AIDS}

There are several other features in our manuscripts that may be indicators of editions: the Euthalian apparatus including prologues, hypotheses, kephalaia, lists of Old Testament citations, and lectionary indices, as well as stichometry. Traces of these exist earlier than the fully developed versions which probably date from the fourth century. ${ }^{6}$ An even earlier feature of manuscripts which may indicate lines of transmission and collection of the texts is the division of the text into sense units, whether by line breaks, spacing, punctuation, or other indicators, features which have been noted in some of the recently published Oxyrhynchus papyri. 7 Simon Crisp examined sense units in a set of manuscripts in Galatians 1, concluding that there is a relatively stable tradition in the manuscripts. ${ }^{8}$

The natural purpose for delineating the text is to aid its understanding, whether in private or public reading or in interpretation. If the division into sense units are transmission markers, we would expect to see this most clearly in commentary manuscripts. We picked Romans 12 as a test case, first looking at sense units in a set of continuous text manuscripts. Unfortunately the fifth/sixth-century manuscript GA 015, Codex Coislinianus, which is a well known colometrically-arranged text, does not have Romans, but there are other manuscripts with well-developed text divisions.

The table below shows the divisions for GA 03, 012, 93, 177, 457 and 1720. The running text of Romans 12 is shown in the left column, broken into segments whenever one of the manuscripts listed to the right has a text break. The manuscripts which break the text at that point are indicated by a

6 Louis Charles Willard, A Critical Study of the Euthalian Apparatus. ANTF 41. Berlin: de Gruyter, 2009, $111 \mathrm{ff}$.

7 Larry W. Hurtado, 'The New Testament in the Second Century: Text, Collections and Canon' in Transmission and Reception: New Testament Text-Critical and Exegetical Studies, ed. J.W. Childers and D.C. Parker. T\&S 3.4. Piscataway, NJ: Gorgias, 2006, 3-27, especially 12-14.

8 Simon Crisp, 'Scribal Marks and Logical Paragraphs: discourse segmentation criteria in manuscripts of the Pauline corpus' in Current Trends in Scripture Translation: Definitions and Identity, ed. Philip A. Noss, New York: UBS, 2005, 77-87. 
character in their column, while a blank cell indicates that the manuscript does not break the text at that point. The characters used are:

. for a point on the line;

, for a comma;

$\mathrm{p}$ for a middle or high point;

C for a break indicated by a following capital letter;

$\mathbf{L}$ for a break indicated by a lectionary notation;

[ ] for a break indicated by extra space;

omit for the text segment omitted in the manuscript.

\begin{tabular}{|c|c|c|c|c|c|c|c|}
\hline Verse & Text & 03 & 012 & 93 & 177 & 457 & 1720 \\
\hline 12:1 & $\pi \alpha \rho \alpha \kappa \alpha \lambda \omega$ ouv $v \mu \alpha \varsigma \alpha \delta \varepsilon \lambda \lambda \varphi$ ol & & & & $\mathrm{p}$ & $\mathrm{p}$ & . \\
\hline & 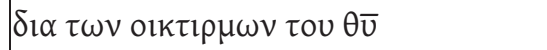 & $\mathrm{p}$ & $\mathrm{C}$ & , & $\mathrm{p}$ & $\mathrm{p}$ & . \\
\hline & $\pi \alpha \rho \alpha \sigma \tau \eta \sigma \alpha l \tau \alpha \sigma \omega \mu \alpha \tau \alpha \nu \mu \omega \nu$ & & & , & $\mathrm{p}$ & $\mathrm{p}$ & . \\
\hline & $\theta v \sigma \iota \alpha \nu \zeta \omega \sigma \alpha v \alpha \gamma \iota \alpha \nu$ & & & , & & $\mathrm{p}$ & \\
\hline & $\varepsilon \cup \alpha \rho \varepsilon \sigma \tau o v \tau \omega \theta \bar{\omega}$ & & & , & , & . & \\
\hline & 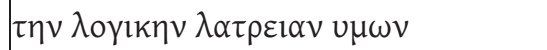 & $\mathrm{p}$ & $\mathrm{C}$ & $\mathrm{p}$ & $\mathrm{p}$ & $\mathrm{p}$ & $\mathrm{p}$ \\
\hline $12: 2$ & 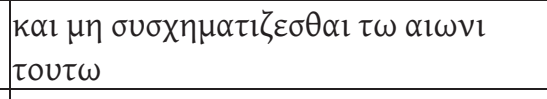 & & C & $\mathrm{p}$ & , & $\mathrm{p}$ & . \\
\hline & $\alpha \lambda \lambda \alpha \mu \varepsilon \tau \alpha \mu о \rho \varphi о \nu \sigma \theta \alpha l$ & & & & & $\mathrm{p}$ & \\
\hline & $\tau \eta \alpha v \alpha \kappa \alpha \iota v \omega \sigma \varepsilon l$ & & & & & & $\mathrm{p}$ \\
\hline & $\tau o v$ voos $v \mu \omega v$ & & & , & $\mathrm{p}$ & . & . \\
\hline & 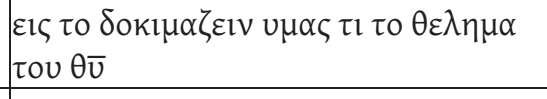 & & & , & & - & \\
\hline & 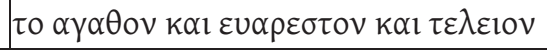 & $\mathrm{p}$ & $\mathrm{C}$ & $\mathrm{p}$ & $\mathrm{p}$ & $\mathrm{p}$ & $\mathrm{p}$ \\
\hline $12: 3$ & 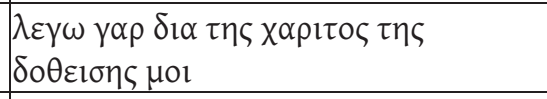 & & & , & $\mathrm{p}$ & & \\
\hline & $\pi \alpha \nu \tau l \tau \omega$ ov $\tau l \varepsilon \nu$ $v \mu l v$ & & & , & . & $\mathrm{p}$ & $\mathrm{p}$ \\
\hline & 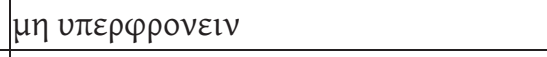 & & & . & & & \\
\hline & $\pi \alpha \rho$ o $\delta \varepsilon l \varphi \rho \circ v \varepsilon l v$ & & $\mathrm{C}$ & $\mathrm{p}$ & $\mathrm{p}$ & . & $\mathrm{p}$ \\
\hline & 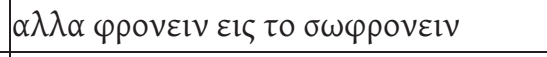 & & $\mathrm{C}$ & & $\mathrm{p}$ & $\mathrm{p}$ & . \\
\hline & $\varepsilon \kappa \alpha \sigma \tau \omega \omega \varsigma$ o $\theta \bar{\zeta} \varepsilon \mu \varepsilon \rho 1 \sigma \varepsilon \nu$ & & $\mathrm{C}$ & & & . & \\
\hline & $\mu \varepsilon \tau \rho \circ \nu \pi l \sigma \tau \varepsilon \omega \varsigma$ & & $\mathrm{C}$ & $\mathrm{p}$ & $\mathrm{p}$ & $\mathrm{p}$ & $\mathrm{L}$ \\
\hline 12:4 & 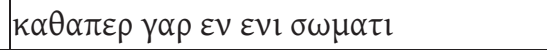 & & $\mathrm{C}$ & & $\mathrm{p}$ & & \\
\hline
\end{tabular}




\begin{tabular}{|c|c|c|c|c|c|c|c|}
\hline Verse & Text & 03 & 012 & 93 & 177 & \begin{tabular}{|l|l}
457 \\
\end{tabular} & 1720 \\
\hline & $\mu \varepsilon \lambda \eta \pi 0 \lambda \lambda \alpha \varepsilon \chi 0 \mu \varepsilon \nu$ & & $\mathrm{C}$ & $\mathrm{p}$ & $\mathrm{C}$ & $\mathrm{p}$ & $\mathrm{p}$ \\
\hline & $\tau \alpha \delta \varepsilon \mu \varepsilon \lambda \eta \pi \alpha \nu \tau \alpha$ & & & . & . & & \\
\hline & 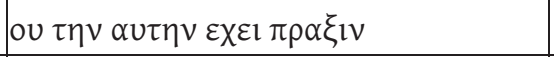 & & $\mathrm{C}$ & $\mathrm{p}$ & $\mathrm{p}$ & . & \\
\hline \multirow[t]{2}{*}{$12: 5$} & 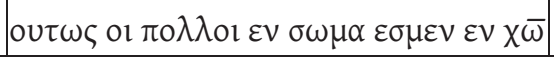 & $\mathrm{p}$ & $\mathrm{C}$ & $\mathrm{p}$ & $\mathrm{p}$ & . & \\
\hline & o $\delta \varepsilon \kappa \alpha \theta \varepsilon 1 \zeta \alpha \lambda \lambda \eta \lambda \omega \nu \mu \varepsilon \lambda \eta$ & $\mathrm{p}$ & $\mathrm{C}$ & $\mathrm{p}$ & $\mathrm{p}$ & $\mathrm{p}$ & $\mathrm{p}$ \\
\hline \multirow[t]{3}{*}{$12: 6$} & 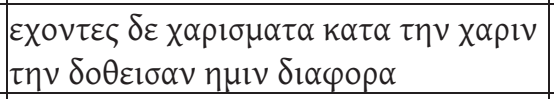 & $\mathrm{p}$ & $\mathrm{C}$ & $\mathrm{p}$ & $\mathrm{p}$ & $\mathrm{p}$ & \\
\hline & $\varepsilon ı \tau \varepsilon \pi \rho \circ \varphi \eta \tau \varepsilon \downarrow \alpha \nu$ & & & & & & \\
\hline & 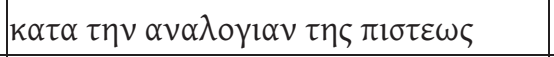 & $\mathrm{p}$ & $\mathrm{C}$ & $\mathrm{p}$ & $\mathrm{p}$ & $\mathrm{p}$ & $\mathrm{p}$ \\
\hline \multirow[t]{4}{*}{$12: 7$} & 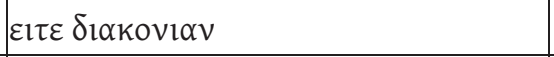 & & & & . & . & \\
\hline & $\varepsilon \vee \tau \eta \delta 1 \alpha k o v i \alpha$ & $\mathrm{p}$ & $\mathrm{C}$ & $\mathrm{p}$ & $\mathrm{p}$ & $\mathrm{p}$ & $\mathrm{p}$ \\
\hline & $\varepsilon 1 \tau \varepsilon$ o $\delta 1 \delta \alpha \sigma K \omega \nu$ & & & & . & . & \\
\hline & $\varepsilon \nu \tau \eta \delta_{1} \delta \alpha \sigma \kappa \alpha \lambda_{l} \alpha$ & $\mathrm{p}$ & $\mathrm{C}$ & $\mathrm{p}$ & $\mathrm{p}$ & $\mathrm{p}$ & $\mathrm{p}$ \\
\hline \multirow[t]{5}{*}{ 12:8 } & $\varepsilon I \tau \varepsilon$ o $\pi \alpha \rho \alpha \kappa \alpha \lambda \omega \nu$ & [] & & & , & . & \\
\hline & $\varepsilon \nu \tau \eta \pi \alpha \rho \alpha \kappa \lambda \eta \sigma \varepsilon l$ & $\mathrm{p}$ & $\mathrm{C}$ & $\mathrm{p}$ & $\mathrm{p}$ & $\mathrm{p}$ & $\mathrm{p}$ \\
\hline & 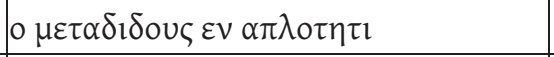 & $\mathrm{p}$ & $\mathrm{C}$ & $\mathrm{p}$ & $\mathrm{p}$ & $\mathrm{p}$ & $\mathrm{p}$ \\
\hline & 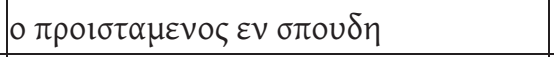 & $\mathrm{p}$ & $\mathrm{C}$ & $\mathrm{p}$ & $\mathrm{p}$ & $\mathrm{p}$ & \\
\hline & o $\varepsilon \lambda \varepsilon \omega \nu \varepsilon v \imath \lambda \alpha \rho \circ \tau \eta \tau l$ & $\mathrm{p}$ & $\mathrm{C}$ & $\mathrm{p}$ & $\mathrm{p}$ & $\mathrm{p}$ & $\mathrm{p}$ \\
\hline \multirow[t]{3}{*}{ 12:9 } & 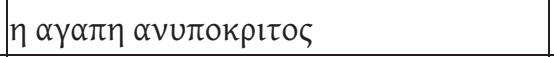 & $\mathrm{p}$ & & $\mathrm{p}$ & $\mathrm{p}$ & $\mathrm{p}$ & $\mathrm{p}$ \\
\hline & 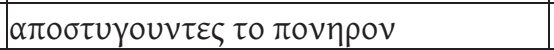 & $\mathrm{p}$ & & $\mathrm{p}$ & 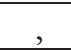 & . & \\
\hline & ко $\lambda \lambda \omega \mu \varepsilon v o l ~ \tau \omega \alpha \gamma \alpha \theta \omega$ & $\mathrm{p}$ & & $\mathrm{p}$ & $\mathrm{p}$ & $\mathrm{p}$ & $\mathrm{p}$ \\
\hline \multirow[t]{2}{*}{$12: 10$} & 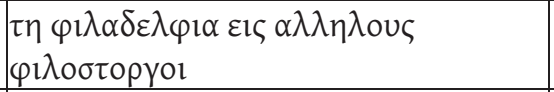 & & & $\mathrm{p}$ & $\mathrm{p}$ & $\mathrm{p}$ & $\mathrm{p}$ \\
\hline & 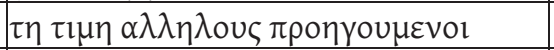 & & & $\mathrm{p}$ & $\mathrm{p}$ & $\mathrm{p}$ & $\mathrm{p}$ \\
\hline \multirow[t]{3}{*}{$12: 11$} & 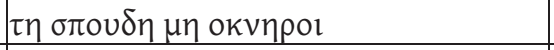 & & & $\mathrm{p}$ & $\mathrm{p}$ & $\mathrm{p}$ & $\mathrm{p}$ \\
\hline & $\tau \omega \pi \bar{v} l \zeta \varepsilon \circ \nu \tau \varepsilon \varsigma$ & & & $\mathrm{p}$ & . & $\mathrm{p}$ & 1 \\
\hline & $\tau \omega \kappa \bar{\omega} \delta$ ou $\lambda \varepsilon v o v \tau \varepsilon \varsigma$ & & $\mathrm{C}$ & $\mathrm{p}$ & $\mathrm{p}$ & $\mathrm{p}$ & $\mathrm{p}$ \\
\hline \multirow[t]{3}{*}{$12: 12$} & 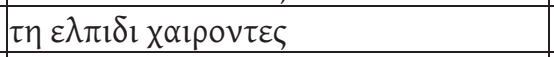 & & $\mathrm{C}$ & $\mathrm{p}$ & . & $\mathrm{p}$ & \\
\hline & 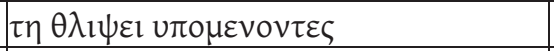 & & $\mathrm{C}$ & $\mathrm{p}$ & . & $\mathrm{p}$ & 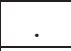 \\
\hline & $\tau \eta \pi \rho \circ \sigma \varepsilon v \times \eta \pi \rho \circ \sigma \alpha \alpha \tau \varepsilon \rho \circ o u v \tau \varepsilon \zeta$ & & & $\mathrm{p}$ & $\mathrm{p}$ & $\mathrm{p}$ & $\mathrm{p}$ \\
\hline \multirow[t]{2}{*}{$12: 13$} & 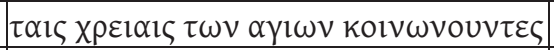 & & & $\mathrm{p}$ & & $\mathrm{p}$ & \\
\hline & $\tau \eta \nu \varphi \imath \lambda o \xi \varepsilon v 1 \alpha \nu \delta 1 \omega \kappa o v \tau \varepsilon \zeta$ & $\mathrm{p}$ & $\mathrm{C}$ & $\mathrm{p}$ & $\mathrm{p}$ & & \\
\hline \multirow[t]{2}{*}{$12: 14$} & 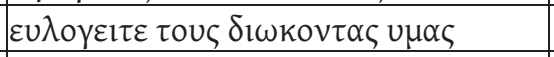 & & omit & $\mathrm{p}$ & . & $\mathrm{p}$ & . \\
\hline & $\varepsilon \cup \lambda \circ \gamma \varepsilon ı \tau \varepsilon \kappa \alpha \iota \mu \eta$ $\kappa \alpha \tau \alpha \rho \alpha \sigma \theta \varepsilon$ & $\mathrm{p}$ & $\mathrm{C}$ & $\mathrm{L}$ & $\mathrm{p}$ & $\mathrm{p}$ & $\mathrm{L}$ \\
\hline
\end{tabular}




\begin{tabular}{|c|c|c|c|c|c|c|c|}
\hline Verse & Text & 03 & 012 & 93 & 177 & 457 & 1720 \\
\hline \multirow[t]{2}{*}{$12: 15$} & 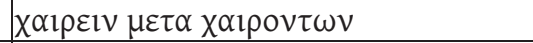 & $\mathrm{p}$ & & $\mathrm{p}$ & & & . \\
\hline & 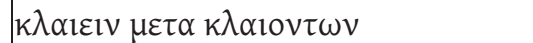 & $\mathrm{p}$ & & $\mathrm{p}$ & $\mathrm{p}$ & $\mathrm{p}$ & \\
\hline \multirow[t]{4}{*}{ 12:16 } & 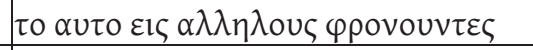 & $\mathrm{p}$ & & $\mathrm{p}$ & $\mathrm{p}$ & $\mathrm{p}$ & . \\
\hline & 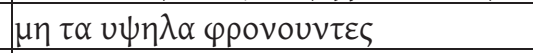 & & $\mathrm{C}$ & $\mathrm{p}$ & . & . & . \\
\hline & 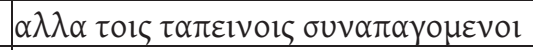 & $\mathrm{p}$ & $\mathrm{C}$ & $\mathrm{p}$ & $\mathrm{p}$ & $\mathrm{p}$ & $\mathrm{p}$ \\
\hline & 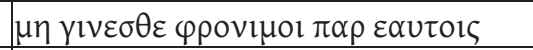 & $\mathrm{p}$ & $\mathrm{C}$ & $\mathrm{p}$ & $\mathrm{p}$ & $\mathrm{p}$ & . \\
\hline \multirow[t]{3}{*}{$12: 17$} & 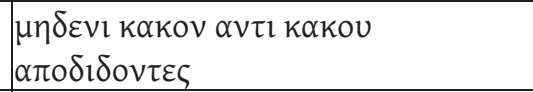 & & & $\mathrm{p}$ & $\mathrm{p}$ & $\mathrm{p}$ & $\mathrm{p}$ \\
\hline & $\pi \rho o v o o v \mu \varepsilon v o l k \alpha \lambda \alpha$ & & $\mathrm{C}$ & & 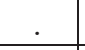 & & \\
\hline & $\varepsilon v \omega \pi 10 v \pi \alpha v \tau \omega v \alpha \bar{v} \omega v$ & $\mathrm{p}$ & $\mathrm{C}$ & $\mathrm{p}$ & $\mathrm{p}$ & $\mathrm{p}$ & . \\
\hline \multirow[t]{2}{*}{ 12:18 } & 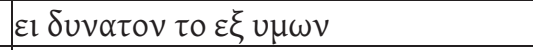 & & & & . & . & . \\
\hline & $\mu \varepsilon \tau \alpha \pi \alpha v \tau \omega \nu \alpha \bar{v} \omega \nu \varepsilon \varepsilon \eta \rho \eta v \varepsilon v o v \tau \varepsilon \zeta$ & $\mathrm{p}$ & $\mathrm{C}$ & $\mathrm{p}$ & $\mathrm{p}$ & $\mathrm{p}$ & $\mathrm{p}$ \\
\hline \multirow[t]{5}{*}{ 12:19 } & 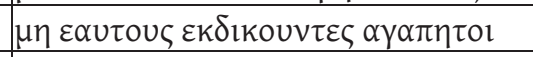 & $p$ & $\mathrm{C}$ & $\mathrm{p}$ & . & . & . \\
\hline & 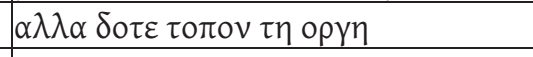 & & & $\mathrm{p}$ & $\mathrm{p}$ & $\mathrm{p}$ & . \\
\hline & $\gamma \varepsilon \gamma \rho \alpha \pi \tau \alpha l \gamma \alpha \rho$ & & $\mathrm{C}$ & $\mathrm{p}$ & . & . & . \\
\hline & $\varepsilon \mu 01 \varepsilon \kappa \delta 1 k \eta \sigma l \varsigma$ & & & $\mathrm{p}$ & . & $\mathrm{p}$ & $\mathrm{p}$ \\
\hline & $\varepsilon \gamma \omega \alpha \nu \tau \alpha \pi \circ \delta \omega \sigma \omega \lambda \varepsilon \gamma \varepsilon l \kappa \varsigma$ & $\mathrm{p}$ & $\mathrm{C}$ & $\mathrm{p}$ & $\mathrm{p}$ & $\mathrm{p}$ & $\mathrm{p}$ \\
\hline \multirow[t]{6}{*}{$12: 20$} & $\alpha \lambda \lambda \varepsilon \alpha \nu \pi \varepsilon 1 v \alpha$ o $\varepsilon \chi \theta \rho \circ \zeta$ бov & & $\mathrm{C}$ & 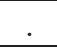 & . & . & . \\
\hline & $\psi \omega \mu \iota \zeta \varepsilon \alpha \nu \tau \tau^{\prime} \nu$ & $\mathrm{p}$ & $\mathrm{C}$ & $\mathrm{p}$ & $\mathrm{p}$ & $\mathrm{p}$ & . \\
\hline & $\varepsilon \alpha \nu \delta 1 \psi \alpha$ & & & 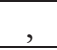 & omit & . & , \\
\hline & $\pi 0 \tau \imath \zeta \varepsilon \alpha \cup \tau O V$ & $p$ & $\mathrm{C}$ & $p$ & omit & $p$ & $p$ \\
\hline & 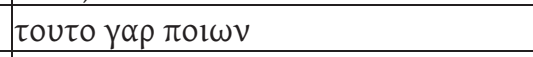 & & $\mathrm{C}$ & $\mathrm{p}$ & . & . & . \\
\hline & 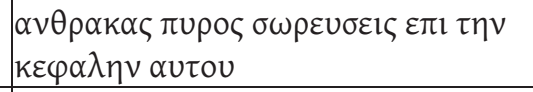 & $\mathrm{P}$ & $\mathrm{C}$ & $\mathrm{p}$ & $\mathrm{p}$ & $\mathrm{p}$ & $\mathrm{p}$ \\
\hline \multirow[t]{3}{*}{ 12:21 } & 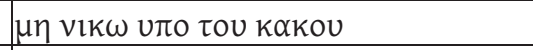 & & $\mathrm{C}$ & $\mathrm{p}$ & . & . & . \\
\hline & $\alpha \lambda \lambda \alpha$ vik $\alpha \varepsilon v \tau \omega \alpha \gamma \alpha \theta \omega$ & & & & & & \\
\hline & 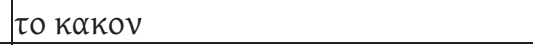 & $\mathrm{p}$ & $\mathrm{C}$ & $\mathrm{L}$ & $\mathrm{p}$ & $\mathrm{p}$ & $\mathrm{L}$ \\
\hline
\end{tabular}

Of course some of these may be disputable, particularly as to whether space in the text is meant to indicate a break in sense. Similarly, punctuation may be problematic because it is not clearly visible, it is not clear when it was added, or it was used differently by different scribes. Nevertheless, a consistency is shown among these manuscripts, particularly in the poetic text and for major sense-segments. This provides a baseline for sense segments that we would expect to be followed by commentators, as described in the next section. 


\section{SAMPling Divisions in Pauline Commentaries}

Commentary manuscripts provide clear segmentation of the text, so we made a survey of Pauline commentaries looking specifically at how the text of Paul's letters was divided by the various exegetes and to note variety in the transmission of the Pauline text and the comments of the exegete. We also noted the relationships between the divisions of the text for comments and the divisions for the text's use in the lectionary.

The method was relatively simple. We chose Romans 12 as a test chapter, again, because of the varying number of divisions. Commentators divide this chapter into anything from six to sixty-nine sections. The contents of Romans 12 also guaranteed lively comment, in the form of the popular exhortation from Paul in 12:2 to be transformed rather than conformed, and the surprising motive for doing good to one's enemies in 12:20 (NRSV: 'for by doing this you will heap burning coals on their heads'). We made a transcription of the text of Romans 12 and noted the manner in which the text was divided for comment in all the manuscripts to which we had access. We consulted a total of 107 commentary manuscripts. The manuscripts available to us include the commentaries of Theophylact, Oecumenius, Chrysostom, Theodoret, Andreas, Zigabenus, and those whose authors or compilers are unknown.

\section{Zigabenus}

\begin{tabular}{|l|l|l|l|l|l|l|l|l|}
\hline GA & Cent. & Format & $\begin{array}{l}\text { No. of } \\
\text { Divisions }\end{array}$ & $\begin{array}{l}\text { Divisions } \\
\text { numbered }\end{array}$ & $\begin{array}{l}\text { Lectionary } \\
\text { notations }\end{array}$ & \multicolumn{2}{|l|}{ Lections Marked } \\
\hline 2008 & 13 & Alt. & 47 & No & Yes & $12: 1-?$ & $12: 6-?$ & $12: ?-21$ \\
\hline
\end{tabular}

Zigabenus is represented by one manuscript in this study. GA 2008 is a thirteenth-century manuscript in alternating catena format. ${ }^{9}$ Romans 12 is divided into 47 comments. The divisions are not numbered. Individual lections are marked by notations in the margins indicating the occasion for the passage's use in the church year but what is contained in the lections is not clear.

${ }^{9}$ For the different formats of catena manuscripts, see pages 8-10 above. 


\section{Andreas}

\begin{tabular}{|l|l|l|l|l|l|l|l|l|l|}
\hline GA & Cent. & Format & $\begin{array}{l}\text { No. of } \\
\text { Divisions }\end{array}$ & $\begin{array}{l}\text { Divisions } \\
\text { numbered }\end{array}$ & $\begin{array}{l}\text { Lectionary } \\
\text { notations }\end{array}$ & \multicolumn{4}{|l|}{ Lections Marked } \\
\hline 1678 & 14 & Frame & 46 & Yes $(\alpha)$ & Yes & $12: 1-3$ & $12: 4-5$ & $12: 6-13$ & $12: 14-21$ \\
\hline
\end{tabular}

Von Soden identifies GA 1678 (A $\left.{ }^{\pi \rho} 41\right)$ as a commentary by Andreas the Presbyter. ${ }^{10}$ This would make it the only representative of Andreas in our study, but the comments presented in Romans 12 come from John Chrysostom. GA 1678 is a fourteenth-century manuscript and the commentary is presented in frame format. The text features numbers above the text which correspond to numbered comments in the margins. In this manuscript Romans 12 is divided into 46 comments. Lectionary equipment is found in the margin between the text and the comments or in the gutter. Individual lections are indicated with $\alpha \rho \chi \eta$ and $\tau \varepsilon \lambda(\circ \varsigma)$.

\section{Theodoret}

\begin{tabular}{|l|l|l|l|l|l|}
\hline GA & Cent. & Format & $\begin{array}{l}\text { No. of } \\
\text { Divisions }\end{array}$ & $\begin{array}{l}\text { Divisions } \\
\text { numbered }\end{array}$ & $\begin{array}{l}\text { Lectionary } \\
\text { notations }\end{array}$ \\
\hline 606 & 11 & Alt. & 26 & No & No \\
\hline 2242 & 12 & Alt. & 27 & No & No \\
\hline 1945 & 13 & Alt.-2 col & 27 & No & No \\
\hline 1999 & 14 & Alt.-2 col & 27 & No & No \\
\hline 2012 & 14 & Alt. & 27 & No & No \\
\hline 1996 & 15 & Alt. & 27 & No & No \\
\hline 1939 & 16 & Alt. & 27 & No & No \\
\hline
\end{tabular}

The commentary on Romans 12 by Theodoret is found in GA 606, 2242, 1945, 1999, 2012, 1996, and 1939, representing dates from the eleventh to the sixteenth century. They are in alternating format but GA 1945 and 1999 are copied in two columns per folio. GA 606 is divided into 26 comments

${ }^{10}$ Hermann von Soden, Die Schriften des neuen Testaments in ibrer ältesten erreichbaren Textgestalt. Berlin: Alexander Duncker, 1907, 281. 
and the remainder have 27 comments. Those divisions are not numbered and there are no lectionary notations.

\section{Chrysostom}

\begin{tabular}{|l|l|l|l|l|l|l|l|l|l|}
\hline GA & Cent. & Format & $\begin{array}{l}\text { No. of } \\
\text { Divis. }\end{array}$ & $\begin{array}{l}\text { Divis. } \\
\text { num. }\end{array}$ & \multicolumn{2}{l|}{$\begin{array}{l}\text { Lect. } \\
\text { notat. }\end{array}$} & \multicolumn{5}{|l|}{ Lections Marked } \\
\hline 0151 & 10 & Alt. & 29 & No & No & & & & \\
\hline 2110 & 10 & Alt. & 19 & No & No & & & & \\
\hline 1962 & $11 / 12$ & Alt. & 19 & No & Yes & $12: 1-3$ & $12: 4-5$ & $12: 6-15$ & $12: 16-19$ \\
\hline 1956 & 13 & Frame & 11 & Yes & Yes & $12: 1-3$ & $12: 4-5$ & $12: 6-21$ & \\
\hline 1969 & 13 & Alt. & 33 & No & No & & & & \\
\hline 1506 & 14 & Alt. & 19 & No & No & & & & \\
\hline 1678 & 14 & Frame & 44 & Yes $(\alpha)$ & Yes & $12: 1-3$ & $12: 4-5$ & $12: 6-13$ & $12: 14-21$ \\
\hline 2739 & 14 & Alt. & 46 & No & Yes & & & & \\
\hline 1840 & 16 & Alt. & 47 & No & No & & & & \\
\hline 2690 & 16 & Alt. & 47 & No & No & & & & \\
\hline
\end{tabular}

Our collection includes nine commentaries assigned to John Chrysostom, GA 0151, 2110, 1962, 1969, 1506, 1840, 1956, 2690, and 2739. The oldest manuscripts (0151 and 2110) date to the tenth century and the youngest are GA 1840 and 2690 which were copied in the sixteenth century. GA 0151, 2110, 1962, 1969, 1506, 2739, 1840, and 2690 are copied in alternating format; GA 1956 and 1678 are presented in frame format. Divisions are numbered in GA 1956 and 1678.

Individual lections in GA 1962 are marked with $\alpha \rho x \eta$ in the margins. GA 1840, 2690 and 2739 have sparse lectionary notations indicating the beginning of individual lections and they are present in the margins.

The number of divisions for comment varies widely in these manuscripts. GA 2110, 1962, and 1506 have 19 divisions. GA 0151 has 29 divisions. GA 1969 has 33 divisions, 1678 has 44, 2739 has 46, and GA 1840 and 2690 have 47.

GA 1962 is also notable for the fact that its final lection is 12:16-19, thereby avoiding the difficult advice of 12:20. The first folio of GA 1956 notes that this commentary is by Chrysostom, but in Romans 12 the opening comment for 12:1 and the closing comment at 12:20b come from Oecumenius. The same opening and closing comments in GA 1956 are 
found in GA 1862, an anonymous commentary, and they are divided in similar number and manner; this coincidence inspires curiosity.

\section{Oecumenius}

\begin{tabular}{|c|c|c|c|c|c|c|c|c|c|}
\hline GA & Cent. & Format & No. of & Divisions & Lect. & \multicolumn{4}{|c|}{ Lections Marked } \\
\hline 619 & 10 & Frame & 48 & Yes $(\xi \delta)$ & Yes & $12: 1-3$ & $12: 4-5$ & $12: 6-14$ & $12: 15-21$ \\
\hline 454 & 10 & Frame & 46 & Yes $(\xi \delta)$ & No & & & & \\
\hline 1905 & 10 & Frame & 48 & Yes $(\xi \delta)$ & No & & & & \\
\hline 1920 & 10 & Frame & 49 & Yes $(\xi \delta)$ & No & & & & \\
\hline 1927 & 10 & Frame & 47 & Yes $(\xi \delta)$ & No & & & & \\
\hline 1997 & 10 & Frame & 47 & Yes $(\xi \delta)$ & No & & & & \\
\hline 1998 & 10 & Frame & 48 & Yes $(\xi \gamma)$ & Yes & $12: 1-3$ & $12: 4-5$ & 12:6-14 & $12: 15-21$ \\
\hline 91 & 11 & Alt. & 48 & No & No & & & & \\
\hline 607 & 11 & Alt. & 48 & Yes $(\xi)$ & No & & & & \\
\hline 641 & 11 & Frame & lacunose & Yes $(\xi \delta) ?$ & Yes & & & & \\
\hline 1878 & 11 & Frame & 48 & Yes $(\xi \delta)$ & No & & & & \\
\hline 1906 & 11 & Frame & 47 & Yes $(\xi \delta)$ & No & & & & \\
\hline 1907 & 11 & Frame & 48 & Yes $(\xi \delta)$ & Yes & $12: 1-3$ & $12: 4-5$ & 12:6-14 & -- \\
\hline 1908 & 11 & Frame & 47 & Yes $(\xi \delta)$ & No & & & & \\
\hline 1919 & 11 & Alt. & 47 & No & No & & & & \\
\hline 1921 & 11 & Frame & 48 & Yes $(\xi \delta)$ & No & & & & \\
\hline 1933 & 11 & Frame & 46 & Yes $(15)$ & Yes & & & & \\
\hline 1982 & 11 & Frame & 47 & Yes $(\xi \delta)$ & Yes & $12: 1-3$ & $12: 4-5$ & 12:6-14 & $12: 15-21$ \\
\hline 2007 & 11 & Alt. & 3 & No & Yes & $12: 1-3$ & $12: 4-5$ & 12:6-14 & $12: 15-21$ \\
\hline 2183 & 11 & Frame & 51 & Yes $(\kappa \varepsilon)$ & No & & & & \\
\hline 622 & 12 & Frame & 47 & Yes $(\xi \delta)$ & No & & & & \\
\hline 911 & 12 & Frame & 47 & Yes $(\xi \delta)$ & Yes & $12: 1-3$ & $12: 4-5$ & 12:6-14 & $12: 15-21$ \\
\hline 1917 & 12 & Frame & 45 & Yes $(\xi \delta)$ & No & & & & \\
\hline 1360 & 12 & Frame & ? & ? & ? & & & & \\
\hline 2001 & 12 & Frame & 47 & Yes $(\xi \delta)$ & No & & & & \\
\hline 2189 & 12 & Frame & 46 & Yes $(\theta)$ & No & & & & \\
\hline
\end{tabular}




\begin{tabular}{|c|c|l|c|c|c|c|c|c|c|}
\hline GA & Cent. & Format & $\begin{array}{c}\text { No. of } \\
\text { Divisions }\end{array}$ & $\begin{array}{c}\text { Divisions } \\
\text { numbered }\end{array}$ & $\begin{array}{c}\text { Lect. } \\
\text { notat. }\end{array}$ & \multicolumn{5}{|c|}{ Lections Marked } \\
\hline 94 & 13 & Frame & 41 & Yes $(\theta)$ & No & & & & \\
\hline 1922 & 13 & Frame & 47 & Yes $(\lambda \varepsilon)$ & No & & & & \\
\hline 1953 & 13 & Alt. & $\begin{array}{c}\text { not } \\
\text { continuous }\end{array}$ & text & No & & & & \\
\hline
\end{tabular}

We looked at twenty-nine commentaries identified as Oecumenius: GA 619, 454, 1905, 1920, 1927, 1997, 1998, 91, 607, 641, 1878, 1906, 1907, 1908, 1919, 1921, 1933, 1982, 2007, 2183, 622, 911, 1917, 1360, 2001, 2189, 94, 1922, and 1953. These manuscripts are dated from the tenth to the thirteenth century; nearly half the manuscripts are dated to the eleventh century. The majority of the manuscripts are copied in frame format, but GA 91, 607, 1919, 2007, and 1953 are in alternating format. GA 641 is lacunose and GA 1953 does not have a continuous text. The photos of GA 1360 are sufficiently unclear as to prevent analysis. All of the manuscripts in frame format feature numbered divisions. With the exception of GA 607, which has numbered divisions, the divisions of the three remaining manuscripts in alternating format are not numbered.

The individual lections in GA 641 and 1933 are indicated by the occasion in the church year when the passage would be read. GA 619, 1998, 1982, 2007 and 911 indicate the lections with $\alpha \rho x \eta$ and $\tau \varepsilon \lambda($ (o), and the occasion when the lection would be read. GA 1907 has $\alpha \rho x \eta$ near the beginning of the lection with the occasion noted in the margin.

Among these manuscripts there is an interesting sub-group. Sixteen of the twenty-four manuscripts in frame format are so copied that the first comment in Romans 12 is always numbered $\xi \delta$ and the final comment at $12: 21$ is always $1 \alpha .{ }^{11}$ In this group the number of divisions ranges between forty-five and forty-nine. An exceptional manuscript among the Oecumenian commentaries is GA 2007, which has only three divisions. ${ }^{12}$ The average number of divisions for the other manuscripts of this tradition is 47. There are lectionary markings of varying detail in GA 619, 1998, 1907, 1933, 1982, 2007 and 911.

11 These manuscripts are GA 619, 454, 1905, 1920, 1927, 1997, 641(?), 1878, 1906, 1907, 1908, 1921, 1982, 622, 911, 1917 and 2001.

12 Romans 12:1-5, 6-14, 15-21. 
Theophylact

\begin{tabular}{|c|c|c|c|c|c|c|c|c|c|}
\hline GA & Cent. & Format & No. of & Divisions & Lect. & \multicolumn{4}{|c|}{ Lections Marked } \\
\hline 103 & 12 & Frame & 36 & symbols & Yes & $12: 1-3$ & $12: 4-6$ & $12: 7-14$ & $12: 15-21$ \\
\hline 720 & 12 & Alt. & 36 & No & Yes & & & & \\
\hline 1798 & 12 & Frame & 36 & Yes & No & & & & \\
\hline 1988 & 12 & Alt. & 36 & No & No & & & & \\
\hline 2104 & 12 & Alt. & 36 & No & Yes & $12: 1-3$ & & & $12: 15-21$ \\
\hline 1977 & $12 / 13$ & Alt. & 37 & No & No & & & & \\
\hline 1913 & 13 & Alt. & 36 & No & No & & & & \\
\hline 1991 & 13 & Alt. & 36 & No & No & & & & \\
\hline 1992 & 13 & Alt. & 36 & No & No & & & & \\
\hline 2576 & 13 & Alt. & 37 & No & No & & & & \\
\hline 455 & $13 / 14$ & Alt. & 37 & No & Yes & & & & \\
\hline 1523 & $13 / 14$ & Alt. & 36 & No & No & & & & \\
\hline 254 & 14 & Alt. & 36 & No & No & & & & \\
\hline 608 & 14 & Alt. & 36 & No & No & & & & \\
\hline 858 & 14 & Alt. & 36 & No & No & & & & \\
\hline 891 & 14 & Alt. & 36 & No & No & & & & \\
\hline 1267 & 14 & Alt. & 36 & No & No & & & & \\
\hline 1524 & 14 & Alt. & 36 & No & Yes & & & & \\
\hline 1929 & 14 & Alt. & 32 & No & No & & & & \\
\hline 1943 & 14 & Alt. & 36 & No & No & & & & \\
\hline 1950 & 14 & Alt. & 36 & No & No & & & & \\
\hline 1961 & 14 & Alt. & 37 & No & No & & & & \\
\hline 1984 & 14 & Alt. & 36 & No & No & & & & \\
\hline 1987 & 14 & Alt. & 36 & No & No & & & & \\
\hline 2000 & 14 & Alt. & 37 & No & No & & & & \\
\hline 2105 & 14 & Alt. & 36 & No & No & & & & \\
\hline 2197 & 14 & Alt. & 35 & No & No & & & & \\
\hline 2248 & 14 & Alt. & 36 & No & No & & & & \\
\hline 2257 & 14 & Alt. & 36 & No & No & & & & \\
\hline 2482 & 14 & Alt. & 35 & No & No & & & & \\
\hline
\end{tabular}




\begin{tabular}{|c|c|c|c|c|c|c|c|c|c|}
\hline GA & Cent. & Format & $\begin{array}{c}\text { No. of } \\
\text { Divisions }\end{array}$ & $\begin{array}{c}\text { Divisions } \\
\text { numbered }\end{array}$ & $\begin{array}{c}\text { Lect. } \\
\text { notat. }\end{array}$ & \multicolumn{5}{|c|}{ Lections Marked } \\
\hline 2889 & 14 & Alt. & 32 & No & No & & & & \\
\hline 886 & 15 & Alt. & 36 & No & Yes & & & & \\
\hline 1978 & 15 & Alt. & 36 & No & No & & & & \\
\hline 1995 & 15 & Alt. & 36 & No & No & & & & \\
\hline 2102 & 15 & Alt. & 36 & No & No & & & & \\
\hline 1930 & 16 & Alt. & 36 & No & No & & & & \\
\hline 1979 & 16 & Alt. & 36 & No & No & & & & \\
\hline 1985 & 16 & Alt. & 35 & No & No & & & & \\
\hline 2659 & 16 & Alt. & 14 & No & No & & & & \\
\hline
\end{tabular}

The most numerous commentaries in our study belong to the exegete Theophylact. Our group contains thirty-nine representatives: GA 103, 720, 1798, 1988, 2104, 1977, 1913, 1991, 1992, 2576, 455, 1523, 254, 608, 858, 891, 1267, 1524, 1929, 1943, 1950, 1961, 1984, 1987, 2000, 2105, 2197, 2248, 2257, 2482, 2889, 886, 1978, 1995, 2102, 1930, 1979, 1985 and 2659. These manuscripts are dated from the twelfth to the sixteenth century. With the exception of two of the earliest witnesses, GA 103 and 1798, these commentaries are presented in alternating format. GA 103 uses symbols, signes-de-renvoi, to link text and comments; GA 1798 uses numbers. Nearly half the Theophylact manuscripts in our study date from the fourteenth century.

The majority of Theophylact commentaries divide Romans 12 into thirty-six comments. GA 1977, 2576, 455, 1961, and 2000 have thirty-seven. GA 2197, 2482, and 1985 have thirty-five divisions. GA 1929 has thirtytwo, and GA 2659 has fourteen divisions.

The individual lections of GA 103 and 720 are marked with $\alpha \rho x \eta$ and $\tau \varepsilon \lambda(o \varsigma)$ and the occasion for the lection is noted in the margin. GA 1798 notes the lections with $\alpha \rho \chi \eta$ and $\tau \varepsilon \lambda(o \zeta)$ but without noting occasions. The ending of some lections in GA 455 are indicated with $\tau \varepsilon \lambda($ o५) and only some occasions recorded. The lections of GA 1524 are sometimes indicated with the occasion noted at the beginning of that reading. The same is true for GA 2576 and 886 but with much greater regularity. 


\section{Biblical Text}

The text of Romans 12 in the other exegetes is very nearly identical to the Textus Receptus (TR). ${ }^{13}$ The text of Theophylact in Romans 12 is distinctive on three occasions.

1.) In Romans $12: 3$, twenty-five of the thirty-nine manuscripts add $\tau$ vov

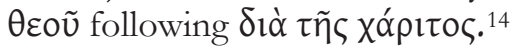

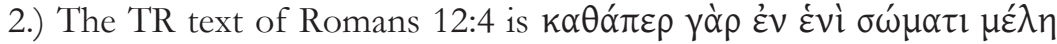

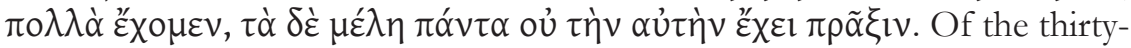

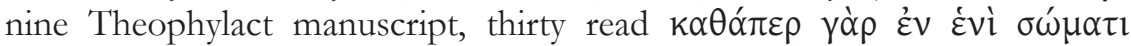

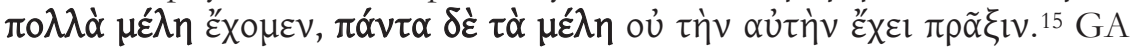
608, 1961, 1987 and 2105 have one instance of a change in word order,

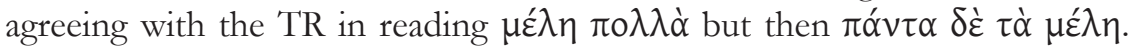
GA 2197 also has only one instance of a change in word order but here it is

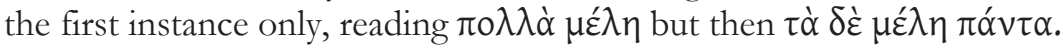

3.) In Romans 12:5, twenty-two of the thirty-nine Theophylact

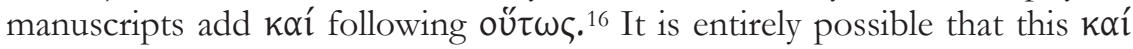
was present in Theophylact's exemplar. With the exception of this third reading, the text of Theophylact in Romans 12 is identical to GA 1241, a twelfth-century manuscript held at St. Catherine's Monastery in Sinai.

\section{Anonymous Commentaries}

Nineteen of the manuscripts in our study are anonymous commentaries, namely GA 1862, 1900, 1424, 0142, 1915, 2125, 250, 424, 617, 621, 1934, 97, 441, 2011, 442, 327, 1780, 1956, and 918. They are nearly evenly divided in format, eleven being frame commentaries and eight in alternating format. They range in date from the ninth to the sixteenth century and vary in the number of divisions from seven (GA 0142) to sixty-nine (GA 1900). One

13 Robert Étienne (Stephanus), Novum Iesu Christi Dominum Nostrum Testamentum, Paris: Stephanus, 1550. The principal exception is in Romans 12:11, where for $\tau \tilde{\omega}$

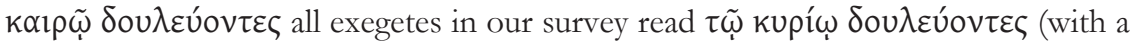
nomen sacrum).

14 GA 103, 254, 455, 608, 858, 891, 1267, 1798, 1913, 1930, 1943, 1961, 1977, 1979, 1984, 1985, 1987, 1988, 1991, 1992, 1995, 2000, 2104, 2257 and 2576.

15 GA 103, 254, 455, 720, 858, 886, 891, 1267, 1524, 1798, 1913, 1930, 1943, 1977, 1978, 1979, 1984, 1985, 1988, 1991, 1992, 1995, 2000, 2102, 2104, 2248, 2257, 2482, 2576 and 2659.

16 GA 254, 455, 720, 858, 1524, 1913, 1930, 1943, 1961, 1977, 1978, 1979, 1984, $1991,1995,2000,2102,2105,2257,2482,2576$, and 2659. 
of the questions we were curious about with the anonymous catenae was the practice of including indications of sources and whether that changed over time. Three of the nineteen commentaries include author indications: GA 1900 from the ninth century, GA 1424 from the ninth or tenth century, and GA 1915 from the tenth century. No authors are indicated in these manuscripts after the tenth century. While this sample is too small to be conclusive, it might reflect a trend.

\section{CONCLUSIONS}

We acknowledge that the selection used in the present survey is incomplete, even though the 107 manuscripts we explore represent a larger body of data than any previous work of which we are aware. ${ }^{17}$ Our hope is that this study might have some heuristic value by suggesting areas for further enquiry. What we have observed in our sample is that the manuscript tradition among commentaries is open to the same vagaries as the rest of the textual tradition of the New Testament. There are luxurious copies in a neat hand, presented with precision. There are manuscripts in scholarly hands that are difficult to read because every square inch of page is dedicated to text. The study of the transmission is frustrated by lacunae, images which are unusable and witnesses which we are unable to access.

One enquiry which could be taken further concerns the relationship of the divisions in the commentaries to the lectionary divisions. The most common lectionary divisions are Romans $12: 1-3,4-5,6-14$, and 15-21. Numerous commentaries copied in the frame format have lectionary apparatus either added by another hand, or incorporated into the text from its inception. One can imagine that public reading of Scripture would not be difficult from a manuscript in this format and so it is not surprising to find lectionary notations present. An interesting example for the possibility of public or liturgical reading is GA 2007, a manuscript of Oecumenius copied in the alternating catena format. As noted above, the text of Romans 12 is divided in three sections for comment, marked by the first hand with $\alpha \rho \times \eta$ and $\tau \varepsilon \lambda(o \varsigma)$ in the body of the text, with the liturgical occasion for each of the three readings noted in the margin. The first section seems to have been regarded as a single lection, but there is a four-dot diamond at the end of verse 3 , and a helios symbol in the margin next to verses 4-5.

17 In the terms of the saying attributed to Ernest Rutherford that 'all science is either physics or stamp-collecting', we feel we have done no more than assemble a stamp collection. 
There is no indication of the occasion in the church year when that subtly demarcated passage would be read.

In general, the texts of the manuscripts of named exegetes are relatively consistent in the manner they are divided for comment. The exception here are the manuscripts of Chrysostom, whose divisions in Romans 12 range from 11 to 47. Could this be because Chrysostom's commentary began its life as homilies? Does the opposite apply to those commentaries of Oecumenius where in Romans 12 the text is so carefully reproduced that comments begin with the number 64 and end with 11? Did Oecumenius have an official exemplar that intimidated those who copied it and encouraged a discipline? Would a similarly powerful exemplar explain how Theophylact's text resisted temptations to make it conform to the majority text?

The uniformity of the order of books in the manuscripts suggests that the edition of the collection of letters occurred very early in their transmission history. The lack of uniformity in the commentary manuscripts is thus even more surprising; by itself, this would suggest that the collection of the commentator's works did not follow a similar history of origin or transmission.

We were unable to correlate the division of the text between the manuscripts and the commentators. The evidence of many more manuscripts would be required for any meaningful comparison.

Our final note is perhaps of greater interest to exegetes: it was interesting to observe the number of occasions when manuscripts which had previously shown no particular interest in identifying quotations from the Hebrew Scriptures went out of their way to indicate that Romans 12:20 is a quotation from Proverbs. Were they embarrassed by the Apostle's reference to passive-aggressive charity? 


\title{
6. RESURRECTION APPEARANCES IN THE Pauline Catenae
}

\author{
THEODORA PANELLA ${ }^{1}$
}

\section{BACKGROUND AND SOURCES}

This investigation of 1 Corinthians 15:5-8 in the Pauline catenae is based on a comparative study of editions of the Greek catenists and on the analysis of fifty-six manuscripts available in the New Testament Virtual Manuscript Room (NTVMR) hosted at the University of Münster and other online sources. ${ }^{2}$ The first part considers the biblical text of the catenae, along with observations on their manuscript layout, which reveal connections between certain witnesses and occasional divergences from mainstream tradition. This is followed by a phrase-by-phrase examination of the catenae on these verses: not only do these bring into focus the way in which catenists used and adapted their sources, but they also provide evidence for the date at which they were compiled as well as some intriguing anomalies.

Beginning with the most recent compiler of Pauline catenae in Greek, the twelfth-century monk Euthymius Zigabenus, I have used the edition of Nikephoros Kalogeras published in $1897 .^{3}$ A collation of manuscripts of

\footnotetext{
1 The research leading to these results has received funding from the European Union Seventh Framework Programme (FP7/2007-2013) under grant agreement no. 283302 (COMPAUL: 'The Earliest Commentaries on Paul in Greek and Latin as Sources for the Biblical Text'). This work is also supported by an Arts and Humanities Research Council Midlands3Cities Doctoral Training Partnership award.

2 http://ntvmr.uni-muenster.de. I also made use of digitisations hosted by the holding institutions and http://www.csntm.org/manuscript.

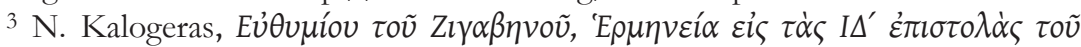

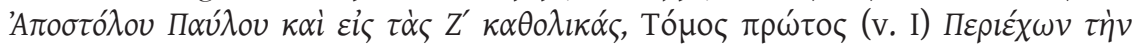


Zigabenus produced no variant readings in the text of these verses. Kalogeras notes on his title page that he edited Zigabenus' Pauline catena 'for the first time, from an old manuscript'. It should be mentioned that Matthaei, the first editor of Zigabenus' catena on the Gospels, had also found a manuscript in Munich containing Zigabenus' catena on Romans and 1 Corinthians but he did not edit it. ${ }^{4}$

The next oldest catenist is Theophylact, archbishop of Ohrid in the late eleventh and early twelfth century. The earliest printed text of Theophylact's catena on the Pauline Epistles, edited by Augustine Lindsell and published in London in 1636, relied on a single 'very old manuscript' (codex uetustus) belonging to the Earl of Arundel. ${ }^{5}$ Although some twelfthcentury manuscripts still survive, my survey relies on ten manuscripts from the thirteenth to the sixteenth centuries available in the NTVMR and the text reproduced in Migne (PG 124).

Nicetas of Heraclea (or of Serrae) in the eleventh century is named as the author of a catena on 1 Corinthians 1-8 in Florence, BML, Plutei IX. 10. This was published by Giovanni Lami in his multi-volume work Deliciae Eruditorum of 1738. Turner, however, noticed that 'the relation between the two catenae of Oecumenius and Nicetas is exceedingly close', concluding that the Florence catena ascribed to Nicetas 'simply represents one of the numerous subdivisions of the Oecumenian tradition' and that 'until more has been done for a critical edition of Oecumenius it is hardly possible to be certain that the Florence manuscript may not, after all, embody a recension by Nicetas of the Oecumenian Catena'. ${ }^{6}$ The later researches of Staab confirmed that this catena is part of the Oecumenian tradition,

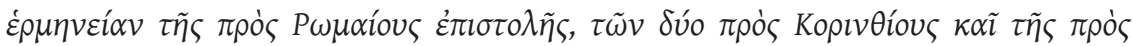

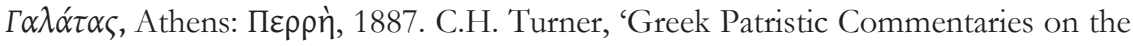
Pauline Epistles', in A Dictionary of the Bible, ed. J. Hastings, New York: Scribner, 1905, 486, mistakenly expands the editor's first name as 'Nicolas' instead of 'Nikephoros'.

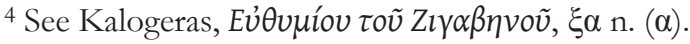

${ }^{5}$ On the history of this edition, see Turner, 'Greek Patristic Commentaries', 486. The Arundel Collection subsequently passed to the British Library.

6 Turner, 'Greek Patristic Commentaries', 486. For the Arundel Manuscript Collection see also: http://www.bl.uk/reshelp/findhelprestype/manuscripts/closedcollections/ 
belonging to his Pseudo-Oecumenius type ' $a$ '. ${ }^{7}$ There is therefore no witness to Nicetas' catena in 1 Corinthians. ${ }^{8}$

The earliest catena on the Pauline Epistles is that of Oecumenius, now believed to have lived at the end of the sixth century. ${ }^{9}$ The earliest surviving Pauline catena manuscripts are witnesses to the Oecumenian tradition. Staab divided it into five types $(\mathrm{a}-\mathrm{e})$, which are all found in manuscripts of the ninth to the eleventh centuries. Most of the manuscripts of the PseudoOecumenian tradition come from this period, and I have used a selection of these. The first printed catena on the Pauline Epistles relied on a manuscript of Oecumenius. It was published in 1532 at Verona by Bernardus Donatus, and then re-edited and translated into Latin by Morellus in 1633. This is the edition reproduced by Migne (PG 118). The majority of Oecumenian manuscripts in my sample agree with the $P G$ edition, apart from a few divergences noted below. It is also worth noting that several differences which could be used to create subdivisions do not always agree with Staab's subdivisions of Pseudo-Oecumenian types.

I have also added information from two further sources normally described as Pauline commentators rather than catenists: Theodoret, represented by GA 606, and John of Damascus (GA 018 and 2110). ${ }^{10}$ In addition, five manuscripts are included which are classified as compilations of extracts from John Chrysostom. ${ }^{11}$ As I will show below, several of these are actually witnesses to John of Damascus.

The full list of manuscripts that have been checked is as follows: GA 018, 056, 0142, 0150, 0151, 82, 91, 250, 254, 314, 454, 457, 605, 606, 617, 619, 621, 627, 641, 858, 891, 1162, 1277, 1424, 1480, 1862, 1871, 1878, 1888, 1900, 1905, 1908, 1915, 1916, 1920, 1923, 1927, 1930, 1942, 1943,

7 K. Staab, Die Pauluskatenen nach den handschriftliche Quellen untersucht. Rome: Pontifical Biblical Institute, 1926.

8 Three further catena manuscripts ascribed to Nicetas only contain Hebrews (GA 1938, 1983 and 2890).

9 F. Diekamp, 'Mittheilungen über den neuaufgefundenen Commentar des Oekumenius zur Apokalypse', Sitzungsberichte der Preußischen Akademie der Wissenshaften zu Berlin (Phil.-hist. Klasse) 43 (1901)1046-56. See also page 19 above.

${ }^{10}$ Until recently, the only edition of John of Damascus was that in PG 95, cols 569-705. I have not been able to gain access to a copy of R. Volk, Die Schriften des Johannes von Damaskos. Vol. 7. Commentarii in epistulas Pauli. PTS 68. Berlin: de Gruyter, 2013.

11 GA 0150, 0151, 1942, 1962 and 1969. 
1962, 1969, 1980, ${ }^{12}$ 1982, 1988, 1992, 1993, 1997, 1998, 2000, 2008, 2110, 2125, 2183, 2817 and 2889.

\section{THE Biblical TEXT}

The biblical text of all these catenae appears to be Byzantine. The key verse that demonstrates it is the second part of 1 Cor. 15:6. In NA28, this reads:

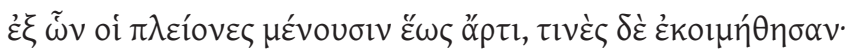

The Byzantine text has $\pi \lambda \varepsilon$ ríous instead of $\pi \lambda \varepsilon$ cíoveৎ and also adds the

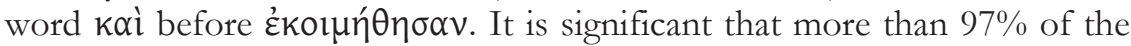
manuscripts used for the present study support these readings. In general, the earliest Church Father to witness to the Byzantine text-type in New Testament quotations is John Chrysostom (349-407). As his Homilies are probably also the source of the first Pauline catena ever compiled, it is not surprising that the same form of text is reflected in the catenae.

Another verse of interest is the one immediately preceding the passage on which this study focusses. In 1 Cor. 15:4, the Byzantine text and almost

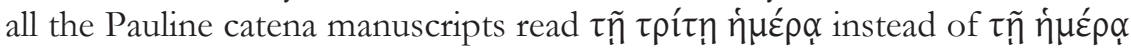

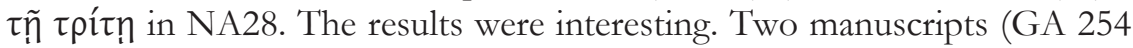
and 1962) support the reading of NA28 in 1 Cor. 15:4, but of these, only

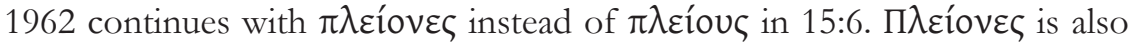
found in GA 0150 and 858 . This shows that commentary manuscripts are also susceptible to contamination between textual traditions. Although it would be relatively easy to introduce a new form of text into the block of biblical text in a frame commentary, the above-mentioned manuscripts are laid out as alternating rather than frame catenae. This could point to exemplars, now lost, in a different format.

The biblical text of Theophylact's Pauline catena in 1 Cor. 15:4 is particularly intriguing. ${ }^{13}$ GA 254 is the only one of the ten witnesses used for Theophylact which supports NA28. Two of the other manuscripts differ in the same verse, where NA28 and the Byzantine text both read

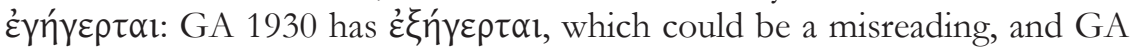
2889 reads $\eta \gamma \gamma \varepsilon \rho \theta \eta$. This high proportion of variant readings suggests that the biblical text in Theophylact manuscripts is worthy of fuller

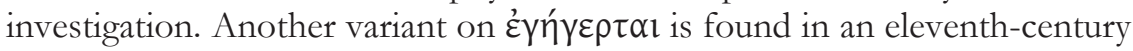

${ }^{12}$ GA 1980 is missing a page which covers part of the passage under

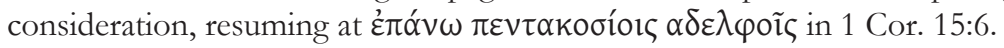

13 See also the observations of Morrill and Gram on page 114 above. 
manuscript of the Pseudo-Oecumenian tradition, which has ơvv́์ $\tau\rceil \eta$ (GA 1916). The same verb occurs in a manuscript with extracts from

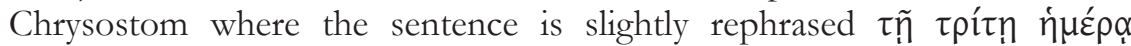

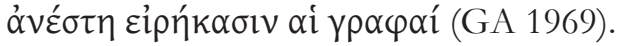

The Text und Textwert volume for 1 Corinthians reports a variant in the next verse. ${ }^{14}$ All Pauline catena manuscripts agree with the majority reading $\tau o i ̃ \varsigma ~ \delta \omega \delta \varepsilon \kappa \alpha$ regarding the number of the disciples that saw Jesus after his resurrection. In only one of the manuscripts investigated for the present chapter is this written as a numeral, $1 \beta^{\prime}$ (GA 91, not included in Text und Textwert). The only witnesses in the selection of manuscripts which read

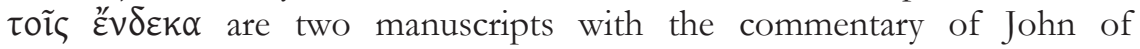
Damascus: GA 0150 and $2110 .{ }^{15}$ While the variant could have arisen independently, owing to the logic of the passage, other shared readings in these two manuscripts indicates that they are related. ${ }^{16}$ This is confirmed by the presentation: both have the same ruling pattern, the same number of lines, and the same numbering system; the lemma is written in majuscule and the comment in minuscule. Although further research is needed, the hands appear to be identical and it seems highly likely that these are exemplar and copy, probably by the same scribe. Although the Liste dates GA 0150 to the ninth century, in the Pinakes catalogue both are assigned to the tenth century. ${ }^{17}$

There seems to be another instance of exemplar and copy among the manuscripts of Oecumenius. GA 056 and 0142 are both witnesses to the Pseudo-Oecumenian type 'd'. Although Staab notes that this type could stand as a separate catena, it has a lot in common with the rest of the Pseudo-Oecumenian family. ${ }^{18}$ These two witnesses share the same ruling

14 K. Aland et al., Text und Textwerte der Griechischen Handschriften des Neuen Testaments, II. Die Paulinischen Briefe, Band 2: Der 1. und der 2. Korintherbriefe. Berlin: de Gruyter, 1991, 301-4.

15 Although von Soden categorizes GA 018 and 2110 as John of Damascus manuscripts, he only describes GA 0150 as excerpts from Chrysostom. The commentary of John of Damascus is, in fact, made up of excerpts from John Chrysostom.

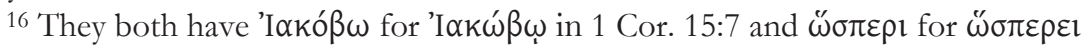

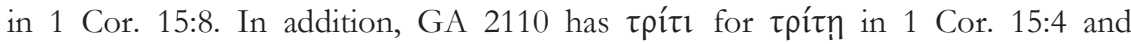

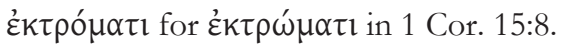

17 See http://pinakes.irht.cnrs.fr and also G. Mercati, 'Il catologo dei mss. notevoli di Patmo e le copie Lolliane', Studi e testi 68 (1935) 129.

18 Staab, Die Pauluskatenen, 160. 
system and have an identical number of pages: the contents of any page chosen at random corresponds to the equivalent folio of the other manuscript, sometimes with slight differences in the distribution of words on each line. The verse 1 Cor. 15:4 is missing from both manuscripts. The biblical text is written in a large block of majuscule script. Indirect speech is a particular feature of the commentary, and biblical verses are repeated within the exegesis in such a way that they are not clearly distinguished but have to be extracted as follows:

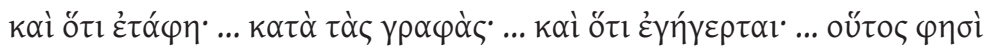

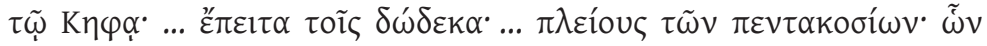

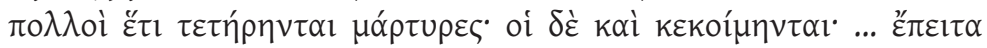

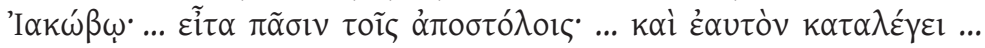

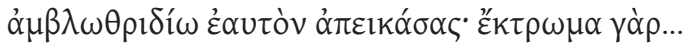

The Byzantine character of the text is preserved in these repetitions (e.g.

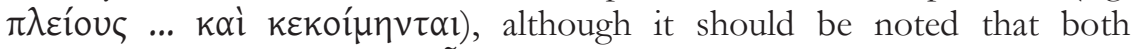
manuscripts read हैं $\varepsilon \varepsilon \imath \alpha$ for $\varepsilon \tilde{i} \tau \alpha$ in 1 Cor. 15:5.

The last couple of manuscripts that I would like to discuss here are both from the ninth century. GA 018 is traditionally described as a copy of John of Damascus, while GA 0151 is characterised as extracts from Chrysostom. However, there is a variant reading in 1 Cor. 15:6 which is peculiar to these two manuscripts among all those investigated in the

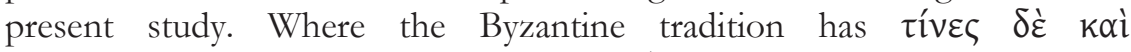

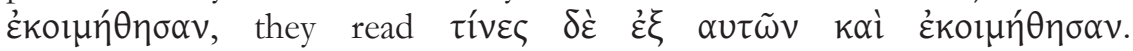
Furthermore, both are written in two columns per page and have the same numbering system that goes all the way through to the last comment at the end of the Epistle. Interestingly, however, these numbers do not simply indicate the comments, but precede the biblical text. It appears that they should both be identified as a shortened form of John of Damascus' commentary on the Pauline Epistles, a conclusion which is reinforced by comparison with GA 0150 and 2110 as discussed above. Nevertheless, there are three differences in their presentation. Firstly, the entire biblical text in GA 0151 is written in majuscule, whereas in GA018 this is only true for the first verse of every block; the rest is in minuscule. Secondly, 018 starts each comment on a new line, whereas the copyist of GA 0151 is more economical and continues directly from biblical text to comment and vice versa. Thirdly, GA 018 occasionally adds the abbreviation $\imath \bar{\omega}$ before the comment numbers. It is not clear whether this is by the scribe or a later hand, but it is presumably an indication of the author.

This analysis of the biblical text has already brought to light a number of interesting features and distinctive characteristics of Pauline catena 
manuscripts. It is also clear that the traditional descriptions of their contents need to be revisited, especially in the case of manuscripts classified as 'Extracts from Chrysostom'. Further investigation on a more extensive portion of the Pauline Epistles may provide more information which could help us to understand the history of these commentaries and the transmission of the biblical text.

\section{THE COMMENTARY}

An examination of the commentary on 1 Cor. 15:5-8 reveals the development and interrelationship of Pauline catenae. These verses constitute the oldest evidence for the resurrection appearances, going even further back than the Gospels. The principal sources for the catenae are the three eponymous compilers: Oecumenius, Theophylact and Zigabenus. I will also use additional primary sources in places where this illuminates the history of their text. The catena printed by Cramer and known as Typus $V$ aticanus is included in order to connect this study with previous work on catenae: in some places it provides an example of the early reuse of the Oecumenian tradition, but on other occasions it goes its own way. ${ }^{19}$

The biblical text is set out below phrase by phrase, with extracts from primary sources in approximate chronological order. I have kept the punctuation and formatting of the editions. ${ }^{20}$

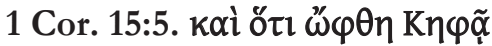

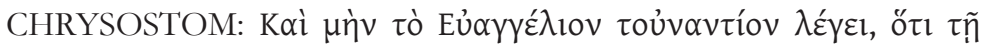

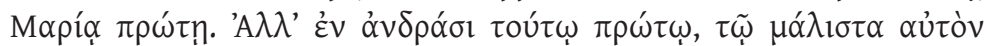

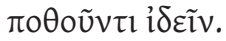

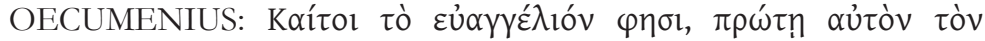

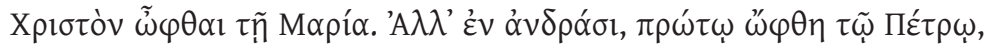

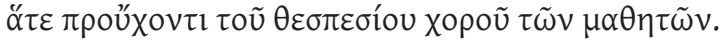

19 On Cramer's edition of the catenae, see pages 20-1 above.

20 Chrysostom is reproduced from PG 61, cols 9-382; Oecumenius from PG 118, cols 307-455; Typus Vaticanus from Cramer; Theophylact from PG 124, cols 563-794; Zigabenus from the edition of Kalogeras (see note 3). Origen is cited once, from M. Borret, Origène. Contre Celse, t. 1. SC 132. Paris: Éditions du Cerf, 1967. 


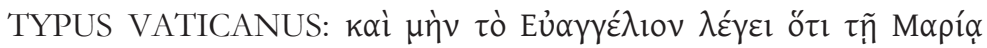

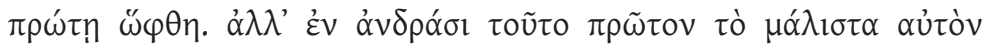
$\pi \circ \theta 0 \tilde{v} v \tau \iota ~ i \delta \delta \varepsilon \tilde{v}{ }^{\circ}$

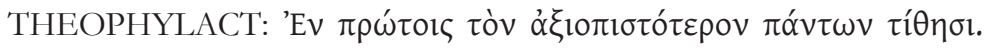

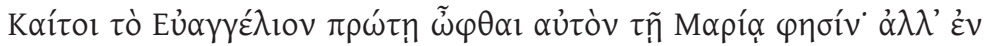

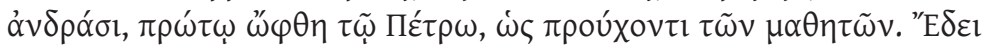

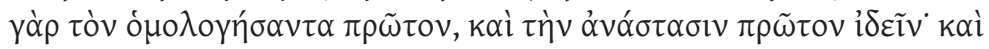

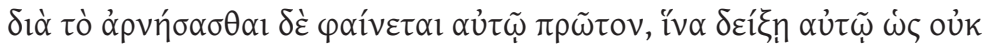
$\dot{\alpha} \pi \varepsilon \dot{\varepsilon} \rho \dot{\rho} \imath \pi \tau \alpha$.

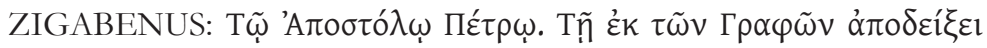

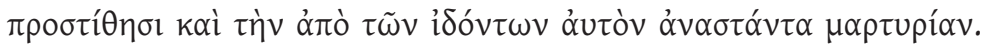

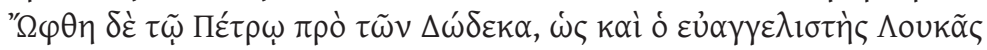

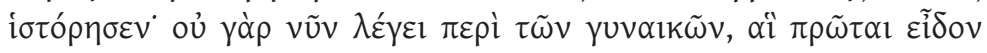

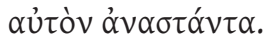

It is interesting how the catenists handle the differences between the Pauline account of the resurrection and that in the Gospels. Oecumenius says that the gospel certainly says that Mary first saw him, but among men it was Peter who first saw him. This is echoed by Theophylact: the phrase $\dot{\omega} \varsigma$ $\pi \rho o u ́ x o v \tau \imath \tau \tilde{\omega} v \mu \alpha \theta \eta \tau \tilde{\omega} \nu$ suggests that he relied on Oecumenius, although he also adds that the reason was the denial of Peter. The difference in the causal particle is interesting: Oecumenius has ö $\tau \varepsilon \pi \rho o u ́ x o v \tau l$, presenting the cause as a fact, whereas Theophylact's $\omega \varsigma$ $\pi \rho o u x$ xov $\tau$ implies that the writer does not vouch for the accuracy of the stated cause. The mention of Jesus' appearance to Mary derives from Chrysostom's Homilies on 1 Corinthians. Interestingly, Typus Vaticanus follows Chrysostom more closely than the standard edition of Oecumenius, although it is clear that the latter is based on the same source without adding anything. Zigabenus alludes to the Gospel of Luke, which mentions both the women and Peter, but in his view it is more specific to say that here Paul is silent on the women who

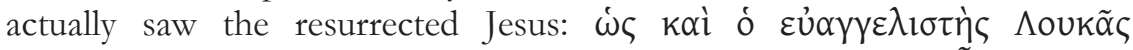

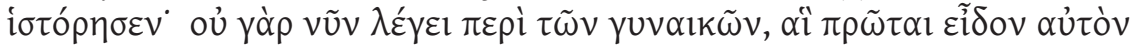

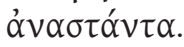

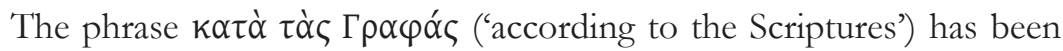
used twice in the previous two verses (1 Cor. 15:3-4). It should also be noted that the proof of the scriptures is used once more by Zigabenus and Theophylact to stress the fact of the Resurrection. They both repeat the

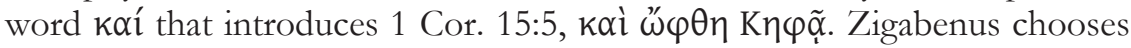
to cite the Scriptures for the testimony of all in every instance from the beginning while he was commenting on the appearance to Peter, but 
Theophylact uses it later to connect it with the testimony of the five hundred:

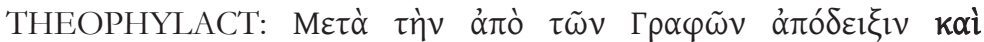

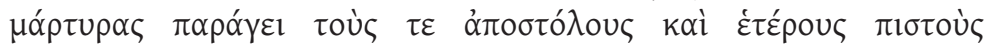

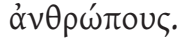

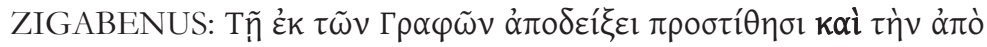

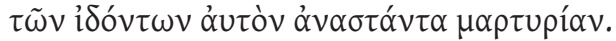

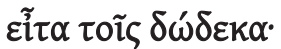

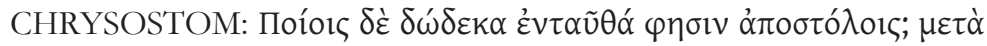

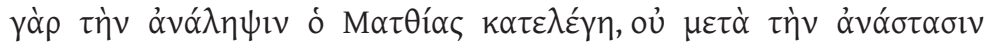

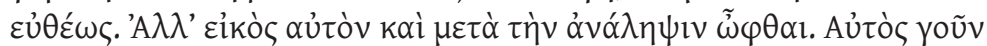

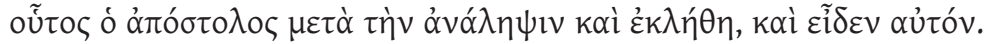

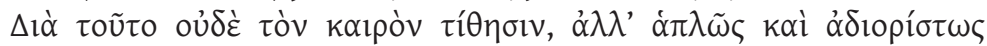

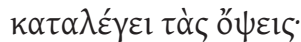

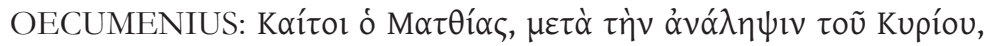

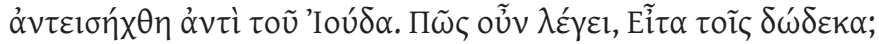

TYPUS VATICANUS: -

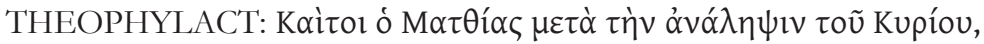

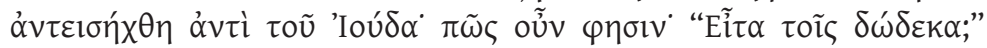

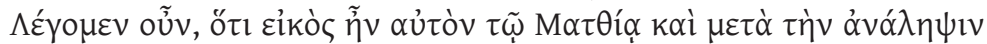

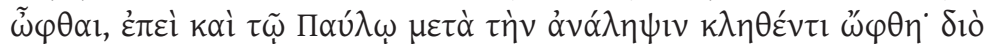

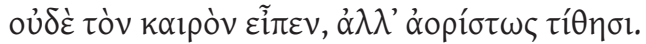

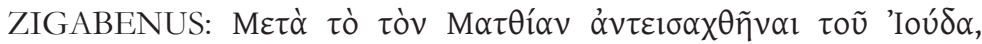

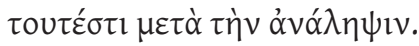

Paul presents the witnesses in ascending numerical order: the first to see the resurrected Jesus was one man, Peter, then the twelve disciples, and later (as will be discussed below) he appeared to more than five hundred Christians. This elliptic sentence raises two issues. The first is the discussion that follows about replacing the twelfth disciple after the suicide of Judas. The Oecumenian tradition is the first to address the issue, following Chrysostom. Oecumenius wonders why Paul refers to the twelve and justifies it by claiming that this is an appearance of the Lord after the Ascension, and so the disciples were twelve because Matthias had already been included among them. Chrysostom also observes that Paul too saw Jesus after the Ascension and for this reason the time of this occurrence is not defined. Theophylact not only repeats Oecumenius word for word but 
also adds two phrases taken directly form Chrysostom (Eikò ... $\tilde{\omega} \varphi \theta \alpha 1$ and

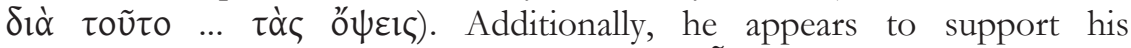

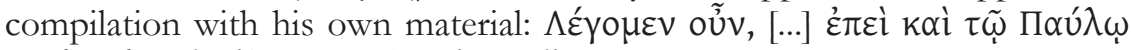

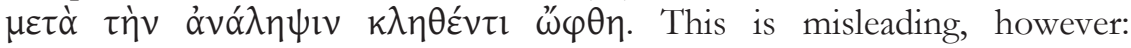

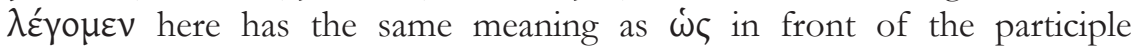
discussed above. Zigabenus is most concise and does not question this fact. It must be noted that Paul in 1 Corinthians only refers to the twelve disciples, relying on the traditional formula. ${ }^{21}$

The second and perhaps most interesting point of the whole paragraph with regard to the relationship between the compilers is the following comment:

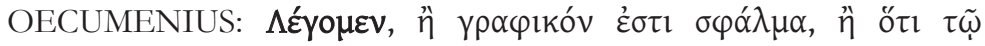

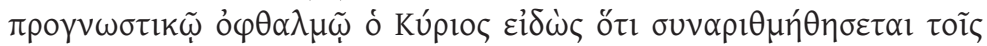

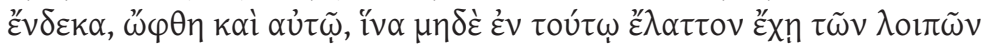

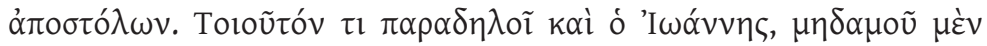

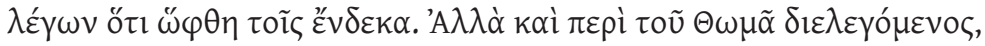

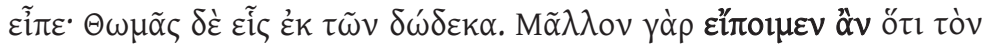

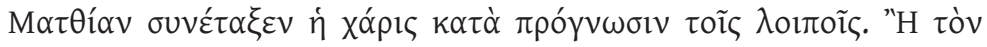

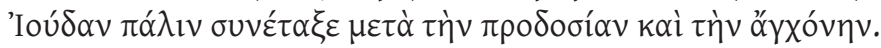

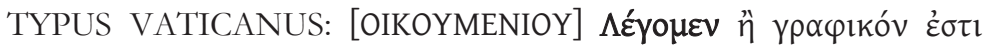

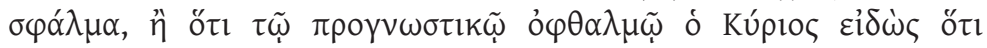

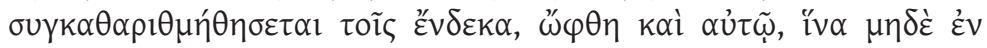

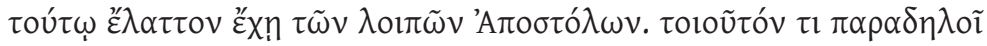

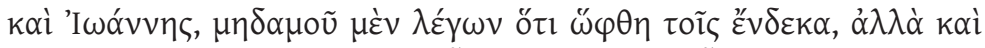

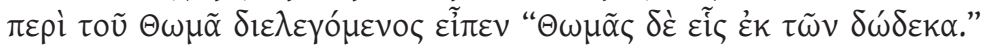

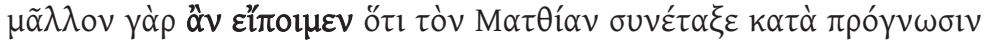

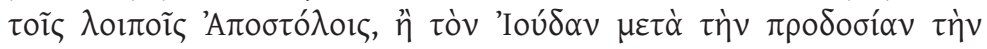

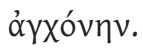

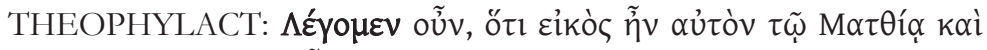

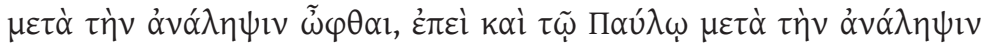

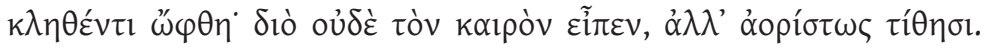

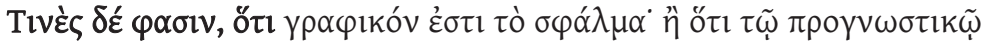

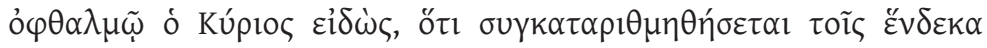

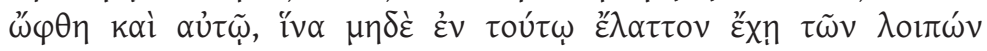

21 See A. Robertson \& A. Plummer, A Critical and Exegetical Commentary on the First Epistle of St. Paul to the Corinthians. $2^{\text {nd }}$ edn. Edinburgh: T \& T Clark, 1914 (reprinted 1958), 336. 


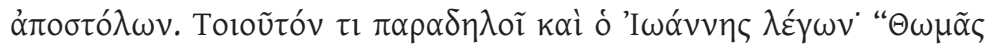

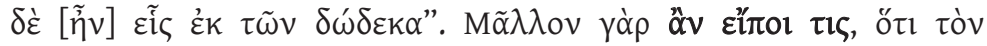

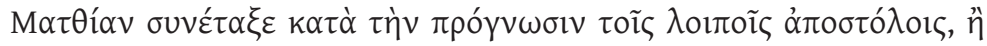

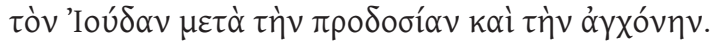

ZIGABENUS:

Not only is Oecumenius' originality obvious here, but so is the use of his words several centuries later by Theophylact. While Oecumenius uses the

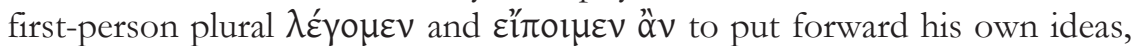

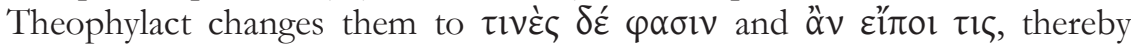
attributing these ideas vaguely to an unnamed source. This lack of specificity may be due either to Theophylact's choice not to name Oecumenius, or the absence of an author indication for this comment in his source manuscript. ${ }^{22}$ In addition, Theophylact's use of $\lambda \dot{\varepsilon} \gamma o \mu \varepsilon v$ in the preceding sentence offers another reason for its replacement here.

This is the only innovative contribution made by Oecumenius on this passage, and demonstrates not only his chronological priority but also the extensive use of his catena by in subsequent compilations, such as Typus $V$ aticanus and Theophylact. Oecumenius' originality, signalled by the firstperson verbs, is also shown by his naming of John in order to distinguish his own words from those of the evangelist. In the manuscript tradition, however, this comment is accorded several different treatments. The use of numbers to match comments with the biblical text, particular in catenae laid out in frame format, is common in Oecumenian tradition. ${ }^{23}$ In some witnesses, however, Oecumenius' own comment is not indicated by a number, but by a symbol shaped like a hook. In others, the extract is appended to the end of the previous unit, without any indication. Finally, the comment is missing completely from some manuscripts. ${ }^{24}$ It seems that this points to a secondary stage of editing in the Oecumenian catena tradition, when his own comments were identified by a later editor and marked, but in such a way as not to disturb the original numerical sequence.

22 Oecumenius' name is found in front of this extract in GA 1927 (fol. 72), GA 619 (fol. 157r), GA 1997 (fol. 88), but it is missing from GA 2183 (fol. 164), GA 82 (fol. 133v), Plut. VIII. 19 (fol. 128v).

23 Compare also the observations of Morrill and Gram on pages 110-1 above.

24 Examples of the comment being marked by Oecumenius' name or initials (OIK) include GA 1905 and 1923; it has no indication but is present in GA 1888 and 1916; it is absent from GA 454 and 1920. 
The matter is worthy of more thorough exploration than is possible in the present study.

Theophylact's addition of material is balanced by his omission of

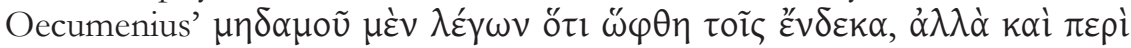

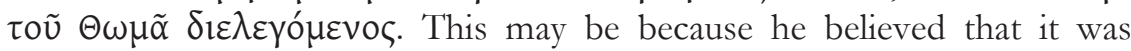
redundant, based on the previous sentence.

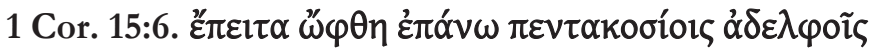

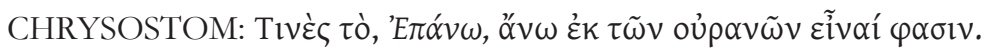

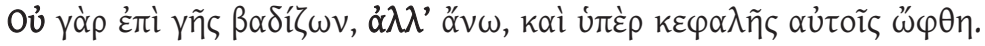

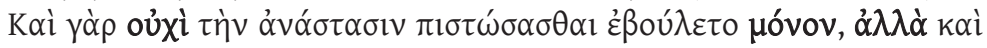

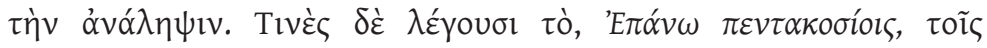

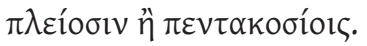

OECUMENIUS: Tò, દ̇đáv

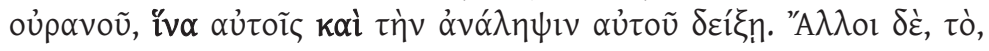

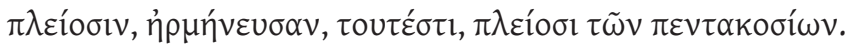

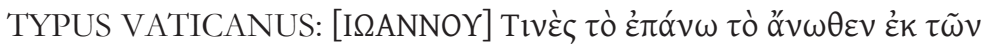

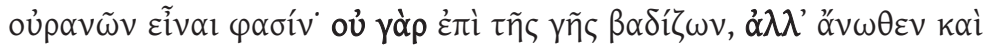

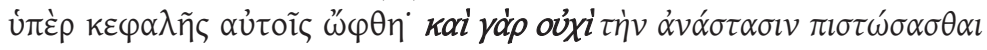

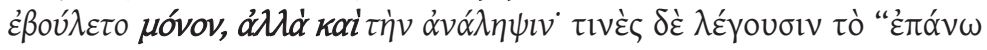

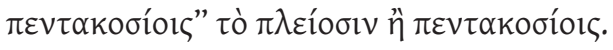

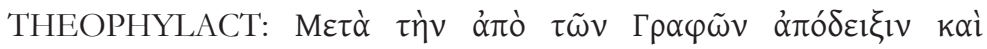

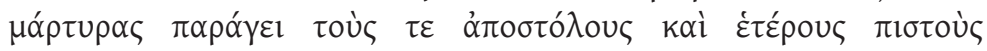

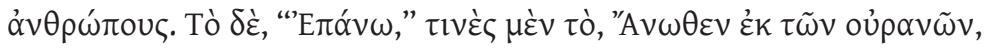

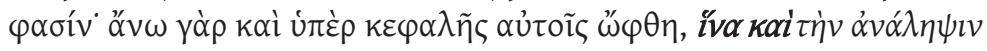

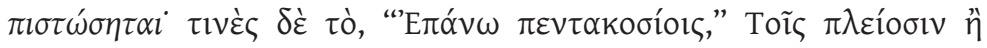

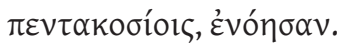

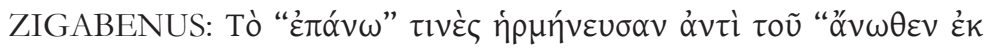

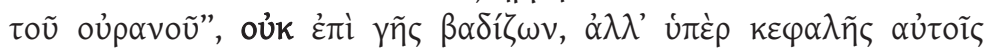

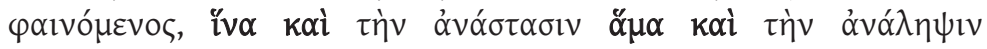

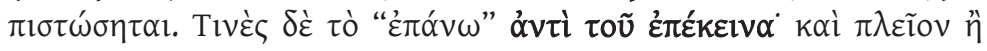

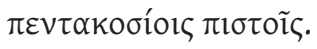

Paul, continuing with his original account, refers to five hundred believers as witnesses to a resurrection appearance of Jesus. This might better be termed a 'post-Ascensional' appearance, as Ėđó́v $v \omega$ here ('above') has a double meaning. This is explained by Chrysostom and reflected in all three compilers. The strongly rhetorical effect of the double antithesis shows the

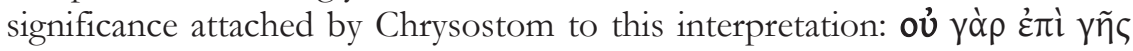




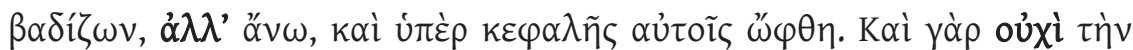

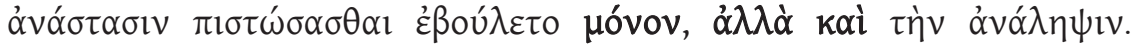
Chrysostom's use of 'o $v \omega$ ('upwards') differentiates him from the catenists, who have ớ $v \omega \theta \varepsilon v$ ('from above'). However, as the edition of Chrysostom in Migne was based on a single manuscript it is possible that other witnesses (and possibly even the source used by the compilers of the catena) read

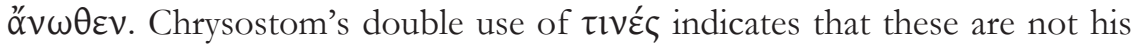
own interpretations, but come from elsewhere. This detail is preserved by the catenists. In the catenae, however, the verb $\lambda \dot{\varepsilon} \gamma o v \sigma l$ is changed to

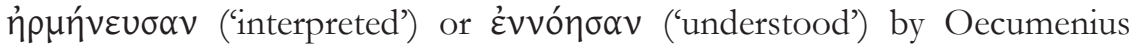
and Theophylact respectively, adding an extra shade of meaning.

The wording of the extracts offers an indication of their ancestry.

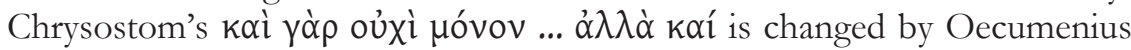

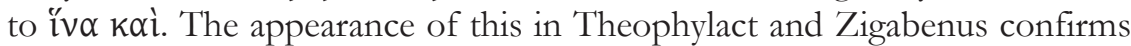
their reliance on Oecumenius. In contrast, Typus Vaticanus preserves Chrysostom's text literally, indicating that it does not derive from Oecumenius.

Once again, Theophylact adds additional argumentation. In this case, he tries to explain the large number, by stating that it was not only the

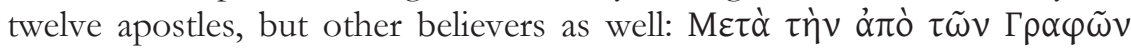

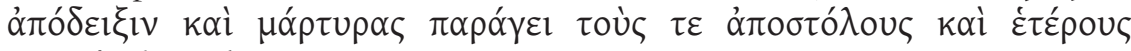

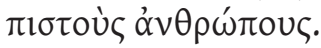

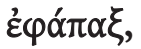

OECUMENIUS:

TYPUS VATICANUS:

THEOPHYLACT:

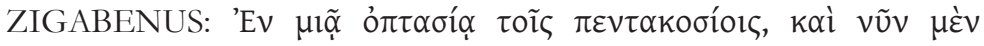
$\tau ం \sigma \circ \tilde{\imath} \sigma \delta \varepsilon, v \tilde{u} v \delta \dot{\varepsilon} \tau 0 \sigma \circ \tilde{\imath} \sigma \delta \varepsilon$.

Paul uses an adverb, $\dot{\varepsilon} \varphi \alpha ́ \pi \alpha \xi$ ('at once'), to comment on this appearance to five hundred and perhaps underline its significance. This is only

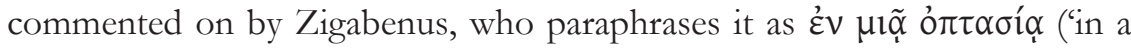
single appearance').

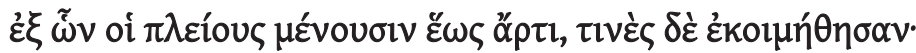

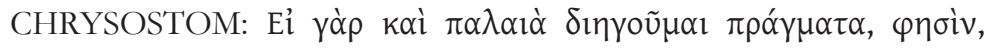

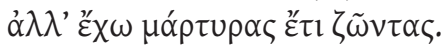

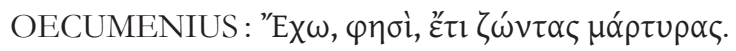


TYPUS VATICANUS:

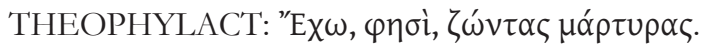

ZIGABENUS:

In this phrase, Paul emphasises his proximity to the events, and the ongoing possibility of independent verification. Oecumenius, followed by Theophylact, repeat Chrysostom's reference to living witnesses. ${ }^{25}$

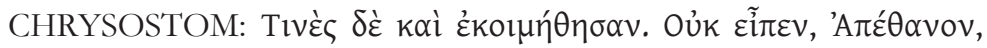

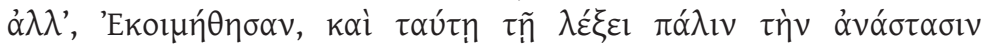
$\beta \varepsilon \beta \alpha i \tilde{\omega} v$.

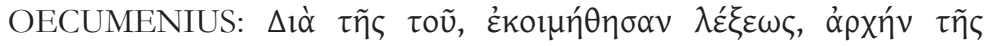

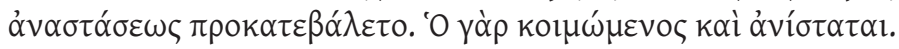

TYPUS VATICANUS: -

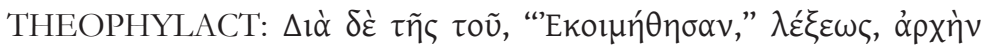

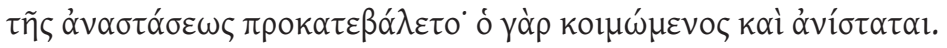

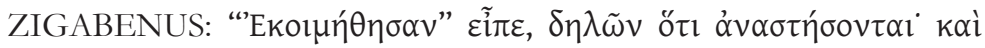

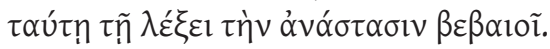

The compilers once again follow Chrysostom's explanation of the word $\varepsilon$ ḱ $\mu$ ń $\theta \eta \sigma \alpha v$ and his connection of it to the general resurrection. Theophylact once more reproduces Oecumenius verbatim: the latter

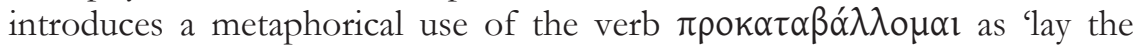
foundations in advance'. Zigabenus, on the other hand, shows his independence, but he is also close to Chrysostom in his use of the verb $\beta \varepsilon \beta \alpha i \tilde{\omega}$.

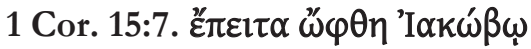

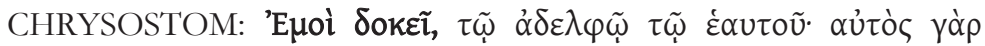

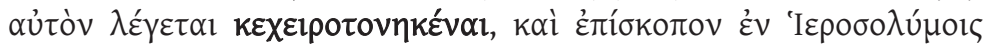

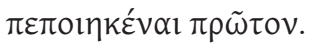

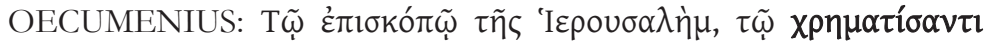

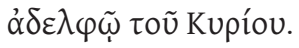

TYPUS VATICANUS: -

${ }^{25}$ On the biblical text of this verse, see page 120 above. 


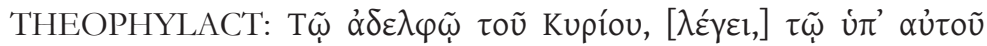

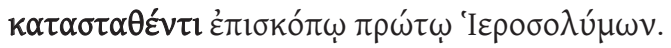

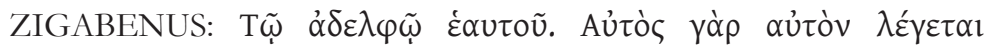

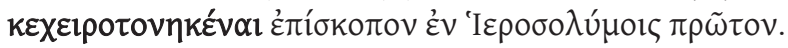

Paul carries on with the list of the people who saw Jesus. James comes next, with no further information. Chrysostom adds his own identification ( $\varepsilon$ k i

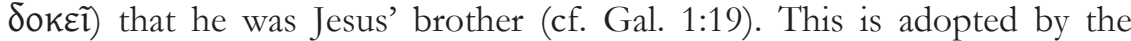
compilers. Zigabenus once again is closest to Chrysostom: Theophylact, for once, differs from Oecumenius, and is also close to Chrysostom although he uses a different verb, $\kappa \alpha \tau \alpha \sigma \tau \alpha \theta \varepsilon \dot{v} \tau \imath$ instead of $\kappa \varepsilon \chi \varepsilon 1 \rho o \tau o v \eta \kappa \varepsilon ́ v \alpha 1$. Oecumenius diverges from the rest not only in his word order but also in

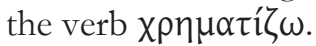

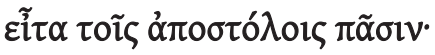

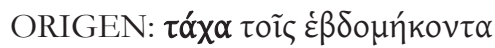

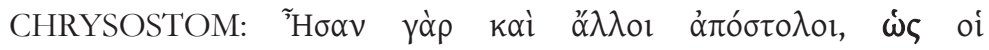

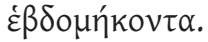

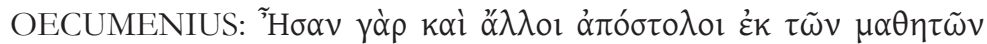

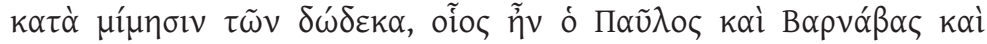
$\Theta \alpha \delta \delta \alpha \tilde{i} о \zeta$.

TYPUS VATICANUS: -

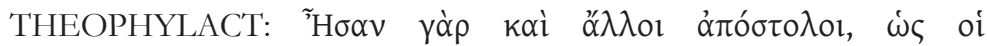

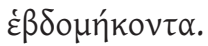

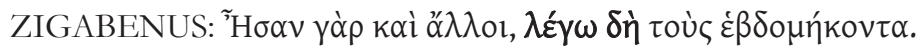

The next resurrection appearance of Jesus, according to Paul, was before all the disciples/apostles. All commentators agree that these were the seventy apostles, apart from Oecumenius, who claims that they were apostles who were among Jesus' disciples in imitation of the Twelve, such as Paul, Barnabas and Thaddeus. Theophylact once again copies Chrysostom, and appears to be followed by Zigabenus. It is not clear whether Zigabenus' use of $\lambda \varepsilon^{\prime} \gamma \omega$ is a (misleading) attempt to make the interpretation appear to be his own or a more natural phrasing which simplifies the use of $\omega \varsigma$. The identification of these as the seventy apostles goes back to Origen. ${ }^{26}$

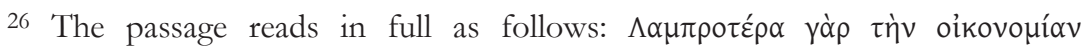


However, over the centuries we may note the growth in confidence from

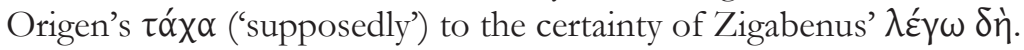

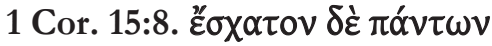

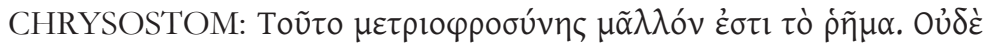

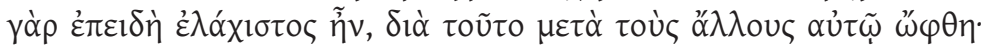

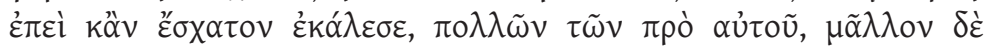

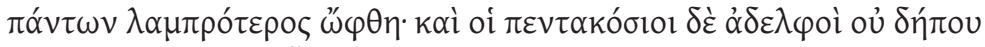

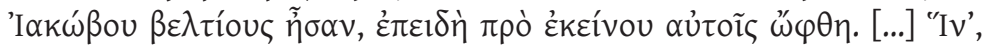

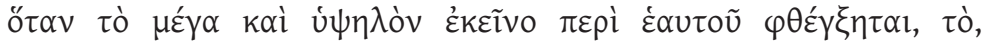

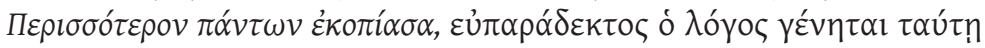
$[\ldots]$

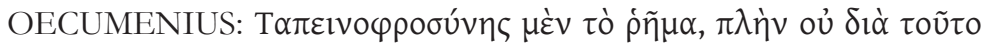

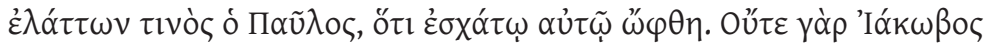

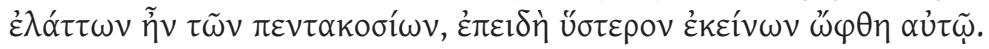

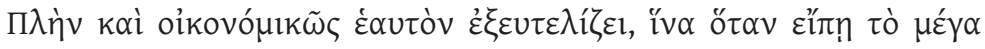

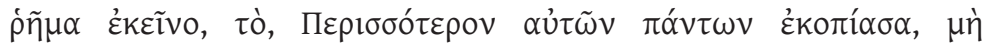

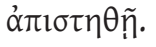

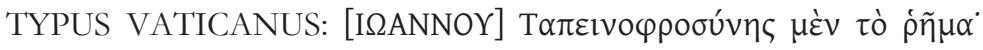

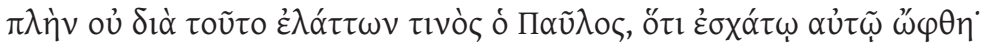

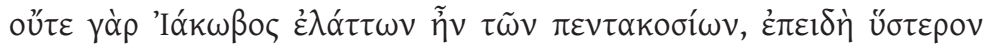

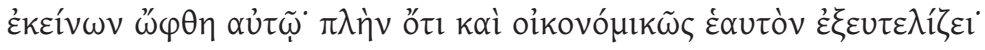

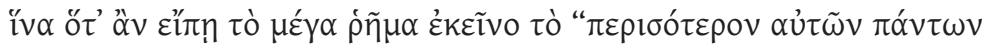

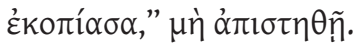

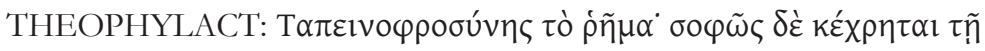

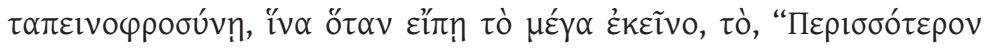

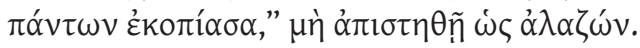

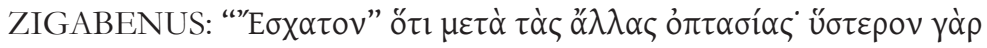

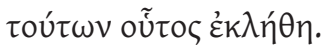

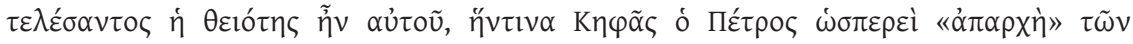

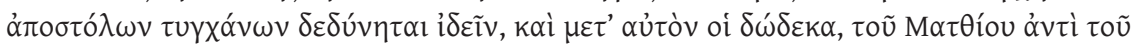

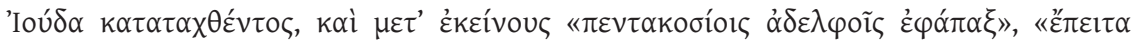

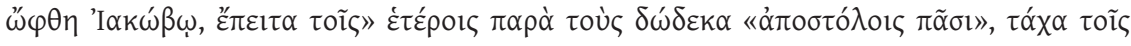

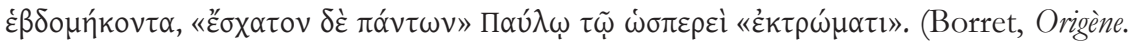
Contre Celse.) 
Perhaps this is the passage where there is the greatest need to have the full text of John Chrysostom in parallel for the whole biblical passage. ${ }^{27}$

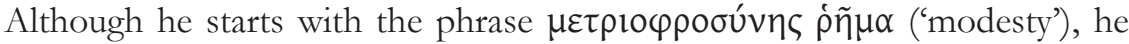
continues exclusively with $\tau \alpha \pi \varepsilon 1 v o \varphi \rho o \sigma u ́ v \eta$ ('lowliness, humility'). ${ }^{28}$ This offers the key to showing how the use of the passage evolved in the subsequent compilers. First of all, Oecumenius quotes from Chrysostom

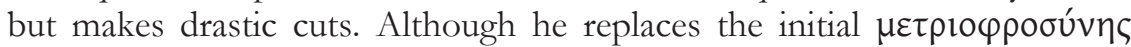
with $\tau \alpha \pi \varepsilon i v o \varphi \rho \circ \sigma u ́ v \eta \varsigma$, the rest of the text agrees almost word-for-word with Chrysostom. The text which Typus Vaticanus ascribes to Chrysostom (ISANNOY) actually reproduces Oecumenius' abbreviated form word-for-

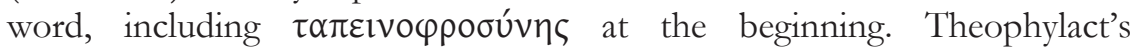

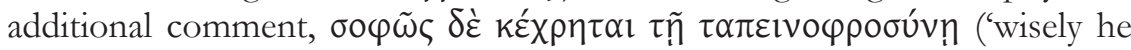
took on lowliness'), does not make it clear whether the subject is Chrysostom in his Homily or, inaccurately, Paul in his Epistle.

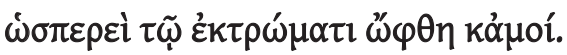

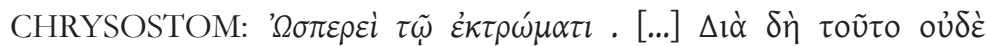

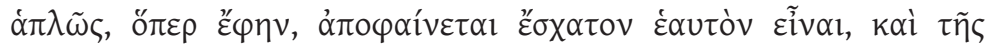

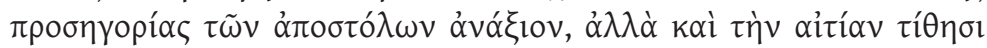
$\lambda \varepsilon \dot{\gamma}\left(\omega v \cdot{ }^{\prime \prime} 0 \tau \imath \varepsilon \dot{\varepsilon} \delta i \omega \xi \alpha \tau \dot{\eta} \nu{ }^{\prime} E \kappa \kappa \lambda \eta \sigma i \alpha \nu\right.$.

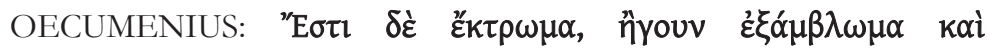

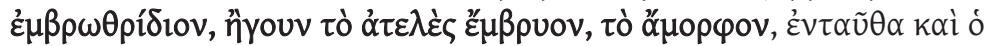

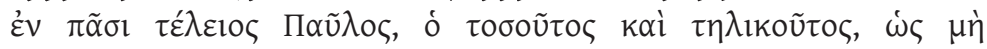

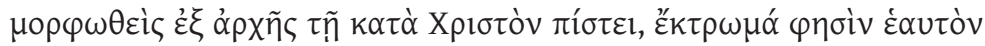

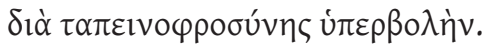

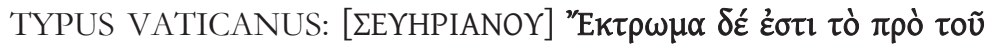

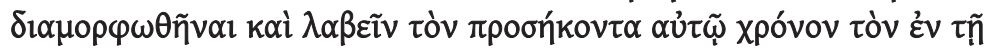

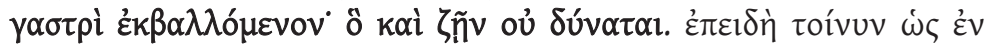

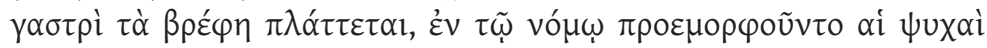

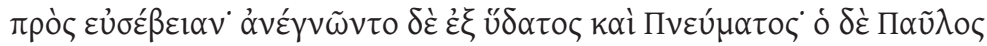

27 Chrysostom's comment on 1 Cor. 5:8-11 is reproduced in full in the Appendix to the present article.

28 Compare the occurrences of $\tau \alpha \pi \varepsilon l v o \varphi \rho \circ \sigma u ́ v \eta s ~ \tau \dot{\alpha} \rho \dot{\rho} \mu \alpha \tau \alpha$,

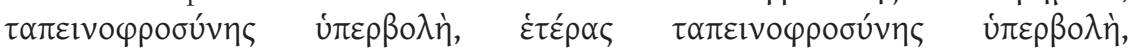

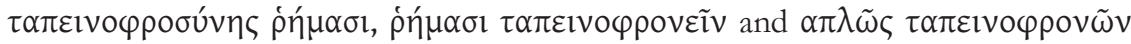
in the Appendix. 


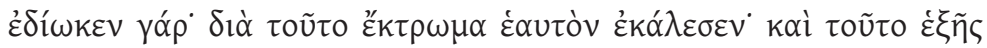

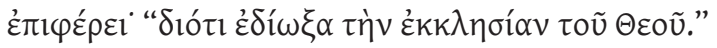

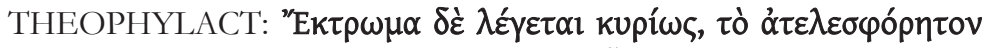

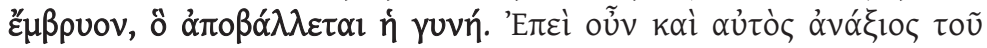

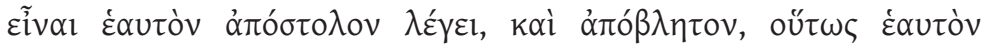

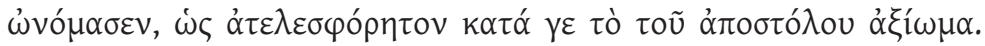

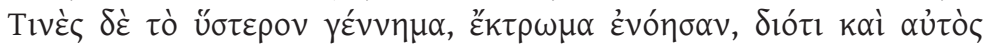

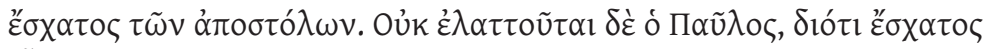

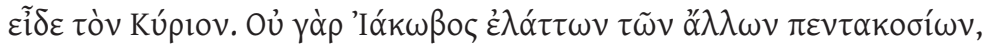

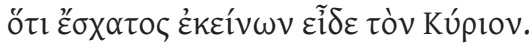

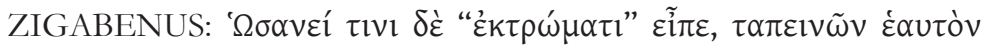

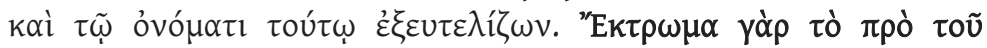

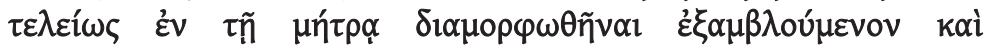

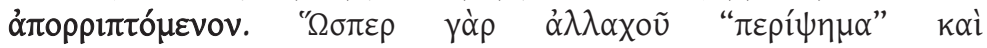

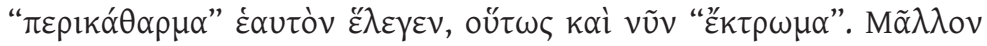

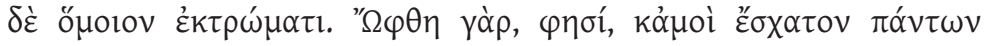

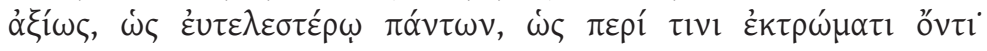

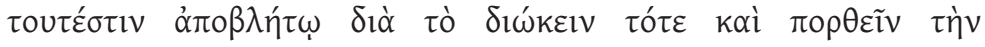

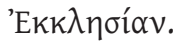

It is interesting that all four Pauline catenae give different definitions of the word $\varepsilon^{\prime} k \tau \rho \omega \mu \alpha$. The only one for which I have been able to find a parallel is that of Oecumenius, and even this raises more questions than it answers. It has often been repeated that Bernardus Donatus used the eleventh-century Paris, BnF, grec 219 for his edition of Oecumenius later reproduced by Migne, even though Geerard describes this as 'the most corrupt of all' (omnium fere depranatissimum). ${ }^{29}$ However, this identification appears to be incorrect, as shown by comparison with a number of verses including the present one: Grec 219 does not contain the definition for the word Ék $\tau \omega \mu \alpha$. In fact, none of the manuscripts I checked from the ninth to the eleventh centuries has this form of the definition. This suggests that Donatus' manuscript might have been a type of Oecumenian catena which is not otherwise attested, and the manuscript itself is lost.

29 M. Geerard, Clavis Patrum Graecorum, vol. IV. Turnhout: Brepols, 1980, 250; another recent example of the assertion is found in M. De Groote, 'Opera (Pseudo) Oecumeniana: Das sonstige echte und vermeinte Oeuvre des Apokalypse-Exegeten Oecumenius.' Byzantinische Zeitschrift 94 (2001) 20-8, who describes the Paris manuscript as Donatus' source 'in all probability' (aller Wabrscheinlichkeit, 20). 
The text of this definition is also problematic. A search on the Thesaurus Linguae Graecae only provides two results for two or more of the

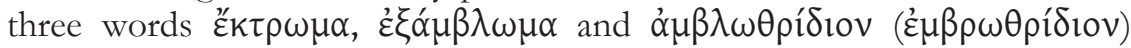
appearing in the same context. ${ }^{30}$ Both, in fact, use all three words. The first is the second-century lexicographer Phrynichus:

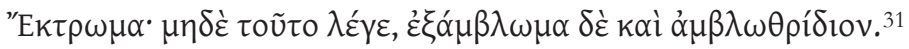

The other is in the Pseudo-Zonaras Lexicon dated to the thirteenth century:

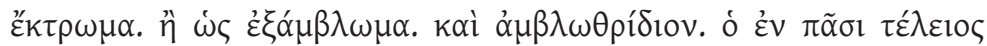

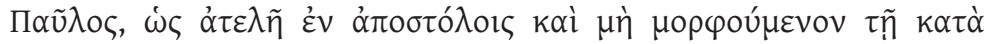

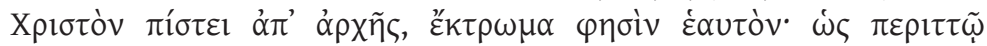

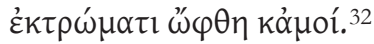

How might this overlap be explained? First, could a catena manuscript cite Phrynichus? It is possible. However, one of the peculiarities of this work is that the entries are not in alphabetical order. This would have made it very difficult to use as a lexicon, so it would not be an obvious source for a catenist. Second, could the thirteenth-century compiler of the PseudoZonaras Lexicon have used a catena manuscript as a source rather than a named author? Although possible, again, this is most unlikely since it would jeopardise the quality of their work. Third, could the Lexicon have influenced the compiler of the catena? This seems to be the most likely explanation, as the wording is almost identical with Pseudo-Zonaras. However, it entails assuming later intervention in the Oecumenian tradition in the manuscript used by Donatus, which must have taken place between the creation of the Lexicon in the thirteenth century and 1532 (the date of Donatus' edition).

\section{CONCLUSIONS}

As noted above, the presence of non-Byzantine readings alongside the expected Byzantine form of the biblical text is interesting and deserves further investigation. Codicological as well as textual similarities can be used to demonstrate relationships between certain manuscripts, as in the case of

30 Online at http://stephanus.tlg.uci.edu.

31 E. Fischer, Die Ekloge des Phrynichos. Sammlung griechischer und lateinischer Grammatiker 1. Berlin: de Gruyter, 1974, lexical entry 258.

32 J.A.H. Tittmann, Iobannis Zonarae lexicon ex tribus codicibus manuscriptis. Leipzig: Crusius, 1808 (repr. Amsterdam: Hakkert, 1967). 
the two new witnesses to John of Damascus' commentary identified among those traditionally described as 'Extracts from Chrysostom'.

Regarding the comments in the main catena traditions, the importance of Chrysostom is paramount. This may be direct or mediated through Oecumenian tradition. It is clear that Theophylact used Oecumenius: in addition, Theophylact sometimes adds his personal opinion and has a tendency to join the extracts together with linking phrases and conjunctions in order to create a flowing literary text. Zigabenus often seems to be independent of the other compilers but to have had separate recourse to Chrysostom.

Finally, the manuscripts of the Oecumenian tradition are striking both for their similarity and their differences. The numbering of the extracts, where this is present, is identical in most of these witnesses. This proves that this catena type was already well established by the ninth century. However, certain aspects, such as the definition of हैk $\rho \omega \mu \alpha$ or the treatment of the sole comment of Oecumenius himself on this passage (1 Cor. 15:6) vary in different witnesses. Indeed, the sequence in which Oecumenius' own observations were added and identified is worthy of more attention than it has so far received. It could even be the case that Oecumenius added this material, indicated by first-person plural verbs, to a pre-existing Pauline catena with numbered comments, and that his own contributions were identified and marked with his name in front of the comment by a later editor familiar with this early catena. This would place the origin of the catena on the Pauline Epistles before Oecumenius in the sixth century, but after the fourth century and the homilies of Chrysostom which form the basis for so much of the material in these commentaries.

\section{APPENDIX: CHRYsostom's COMMENTARY ON 1 CoR. 15:8-11}

The full text of this commentary is given here from $P G$ 61, cols 326-9, in order to show its influence on Oecumenius. I have indicated the numerous occurrences of the word stem $\tau \alpha \pi \varepsilon l v-$.

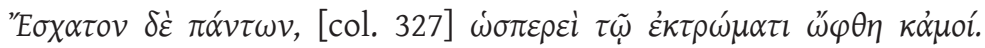

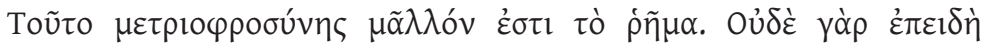

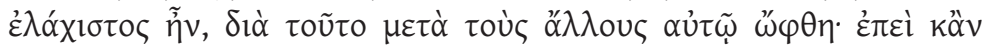

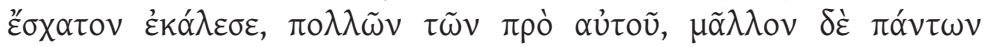

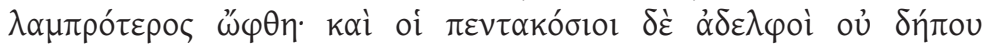

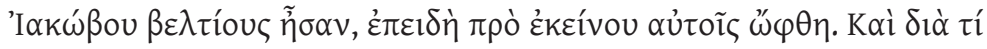

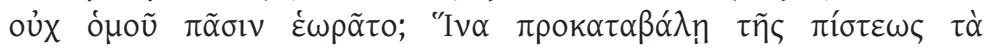

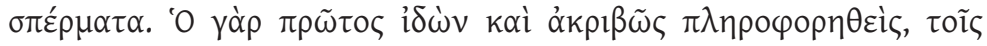




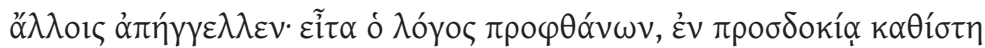

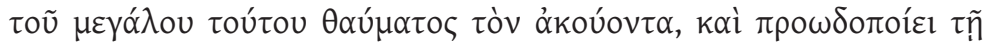

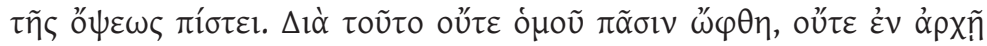

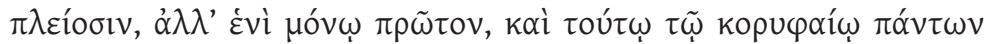

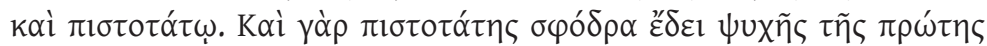

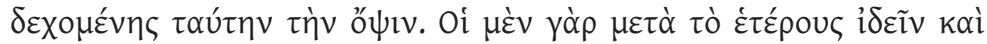

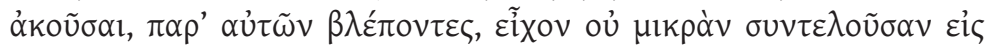

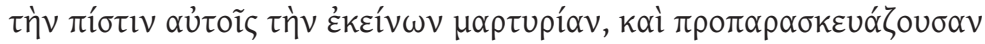

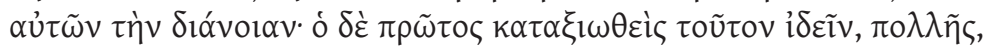

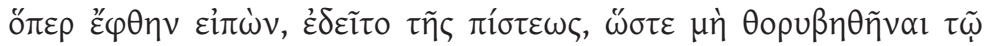

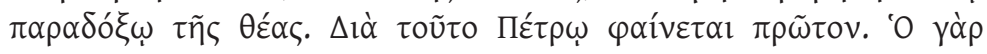

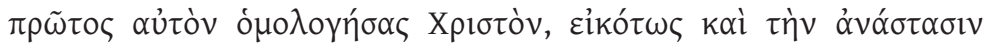

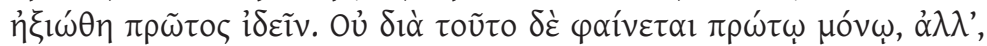

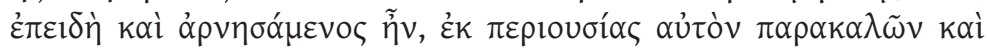

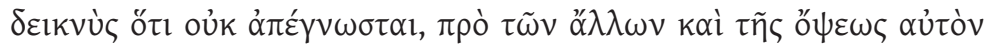

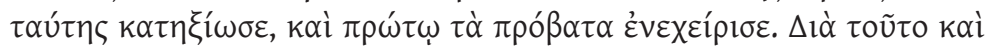

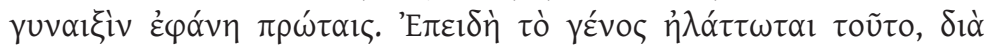

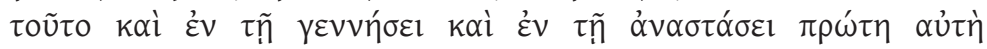

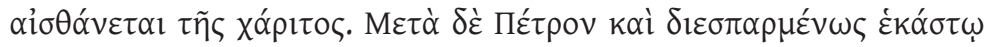

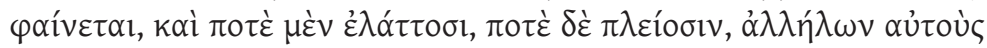

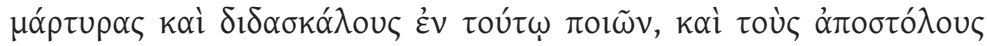

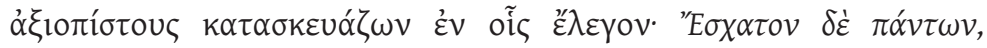

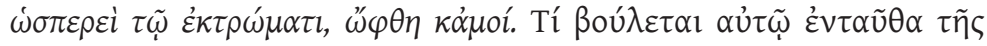

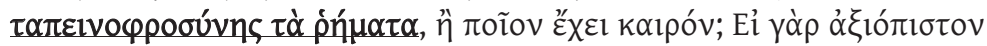

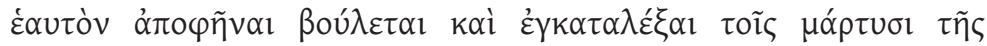

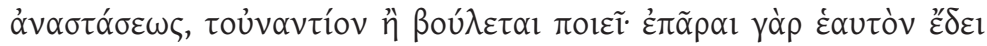

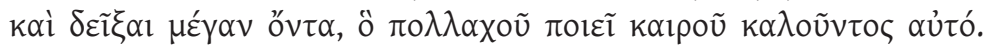

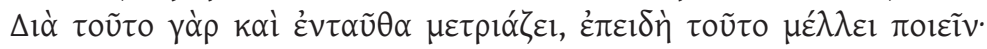

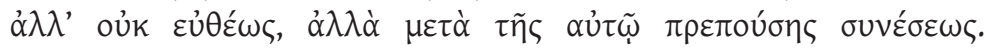

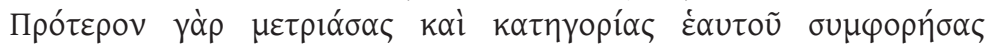

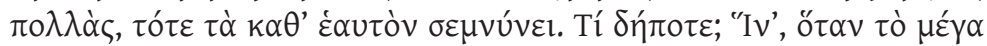

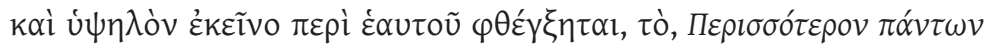

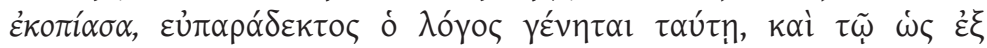

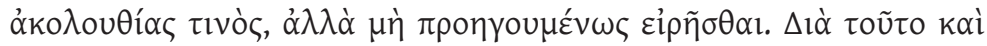

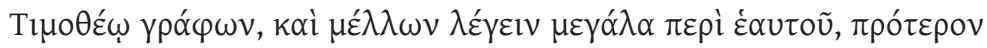

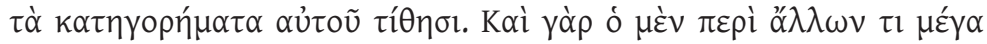

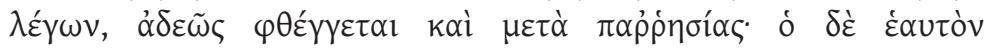

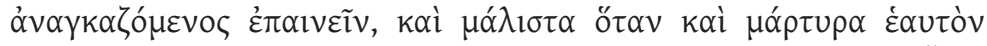

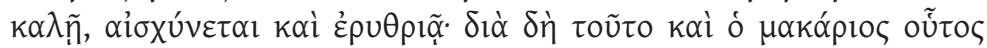

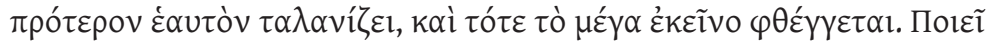

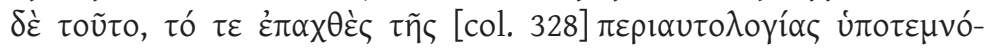




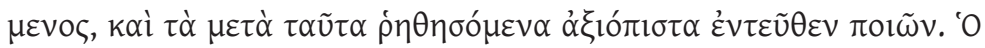

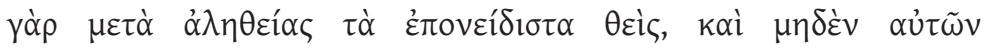

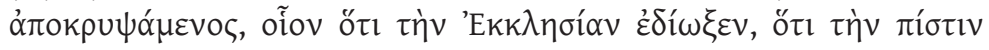

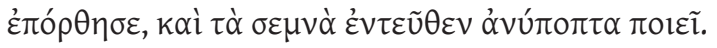

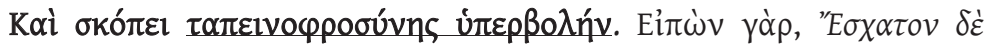

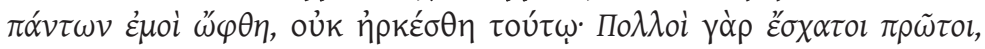

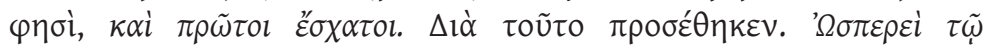

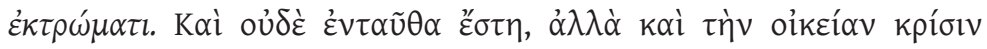

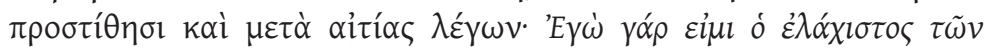

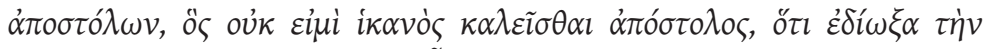

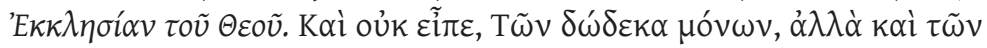

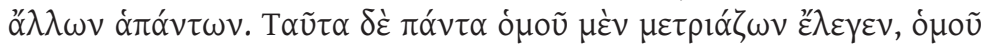

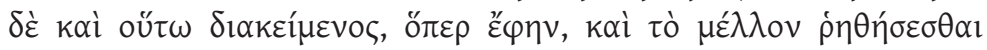

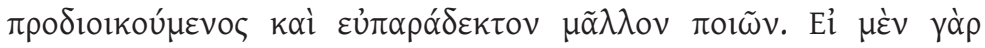

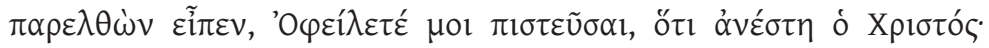

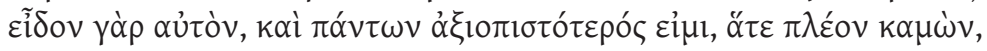

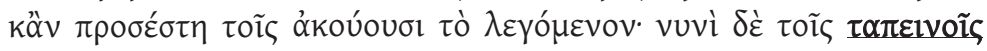

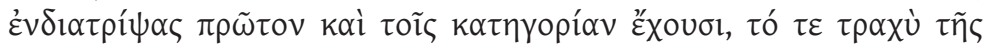

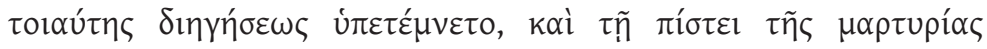
$\pi \rho \circ \omega \delta$ o

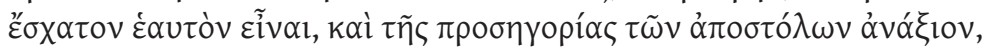

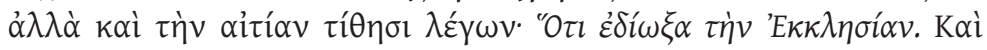

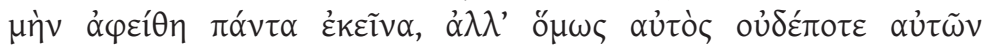

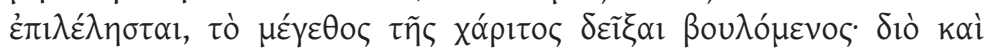

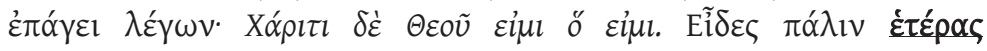

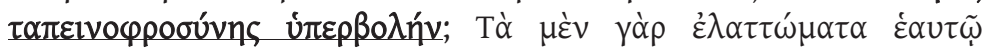

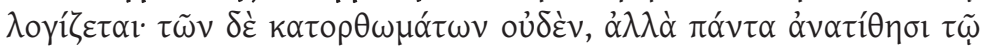

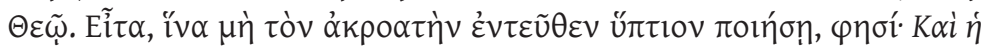

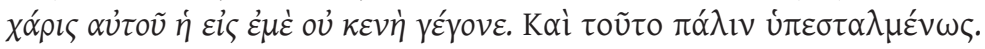

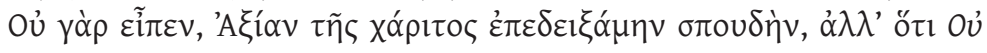

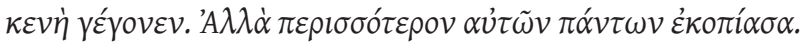

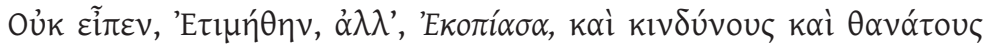

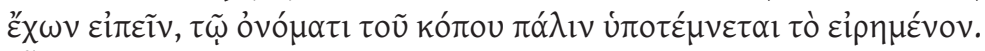

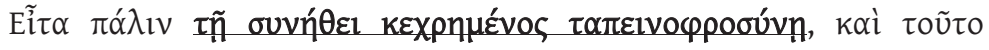

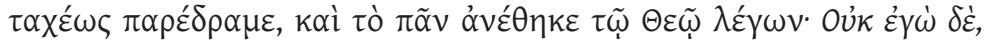

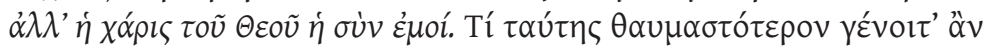

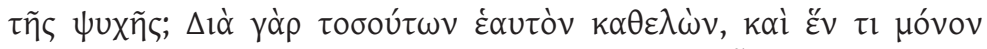

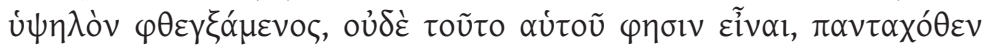

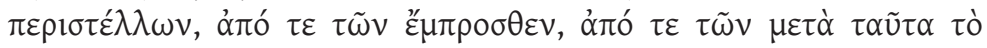

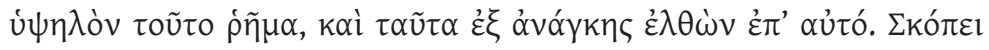




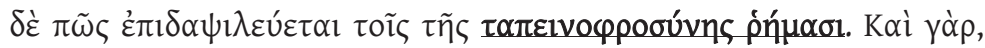

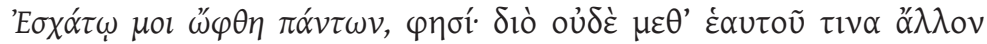

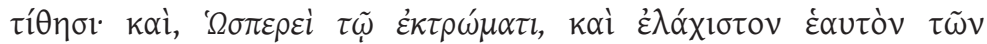

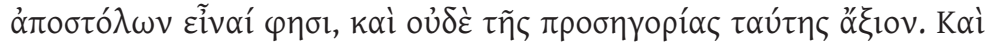

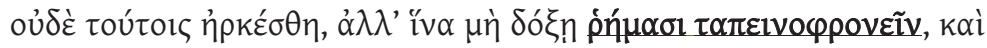

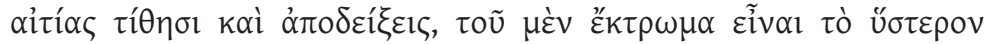

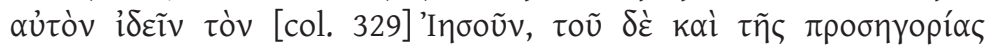

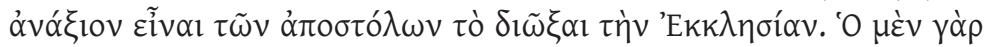

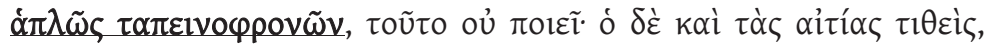

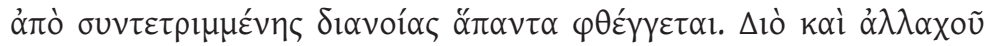

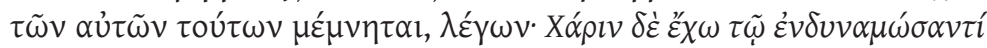

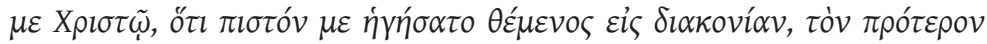

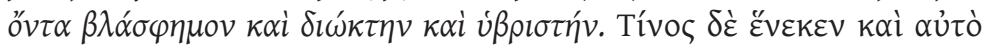

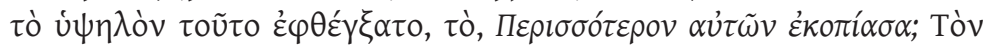

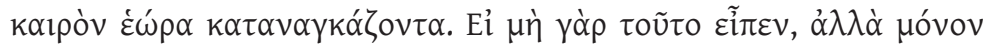

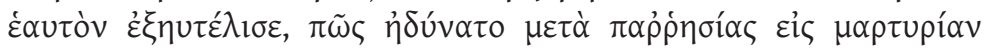

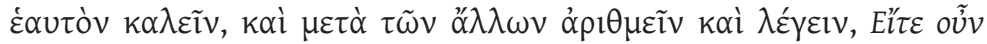

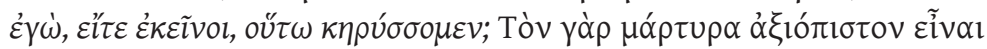

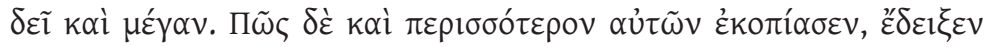

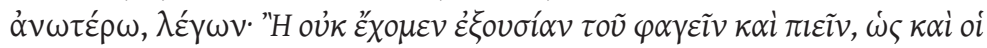

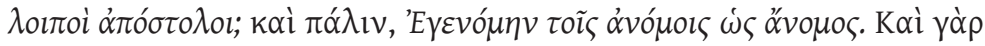

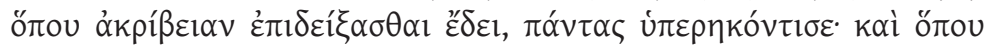

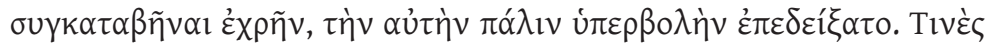

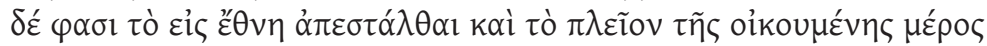

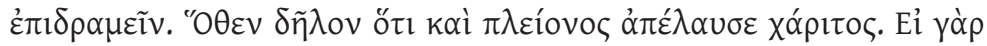

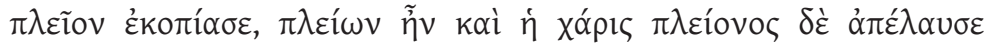

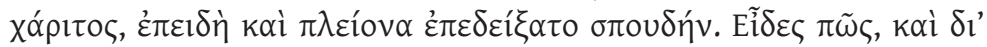

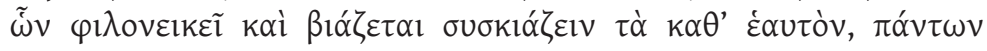

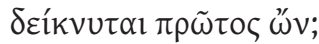





\title{
7. THE RECEPTION OF SCRIPTURE AND EXEGETICAL RESOURCES IN THE SCHOLIA IN APOCALYPSIN (GA 2351)
}

\author{
GARRICK V. ALLEN
}

\section{INTRODUCTION}

The initial publication of the Scholia in Apocalypsin (GA 2351) in 1911 was welcomed with a great deal of scholarly interest: a new ancient commentary on Rev. 1:1-14:8, preserved in a single manuscript, had been discovered. ${ }^{1}$ From the beginning, energy was expended to identify the author of this intriguing new work. Constantin Diobouniotis and Adolf Harnack, the Scholia's first editors, analysed its contents through the lens of the question of authorship, arguing that the idiom and theological content of the work pointed to Origen as its author. ${ }^{2}$ This attribution increased the significance of the discovery, and many commentators on the Scholia since, with some notable exceptions, have adopted Harnack's identification. ${ }^{3}$ As a result, the

${ }^{1}$ C. Diobouniotis and A. Harnack, Der Scholien-Kommentar des Origenes zur Apokalypse Johannis. TU 3.8. Leipzig: Hinrichs, 1911. H.C. Hoskier, Concerning the Text of the Apocalypse. Vol. 1. London: Quaritch, 1929, derides this edition as 'woefully deficient in accuracy' (657) noting many errata on 659-62. My transcription has also found a similar number of errors. Additionally, E. Junod, ' $\grave{A}$ propos des soi-disant scolies sur l'Apocalypse d'Origène' Rivista di storiae letteratura religiosa 20 (1984) 112-21 describes this edition as 'défectueuse' (116-7). Harnack was introduced to the manuscript in July 1911 and the edition was published before the end of the year.

2 Diobouniotis and Harnack, Der Scholien-Kommentar, 45-81.

3 See J.A. Robinson, 'Origen's Comments on the Apocalypse' JTS os 13 (1911) 295-7; C.H. Turner, 'The Text of the Newly Discovered Scholia of Origen on the Apocalypse' JTS os 13 (1912) 386-97; E. Klostermann, 'Des Origenes Scholien- 
Scholia have been primarily valued for their connection to Origen. Recently, just over one hundred years after the publication of the initial editio princeps of the Scholia, Panayiotis Tzamalikos proposed in a flurry of monographs and editions an alternative to the authorship of the commentary preserved in GA 2351 in the light of the other material preserved in Meteora, Metamorphosis, Codex 573, of which the Scholia are a part. ${ }^{4}$ He forcefully, and often polemically, argues that the Scholia are the work of a hitherto unknown Greek church father: Cassian the Sabaite, a monk who drew extensively from Didymus the Blind's lost Revelation commentary. ${ }^{5}$ While Tzamalikos' energetic work has made some valuable contributions, including a more accurate edition of the manuscript, the contents of the anonymous Scholia, and their place in the early reception history of Revelation, remain under the shadow of attribution, their analysis limited to

Kommentar zur Apocalypse Johannis' Theologische Literaturzeitung 37 (1912) 73-4; N. Beis, 'Die Kollation der Apokalypse Johannis mit dem Kodex 573 des Meteoronklosters' ZNW os 13.3 (1912) 260-5; A. de Boysson, 'Avons-nous un commentaire d'Origène sur l'Apocalypse?' Revue Biblique Internationale 10 (1913) 555-67; R.H. Charles, A Critical and Exegetical Commentary on the Revelation of St. John. Edinburgh: T. \& T. Clark, 1920, clxxvi; C.H. Turner, 'Origen Scholia in Apocalypsin' JTS os 25 (1923): 1-16; E. Skard, 'Zum Scholien-Kommentar des Origenes zur Apokalypse Johannis' Symbolae Osloenses 15-16 (1936): 204-8. A more nuanced approach to the authorship of the Scholia is found in G. Wohlenberg, 'Ein neuaufgefundener Kodex der Offenbarung Johannis nebst alten Erläuterungen,' Theologisches Literaturblatt 33 (1912) 49-57 (esp. 54), who suggests that they are a collection of early Christian traditions on the Apocalypse collected by an anonymous editor. See also Junod, 'Scolies,' 112-121; I.L.E. Ramelli, 'Origen's Interpretation of Violence in the Apocalypse: Destruction of Evil and Purification of Sinners' in Ancient Christian Interpretations of 'Violent Texts' in the Apocalypse, ed. J. Verheyden, T. Nicklas, and A. Merkt. Göttingen: Vandenhoeck \& Ruprecht, 2011, 46 n. 2; O. Stählin, 'Der Scholien-Kommentar des Origenes, Pbilologische Wochenschrift (1912) 132-140.

${ }^{4}$ See P. Tzamalikos, A Newly Discovered Greek Father: Cassian the Sabaite Eclipsed by John Cassian of Marseilles. VC supp. 111. Leiden: Brill, 2012; P. Tzamalikos, The Real Cassian Revisited: Monastic Life, Greek Paideia, and Origenism in the Sixth Century. VC supp. 112. Leiden: Brill, 2012; P. Tzamalikos, An Ancient Commentary on the Book of Revelation: A Critical Edition of the Scholia in Apocalypsin. Cambridge: CUP, 2013.

${ }^{5}$ An example of the polemic may be seen at Tzamalikos, An Ancient Commentary, ix. Tzamalikos also argues that his work is more careful than Harnack's, commenting that Harnack 'issued his verdict attributing the Scholia to Origen, after having studied the text for a couple of months. I myself was slower: the project occupied four years of my life, including a one-year sabbatical' (86). 
the broader historical concern of locating an author and this person's sphere of influence. ${ }^{6}$

In contrast to the majority of previous scholarship on the Scholia, the following discussion does not directly address the question of attribution but instead explores the modes of scriptural interpretation embedded in GA 2351 as a witness to the early reception and exegesis of the Apocalypse. ${ }^{7}$ General descriptions of the interpretative strategies preserved in the Scholia are readily available in previous studies. ${ }^{8}$ It suffices here to note that the numerous images and symbols in Revelation are not interpreted eschatologically in the Scholia, nor does the author assign historical realities to particular symbols. The author's interpretative strategy is largely explanatory and focussed on perceived ambiguities or lexical issues - the entirety of a single scholion is often devoted to the clarification of a single textual ambiguity. ${ }^{9}$

In addition to commenting on the text of Revelation, the Scholia preserve quotations of numerous other scriptural texts throughout the canon. ${ }^{10}$ It is impossible here to comment on each scholion; instead, in

6 While Tzamalikos' philological acumen is impressive, his deployment of philological data to make conclusions on authorship is less so. The polemical undercurrent that runs throughout the volume calls his conclusions about authorship and social context into serious question. Additionally, his grasp of exegetical practices and scriptural interpretation is minimal. His translations of the Scholia are helpful, but are crafted to support is argument for Cassian authorship, a conclusion which is not well argued, but instead repeatedly asserted. The volume is valuable, but should be approached with critical caution.

7 Diobouniotis and Harnack, Der Scholien-Kommentar, 45-6 argue for a thirdcentury date, in line with Origen, while Tzamalikos, An Ancient Commentary, 75 argues for the sixth century. In all likelihood, the Scholia are a collection of variously composed and chronologically disparate traditions. The appearance of material from Clement's Stromateis, 4.25.162.2 in Scholion V, and material from Irenaeus (see Junod, 'Scolies', 114) in Scholia XXXVIII and XXXIX suggests that many of the other traditions preserved in the manuscript date from long before its production in the tenth century.

8 Diobouniotis and Harnack, Der Scholien-Kommentar, 45-66; Tzamalikos, An Ancient Commentary, 79-83; Ramelli, 'Interpretation', 51-3.

${ }^{9}$ E.g. Scholion XXXIV, among many others.

10 See Diobouniotis and Harnack, Der Scholien-Kommentar, 83. The text of the Old Testament in the Scholia derives from the Greek scriptural tradition (OG/LXX). The commentary tradition of Andreas of Caesarea also follows this pattern. See Juan Hernández, Jr., 'Andrew of Caesarea and His Reading of 
what follows, I examine some representative test cases to examine how the author handled the scriptural sources embedded within the comments. I am interested primarily in the questions of techniques of reuse and the author's exegetical resources. For example, what triggered the author's deployment of scriptural traditions to comment on the Apocalypse and how were these traditions incorporated into the Scholia? Why were these quotations selected, and how do they structure and authorise the author's explanation of Revelation? I answer these questions by analysing three clear examples of textual exegesis in the Scholia, mapping the author's exegetical repertoire.

Before exploring these questions, however, it is first necessary to place the Scholia in their physical context, by briefly commenting on Meteora, Metamorphosis, Codex 573, and the physical layout of the Scholia in relation to the lemma text of Revelation in GA 2351. The form and layout of the Scholia influence the way that the manuscript is read and provide evidence for the form of the commentary in its now-lost Vorlage(n). Additionally, placing the codex in its physical context explains some of the peculiar features of the manuscript itself.

\section{CODEX 573 AND THE SCHOLIA}

Codex 573 of the Great Meteoron monastery in Thessaly contains a diverse collection of Patristic, monastic and biblical writings. ${ }^{11}$ Its contents are outlined in the following table:

Revelation: Catechesis and Paranesis' in Die Johannesapokalypse: Kontexte-KonzepteRezeption, ed. J. Frey, A. Kelhoffer, and F. Tóth. WUNT 287. Tübingen: Mohr Siebeck, 2012, 755-74, especially 761.

${ }^{11}$ For a critical edition of the manuscript up to folio $118 \mathrm{v}$ (including $209 \mathrm{r}-\mathrm{v}$, but excluding the text of Revelation and the minor works) see Tzamalikos, $A$ Newly Discovered Greek Father. See also the previous descriptions of this manuscript and its constituent works in L. Mariès, Hippolyte de Rome: Sur les bénédictions d'Isaac, de Jacob ed de Moïse. PO 27.1-2. Paris, Firmin-Didot: 1954, iii-viii; D. Diobouniotis and N. Beïs (BEn)), Hippolyts Schrift über die Segnungen Jakobs: Hippolyts Danielcommentar in Handschrift No. 573 des Meteoronklosters. TU 38.1. Leipzig: Hinrichs, 1911), 45-6;

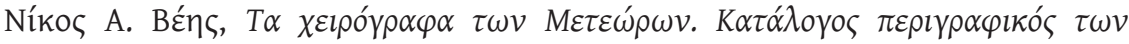

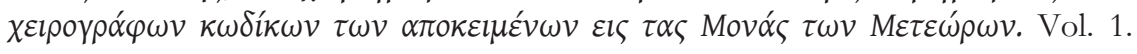
Athens: Academy of Athens, 1967, 598-601. 


\begin{tabular}{|c|c|c|c|}
\hline Folio & Title & Colophon & Authorship \\
\hline $1 \mathrm{r}-22 \mathrm{r}$ & $\begin{array}{l}\text { On the Rules and } \\
\text { Regulations of the } \\
\text { Coenobia in the East } \\
\text { and Egypt }\end{array}$ & 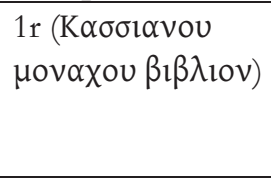 & Anonymous \\
\hline $22 \mathrm{v}-56 \mathrm{r}$ & $\begin{array}{l}\text { On the Eight } \\
\text { Considerations of Evil }\end{array}$ & & Anonymous \\
\hline $56 \mathrm{v}-80 \mathrm{r}$ & $\begin{array}{l}\text { On the Holy Fathers at } \\
\text { Scetis }\end{array}$ & & Anonymous \\
\hline $80 \mathrm{r}-100 \mathrm{v}$ & $\begin{array}{l}\text { First contribution by } \\
\text { Abba Serenus }\end{array}$ & & Anonymous \\
\hline $101 \mathrm{r}-118 \mathrm{v}$ & $\begin{array}{l}\text { Contribution by Abba } \\
\text { Serenus on the } \\
\text { Panaretus }\end{array}$ & & Anonymous \\
\hline $119 r-200 v$ & $\begin{array}{l}\text { Blessings of Jacob by } \\
\text { Irenaeus of Lyons }\end{array}$ & & Hippolytus \\
\hline $201 \mathrm{r}-204 \mathrm{v}$ & $\begin{array}{l}\text { Exegesis on } \\
\text { Melchizedek }\end{array}$ & & Cyril of Alexandria \\
\hline $205 r-207 r$ & Chronicon & & Hippolytus \\
\hline $207 v-208 r$ & 'Birth of Joseph' & & $\begin{array}{l}\text { James the newly } \\
\text { baptized }\end{array}$ \\
\hline $209 \mathrm{r}-\mathrm{v}$ & Astronomical text & & Anonymous \\
\hline $210 r-245 r$ & $\begin{array}{l}\text { Book of Revelation } \\
\text { (GA 2329) }\end{array}$ & $\begin{array}{l}245 \mathrm{r} \text { (prayer of } \\
\text { the scribe } \\
\text { Theodosius) }\end{array}$ & \\
\hline $245 v-290 r$ & $\begin{array}{l}\text { Scholia in Apocalypsin } \\
\text { (GA 2351) }\end{array}$ & 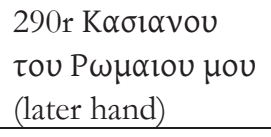 & \\
\hline $290 v$ & Blank folio & & \\
\hline
\end{tabular}

The codex begins with a collection of related monastic compositions (1r$118 \mathrm{v})$. The first work, entitled $O n$ the Rules and Regulations of the Coenobia in the East and Egypt, is a monastic treatise that discusses communal and personal behaviour. ${ }^{12}$ The emphasis is heavily upon self-sacrifice, penitence and the perfection of the soul through abstinence from earthly pleasures. The second work, On the Eight Considerations of Evil, is closely related to the first,

12 Text and English trans. in Tzamalikos, A Newly Discovered Greek Father, 19-65. 
adjuring monastic practitioners to 'conquer the arousals of the flesh and the pleasures pertinent to it' (fol. 26v). ${ }^{13}$ The third work in the codex, On the Holy Father at Scetis, and the next two compositions actually constitute a single work, comprising fol. $56 \mathrm{v}-118 \mathrm{v}$, which may have been artificially divided in the codex. It is an extended dialogue between monks and various monastic overseers regarding the pious life and overcoming the devil. ${ }^{14} \mathrm{It}$ was composed by the same author as the first two pieces. The subject matter, idiom, and governing voice of all these texts is identical, and there are references to the preceding work in the first paragraph of both $O n$ the Eight Considerations of Evil (fol. 22v) and On the Holy Father at Scetis (fol. 56v).

The colophon at the beginning of the monastic works (fol. 1r) identifies the book as belonging to a monk Cassian. This may signify authorship or, as Tzamalikos argues, attribution, but the works themselves remain functionally anonymous: the wording on which Tzamalikos bases his case could simply mean that a monk named Cassian once owned the codex (or parts of it). ${ }^{15}$ The works preserved on fol. $119 \mathrm{r}-209 \mathrm{v}$ are copies of other ancient Christian works, some quite obscure, that were composed by different authors, including fragments of Hippolytus and Cyril of Alexandria. The codex concludes with a copy of the book of Revelation (GA 2329) copied by the scribe Theodosius (see fol. 245r) and the Scholia in Apocalypsin (GA 2351) attributed, perhaps by a later hand, to the same Cassian whose works are preserved in the first part of the manuscript (see colophon on fol. 290r). Codex 573 is a composite collection of ancient monastic works, exegetical traditions, and traditions pertaining to the book of Revelation. It is an archive with no discernible editorial agenda.

\section{The Scholia (GA 2351)}

The Scholia, too, are an aggregation of patristic and early medieval traditions of reading Revelation. The text is written on 45 folios, in a single column of 21 lines. Rulings for the margins and each line are visible in some of the photographs that I have inspected (e.g. fol. 256r). ${ }^{16}$ The first three sections

13 Text and English translation in Tzamalikos, A Newly Discovered Greek Father, 78-151.

14 Tzamalikos attributes this dialogical work to Cassian the Sabaite, but the work itself and its governing voice are anonymous.

15 See Tzamalikos, The Real Cassian Revisited, although he does not distinguish between authorship and attribution.

16 A full digitisation of the manuscript from microfilm is now available at: http://ntvmr.uni-muenster.de/manuscript-workspace/?docID=32351. 
of scriptural text (Rev. 1:1-4) are written in a majuscule script, while the remainder of the manuscript, including the first three scholia, is transcribed in a semi-cursive minuscule. A change of hand occurs midway through the scriptural lemma attached to Scholion V (fol. 248r). ${ }^{17}$ The layout of the scriptural text and the comments varies throughout (see Appendix), but some common features are deployed to distinguish between sections. Most scholia are denoted by an $\varepsilon \rho /$ abbreviation ( $\dot{\varepsilon} \rho \mu \eta v \varepsilon i ́ \alpha)$ in the left margin of the first full line of a comment section. Additionally, the first letter of the first full line following a change from lemma or comment is usually enlarged and slightly displaced into the left margin. Small vacats and middle dots (e.g. fol. 253v) distinguish the different text segments if the change from lemma to comment occurs within a single line. Also, occasionally, the lemma text is highlighted in the left margin with a series of diplai (e.g. Rev. 1:4-7 on fol. 246v-247r), but this is exceptional. The lemmata are also sometimes demarcated with Greek numbers (e.g. IB on fol. 253r). GA 2351 is a professionally-produced copy: it is ruled, contains a consistent number of lines per folio, has relatively few corrections and ligatures, and uses numerous devices to distinguish lemma from comment.

Additionally, it is likely that the comment segments were not integrated into the main text of the manuscript in preceding copies. ${ }^{18}$ The commentary in the Scholia does not always correspond to the preceding scriptural segment, suggesting that the comments may have begun their life as marginal comments or were once in the form of a frame commentary. The disruption of the scriptural text by comments is a secondary feature of this commentary tradition. ${ }^{19}$ The division of the scriptural text also appears somewhat arbitrary, occasionally breaking off mid-sentence only to be continued after an intervening commentary segment (e.g. Scholion V, VIII, XXVIII). Although the comments and scriptural lemmata are integrated into a continuous text in GA 2351, this textual arrangement is secondary in the development of this tradition. With the context of Codex 573 and the broader contours of the form of the manuscript in mind, we now turn to the primary interest of the article: scriptural interpretation in the Scholia.

17 So Tzamalikos, An Ancient Commentary, 83.

18 See also I. de la Potterie and A.-G. Hamman, 'Les Scholies attribuées à Origène' in L'Apocalypse expliquée par Césaire d'Arles ed. I. de la Potterie and A.-G. Hamman. Paris: de Brouwer, 1989, 163-4.

${ }^{19}$ So also Diobouniotis and Harnack, Der Scholien-Kommentar, 2-3. 


\section{EXAMPLES OF SCRIPTURAL INTERPRETATION ${ }^{20}$}

\section{Scholion VI}

The first example of interpretation examined here is located in Scholion VI (fol. 248r-249r). Tzamalikos suggests that 'Scholion VI draws heavily on Didymus, and probably this is a paraphrase quoted from his Commentary on the Apocalypse, with some adaptation to Cassian's own style formed under the influence of 'Theodoret'. ${ }^{21}$ As Didymus' commentary is lost, this series of assertions is unconvincing.

\begin{tabular}{|c|c|}
\hline \multicolumn{2}{|r|}{ Scholion VI } \\
\hline $\begin{array}{l}\text { Rev. } \\
1: 16 \mathrm{~b}-17 \mathrm{a}\end{array}$ & 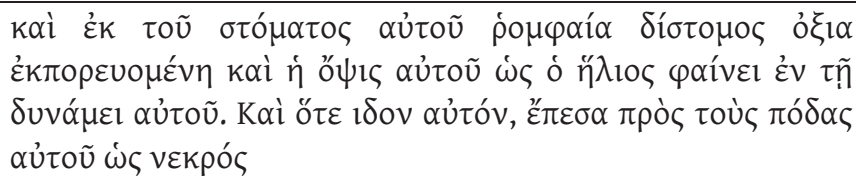 \\
\hline Translation & $\begin{array}{l}\text { And coming from his mouth was a doubled-edged sharp } \\
\text { sword, and his appearance was like the sun shining its power } \\
\text { and when I saw him, I fell to his feet as if dead. }\end{array}$ \\
\hline Comment $^{22}$ & 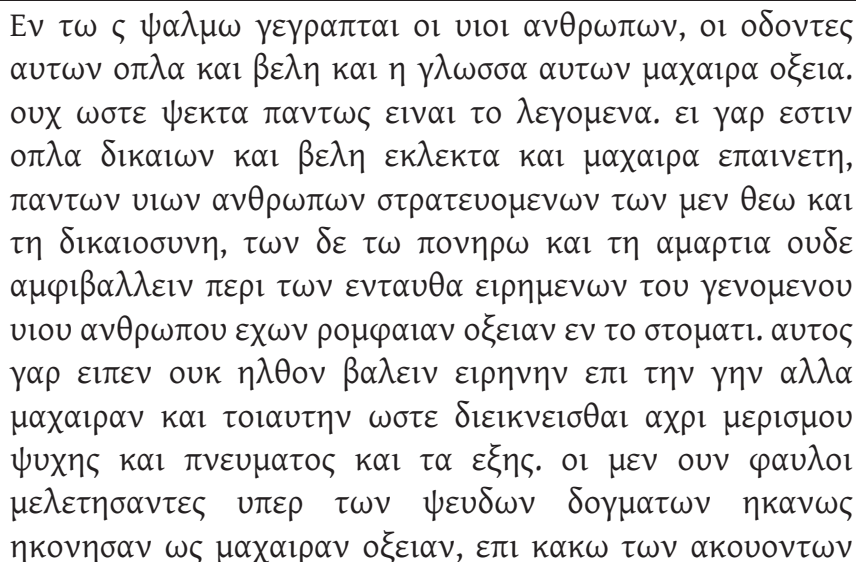 \\
\hline
\end{tabular}

20 The present author is responsible for the transcription of the text and its translation in this section. Words transcribed from the manuscript have not been provided with accents or breathings.

21 Tzamalikos, An Ancient Commentary, 80.

22 Comment begins on the last line of fol. 248r. The text is slightly indented into the left margin, but no other features distinguish the comment from the biblical text. 


\begin{tabular}{|c|c|}
\hline & 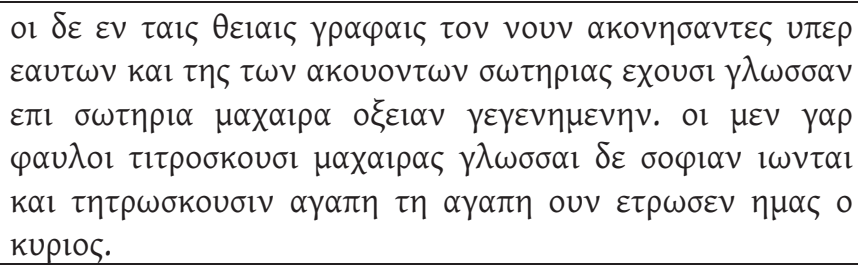 \\
\hline Translation & $\begin{array}{l}\text { In Psalm } 6 \text { it is written: 'the sons of men are those whose } \\
\text { teeth are weapons and arrows and whose tongues are sharp } \\
\text { swords.' Thus, the ones spoken of should not be assumed to } \\
\text { be blameworthy. For if a spear is righteous and an arrow } \\
\text { chosen and a sword praiseworthy, of all the sons of men } \\
\text { engaged in battle, some of them are for God and for } \\
\text { righteousness, others for wickedness and for sin. Nor should } \\
\text { it be assumed that the placement of the saying here regarding } \\
\text { the one who became the son of man, having a sharp sword in } \\
\text { the mouth [is problematic]. For he said, 'I did not come to } \\
\text { bring peace on the earth, but a sword,' and additionally, 'to } \\
\text { penetrate until it divides soul and spirit' and what follows. } \\
\text { Therefore the corrupt that meditate on and are provoked by } \\
\text { means of sufficiently false doctrines, are sharpened like a } \\
\text { sharp sword so as to cause evil in those who hear. Conversely, } \\
\text { the ones that sharpen the mind by means of the divine } \\
\text { scriptures, for the sake of those that hear them and their } \\
\text { salvation, they have a tongue which has become a sharp sword } \\
\text { for salvation. For the wicked wound with a sword, but the } \\
\text { tongues of the wise heal, and love wounds with love. } \\
\text { Therefore, the Lord wounded us with love. }\end{array}$ \\
\hline
\end{tabular}

This scholion comments upon a particular feature of the vision of Jesus in Rev. 1:9-20, meditating on the theological meaning of the sharp sword that protrudes from his mouth. The comments commence with a quotation of Psalm 56:5LXX, a text that describes the sons of men as those whose

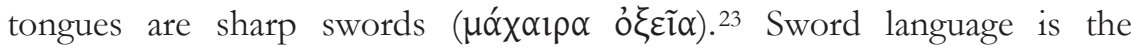

23 The text of the manuscript identifies this Psalm as $\varsigma$ (6), a number that does not correspond to this Psalm in the OG/LXX tradition. This numeration may have been employed to correspond to the identical number placed in the margin (located just above line 16 in the left margin of fol. 248r) at the beginning of the lemma preceding the sixth scholion. This anomaly strengthens the connection between the commentary text and the biblical text. 
organising principle of this scholion, as the author quotes numerous other texts that bear witness to $\mu \alpha \alpha_{\alpha} \alpha \iota \rho \alpha$, even though Revelation only preserves this lexeme in other pericopae. ${ }^{24}$ In Rev. 1:16, the manuscript tradition unanimously employs the synonym $\rho \circ \mu \varphi \alpha i ́ \alpha$, described as double-sided

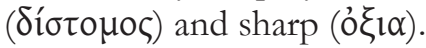

Next, the author comments on his quotation, arguing that the 'sons of men' described in the Psalm are not necessarily negative figures, since those who use weapons for righteousness sake are laudable. ${ }^{25}$ Therefore, he suggests, it is logical that the son of man should 'have a sharp sword in the

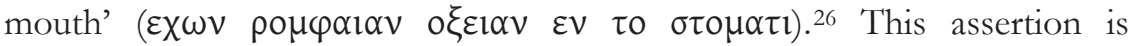
supported by two additional quotations, the first of which is a reworked version of Matthew 10:34: 'I did not come to bring peace on the earth, but a sword' $\left(\mu \alpha \alpha_{\alpha} \alpha 1 \rho \alpha\right) .{ }^{27}$ This utterance is coupled with a quotation from Hebrews 4:12: 'to penetrate until it divides soul and spirit'. ${ }^{28}$ In its original context, this expression immediately follows a description of the word of God as 'living and active and shaper that any double-edged sword'

${ }^{24}$ Rev. 6:4; 13:10, 14.

${ }^{25}$ Cf. Scholion XII.

${ }^{26}$ The quotation of Rev. 1:16b differs from the lemma. The quotation reworks 1:16b by borrowing the syntax of 1:16a ( $\varepsilon \chi \omega \vee \varepsilon v+$ dative). Additionally, the quotation omits $\delta 1 \sigma \tau o \mu \circ \zeta$, and, in this manuscript, the spelling conventions of o $\xi \varepsilon l \alpha$ (o $\xi_{1 \alpha}$ in the lemma) differ.

27 The main portion of the quotation is borrowed from Matthew 10:34b, but material has also been taken from Matthew 10:34a (underlined): ouk $\eta \lambda \theta$ ov $\beta \alpha \lambda \varepsilon$ เv

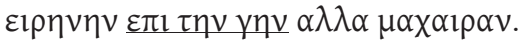

28 The text of this quotation, too, differs slightly from its source. The morphology and spelling convention of $\delta 1 \varepsilon ı k v \varepsilon l \sigma \theta \alpha 1$ potentially differs from its

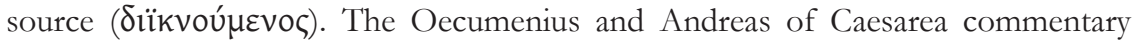
traditions also re-use Hebrews 4:12 in their comments on Rev. 1:16. See the text of Oecumenius in M. de Groote, ed., Oecumenii Commentarius in Apocalypsin. TEG 8. Leuven: Peeters, 1999, 79-80 and Andreas in J. Schmid, Studien zur Geschicbte des griechischen Apokalypse-Textes. vol. 1.2. Munich: Karl Zink, 1955, 21-2. The Armenian commentary on Revelation by Nerses of Lambron (1153-98), probably borrowing from the Andreas tradition, also cites Hebrews 4:12 here: see Robert W. Thompson, Nerses of Lambron: Commentary on the Revelation of Saint John. Hebrew University Armenian Studies 9. Leuven: Peeters, 2007, 52-3. Apart from this similarity, the other Greek commentary traditions on Revelation differ significantly in their exposition of this passage, devoting less attention to this small segment. 


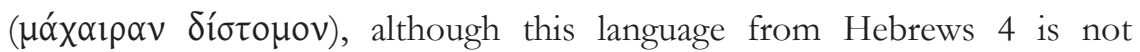
present in the scholion.

The author continues with the observation that the wicked, by means of their false doctrines, are sufficiently sharpened ( $\eta \kappa \alpha \nu \omega \varsigma \eta$ $\kappa o v \eta \sigma \alpha v)$ like

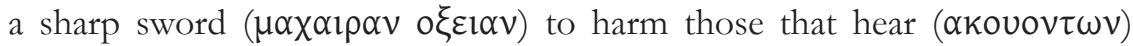

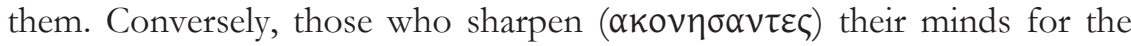
sake of those who listen ( $\alpha$ kovov $\tau \omega v)$, have made their tongue $(\gamma \lambda \omega \sigma \sigma \alpha v)$ like a sharp sword ( $\mu \alpha \chi \alpha \iota \rho \alpha$ o $\xi \varepsilon l \alpha v)$ for salvation. This second group, according to the author, is described elsewhere in the Scriptures: the scholion closes with additional instances of biblical reuse from the Greek Old Testament. First, the author quotes Proverbs 12:18, noting that 'the wicked wound with a sword ( $\mu \alpha \chi \alpha i$ íp $\alpha)$, but the tongues $(\gamma \lambda \tilde{\omega} \sigma \sigma \alpha 1)$ of the wise heal.' Finally, the scholion closes with an allusion to Song of Songs 2:5 or 5:8: 'therefore love has wounded us with love'.

This scholion is dense with sophisticated exegetical reasoning, and some of the features of this interpretation deserve further comment. First, each of the quotations is intricately linked through the deployment of shared lexical items. The quotations are organized around the phase 'sharp

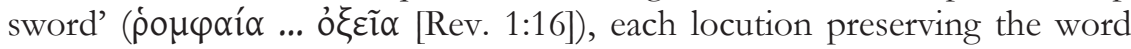

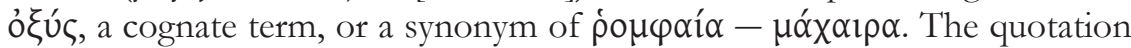
of Psalm 56:5 preserves a synonymous collocation ( $\mu \alpha \alpha_{\chi x \alpha} \rho \alpha$ ỏ $\left.\xi \tilde{i} \alpha\right)$. This text is then connected to an inexact quotation of the lemma, followed by the quotation of the words of the Matthaean Jesus who states that he has come to bring a sword ( $\left.\mu \alpha x_{\chi \alpha} \alpha \mathbf{\rho} \alpha v\right)$. The quotation of Hebrews 4:12 also employs language pertaining to the use of a sword $(\delta 1 \varepsilon \imath \kappa v \varepsilon \tilde{\imath} \sigma \theta \alpha \mathrm{l})$, and the locution immediately preceding the quoted text in the source text preserves

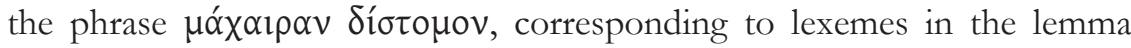
and the previously quoted biblical texts. The next section of the scholion, culminating in the Proverbs quotation, also includes the phrase $\mu$ ó $\chi \alpha \iota 1 \rho \alpha$ ó $\xi \varepsilon \tilde{\imath} \alpha$ twice and an additional reference to $\mu \alpha \chi \alpha i ́ p \alpha \varsigma$. Beyond this lexical connection, another paronomastic lexical thread related to the sharpness of swords is present in this part of the scholion. Twice, forms of ákovóc ('to sharpen', 'prod') are coupled with graphically similar forms. The wicked that propagate false doctrine are sufficiently sharpened ( $\eta \kappa \alpha v \omega \varsigma \eta \eta \kappa v \eta \sigma \alpha v$ ), perpetrating harm to those who hear ( $\alpha$ kovov $\tau \omega v)$ them. Similarly, those

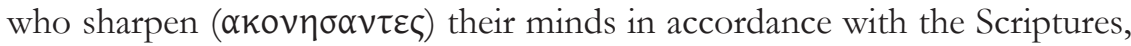
aid those who hear ( $\alpha$ Kovov $\tau \omega v)$. Finally, the reuse of material from the Song of Songs includes a lexeme that pertains to the use of swords- the Lord wounded ( $\tau \imath \tau \rho \omega ́ \sigma \kappa \omega)$ us with love.

The choice of texts quoted in this scholion revolves around the lexical characteristics of the locution, and their relationship to a small segment of 
text in the lemma. However, this is not idiosyncratic. A complex system of synonym, semantic grouping, and paronomastic relationships govern the

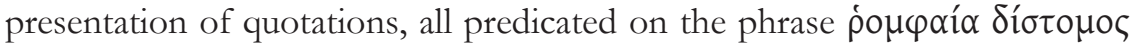
$\hat{o} \xi 1 \alpha$ in Rev. 1:16b. Each quotation is a component of a multifaceted exegetical procedure, a procedure that expends a significant amount of energy to interpret the image of Christ with a sword protruding from his mouth. ${ }^{29}$ Word associations of this kind are also common in the Oecumenius and Andreas of Caesarea commentary traditions, but not always to this degree. ${ }^{30}$

The intricate composition of the scholion seems to be designed to assuage an unexpressed anxiety about the image it interprets. It is true, so the logic of the commentary goes, that some might interpret the association of weapons and Jesus' words negatively. However, Jesus himself tells us that he has come with a sword (Matthew 10:34), while Hebrews 4:12 conveys that this sword penetrates the very being of a man. This wound, however, is the wound of divine wisdom (Proverbs 12:18) and love (Song of Songs 2:5, 5:8). This scholion is concerned with interpreting a small textual segment of the lemma, understanding it in the light of similar biblical locutions. The undercurrent of lexical affiliation supports the logic of the scholion.

\section{Scholion XV}

An additional representative example of scriptural interpretation in the Scholia is located in Scholion XV (fol. 254v-255v). ${ }^{31}$

29 Similar detailed attention to the lexical value of the lemma, in conversation with other biblical texts, is found in the Latin Commentary on the Apocalypse of Victorinus of Poetovio. See Konrad Huber, 'Aspekte der ApokalypseInterpretation des Victorinus von Pettau am Beispiel der Christusvision in Offb 1' in Ancient Christian Interpretations of 'Violent Texts' in The Apocalypse, ed. J. Verheyden, T. Nicklas, and A. Merkt. Göttingen: Vandenhoeck \& Ruprecht, 2011, 100-4.

30 See Eugenia Scarvelis Constantinou, Guiding to a Blessed End: Andrew of Caesarea and his Apocalypse Commentary in the Ancient Church. Washington DC: Catholic University of America Press, 2013, 162-8.

31 Tzamalikos, An Ancient Commentary, 80 asserts that this scholion too 'is distinctly close to Didymus' Commentary on the Apocalypse, yet there are points which suggest adaptation by Cassian himself.' Again, this string of assertions is unconvincing. 


\begin{tabular}{|c|c|}
\hline \multicolumn{2}{|r|}{ Scholion XV } \\
\hline $\begin{array}{l}\text { Rev. } \\
2: 18 b-20 a\end{array}$ & 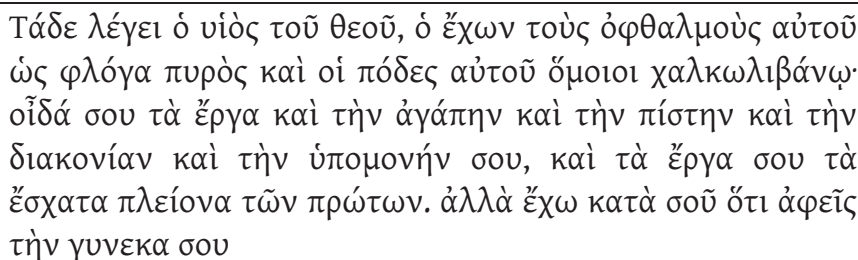 \\
\hline Trat & $\begin{array}{l}\text { Thus says the Son of God, the one whose eyes are like burning } \\
\text { fires and his feet are like burnished bronze. I know your works } \\
\text { and the love and the faith and the service and your patient } \\
\text { endurance, and your last works are greater than your first. But } \\
\text { I have against you that you have left your wife. }\end{array}$ \\
\hline $\begin{array}{l}\text { Com } \\
\text { Exce }\end{array}$ & 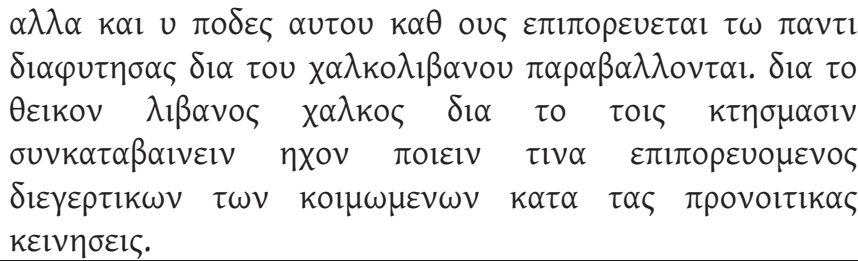 \\
\hline Trans & $\begin{array}{l}\text { But also his feet, which he uses to roam about, are exposed to } \\
\text { be burnished bronze }\left(\chi \alpha \lambda_{\kappa \circ} \lambda_{1} \beta \alpha v o v\right) \text {. Frankincense } \\
\left(\lambda_{1} \beta \alpha \vee \circ\right) \text { because [he] is divine, bronze }(\chi \alpha \lambda \kappa \circ \varsigma) \text { because he } \\
\text { went down to the creatures. [His feet] make a certain sound } \\
\text { that stimulates those who are asleep, according to his } \\
\text { providential movements. }\end{array}$ \\
\hline
\end{tabular}

The first portion of the scholion comments upon the description of the Son of God's burning eyes (Rev. 2:18; cf. Heb. 1:7). The author suggests that this image relates to Jesus' purifying quality and ability to lay bare the absurdity of idolatry, quoting Psalm 103:32LXx. The second portion, which is of primary interest here, comments upon the description of Jesus' feet as $\chi \alpha \lambda_{\kappa o} \lambda_{1} \beta \alpha{ }^{\prime} v \omega .{ }^{33}$ This term, appearing also in Rev. 1:15, is a neologism that first appears in Revelation, and potentially derives from a similar collocation

32 The transition from lemma to comment is marked here in multiple ways (fol. 255r): a middle dot and vacat separate the sections (they share a line). The first full line of commentary has a capital, is indented, and is accompanied by the marginal notation $\varepsilon \rho /$.

33 Written as $\chi \alpha \lambda \kappa \underline{\omega} \lambda_{1} \beta \alpha{ }^{\prime} \nu \omega$ in the lemma. 


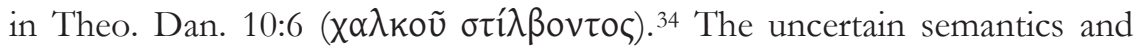
rarity of this word coalesced to make it the object of exegetical attention. In this instance, the author takes a unique tack in comparison to the other ancient commentaries on Revelation, juxtaposing two common Greek lexemes that make up the rare compound. ${ }^{35}$ The Son of God's feet are burnished bronze ( $\chi \alpha \lambda_{\kappa} \lambda_{1} \beta \alpha v_{v o v}$ ), because they represent his divine and human characteristics: frankincense $(\lambda i ́ \beta \alpha \vee \circ \zeta)$ denotes his divine qualities, while bronze ( $\chi \propto \lambda \kappa o ́ \varsigma)$ indicates his humanity. Together, these two parts of his feet cause those who are attuned to his movements to awake. The division of the word also creates an allusion, or least a lexical link, to Matthew 2:11 and the gifts presented to Jesus at his birth ( $\lambda$ í $\beta \alpha \vee o \varsigma)$.

The author's overarching interpretation, that the constitution of the feet corresponds to the two natures of Christ, follows that preserved in the Andreas of Caesarea commentary tradition. Andreas, too, takes the strange combination of lexemes preserved in this term as indicative of the unity of Christ's natures. While their understanding of the significance of $\chi \alpha \lambda \kappa_{\text {o }} \lambda_{1} \beta \alpha$ óvou is comparable, the present commentator's exegetical instincts differ. His dissolution of the compound word into its constituent parts, a tack that Andreas does not take, combined with their inversion in

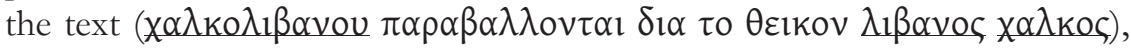
is part of an exegetical strategy that appeals to etymology, a strategy designed to showcase the exegetical dexterity of the author, not necessarily to convey a clear or explicit interpretation. ${ }^{36}$ The Greek text of this portion of the scholion requires the reader to fill the gaps, as referents and antecedents are left implied, even though the text of the comment is

34 See Craig R. Koester, Revelation. Anchor Yale Bible Commentaries 38A. London: Yale UP, 2014, 246. The word probably describes some sort of metal alloy. See W. Bauer, F. W. Danker, W. F. Arndt and F. W. Gingrich, Greek-English Lexicon of the New Testament and Other Early Christian Literature. $3^{\text {rd }}$ edn. Chicago: UP, 1999, 1076.

35 Oecumenius implicitly understands this word as a reference to a metal alloy, suggesting that it is a metaphor for faithfulness and stability. Andreas understands the word as a metaphor for the complete unity of Christ's divinity and humanity. In his Latin commentary, Apringius of Beja (sixth century) suggests that auricalco describes the purity of Christ's flesh. See Roger Gryson, ed., Commentaria Minora in Apocalypsin Johannis. CCSL 107. Turnhout: Brepols, 2003.

36 Andreas of Caesarea, too, demonstrates philological skill by unpacking the etymology of certain Hebrew words ('Satan' [34.143] and 'amen' [1.59]). See Constantinou, Guiding to a Blessed End, 132-3. 
carefully structured. ${ }^{37}$ The craft of this move lies not in the innovative or clear exposition of the meaning of the text, but in the way that the road is travelled to arrive at the interpretative destination. The lexical play and etymologizing of the commentary demonstrates that, at least in this scholion, the exegetical means are more important than the interpretative ends. This scholion preserves a heightened exegetical aesthetic that takes precedence over the clarity of the exposition. ${ }^{38}$

Although this portion of the scholion does not directly quote other scriptural texts, the author plays with the graphic and lexical value of the scriptural lemma. ${ }^{39}$ The potential allusion to the Matthaean birth narrative, the point where Christ's two natures are perhaps most poignantly contrasted, suggests that broader scriptural themes are still operative in the composition. Apart from this allusion, the author engages with the scriptural lemma in an exegetically sophisticated fashion, creatively solving a semantic ambiguity created by a rare lexeme. Like the previous example, the author of this scholion is attentive to the minute features of the scriptural lemma. ${ }^{40}$

37 'This phenomenon is seen clearly in Tzamalikos' translation. See An Ancient Commentary, 123-4.

38 It is also possible that the clarity of expression was corrupted at some point in the process of transmission.

39 The first portion of the scholion, although not analyzed here, mimics language from 1 Cor. 3:12 and Psalm 103:32LXx.

40 Although the textual variation between the lemma and comment is relatively insignificant $\left(\chi \alpha \lambda_{\kappa} \underline{\omega} \lambda_{\imath} \beta \alpha{ }^{\prime} \nu \omega\right.$ vs. $\left.\chi \alpha \lambda_{\kappa} \alpha \lambda_{1} \beta \alpha v o v\right)$, other variant readings in the commentary may suggest that the scriptural text preserved in GA 2351 is not identical to that upon which the Scholia originally commented: see also Scholion XXVIII below. 


\section{Scholion XXVIII}

The final sample of exegesis that I explore in this study is located in Scholion XXVIII (fol. 265r-v). ${ }^{41}$

\begin{tabular}{|c|c|}
\hline \multicolumn{2}{|r|}{ Scholion XXVIII } \\
\hline Rev. 5:6-8a & 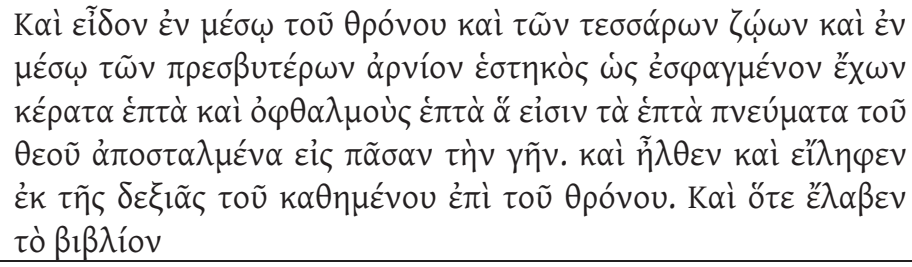 \\
\hline Translation & $\begin{array}{l}\text { And I saw in the middle of the throne and the four living } \\
\text { creatures and in the middle of the elders, a lamb, standing as } \\
\text { though it had been slain, having seven horns and seven eyes, } \\
\text { which are the seven spirits of God that have been sent into all the } \\
\text { earth. And he came and took from the right hand of the one } \\
\text { sitting on the throne. And when he took the book... }\end{array}$ \\
\hline Comment $^{42}$ & 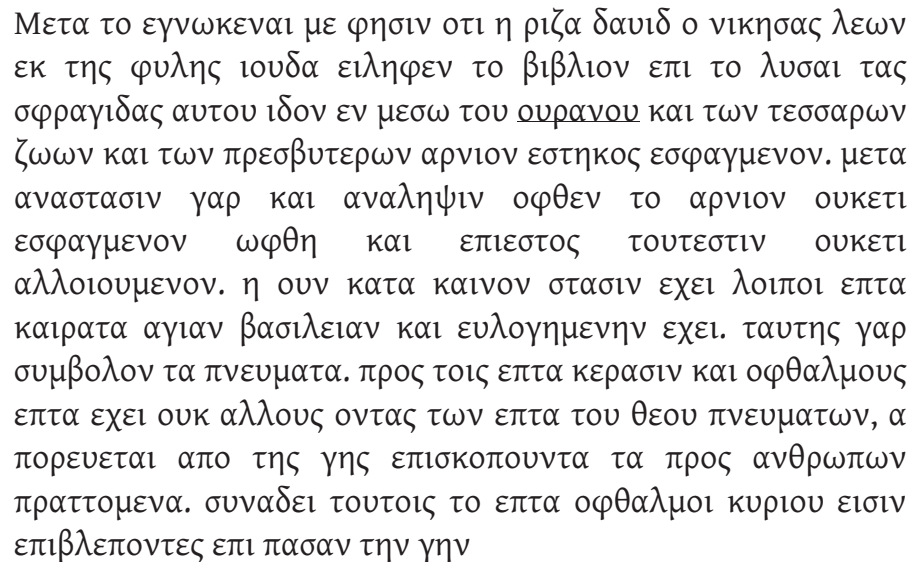 \\
\hline Translation & $\begin{array}{l}\text { After I observed this, it says that 'the root of David, the } \\
\text { conquering lion for the tribe of Judah, took the book' in order to }\end{array}$ \\
\hline
\end{tabular}

${ }^{41}$ Tzamalikos, An Ancient Commentary, 81 claims once more that this scholion 'by and large reproduces Didymus' Commentary on the Apocalypse, with Cassian applying his own phraseology, which is partially taken up from Gregory of Nyssa.'

42 The transition between lemma and comment (fol. 265r lines 8-9) includes the following features: middle dot, vacat, capital, indentation, $\varepsilon \rho /$ marginal note. 


\begin{tabular}{|l|l|}
\hline & $\begin{array}{l}\text { 'loosen its seals, I saw in the in the middle of heaven and the four } \\
\text { living creatures, and the elders, a lamb standing as though it had } \\
\text { been slain.' For after the resurrection the lamb who was seen } \\
\text { ascending no longer appears as slain; that is fixed, no longer } \\
\text { subject to alteration. If, } 43 \text { therefore, in his new state, he has seven } \\
\text { horns, this means that he has a holy and blessed kingdom. For the } \\
\text { spirits are symbols of this. In addition to the seven horns, he also } \\
\text { has seven eyes, which are none other than the seven spirits of } \\
\text { God, which go about the earth overseeing human actions. It } \\
\text { agrees with such things that 'the seven eyes of the Lord are going } \\
\text { out into all the world'. }\end{array}$ \\
\hline
\end{tabular}

Three features of this scholion require further comment. First, the initial interpretative focus of the commentary is a text that is not preserved in the lemma which comes immediately before: Rev. 5:5 is incorporated into the lemma that precedes the previous scholion (XXVII). That section of commentary, too, explores Jesus as the root of David, arguing that the seven-sealed scroll represents the Old Testament, quoting Luke 24:32 ('Did not our heart burn within us, while he opened the Scriptures?'). Like the previous comment, Scholion XXVIII begins by quoting a portion of Rev. 5:5 but focusses instead on the image of the lamb (Rev. 5:6). The incongruity of the lemma and commentary suggests that the division of textual segments and the form of the textual layout of GA 2351 is a late innovation in this commentary tradition. The interpretation of a single lemma may extend across multiple commentary sections in the Scholia in Apocalypsin.

Second, the commentary section of this scholion bears witness to an interesting example of textual variation from the lemma. The lemma reads

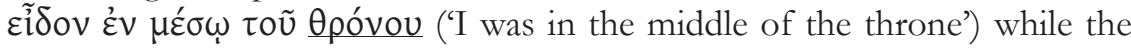
commentary has $i \delta o v \varepsilon v \mu \varepsilon \sigma \omega$ tou oupavou ('I was in the middle of the heaven'). Beyond the difference in the spelling of $\varepsilon \tilde{i} \delta o v$, the exchange of Өpóvou for oủpavoũ is significant. This variant reading in the commentary is unique in the textual history of Revelation. The rarity of this reading, and perhaps the graphic similarity of these words, led Tzamalikos to correct the reading back to $\theta$ póvou, suggesting that 'the scribe evidently misheard the recitation of the scriptural text'. ${ }^{44}$ While a plausible explanation, the presence of an exegetical motivation for this example of textual variation

\footnotetext{
43 Reading $\varepsilon \mathfrak{l}$ for $\eta$.

44 Tzamalikos, An Ancient Commentary, 152.
} 
indicates that this is a conscious alteration. ${ }^{45}$ Graphic similarity often stimulates deliberate attempts to improve or explicate the text. ${ }^{46}$ In this case, the alteration of wording (via lexical substitution) is sensitive to a number of features of the text and narrative of Revelation. First, beyond graphic/aural resemblance, the choice of oujpavov is logical due to the narrative setting of the throne vision. The choice of lexemes connects Rev.

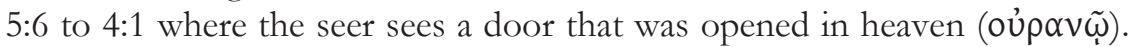
Upon crossing this threshold, John beholds the glory of the throne and affairs of the heavenly court that continues through Rev. 5:14. The employment of oúpavov in the comment creates a heightened sense of thematic and narrative unity across the entirety of the heavenly court vision

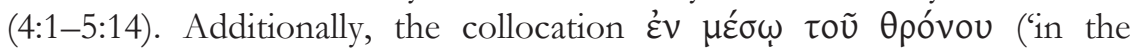
middle of the throne') is ambiguous, and commentators have offered numerous solutions to the precise position of the lamb in reference to the throne. ${ }^{47}$ While it is possible to understand the lamb located somewhere in proximity to the throne, the author's deployment of oujpavou solves a potential semantic problem by utilizing a graphically/aurally similar lexeme that is already textually linked (Rev. 4:1) to the current scene. The evidence suggests that the author consciously altered the text of the lemma in an effort to side-step a grammatically ambiguous construction, opting for a lexeme that creates greater semantic clarity. ${ }^{48}$ Andreas of Caesarea, too, is

${ }^{45}$ See D.C. Parker, The Living Text of the Gospels. Cambridge: CUP, 1997, 37-8.

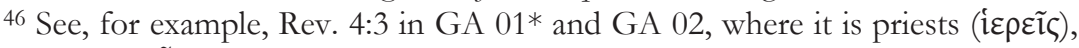
not a rainbow (ĩpic) that encircle the throne. Further comment on similar examples is given in Martin Karrer, 'Der Text der Johannesapokalypse' in Die Johannesapokalypse: Kontexte—Konzepte—Rezeption. ed. J. Frey, J. A. Kelhoffer, and F. Tóth. WUNT 287. Tübingen: Mohr, 2012, 43-78. This phenomenon was also operative in other textual traditions: see Emanuel Tov, The Text-Critical Use of the Septuagint in Biblical Research. Jerusalem Biblical Studies 3. Jerusalem: Simor, 1997, 100-1. He describes this type of exegetical impulse as 'tendentious paleographic exegesis'. See also David Andrew Teeter, Scribal Laws: Exegetical Variation in the Textual Transmission of Biblical Law in the Late Second Temple Period. Forschungen zum Alten Testament 92. Tübingen: Mohr Siebeck, 2014), 190-191.

${ }^{47}$ For a summary, see Koester, Revelation, 376.

48 There are numerous examples where $\dot{\varepsilon} v \mu \varepsilon \dot{\varepsilon} \sigma \omega$ is used before more general locations (cf. Mark 6:47; Luke 22:55a; Rev. 22:2), instead of an inanimate object. Additionally, the exegetical use of textual variation was an accepted mode of interpretation, at least in the Antiochene School. See Robert C. Hill, Reading the Old Testament in Antioch. BAC 5. Leiden: Brill, 2005, 63-83. 
aware of textual variation in the Apocalypse, and uses this variation to his exegetical advantage. ${ }^{49}$ Again, the present author is aware of the minute details of the scriptural text upon which he comments.

Finally, the scholion concludes with a quotation of Zechariah $4: 10 \mathrm{~b}^{\mathrm{LXX}}$, following a brief discussion of the significance of the lamb's seven horns and seven eyes. ${ }^{50}$ The Andreas of Caesarea commentary tradition, too, connects Rev. 5:6b to Zechariah (and Isaiah), but without qualification. ${ }^{51}$ In Scholion XXVIII, the exegetical deployment of the quotation controls the interpretative arch of the argument. The section of the comment that culminates in the quotation is comprised of a series of ' $x$ is $y$ because $z$ identifications: the lamb's seven horns signify his kingdom and blessedness, a reality symbolized by 'the spirits'; the lamb's seven eyes are the 'seven spirits of God', an identification supported by the quotation of Zech. 4:10b. The association of the lamb's eyes with the spirits of God is key to the author's exegetical logic. Understanding the horns as symbols of the lamb's regal power is supported by the assertion that 'the spirits are

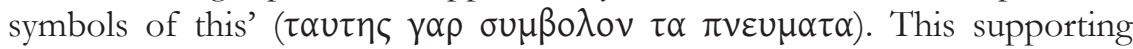
evidence is explicated further in the next locution: the lamb's eyes are divine spirits, an association sustained by the quotation of Zech. 4:10b. In this way, the quoted material is the exegetical linchpin that organizes the logic of the interpretation. The quotation also provides a rhetorical climax, appealing to antecedent scriptural traditions to support the association of eyes and spirits already present in the lemma of the Apocalypse.

Once again, the exegetical techniques that coalesce to create the author's interpretation of certain textual segments of Revelation provide evidence of an abiding attentiveness to the textual features of the lemma.

${ }^{49}$ See his comments on Rev. 3:7 and 15:6, for example. See also Constantinou, Guiding to a Blessed End, 128-31 and Juan Hernández Jr., 'The Relevance of Andrew of Caesarea for New Testament Textual Criticism' JBL 130.1 (2011) 183-96.

${ }^{50} \mathrm{I}$ have written on textual issues surrounding the use of Zechariah 4 in Revelation in G. V. Allen, 'Textual Pluriformity and Allusion in the Book of Revelation. The Text of Zechariah 4 in the Apocalypse' ZNW 106.1 (2015) 136-45. The quotation in Scholion XXVIII differs slightly from the majority of Greek

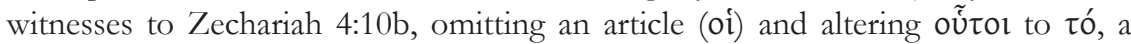
change that embeds the quoted text into the syntactical arrangement of the target composition.

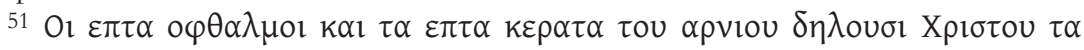

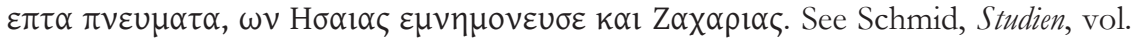
1.2, 56 and also the Nerses of Lambron tradition (Thompson, Nerses, 76). 
The moves in Scholion XXVIII suggest that the author intended to explicate potential ambiguities in the text. The lexical alteration solves a perceived semantic issue, and the quotation from Zechariah supports the association in Revelation of the eyes of the lamb with the divine spirits, an issue of potential Trinitarian consequence. Underlying this commentary is the implicit belief that the text of Revelation contains grammatical and theological problems that require explanation. The exegetical techniques employed in this scholion create an avenue to smooth the rutted texture of Revelation.

\section{CONCLUSION}

I conclude with a few reflections on the previous discussion. First, the form of the manuscript, determined by its paratextual features and textual organization, shapes the way one approaches the comments. The occasional incongruity between comment and lemma requires that readers approach the commentary through the scholia, even though the scholia themselves have no overarching structure but are an aggregate of interpretative traditions from disparate sources. Additionally, the composition of the Scholia parallels the form of Codex 573: both are collections of thematicallyrelated entities within the constraints of a single physical entity. The contents of the codex are more diverse than the traditions related to the Apocalypse collected in the Scholia, but the parallel provides a helpful analogy for describing the composition of the Scholia. ${ }^{52}$

Second, the textual features of Revelation are selectively addressed in the Scholia. A key phrase, and in some cases a single word, receive the lion's share of exegetical attention. Traditions external to the lemma are used to comment on these features, but there is rarely any concerted attempt to tie the comments to a broader or all-encompassing interpretative agenda.

Third, the Scholia betray an acute attention to the detailed textual features of the lemma. Carefully coordinated lexical threads, uses of synonyms, paronomasia, etymology, attention to related canonical texts and traditions, and word substitution are the exegetical resources which the author expends in the process of interpreting Revelation. Grasping the

52 Tzamalikos, An Ancient Commentary, 8-9 argues that it was manufactured at the St. Sabas Monastery in Jerusalem, based on palaeographic considerations and his presumption of authorship. I am not yet convinced by this argument, although this is certainly a collection from some monastic community. 
employment of these resources should aid in understanding the way in which Revelation is interpreted in each individual scholion.

\section{Appendix: Physical Presentation of Lemma and COMMENT IN THE SCHOLIA IN APOCALYPSIN}

The following table details the way in which the lemma and scholia are presented and features of the transition between the two. The marginal notation in the sixth column may take the form of $\varepsilon \rho /$, a number (\#) or a diple (〉).

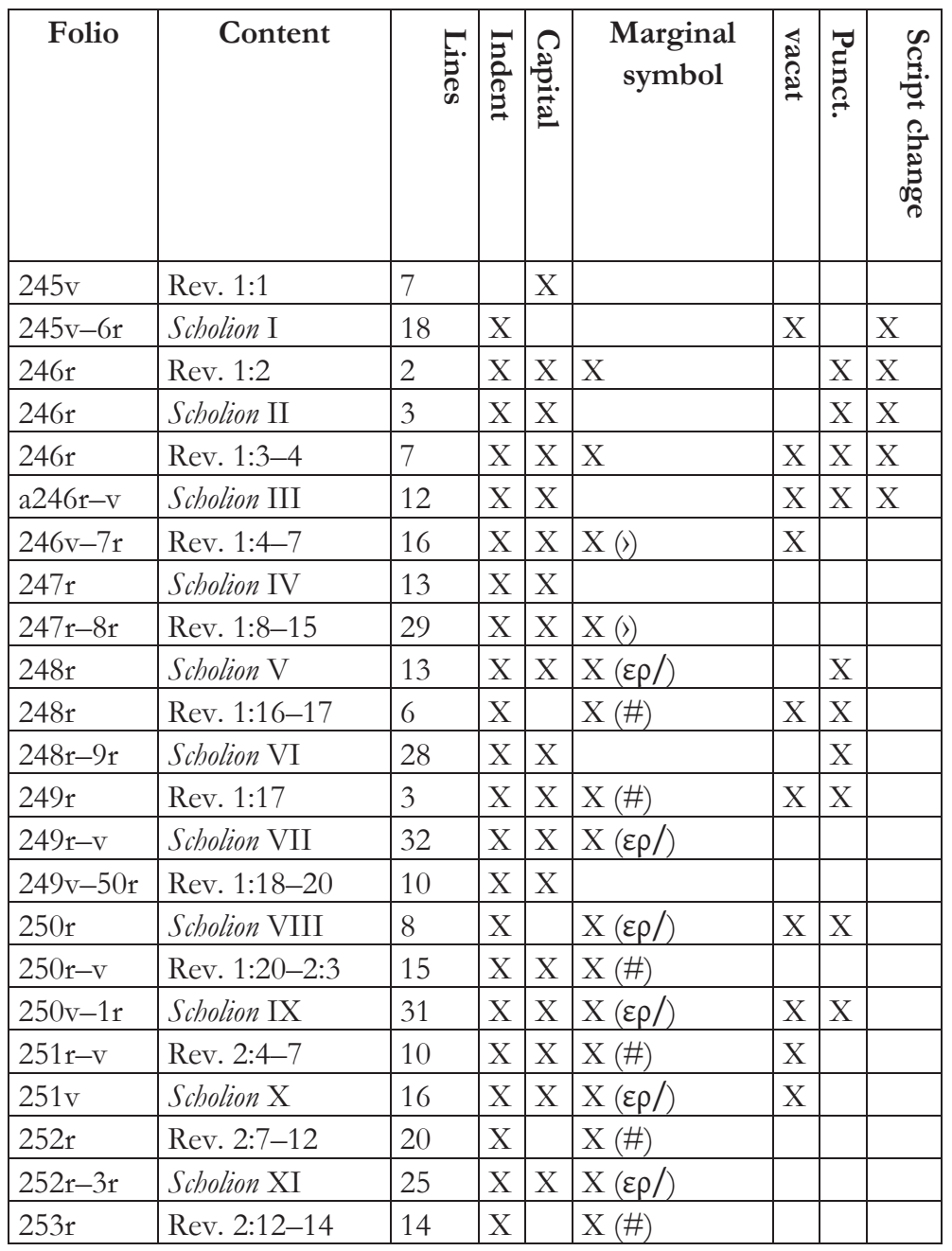




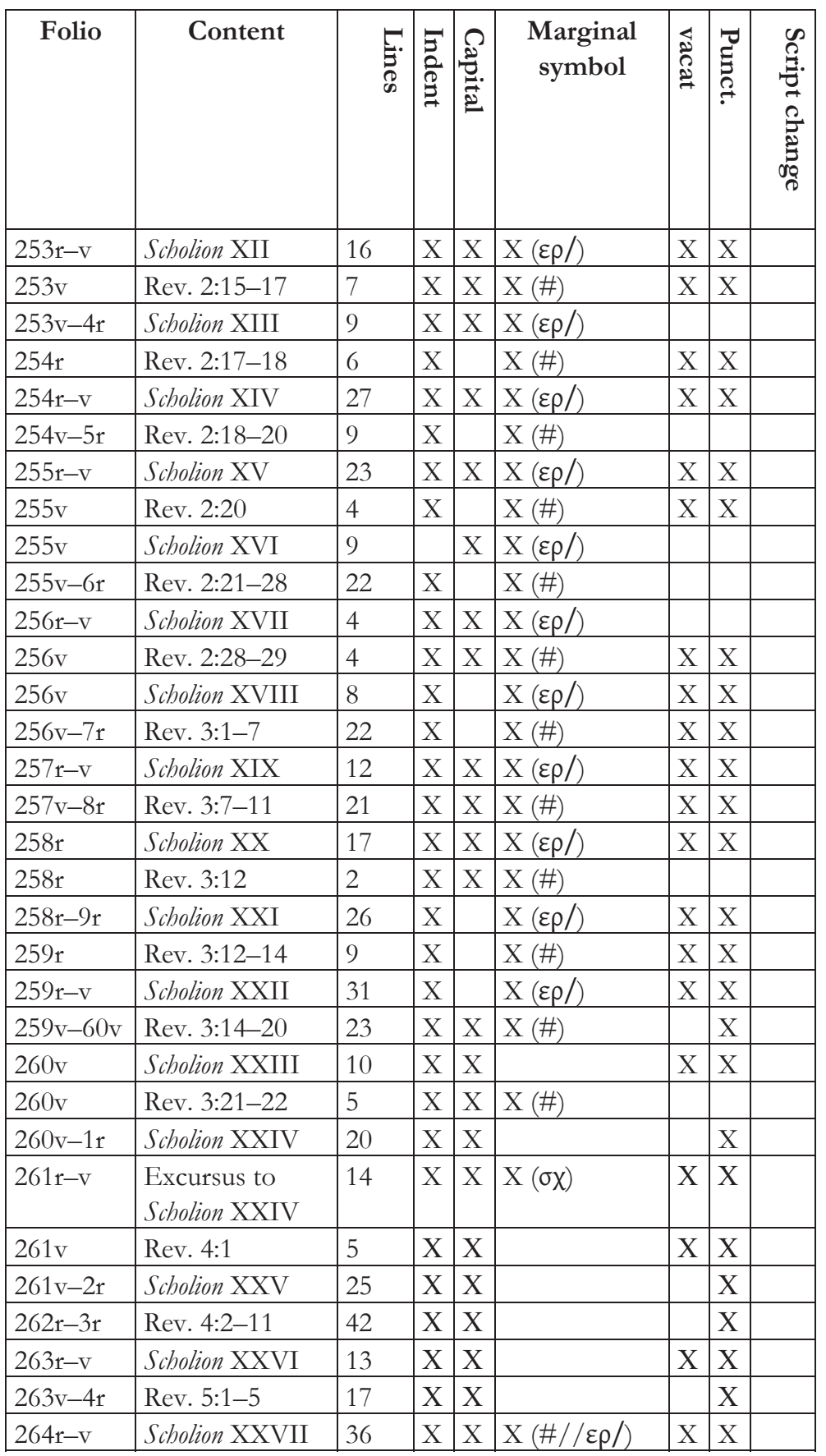




\begin{tabular}{|c|c|c|c|c|c|c|c|c|}
\hline Folio & Content & $\begin{array}{l}\overrightarrow{5} \\
\overrightarrow{8} \\
\infty\end{array}$ & 营 & 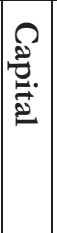 & $\begin{array}{c}\text { Marginal } \\
\text { symbol }\end{array}$ & ڤ゙્ & 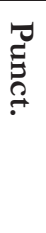 & 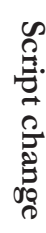 \\
\hline $264 v-5 r$ & Rev. 5:6-8 & 9 & $\mathrm{X}$ & $\mathrm{X}$ & $\mathrm{X}(\#)$ & $\mathrm{X}$ & $\mathrm{X}$ & \\
\hline $265 \mathrm{r}-\mathrm{V}$ & Scholion XXVIII & 21 & $\mathrm{X}$ & $\mathrm{X}$ & $\mathrm{X}(\varepsilon \rho /)$ & $\mathrm{X}$ & $\mathrm{X}$ & \\
\hline $265 v-6 v$ & Rev. 5:8-6:2 & 28 & $\mathrm{X}$ & $\mathrm{X}$ & $\mathrm{X}(\#)$ & $\mathrm{X}$ & $\mathrm{X}$ & \\
\hline $266 \mathrm{v}-7 \mathrm{r}$ & Scholion XXIX & 41 & $\mathrm{X}$ & & $\mathrm{X}(\varepsilon \rho /)$ & $\mathrm{X}$ & $\mathrm{X}$ & \\
\hline $267 v-8 r$ & Rev. 6:3-8 & 23 & $\mathrm{X}$ & $\mathrm{X}$ & $\mathrm{X}(\#)$ & & & \\
\hline $268 \mathrm{r}-70 \mathrm{v}$ & Scholion XXX & 107 & $\mathrm{X}$ & $\mathrm{X}$ & $\mathrm{X}(\# / / \varepsilon \rho /)$ & & & \\
\hline $270 v-2 r$ & Rev. 6:9-7:8 & 67 & $\mathrm{X}$ & $\mathrm{X}$ & $\mathrm{X}(\#)$ & & & \\
\hline $272 r-3 r$ & Scholion XXXI & 50 & $\mathrm{X}$ & $\mathrm{X}$ & & & & \\
\hline $273 \mathrm{r}-\mathrm{v}$ & Rev. 7:9 & 6 & $\mathrm{X}$ & $\mathrm{X}$ & $\mathrm{X}(\#)$ & $\mathrm{X}$ & $\mathrm{X}$ & \\
\hline $273 v$ & Scholion XXXII & 16 & $\mathrm{X}$ & & $\mathrm{X}(\varepsilon \rho /)$ & & $\mathrm{X}$ & \\
\hline $273 v-4 r$ & Rev. 7:9-13 & 16 & $\mathrm{X}$ & $\mathrm{X}$ & $\mathrm{X}(\#)$ & $\mathrm{X}$ & $\mathrm{X}$ & \\
\hline $274 \mathrm{r}-\mathrm{v}$ & Scholion XXXIII & 19 & $\mathrm{X}$ & $\mathrm{X}$ & $\mathrm{X}(\varepsilon \rho /)$ & $\mathrm{X}$ & $\mathrm{X}$ & \\
\hline $274 v-8 r$ & Rev. 7:13-9:19 & 156 & $\mathrm{X}$ & $\mathrm{X}$ & & $\mathrm{X}$ & $\mathrm{X}$ & \\
\hline $278 \mathrm{r}-\mathrm{v}$ & Scholion XXXIV & 6 & $\mathrm{X}$ & $\mathrm{X}$ & $\mathrm{X}(\varepsilon \rho /)$ & & & \\
\hline $278 v-9 r$ & Rev. 9:20-10:3 & 24 & $\mathrm{X}$ & $\mathrm{X}$ & $\mathrm{X}(\#)$ & $\mathrm{X}$ & $\mathrm{X}$ & \\
\hline $279 \mathrm{r}-\mathrm{v}$ & Scholion XXXV & 21 & $\mathrm{X}$ & & $\mathrm{X}(\varepsilon \rho /)$ & $\mathrm{X}$ & $\mathrm{X}$ & \\
\hline $279 v-82 r$ & Rev. 10:3-11:18 & 113 & $\mathrm{X}$ & $\mathrm{X}$ & $\mathrm{X}(\#)$ & $\mathrm{X}$ & $\mathrm{X}$ & \\
\hline $282 r-3 r$ & Scholion XXXVI & 35 & $\mathrm{X}$ & $\mathrm{X}$ & $\mathrm{X}(\varepsilon \rho /)$ & $\mathrm{X}$ & $\mathrm{X}$ & \\
\hline $283 r-3 v$ & Rev. 11:18-12:2 & 19 & $\mathrm{X}$ & $\mathrm{X}$ & $\mathrm{X}(\#)$ & & & \\
\hline $283 \mathrm{v}-4 \mathrm{r}$ & Scholion XXXVII & 28 & $\mathrm{X}$ & $\mathrm{X}$ & $\mathrm{X}(\varepsilon \rho /)$ & $\mathrm{X}$ & $\mathrm{X}$ & \\
\hline $284 r-7 r$ & Rev. 12:3-13:18 & 139 & $\mathrm{X}$ & $\mathrm{X}$ & $\mathrm{X}(\#)$ & $\mathrm{X}$ & $\mathrm{X}$ & \\
\hline $287 \mathrm{r}-9 \mathrm{v}$ & Schol. XXXVIII & 106 & & & $\mathrm{X}(\varepsilon \rho /)$ & $\mathrm{X}$ & $\mathrm{X}$ & \\
\hline $290 \mathrm{r}$ & Rev. 14:3-5 & 9 & $\mathrm{X}$ & $\mathrm{X}$ & $?$ & $\mathrm{X}$ & $\mathrm{X}$ & \\
\hline $290 \mathrm{r}$ & Scholion XXXIX & 12 & $?$ & $?$ & $?$ & $?$ & $?$ & \\
\hline
\end{tabular}





\title{
8. THEODORET'S TEXT OF ROMANS
}

\author{
AGNÈS LORRAIN ${ }^{1}$
}

In memory of Revd Dr Jerome Murphy O’Connor (o.p.)

Attempting to reconstruct the text of Romans in an early Christian writer means both to follow in the footsteps of the scholar who long ago wrote the Codex von der Goltz (GA 1739) and, I hope, to make a small contribution to the great project of the Editio critica maior. ${ }^{2}$ Within the compass of my own critical edition of Theodoret's Interpretatio in epistulam ad Romanos (In Rom., CPG 6209), the biblical text poses a central problem. ${ }^{3}$

The evidence for the text of Paul in Theodoret of Cyr (393-c.460) is particularly important, because he is the only Greek author from the patristic era whose commentary on the Epistles is entirely preserved in its

1 The English translation of Theodoret's commentary in this paper is taken from R.C. Hill, Theodoret of Cyr. Commentary on the Letters of St. Paul. Brookline MA: Holy Cross Orthodox Press, 2001, in spite of its lack of precision at some points. I am very grateful to Kevin Stephens (o.p.) for helping me write the English text of this paper.

2 On the purpose of the scribe who wrote the Codex von der Goltz, see the introductory remark in O. Bauernfeind, Der Römerbrief des Origenes nach dem Codex von der Goltz (Cod. 184 B 64 des Athosklosters Lawra). TU 44.3. Leipzig: Hinrichs, 1923, 91. Concerning the Editio critica maior, only the Catholic Letters have so far been published (B. Aland, K. Aland et al., Novum Testamentum Graecum: Editio Critica Major. IV, Die Katholischen Briefe. $2^{\text {nd }}$ edn. 2 vols. Stuttgart: Deutsche Bibelgesellschaft, 2013). As Morrill and Gram note on page 99 above, preparations are underway for the Pauline Epistles.

3 The edition is part of my doctoral dissertation (Paris-Sorbonne, 2015); further information about the biblical text of Theodoret, especially concerning the whole Pauline corpus, is provided in the introductory chapter. References to this critical text are provided in brackets in the present paper. 
original language. This affords us the opportunity to know precisely the state of his own Pauline corpus. In addition, three features of his exegesis allow us to hope to be able to find interesting details concerning textual variants: first, he respects the sequence of the text, quoting and commenting on every verse; second, he pays close attention to the letter of the text; and third, he is often interested in textual criticism. In the course of this investigation, however, it was more the limitations of the approach than the positive results which came to the fore. For this reason we will focus on methodological issues before considering some features of the text. The vast majority of the variants we found affect neither the meaning nor the characterisation of the text. We have therefore focussed our attention on some variants presented by Bruce Metzger in his Textual Commentary on the Greek New Testament. ${ }^{4}$

\section{Methodological Issues}

In order to reconstruct the biblical text of Theodoret, we shall examine the manuscripts, analyse the commentary, and compare Theodoret with other authors. Nevertheless, we quickly notice that these methods present very little certain information.

\section{The problem of the manuscript tradition}

The first requirement for determining Theodoret's text is the examination of the manuscripts. ${ }^{5}$ However, besides the difficulty of choosing between the different surviving witnesses, we cannot exclude the possibility of editorial intervention between Theodoret and the archetype we may reconstruct based on the manuscripts we have.

The textual tradition of this work provides a clear illustration of the intervention of a copyist and the autonomy of the biblical text in the lemma when compared with the stemma built from the text of the commentary. So, while Paris, BnF, Supplément gr. 1299 (GA 2242) is a copy of Vatican,

4 B.M. Metzger, A Textual Commentary on the Greek New Testament. $2^{\text {nd }}$ edn. London \& New York: UBS, 1994, 505-41. Our comparison with the variant readings already noted by the editors of the New Testament is based on the information of both NA28 and K. Aland, Text und Textwert der griechischen Handschriften des Neuen Testament I, 1. Berlin-New York: de Gruyter, 1991.

${ }^{5}$ For the witnesses of Theodoret's In epistulas Pauli, we not only studied the In Romanos but also the biblical quotations throughout the commentary. For his other works, we made reference to available critical editions. 
BAV, Vaticanus gr. 1649 (GA 1945), its biblical text is sometimes different. Some details show that the copyist paid more attention to the biblical text than to the commentary and used a biblical manuscript to correct and complete what he considered omissions. Indeed, we found phrases added at the end of a lemma which correspond to parts of verses written in the following sentences but which were not indicated by a diple. ${ }^{6}$

We may assume that this sort of intervention also occurred at an earlier stage. So the 'text' of Theodoret which forms the subject of the present paper, that is to say the biblical text of the archetype (to the extent that it can be reconstructed), may be quite far from the text actually commented upon by the Bishop of Cyr. ${ }^{7}$

\section{The problem with studying the commentary}

Since the lemmata and quotations do not provide solid evidence, we must base our investigation on the content of the commentary. Contrary to what one might expect from Theodoret, his commentary on Romans provides little information because the explanations seldom relate to words which are subject to variation. Most surprising is the lack of text-critical remarks in comparison with Origen's commentary on Romans and in contrast to Theodoret's interest in the versions of the Old Testament. ${ }^{8}$

Only one comment may possibly refer to a variant reading. It concerns the name Priscilla. Theodoret says:

Priscilla, or Prisca (you can find both forms in the books). ${ }^{9}$

Is this a comment about different copies of Romans? Both readings are to be found in surviving manuscripts. However, Theodoret does not seem to use the word $\beta$ i $\beta \lambda$ íov in reference to different copies of one text, whereas

6 This is described more precisely in my dissertation.

7 The quotations of Romans in other works are probably less subject to correction. We consider them a good witness if they confirm a rare reading.

8 B.M. Metzger, 'Explicit References in the Works of Origen to Variant Readings in New Testament Manuscripts' in Biblical and Patristic Studies in Memory of Robert Pierce Casey, ed. J.N. Birdsall and R.W. Thomson, Freiburg im Breisgau: Herder, 1963, 78-95, lists the text-critical remarks of Origen on Romans, according to Rufinus on 88-90. For Theodoret's other works, see J.-N. Guinot, L'Exégèse de Théodoret de Cyr. Théologie historique 100. Paris: Beauchesne, 1995, 167-252.

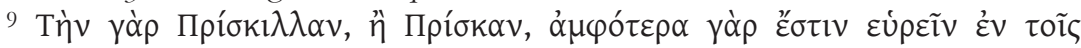

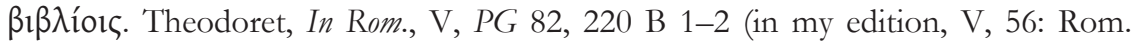
$16: 3)$. 
he often uses it in reference to a book of the Bible. ${ }^{10}$ Therefore, the exegete is probably referring to other books of the New Testament (e.g. Acts 18:2, 18; 1 Cor. 16:19) rather than to other copies of Romans, in the same way as Origen, who, with reference to the same verse, reads 'Prisca' and notes that we find 'Priscilla' in Acts. ${ }^{11}$

The commentary does not often indicate a particular reading, although examples of this will be given below. Sometimes a remark seems to be more satisfactory if we suppose a particular reading, and in that case we consider the reading likely but not certain. Let us see, for example, how Theodoret explains Romans 4:11:

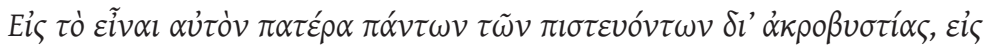

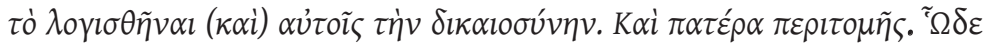

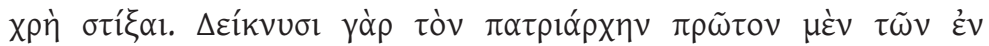

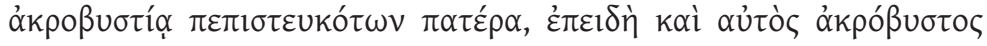

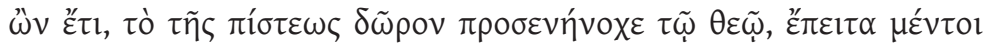

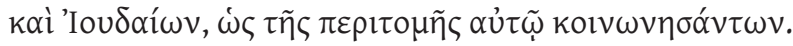

So that he might be father of all who believe despite not being circumcised in order that rigbteousness be reckoned (also) to them, and father of the circumcised. Here there is need of distinction: he shows the patriarch as father first of those who believed while uncircumcised, since he himself while still uncircumcised offered God the gift of faith, then of course also of Jews on the grounds of their sharing circumcision with him. ${ }^{12}$

The commentary is more coherent without the adverbial koì, which would seem to mean that the justification of pagans occurs after that of the Jews: according to Theodoret, Paul affirms that Abraham is 'first of all' father of the pagans. In a case such as this, we choose the reading without koi, as it is attested in the textual tradition of Theodoret. ${ }^{13}$

Some embarrassing examples show that the proof is sometimes more apparent than real. This is the case in Romans 7:25. Manuscripts of the

10 See Guinot, L'Exégèse, 180-1. For examples of the of the word $\beta 1 \beta \lambda$ íov meaning a biblical book, see Theodoret, Commentarius in Isaiam, XIX, SC 315, 266 (Is. 61:1); Commentarius in Canticum, PG 81, 49A 2.

11 According to Rufinus' translation, cf. Origen, Commentarius in Romanos, X.18. 2, SC 555, 372.

12 Theodoret, In Rom., II, PG 82, 89 C 13-D 6 (in my edition: II, 14).

13 One old manuscript of Theodoret quotes the text without kaí. 


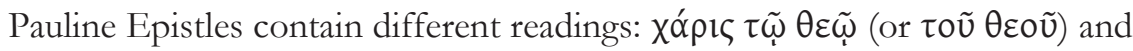
$\varepsilon \dot{u} \chi \alpha \rho ı \tau \tau \tilde{\omega} \tau \tilde{\omega} \theta \varepsilon \tilde{\omega}$. Here is Theodoret's commentary:

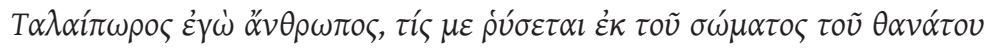

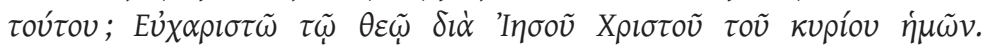

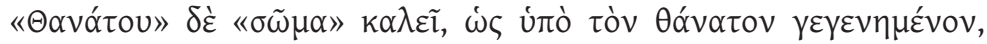

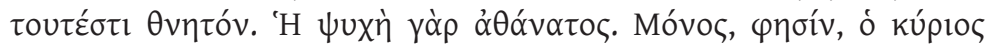

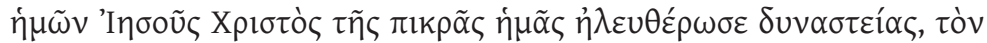

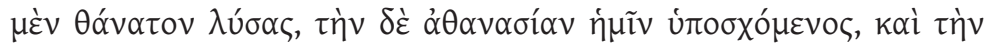

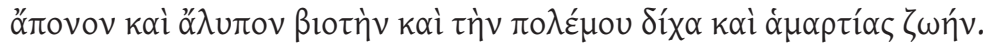

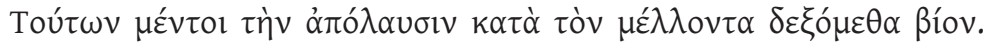

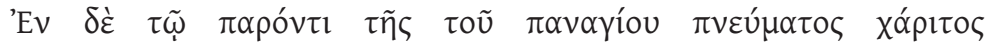

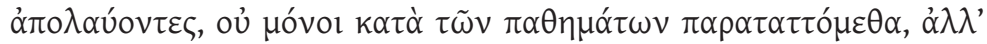

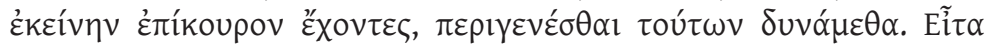

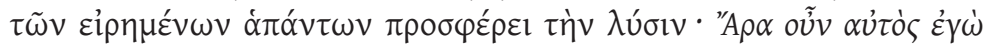

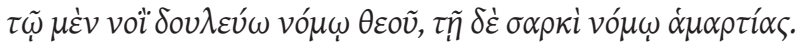

Wretch that I am, who will rescue me from the body of this death? I thank my God through Jesus Christ our Lord. Now, he speaks of a 'body of death', as though made subject to death — that is, mortal, the soul being immortal. Our Lord Jesus Christ alone, he is saying, freed us from that harsh domination, undoing death and promising us immortality, an existence free from hardship and grief, and a life without hostility and sin. Of course, we shall receive the enjoyment of these things in the future life, whereas in the present, enjoying the grace of the all-holy Spirit, we are not alone in being drawn up in battle array against the passions, and instead with that to help us we are able to prevail over them. Then he offers a solution to all that has been said: In my mind, then, I am a slave of God's law, but in the body a slave of the law of $\sin { }^{14}$

The manuscripts of the commentary unanimously read $\varepsilon \dot{v} \chi \alpha \rho 1 \sigma \tau \tilde{\omega}$. In his edition, J.A. Nœsselt holds the view that, according to Theodoret's

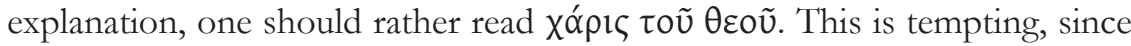
the exegete says the grace of the Holy Spirit helps combat the passions. However we must be cautious for three reasons. First, the evocation of grace does not appear as an explanation of the words: Theodoret has already developed the idea of the salvation brought by Jesus Christ, which can depend on both readings, and then introduces a distinction, absent from the text, between the future life and the condition of the present life.

14 Theodoret, In Rom., III, PG 82, 128 A 5-B 7 (III, 32-33). 
In this framework he speaks about grace, specifying 'the grace of the Holy Spirit'. In addition, his characterisation of the following verse as a 'solution' is more difficult to understand if we read xóplৎ, which appears to be a response.

The second reason rests on the observation of exegetical practice in this commentary. Even if one considers that the comment on 'grace'

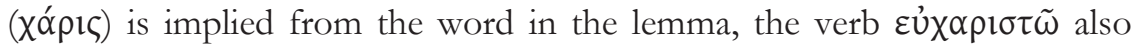
works. Indeed, Theodoret repeatedly picks up a word when the text presents a derivative of it. For example, he says:

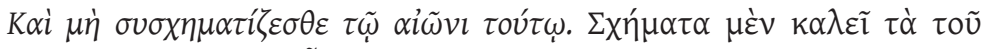

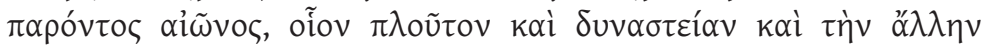

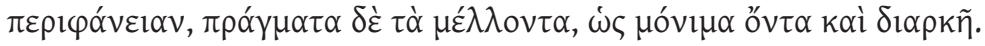

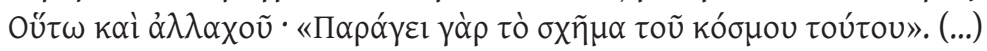

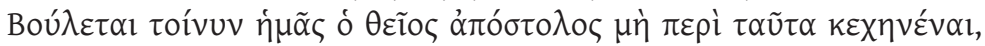

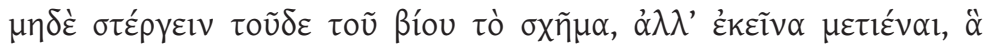

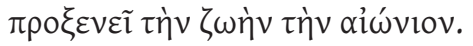

Far from being configured to this age. By the figures of the present age he is referring to things like wealth and influence and other pomp and circumstance, implying future things are stable and lasting. Likewise elsewhere, too, 'The figure of this world is passing away, after all.' (...) The divine apostle, accordingly, wants us not to long for such things nor fall in love with the figure of this life, but rather go after those things that bring life everlasting. ${ }^{15}$

Since Theodoret here claims that Paul is using ( $\kappa \alpha \lambda \varepsilon \tilde{\mathfrak{l}})$ the word $\sigma \times \tilde{\eta} \mu \alpha$, whereas in fact he certainly reads $\sigma v \sigma x \eta \mu \alpha \tau i$ ' $\varepsilon \sigma \theta \alpha \mathrm{l}$, then it is not at all unlikely that Theodoret reads $\varepsilon \dot{x} \propto \alpha \rho \imath \tau \tilde{\omega}$ in Romans 7:25 but speaks about xóplc. Indeed, a play on these two words is to be found in Chrysostom with regard to the same verse, which offers a third reason to be cautious:

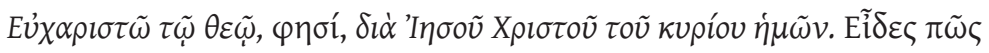

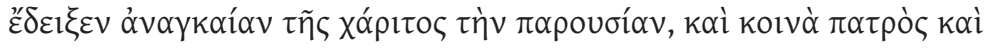

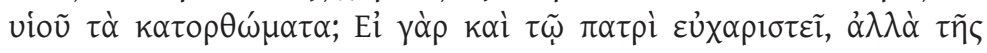

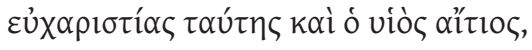

15 Theodoret, In Rom., V, PG 82, 185 B 13-C 13 (V, 3: Rom. 12:2). There are similar examples at In Rom., III, PG 82, 133 A 1 (III, 41: Rom. 8:13), where there is

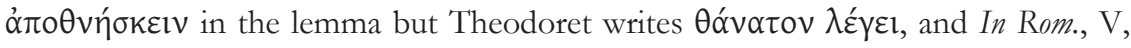

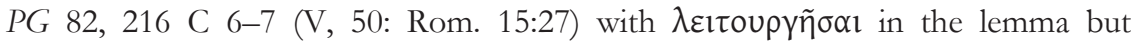

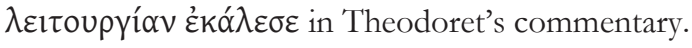


I thank. my God, he says, through Jesus Christ our Lord. Do you see how he showed that the presence of grace is necessary and that virtues are common to the Father and to the Son? For if he is giving thanks to the Father, then the Son is also responsible for that thanksgiving. ${ }^{16}$

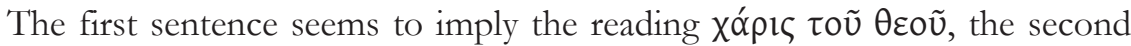

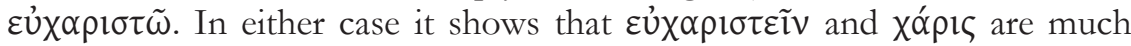
closer than the English words 'thanksgiving' and 'grace'.

Having found no case where the commentary is clearly incompatible with the lemma of the manuscripts, we have therefore not corrected the lemmata away from the manuscript tradition even when a reading found in biblical manuscripts could be considered to be more probable.

\section{The use of other authors}

A comparison between the text transmitted by Theodoret's commentary and quotations by other authors is sometimes useful, for it allows us to take account of readings which are not widely or at all attested in surviving manuscripts of the Epistles and which do not feature in the apparatus of critical editions of the New Testament. We generally prefer these readings to those which are to be found in direct tradition. ${ }^{17}$

With regard to searching for parallels in the interpretation, we limited ourselves to some very basic comparisons whith Origen and a survey of Chrysostom's Homilies on Romans, because of the obvious kinship of the latter with the bishop of Cyr. It should be emphasised that this was not in order to rely on material found in John Chrysostom to reconstruct the text of Theodoret (presupposing the dependence), but rather to compare certain evidence provided by both in order to identify similarities and differences.

\section{SOME RESULTS}

The examination of the manuscripts mostly confirms what earlier editions already allow us to affirm about Theodoret's text of Romans. The errors found in these earlier editions only affect details about which the commentary does not allow us to affirm anything. ${ }^{18}$ In the following we will

16 Cf. John Chrysostom, Homiliae in Romanos, XIII, PG 60, 512, 11-15 (Rom. 7:25).

${ }^{17}$ For example, the word order in Romans 2:8, 3:28 and 6:3 is not mentioned in NA28 but is to be found in other Fathers.

18 See for example Theodoret, In epist. Pauli, prol., PG 82, 39 B 1 (prol., 7: quotation of 2 Cor. 8:1); In Rom., IV, PG 82, 161 A 3-4 (IV, 18: Rom. 9:28). 
focus on characterising Theodoret's text from the evidence of the commentary, leaving aside variants which do not allow the classification of the text with regard to a group. ${ }^{19}$

\section{Features of Theodoret's text of Romans}

With regard to Romans as a whole, this commentary provides valuable evidence concerning the organisation of the last chapters. Theodoret's text corresponds to what Kurt Aland describes as the Byzantine Majority form, consisting of Romans $1: 1$ to $14: 23$, then $16: 25$ to 27 , followed by $15: 1$ to $16: 24 . .^{20}$

A few additional details confirm this kinship with the Byzantine text. For example, in Romans 3:22 ('God's righteousness through the faith of Jesus Christ for all and upon all who believe'), Theodoret does not just read

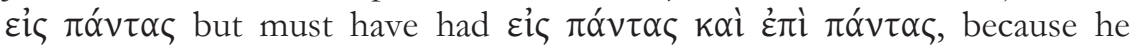
comments on the difference between both phrases:

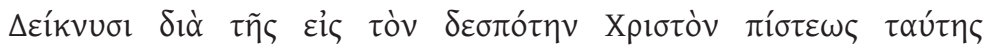

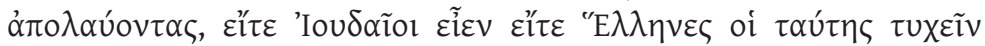

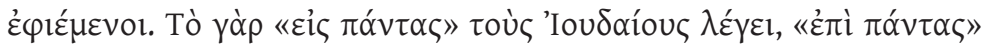
$\delta \grave{\varepsilon} \tau o \dot{c} \varsigma \dot{\varepsilon} \kappa \tau \tilde{\omega} v \stackrel{\alpha}{\lambda} \lambda \omega \omega v \dot{\varepsilon} \theta v \tilde{\omega} v$.

${ }^{19}$ For example, Theodoret's commentary on Romans 5:1, indicating that Paul is moving to the exhortation and paraphrasing the verse as 'It behooves [you] to

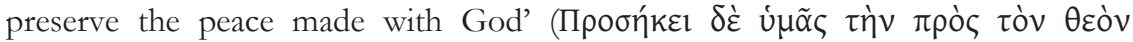

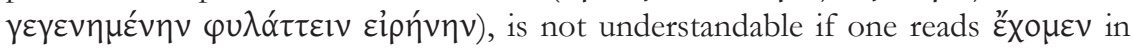
the indicative (Theodoret, In Rom., II, PG 82, 96 B 3-5 (II, 20).). A similar case is to be found in In Rom., V, PG 82, 205 A 13-15 (V, 32: Rom. 14:19).

20 In PG 82, 208 A 5-B 10, Romans 16:25-7 are set out as quotations rather than lemmata, with no verse numbers. On the text-critical problems at the end of Romans, see K. Aland, 'Glosse, Interpolation, Redaktion und Komposition in der Sicht der neutestamentlichen Textkritik' in Studien zur Überlieferung des Neuen Testaments und seines Textes, ed. K. Aland. ANTF 2. Berlin: de Gruyter, 1967, 46-8; K. Aland, 'Der Schluß und die ursprüngliche Gestalt des Römerbriefes', in K. Aland, Neutestamentliche Entwürfe, Munich: Kaiser, 1979, 284-301; P. Lampe, 'Zur 'Textgeschichte des Römerbriefes’ NovT 27 (1985) 273-7; J.A. Fitzmyer, Romans, A New Translation with Introduction and Commentary. Anchor Bible 33. New York: Doubleday, 1993, 44-54. 
He shows that they enjoy this through faith in Christ the Lord, whether they be Jews or Greeks who long to attain it. For the phrase 'for all' means the Jews and 'upon all' those from the other Nations. ${ }^{21}$

Other remarks allow us to oppose his text to the 'Western' text. For

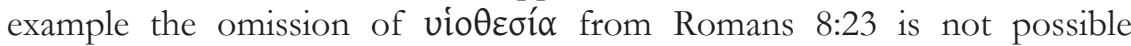
because Theodoret picks out the word and comments on its contradiction with Romans 8:15.22 Further examples of opposition to 'Western' readings include $\delta 1 \alpha \theta \tilde{\eta} k \alpha 1$ in Romans 9:4, kupíw in 12:11, and probably also toù $\pi \alpha ́ v \tau \alpha \varsigma$ in 11:32. ${ }^{23}$ No observation has been found in the commentary which agrees with a 'Western' reading or opposes the Byzantine text. However, as noted above, the commentary rarely permits confirmation or contradiction of the text of the lemmata, which usually provide Byzantine readings but might have been introduced at a later stage.

\section{A comparison with Origen}

A thorough comparison of Theodoret with the texts of other ancient authors is not possible within the parameters of the present study, but some observations may be made regarding the two authors mentioned earlier.

The most obvious difference from Origen, according to the translation of his commentary by Rufinus, concerns the end of Romans. Origen attributes the shorter text ending with 14:23 to Marcion and instead has 16:25-27 at the end of the Epistle, although he also knows of manuscripts with these verses after 14:23.24 Other clear oppositions are evident from their commentaries, as in the variation between $\theta \varepsilon$ co (the reading of

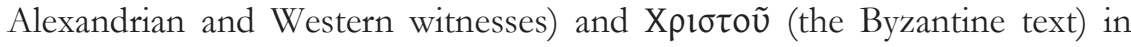
Romans 14:10 ('After all, we shall all stand before the judgment seat of God' or 'of Christ'). Theodoret's interpretation would not be

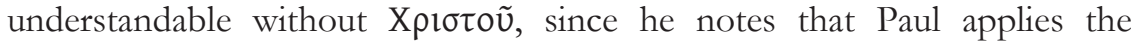
following quotation of Isaiah to Christ and so proves the divinity of

21 Theodoret, In Rom., II, PG 82, 84 B 11-15 (II, 6). I have translated the last sentence, which is not to be found in R.C. Hill. A similar example may be found in IV, PG 82, 168 B 4-6 (IV, 26: Rom. 10:15), with the addition of $\tau \tilde{\omega} v$

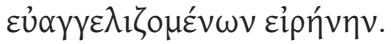

22 Theodoret, In Rom., III, PG 82, 137 D 2-6 (III, 50).

23 See, respectively, In Rom., IV, PG 82, 149 D 3-7 (IV, 5); In Rom., V, PG 82, 189 C 14-D 1 (V, 8); In Rom., IV, PG 82, 181 C 11-D 5 (IV, 47).

24 Cf. Origen, Com. in Rom., X, 43, 1, SC 555, 440. 
Christ. ${ }^{25}$ The commentary of Origen-Rufinus allows us to affirm that his text has 'the judgment seat of God', since he notes the difference whith 'the judgment seat of Christ' used elsewhere by the Apostle. ${ }^{26}$

\section{A comparison with John Chrysostom}

The comparison of the biblical text in Theodoret's and Chrysostom's commentaries presents more than one scenario. The most simple is when both authors imply the existence of the same text. For example, they have the same arrangement of verses in Romans 14-16, and share some similar oppositions to 'Western' readings. ${ }^{27}$ Furthermore, both Chrysostom and

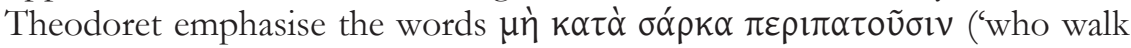
not according to the flesh') in Romans 8:1, which is considered to be a Byzantine addition. ${ }^{28}$

In the second scenario, only one of the commentaries can be taken in support of a particular form of text, so we cannot affirm a similarity between the two authors. We find several remarks in Chrysostom confirming that he is commenting on the Byzantine text, transmitted in the lemmata of Theodoret's manuscripts but not confirmed from his commentary. For example, Chrysostom insists on the word $\pi \rho \tilde{\omega} \tau o v$ in Romans 1:16 ('the Jew first of all'). ${ }^{29}$ When speaking about Abraham's faith,

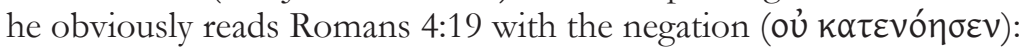

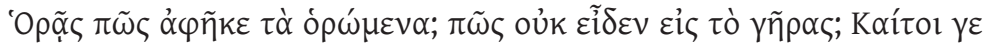

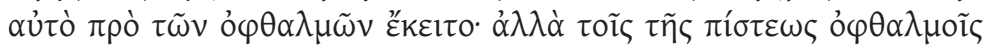

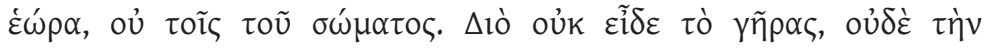

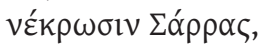

25 Cf. In Rom., V, PG 82, 201 C 11-D 5 (V, 27). This reading is confirmed by the commentary in Theodoret, In Isaiam, XIV, SC 315, 40. There is a similar remark in Didymus the Blind (?), De Trinitate, I.15.3 (J. Honscheid, ed. and trans., Didymus der Blinde, De trinitate, Buch I. Beiträge zur klassischen Philologie 44. Meisenheim am Glan: Hain, 1975, 47).

${ }^{26}$ E.g. 2 Corinthians 5:10. Origen, Com. in Rom., IX, 41, 7, SC 555, 232-5.

27 Similar comments to those of Theodoret may be found in Chrysostom about Romans 8:23 (John Chrysostom, Hom. in Rom., XIV, PG 60, 551.33-6); Romans 11:32 (Hom. in Rom., XIX, PG 60, 592.35-52); Romans 12:11 (Hom. in Rom., XXI, PG 60, 605.52-6).

28 John Chrysostom, Hom. in Rom., XIII, PG 60, 513.8-12; Theodoret, In Rom., III, PG 82, 129 B 9-11 (III, 37: Rom. 8:5). See Metzger, A Textual Commentary, 515.

29 Cf. John Chrysostom, Hom. in Rom., II, PG 60, 408.60-409.14. 
Can you see how he left behind what was seen, how he did not look at old age? However it was in front of his eyes! But he looked with the eyes of faith, not with the eyes of the body. That is why he did not look at his old age or at the decrepitude of Sarah. ${ }^{30}$

Conversely, the insertion of ropveía ('immorality') at the beginning of the list of vices in Romans 1:29 is implied by the commentary of Theodoret, who explains each term of the list. ${ }^{31}$ According to the quotation of the verse to be found in his homily, Chrysostom does not have this Byzantine addition in his text, but his comment does not allow us to confirm the absence of the term.

A further scenario would be that the comments imply a different text. We found no example of this.

The overall similarity between the form of Romans in the two authors is obvious. With regard to particular details of the text, we are rarely able to affirm the existence of a common reading, but we nevertheless do not find any evidence for divergence. From what has been seen above it is plain that the few readings attested to by each commentary always correspond to the Byzantine text. Nothing therefore prevents us from assuming that they both had a similar text, as their historical and geographical proximity suggests.

\section{CONCLUSION}

The investigation of Theodoret's commentary on Romans allows us to confirm that his biblical text has Byzantine features, similar to those found in Chrysostom. However, indications of his biblical affiliation are few and far between, and it is possible that this impression has been accentuated by the rearrangement of the biblical lemma by later copyists where no particular reading is implied in the commentary. Indeed, we found clear evidence of this practice in the manuscript tradition of this text, with the replacement of the biblical lemmata in Paris, BnF, Supplément gr. 1299 (GA 2242). We also found evidence in the variant readings among the earliest surviving manuscripts of this commentary. If this happened at an

30 John Chrysostom, In illud: Hoc scitote quod in nonissimis diebus, PG 56, 272.37-

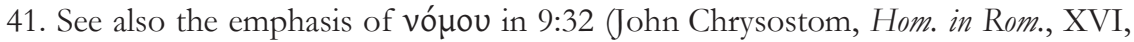
$P G$ 60, 564.5-7), of $\pi \tilde{\alpha} \varsigma$ in 9:33 (Hom. in Rom., XVI, PG 60, 564.11-17), and the

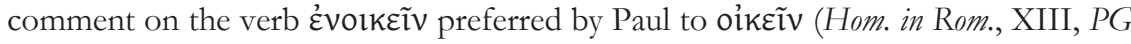
60, 520.30-2).

31 Theodoret, In Rom., I, PG 82, 65 B 7-9 (I, 28). 
earlier stage in the textual tradition as well, which is probable, the text of Romans known to Theodoret may have been different from what we see in the lemmata.

This study has made us aware of the importance of the exegetical practice of Theodoret in this commentary. It is necessary to know the habits of the author in order to evaluate the extent to which an apparent indication of his biblical text is reliable. The difficulties encountered by the present author suggest the magnitude of the task for examining patristic evidence for the Editio critica maior.

Further, the lack of text-critical remarks in this commentary encourages one to wonder whether Theodoret had read Origen's commentary. However, Theodoret's autonomy with regard to the textual remarks of Origen has already been demonstrated. ${ }^{32}$ Perhaps this issue did not seem important to him. It is our good fortune that some points upon which he focussed his attention for the purposes of his explanation allow us to locate his text with regard to the broader textual tradition of the Pauline Epistles.

32 J.-N. Guinot, 'La fortune des Hexaples d'Origène aux IVe et Ve siècles en milieu antiochien' in J.-N. Guinot, Théodoret de Cyr, exégète et théologien. I. Le dernier grand exégète, Paris: Cerf, 2012, 431-44. 


\title{
9. BETHANIA, BETHARA, OR BETHABARA: FORTUNATIANUS OF AQUILEIA AND ORIGEN'S COMMENTARY ON JOHN, WITH PARTICULAR REFERENCE TO JOHN 1:28
}

\author{
LUKAS J. DORFBAUER
}

The primary aim of the present article is simply to make known a 'new' patristic text dealing with the exegesis of John 1:28. It is found in the Commentary on the Gospels which was written by bishop Fortunatianus of Aquileia in the middle of the fourth century; this work has traditionally been thought to be lost, until a (nearly) complete manuscript copy was discovered in $2012 .{ }^{1}$ The relevant passage of Fortunatianus' commentary is an important witness for the reception of both the interpretation of John 1:28 and an emendation of the biblical text proposed by Origen. In what follows I will first address a crucial problem regarding the constitution of the text of both writers; then, I will compare and discuss them with regard to contents; finally, I will present some further cases of possible dependence on Origen's Commentary on John by Fortunatianus. It is hoped that the present contribution will encourage interest in and further research on Fortunatianus and his gospel commentary.

${ }^{1}$ Cf. L.J. Dorfbauer, 'Der Evangelienkommentar des Bischofs Fortunatian von Aquileia (Mitte 4. Jh.): Ein Neufund auf dem Gebiet der patristischen Literatur' Wiener Studien 126 (2013) 177-98. For what is known about the life of Fortunatianus, see L.J. Dorfbauer, 'Zur Biographie des Bischofs Fortunatian von Aquileia' ZAC 17 (2013) 395-423. I am currently preparing a critical edition of Fortunatianus' commentary for the CSEL series. 


\section{The Place Name in John 1:28}

In a famous attempt to emend the biblical text, Origen, in his Commentary on John (6.40.204-7), explains why the place name 'Bethania' mentioned in John 1:28, although found in nearly all the witnesses known to him, cannot be correct: ${ }^{2}$

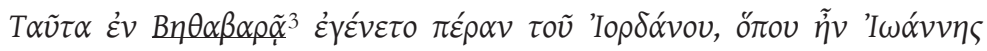
$\beta \alpha \pi \tau i ́ \zeta \omega v$. [204] "O

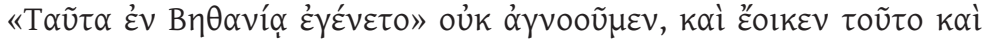

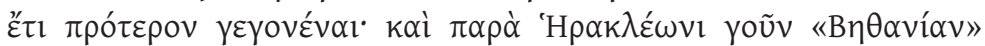

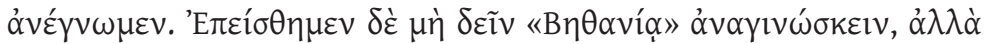

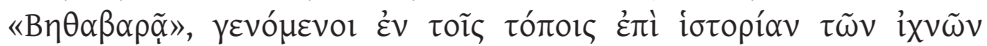

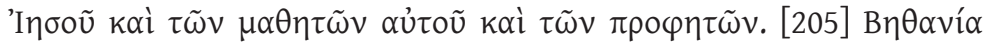

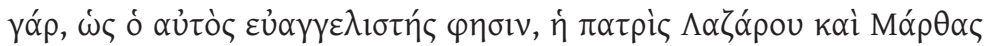

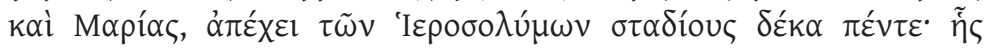

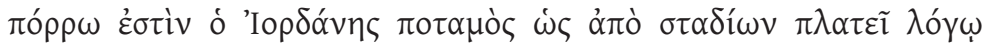

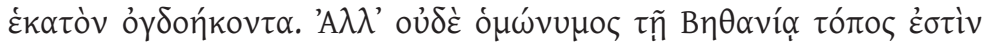

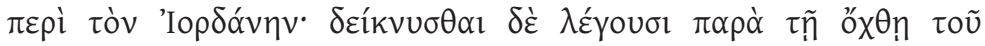

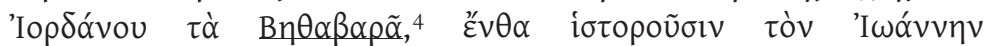

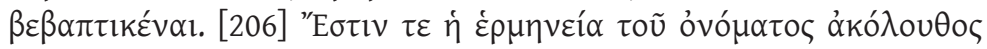

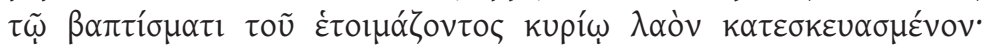

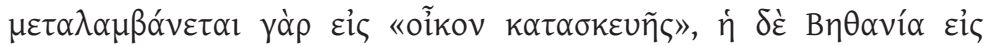

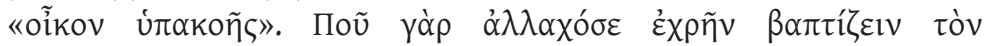

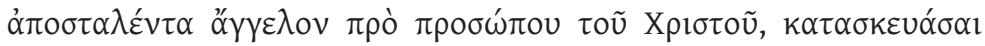

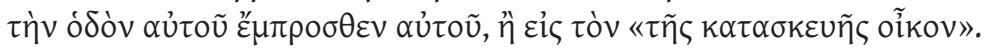

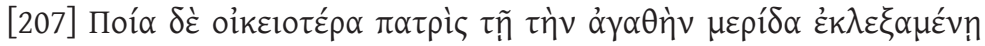

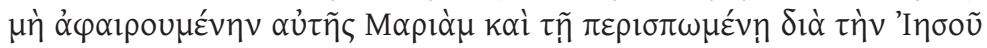

${ }^{2}$ For the Greek text I use the critical edition by E. Preuschen, Origenes Werke 4: Der Johanneskommentar. GCS 10. Leipzig: Hinrichs, 1903, as well as C. Blanc, Origène. Commentaire sur Saint Jean. SC 120, 157, 222, 290, 385. Paris: Cerf, 1966-92, who offers a French translation and useful notes. I have also checked the relevant portions of text in the one authoritative manuscript $M$ (see below), a digital reproduction of which can be found online via:

http://daten.digitale-sammlungen.de/ db/0004/bsb00046889/images/ (last accessed 28.5.2015). The English translations I give are my own, but I have gratefully used R.E. Heine, Origen. Commentary on the Gospel according to John. 2 vols. Washington DC: CUA, 1989-93.

${ }^{3} \mathrm{~B} \eta \theta \alpha \beta \alpha \rho \tilde{\alpha}$ scripserunt editores nonnulli : $\mathrm{B} \eta \theta \alpha \rho \tilde{\alpha} M$.

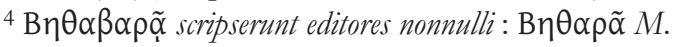




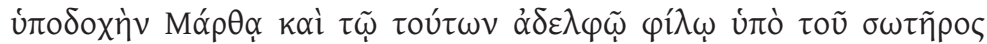

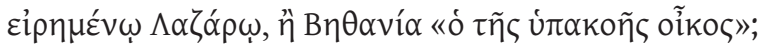

'This happened in Bethabara on the other side of the Jordan, where John was baptizing.' [204] We are not unaware that in nearly all the manuscript copies one reads 'This happened in Bethania', and it seems that this reading is quite old; and, to be sure, we have read 'Bethania' in Heracleon too. But since we have been in the places in search of the footprints of Jesus, his disciples, and the prophets, we have convinced ourselves that one ought not to read 'Bethania', but 'Bethabara'. [205] For Bethania, as the same evangelist says, the home of Lazarus, Martha, and Maria (cf. John 11:1), is 15 stades from Jerusalem (cf. John 11:18); and the river Jordan is about 180 stades distant from Bethania. Also, there is no place with the same name as Bethania around the Jordan. But they say that Bethabara presents itself around the bank of the Jordan, and there-so they report—John was baptizing. [206] The meaning of the name is also appropriate for the baptism of a person making ready a people prepared for the Lord, for it is translated 'house of preparation'; and Bethania is translated 'house of obedience'. Where else would it have been necessary to baptize for the angel sent before the face of Christ in order to prepare his way before him, if not in the 'house of preparation'? [207] And what kind of home could have been more suitable for Mary, who chose the good part which shall not be taken from her (cf. Luke 10:42), and for Martha, who busied herself with the accomodation of Jesus (cf. Luke 10:41), and for their brother Lazarus, who is said to be a friend of the Savior (cf. John 11:11), than Bethania, the 'house of obedience?'

Origen wants the reading 'Bethania', which is found in nearly all the manuscript copies', as he says, to be abandoned, but there is a textual problem as to his replacement for that reading. Our text of the Commentary on John is ultimately based on a single manuscript, München (Munich), BSB, cod. Graec. 191 (s. XIII') = M; all other known manuscripts containing the commentary depend directly or indirectly on $M$ and are therefore of very limited value regarding the constitution of the text. ${ }^{5}$ The reading 'Bethabara', printed throughout in the main text above, is only ambiguously

${ }^{5}$ Cf. Preuschen, Der Johanneskommentar, ix-xx (description of $M$ ) and xxxiv-lxi (on the stemmatical position of $M$ ). A modern description of $M$ is provided by $\mathrm{K}$. Hajdú, Katalog der griechischen Handschriften der Bayerischen Staatsbibliothek. München 4: Codices Graeci Monacenses 181-265. Wiesbaden: Harrassowitz, 2012, 64-7. 
supported by $M$ : in the relevant section of the manuscript, it appears once (in section 204 of the commentary), whereas we find 'Bethara' two times (in the introductory lemma as well as in section 205). Since Origen cannot possibly have written alternately 'Bethara' and 'Bethabara', one reading must be regarded as erroneous and therefore be emended. The Alexandrian exegete mentions the place name in question three more times in the extant text of his commentary: in these passages, $M$ offers the reading 'Bethara' two times (6.45.237; 13.64.455) and 'Betharaba' [sic!] once (6.42.221). Taking into account this evidence, the natural assumption would be that Origen is more likely to have written 'Bethara', which occurs four times in $M$, and that the readings 'Bethabara' and 'Betharaba', which both occur only once, are to be regarded as errors.

However, Ambrogio Ferrari (Ambrosius Ferrarius), in his Latin translation of Origen's text made in 1551, which was actually the first edition of the Commentary on John to appear in print, printed 'Bethabara' throughout, apart from 13.64.455 where he printed 'Bethara', without stating his reasons for doing so. ${ }^{6}$ Pierre Daniel Huet, who in 1668 was the first to publish the original Greek text, printed sometimes 'Bethara', sometimes 'Bethabara', and in 13.64.455 'Bathara' [sic!]; opposite the Greek text he printed the Latin translation produced by Ferrari which constantly reads 'Bethabara' (apart from 'Bethara' in 13.64.455), and in his accompanying 'Notes' he argued that 'Bethabara' was in fact the true reading, because it is found in some manuscripts of the Greek text of John, and because only 'Bethabara' would account for the Hebrew etymology as adduced by Origen. ${ }^{7}$ Huet's confusing way of dealing with the textual

6 Origenis Adamantii in Euangelium Ioannis Explanationum tomi XXXII quos nunc primum in latinum vertit Ambrosius Ferrarius Mediolanensis Monachus Cassinensis Vir doctissimus, [Venice] 1551. The section corresponding to 6.40.204-45.237 of Origen's commentary is found on fol. $71 \mathrm{v}-74 \mathrm{v}$, the section corresponding to 13.64.455 on fol. 148r. Ferrari did not know $M$; he worked with the first manuscript he managed to get hold of, which happened to be the oldest of M's descendants, Venice, BNM, cod. Graec. 43 (anno 1374); cf. Preuschen, Der Johanneskommentar, xxi-xxix (on the manuscript) and lvii-lviii (on Ferrarius). A modern description of this manuscript is provided by E. Mioni, Bibliothecae divi Marci Venetiarum codices Graeci manuscripti 1: Thesaurus antiquus. Codices 1-299, Rome: Istituto Poligrafico e Zecca dello Stato, 1981, 63-4.

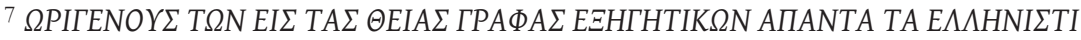
EYPISKOMENA. Origenis in sacras scripturas commentaria quaecunque Graece reperiri potuerunt ... pars posterior, Rothomagi [Rouen], 1668. The section corresponding to 
problem was adopted in the following edition of the Commentary on John, produced by Charles de la Rue und his nephew Charles Vincent de la Rue in 1759: in the main Greek text, the editors printed sometimes 'Bethara', sometimes 'Bethabara', and 'Bathara' in 13.64.455; Ferrari's Latin translation, constantly offering 'Bethabara' in book 6, but 'Bethara' in 13.64.455, was printed opposite the Greek text; a footnote was attached, taken almost verbatim from Huet's 'Notes' (see n. 7), which declares 'Bethabara' to be the true reading. ${ }^{8}$ Alan England Brooke, in the first edition of Origen's commentary to make use of $M$, obviously accepted Huet's arguments, when he invariably printed 'Bethabara' in the main text of the sixth book, recording 'Bethara' in the apparatus without comment; however, for some obscure reason he retained 'Bethara' in 13.64.455. ${ }^{9}$ With the edition produced by Erwin Preuschen, which now is regarded as standard, the reading 'Bethabara' definitely became the accepted one; the better attested 'Bethara' was ultimately banished into the apparatus throughout, and it was recorded that Huet made the decision in favour of 'Bethabara' with a view to biblical manuscripts as well as Hebrew etymology. ${ }^{10}$

Since Preuschen, scholarly discussion of Origen's remarks regarding the place name mentioned in John 1:28 has concentrated on the etymologies adduced by the Alexandrian exegete and, first and foremost, on

6.40.204-45.237 of Origen's commentary is found on 130-6, the section corresponding to 13.64 .455 on 260. Huet's 'Ad Origenis commentaria observationes et notae' are printed as an appendix to the edition with separate pagination; the relevant note is found on 102. For his edition Huet used the manuscript Paris, BnF, grec 455, a copy of $M$ dating from the sixteenth century; $c f$. Preuschen, Der Johanneskommentar, xxxii (on the manuscript) and lviii-lix (on Huet).

8 SPIГENOY $\Sigma$ TA EYPISKOMENA ПANTA. Origenis opera omnia quae Graece vel Latine exstant ... tomus quartus et ultimus, Paris, 1759 (reprinted in $P G$ 14, 10-830). The section corresponding to $6.40 .204-45.237$ of Origen's commentary is found on 140-4, the section corresponding to 13.64 .455 on 280. The De la Rues consulted, apart from Huet's edition, some manuscripts at random, which, however, all are ultimately dependent on $M$ and therefore of little value; cf. Preuschen, Der Johanneskommentar, lix.

9 A.E. Brooke, The Commentary of Origen on S. John's Gospel. 2 vols. Cambridge: CUP, 1896. The section corresponding to 6.40.204-45.237 of Origen's commentary is found in vol. 1, 157-164, the section corresponding to 13.64.455 in vol. $1,327$.

10 Preuschen, Der Johanneskommentar. The section corresponding to 6.40 .204 45.237 of Origen's commentary is found on $149-55$, the section corresponding to 13.64.455 on 297. 
geographical problems, whereas the basic question whether Origen wrote 'Bethara' or 'Bethabara' is hardly seen at all. ${ }^{11}$ However, the newly found Commentary on the Gospels by bishop Fortunatianus of Aquileia sounds a note of caution. The main exegetical part of this work consists of three sections dedicated to the interpretation of selected portions of the Gospels according to Matthew, Luke, and John. ${ }^{12}$ The section on Matthew comprises 129 chapters, which cover almost the whole Gospel; the section on Luke comprises 13 chapters, corresponding to the modern Luke 2:15:14; the section on John comprises 18 chapters, corresponding to the modern John 1:1-2:11. It is Chapter 13 of the section on John that is of importance for the present study: ${ }^{13}$

[13] 'Haec in Bethania facta sunt trans Iordanem, ubi erat Iohannis baptizans, et cetera.' Hic ergo error aut interpretis in Latinum invenitur aut scriptorum: ceterum Bethania locus est, ubi Maria et Martha et Lazarus erant; trans Iordanen autem locus $\underline{B e t h a r a}^{14}$ dicitur, quod interpretatur 'domus praeparationis'. Bethania autem 'domus auditionis', 15 et merito domus auditionis, ubi Maria ad pedes Iesu sedens, id est audiens, et lacrimis pedes Iesu lavabat. Nam ${ }^{16}$ Bethara $^{17}$ 'domus praeparationis': ibi enim praeparabat Iohannis adventum domino populum baptismo paenitentiae purgans. Bethania autem domus auditionis, ${ }^{18}$ ut, qui fuerant praeparati domino, ipsum audirent, in domo scilicet auditionis, ${ }^{19}$ quod est ecclesia dei, in qua praecepta eius omnibus praeparatis ad salutem ingeruntur atque insinuantur.

[13] 'This happened in Bethania on the other side of the Jordan, where John was baptizing, et cetera.' Here one finds a mistake, committed

11 A rich bibliography can be found in S. Timm, Eusebius und die Heilige Scbrift. Die Schriftvorlagen des Onomastikons der biblischen Ortsnamen. TU 166. Berlin: de Gruyter, 2010, 515-6, n. 45.

${ }^{12}$ For an overview of the structure and contents of Fortunatianus' commentary cf. Dorfbauer, 'Der Evangelienkommentar', 179-87.

${ }^{13}$ I quote the Latin text of Fortunatianus according to a provisional version of my forthcoming edition. A digital reproduction of $K$ (see below), can be found online via http://www.ceec.uni-koeln.de/ (last accessed 28.5.2015). The English translation I give is my own.

${ }^{14}$ Bethara scripsi : Betthara $K$

${ }^{15}$ Bethania autem domus auditionis $K$ : Bethania domus oboedicionis exp.

16 et merito ... nam omittit exp.

${ }^{17}$ Bethara exp. : Bethania $K$ : Bethabara coniecit D. Brearley

${ }^{18}$ purgans .... auditionis $K$ : populum venienti deo exp.

19 scilicet auditionis $K$ : oboeditionis $\exp$. 
either by the translator into Latin or by the scribes, because Bethania is the place where Mary and Martha and Lazarus were living (cf. John 11:1); but the place on the other side of the Jordan is called Bethara, which is translated 'house of preparation'. Bethania, in contrast, is translated 'house of listening', and rightly house of listening, where Mary was sitting at Jesus' feet, that is: she was listening to him, and wiped Jesus' feet with her tears (cf. John 12:3 + Luke 7:38; 10:39). Now, Bethara means 'house of preparation': for it was there that John was preparing the coming of the Lord by purifying the people through the baptism of repentance. But Bethania means 'house of listening', so that those who have been prepared for the Lord might listen to him, of course in the house of listening, which is the church of God, in which his commandments are conveyed to and inculcated in everyone prepared for salvation.

Some words are necessary on the constitution of the text. The most important witness for Fortunatianus' commentary is Köln (Cologne), Erzbischöfliche Dom- und Diözesanbibliothek, cod. 17 (s. IX $\left.{ }^{1 / 3}\right)=K$, which goes back to an exemplar from late antiquity by only a few intermediate copies; unfortunately, its text abounds with scribal errors of every kind. ${ }^{20}$ The latter part of the passage in question, consisting of parts of the last three sentences (Bethania domus oboedicionis to ad salutem ingeruntur) is also present in an exegetical compilation which is found, under the title Expositio Iohannis iuxta Hieronimum, on fol. 30r-44v of Angers, BM, 275 (s. $\left.\mathrm{IX}^{1 / 3}\right)=$ exp. This compilation is, on the one hand, an important witness to Fortunatianus' text because it was created from a manuscript independent of $K$, and therefore preserves true readings against $K$ in many places; on the other hand, exp. has to be used with caution, because its compiler constantly cut down and deliberately reshaped the text he took from his sources. ${ }^{21}$

20 Cf. L. J. Dorfbauer, 'Der Codex Köln, Erzbischöfliche Diözesan- und Dombibl. 17. Ein Beitrag zur Überlieferung des Evangelienkommentars des Bischofs Fortunatian von Aquileia' in Mittelalterliche Handschriften der Kölner Dombibliothek. Fünftes Symposion am 30. November und 1. Dezember 2012, ed. H. Finger \& H. Horst, Cologne: Dombibliothek, 2014, 21-68.

21 The Expositio Iohannis iuxta Hieronimum was published by D. Brearley, 'The Expositio Iohannis in Angers BM 275. A commentary on the Gospel of St John showing Irish influence.' Recherches augustiniennes 22 (1987) 151-221. For the importance of this witness regarding the constitution of Fortunatianus' text, cf. L. J. Dorfbauer, 'Neue Zeugnisse für die Überlieferung und Rezeption des Evangelienkommentars des Bischofs Fortunatian von Aquileia' in Edition und 
One need not worry about the transmitted 'Betthara' on the first occurrence of this word, which I have changed to 'Bethara', because the scribes of $K$ write 'th' and 'tth' indiscriminately in the middle of words. ${ }^{22}$ Some more explanation is necessary for the second occurrence of 'Bethara': this is found in exp., whereas $K$ reads 'Bethania'. The latter reading leads to a contradictory and therefore nonsensical text, offering a second, differing interpretation of 'Bethania' which would, moreover, coincide with the interpretation of 'Bethara' given before. ${ }^{23}$ We must therefore assume that the scribe of $K$ made a mistake in writing down the much more familiar 'Bethania' again, instead of the correct, but unfamiliar 'Bethara', which has been preserved in exp. ${ }^{24}$ All in all, there cannot be any doubt that what Fortunatianus wrote in both instances was 'Bethara'. So this new, indirect witness for Origen's text unambiguously corroborates the reading 'Bethara', which is the better attested one in $M$, but has been abandoned by editors.

Yet this does not strictly prove that Origen actually wrote 'Bethara'. In fact, the arguments brought forward in favour of 'Bethabara' remain strong. First among these is the Hebrew etymology as adduced by the Alexandrian exegete, which, admittedly, is controversial. ${ }^{25}$ Then, there is the

Erforschung lateinischer patristischer Texte. 150 Jabre CSEL, ed. V. Zimmerl-Panagl, L. J. Dorfbauer \& C. Weidmann, Berlin: de Gruyter, 2014, 17-40 (especially 21-5).

22 To give just one example, we find the name of the Evangelist Matthew in $K$ written as 'Matheus' 19 times, and written as 'Mattheus' 15 times.

${ }^{23}$ The text would run as follows: ' (...) Bethara, which is translated 'house of preparation'. Bethania, in contrast, is translated 'house of listening' (...) Now, Bethania means 'house of preparation'.'

${ }^{24}$ Note that Brearley, Expositio Iohannis iuxta Hieronimum, 165, emends 'Bethara' to 'Bethabara' without stating his reasons for doing so. It seems clear that he was following the main text of a modern edition of Origen's Commentary on John without considering the actual text offered by $M$.

${ }^{25}$ See the notes in Blanc, Origène. Commentaire sur Saint Jean, vol. 2, 284-7, the literature mentioned in Timm, Eusebius und die Heilige Schrift, 515-6 n. 45 and, to give one recent example, J. M. Hutton, 'Topography, Biblical Traditions, and Reflections on John's Baptism of Jesus' in Jesus Research: New Methodologies and Perceptions, ed. J.H. Charlesworth, B. Rhea and P. Pokorný. Grand Rapids: Eerdmans, 2014, 149-77 (153-4). The only modern scholar ready to accept the reading 'Bethara' for linguistic reasons seems to have been A. Merx, Das Evangelium des Johannes nach der syrischen im Sinaikloster gefundenen Palimpsesthandschrift. Berlin: Reimer, 1911, 43. He was contradicted by W. Wiefel, 'Bethabara jenseits des Jordan (Joh. 1,28)' Zeitschrift des Deutschen Palästina-Vereins 83 (1967) 72-81 (73, note 11), whose report on the readings offered by the manuscripts and editions is, however, 
transmission of the biblical text, because some Greek, Syriac, and Sahidic manuscripts in fact offer 'Bethabara' (or orthographical variants like 'Bethebara' etc.) in John 1:28, but no biblical manuscript, as far as we know, offers 'Bethara' ${ }^{26}$ Finally, there are some other early patristic writers who refer to Origen's exegesis of John 1:28 and thus also serve as indirect witnesses to his text, and their testimony unanimously corroborates the reading 'Bethabara': The one authoritative manuscript of Eusebius' Onomastikon, a work originally composed around 330, reads $B \eta \theta \alpha \alpha \beta \alpha \rho \alpha$, and this seems normally to have been rendered as 'Bethabara' in Latin, to judge from the manuscripts transmitting Jerome's translation of the dictionary (c.390); ${ }^{27}$ the two manuscripts of importance preserving the relevant passage of Epiphanius' Panarion (51.13.1), a work originally

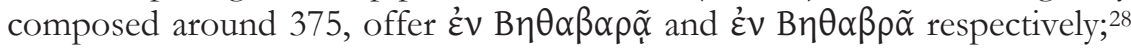
and John Chrysostom, in one of his Homilies on the Gospel according to John (17.1), which have been dated variously between 388 and 395, apparently

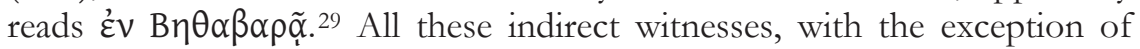
Eusebius, are somewhat later than Fortunatianus.

What are we to make of this evidence? I leave the problem of the Hebrew etymology to those competent to judge, and concentrate on the

inaccurate. R.G. Clapp, 'A Study of the Place-names Gergesa and Bethabara' JBL 26 (1907) 62-83 (78-81) argued on exegetical, geographical and linguistic grounds that Origen could have written 'Bethbara', which subsequently would have been corrupted to 'Bethara', 'Bethabara', and 'Betharaba' in the manuscript transmission.

26 See the apparatus in NA28; it is also not attested in the manuscripts selected for the Editio Critica Maior of John, although only the initial letters of this word are extant in $\mathbb{Z} 5$ and 755 . The occurrence of 'Bethabara' in biblical manuscripts does not necessarily mean that it is a variant reading for 'Bethania' older than Origen; it seems far more probable that the manuscripts in question have been influenced by knowledge of Origen's exegesis (as shown, perhaps, by the inclusion of 'Bethabara' as an alternative reading in GA 892).

27 Cf. the critical edition by E. Klostermann, Eusebius Werke 3/1: Das Onomastikon der biblischen Ortsnamen, Leipzig: Hinrichs, 1904, 58-9. Timm, Eusebius

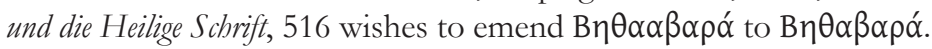

${ }^{28}$ Cf. the critical edition by K. Holl, Epiphanius 2: Panarion haer. 34-64, Leipzig: Hinrichs, 1922, 265.

29 'Apparently', because we still have to rely on the uncritical text printed in $P G$ 59.107. For the date of the Homilies, see the table given in W. Mayer, The Homilies of St John Chrysostom - Provenance. Reshaping the Foundations. OCA 273. Rome: Pontificium Institutum Orientalium Studiorum, 2005, 267 (CPG 4425). Clapp, 'A Study of the Place-names', 81, mentions some later Greek writers whom he says are dependent on John Chrysostom for the reading 'Bethabara'. 
information given by the manuscripts: Since the reading 'Bethabara' is attested - albeit scantily — in the direct tradition represented by $M$ andmuch better - in the indirect tradition represented by biblical manuscripts, by Eusebius (and his translator Jerome), Epiphanius, and John Chrysostom, it most probably is to be accepted as true, i.e. as what Origen actually wrote. But since the reading 'Bethara' is so well attested, both in $M$ and in Fortunatianus, I think it can hardly be regarded as an error commited independently by two medieval scribes, one working in the Greek East, the other in the Latin West. More probably, it is a very old error, going back already to the manuscript transmission of the Commentary on Jobn in the late third century: Fortunatianus_-or, rather, his immediate source (see below) —is likely to have read 'Bethara' in a manuscript of Origen's work, and, unable to confirm its linguistic soundness, adopted it. In fact, we may expect any ancient reader of Origen without knowledge of Hebrew to have accepted 'Bethara' (just as well as 'Bethabara', 'Betharaba' etc.) as a perfectly possible reading. So, if Fortunatianus found 'Bethara' written in his source and readily adopted it because he had no reason to doubt its validity, we have to abstain from emending the transmitted 'Bethara' to 'Bethabara' in his text, even if 'Bethabara' actually seems to be the true reading in Origen.

\section{ForTunATIANUS, ORIGEN AND THE EXEGESIS OF JOHN 1:28}

I now turn to questions regarding sources and content. First, there can be no doubt that Fortunatianus is dependent, directly or indirectly, on Origen rather than a hypothetical common source. Whatever lies behind Origen's assertion to 'have been in the places in search of the footprints of Jesus, his disciples, and the prophets' (Commentary on John 6.40.204), it seems clear that he is bringing forward his own exegesis of John 1:28, not one originally proposed by someone else; also, it has never been seriously doubted that later writers like Eusebius, when speaking of 'Bethabara' with regard to John 1:28, are dependent on Origen, even though they do not mention his name. As a matter of fact, Fortunatianus not only depends on Origen, he even conforms more closely to his interpretation than Eusebius, Epiphanius, or John Chrysostom do. ${ }^{30}$ Like Origen, he emphasises the fact that the place where Mary, Martha, and Lazarus were living was called

30 It is also to be noted that - with the exception of Jerome's translation of Eusebius' Onomastikon, which, however, is a special case of reception Fortunatianus is the only known ancient writer to take up Origen's discussion of 'Bethania' - 'Betharaba' in the Latin West. 
'Bethania'; and, like Origen, he refers to the etymology of 'Bethara'/ 'Bethabara' and says that a place named 'house of preparation' was the right one for John to prepare the coming of the Lord.

Furthermore, the bishop of Aquileia, like Origen, refers to the etymology of 'Bethania' and points to Mary's behaviour which he says was in accordance with the meaning of this place name, but he offers the translation 'house of listening' (domus auditionis) instead of Origen's 'house

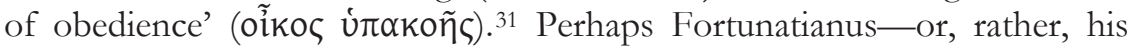
immediate source (see below) - deemed auditio to be an acceptable

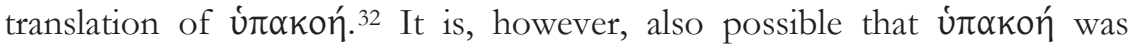
simply mistaken for ókoń by a slip of the eye, or that the manuscript of Origen's Commentary on John used by Fortunatianus-or, rather, by his immediate source-erroneously read ákoń instead of úrakoń.

In any case, due to the differing translation of 'Bethania', Fortunatianus exemplifies the interpretation of the name in a way different to that of Origen. The latter speaks of Mary 'who chose the good part which shall not be taken from her': he clearly has in mind Luke 10:42. Fortunatianus, on the other hand, speaks of Mary who 'was sitting at Jesus' feet, that is: she was listening to him, and wiped Jesus' feet with her tears': he seems to have combined John 12:3, where Mary is said to have poured perfume on Jesus' feet and to have wiped them with her hair, with Luke $7: 38$, where it is said that an unnamed woman brought perfume to Jesus, wetted his feet with her tears and wiped them with her hair. ${ }^{33}$ Luke 10:39,

31 As can be seen from the apparatus to the Fortunatianus passage printed above, the compiler of the Expositio Iohannis iuxta Hieronimum constantly replaced domus auditionis by domus oboeditionis, and he took pains to shorten and to reshape Fortunatianus' text, so that allusions to the notion of listening were eliminated. In doing so, he was, of course, not following Origen (whose Greek text was inaccessible - and would have been incomprehensible anyway - to a compiler working in the early medieval Latin West), but the Latin tradition after Fortunatianus: beginning with Ambrose, 'Bethania' is invariably interpreted as domus oboeditionis (or oboedientiae) in Latin patristic texts. The compiler of exp. was certainly familiar with this conventional interpretation and wanted to get rid of the unusual domus anditionis he found in his source.

32 TLL 2.1292 reports two instances of auditio in the sense of oboedientia (Tert. adv. Marc. 4.22; Cod. Theod. 8.4.26).

33 The conflation of Mary of Bethany with the unnamed woman from Luke 7:38 (as well as with Mary of Magdala) goes back to early Christian tradition. It cannot be totally ruled out, however, that there is something wrong with the 
where it is said that Mary was sitting at Jesus' feet and listening to what he was saying, clearly played a role for Fortunatianus too.

Both writers close their sections with quite long sentences dedicated to the interpretation of 'Bethania', the 'house of obedience/listening'. But whereas Origen confines himself to the biblical examples of Mary, Martha, and Lazarus, who all are shown to represent various ways of 'obeying' Jesus, Fortunatianus, in the end, gives an interpretation which establishes a sort of progression from 'Bethara', the 'house of preparation', to 'Bethania', the 'house of listening', by saying that 'those, who have [already] been prepared for the Lord, might [then] listen to him, of course in the house of listening, which is the Church of God, in which his commandments are conveyed to and inculcated in everyone prepared for salvation'. This is one of several passages of the Commentary on the Gospels in which the bishop of Aquileia seeks to explain the biblical account with a view to the contemporary church and its customs. ${ }^{34}$

It comes as no big surprise that Fortunatianus mentions neither Heracleon nor any attempts of his own to investigate the question of whether the place where John had been baptizing could possibly have been called 'Bethania', as Origen does. It is, however, very strange that the bishop of Aquileia wishes to blame, aside from the scribes, 'the translator into Latin' for potentially having introduced the wrong reading into the biblical text. This supposition makes no sense, because the whole debate concerning the place name was initiated by the Greek Origen who had been working with the Greek text of John: the underlying problem could not by any means have been caused by the translation of the Greek Gospel text into Latin, and one would expect Fortunatianus to know that-had he derived his information from direct knowledge of Origen's Commentary on John.

As things stand, I think the most plausible explanation is that Fortunatianus was not aware of the fact that this debate originated in a Greek environment; hence, he cannot have been working with Origen's text himself, but must have used an intermediary Latin source depending on Origen. I have argued elsewhere that Fortunatianus derived his knowledge of some allegorical interpretations of animals, which are brought forward in

transmitted text of Fortunatianus.

${ }^{34}$ Cf., for example, what Fortunatianus has to say on Matt. 11:11 (Sic etiam nunc in ecclesiae ordinationibus non debere aliquem per ambitionem ad locum accedere, sed qui fuerit electus...), or on Matt. 25:28 (Quod etiam nunc in ecclesia fit, ut, si forte quis inventus fuerit eius vitae, qui non mereatur sacrificiis vel mysteriis praeesse, auferatur ab eo talentum, id est praedicatio, et detur alii). 
a similar manner in the Physiologus and seem to go back ultimately to Origen, most probably from the lost Gospel commentary written by Victorinus of Poetovio. ${ }^{35}$ Victorinus is also likely to be the intermediate source who conveyed Origen's exegesis of John 1:28 to Fortunatianus. ${ }^{36}$

In any case, it seems probable that Fortunatianus' immediate source was not only a Latin text, but also a text offering a mere selection of Origen's interpretations. To corroborate this assumption one can point to some significant discrepancies between the two writers, the most striking of which, I think, is the following: Origen, after having discussed the subject of 'Bethania/Bethabara', seeks to give further examples of scribal errors which have garbled the biblical text, and he offers a discussion of why the name of the town in Matthew 8:28-34 should be 'Gergesa' rather than 'Gerasa' (6.41.208-11). Fortunatianus dedicates two chapters of his section on Matthew (cap. Mt. 39 and 40) to the Gospel passage in question, but he does not mention any uncertainty concerning the relevant place name. If he had first-hand knowledge of the full text of Origen's Commentary on John, why would he have stuck so closely to its discussion of 'Bethania/ Bethabara', but have altogether ignored the discussion of 'Gerasa/Gergesa' which follows immediately?

It is not easy to say why Fortunatianus did include the discussion of 'Bethania/Bethabara ('Bethara')' in his commentary at all. This is almost the only passage in the whole work to betray an interest in discussing a question of biblical textual criticism. ${ }^{37}$ In addition, since we possess no evidence that a Latin Gospel manuscript offering a variant reading to 'Bethania' in John 1:28 did ever exist, this might well be regarded as a pseudo-problem tackled by the bishop of Aquileia. ${ }^{38} \mathrm{I}$ believe we are correct to assume that

${ }^{35}$ L. J. Dorfbauer, 'Fortunatian von Aquileia, Origenes und die Datierung des Physiologus' Revue d'études augustiniennes et patristiques 59 (2013) 219-45.

36 See also M. Dulaey, Victorin de Poetovio. Premier exégète latin. 2 vols. Paris: Institut d'études augustiniennes, 1993, vol. 1, 323, and note 49 below.

37 One could also point to the well known controversy between Jews and Christians about the translation of Isaiah 7:14, on which Fortunatianus says (praef. 2): 'Ecce virgo in utero accipiet et pariet filium' et cetera. Hanc periocham, posteaquam septuaginta et duo interpretes Ptolomeo iubente segregati tamquam uno ore et sermone totam legem ex Hebreo in Grecum interpretassent, quidam ex Iudeis adulteratores et interpolatores scripturarum non 'virginem', sed 'invenculam' fecerunt. Quod enim signum facturus dominus diceretur, si invencula conciperet ex viro? Hoc naturae consuetudo est. Sed signum dominus repromittit, quia virgo parere baberet Emmanuelem, quod est 'Nobiscum deus'.

${ }^{38}$ Cf. P. H. Burton, H. A. G. Houghton et alii, Evangelium secundum Iohannem, vol. 
Fortunatianus was interested not so much in the textual problem of whether 'Bethania' or 'Bethara' should be read in John 1:28, but, first and foremost, in offering an interpretation of the Gospel passage in question which would extract an edifying meaning from it. Accordingly, we need not wonder at the fact that Fortunatianus, unlike Origen, opens his chapter with a quotation of the biblical lemma offering 'Bethania', even though he qualifies this reading as erroneous in the very first sentence of the interpretation proper.

Origen has always been regarded as the prime example of a biblical commentator combining theological interpretation and reasoning with a keen interest in philology and textual criticism. ${ }^{39}$ The same cannot be said of Fortunatianus: in his Commentary on the Gospels, the bishop of Aquileia certainly proves to be a committed pastor and a fighter for what he regards as the essentials of the Christian message; but he does not seem to have concerned himself much with philological problems regarding the biblical text.

\section{OTHER POSSIBLE MATERIAL FROM ORIGEN'S COMMENTARYON JOHN IN FORTUNATIANUS}

Although Chapter 13 of Fortunatianus' section dedicated to the exegesis of John is, in my opinion, the only part of his commentary for which dependence on Origen's Commentary on John is beyond all possible doubt, there are some other passages for which such a dependence seems conceivable, to varying degrees. ${ }^{40} \mathrm{I}$ have considered it convenient to assemble the relevant passages and to comment on each briefly. ${ }^{41}$

1 (Jo 1,1-4,48). Vetus Latina 19. Freiburg: Herder, 2011 ad loc.

${ }^{39}$ Cf., for example, B. Neuschäfer, Origenes als Philologe. Schweizerische Beiträge zur Altertumswissenschaft, 18/1-2. Basel: Reinhardt, 1987.

40 If Fortunatianus really is dependent on Origen's Commentary on John in any of these, I assume that this dependence is indirect, just as in the case of his exegesis of John 1:28.

${ }^{41}$ It is most unfortunate that the end of Book 6, Books 7-9, and the beginning of Book 10 of Origen's commentary, covering his exegesis of John 1:30-2:11, are lost, because Fortunatianus' exegesis of this section of John contains some of his most notable interpretations (e.g. the identification of the master of the banquet in John 2:8-10 with James, the 'Lord's brother' and alleged first bishop of Jerusalem), and it would be highly interesting to know if anything similar were to be found in Origen. I have not examined the supposed fragments from lost books of the Commentary on John which are ascribed to Origen in the catenae; for an assessment of their value, see R.E. Heine, 'Can the Catena Fragments of Origen's Commentary 
When Fortunatianus, in his preface to the section dedicated to the exegesis of John, identifies John the Evangelist with the disciple of the same name and speaks about the importance of the Gospel, he might be echoing a passage from Origen's first book which briefly treats the same subject; unfortunately, this part of Origen's work has suffered seriously from the loss of text:

\begin{tabular}{|c|c|}
\hline Fortun. pr. Io. & Orig. comm. Io. 1.4.22-23 \\
\hline $\begin{array}{l}\text { Ipse est, qui super pectus domini } \\
\text { recumbebat (...) Huic et Mariam } \\
\text { matrem et ipsum Mariae filium } \\
\text { tradidit (...) Nam super pectus } \\
\text { recumbere Iesu, boc est secreta } \\
\text { mysteria et omnia arcana nosse. }\end{array}$ & 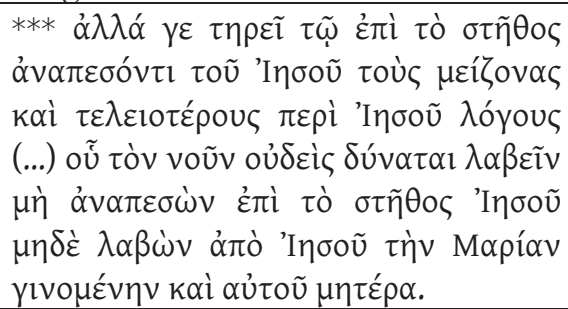 \\
\hline $\begin{array}{l}\text { It is he [ohn the Evangelist] who } \\
\text { was leaning against the breast of } \\
\text { the Lord ... to him he [Jesus] } \\
\text { recommended Mary as a mother, } \\
\text { and him to her as a son ... } \\
\text { leaning against the breast of Jesus } \\
\text { means knowing about the secret } \\
\text { mysteries and about all things } \\
\text { arcane. }\end{array}$ & $\begin{array}{l}\text { *** but preserves for the one leaning } \\
\text { against the breast of Jesus the greatest } \\
\text { and most perfect words about Jesus... } \\
\text { whose [John's] meaning no one is able } \\
\text { to comprehend, if he has not been } \\
\text { leaning against the breast of Jesus and if } \\
\text { he has not received Mary from Jesus to } \\
\text { become his mother too. }\end{array}$ \\
\hline
\end{tabular}

This parallel appears to be even more notable because Origen, right before this passage, compares the beginnings of the Gospels according to Matthew, Mark, and Luke in a similar way as Fortunatianus does in the opening of the general preface to his commentary. ${ }^{42}$ What is more, immediately after this passage Origen speaks approvingly of the 'sane opinion' of those who say that Mary had no other child than Jesus, an idea which is qualified by Fortunatianus in a very similar manner, when he speaks of the same subject. ${ }^{43}$ In addition, Origen returns to the meaning of the words 'leaning against the breast of Jesus' (cf. John 13:23) in Book 32;

on John be trusted?' VC 40 (1986) 118-34.

42 So it seems, although there is a gap in the transmitted text of Origen concerning Luke.

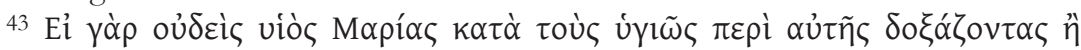

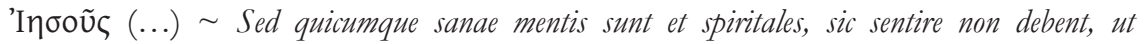
potuisset Ioseph vir iustus ... Mariam contingere. 
there again, he identifies John the Evangelist with the disciple loved by Jesus who was leaning against his breast. ${ }^{44} \mathrm{He}$ also explains the relevant verse in a similar way to Fortunatianus. ${ }^{45}$

When Fortunatianus, in interpreting John 1:3 ('Through him all things were made; without him nothing was made that has been made'), explains that the word 'nothing' refers to idols and to sin, which are made by man, not by god, this might well be ultimately derived from Origen's exegesis of the same verse:

\begin{tabular}{|c|c|}
\hline Fortun. cap. Io. 2 & Orig. comm. Io. 2.13.92-3 \\
\hline $\begin{array}{l}\text { 'Sine ipso factum est nibil': Idola scilicet } \\
\text { significat, quae non deo auctore in mundo } \\
\text { constituta videntur, sed errore humano et } \\
\text { vanissima adinventione instituta. (...) } \\
\text { Sed et peccatum, quia non per ipsum } \\
\text { factum est, nibil est. }\end{array}$ & 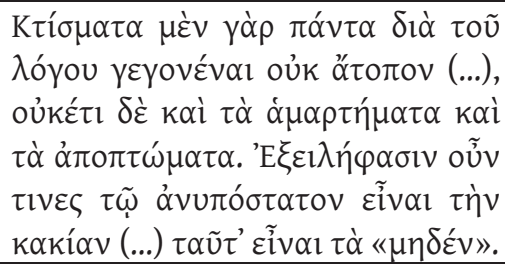 \\
\hline $\begin{array}{l}\text { "Without him nothing was made". This } \\
\text { naturally points to idols which appear } \\
\text { in the world as not having been made } \\
\text { by God, but as having been introduced } \\
\text { by human error and most idle invention } \\
\text { (...) Also, sin is nothing, because it was } \\
\text { not made through Him. }\end{array}$ & $\begin{array}{l}\text { It is not absurd that all creatures } \\
\text { have been made through the Word } \\
(\ldots) \text {, but this is not also the case as } \\
\text { for sins and aberrations. Therefore, } \\
\text { some say that these things are } \\
\text { "nothing", because evil is of no } \\
\text { existence proper. }\end{array}$ \\
\hline
\end{tabular}

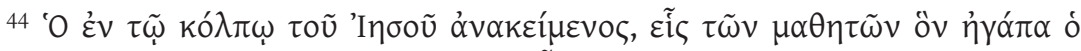
'I the breast of Jesus, the one of the disciples whom Jesus loved, seems to be John, the author of the Gospel'; 32.20.260).

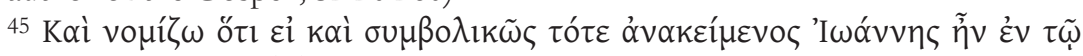

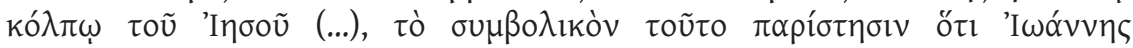

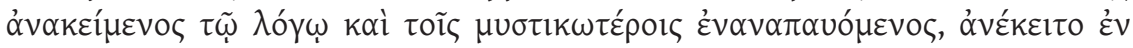

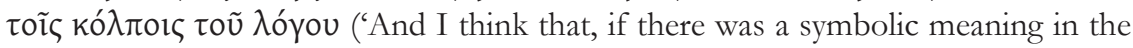
fact that John was leaning against the breast of Jesus [...], this symbol proves that John, reclining in the Word and having a rest in the most important mysteries, rested at the heart of the Word'; 32.20.264). As Blanc, Origène. Commentaire sur Saint Jean vol. 5, 300 demonstrates in her note ad loc., this is an interpretation found in many of Origen's works. 
In any case, it comes as no surprise that in Fortunatianus there is no trace to be found of the allusions to the opinions of Greek philosophers regarding the problem of evil and non-existence which follow in Origen.

When Fortunatianus in interpreting Mark 13:32 ('But about that day or hour no one knows, not even the angels in heaven, nor the Son, but only the Father') asserts that Jesus by his words encourages us to pray in order that he might fulfil our desires, this could ultimately be derived from Origen's assumption that no one obtains a divine gift without explicitly asking for it:

\begin{tabular}{|c|c|}
\hline Fortun. cap. Mt. 110 & Orig. comm. Io. 13.1.3-5 \\
\hline $\begin{array}{l}\text { Superest, ut se nescire dicat, non quia ne- } \\
\text { sciat, sed ut frequenti petitione admonitus } \\
\text { demonstret (...) docet perseverantiam in } \\
\text { petendo et orationem infatigabilem, ut, quod } \\
\text { petitur, concedat et tribuat. }\end{array}$ & 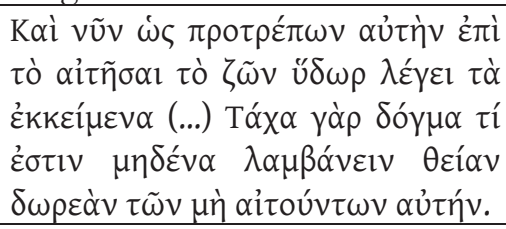 \\
\hline $\begin{array}{l}\text { It remains to say that he claims not to } \\
\text { know it, not because he does not know } \\
\text { it, but in order that he may reveal it, if he } \\
\text { is asked again and again ... he teaches } \\
\text { persistence in asking and indefatigable } \\
\text { prayer, so that he concedes and grants } \\
\text { what he is asked for. }\end{array}$ & $\begin{array}{l}\text { Now, he says to her what we have } \\
\text { quoted, as if he encourages her to } \\
\text { ask for the living water ... Perhaps } \\
\text { there is a kind of command that no } \\
\text { one receives a divine gift without } \\
\text { asking for it. }\end{array}$ \\
\hline
\end{tabular}

However, since Origen's words occur in the context of his interpretation of John 4:10-14, a passage which has little in common with Mark 13:32, the possibility of dependence appears to be slight at best.

When Fortunatianus, on the occasion of commenting on Matthew 12:39, gives a brief explanation of the first part of John 8:44 ('You belong to your father, the devil, and you want to carry out your father's desires'), he says very much the same as Origen: 


\begin{tabular}{|c|c|}
\hline Fortun. cap. Mt. 66 & Orig. comm. Io. 20.23.19346 \\
\hline $\begin{array}{l}\text { Sicut enim qui voluntatem } \\
\text { patris dei facit, filius dei dicitur, } \\
\text { sic qui voluntati Satanae } \\
\text { famulatur, filius eius appellatur. }\end{array}$ & 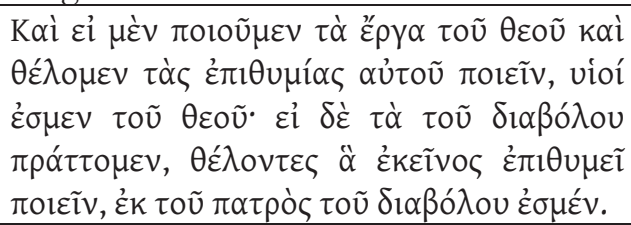 \\
\hline $\begin{array}{l}\text { For just as one, who } \\
\text { accomplishes the will of God } \\
\text { the Father, is called a son of } \\
\text { God, so one, who serves the } \\
\text { will of Satan, is called the } \\
\text { latter's son. }\end{array}$ & $\begin{array}{l}\text { If we accomplish the works of God and } \\
\text { desire to accomplish his wishes, we are sons } \\
\text { of God; but if we perform the works of the } \\
\text { devil, desiring to accomplish what he wishes, } \\
\text { we are of this father, the devil. }\end{array}$ \\
\hline
\end{tabular}

Of course, it must be admitted that this idea does not appear to be particularly uncommon.

Finally, there are some notable parallels between one of two interpretations of the account of Jesus' entry into Jerusalem, as told in Matthew 21:1-11, which Origen proposes in the tenth book of his Commentary on John (10.28.174-30.190), and two chapters in Fortunatianus' section dedicated to the exegesis of Matthew (cap. Mt. 98 and 99). Origen first presents what appears to be his own interpretation of the Matthaean passage (10.28.174-29.179); there are no similarities to Fortunatianus here. But then, the Alexandrian exegete offers a second interpretation, which he states originally to have come from someone else: he speaks vaguely of the opinion of

some who say that the tied donkey stands for the believers [coming] from circumcision, who have been released from many ties (...), and the colt stands for the believers [coming] from the Gentiles, who had been unrestrained and without any yoke corresponding to their intemperance and inordinate love of pleasure, before they received the word of Jesus. ${ }^{47}$

46 Cf. also Origen, Commentary on John, 20.8.77-78 and 20.13.96-105.

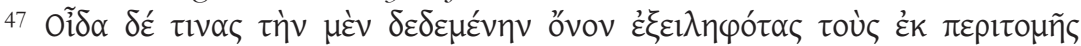

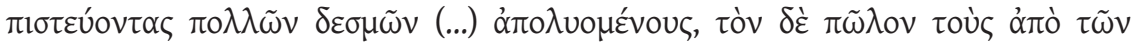

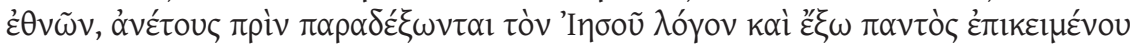

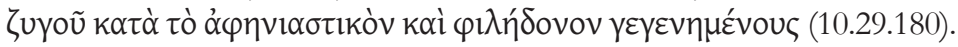


This second interpretation resembles in some respects the one given by Fortunatianus, who once again establishes a sort of progression, when he says that 'the tied donkey stands for the synagogue, as it had existed under the ties of the law', and the colt, untied by the apostles, also stands for the synagogue, but after it had been released from the burden of the law. Fortunatianus' description of the former intemperance of the colt, before being tamed by Jesus, is quite similar to Origen's characterisation of the animal. ${ }^{48}$ The major difference is, of course, that for Fortunatianus both the donkey and the colt represent the Jews (before and after having accepted the Christian faith), whereas in the interpretation reported by Origen only the donkey does. On the other hand, Origen identifies the crowd going ahead of Jesus with Moses and the prophets, while the crowd following him is identified with the apostles, just as in Fortunatianus (who, however, does not mention Moses by name). ${ }^{49}$

In fact, Fortunatianus' interpretation should rather be compared with what Origen says on Matthew 21:1-11 in his Commentary on Matthew, which was written some years after the Commentary on John. In this later work, the Alexandrian exegete retains only the explanation which in his earlier commentary is said to originate from someone else, and he presents it in a much more elaborate form (16.15-18)..$^{50}$ All the parallels between Origen

48 'Invenietis asinam alligatam': Synagogam dicit sub legis vinculo constitutam (...) Pullum autem asinae solvi, id est praedicatione apostolica factum, ut omnia illa, quae erant gravia legis, auferrentur (...) Est ergo pullus credens populus ex Iudeis, quem nemo domaverat (...) Ideo ergo frenis frenatur, id est disciplina regitur, ut, qui forte fuerat blasphemus, iam ori suo custodiam inponat, et, qui per pervia lascivus currebat, in via recta gradiatur, et, qui forte per luxuriam cadere solebat, iam firmus et stabilis ac fortis sit, ut possit dominum, quem gestat, promereri (cap. Mt. 99).

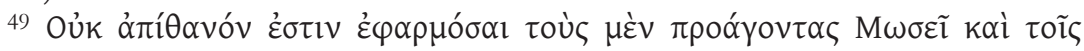

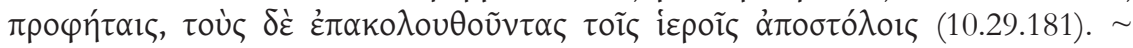
Praecedentes' patres significat, qui ante eum prophetaverunt, 'sequentes' apostolos (...) (cap. Mt. 99). Dulaey was the first to ascribe these details of Fortunatianus' exegesis to influence from Origen (Victorin de Poetovio, 323). According to her, Fortunatianus' interpretation of the colt as the ecclesia ex circumcisione probably goes back to Hippolytus of Rome, mediated through Victorinus of Poetovio.

${ }^{50}$ I use the critical edition by E. Klostermann \& E. Benz, Origenes Werke 10-12: Origenes Matthäuserklärung. 3 vols. Leipzig: Teubner, 1933-55. Of great importance for understanding the transmitted form of Origen's text is now L. Bossina, 'Le diverse redazioni del Commento a Matteo di Origine. Storia in due atti', in Il Commento a Matteo di Origene. Atti del X Convegno di Studi del Gruppo Italiano di Ricerca su 
and Fortunatianus noted above are found here too, and there is one additional detail which, in my opinion, makes it more than likely that the explanation given by the bishop of Aquileia ultimately derives from the Commentary on Matthew. Commenting on the place name Bethphage which is mentioned in Matthew 21:1 ('As they approached Jerusalem and came to Bethphage on the Mount of Olives, Jesus sent two disciples'), Fortunatianus gives the following, somewhat bizarre, interpretation:

Beth means 'house' in Hebrew, fage 'to eat' in Greek. This house can easily be understood as the church, in which the Body of Christ is eaten by the believers. ${ }^{51}$

Now, Origen, in the Commentary on John (10.30.190), claims that Bethphage literally means 'house of jaws' (oî̃koৎ $\sigma l \alpha \gamma o ́ v \omega v$ ). Martine Dulaey was certainly right to suspect some kind of connection between Fortunatianus' interpretation and this translation. ${ }^{52}$ In the Commentary on Matthew, Origen not only repeats the translation but he also emphasises that Bethphage was located at the Mount of Olives, and he interprets the latter as the church:

This was at the so-called Mount of Olives. We declare that Bethphage means translated 'house of jaws' (...) and the Mount of Olives is the church. ${ }^{53}$

I suggest that Fortunatianus — or, rather, his immediate source, which might well be the same that also conveyed knowledge of Origen's Commentary on John to him-somehow muddled up the translation of the place name and the interpretation of the Mount of Olives as the church, which are closely

Origine e la Tradizione Alessandrina (Napoli, $24-26$ settembre 2008), ed. T. Piscitelli, Brescia: Editrice Morcelliana, 2011, 27-97.

51 Beth Hebraice dicitur 'domus', fage Grece 'manducare'. Domus facile intellegitur ecclesia, in qua corpus Christi editur a fidelibus (cap. Mt. 98).

52 Dulaey, Victorin de Poetovio, vol. 2, 163, note 4: 'L'étymologie mixte (...) est une variation, faite par quelqu'un qui sait le grec (mais non l'hébreu) sur l'étymologie donnée par ORIG. in Ioh. 10,190.'

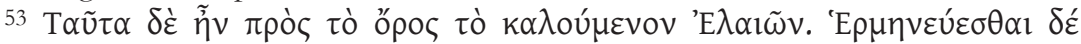

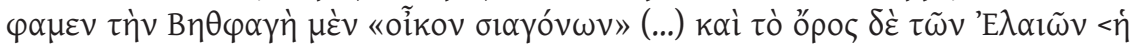

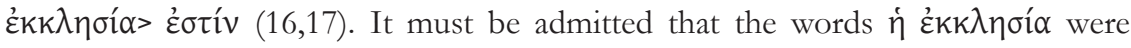
supplemented by the editor Erich Klostermann, but I think he was right in doing so: something seems to be missing in the Greek text as transmitted, and there exists a Latin translation of Origen's commentary, dating from late antiquity, which reads: Mons autem Olivarum est ecclesia. 
linked in the Commentary on Matthew, and this ultimately resulted in the curious explanation of Matthew 21:1 as it is found in the commentary by the bishop of Aquileia. ${ }^{54}$

54 There are more passages which also suggest dependence on Origen's Commentary on Matthew by Fortunatianus; they shall be discussed elsewhere. 



\title{
10. AMBROSE THE APPROPRIATOR: BORROWED TEXTS IN A NEW CONTEXT IN THE COMMENTARY ON LUKE
}

\author{
SUSAN B. GRIFFITH ${ }^{1}$
}

\section{Two Views of Ambrose}

Two views circulated during his lifetime about Ambrose, the fourth-century bishop of Milan, and to a certain extent they persist to this day. Heralded in his city and beyond as a skilled yet accessible orator, as well as a sophisticated politician, Ambrose had many keen admirers, most notably Augustine. In this perspective, he is the clear-voiced preacher and teacher, the epitome of Roman civic duty: first in a governmental position, following in the footsteps of his father who served as a Roman governor in Trier, where Ambrose was born; and then drafted against his will, and prior to his baptism, to put those gifts to use in the Church. In one of the basilicas he founded in Milan, in which his remains still lie on display in pontifical vestments, the mosaic of the reluctant bishop offers a physical likeness completed after his death but almost certainly based on a portrait completed within his lifetime (Image 1). Here he stands clad in the simple but elegant white folds of a long Roman dalmatic tunic with clavi, partially covered by a golden tan cloak; his face is slim, slightly weary, with sober, deep-set eyes and jug ears. Augustine paints a similar portrait in the Confessions: articulate, wise, slightly but not overly ascetic, an expositor of Scripture who won him over with his exegetical insight, refined but restrained rhetoric, and example of holy living. ${ }^{2}$

1 The research leading to these results has received funding from the European Union Seventh Framework Programme (FP7/2007-2013) under grant agreement no. 283302 (COMPAUL).

2 Augustine, Confessions, 5.13-14 (23-5) and 6.4 (6). 


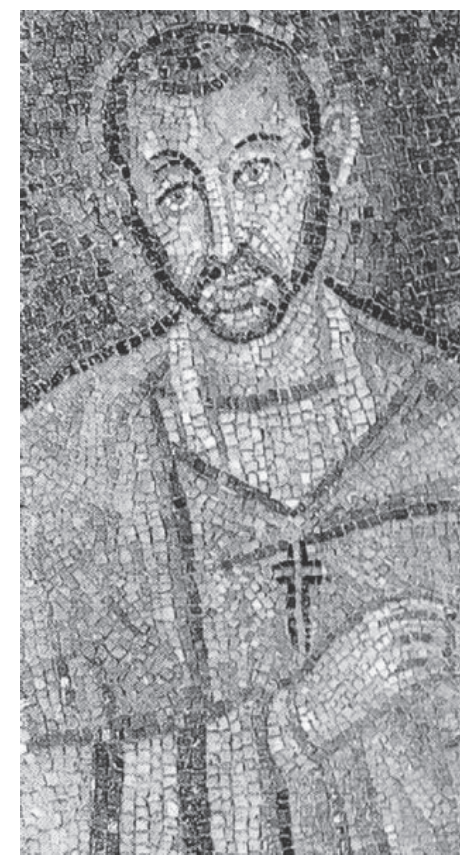

\section{Image 1. Mosaic of Ambrose}

Mosaic of Ambrose in the Chapel of San Vittore, Basilica Sant'Ambrogio in Milan. ${ }^{3}$

Public Domain

(Source: Wikimedia Commons).

Jerome, on the other hand, accused Ambrose more than once of being a literary thief, whose work was highly derivative and inferior. In Jerome's descriptions the Bishop of Milan appears as a serial plagiarist who never had an original thought, stealing shamelessly from the writings of others, too lazy to do his own work and too arrogant to credit his sources:

3 The Chapel of San Vittore originated as a shrine to St Victor prior to Ambrose's episcopate and the building of the basilica, but was later supplied with a more permanent superstructure and mosaics and attached to the Basilica Sant' Ambrogio (formerly Basilica Martyrum). Foletti provides a summary of the various options for the dating of the mosaic and narrows the range to 490-512, during the episcopacy of Lawrence I (Ivan Foletti, 'Physiognomic representations as a rhetorical instrument: "portraits" in San Vittore in Ciel d'Oro, the Galla Placidia "mausoleum" and San Paolo Fuori le Mura' in The Face of the Dead and the Early Cbristian World, ed. Ivan Foletti and Alžběta Filipová. Rome: Viella, 2013, 61-6). The mosaic shows Ambrose dressed as a layperson in civil service, which has led to the hypothesis that it is based on a very early portrait. Even if it merges Ambrose's actual appearance with the stereotypical features of portraits of philosophers, this became the iconographic prototype for later images of the bishop. 
Certe qui bunc legerit latinorum furta cognoscet, et contemnet riuulos cum coeperit baurire de fontibus. ${ }^{4}$

Whoever reads this [Ambrose's work] will certainly recognise the 'thefts of the Latins' and will despise his dribbling rivulet once they drink from its fountainhead.

In this case, the fountain from which Ambrose's De spiritu sancto flows as but a little gutter is Didymus the Blind's treatise on the Holy Spirit; the above observation in the prologue to Jerome's later translation of Didymus serves as a piece of self-promotion. In the same prologue, Jerome compares an author, unnamed but transparently Ambrose, to an ugly jackdaw (informis cornicula) who steals the bright plumage of other birds to brighten up his drab, black feathers, and struts around as if they were his own. ${ }^{5}$ Jerome goes on to denigrate this anonymous writer's 'little books' with an epigram of Terence: ex graecis bonis latina widi non bona. ${ }^{6}$ Ambrose's libelli have, in Jerome's opinion, no real 'manliness' of expression but instead only pretty makeup. ${ }^{7}$ In another preface, this time to his translation of Origen's Homilies on Luke, Jerome deploys a similar avian image:

cum a sinistro oscinem coruum audiam crocitantem et mirum in modum de cunctarum anium ridere coloribus, cum totus ipse tenebrosus sit. ${ }^{8}$

On my left I hear an ominous crow cawing; in remarkable fashion it gleams with the coloured feathers of all the birds, although the bird itself is black as night.

4 Jerome, Prologue to Didymus the Blind's De spiritu sancto, 31-3 (Louis Doutreleau, ed., Didyme l'Avengle, Traité du Saint-Esprit. SC 386. Paris: Cerf, 1992, 140). A more recent edition with German translation is based on Doutreleau's text: Hermann Josef Sieben, ed. and trans., Didymus der Blinde. De Spiritu Sancto. Über den Heiligen Geist. Fontes Christiani 78. Turnhout: Brepols, 2004.

5 Jerome, Prologue to Didymus, 19-21.

6 qui bene uortendo et easdem scribendo male ex Graecis bonis Latinas fecit non bonas (Terence, Eunuchus, prologus 7-8; John Barsby, ed., Terence, Eunuchus. Cambridge: CUP, 1999).

7 Jerome, Prologue to Didymus, 22-7.

8 Jerome, Prologus in omilias Origenis super Lucam enangelistam 1.16; Max Rauer, ed., Origenes Werke IX. Die Homilien zu Lukas in der Übersetzung des Hieronymus und die griechischen Reste der Homilien und des Lukas-Kommentars. 2nd edn. GCS 49. Berlin: Akademie, 1959). Translation from Joseph T. Lienhard, trans., Origen, Homilies on Luke; Fragments on Luke. Fathers of the Church 94. Washington DC: CUA, 1996, 4. 
Jerome never names Ambrose in his derogatory remarks, but the connection would have been obvious to his readers. ${ }^{9}$ It was made unambiguous by Rufinus: in his Apologia against Jerome, Rufinus explains that this invective imagery, drawn from a tale of Aesop—or possibly, rather ironically, Horace's reframing of it—was aimed at Ambrose. ${ }^{10}$ Rufinus takes Jerome to task over this slander. He admits that Ambrose may have borrowed, emphasising the catholicity shared by the Greek and Latin churches. Nevertheless, Rufinus does not see this to be as troublesome as Jerome's unfairness towards Ambrose in choosing 'to blaze abroad what you call his plagiarisms [furta illius]', adding:

qui fortassis etiam necessitatem scribendi passus est, ut insanientibus tunc haereticis responderet? 11

who quite possibly was undergoing a pressing need in order to reply right then to some heretical ravings.

The pressures and flux of Ambrose's context, as a Catholic bishop standing against Milan's Arian imperial court and clergy, could excuse a solution of expediency. Further, Rufinus points out Jerome's own habit of uncredited borrowing in his writings - a case of the raven calling the crow black. ${ }^{12}$ Why would Jerome persist in such a line of attack? Layton connects this string of invectives to Jerome's insecurity over maintaining his status and financial support in the patronage system. ${ }^{13}$ Yet Jerome's opinion has over time been folded into the common assessment of Ambrose's contribution, or lack thereof, to theological development. ${ }^{14}$

${ }^{9}$ In De uiris illustribus 124, Jerome thinly veils his negative criticism by stating that he would refrain from comment because Ambrose was still writing.

10 Rufinus, Apologia 2.25-8 (Manlio Simonetti, ed., Tyrannii Rufini Opera. CCSL 20. Turnhout: Brepols, 1961, 101-5); in the English translation of Fremantle, it is 2.22-5 (Henry Fremantle, trans., Theodoret, Jerome, Gennadius, Rufinus. Nicene and Post-Nicene Fathers 2.3. Oxford and New York: Christian Literature Publishing Co., 1892, 471). Layton makes no mention of Aesop, focussing instead on Horace (Epistula 1.3.18) as the source for the image (Richard A. Layton, 'Plagiarism and Lay Patronage of Ascetic Scholarship: Jerome, Ambrose and Rufinus.' JECS 10.4 (2002) 489-522, here 505-6).

${ }^{11}$ Rufinus, Apologia 2.28.10-16.

12 Rufinus, Apologia, 2.28.19ff.

13 Layton, 'Plagiarism', especially 489, 503, 520-1.

14 As seen, for example, in the classic two-volume biography of Homes Dudden which represented the consensus for much of the twentieth century $(\mathrm{F}$. 


\section{TEXTS AND CONTEXTS}

These conflicting portraits come to mind when reading Ambrose's commentary on Luke, the Expositio enangelii secundum Lucam. ${ }^{15}$ This and the Homilies on Luke of Origen (surviving primarily in the Latin translation by Jerome and secondarily in Greek fragments) are virtually the only significant surviving exegetical works on Luke from the patristic period, which overall favoured Matthew and John as the gospel accounts most frequently accorded sustained commentary. ${ }^{16}$ The Bishop of Milan writes with fluidity in rhetorically polished but not overly elaborate Latin. Yet echoes and even verbatim translations from other exegetical works on the Gospel of Luke can be identified. Origen's homilies, one of his main sources, were composed in Greek and unavailable in Latin until after the publication of Ambrose's commentary. Assessment of the intertextuality of Ambrose's Latin text thus depends on fragmentary Greek evidence from Origen's Homilies and Jerome's later translation of that lost collection. ${ }^{17}$

Origen preached his homilies on Luke some time between 233 and 244 in Caesarea. ${ }^{18}$ Copies of the texts, taken down by notarii, were available

Homes Dudden, The Life and Times of St. Ambrose. Oxford: Clarendon, 1935; e.g. 455).

15 Ambrose, Expositio enangelii secundum Lucam; Fragmenta in Esaiam (M. Adriaen, ed., Sancti Ambrosi Mediolanensis Opera IV. CCSL 14. Turnhout: Brepols, 1957; see also PL 15.1527-1850; Karl Schenkl, ed., Expositio evangelii secundum Lucam. CSEL 32.4. Vienna: Tempsky, 1902; Gabriel Tissot, ed., Traité sur l'Évangile de S. Luc. SC 45 \& 52. Paris: Cerf, 1956, 1958). A recent English translation is Íde M. Ní Riain, Commentary of Saint Ambrose on the Gospel according to Saint Luke. Dublin: Halcyon, 2001.

16 Apart from a few fragments, the only other principal exegetical work to survive on Luke is a Syriac translation of Cyril of Alexandria's Lucan homilies. See Lienhard, Origen, Homilies on Luke, xxiv.

17 The present discussion relies on Rauer, Origenes Werke IX, although Rauer's first edition (Leipzig, 1930) was also consulted; see also Hermann Josef Sieben, ed. and trans., Origenes. Homilien zum Lukasevangelium. 2 vols. Fontes Christiani 4. Freiburg: Herder, 1991-2, and Henri Crouzel, François Fournier, Pierre Périchon, ed. and trans., Origène, Homélies sur S. Luc. SC 87. Paris: Cerf, 1962. Both these translations use Rauer's text.

18 Lienhard postulates that the homilies date from c. 233-44, after Origen's move to Caesarea and before his commentary on Matthew (Origen, Homilies on Luke, xxiv); Rauer suggests 231-44, though favouring the earlier part of that timeframe (Origenes Werke IX, viii); François Fournier and Sieben both date the initial preaching to 233-4, 'at the start of his second stay in Caesarea' (Crouzel et al., 
in the famous library of Caesarea. ${ }^{19}$ Intriguingly, these homilies contain the first treatment of the account of the Nativity prior to Hilary of Poitiers in the fourth century. Unfortunately, only a few Greek fragments remain and many of these are transmitted in catenae, which makes them difficult to use. ${ }^{20}$ The whole work is available in Latin through Jerome's translation, a collection of thirty-nine homilies completed around 389-90.21 Rauer's edition includes Jerome's text, the Greek catena fragments which correspond most closely to this, and other fragments of Lucan exegesis: the last of these could come from Origen's lost Commentary on Luke rather than the Homilies, or be spurious.

The exegetical connection between Origen and Ambrose is well known. While Ambrose was not the only Church Father who found Origen's biblical interpretation useful, it was his preaching which served as the main conduit of Alexandrian, and specifically Origenist, exegesis into the West. Approximately ten years before Jerome's translation of Origen, Ambrose preached a series of sermons on Luke in Milan in around 377-8.

Origène, Homélies sur S. Luc, 81); Sieben, Origenes Homilien, I.30-1.

${ }^{19}$ Hughes Oliphant Old, The Reading and Preaching of the Scriptures in the Worship of the Christian Church. 2 vols. Grand Rapids: Eerdmans, 1998, 1:321. See also Anthony Grafton and Megan Williams, Christianity and the Transformation of the Book: Origen, Eusebius, and the Library of Caesarea. Cambridge, MA: Harvard UP, 2006, 5. Grafton and Williams cite Johannes Trithemius, Catalogus scriptorum ecclesiasticorum. Cologne: Peter Quentel, 1531, viii recto, xi recto, xiii recto.

20 Sieben, Origenes Homilien, I.46-53 discusses briefly the complicated Greek and Latin textual traditions of Origen's Lucan homilies. The classic treatment is Max Rauer, Form und Überlieferung der Lukas-homilien des Origenes. TU 47.3. Leipzig: Hinrichs, 1932. Rauer attempted to catalogue all of Origen's Lucan fragments from Greek catenae in his GCS edition, which appeared two years earlier. Lienhard remains wary of the fragments due to the way in which catenae often mangled, truncated, or adapted the original text (Lienhard, Origen, Homilies on Luke, xxxvi). Sieben includes some but not all of Rauer's identified fragments in his edition: he renumbers them but gives details of Rauer's original numbering for reference (e.g. Sieben's Fragment 60 is Rauer's Fragment 113, on Luke 7:37; see Sieben, Origenes Homilien, II.442-3).

21 This date is relatively secure, as it needs to be after Ambrose's commentary but before the turn against Origenism which started around 393. See J.N.D. Kelly, Jerome: His Life, Writings, and Controversies. London: Duckworth, 1975, 143 (esp. note 12). Sieben, however, based on a possible reference to the Massacre at Thessaloniki in Ambrose's exegesis, places both works slightly later: Ambrose's commentary in 391 and Jerome's translation of Origen in 392 (Sieben, Origenes Homilien, I.34, 36. 
Sometime in the following decade he revised these homilies into a commentary, the Expositio enangelii secundum Lucam, which stands as his only extant work on the New Testament. ${ }^{22}$ While evidence of his editorial hand can be discerned in places, the commentary's origin in the liturgy is never completely absent.

Some key questions remain about Origen's homilies and the source used by Jerome. How many sermons did Origen preach on Luke? Did collections with differing numbers of sermons circulate? Furthermore, how many of Origen's homilies were available to Jerome and Ambrose? It is impossible to know the exact number, but Old proposes that Origen preached well over 150 sermons in his series on Luke, covering the entire Gospel. ${ }^{23}$ If that is the case, then perhaps $80 \%$ of the sermons are now missing. As far as the textual evidence goes, in addition to the missing parts of the now-fragmentary homilies surviving in Greek (some of which could be remnants of Origen's lost commentary), at least two more of Origen's Lucan sermons are known to have been lost, as he refers to them elsewhere. ${ }^{24}$ The fragments that do not correspond to any part of Jerome's work, and Origen's own comments on his preaching, indicate that Jerome did not translate all of Origen's homilies on the Gospel. The sermons he does translate are drawn from Luke 1-4, followed by six further sermons on isolated passages from Luke 10-20. Whether Jerome had a complete or a partial source text, or was aware of any gaps, is unclear. ${ }^{25}$ If he had a complete edition in front of him, perhaps he lost interest, or had other things to do, or believed that he could skip some sermons if their topic was covered in a commentary on Matthew or John. The one thing that seems clear is that Ambrose makes use of homilies that Jerome did not translate.

22 Lienhard, Origen, Homilies on Luke, xxxiv, dates the initial publication to 3901; Rauer, Origenes Werke IX, x, prefers 388.

23 Old, Reading and Preaching, I.321.

24 Origen refers in his commentaries to his homilies on Luke 14:16-24 (Commentary on John 32.2) and 15:4-7 (Commentary on Matthew 13.29): see Lienhard, Origen, Homilies on Luke, xxxv n. 22.

25 Lienhard, Origen, Homilies on Luke, xxv, is convinced that Jerome translated all of the homilies he had, which would indicate that some had already been lost or excluded from the corpus. Old, Reading and Preaching, I.322, on the other hand, thinks that Jerome intended to translate more but did not finish his work. Rauer, Form und Überlieferung, 40, says that the manuscript tradition is too complex to enable the question to be answered. 
Furthermore, the text of Origen's sermons that Ambrose and Jerome are likely to have had before them may have been quite condensed. The main ideas would have been recorded by stenographers, but the extent to which Origen would have developed these in his spoken presentation is unknown. Old argues that, based on the length of Origen's Homilies on Genesis, it seems that not much more than an outline is preserved of those on Luke. ${ }^{26}$ Heine, following Nautin, notes that while (in Jerome's translations) Origen's Genesis homilies are indeed three times longer than the sermons on Luke, this is due to the shorter preaching time at a Eucharist, when the Gospels would be expounded. The sermons on Genesis would have been delivered during a non-Eucharistic morning or evening service devoted to teaching the catechumenate. ${ }^{27}$ The difference in the way that Jerome and Ambrose handle Origen's homilies- the former treating the text with considerable reverence and translating more rigorously, the latter using it more as an outline-may reflect their own opinions on the status of the text in the manuscript in front of them.

\section{THE MAIN SOURCES FOR AMBROSE's COMMENTARY}

Ambrose borrows ideas, scriptural references, and even word-for-word passages from a range of authors. It is noticeable, however, that he varies his sources. For example, the most frequent usage of Origen's Homilies on Luke occurs in Books 1 and 2 of Ambrose's Commentary on Luke. ${ }^{28}$ In Book 3, he shifts to Eusebius, in particular the Quaestiones enangelii, as his main source; he also returns to Eusebius towards the end of Book 10. Scattered throughout are further echoes of Origen, including, rather significantly, portions which were not translated by Jerome but which can be identified in the catena fragments. While working with catenae presents a variety of questions about authenticity and reliability, the number of passages with a very clear parallel in either Jerome's translation or Ambrose's commentary, or both, is quite high. In addition to Origen and Eusebius, Ambrose makes use of the Commentary on Matthew by Hilary of Poitiers for insight into some

26 Old, Reading and Preaching, I.322.

27 Ronald E. Heine, trans., Origen: Homilies on Genesis and Exodus. Fathers of the Church 71. Washington DC: CUA, 1982, 20. See also P. Nautin, Origène: sa vie et son auvre. Paris: Beauchesne, 1977, 389-409.

28 A useful chart listing the passages in Ambrose's Lucan commentary (based on the text of Tissot in SC 45 and 52) that borrow quite clearly from Origen can be found in Crouzel et al., Origène, Homélies sur S. Luc, 563-4. 
of the Lucan passages that have parallels in Matthaean texts. ${ }^{29}$ As noted above, commentaries on Matthew and John were more common in the period than those on Luke or Mark, and it should be no surprise that Ambrose would look in particular to a Matthaean commentary when discussing a synoptic parallel in Luke; however, this can cause some anxiety where the passages differ, as can be seen in the discussion below of the Anointing at Bethany. As a Roman-educated former consular prefect, allusions drawn from the classical canon (Virgil, Cicero, Ovid, Pliny, and even Homer) can be found scattered throughout. ${ }^{30}$ Most significantly, and too often overlooked in discussions of intertextuality, Ambrose cites nearly every book of the New Testament (only 2 and 3 John are missing), and much of the Old Testament (apart from Ezra, Nehemiah, Judith, Esther, Joel, Obadiah, Nahum, 1 Maccabees). ${ }^{31}$ The most frequent citations, apart from Luke, are drawn from Matthew (as the closest parallel gospel), John, and Psalms - the last as a rich source of Christological interpretation for the early Church.

\section{A COMPARISON WITH INTERTEXTUALITY IN AMBROSE'S EXPLANATIO PSALMORUM XII}

What was Ambrose's modus operandi for composing a commentary? By way of comparison, I will summarise briefly his method in his commentary on twelve of the Psalms. ${ }^{32}$ In these, Ambrose borrowed frequently from the Psalm homilies of Basil of Caesarea, although there are only four psalms which they both expound: Psalms 1, 45, 48 and 61.33 Perhaps Ambrose would have included others, but he died in 397 in the midst of writing his commentary on Psalm 43. ${ }^{34}$ For the four Psalms on which the two Fathers

29 Jean Doignon, ed., Hilaire de Poitiers sur Matthieu. SC 254, 258. Paris: Cerf, 1978-9.

30 A list of non-scriptural sources (both classical and Christian) and later re-use of Ambrose's homilies can be found in Adriaen, Sancti Ambrosi Mediolanensis Opera IV , 435-40.

31 Adriaen, Sancti Ambrosi Mediolanensis Opera IV, 409-34.

32 Michael Petschenig and Michaela Zelzer, ed., Sancti Ambrosi opera. Pars VI. Explanatio psalmorum XII. 2nd edn. CSEL 64. Vienna: ÖAW, 1999. Ambrose also composed a separate commentary on Psalm 118 (119).

33 Thirteen of Basil's psalm homilies are contained in PG 29, and another four that are dubious or spurious are in the Appendix to PG 30. No modern critical edition has been produced.

34 There is no evidence that Ambrose intended to expound every Psalm, 
both comment, Basil's homilies provide a framework for Ambrose's thought and, specifically, a number of references to related scriptural passages. In places, Ambrose translates Basil directly, which indicates that he had Basil's text open while he was writing or dictating. In sections 1-29 of Ambrose's exegesis of Psalm 1, there are over forty direct parallels with Basil's homily on the same Psalm. Some are paraphrases, but many are translations that correspond closely to the source. What sparked Jerome's accusations of plagiarism was the lack of references to Basil as the source of these obvious borrowings. Such an omission, however, is not without precedent in late antiquity, particularly when translation is involved. ${ }^{35} \mathrm{On}$ the other hand, providing the source's name was not an unknown practice, although the wrong author may have been cited occasionally by writers relying on memory. Accusations of plagiarism tend to arise in polemical contexts, for example as an apologetic strategy in which pagan philosophers are declared to have taken their ideas from Moses. While Ambrose does appropriate elements of Basil's structure for the exegesis of those four Psalms, as well as citing some of the same biblical texts and even translating some passages verbatim, he nonetheless goes far beyond Basil. First, Ambrose cites scripture far more frequently. He may use some of the same biblical texts as Basil to illuminate the verse under consideration, but he then adds even more. Second, Ambrose has more rhetorical flourishes, including more elaborate figurative language, drawing from different categories. Where Basil opts for a metaphor from nature, Ambrose may replace it by a military or athletic one. Third, he covers far more ground than Basil. In the case of Psalm 1, Basil limits his exegesis to the first verse; Ambrose comments on the entire Psalm. Finally, Ambrose's commentary differs markedly in tone, with more emphasis on paraenesis and moral application.

although this gargantuan task was undertaken by Augustine in the following two decades.

35 The idea of plagiarism was well known in antiquity, but lacked a specific term. It is generally referred to simply as 'theft' (furtum or k $\lambda$ orń). Clement of Alexandria, in Stromata VI, cites a Hellenistic pagan treatise On Plagiarism (Пгpi $\kappa \lambda \circ \pi \tilde{\eta} \varsigma$ - literally, 'On Theft'), which probably dates from some time after the third century BCE. This connection is mentioned in Miguel Herrero de Jáuregui, Orphism and Christianity in Late Antiquity. Sozomena 7. Berlin \& New York: de Gruyter, 2010, 201. In general, see further Layton, Plagiarism and Lay Patronage, and Scott McGill, Plagiarism in Latin Literature. Cambridge: CUP, 2012. 


\section{INTERTEXTUALITY IN AMBROSE'S COMMENTAR Y ON LUKE}

To what extent does Ambrose's approach to his sources for his Psalm commentary correspond to his exegetical process in the Commentary on Luke? Again, his method appears to be somewhat eclectic, relying on a single main author in some passages (typically either Origen or Hilary), cherry-picking from a range of sources in others, and developing his own interpretations. This will be illustrated from two different passages. The opening discussion of Luke 1:1 in the fragmentary material of Origen, in Jerome's translation and in Ambrose's commentary offers numerous comparisons, while a shorter, briefer sample from Luke 7:37-50 (the Anointing at Bethany) will focus on the narrative, the variation in the interpretation of this pericope between Ambrose's two main sources (Origen and Hilary), and the way in which he attempts to resolve the apparent inconsistencies.

\section{Luke 1:1}

The table below consists of the discussion of Luke 1:1 from Jerome's translation of Origen, the Greek text of Origen reconstructed from fragments by Rauer, and Ambrose. The parallel sections are numbered according to the order in which they appear in Ambrose's text. Bold typeface is used to help differentiate between sections and to connect the parallels with one another. A double slash $(/ /)$ marks the boundaries between the Greek fragments.

\begin{tabular}{|c|c|c|}
\hline Ambrose, Exp. Luc. & $\begin{array}{l}\text { Origen, Fragments } \\
\text { in Luke }\end{array}$ & $\begin{array}{l}\text { Origen, Hom. } \\
\text { Luc. } \\
\text { (via Jerome) }\end{array}$ \\
\hline (1.1-4; CCSL 14.6-8) & (Hom. 1; GCS 49.3-6) & (Hom. 1; GCS 49.3-6) \\
\hline $\begin{array}{l}\text { [Lemma text:] } \\
\text { 'quoniam' inquit 'multi }\end{array}$ & 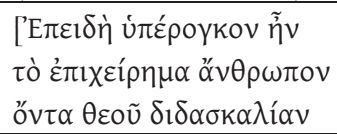 & \\
\hline
\end{tabular}

36 The texts in square brackets in this section are taken from catena fragments as catalogued and edited by Rauer. Fragments 1a, 1b, 1c, and 2 were presented alongside the other fragments in the 1930 edition, but removed to an appendix of doubtful evidence in the second edition of 1959. Some may derive from Origen's Commentary on Luke rather than the homilies. For simplicity, textual variants are omitted from this table, although they are presented in the critical apparatus of the editions. 


\begin{tabular}{|c|c|c|}
\hline $\begin{array}{l}\text { pleraque nostrorum } \\
\text { (1) quemadmodum } \\
\text { ueterum Iudaeorum } \\
\text { paribus et generibus } \\
\text { formantur et causis atque } \\
\text { exemplorum similium } \\
\text { pari usu exitu que } \\
\text { conueniunt principio que } \\
\text { rerum et fine } \\
\text { concordant. nam sicut } \\
\text { multi in illo populo } \\
\text { diuino infusi spiritu } \\
\text { prophetarunt, } \\
\text { (1) alii autem } \\
\text { prophetare se } \\
\text { pollicebantur et } \\
\text { professionem } \\
\text { destituebant mendacio } \\
\text { (1) erant enim } \\
\text { pseudoprophetae } \\
\text { potius quam prophetae, } \\
\text { sicut Ananias filius } \\
\text { Azot, } \\
\text { (2) erat autem populi } \\
\text { gratia discernere } \\
\text { spiritus, ut cognosceret } \\
\text { quos referre deberet in } \\
\text { numerum prophetarum, } \\
\text { quos autem } \\
\text { (3) quasi bonus }\end{array}$ & 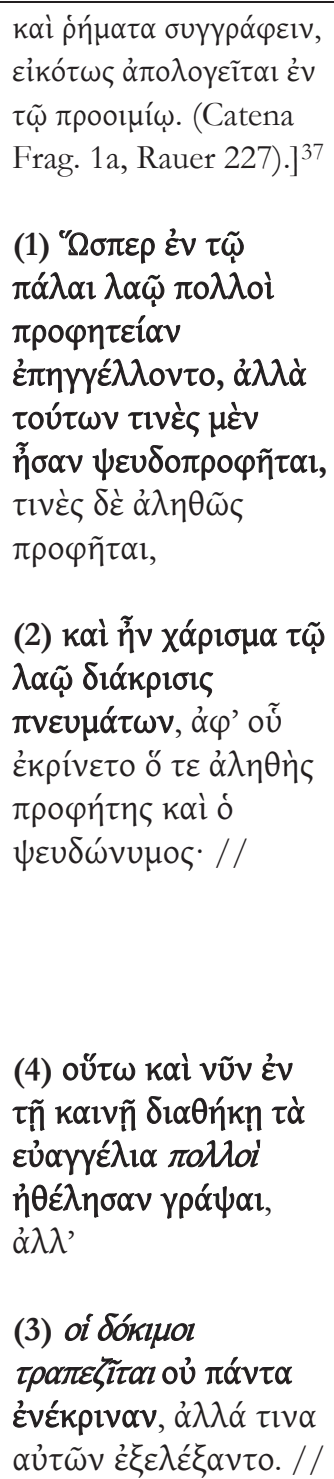 & $\begin{array}{l}\text { (1) Sicut olim in } \\
\text { populo Iudaeorum } \\
\text { multi prophetiam } \\
\text { pollicebantur, et } \\
\text { quidam erant } \\
\text { pseudoprophetae - } \\
\text { e quibus unus fuit } \\
\text { Ananias, filius Azor } \\
\text { - alii uero ueri } \\
\text { prophetae, et } \\
\text { (2) erat gratia in } \\
\text { populo } \\
\text { discernendorum } \\
\text { spirituum, per quam } \\
\text { alii inter prophetas } \\
\text { recipienbantur, } \\
\text { (3) nonnulli quasi } \\
\text { ab exercitatissimis } \\
\text { trapezitis } \\
\text { reprobabantur, } \\
\text { (4) ita et nunc in } \\
\text { nouo instrumento } \\
\text { multi conati sunt } \\
\text { scribere euangelia, } \\
\text { sed non omnes } \\
\text { recepti. Et ut sciatis } \\
\text { non solum quatuor } \\
\text { euangelia, sed plurima } \\
\text { esse conscripta, e }\end{array}$ \\
\hline
\end{tabular}

37 This fragment does not seem to have a correspondence with either Latin version, apart perhaps from Jerome's own apology in his prologue about how difficult an undertaking translation can be (Rauer, Origenes Werke IX, 1). Ambrose's more academic prologue focuses on the different genres of scripture. 


\begin{tabular}{|c|c|c|}
\hline $\begin{array}{l}\text { A scribere, } \\
\text { Basilidem. } \\
\text { aliud } \\
\text { a, quod } \\
\text { cundum } \\
\text { oui aliud } \\
\text { ecundum } \\
\text { aliqua, ne } \\
\text { gimus, ne } \\
\text { legimus, } \\
\text { amus, sed } \\
\text { nus et ut }\end{array}$ & 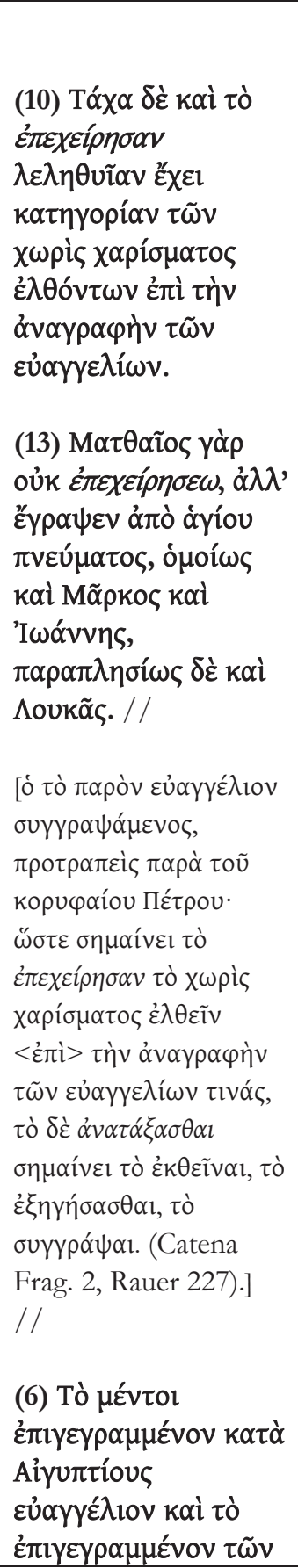 & $\begin{array}{l}\text { quibus haec, quae } \\
\text { habemus, electa sunt } \\
\text { et tradita ecclesiis, ex } \\
\text { ipso prooemio Lucae } \\
\text { quod ita contexitur } \\
\text { cognoscamus: quoniam } \\
\text { quidem multi conati sunt } \\
\text { ordinare narrationem. } \\
\text { (10) Hoc quod ait; } \\
\text { conati sunt, } \\
\text { latentem habet } \\
\text { accusationem } \\
\text { eorum, qui absque } \\
\text { gratia Spiritus } \\
\text { sancti ad scribenda } \\
\text { euangelia } \\
\text { prosiluerunt. } \\
\text { (13) Matthaeus } \\
\text { quippe et Marcus et } \\
\text { Ioannes et Lucas } \\
\text { non sunt conati } \\
\text { scribere, sed Spiritu } \\
\text { sancto pleni } \\
\text { scripserunt } \\
\text { euangelia. Multi } \\
\text { igitur conati sunt } \\
\text { ordinare narrationem de } \\
\text { bis rebus, quae } \\
\text { manifestissime cognitae } \\
\text { sunt in nobis. } \\
\text { (5) Ecclesia quatuor } \\
\text { habet euangelia, } \\
\text { (9) haeresis } \\
\text { plurima, } \\
\text { (6) e quibus } \\
\text { quoddam scribitur } \\
\text { secundum } \\
\text { Aegyptios, aliud } \\
\text { iuxta Duodecim } \\
\text { Apostolos. Ausus } \\
\text { fuitides }\end{array}$ \\
\hline
\end{tabular}




\begin{tabular}{|c|c|c|}
\hline $\begin{array}{l}\text { ultis noui } \\
\text { unum } \\
\text { es }\end{array}$ & 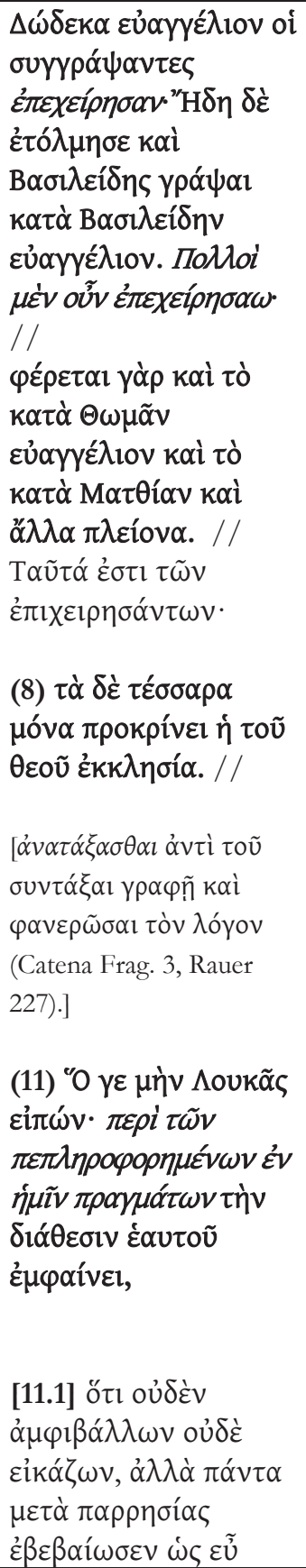 & $\begin{array}{l}\text { Multi } \\
\text { unt scribere, } \\
\text { quatuor } \\
\text { euangelia } \\
\text { obata, e } \\
\text { b persona } \\
\text { et Saluatoris } \\
\text { oferenda sunt } \\
\text { quoddam } \\
\text { lium, quod } \\
\text { tur } \\
\text { um } \\
\text { m, et iuxta } \\
\text { m; } \\
\text { ia plura }\end{array}$ \\
\hline
\end{tabular}




\begin{tabular}{|c|c|c|}
\hline $\begin{array}{l}\text { gratia dei, quae, ubi se } \\
\text { infuderit, rigare } \\
\text { consueuit, ut non } \\
\text { egeat, sed redundet } \\
\text { scriptoris ingenium. } \\
\text { (13) non conatus est } \\
\text { Matthaeus, non } \\
\text { conatus est Marcus, } \\
\text { non conatus est } \\
\text { Iohannes, non conatus } \\
\text { est Lucas, sed diuino } \\
\text { spiritu ubertatem } \\
\text { dictorum rerum que } \\
\text { omnium ministrante } \\
\text { sine ullo molimine } \\
\text { coepta conplerunt. } \\
\text { (10) et ideo bene dicit: } \\
\text { quoniam multi conati } \\
\text { sunt ordinare } \\
\text { narrationem rerum } \\
\text { quae in nobis } \\
\text { conpletae sunt uel } \\
\text { quae in nobis } \\
\text { redundant. quod enim } \\
\text { redundat nulli deficit et } \\
\text { de conpleto nemo } \\
\text { dubitat, cum fidem } \\
\text { effectus adstruat, exitus } \\
\text { prodat. } \\
\text { (11) itaque euangelium } \\
\text { conpletum est et } \\
\text { redundat omnibus per } \\
\text { uniuersum orbem } \\
\text { fidelibus et mentes } \\
\text { omnium rigat animum } \\
\text { (14) que confirmat. } \\
\text { ergo fundatus in petra } \\
\text { et qui omnem fidei } \\
\text { sumserit plenitudinem } \\
\text { firmamentum que } \\
\text { contiae recte dicit: }\end{array}$ & 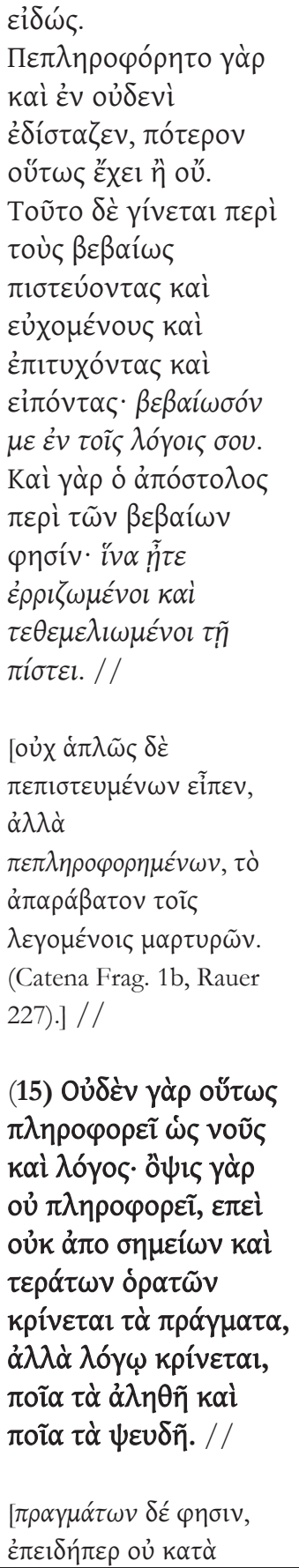 & 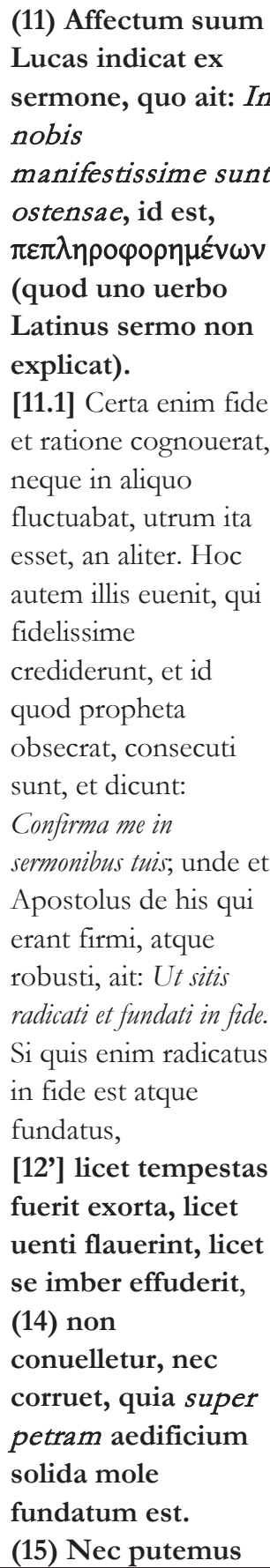 \\
\hline
\end{tabular}




\begin{tabular}{|c|c|c|}
\hline $\begin{array}{l}\text { quae in nobis conpletae sunt, } \\
\text { (15) quoniam non } \\
\text { signis et prodigiis, sed } \\
\text { uerbo uera et falsa } \\
\text { discriminant qui } \\
\text { salutaria domini gesta } \\
\text { describunt uel qui } \\
\text { animum mirabilibus } \\
\text { eius intendunt. quid } \\
\text { enim tam rationabile } \\
\text { quam ut credas, cum } \\
\text { legis ea gesta quae supra } \\
\text { hominem sunt, potioris } \\
\text { esse naturae, at uero cum } \\
\text { legis ea quae sunt } \\
\text { mortalia, suscepti credas } \\
\text { esse corporis passiones? } \\
\text { ita } \\
\text { (15) uerbo atque } \\
\text { ratione, non signis } \\
\text { fides nostra fundatur. }\end{array}$ & 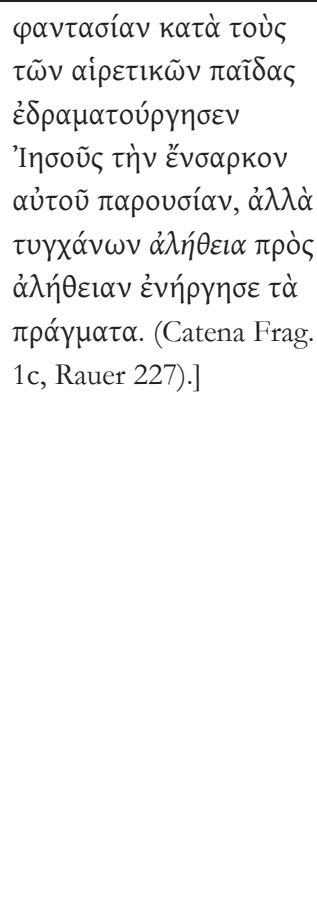 & $\begin{array}{l}\text { oculis istis } \\
\text { carnalibus } \\
\text { firmitatem fidei } \\
\text { dari, quam mens et } \\
\text { ratio tribuit. } \\
\text { Infideles quique } \\
\text { credant signis, } \\
\text { atque portentis, } \\
\text { quae humana acies } \\
\text { contuetur. Fidelis } \\
\text { uero et prudens } \\
\text { atque robustus } \\
\text { rationem sequatur } \\
\text { et uerbum, et sic } \\
\text { diiudicet, quid } \\
\text { uerum quidue } \\
\text { falsum sit. }\end{array}$ \\
\hline
\end{tabular}

\section{Discussion of the parallel texts}

A close reading of the columns above reveals a pattern similar to the methodology Ambrose used in composing his exposition of the Psalms. Short phrases appear to be translated virtually verbatim from Origen: parallels can be identified both in the Greek fragments as well as in Jerome's translation. For the most part, however, the Ambrosian text seems to be more freely translated or paraphrased, one of the characteristics derided by Jerome. Both Jerome and Ambrose include text that is not extant in the Greek fragments. In some cases, these run in parallel, suggesting that the Greek tradition is truncated and that both Latin authors are referring to a section of Origen that is no longer extant. For example, sections annotated in the columns above as $5,7,9,12$, and 15 exist in both Ambrose and Jerome, but not in the Greek fragments. It is possible that Jerome imitated Ambrose at those points, but this is unlikely given his statement in his prologue of his intention to translate Origen's Greek as faithfully as possible. In places, Jerome translates sections of Origen that have no parallel in Ambrose. One such extended section is noted above with the designation [11.1]. 
Overall, Ambrose adds more commentary than is paralleled in Jerome's translation, let alone the fragments of Origen. The most obvious explanation is that these sections represent Ambrose's own thought. For example, the very first section, marked (1), is pithy in both Origen and Jerome; Ambrose takes nearly three times as long to say the same thing, weaving a few phrases from Origen into his own ideas. Some of Ambrose's text expands an idea while on other occasions he injects paraenesis, in keeping with the homiletic origin of this commentary. It is possible that the original form of Origen's text, as homily, included more of this sort of exhortation, which Jerome omitted. Given the lack of evidence and the clear examples of the way in which Ambrose added significantly to Basil's Homily on Psalm 1, the former hypothesis that these additions are Ambrosian fits more convincingly.

The opening sentences in each column above reveal the same pattern. Jerome's translation closely follows the text as found in the catena fragment, suggesting that this fragment is likely to be authentic. The only departure is that Jerome moves the reference to exercitatissimis traperitis (oi

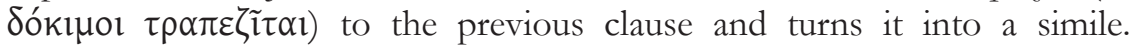
Jerome keeps the Greek noun in transliteration, a frequent habit of his when translating. Ambrose, on the other hand, refers to the moneyhandlers twice: the first time, like Jerome, with the addition of quasi, the second without. The bishop translates the phrase as bonus nummularius rather than using the Greek term. A few sentences in Jerome's text that are not in the fragments could be understood either as his own clarifications (as when he offers multiple translations for $\pi \varepsilon \pi \lambda \eta \rho \circ \varphi \circ \rho \eta \mu \varepsilon ́ v \omega v)$ or as his translation of Greek text no longer extant. The latter explanation fits the majority of the extra sentences in Jerome. In Ambrose, however, there are so many interpolated sentences that his use of Origen's homily could be characterised as an outline which he amplifies in his own way. As the additions in Ambrose do not always correspond to those in Jerome, the possibilities are either that Ambrose was working from a longer or possibly augmented text of Origen, or, far more likely, that he had much of his own to say to those gathered in the basilica in Milan.

\section{Ambrosian transformation}

In addition to the additional material throughout Ambrose's commentary on Luke 1:1, a few passages stand out as inversions of what probably was Origen's text, if Jerome is translating accurately. Jerome makes use of the image of a storm beating against a house with harsh winds and heavy rain, threatening to wipe it off its foundation (marked above as section [12']). Ambrose, by contrast, alters the weather metaphor and chooses to describe 
rain in an agricultural metaphor drawn from Scripture, as God's grace poured out like rain to water a person (12). ${ }^{38}$ In this context, the person is specifically identified as a writer, and probably one of the four evangelists, in keeping with the commentary's discussion of true and false gospel writers. Later, in a section also marked (12), Ambrose refers to rain as the Gospel which enables a believer to stand steadfast. Earlier, in the section labelled (10), Ambrose had pointed out that the heretical gospel writers could only 'try' (conati sunt) because they were devoid of the grace of God. Indeed, all three sources-Origen, Jerome, and Ambrose-refer to the gift of grace (gratia/ $\chi \alpha$ ó $\sigma \mu \alpha)$ of discernment given to the Jews to sort out true from false prophets, and that the writers of the heretical gospels were

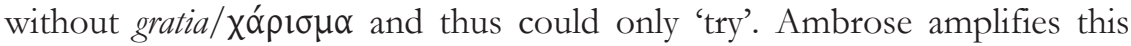
idea of grace further, highlighting its effect not just in the production of Scripture in the past, but also for the average person who listens to the reading of the Gospel. Thus the storm in Jerome (and perhaps Origen) that is a threat to faith becomes in Ambrose a nourishing rain that feeds faith. The transformation of this image is very likely to be based in the rite of baptism, as 'grace' (gratia) was frequently used as a term for baptism in the Latin Church from at least the fourth century. ${ }^{39}$ Thus the connection that Ambrose makes between water and gratia is perhaps best understood as an expressive illustration of the idea of the grace of God poured out in baptism.

Part of the reason for this transformation thus could come from a greater emphasis on grace in Ambrose's preaching. Further, that grace could be interpreted as an association he sought to make for his audience to understand baptism as a stabilising foundation of faith for the believer. But a more technical rationale for the way in which Ambrose departs from Origen's homily at this point could derive from the way in which Origen, and Jerome in imitation, conflates two Pauline texts. Ambrose sidesteps the discussion of the text, perhaps because of the textual confusion: there is no mention of it in his commentary at the point marked as [11.1] in Origen

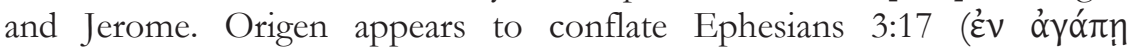

38 Verses relating to water as both a God-provided element for agricultural growth and metaphor for spiritual growth included Deuteronomy 32:2; Psalm 1:3, 72:6; Isaiah 44:3-4, 55:10-11; Hosea 10:12, Zechariah 10:1; Romans 5:5. The last may be the particular image Ambrose has in mind in this context.

39 This can be observed readily in a number of Augustine's sermons in which he implores the catechumens to 'come to grace', i.e. to postpone baptism no longer. See, for example, Augustine, Sermones ad populum 97A.4 and 132.1-2. 


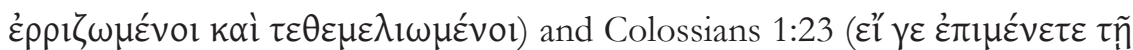

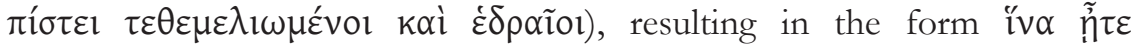

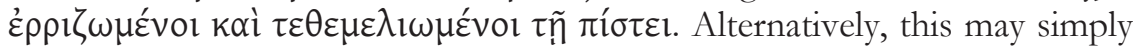
be an error of memory. For Origen and Jerome, the key to surviving the storms of life is thus being 'rooted and grounded in faith'. Ambrose may not have totally abandoned Origen's text, though, as he seems to have the idea from Ephesians 3:17 of 'being rooted' in mind when he transforms the metaphor of the storm into one of a more nourishing rain. For Ambrose, that rain pours out grace, making the writer be fruitful without effort, and in turn feeding the faith that allows the believer to be steadfast. The image then is of plants 'rooted and grounded in love', the full phrasing of Ephesians 3:17. In Origen and Jerome, the emphasis is instead on the role

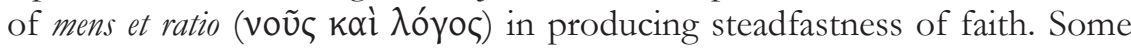
time after the imagery of the rain, at the conclusion of his exegesis of Luke 1:1, Ambrose works in the idea of the Word and Reason, uerbo atque ratione, stating that they provide a better foundation for faith than signs and wonders. Yet Ambrose makes it explicit in the preceding passages that it was grace which had brought them to that foundation.

\section{Gospel text}

The text of Luke 1:1 as extracted from the passages of exegesis quoted above is as follows, along with the standard editions of the New Testament:

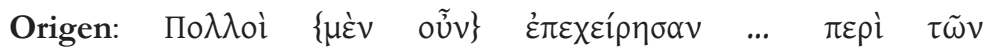

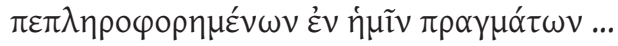

Jerome (translating Origen): Quoniam quidem multi conati sunt ordinare narrationem de his rebus, quae manifestissime cognitae/confirmatae/ostensae sunt in nobis.

Ambrose: Quoniam multi conati sunt ordinare narrationem rerum quae in nobis conpletae sunt [uel quae in nobis redundant].

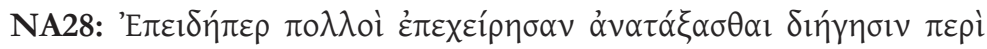

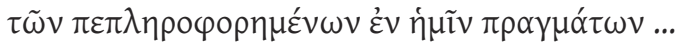

Vulgate: Quoniam quidem multi conati sunt ordinare narrationem, quae in nobis completae sunt, rerum ...

It may seem surprising that Ambrose's text of Luke 1:1 is closer to the form of this verse in Jerome's revision of the Latin Gospels (later adopted as the Vulgate) than Jerome's own citation here. Ambrose would have relied on a Vetus Latina gospel text when he preached on Luke: although it is just possible that he had a copy of Jerome's revision of the Gospels by the time 
he edited his his homilies, the textual affiliation of the commentary in general suggests that he did not refer to the Vulgate. Besides, Jerome's revision was based on an existing Old Latin tradition, and there is little difference between the majority of surviving Old Latin manuscripts and the Vulgate in the wording of this verse. ${ }^{40}$

The main differences in the Latin texts of Luke 1:1 above involve the participle $\pi \varepsilon \pi \lambda \eta \rho \circ \varphi \circ \rho \eta \tilde{\varepsilon} v \omega v$. Jerome, who normally seems more mindful of his target language when translating, here appears to opt for a literal translation of the Greek text in the copy of Origen in front of him. He ends up with the periphrastic, and more awkward, Latin construction de his rebus; Ambrose has the simpler rerum. Furthermore, Jerome cannot make up his mind how to translate the core meaning of the troublesome participle. He ends up translating it three different ways: de his rebus, quae manifestissime cognitae sunt in nobis; de his rebus, quae confirmatae sunt in nobis; in nobis manifestissime sunt ostensae. He excuses his indecision by commenting parenthetically quod uno verbo latinus sermo non explicat (which Latin speech does not express in a single word'). Ambrose consistently translates this participle as rerum quae in nobis conpletae sunt. He does hesitate slightly at one point, adding uel quae in nobis redundant as a gloss or expansion of the thought contained in $\pi \varepsilon \pi \lambda \eta \rho \circ \varphi \rho \rho \eta \mu \varepsilon v \omega \nu$. The irony is that, in striving to render Origen's words, Jerome seems to pay no attention to his Latin version of the Gospel of Luke completed perhaps five or so years earlier. The result makes for overly complicated Latin, especially compared to Ambrose's version. By 398, however, when Jerome composes the preface to his Commentary on Matthew, he cites Luke 1:1 with a text which, at least in modern editions, is much closer to what came to be known as the Vulgate. ${ }^{41}$

\section{The Anointing at Bethany (Luke 7:37-50)}

There are two main reasons why the gospel accounts about the woman who anointed Jesus are difficult for the Church Fathers. First and foremost, the

40 For more detail on the Old Latin tradition and its relationship to Jerome's 'translation', see the discussion in H.A.G. Houghton, The Latin New Testament: A Guide to its Early History, Texts, and Manuscripts. Oxford: OUP, 2016, 31-5.

41 Jerome, Commentariorum in Matheum, Prol. 1.2: quoniam quidem multi conati sunt ordinare narrationem rerum quae in nobis completae sunt. This commentary too relies heavily on Origen, although (ironically, given the discussion here) it is not presented as a translation; the preface, however, is Jerome's own work. 
details in Matthew and Luke seem to contradict each other: does the woman anoint Jesus' feet or his head, or both? ${ }^{42}$ Was Simon a Pharisee or a leper, or both? Did it happen at the beginning of Christ's ministry or in preparation for burial, or both? Second, the description of such an intimate anointing, particularly the more emotive narrative in Luke with its description of the weeping woman drying Jesus' feet with her hair and its reference to the woman as 'sinful', might be considered a bit too racy for a standard homily. Commentary on this passage is not extant in Jerome's translation of Origen's Lucan homilies: perhaps it was too controversial or challenging for him; or perhaps, more plausibly, he omitted it as the passage would be covered in exegesis elsewhere on the parallel Matthaean passage. A Greek fragment that seems to represent a portion of Origen's sermon on this pericope, however, survives in the catena tradition. As explained earlier, it is unclear whether Jerome possessed any text from Origen for this passage and whether or not the catena represents Origen's original text. What is clear is that Ambrose uses something quite similar to this catena, but also incorporates elements from other sources.

For this pericope, we therefore have Ambrose's commentary, a fragment which could be from Origen and silence from Jerome. Exegesis of the parallel text in Matthew, however, is found in Hilary of Poitiers' Commentary on Matthew. A close analysis of the data presented in the following table leads to the conclusion that Ambrose bases his exegesis on a combination of Origen (or at least the tradition represented in the catena fragment) and Hilary at this point:

\begin{tabular}{|c|c|c|}
\hline Hilary, In Matthaeum & $\begin{array}{l}\text { Origen, Frag- } \\
\text { ments in Luke }\end{array}$ & Ambrose, Exp. Luc. \\
\hline 29.1-2 (SC 258:218-20) & $\begin{array}{l}\text { (Fragment 113; } \\
\text { GCS 49:273) }\end{array}$ & $\begin{array}{l}\text { Exp. Luс. 6.14-16 } \\
\text { (CCSL 14:179-80) }^{43}\end{array}$ \\
\hline $\begin{array}{l}\text { cum autem esset Iesus in } \\
\text { Bethania in domo Simonis } \\
\text { leprosi, accessit ad eum } \\
\text { mulier habens alabastrum }\end{array}$ & 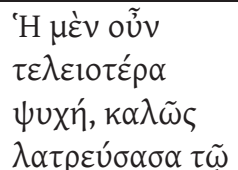 & $\begin{array}{l}\text { hanc ergo mulierem inducit } \\
\text { Matthaeus supra caput } \\
\text { Christi effundentem } \\
\text { unguentum et ideo forte }\end{array}$ \\
\hline
\end{tabular}

42 Luke 7:36-50 and Matthew 26:6-13. Further parallels are located in Mark 14:3-9 (which is similar to the Matthaean version) and John 12:1-8 (which is similar to the Luke version, apart from the identification of the main person at table with Jesus as Lazarus).

${ }^{43}$ This is an extract from Ambrose's much longer exegesis of this passage, extending from $6.12-35$. 


\begin{tabular}{|c|c|c|}
\hline $\begin{array}{l}\text { non ex nihilo est, ut mulier } \\
\text { unguentum pretiosum } \\
\text { recumbentis domini capiti } \\
\text { infuderit, dehinc ut discipuli } \\
\text { irascerentur et dicerent } \\
\text { uendi istud potius in usum } \\
\text { pauperum debuisse, tum ut } \\
\text { dominus et mulieris factum } \\
\text { comprobaret et aeternam } \\
\text { cum praedicatione euangelii } \\
\text { operis huius esse memoriam } \\
\text { sponderet, postremo ut post } \\
\text { id Iudas ad uendendam } \\
\text { salutem eius erumperet. } \\
\text { mulier haec in } \\
\text { praefiguratione gentium } \\
\text { plebis est, quae in passione } \\
\text { Christi gloriam deo reddidit. } \\
\text { caput enim eius perunxit } \\
\text { (caput autem Christi deus } \\
\text { est). nam unguentum boni } \\
\text { operis est fructus. et propter } \\
\text { corporis curam mulierum } \\
\text { sexui maxime gratum est. } \\
\text { igitur omnem curam } \\
\text { corporis sui et totum } \\
\text { pretiosae mentis adfectum in } \\
\text { honorem dei laudem que } \\
\text { transfudit. sed discipuli } \\
\text { fauore saluandi Israelis ut } \\
\text { saepe numero } \\
\text { commouentur: uendi hoc in } \\
\text { suum pauperum debuisse. } \\
\text { sed neque mulier haec } \\
\text { uenale unguentum } \\
\text { circumferebat et pauperes } \\
\text { fidei indigos instinctu }\end{array}$ & 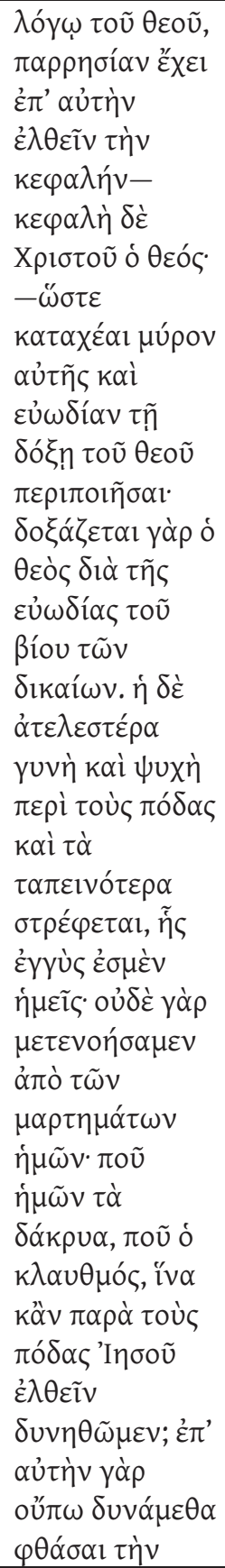 & $\begin{array}{l}\text { tricem; } \\
\text { ndum } \\
\text { ti pedes } \\
\text { potest } \\
\text { se, ne } \\
\text { ingelistae } \\
\text { otest } \\
\text { iti et } \\
\text { e } \\
\text { lla } \\
\text { ta } \\
\text { n } \\
\text { tamet } \\
\text { taque si } \\
\text { fideliter } \\
\text { deo, non } \\
\text { eruien- } \\
\text { entem } \\
\text { im } \\
\text { quod ad } \\
\text { idit } \\
\text { Christi } \\
\text { suorum. } \\
\text { odor } \\
\text { glaippe } \\
\text { um. si }\end{array}$ \\
\hline
\end{tabular}




\begin{tabular}{|c|c|c|}
\hline $\begin{array}{l}\text { atque hanc gentium fidem } \\
\text { emi potius ad salutem egeni } \\
\text { huius populi debuisse. } \\
\text { quibus dominus ait } \\
\text { plurimum esse temporis, } \\
\text { quo habere curam pauperum } \\
\text { possent; ceterum non nisi ex } \\
\text { praecepto suo salutem } \\
\text { gentibus posse praestari } \\
\text { quae se cum infuso mulieris } \\
\text { huius unguento sint } \\
\text { consepultae, quia regeneratio } \\
\text { non nisi commortuis in } \\
\text { baptismi professione } \\
\text { redhibetur. et idcirco ubi } \\
\text { praedicabitur hoc } \\
\text { euangelium, narrabitur opus } \\
\text { eius, quia, cessante Israel, } \\
\text { euangelii gloria fide gentium } \\
\text { praedicatur. qua aemulatione } \\
\text { in Iudae persona Israel } \\
\text { profanus accensus omni } \\
\text { odio ad exstinguendum } \\
\text { nomen domini incitatur. }\end{array}$ & 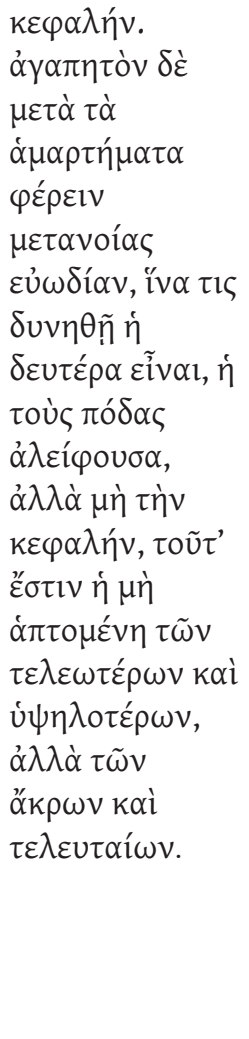 & $\begin{array}{l}\text { unguentum. qui accedit ad } \\
\text { caput nescit extolli, sicut ille } \\
\text { frustra inflatus mente carnis } \\
\text { suae et non tenens caput. } \\
\text { sed qui caput non tenet } \\
\text { Christi uel pedes teneat, } \\
\text { quia corpus unum } \\
\text { copulatum et subministra- } \\
\text { tum crescit in incrementum } \\
\text { dei. altera est illa, uel } \\
\text { persona altera uel profectu, } \\
\text { quae propinqua nobis est; } \\
\text { nondum enim peccatis } \\
\text { nostris renuntiauimus. ubi } \\
\text { sunt nostrae lacrimae, ubi } \\
\text { gemitus, ubi fletus? uenite, } \\
\text { adoremus et procidamus } \\
\text { ante eum et ploremus ante } \\
\text { dominum nostrum, qui } \\
\text { fecit nos, ut saltim ad pedes } \\
\text { Iesu uenire possimus. } \\
\text { nondum enim possumus, } \\
\text { peccator ad pedes, iustus ad } \\
\text { caput. }\end{array}$ \\
\hline
\end{tabular}

Hilary summarises the Matthaean version for his audience, sticking closely to the text before offering several figurative interpretations. He reminds them that Jesus is at the home of Simon the Leper in Bethany, and that the anointing takes place just before the Crucifixion. The woman anoints Christ's head, which Hilary takes as representing divinity, since 'the head of Christ is God' (1 Cor. 11:3). The disciples, though, argue over the cost. Yet for Hilary the woman prefigures the Gentiles who would give glory to God in Christ's Passion, and her story would be retold wherever the Gospel is preached to the Gentiles. The poor whom 'you will always have' (Matt. 26:11) represent those who are poor in faith, unbelieving. The perfume stands for the fruit of good work.

Origen, in Fragment 113, appears to comment on both main versions of the story-the one in which the woman anoints Christ's head (as in Matthew and Mark) and the one in which she anoints his feet (as in Luke and John). The fragment, however, begins in the middle of his explanation without any context or orientation. He interprets each woman allegorically 
and archetypically. The woman who stands at Christ's head and breaks the jar of perfume represents 'the more perfect soul ( $\dot{\eta} \tau \varepsilon \lambda \varepsilon 10 \tau \varepsilon$ p $\alpha$ $\psi u x \eta ́)$, serving the word of God well' and who has freedom ( $\pi \alpha \rho \rho \eta \sigma i ́ \alpha)$ to walk up to the head. Here Origen makes the same connection as Hilary with the verse declaring that 'the head of Christ is God'. Thus he explains that she who can approach Christ's head has by implication clear access to God. On the other hand, the 'less perfect woman — and soul' must remain at Christ's feet in humility. Origen shifts at this point into paraenesis: we, too, should be standing at Christ's feet, rather than his head, weeping as the sinful woman does.

So how does Ambrose expound the text? In a preceding section, just after the lemma, he launches into his interpretation by acknowledging the challenge:

Hoc loco plerique pati videntur scrupulum, serere quaestiones, utrumnam nideantur euangelistae duo discordasse de fide an uero aliquam in diuersitate dictorum dinersitatem signare noluisse mysterii.

This passage seems to embarrass many readers. They raise questions. Are two evangelists contradicting each other? Or did they, by each telling the story differently, wish to underline a different mystery? ${ }^{44}$

He then launches into a basic explanation of the differences between the story in Matthew and in Luke, highlighting three main points of conflict:

\begin{tabular}{|l|l|}
\hline Matthew & Luke \\
\hline Perfumed oil poured on head & Perfumed oil poured on feet \\
\hline $\begin{array}{l}\text { 'Perhaps this is why he is } \\
\text { unwilling to call her a sinner.' }\end{array}$ & $\begin{array}{l}\text { 'According to Luke, though, she } \\
\text { iHead = good] }\end{array}$ \\
\hline $\begin{array}{l}\text { Pharisees protest: concern over } \text { onclean] } \\
\text { sin }\end{array}$ & $\begin{array}{l}\text { Disciples protest: concern over } \\
\text { money }\end{array}$ \\
\hline
\end{tabular}

Ambrose tries to reconcile the differences. He posits that perhaps these are two different women. Another possibility is that it is one woman but at different times, demonstrating the possibility of 'progress in merit':

potest etiam quaestio meriti et diversitate temporis dissolui ... uel persona altera uel profectu. $^{45}$

${ }^{44}$ Ambrose, Exp. Luc. 6.12. 
Thus, when she was still a 'sinner', she stood at Jesus' feet; once she has progressed and has become 'more perfect' (perfectior, Exp. Luc. 6.14), she could move to his head. This attempt at harmonisation reveals that Ambrose cannot make up his mind: is there one woman or are there two? More significantly, he has more of an inclination to solve the problem than is apparent in the fragment from Origen. Origen seems content to let the two women represent two states of the soul. Ambrose borrows the figurative exegesis, but still wants to figure out the facts behind the story. He devotes a lot more time to this, discussing the pericope in twenty-four chapters, compared to just two in Hilary.

Unable to decide how to resolve this conundrum, Ambrose shifts into high paraenetic pathos, thereby providing further evidence of the commentary's homiletic origins in the basilica in Milan. Moreover, the exegesis here is about the right length for a sermon but, perhaps, too long for a commentary which, at that time, typical tended toward shorter, pithier exegesis. This paraenesis echoes the catena fragment of Origen, in which he

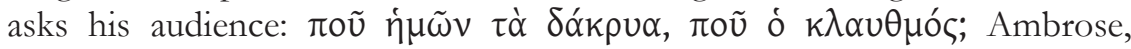
however, adds one more phrase to make it an even more emotional tricolon: ubi sunt nostrae lacrimae, ubi gemitus, ubi fletus? 46 The congregation is drawn into the scene, and their responsibility is made very clear. In the end, the hermeneutical turn is perhaps the only way to resolve the exegetical dilemma, at least in the homiletical Sitz im Leben for the texts of Origen and Ambrose.

\section{CONCLUSIONS}

\section{Ambrosius Interpres}

Does Ambrose commit plagiarism? Does he appropriate Origen for his own purposes? Does he misunderstand Origen's Greek? Or does he interpret Origen and recast his thought for a new pastoral context? In examining a couple of passages, a glimpse into the way he interacted with his sources has emerged. Ambrose's approach involves the complex synthesis of a range of sources with his own thoughts and pastoral concerns. To rephrase the title of Thomas Graumann's monograph on Ambrose's Commentary on Luke, it could be said that the Bishop of Milan

45 Ambrose, Exp. Luc. 6.14, 16.

46 Origen, Fragments in Luke, Fragment 113 (GCS 49.273); Ambrose, Exp. Luc. 6.16 (CCSL 14.180). Of course, it is possible that Origen's original phrase became truncated in the catena. 
was Ambrosius interpres - a broker of exegetical ideas. ${ }^{47}$ His specific methodology in incorporating a range of material remains a topic to be explored. Did he preach with commentaries or collections of homilies open? Or perhaps he spoke extemporaneously after reading a range of commentaries and then went over the transcripts with texts from Origen, Hilary and others in hand in order to form a commentary. The fact that he circles around and does not follow Origen's text in a purely linear fashion favours the latter explanation. Ambrose's approach still leaves plenty of room for his own interpretation.

\section{Polemic}

If plagiarism, or literary 'theft'-particularly of Greek texts by Latin authors-was so common in antiquity, and if Jerome himself borrowed from Origen without attribution, why would he make such a fuss over Ambrose's appropriation? Layton has proposed Jerome's fear of losing Roman patronage as one possible reason. On a broader scale, however, the accusation of plagiarism is a topos in ancient rhetoric, a form of intellectual one-upmanship. Perhaps Jerome was annoyed that Ambrose anticipated him in producing a commentary on Luke, just as he had with Didymus' On the Holy Spirit. Or perhaps he felt like picking a fight. Maybe he was truly frustrated to see how 'poorly' Ambrose translated Origen. But if that were the case, Jerome clearly misunderstood the nature of Ambrose's text: not a translation, not even really a pastiche, but more a patchwork in which the borrowed sections are quite obvious while the material on which they are sewn is also clearly seen and holds it all together.

\section{Nachleben}

Perhaps somewhat ironically, at least from Jerome's perspective, Ambrose became the authority on Luke in the Middle Ages. Partly this was by default, as the only other main ancient commentary was that of Origen, who began to be viewed as problematic around the end of the fourth century. Ambrose's Expositio was thus unchallenged as the main point of reference for further exposition and preaching on this Gospel. Despite Jerome's complaints and mocking, Ambrose's commentary carried the day.

47 Thomas Graumann, Christus interpres: Die Einheit von Auslegung und Verkündigung in der Lukaserklärung des Ambrosius von Mailand. PTS 41. Berlin \& New York: de Gruyter, 1994. 
The ascendancy and authority of Ambrose's Lucan homilies were further sealed by their incorporation into the Roman liturgy for Advent and Christmas. The faithful would thus hear his words read out alongside the passages of the Christmas story. For example, on the Fourth Sunday of Advent, congregations in the Western Church might hear the words of the Bishop of Milan describing Mary's visit to her cousin Elizabeth, from Book $2 .{ }^{48}$ In a broader sense, beyond the Commentary on Luke, Ambrose becomes the key conduit of Origen's exegesis to the West, not only in his own works, but also through those exegetes directly influenced by him, in particular Augustine.

48 Ambrose, Exp. Luc. 2.19, 22-3, 26-7. Some contemporary versions of the Divine Office still maintain this tradition, e.g.:

http://divineoffice.org/1221-or/\#sthash.sMfgtYoU.dpbs (last accessed on 25 February 2016). 



\title{
11. RUFINUS' TRANSLATION OF ORIGEN'S COMMENTARYON ROMANS
}

\author{
CHRISTINA M. KREINECKER ${ }^{1}$
}

Without Rufinus and his ambitions as a translator of early Christian Greek authors, the modern world would hardly know anything about Origen's Commentary on Romans. Rufinus' version is far from being a literal, formally equivalent translation. Reading between the lines of his text prompts many questions about themes relating to early Christianity. The main focus of the present contribution, however, is to take a closer look at the biblical text of Romans, both in the lemmata and the exegesis of this commentary. After some general observations on Rufinus and his translation 'policy', the article will investigate the character of the Latin biblical text and will finally give examples of various treatments of the biblical text detectible in Rufinus' commentary. The aim is to highlight Rufinus' work as a translator by illustrating and analysing some of the most prominent phenomena regarding the biblical text. It will be argued that there is not one single 'technique' or 'pattern' present in how Rufinus treats the biblical text, but that he is flexible and versatile in his treatment. The various different ways in which Rufinus refers to the Bible enable us to draw conclusions about the different texts on which he drew, including his use of Latin biblical manuscripts, reliance on his 'mental text' and direct translation from Greek.

Before proceeding any further, I must pay tribute to the extensive and thorough research on Rufinus undertaken by Caroline P. Hammond Bammel, as witnessed by her remarkably rich volumes and many articles on Rufinus' Commentary on Romans. The present conspectus relies in large part

1 The research leading to these results has received funding from the European Union Seventh Framework Programme (FP7/2007-2013) under grant agreement no. 283302 (COMPAUL). 
on these studies, and it can only attempt to revisit some of her many important observations.

\section{RUfinus BETWEen AUTHOR AND Translator}

Tyrannius Rufinus was born in 344/345 in the region of Concordia, west of Aquileia. He studied in Rome for around a decade (358/9-368) and was baptised upon his return to Aquileia in an ascetic community of clerics in the early 370s. His travels around the Mediterranean began in about 373, when he studied for eight years in Egypt, spending time with Didymus the Blind in Alexandria as well as with ascetics in the desert. Afterwards he went to Jerusalem, where he founded a monastery on the Mount of Olives, close to the convent established by Melania the Elder, whom he had got to know in Alexandria. In 397 he returned to Rome and in 399 he went back to Aquileia. Those years until his death were the ones in which he produced most of his translations, including many of Origen. The invasion of the Goths in the early years of the fifth century 'forced him to seek refuge at Rome, then at the monastery of Pinetum (on the Tyrrhenian Coast, near Terracina) and finally in Sicily'. ${ }^{2}$ It is still debated whether he translated Origen's commentary somewhere close to Aquileia or in the south of Italy like Campania. ${ }^{3}$ He died in Messina in Sicily around 411.4

The Greek text of Origen's Commentary on Romans is more or less lost to us. The principal remains are excerpts in the Philocalia, an anthology of Origen's works and texts compiled by Basil the Great and Gregory of Nazianzus at some point in the mid fourth century. ${ }^{5}$ The Philocalia constitutes the largest portion preserved in Greek, though it does not even represent a single section of Origen's commentary. Some of the text is

2 Angelo Di Berardino, ed. The Golden Age of Latin Patristic Literature: From the Council of Nicea to the Council of Chalcedon. Vol. 4 of Patrology. 14 $4^{\text {th }}$ edn. Allen: Christian Classics, 2001, 248.

3 See Caroline P. Hammond, 'The Last Ten Years of Rufinus' Life and the Date of his Move South from Aquileia.' JTS ns 28 (1977) 372-429, who argues that Rufinus left Aquileia in the early fifth century and finished the translation of the Commentary on Romans around 405/406.

${ }^{4}$ Hubertus R. Drobner, The Fathers of the Church: A Comprehensive Introduction. Translated by Siegfried S. Schatzmann. Peabody: Hendrickson, 2007, 338.

5 See, for example, Marguerite Harl and Nicholas R. M. De Lange, ed., Origène: Philocalie, 1-20. Sur les écritures et la lettre à Africanus sur l'histoire de Suzanne. SC 302. Paris: Cerf, 1983; Éric Junod, ed., Origène: Philocalie, 21-27. Sur le libre arbitre. SC 226. Paris: Cerf, 1976. 
preserved in catenae, such as Vatican, BAV, Vat. gr. 762 (GA 1915, tenth century) and Vienna, ÖNB, gr. 166 (GA 1953, fourteenth century). ${ }^{6}$ In addition there is the famous papyrus from Tura (close to Cairo), discovered in 1941, which may date back to the seventh century. ${ }^{7}$ Other clues to the Greek text may be seen in marginal notes in the so-called Codex von der Goltz (GA 1739). ${ }^{8}$ There are also quotations preserved in some other works of Origen, in the Apologia pro Origene by Pamphilus (itself only preserved in a Latin translation), in the De Spiritu Sancto by Basil and some others. ${ }^{9}$

A comparison between the remaining parts in Greek and the Latin translation provided by Rufinus shows that the translation is not literal or formally equivalent in a modern sense. ${ }^{10}$ First of all, Rufinus shortened

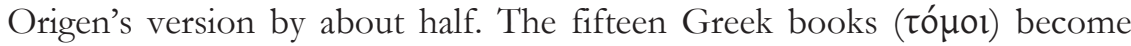
ten Latin ones, resulting in one Latin book covering between one and two Greek tópol. Despite Rufinus' shortening, the Latin version is enormous. In fact the transmission of the text is indicative of its rather inconvenient length, because for a long period Books 1-5 and Books 6-10 were transmitted separately. They therefore show different traces of reception and handling and reflect different linguistic influences. ${ }^{11}$

No general pattern has emerged from comparisons between the remaining Greek text and the Latin translation. ${ }^{12}$ Rufinus neither systematically omits digressions, nor does he change the overall structure.

6 See A. Ramsbotham, 'The Commentary of Origen on the Epistle to the Romans.' JTS os 13 (1911) 209-224; 357-368; 14 (1912) 10-22.

${ }^{7}$ See Jean Scherer, Le Commentaire d'Origène sur Rom III.5-V.7 d'après les extraits du papyrus no. 88748 du musée du Caire et les fragments de la Philocalie et du Vaticanus gr. 762: Essai de reconstitution du texte et de la pensée des tomes $V$ et $V I d u$ 'Commentaire sur l'Épitre aux Romains'. Cairo: Institut Français d'Archelogie Orientale, 1957; H. Chadwick, 'Rufinus and the Tura Papyrus of Origen's Commentary on Romans.' JTS ns 10 (1959) 10-42.

8 Otto Bauernfeind, Der Römerbrieftext des Origenes nach dem Codex von der Goltz: (Cod. 184 B 64 des Athosklosters Lawra). Leipzig: Hinrichs, 1923.

9 See Caroline P. Hammond Bammel, Der Römerbrieftext des Rufin und seine Origenes-Übersetzung. AGLB 10. Freiburg: Herder, 1985, 18-39.

${ }^{10}$ When looking at the Tura Papyrus, Chadwick claims that in general Rufinus's method appears to be the same' as in his other translations: 'he gives a prolix but more or less faithful paraphrase, which frequently takes mild liberties with the text and pays no special heed to exactitude, but normally preserves the general sense' ('Rufinus and the Tura Papyrus', 15).

${ }^{11}$ See Hammond Bammel, Der Römerbrieftext des Rufin, 173-4; 104-134.

12 See Hammond Bammel, Der Römerbrieftext des Rufin, 47 note 16; 55-6. 
On the contrary, Rufinus seems to have followed the sections he found in his Vorlage of Origen's commentary and he also seems to have kept the general structure both of the alternation of lemma and exegesis as well as the extent of each lemma. So the shortening takes place within the exegesis, but-again — not in a systematic way that allows the identification of a pattern. Despite the fact that Rufinus shortens Origen's text he himself is still rather 'epic' and verbose in his own Latin style. This, of course, leaves numerous questions about the Greek text as written by Origen. ${ }^{13}$

Characteristics of Rufinus' translation technique have been established from his translations of other Greek authors. ${ }^{14}$ Paraphrase and the liberal rendering of his Vorlage are the most significant. He extends, shortens, emphasises or compresses the Greek text, he sometimes gives more than one Latin word or phrase to represent the Greek and offers additional explanations. Rufinus does not hesitate to leave out entire passages and he has no qualms about changing the text slightly for his readers' benefit. ${ }^{15}$ Particular caution was needed when translating Origen's theological arguments that were suspected of heresy. Rufinus was aware of the risks he was putting himself under by translating a debated author: this is seen especially in his methodological reflections on his translation of De Principiis

${ }^{13}$ See Hammond Bammel, Der Römerbrieftext des Rufin, 54.

14 See M. Monica Wagner, Rufinus, the Translator: A Study of his Theory and his Practice as illustrated in his Version of the Apologetica of St. Gregory Nazianzen. CUA Patristic Studies 73. Washington: CUA, 1945 (pages 77-96 focus on Rufinus' treatment of the biblical text). Wagner sums up her analysis as follows:

'[Rufinus'] method, admittedly involving adaptation devices such as; e.g., paraphrase, expurgation, explanation, he regarded as essential to the clear and innocuous presentation required for his purpose; and he invoked as precedent the practice of other translators, particularly that of his contemporary, St. Jerome. At the same time his many protestations would suggest that Rufinus was aware of other methods of procedure but that he intentionally adopted a methodology more serviceable to him as a popularizer' (97).

See also Gustave Bardy, 'Le Texte de l'Épitre aux Romains dans le Commentaire d'Origène-Rufin.' RevBib 29 (1920) 229-41.

15 Many reasons may be suggested for Rufinus' abbreviations and alterations, though it has been suspected that in some instances he does not want to exhaust his readers with excessively theological statements: see Hammond Bammel, Der Römerbrieftext des Rufin, 47-8; 57. One of the rare occasions on which Rufinus provides a justification for his deliberate changes is his desire to keep his readers' consuetudo undisturbed. See also Section (e) below. 
present in his Apology against Jerome, one of his major critics. ${ }^{16}$ There he distinguishes between the text he translates and the translation he produces in terms of orthodoxy:

non enim generaliter promisi me non prolaturum quae essent fidei contraria, sed quae sibi ipsi essent contraria, uel quae a semetipso discreparent, non quae a me uel ab alio aliquo discreparent. non ergo ex boc sermone subripientes inimici calumnias generent, ut dicant me promisisse quia, si quid contrarium est uel discrepat a fide nostra, non proferam. hoc etiam si facere potui, tamen promittere non auderem. ${ }^{17}$

For I did not promise generally that I would not publish what was contrary to faith, but what was contrary to himself [ $=$ Origen] or what differed from himself, not what differed from me or anyone else. For my opponents shall not give rise to calumny by dodging this statement with the result that they say that I had promised not to publish if anything was contrary or differed from our faith. For if I had been able to do this I nevertheless would not have dared to promise it.

In short, Rufinus claims that he is not responsible for the orthodoxy of his translation, only for his translation to be faithful to Origen.

The fact that Rufinus' translation is rather a translation of Origen's ideas and thoughts while keeping the same structure he saw in his Vorlage, is not a modern discovery and was already clear to Rufinus' contemporaries. ${ }^{18}$ Apparently Rufinus had been criticised for keeping Origen's name as the author while he presents himself as the mere translator. In his epilogue, Rufinus writes about his critics:

aiunt enim mibi: in bis quae scribis, quoniam plurima in eis tui operis babentur, da titulum nominis tui et scribe: Rufini - uerbi gratia - in epistulam ad Romanos explanationum libri, sicut et apud auctores - inquiunt - saeculares non illius, qui ex Graeco translatus est, sed illius, qui transtulit, nomen titulus tenet. hoc autem totum mibi donant non amore mei, sed odio auctoris. ${ }^{19}$

16 See Hammond Bammel, Der Römerbrieftext des Rufin, 50.

17 Apologia contra Hieronymum I 14. Apart from the capitalisation the text follows Manlio Simonetti, ed., Tyrannii Rufini Opera. CCSL 20. Turnhout: Brepols, 1961, 47. See also Hammond Bammel, Der Römerbrieftext des Rufin, 49.

18 See Hammond Bammel, Der Römerbrieftext des Rufin, 43-58.

19 The text (apart from capitalisation) follows Hammond Bammel, Caroline P. Der Römerbriefkommentar des Origenes: Kritische Ausgabe der Übersetzung Rufins. Buch 710. aus dem Nachlass herausgegeben von H.J. Frede und H. Stanjek. AGLB 34. Freiburg: Herder, 1998, 861, lines 27-33. 
For they say to me: 'Because many things in those that you write are of your own doing, put your name on top and write for example "Commentary on Romans by Rufinus", just as - they say - is also the case with pagan authors. These do not have the name of the one who is translated from the Greek, but the name of the one who translated it. Yet all of this they grant me not because of love for me, but because of hate of the author.

From these observations, and even more from the theological statements made throughout the commentary, it becomes obvious that Rufinus has everything but 'hate of the author'. The hate he mentions seems to refer to the increasing dislike of Origen in the fourth century CE and the rejection of many of his teachings. Epiphanius of Salamis, for example, listed Origen as a heretic in his Panarion written in the 370s. The growing rejection of Origen's views would result in his official condemnation at the Synod of Constantinople in $543 \mathrm{CE}$ and its confirmation at the Second Council of Constantinople ten years later. Rufinus, however, was a supporter of Origen. The people he met and with whom he studied were regularly supporters of Origen themselves (e.g. Didymus, John of Jerusalem) and the most prominent figures in theological debates at this time were all heavily influenced by Origen (cf. Basil the Great, Gregory of Nyssa, Gregory of Nazianzus, Hilary, Ambrose etc.). Furthermore, for his translations Rufinus chose authors who were positive towards Origen's ideas, such as Eusebius, Pamphilus, Basil, Gregory of Nazianzus and Evagrius. ${ }^{20}$ Rufinus tried to translate not only Origen's Greek words but, even more, his ideas in order to make them available in the West:

Rufinus did not pursue the philosophical goal of producing literal transmission but aspired to provide his contemporaries with what was needed to manage the problems of their present, by means of the Greek cultural and theological heritage, which was being passed on less and less because of dwindling conversance with the language. ${ }^{21}$

He brings Origen's ideas to life in his own surroundings and updates them to match a context different to that for which Origen wrote.

\footnotetext{
20 See Hammond Bammel, Der Römerbrieftext des Rufin, 50-1.

${ }^{21}$ Drobner, The Fathers of the Church, 338.
} 


\section{The Biblical TeXT IN LEMma AND EXegesis}

Rufinus seems to have kept the structure (lemma - exegesis) that he found in Origen. In addition, he also seems to have preserved the same extent of each lemma in Origen's commentary. Rufinus' lemmata can comprise one or more biblical verses. In addition to the 'initial lemmata' (Hauptlemmata), Rufinus also has 'side lemmata' (Nebenlemmata), which repeat parts of the initial lemma at a later point in the exegesis. Both the Hauptlemma and the Nebenlemma are usually marked in manuscripts. As for the text, everything in Rufinus' translation points to his lemmata as being taken from a Latin biblical manuscript and not a translation of Origen's text of the Pauline letter. ${ }^{22}$ Extracting all the lemmata out of Rufinus' commentary and assembling them into a single text, as Hammond Bammel did, results in a continuous Latin version of Romans which is unknown to us from surviving manuscripts. ${ }^{23}$ Frede has suggested that the biblical manuscript the lemma text is taken from belongs to the Vetus Latina text-type I, which was primarily used in Italy. ${ }^{24}$

There are many indications of the fact that the biblical text comes from a separate manuscript. ${ }^{25}$ Among these is the fact that Rufinus makes text-critical remarks about his text of Romans, sometimes criticising the Latin with respect to the Greek. If he had made a literal translation it is unlikely that such remarks would have been necessary: he could easily have adapted his translation and would not have had to tell his readers about such matters. Another strong argument for a separate biblical manuscript is

22 Robert Schlarb, Wir sind mit Christus begraben: Die Auslegung von Römer 6,1-11 im Frühchristentum bis Origenes. Beiträge zur Geschichte der biblischen Hermeneutik 31. Tübingen: J.C.B. Mohr (Paul Siebeck), 1990, 21-44, gives a brief overview of Origen's Pauline text.

${ }^{23}$ Hammond Bammel, Der Römerbrieftext des Rufin, 503-37.

${ }^{24}$ Hermann Josef Frede, Altlateinische Paulus-Handschriften. AGLB 4. Freiburg: Herder, 1964, 137-44. See also Hammond Bammel, Der Römerbrieftext des Rufin, $142-4$.

25 See, for example, Hammond Bammel, Der Römerbrieftext des Rufin, 145-57, where she compares the lemma text to Augustine, Ambrosiaster, the anonymous Budapest commentary, Codex Sangermanensis and Claromontanus, Pelagius, Sedulius, the Book of Armagh, the Monza manuscript and the quotations of Romans in Chromatius. Particularly worth mentioning is the connection between Rufinus' lemma text and Budapest (VL 89): the correspondences between these seem to be a result of a revision of the text in Budapest according to the Pauline text given by Rufinus (148-9). 
the observation that two manuscripts of Ambrosiaster (A and W) have a similar text in their lemmata to that given by Rufinus, shown by many readings unique to these witnesses. The Ambrosiaster manuscripts, however, are transmitted independently of Rufinus' commentary: their text is not exactly identical and manuscript $A$ also includes a revised text of 1 Corinthians. ${ }^{26}$ The proximity of the texts could be the result of reliance on the same Vorlage, followed by further independent correction of the texts, or a number of more complicated scenarios also suggested by Hammond Bammel. ${ }^{27}$

The fact that Rufinus took his lemma text from an independent biblical manuscript opens up many new questions that, for the time being, have to remain unanswered: where did Rufinus see this manuscript? Was it his own, which he carried around with him? Or was it in the possession of one of the monasteries in which he stayed during his travels? These questions are closely linked to that already raised above concerning where Rufinus translated this commentary: Aquileia, Sicily, or somewhere in between. ${ }^{28}$ The possibility that Rufinus' biblical text was also influenced by the places in which he spent time (Jerusalem, Rome, etc.) has to be considered too, even if certainty is impossible. One question, however, may be answered with caution: why are there so many correspondences between Origen's biblical text and the Latin lemmata despite the latter not being a translation of the former? Hammond Bammel has plausibly suggested that the Latin text was adapted according to a Greek model at some point, possibly even by Rufinus. ${ }^{29}$ According to her, Rufinus' mental text must have influenced some of his exegetical comments and is most likely to represent a Latin version known in Aquileia, where Rufinus spent so many years of his life. ${ }^{30}$

The practical incorporation of the lemma text into the commentary may have been by means of gaps left between the dictated exegetical

\footnotetext{
26 Hammond Bammel, Der Römerbrieftext des Rufin, 145 and 467-80.

27 Hammond Bammel, Der Römerbrieftext des Rufin, 145.

28 See Hammond Bammel, Der Römerbrieftext des Rufin, 144.

${ }^{29}$ Hammond Bammel, Der Römerbrieftext des Rufin, 146-72, especially 158-9.

30 Hammond Bammel, Der Römerbrieftext des Rufin, 140. In favour of the idea that Rufinus stayed with the Aquileian text is the observation that in his exegesis of the creed (symbolon) for Bishop Laurentius he kept to the Aquileian version despite many comments which show his awareness of other forms (Expositio Symboli 3, cf. Simonetti, Tyrannï Rufini Opera, 136).
} 
sections which were later completed from the biblical exemplar. ${ }^{31}$ From time to time, however, Rufinus simply translated the Greek biblical text from his copy of Origen. This is particularly evident in the out-of-sequence quotations of Romans. One example to illustrate this is Romans 3:28. The text of this verse is preserved not only in both the lemma and exegesis at the relevant place in the commentary but also in an out-of-sequence quotation in the exegesis of Romans 4:1-6. In addition-and this is crucial for the argument here- the exegetical section treating Romans 3:28 has also survived in Greek. ${ }^{32}$

In the lemma of Romans 3:28 Rufinus has arbitramur enim iustificari bominem per fidem sine operibus legis ('for we state that a person is justified by faith without the works of the law'). The word order is 'justify' (iustificari) 'person' (bominem) - 'faith' (per fidem). This is preserved in the exegesis immediately following, e.g. quia recte arbitratur apostolus iustificari hominem per fidem sine operibus legis ('because the apostle rightly states that a person is justified by faith without the works of the law'). ${ }^{33}$ This is particularly interesting when one looks at the Greek in the Tura papyrus, where the Greek biblical text has a different word order, placing 'faith' between

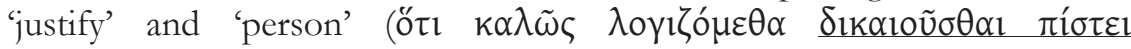
óv $\theta \rho \omega \pi$ ov $\chi \omega \rho i \varsigma$ है $\rho \gamma \omega v$ vópov). The Greek word order corresponds with the editorial text of NA28 ( $\chi \omega$ pis है the exegesis of Romans 4:1-6, however, Rufinus corresponds to the Greek text preserved in the Tura Papyrus and does not follow the word order of his lemma and exegesis a couple of verses earlier. The Greek in the exegesis

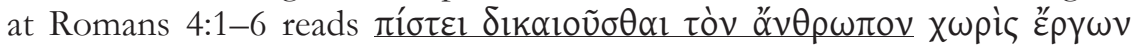
vónou ('by faith the person is justified without the works of the law') with

31 Hammond Bammel, Der Römerbrieftext des Rufin, 182-7. See also Caroline P. Hammond, 'A product of a fifth-century scriptorium preserving conventions used by Rufinus of Aquileia.' JTS ns 29 (1978) 366-91 (especially 387-9).

32 Scherer, Le Commentaire d'Origène sur Rom III.5-V.7, 162-8: the passage occurs on 164, lines 15-16. See also Hammond Bammel, Der Römerbrieftext des Rufin, 312 3.

33 For the text see Caroline P. Hammond Bammel, Der Römerbriefkommentar des Origenes: Kritische Ausgabe der Übersetzung Rufins. Buch 1-3. AGLB 16. Freiburg: Herder, 1990, 247, lines 2-3 (lemma) and 249, lines 52-3 (exegesis). Other examples of the same word order can be found on 248, lines 21-2 and on 252, lines 106-7. 
the word order 'faith' - 'justify' - 'person'.34 Rufinus' translation corresponds exactly to the Greek: fide iustificari hominem sine operibus legis. 35 Although the explanation is speculative, it seems that in the earlier examples Rufinus was following the text prompted by his Latin lemma-if, indeed, he was looking at his biblical exemplar while dictating, given that the lemma text may have been filled in afterwards-while in his out-of-sequence quotation he translated the Greek directly, maintaining formal correspondence. It seems unlikely that he did not recognise the biblical quotation, or that he relied on a Latin mental text that happened to correspond to Origen's Greek and not the Latin manuscript to which he had access. There are, however, plenty of occasions where Rufinus differs from his lemma text in his exegesis. ${ }^{36}$ From this one has to conclude, once again, that there is neither a systematic pattern to Rufinus' translation of Origen's Greek nor a consistent treatment of the biblical text in the lemma or the exegesis. Instead, Rufinus' translation shows a variety of different, sometimes even opposite, treatments of the biblical text, as the following examples will illustrate.

\section{OBSERVATIONS ON THE BIBLICAL TEXT IN LEMMA AND EXEGESIS $^{37}$}

\section{A. The Missing Lemma (or A Lemma Dilemma)}

In order to be able to compare the lemma with how Rufinus treats his biblical text in his exegesis, both must be present in the textual tradition. There are, however, some instances where the lemma is not extant: either it was lost at some point in the work's transmission or it was never there in

34 The relevant passage can be found in Scherer, Le Commentaire d'Origène sur Rom III.5-V.7, 178, line 12.

35 See Caroline P. Hammond Bammel, Der Römerbriefkommentar des Origenes: Kritische Ausgabe der Übersetzung Rufins. Buch 4-6. Zum Druck vorbereitet und gesetzt von H.J. Frede und H. Stanjek. AGLB 33. Freiburg: Herder, 1997, 269, line 15.

36 See Hammond Bammel, Der Römerbrieftext des Rufin, 57. Some examples are given below.

${ }^{37}$ In this section, quotations of the text are taken from the three volumes of Hammond Bammel's critical edition (Der Römerbriefkommentar des Origenes) for which bibliographic details have already been provided: Books 1-3 are indicated by I, Books $4-6$ by II, and Books $7-10$ by III. These are followed by the page number and line number in Arabic numerals. 
the first place. Romans 8:16 seems to offer an example of the former scenario, while the latter is illustrated at Romans 6:7.

Book 6 of Rufinus' translation ends with the explanation of Romans 8:12-13; there is no significant indication that this passage goes beyond the latter verse. ${ }^{38}$ Accordingly, the lemma for Romans 8:14-17 should appear at the beginning of Book 7. However, while there is a quotation from these verses at this point, it is not complete. It is therefore impossible to reconstruct the lemma text Rufinus would have taken from his biblical exemplar. This may be demonstrated in detail with regard to Romans 8:16, which, in the Vulgate, reads ipse spiritus testimonium reddit spiritui nostro quod sumus filii dei. ${ }^{39}$ Rufinus quotes each word of the verse in his exegesis, but not in a consistent or exclusive way. In addition, a comparison of the main manuscripts of Rufinus' commentary shows that it is impossible to reconstruct a single version of Romans 8:16 that can be taken either as Rufinus' mental text or the reading of his Latin biblical manuscript.

The following table presents the text of Romans 8:16 in Rufinus' commentary and the variations in its manuscript tradition:

\begin{tabular}{|c|c|c|c|}
\hline a) & $\begin{array}{l}\text { ipse spiritus } \\
\text { (III 553.12-13; 555.40-41) }\end{array}$ & & \\
\hline b) & $\begin{array}{l}\text { testimonium reddit } \\
\text { (III 553.12-13; 554.14) }\end{array}$ & $\begin{array}{l}\text { reddit testimonium } \\
\text { (III 558.99-100) }\end{array}$ & \\
\hline c) & $\begin{array}{l}\text { reddit } \\
\text { (III 553.13; 554.14; 555.41; } \\
558.99 \text { ) }\end{array}$ & $\begin{array}{l}\text { reddet } \\
\text { (Y M at III 553.13; } \\
554.14 ; 555.41 ; \mathrm{A} \text { at III } \\
553.13 ; 554.14 ; \mathrm{T} \text { at III } \\
554.14)\end{array}$ & $\begin{array}{l}\text { addit } \\
\text { (W at III 555.41) }\end{array}$ \\
\hline d) & $\begin{array}{l}\text { spiritui nostro } \\
\text { (III } 553.12-13 ; 555.40-41 \text {; } \\
\text { K M? at } 554.14 \text { ) }\end{array}$ & $\begin{array}{l}\text { nostro spiritui } \\
\text { (III 554.14) }\end{array}$ & $\begin{array}{l}\text { spiritui } \\
\text { (Y H A T L P M } \\
\text { at III 554.14) }\end{array}$ \\
\hline e) & $\begin{array}{l}\text { quod } \\
\text { (III 559.117) }\end{array}$ & $\begin{array}{l}\text { quia } \\
\text { (III 558.100) }\end{array}$ & \\
\hline f) & $\begin{array}{l}\text { sumus filii } \\
\text { (K at III 558.100) }\end{array}$ & $\begin{array}{l}\text { filii sumus } \\
\text { (III 559.116 and 117) }\end{array}$ & \\
\hline g) & $\begin{array}{l}\text { filii dei } \\
\text { (Y at III } 559.116 \text { and } 117 \text { ) }\end{array}$ & $\begin{array}{l}\text { filii } \\
\text { (III 559.116 and 117) }\end{array}$ & \\
\hline
\end{tabular}

38 See Hammond Bammel, Der Römerbrieftext des Rufin, 200.

39 The Vulgate is quoted from Robert Weber and Roger Gryson, ed., Biblia Sacra Iuxta Vulgatam Versionem. 5th edn. Stuttgart: Deutsche Bibelgesellschaft, 2007. 
The only words which are invariant are the first two, ipse spiritus. The next are quoted as testimonium reddit at III 553.12-13 and 554.14, but reddit testimonium at III 558.99-100. Not only does this make it impossible to determine Rufinus' text, but the matter gets more complicated when the manuscripts of the commentary are taken into consideration. Some manuscripts read reddet, a widely-attested alternative to reddit in biblical tradition, in up to three of the four occurrences of the phrase. There is even one example of addit instead. Similar variations are found for spiritui nostro, also found as nostro spiritui or just spiritui. The causal conjunction is given as quia on the first occurrence but quod the next time. The word order sumus filii occurs in $\mathrm{K}$ at III 558.100 but on the next page it is filii sumus, where manuscript $\mathrm{Y}$ also adds dei. These variations illustrate the impossibility of reconstructing a single form of Romans 8:16 in Rufinus which would represent his lemma. Furthermore, the textual critic is faced with the dilemma that, while numerous readings are supported by the commentary and its manuscripts, there is little in the way of unanimity which would justify the use of Rufinus as a witness for any particular form.

The second scenario, in which the lemma may never have been present, appears to be the case at Romans 6:7.40 Not only is the lemma lacking but this verse is not even quoted in the exegesis of this passage, although Rufinus does refer back to it in his exegesis of Romans 6:12-14, 20-22. Its omission may easily be explained as a scribal error occasioned by eyeskip from an instance of peccatum ( $\alpha \mu \alpha \rho \tau i ́ \alpha)$ in Romans $6: 6$ to that at the end of Romans 6:7, as shown in the following texts from NA28 and the Stuttgart Vulgate:

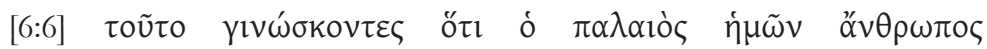

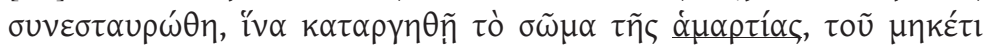

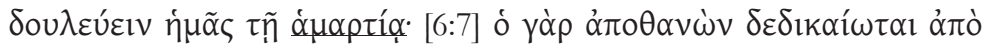
$\tau \tilde{\eta} \varsigma \alpha \dot{\alpha} \mu \alpha \rho \tau i ́ \alpha \varsigma$

[6:6] boc scientes quia vetus homo noster simul crucifixus est ut destruatur corpus peccati ut ultra non serviamus peccato [6:7] qui enim mortuus est iustificatus est a peccato.

What is not clear, however, is the exact point at which this happened. Was the verse missing from Rufinus' copy of Origen, from his biblical exemplar, or from both? Although the identical form of peccato at the end of Romans 6:6 and peccato at the end of 6:7 suggests that Latin is the most likely

40 See Hammond Bammel, Der Römerbrieftext des Rufin, 199-200. 
language in which this happened, this verse is not quoted in any of Origen's works and is also missing from Greek catenae. On the other hand, parts of Romans 6:6 in addition to all of 6:7 are missing from other quotations of this passage in Latin tradition (Tertullian, De Pudicitia and Ambrosiaster, Commentary on Romans). Had it appeared either in his Latin biblical codex or his exemplar for the commentary, Rufinus might have noticed the discrepancy: then again, it could be that it was present in his Latin manuscript but was overlooked when the lemma was added. Either way, the absence of this verse from his copy of Origen is more plausible than Rufinus' deliberate excision of references to it at this point in the commentary based on a defective Latin text of Romans.

\section{B. Contradictions between Lemma and Exegesis}

Instances where the exegesis or its biblical quotations do not correspond to the Latin lemma text are intriguing. It is much more likely that Rufinus did not adapt the exegesis he saw in Origen's text to the Latin text which he used for a lemma than that he made a mistake. He also did not alter the lemma to match the exegesis. In several instances, this results in a contradiction between the Latin lemma and the exegesis, as may be seen in Romans 8:38 and Romans 16:12a. ${ }^{41}$

The text of Romans 8:38-9 in NA28 reads:

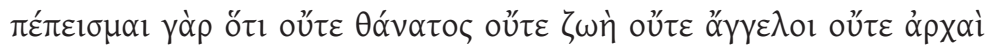

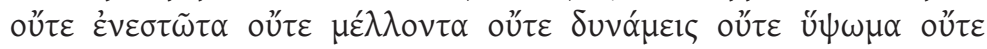

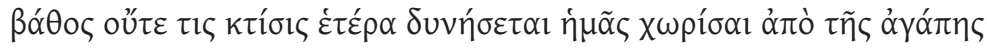

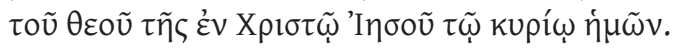

For I am convinced that neither death, nor life, nor angels, nor rulers, nor things present, nor things to come, nor powers, nor height, nor depth, nor anything else in all creation, will be able to separate us from the love of God in Christ Jesus our Lord. (NRSV)

GA 04 (the fifth-century Codex Ephraemi Rescriptus) and GA 81 and 104

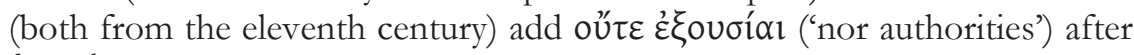
ảpxoí ('rulers') in Romans 8:38. This seems very likely to have been present in Origen's biblical text, as Rufinus' exegesis reads neque principatus neque uirtutes neque praesentia neque futura neque nirtutes. It appears that the first neque

41 See Hammond Bammel, Der Römerbrieftext des Rufin, 57, who lists many more examples on $271-2$. 


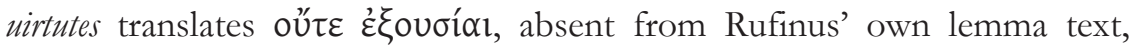

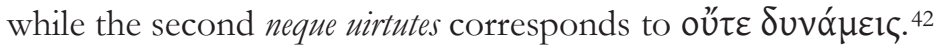

Romans 16:12 in NA28 and the Vulgate reads:

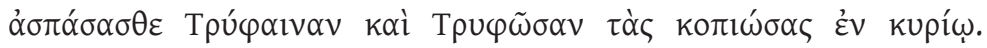

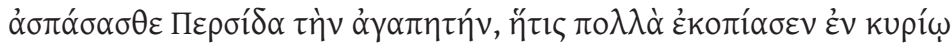

salutate Tryfenam et Tryfosam quae laborant in domino; salutate Persidam carissimam quae multum laboravit in domino.

Greet Tryphaena and Tryphosa, who have worked in the Lord. Greet the beloved Persis, who has worked hard in the Lord. (NRSV)

Rufinus' lemma text, however, reads quae multum laborant ('who have worked hard') at the beginning of the verse in addition to quae multum laboravit at the end, with no variant in the commentary's textual tradition. His exegesis of Romans 16:12a, however, does not refer to multum but focusses on in domino:

salutate Tryfenam et Trifosam quae multum laborant in domino. bonum de his dat testimonium quarum laborem non buius mundi neque communis uitae sed in domino esse testatur. multi enim laborant sed non omnium laborem constat esse in domino.

'Greet Tryphaena and Tryphosa, who work much in the Lord.' He gives them a good reference, when he attests that their work is neither from this world nor part of everyday life, but in the Lord. For many work, but it is clear that not everyone's work is in the Lord.

His exegesis of Romans 16:12b, however, appears to be based on the omission of multum in the first half of the verse:

salutate Persidam carissimam quae multum laboranit in domino. videtur haec magis laudari quam Tryfena et Tryfosa; quoniam quidem illas laborasse dicit in domino, hanc autem multum laborasse in domino, cui addidit et 'carissima'.

'Greet the beloved Persis, who worked much in the Lord.' It seems that this woman is praised higher than Tryphaena and Tryphosa; for he certainly says that those women have worked in the Lord, but this woman has worked much in the Lord, to whom he also attributes the title 'beloved'.

This interpretation, which corresponds both to the Vulgate and Greek (NA28 does not report any textual variants here) shows that Rufinus

${ }^{42}$ See Hammond Bammel, Der Römerbrieftext des Rufin, 271. 
neither accommodated the lemma to the exegesis nor the exegesis to the lemma. Instead, the textual evidence suggests that Origen's commentary followed a biblical text that did not read $\pi 0 \lambda \lambda \alpha_{\alpha}$ in Romans 16:12a. ${ }^{43}$

Both these examples have shown that Rufinus does not seem to have accommodated his lemma text to his exegesis, taken from Origen, nor the other way round. As he does not draw attention to these discrepancies, it is hard to say whether this was done consciously and silently, so not to disturb the reader, or whether Rufinus himself did not notice the differences. ${ }^{44}$ The latter, of course, once more raises the question of whether Rufinus looked at the biblical manuscript from which the lemma was added into his commentary, or whether more than one Latin text was involved in the production of the commentary: Rufinus must have based his text-critical comments on a Latin form of text, although the lemma could have been completed from a different one. ${ }^{45}$ Another possibility could be that, in the instances quoted above, the text of Origen being translated corresponded to Rufinus' own mental text, so he did not notice anything unusual. Be it as it may, both examples allow conclusions to be drawn about the treatment of the Greek biblical text that Rufinus found in his Vorlage of Origen.

\section{Ignoring the Lemma}

Another case of differences between lemma text and exegesis, similar to the previous example but without the resulting contradiction, are inconsistencies in readings or word order. In Romans 6:9 for example, Rufinus' lemma text reads scientes quia Christus surgens ex mortuis iam non morietur mors ei iam non dominabitur ('we know that Christ, being raised from the dead, will never die again, death no longer will have dominion over him'). Both finite verb forms, morietur and dominabitur, are future tense. ${ }^{46}$ This corresponds to Old Latin evidence for Romans 6:9, while the Vulgate usually reads the present tense moritur in the first instance, but keeps the future dominabitur in the second. ${ }^{47}$ In the transmission of Rufinus'

43 See Hammond Bammel, Der Römerbrieftext des Rufin, 271.

44 See further section E below.

45 See Hammond Bammel, Der Römerbrieftext des Rufin, 204-38.

46 For the word order iam ultra and the presence of both words when referring to the verse, see Hammond Bammel, Der Römerbrieftext des Rufin, 348.

47 Three manuscripts with morietur in this verse are reported in the Oxford Vulgate John Wordsworth and Henry Julian White, Novum Testamentum Domini Nostri Iesu Christi Latine secundum editionem Sancti Hieronymi. Vol. 2. Epistulae Paulinae. Oxford: Clarendon Press, 1913-1941). 
commentary moritur is found in the lemma instead of morietur in several manuscripts, sometimes as a correction. In his exegesis, however, Rufinus does not refer to the future tense of his lemma, but quotes the biblical verse with the present tense moritur three times. The variation in his textual tradition at these points and in the lemma are summarised in the following table: 48

\begin{tabular}{|c|c|c|c|c|}
\hline & lemma & $\begin{array}{l}\text { exegesis a } \\
\text { II } 443.50-1\end{array}$ & $\begin{array}{l}\text { exegesis b } \\
\text { II } 444.56\end{array}$ & $\begin{array}{l}\text { exegesis c } \\
\text { II } 453.235\end{array}$ \\
\hline editorial text & morietur & moritur & moritur & moritur \\
\hline $\begin{array}{l}\text { variant } 1 \\
\text { (pres./fut. } \\
\text { indicative) }\end{array}$ & $\begin{array}{l}\text { moritur } \\
\text { D Y }^{2} \mathrm{~T} \mathrm{H}^{4} \mathrm{~L}\end{array}$ & & $\begin{array}{l}\text { morietur } \\
\mathrm{Y}^{2} \mathrm{H} \text { L R }\end{array}$ & $\begin{array}{l}\text { morietur } \\
\mathrm{HL}\end{array}$ \\
\hline $\begin{array}{l}\text { variant } 2 \\
\text { (present } \\
\text { subjunctive) }\end{array}$ & & moriatur Y & & $\begin{array}{l}\text { moriatur } \\
\mathrm{M} \mathrm{Y}^{2} \mathrm{P}\end{array}$ \\
\hline
\end{tabular}

From this, it can be seen that the distribution of manuscript support for the present and future indicative is not only varied but also inconsistent. Even the corrector of Y (Orléans, Bibliothèque de la Ville 87) alters the lemma to read moritur but introduces morietur or moriatur instead of the present indicative on two of the three occasions in the exegesis. ${ }^{49} \mathrm{It}$ is clear that no witness has the future tense for the present in the first quotation at II 443.50. In addition, the out-of-sequence quotation of this verse in the discussion of Romans 1:4 (I 62.8) reads moritur without any variation in the textual tradition. This suggests that the present tense was the form of Rufinus' mental text of this verse and that the future tense was present in the Latin biblical manuscript from which the lemmata where taken but had no influence whatsoever on his interpretation of the verse. For the possible influence of Origen's text, we should also consider the Greek tradition. NA28 features two present tenses in this verse:

48 For an explanation of the sigla and descriptions of the manuscripts containing Rufinus' commentary, see Hammond Bammel, Der Römerbrieftext des Rufin, 110-34.

${ }^{49}$ Hammond Bammel overlooks the reading of R at II 444.56, but morietur is visible in the images at folio $167 \mathrm{r}$ at: http://www.stgallplan.org/stgallmss/viewItem.do?ark=p21198zz00289q34\&pageArk=p21198-zz0028ms4n. 


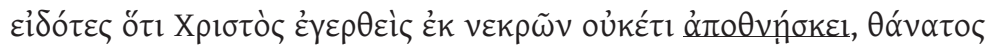

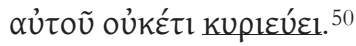

There is some relatively slight evidence for the future in the second half of

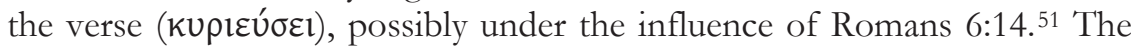
future is much more characteristic of Latin tradition, although once again Rufinus' exegesis is inconsistent: he has dominabitur seven times, including three quotations of the lemma and an out-of-sequence citation, but also reads dominatur twice as well as a present subjunctive. ${ }^{52}$ The manuscripts of Rufinus are almost unanimous on these readings: the exception is the fourth hand of H (Copenhagen, Det Kongelige Bibliotek, Gl. Kgl. Samling $13384^{\circ}$ ) which changes dominabitur in the lemma to dominatur, with the result that this is the only manuscript of Rufinus in which both Latin verbs match the Greek present tense in the lemma. This may or may not be significant.

It is hard to say how these differences between Latin and Greek biblical tradition came about. From Rufinus' way of treating the lemma, one may conclude that his mental text (or whatever other text he was following in his commentary) got the better of the biblical manuscript from which the lemmata were inserted in his commentary. We cannot tell on the basis of the present evidence how influential the text of Origen may have been on Rufinus: the present tense in the first half of the verse provides a good match with Greek, but this is not so with the future tense later on. In relation to the given lemma, however, the two verbs undergo opposite treatments: it appears that Rufinus adapts the Latin text in his exegesis to the Greek in the case of morietur but not in the case of dominabitur.

${ }^{50}$ It may be noted in passing that the NRSV does not reproduce these exactly, but has a future for the first and a present for the second: "we know that Christ, being raised from the dead, will never die again; death no longer has dominion over him'.

51 See Hammond Bammel, Der Römerbrieftext des Rufin, 348, where she also notes that the catena fragments of Origen's commentary have the present tense at Romans 6:9.

52 Dominabitur: II 444.60 (lemma quotation), 444.61-2, 446.110 (lemma quotation), 447.115, 449.153-4 (lemma quotation), 461.113 (out-of-sequence quotation); dominatur. II 445.82, 446.95; ut mors etiam ipsi ultra non dominetur. II 445.88 . 


\section{Turning Away from the Lemma}

A further case where Rufinus differs from the lemma in his exegesis is a combination of the phenomena described above in sections B and C: both the lemma text and an alternative reading are quoted in the exegesis. This is the case for Romans 3:20.53 The lemma at I 221.3-4 reads propterea ex operibus legis non iustificabitur omnis caro in conspectu dei. per legem enim agnitio peccati ('furthermore by deeds prescribed by the law no one will be justified in the sight of God. For through the law comes knowledge of sin'). This contains a quotation from Psalm 143:2, non iustificabitur omnis caro in conspectu dei, which is cited in different ways in the exegesis. The prepositional phrase in conspectu eius occurs at I 226.115. In three further references to the biblical text, however, Rufinus exchanges this phrase for the simple preposition coram: I 226.123 and 124 read coram ipso and I 226.125 has coram deo. The textual tradition is invariant for these four quotations as well as for the lemma text itself. The three occurrences using coram are closest to each other, but even the longer phrase in conspectu stands only a couple of lines ahead and is itself far away from the lemma text (I 221.3-4). It is therefore hardly likely that Rufinus had forgotten about the wording by the time he came to comment on Romans 3:20. On the contrary, Rufinus seems to be familiar with two different versions of the text even though he does not explicitly draw his readers' attention to it by making a text-critical comment.

A possible explanation for the change of the wording in the middle of his exegesis is that Rufinus made an ad hoc translation of Origen's Greek text in front of him, which superseded the form with which he was familiar from Latin tradition. The predominant reading in Greek tradition is

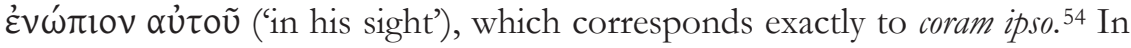
addition, other early Latin Christian writers read coram deo (including Ambrosiaster, the anonymous Budapest commentary and Augustine) and the same preposition is also found in the Vulgate's coram illo. ${ }^{55}$ Another possibility is that the quotation from Psalm 143:2 influenced the Latin

53 Hammond Bammel, Der Römerbrieftext des Rufin, 240, lists many more examples.

54 NA28 lists no variants to this phrase, but von Soden records some

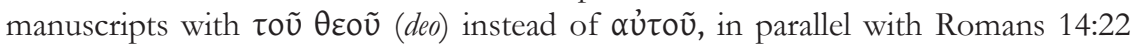
(Hermann von Soden, Die Schriften des Neuen Testaments in ibrer ältesten erreichbaren Textgestalt hergestellt auf Grund ihrer Textgeschichte: II. Teil: Text mit Apparat. Göttingen: Vandenhoeck \& Ruprecht, 1913, 666).

55 See Hammond Bammel, Der Römerbrieftext des Rufin, 309. 
lemma text in Romans 3:20.56 Both the Gallican Psalter (based on the Septuagint) and Jerome's translation of the Psalms from the Hebrew have in conspectu tuo in Psalm 142:2 (143:2). Even so, if these or another version of the Psalms had affected the lemma, it still does not explain why Rufinus changes from one form to the other within a couple of lines.

It seems most likely that Rufinus was familiar with more than one version of the text, as his many text-critical comments throughout his commentary prove. ${ }^{57} \mathrm{He}$ probably had them in his mind, ready to quote, as in his exegesis of Romans 3:20.58 The fact that on this occasion he does not comment on the alternative readings suggests that he was not too concerned by the difference, as the basic semantic meaning is unchanged. Of course, this argument ex silentio offers little grounding for a text-critical decision.

\section{E. Leaving the Lemma Untouched}

In general, Rufinus does not change the text of the Latin lemma text or adapt it to the Greek version if it is different. Rather, he states right at the beginning of his exegesis that the Greek reading differs. This is the case in Romans 12:2. NA28 reads:

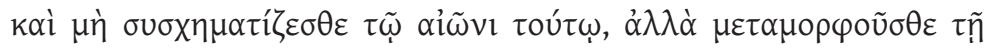

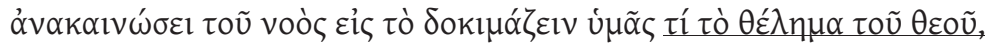

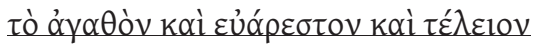

And do not be conformed to this world, but be transformed by the renewing of your minds, so that you may discern what is the good and acceptable and perfect will of God.

Rufinus' lemma, however, reads: et nolite conformari buic saeculo sed reformamini renouatione sensus uestri; ut probetis quae sit uoluntas dei quod bonum et beneplacitum et perfectum ('and do not be conformed to this world, but be transformed by the renewing of your minds, so that you may discern what the will of God is and what is good and acceptable and perfect'). The neutral adjectives bonum et beneplacitum et perfectum are not in correspondence with the feminine uoluntas. Nevertheless, the reading quod bonum et beneplacitum et perfectum,

56 This explanation is preferred by Hammond Bammel, who considers that in conspectu represents an Old Latin reading (Der Römerbrieftext des Rufin, 162).

${ }^{57}$ See Hammond Bammel, Der Römerbrieftext des Rufin, 204-38.

58 For further examples, see Hammond Bammel, Der Römerbrieftext des Rufin, 309-10. 
attested by various other early Latin sources, is kept both in the main lemma (Romans 12:1-2; III 711.12-13) and the side-lemma (III 715.99100). The literal translation of the Greek, as bona et beneplacita et perfecta, is provided by Rufinus immediately following the side-lemma:

sciendum est quod in Graeco babet: 'ut probetis quae sit uoluntas dei bona et beneplacita et perfecta.' sed nos quia unus in utroque potest sensus wideri consuetudinem sequimur Latinorum (III 715.100-3)

One has to know that it says in the Greek [text]: 'so that you may discern what is the good and acceptable and perfect will of God.' But because one can see the same meaning in both we are following the custom of the Latin [manuscripts].

Despite claiming this similarity in meaning, a couple of lines later Rufinus makes it quite clear that there is a difference between the two versions: the Greek could also indicate that people do not always deserve to be guided by the will of God. Rufinus illuminates this with scriptural examples of God sometimes giving people what they want despite the fact that God's initial will had been for something different, such being king over his people himself instead of giving them a human king (as he did eventually with Saul; cf. 1 Samuel 8). Therefore-according to Rufinus-one has always to ask oneself whether it is truly the 'good and acceptable and perfect will' of God or whether God was indulgent to people's desires. From this example it becomes clear that Rufinus is aware of the textual difference between the Greek and the Latin but does not want to upset the reader who is used to a certain Latin text. He wants to keep the consuetudo of his readers undisturbed, that is the Latin version people are used to. On the other hand, however, the Greek text seems to be most prominent in the way Rufinus interprets the text in his exegesis.

The concept of consuetudo sometimes leads Rufinus to harmonise different readings or to pretend that differences between the Greek and the Latin or differences between various Latin traditions do not really matter, despite the fact that this is not always true. ${ }^{59} \mathrm{He}$ makes a particularly bold statement at Romans 12:13 (III 738.12/1-739.12/4), where he recalls Latin manuscripts which, instead of his own lemma usibus sanctorum communicantes ('sharing the needs of the saints'), read memoriis sanctorum communicantes ('sharing the memories of the saints'). He continues by claiming that each is fit for edification and both are therefore adequate readings: nos nec

${ }^{59}$ See Hammond Bammel, Der Römerbrieftext des Rufin, 210-1. 
consuetudinem turbamus nec ueritati praeindicamus maxime cum utrumque conueniat aedificationi ('but we do not want to disturb custom or forestall truth, especially because both are suited for edification'). At Romans 3:25 (I 245.200-202) he states that there is 'no difference' (nibil interest) in the Latin words propitiator ('reconciler'), propitiatio ('reconciliation') and exoratio ('atonement'), because the Greek is always given by 'one and the same word' (uno eodemque sensu). Sometimes Rufinus also gives interpretations for both readings, e.g. at Romans 3:5, 5:14, 8:22 and 12:11. At Romans 3:19 and 12:3b Rufinus introduces Latin variants that express the idea of the Greek in a better way than his own lemma text (though he leaves the latter untouched). On the other hand, at Romans 1:4 (I 57.6-7) Rufinus rejects the Latin of his lemma text: nemo putet nos de hoc sermone curiosius quam res patitur perscrutari ('no one shall think that we ponder over this discourse more carefully than the matter allows').

From these examples one can deduce not only that Rufinus was aware of different readings but also that his treatment of them was determined by his agenda. Of course, Rufinus does not comment on all the instances where differences arise, be it between the Greek and the Latin or between different Latin readings (as in the preceding examples). However, when Rufinus does not pass over differences in silence but points them out, he usually interprets them in a way which suggests to his readers that the meaning is the same (even when this is not the case) and that there is no need to worry about textual differences.

\section{F. Double the Trouble}

Rufinus shows a tendency, especially in the later books of his commentary, to refer to the lemma text in his exegesis not only by quoting the exact word or phrase but also with a semantically similar or close word. Hammond Bammel calls those additional renderings 'Dubletten' (doublets). ${ }^{60}$ These doublets are prefaced by words such as hoc est, id est, uel, sine, et etc. Their origin may be manifold: some represent a textual variant, be it present in a written source Rufinus consulted while translating Origen's text or in a biblical text he knew from memory. To complicate matters, some of those doublets may correspond to a Greek tradition and others to a Latin tradition. In addition, some may be ad hoc translations or synonyms which Rufinus uses to explain the text to his readers. These differing possibilities are illustrated by the following examples.

${ }^{60}$ Hammond Bammel, Der Römerbrieftext des Rufin, 241. 
In Romans 10:2, Rufinus' lemma text reads testimonium enim perbibeo illis quod aemulationem dei habeant sed non secundum scientiam ('for I bear witness to them that they have zeal for God, but not according to knowledge'). In the exegesis, the verse is quoted again with the same wording at III 641.18-19, but a few words later two words are doubled: aemulatio is explained with zelus (and the other way round), the phrase secundum scientiam is also given as secundum intellectum. The first doublet, zelus for aemulatio seems to be a more literal translation from the Greek, which reads $\zeta \tilde{\eta} \lambda$ os $\theta \varepsilon$ cov in Romans 10:2. Zelus is also found in Old Latin sources, including Codex Boernerianus, Codex Augiensis, Jerome and Augustine. ${ }^{61}$ The doublet zelus et aemulatio dei is to be found at III 641.21, and another occurrence of zelus et aemulatio stands at 642.36-7. From its first mention onwards, zelus seems to supplant the lemma: zelus dei in various grammatical forms can be found in III 641.23, 24, 26 and 27, and 642.42. It also becomes an attribute for scientiam: scientiam zeli (III 641.27.29). Towards the end of the exegesis, Rufinus comes back to aemulationem dei at 644.79-80 and 81, although he ends with zelum dei at 644.83 . The alternation between these words shows that Rufinus clearly understood them as equivalents. At the same time, he shows a slight preference for the word zelus. The use of zelus could, however, also be reinforced by his reference to Old Testament passages with the verb zelor, such as Numbers 25:11, 1 Kings 19:10 and 1 Maccabees 2:24.

Romans 10:2 offers a second doublet in its exegesis, which is slightly less complex than the first: the phrase secundum scientiam is repeated constantly in the exegesis. It is referred to more than fifteen times before a doublet, secundum scientiam et intellectum, is introduced in III 643.65. From then on, intellectum is repeated once (III 643.74), but secundum scientiam occurs on at least five occasions up to the end of the exegesis. One can deduce from the number of repetitions that, unlike zelus as a doublet for aemulatio, the word intellectus does not take over but is an alternative that Rufinus does not pursue. It is hard to tell whether Rufinus was actually thinking of a different biblical text or simply tried to give an alternative word to explain

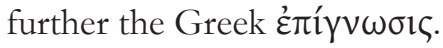

A similar example can be found in Romans 12:8, where the last in the list of activities reads qui miseretur in bilaritate ('the one who shows mercy [may do so] in cheerfulness'). The word bilaritas is an exact match with the Greek i $\lambda \alpha \rho o ́$ ins. Nevertheless, Rufinus gives a doublet in his exegesis: in bilaritate et laetitia (III 735.178). Again, it is impossible to tell whether this is

${ }^{61}$ See Hammond Bammel, Der Römerbrieftext des Rufin, 397. 
an alternative reading known to Rufinus or whether he simply uses it for the sake of his readers' understanding. ${ }^{62}$

An alternative Latin reading seems to be the best explanation for other doublets, such as destruit in Romans 14:20. ${ }^{63}$ In the first part of the verse Rufinus' lemma reads nolite propter cibum solvere opus dei ('do not, for the sake of food, dissolve the work of God'). A more widespread verb than solvere, however, is destruere ('destroy') Rufinus seems to think of this different rendering in an out-of-sequence allusion soon afterwards in his exegesis of Romans 14:22, when he writes ne destruatur opus dei (III 793.71-2). In his exegesis of Romans 14:20 he repeats the verb soluere but offers the doublet destruere (III 790.21-3): soluit enim opus dei et aedificium destruit caritatis qui propter ciborum intemperantiam scandalum fratribus ponit ('for he dissolves the work of God and destroys the house of love, who because of intemperance in food puts up a hindrance to the brothers'). This is a case where both readings are attested in biblical manuscripts: Rufinus seems aware of this, and provides both without any further distinction.

Romans 16:27, the very end of this Letter, provides another case. ${ }^{64}$ Rufinus' lemma has soli sapienti deo per Iesum Christum claritas in saecula saeculorum amen ('to the only wise God through Jesus Christ be glory forever, amen'). The word claritas corresponds to the Greek $\delta$ ó $\xi \alpha$, which is also regularly translated by gloria or honor. Rufinus gives one of these more common renderings in his exegesis as a doublet: gloria et claritas soli sapienti deo redderetur in saecula saeculorum (III 856.28-9). Towards the end of his exegesis, he returns to claritas by itself at III 859.73.

An example where there is no surviving manuscript evidence for Rufinus' doublet is found at Romans 3:31. The lemma reads legem ergo enacuamus per fidem absit sed legem statuimus ('do we therefore overthrow the law by this faith? No, on the contrary we uphold the law'). ${ }^{65}$ Rufinus explains the word statuimus with the doublet confirmamus in I 256-7.7-8 (legem statuimus hoc est confirmamus). The doublet is repeated in the exegesis several times: legem ... confirmare (I 257.8), non statuit neque confirmat ... legem (I

62 For further examples see Hammond Bammel, Der Römerbrieftext des Rufin, 241.

63 See Hammond Bammel, Der Römerbrieftext des Rufin, 432-3.

64 See Hammond Bammel, Der Römerbrieftext des Rufin, 446.

65 The exegesis of this verse contains another example of Rufinus' apparently knowing more than one rendering of a verse: while he uses the verb enacuare in his lemma, he more often refers to it in his exegesis with the verb destruere (well attested in biblical manuscripts). See Hammond Bammel, Der Römerbrieftext des Rufin, 313. 
257.17-18) and statuimus et confirmamus (I 258.38). While the verb from the lemma itself is only found twice in the exegesis (statuit in I 257.25 and statuimus as a quotation of the lemma in I 260.84), the doublet confirmare is found more frequently in various grammatical forms: I 257.13 and 22, $258.29,260.74$ and 87. In I 260.89, the noun confirmatio is used. It therefore seems that the verb confirmare is Rufinus' preferred way of expressing the meaning of Romans 3:31. As an alternative translation of the lemma, this seems to be intended for the benefit of Rufinus' readers.

There is no systematic pattern detectible as to when Rufinus offers doublets and when he does not. The position of the words seems not to provide any additional information about whether the doublet is a different manuscript reading, a literal translation of the Greek, or a reflection of Rufinus' personal preference (possibly as a simplification for his readers). The increase in the number of doublets towards the end of the commentary may not be of any particular significance. Even so, the presence of these doublets serves to underline the nature of Rufinus' commentary as a 'living translation', a reinterpretation of Origen's work intended to be read and understood in a new context.

\section{CONCLUSIONS}

This survey has primarily aimed to investigate the biblical text and how it is treated both in lemma and exegesis in Rufinus' translation of Origen's Commentary on Romans. As Rufinus is less interested in producing a formally equivalent version than in translating Origen's ideas into his own surroundings, he does not translate the lemmata directly from the Greek but takes them from a Latin biblical manuscript. This does not, however, mean that he never translates Greek biblical quotations. Several instances in his exegesis, particularly involving verses quoted out of sequence, suggest that Rufinus there spontaneously translates a Greek biblical text, even if that leads to differences from the lemma or other quotations.

Some contradictions also arise between the lemma and the exegesis, although as Rufinus' lemma text shows traces of adaptation to a Greek version (which he may have carried out himself) these are relatively rare. Where contradictions remain, Rufinus either comments on them or ignores them, although no pattern appears to be visible in his choice of approach. It is also impossible to say whether Rufinus passes over some contradictions on purpose or by accident. He does express a desire not to disturb his readers' consuetudo, i.e. their comfort and trust in the Latin text with which they were familiar. Sometimes Rufinus offers a variety of different readings, which prompts questions such as: What is the origin of these variants? Are 
they genuine readings or simply explanatory? Do they come from manuscripts or are they based on Rufinus' mental text? Examples can be found of all these possibilities: contradictions where Rufinus simply seems unaware of his lemma text, examples where he changes in the middle of the exegesis and later returns to the initial form, indications that he held different versions in parallel in his memory and so on.

At every stage, it has emerged that Rufinus is flexible and versatile in his treatment of Origen's commentary. Nevertheless, he is also a key witness to the transmission and reception of this important early work. The same is true of his treatment of the biblical text: not only does he provide evidence in the lemmata for a Latin form of text which appears to have played a significant role in Pauline commentaries, but the varying treatment of quotations in the exegesis shows the variety of strategies adopted by commentators in their reception and use of earlier models, as well as the range of variations introduced in the textual tradition of this commentary itself. 



\section{The Transmission OF FlorUS OF LyONS' EXPOSITIO EPISTOLARVM BEATI PAVLI APOSTOLI. STATE OF THE ART AND NEW RESULTS}

\section{SHARI BOODTS \& GERT PARTOENS}

\section{INTRODUCTION}

The Expositio epistolarum beati Pauli apostoli ex operibus sancti Augustini is a lineby-line Carolingian commentary on the Pauline Epistles. The commentary takes the form of a monumental anthology consisting of 2218 fragments, sourced from the works of Saint Augustine. ${ }^{1}$ It was compiled around the middle of the ninth century by Florus of Lyons ( $\dagger$ after 855 ), deacon of the Cathedral of Lyons, curator of its library and acclaimed scholar and textual critic. $^{2}$

Florus' Expositio is part of the generic category of Augustinian anthologies, which came into being very early on, possibly even during Augustine's lifetime. These anthologies took the form of short sententiae,

${ }^{1}$ L. De Coninck, B. Coppieters 't Wallant, R. Demeulenaere, 'Pour une nouvelle édition de la compilation augustinienne de Florus sur l'apôtre', RevBén 119 (2009) 316-35 (here 316).

2 C. Charlier, 'Florus de Lyon', in Dictionnaire de Spiritualité. Ascétique et mystique. Doctrine et Histoire, t. 5: Faber-Fyot, Paris: Beauchesne, 1964, col. 514-26. Further biographical information on Florus of Lyons can be found in M. Cappuyns, 'Florus de Lyon', in Dictionnaire d'histoire et de géographie ecclésiastiques, t. 17, Paris: Letouzey et Ané, 1971, col. 648-54 and in K. Zechiel-Eckes, Florus von Lyon als Kirchenpolitiker und Publizist. Quellen und Forschungen zum Recht im Mittelalter 8. Stuttgart: Thorbecke, 1999, 11-18 (with extensive bibliography on xi-xxx). For Florus' reputation as a scholar and a complete overview of his works, see Charlier, 'Florus de Lyon', col. 514-21. 
such as the Sententiae ex operibus S. Augustini by Prosper of Aquitaine (fl. 420450 [CPL 525]), or longer fragments, such as the Excerpta ex operibus $S$. Augustini by Eugippius of Lucullanum (fl. c. 509 [CPL 676]). The latter type includes a number of florilegia in the form of Pauline commentaries composed entirely of Augustinian excerpts. Precursors of Florus' Expositio included a compilation-commentary by a certain Peter of Tripoli that is mentioned in the first book of Cassiodorus' Institutiones, but has not been preserved, as well as the Collectio ex opusculis S. Augustini in epistulas Pauli Apostoli of the Venerable Bede (672/3-735). ${ }^{3}$ Bede's Collectio was used by Florus as a source for numerous fragments in the Expositio. ${ }^{4}$

The Expositio has the conventional structure of a compilationcommentary. Each Pauline verse (or combination of verses) that is commented upon, is presented as a lemma and is followed by a commentary in the form of one or more excerpts from Augustine's œuvre. ${ }^{5}$

3 Petrus abbas Tripolitanae proninciae sancti Pauli epistulas exemplis opusculorum beati Augustini subnotasse narratur, ut per os alienum sui cordis declararet arcanum; quae ita locis singulis competenter aptanit, ut hoc magis studio beati Augustini credas esse perfectum. Mirum est enim sic alterum ex altero dilucidasse, ut nulla uerborum suorum adiectione permixta desiderium cordis proprii complesse nideatur. Qui uobis inter alios codices dinina gratia suffragante de Africana parte mittendus est. (Cassiodorus, Institutiones 1.8.9: R.A.B. Mynors, ed., Cassiodori Senatoris Institutiones. 2nd edn. Oxford: Clarendon, 1961, 30). The Institutiones were written ca. 560 and revised around 580.

${ }^{4}$ See P.-I. Fransen, 'Description de la collection de Bède sur l'apôtre', RevBén 71 (1961) 22-70. The exact extent of Florus' dependence on Bede remains unclear. Elsewhere, Fransen offers a first indication: 'sur les 459 extraits que compte la compilation de Bède, 169 se retrouvent dans Florus' (P.-I. Fransen, 'Le florilège augustinien de Florus de Lyon', in Saint Augustin et la Bible. Actes du colloque de l'université Paul Verlaine-Metz (7-8 avril 2005) ed. G. Nauroy \& M.-A. Vannier. Recherches en littérature et spiritualité 15. Bern: Lang, 2008, 313-24, quotation from 322 n.7). A critical edition of the Collectio, which will provide detailed information on the relation between Bede and Florus, is currently being prepared by Nicolas De Maeyer at KU Leuven. For a description of the transmission of Bede's Collectio, cf. G. Partoens, 'The manuscript transmission of Bede's Augustinian commentary on the Letters of Saint Paul', in La trasmissione dei testi patristici latini: problemi e prospettive, ed. E. Colombi. Instrumenta Patristica et Mediaevalia 60. Turnhout: Brepols, 2012, 201-51, and J. Delmulle, 'La Collectio in Apostolum de Bède le vénérable: tradition manuscrite, codicologie et critique d'authenticité', Scriptorium 70 (2016).

${ }^{5}$ For more information on Florus' method as a compiler, see C. Charlier, 'Les 
As Florus himself indicates in the prologue to the Expositio, only a few verses are not part of the commentary. ${ }^{6} \mathrm{He}$ employed a wide array of highquality sources, including over seventy different Augustinian works (some of them consisting of many individual texts, such as the Sermones ad Populum [nearly 150], the Enarrationes in Psalmos [over 120], the Tractatus in euangelium/epistulam Iohannis [almost 100] and the Epistulae [over 50]). As far as we know, the enormous compilation quotes from only four works now considered to be apocryphal: the Altercatio cum Pascentio, ${ }^{7}$ and Caesarius' Sermones 177 and 180, ${ }^{8}$ all taken from Bede's Collectio, and Contra Felicianum Arianum de unitate Trinitatis. ${ }^{9}$ This attests to Florus' legendary critical sense. ${ }^{10}$

manuscrits personnels de Florus de Lyon', in Mélanges E. Podechard. Études de sciences religieuses offertes pour son éméritat au Doyen honoraire de la Faculté de Théologie de Lyon, Lyon: Facultés catholiques, 1945, 71-84; S. Boodts, 'Florus of Lyon's Expositio epistolarum beati Pauli apostoli and the transmission of Augustine's Sermones ad populum', in On Good Authority. Tradition, Compilation and the Construction of Authority in Literature from Antiquity to the Renaissance, ed. R. Ceulemans \& P. De Leemans. LECTIO Studies 2. Turnhout: Brepols, 2015, 141-55; S. Boodts, 'The reception of Saint Augustine in Florus of Lyons's Expositio epistolarum beati Pauli apostoli. The section on Romans 7', in Actes du Colloque international sur la controverse Carolingienne sur la prédestination. Histoire, textes, manuscrits (Paris, 10-11 octobre 2013), ed. J. Delmulle, P. Chambert-Protat et al., Paris, 2016.

${ }^{6}$ In qua expositione, licet nonnulla ex uerbis Apostoli omissa videantur, tamen Deo auxiliante et per doctorem mirabilem mirabiliter agente quaecumque difficiliora, profundiora uel excellentiora ibi inueniuntur, tam diligenter paene omnia et praeclare tractata sunt, ut dinina gratia adspirante pio et prudenti ac studioso lectori sufficere possint ad instructionem doctrinae, ad exercitationem ingenii et ad ea quae intermissa sunt, facilius inuestiganda atque, in quantum Dominus adiunerit, penetranda (Troyes, BM, 96, fol. 1v). See also Charlier, 'Florus de Lyon', col. 523.

${ }^{7}$ Fragments 568 and 40 in the sections on 1 Cor. 16:22-4 and Phil. 2:6-7 (PL 33, col. 1159-60); see also the modern edition of H. Müller, D. Weber and C. Weidmann (Collatio Augustini cum Pascentio. Einleitung, Text, Übersetzung mit Beiträgen von H. C. Brennecke, H. Reichert und K. Vössing. Vienna: ÖAW, 2008), and P.-I. Fransen, L. De Coninck, B. Coppieters 't Wallant, R. Demeulenaere, ed., Flori Lugdunensis Expositio in epistolas beati Pauli ex operibus S. Augustini. Pars III. In epistolam secundam ad Corinthios. In epistolas ad Galatas, Ephesios et Philippenses. CCCM 220 B. Turnhout: Brepols, 2011, 486-7.

8 Sermo 177 occurs in fragment 559 in the section on Rom. (CCSL 104, 719 [1318]); Sermo 180 in fragments 70, 71, and 75 in the sections on Eph. 4:25 and 27 (CCSL 104, 730 [3-6, 7-10]-731 [5-8]; 731 [11-13]; 731 [14-19, 21-8]).

${ }^{9}$ Fragment 26 in the section on 1 Cor. 1:17 (PL 42, col. 1158).

10 As Lambot observed :

Moins encore que l'antiquité, le moyen âge était capable de distinguer le vrai du faux. 
Over the centuries the Expositio was attributed to several scholars, in particular Bede from the twelfth century up to the printed editions (see below). ${ }^{11}$ Initial arguments in favour of the attribution to Florus of Lyons were offered by Jean Mabillon in 1675 and André Wilmart in 1926. ${ }^{12}$ The definitive argument proving Florus' authorship was furnished by Célestin Charlier in 1945: of some one hundred surviving patristic manuscripts that belonged to the Cathedral Library of Lyons around 850, several contain marginal and interlinear annotations delimiting passages that show a perfect accordance with excerpts in florilegia and other works traditionally attributed to Florus (including the Expositio). ${ }^{13}$

La presque totalité des lecteurs ne se doutait même pas qu'un sermon muni du nom de saint Augustin pût lui être totalement étranger. Un Florus de Lyon est une exception. Je ne vois pas qu'il ait inséré dans son Florilège augustinien sur les Épîtres de saint Paul un seul extrait qui ne fût authentique, et pourtant il puisait dans des sources qui n'étaient pas toutes sans mélange' (C. Lambot, 'Critique interne et sermons de saint Augustin', Studia Patristica 1 (1957) 112-27 [= RevBén 79 (1969) 134-47]; quotation from 113).

Fransen also claimed that Florus worked '[...] sans qu'aucune œuvre apocryphe vienne contaminer les choix opérés' ('Le florilège augustinien', 319). The four counter-examples just noted show that these assessments are not entirely correct.

11 J. Heil, Kompilation oder Konstruktion? Die Juden in den Pauluskommentaren des 9. Jahrhunderts. Forschungen zur Geschichte der Juden, A 6. Hannover: Hahn, 1998, 403-5, offers a chronological overview of the attributions in the manuscript witnesses. On Bede, see C. Charlier, 'La compilation augustinienne de Florus sur l'Apôtre. Sources et authenticité', RevBén 57 (1947) 132-86.

12 A. Wilmart, 'Sommaire de l'Exposition de Florus sur les Épîtres', RevBén 38 (1926) 205-14.

13 Charlier, 'Les manuscrits personnels', 73. Information on the source manuscripts can also be found in Charlier, 'La compilation augustinienne'; J. Bignami-Odier, 'Encore la main de Florus de Lyon dans un manuscrit de la reine Christine à la Bibliothèque du Vatican?', Mélanges d'archéologie et d'histoire 63 (1951) 191-4; L. Holtz, 'La minuscule marginale et interlinéaire de Florus de Lyon', in Gli autografi medievali. Problemi paleografici e filologici, ed. P. Chiesa \& L. Pinelli. Quaderni di cultura mediolatina 5. Spoleto: Centro italiano di studi sull'alto Medioevo, 1994, 149-66; K. Zechiel-Eckes, Florus von Lyon als Kirchenpolitiker, A.-M. Turcan-Verkerk, 'Faut-il rendre à Tertullien l'Ex libris Tertulliani de execrandis gentium diis du manuscrit Vatican latin 3852? I. La composition et l'origine du Vat. lat. 3852: un dossier constitué par Florus de Lyon', Revue des études augustiniennes 46 (2000) 205-34; A.-M. Turcan-Verkerk, 'Florus de Lyon et le manuscrit Roma Bibl. Vallicelliana, E 26. Notes marginales...', in La tradition vive. Mélanges d'histoire des textes en l'honneur de Lonis Holtr, ed. P. Lardet. Bibliologia 20. Turnhout: Brepols, 2003, 307-16; De 


\section{The Manuscript Tradition: State of THE ART}

Despite the Expositio's regular appearance in scholarly studies and editions of Augustinian works, the project of producing its first critical edition has only recently been initiated. ${ }^{14}$ The final edition will occupy four volumes in the Corpus Christianorum. Continuatio Mediaenalis (CCCM 220-220C); a first volume was published in 2011 by an editorial team directed by Luc De Coninck, who remains closely involved with the continuation of the project.

Although the Expositio has been preserved in a significant number of manuscripts, several of which date back to the ninth century (see below), De Coninck's edition was mainly based on only one of them: Lyons, BM, 484 (before 852, copied in Lyons), henceforth L. ${ }^{15}$ The reason for privileging this manuscript is that it has been identified as a partial autograph as well as the archetype of the transmission. ${ }^{16}$

The first volume of the edition does not provide the beginning of Florus' commentary, but instead contains the parts from 2 Corinthians to Philippians (hence its number 220B). The editorial team had two reasons for proceeding this way. Firstly, the beginning of Florus' commentary has been lost from the archetype $L$ through fire damage; today the archetype only contains the sections from 2 Corinthians to Hebrews. Secondly, as Florus employs a very specific standard of punctuation and orthography,

Coninck, 'Pour une nouvelle édition'; L. Holtz, 'Le manuscrit Lyon BM 484 (414) et la méthode de travail de Florus', RevBén 119 (2009) 270-315; K. Zechiel-Eckes, 'Eine neue Arbeitshandschrift des Diakons Florus von Lyon. Der Kommentar des Ambrosius zum CXVIII. Psalm (Cod. Firenze, Bibl. Med. Laur. Plut. XIV.21)', RevBén 119 (2009) 336-70. See also http://florus.hypotheses.org/liste-de-charlier, where P. Chambert-Protat provides continuing updates of Charlier's list, and http://demos.biblissima-condorcet.fr/florus/, where, in the framework of BIBLISSIMA, a 'projet de reconstitution virtuelle de la bibliothèque de Florus de Lyon' is underway.

14 Articles devoted entirely to a description of (specific aspects of) the Expositio include Wilmart, 'Sommaire de l'Exposition'; P.-I. Fransen, 'Extraits non encore repérés dans la compilation augustinienne de Florus sur l'apotre', RevBén 113 (2003) 80-9; Fransen, 'Le florilège augustinien'; De Coninck, 'Pour une nouvelle édition'; Boodts, 'Florus of Lyon's Expositio'; Boodts, 'The reception of Saint Augustine'.

15 The 203 folia of this manuscript have to be completed with Paris, BnF, Baluze 270, fol. $72^{\text {bis }}$ r- $73 \mathrm{v}$.

${ }^{16}$ L. Delisle, Notices sur plusieurs anciens manuscrits de la Bibliothèque de Lyon. Notices et extraits de mss. de la Bibl. Nat., 29. Paris: Imprimerie nationale, 1880, 402; Charlier, 'Les manuscrits personnels', 79; and especially Holtz, 'Le manuscrit Lyon BM 484', passim. 
which he systematically introduced in the partial autograph and which the editors have translated to a modern system, the published section of the commentary was to serve as a guide for the edition of the other parts of the commentary. The whole of the commentary will be edited according to the following scheme:

$\begin{array}{lll}\text { Romans } & \text { lost from } L & \text { CCCM 220 } \\ \text { 1 Corinthians } & \text { lost from } L & \text { CCCM 220A } \\ \text { 2 Cor.-Philippians } & \text { preserved in } L & \text { CCCM 220B } \\ \text { Colossians-Hebrews } & \text { preserved in L } & \text { CCCM 220C }\end{array}$

To supplement the archetype $L$-which is absolutely necessary for the sections on Romans and 1 Corinthians as well as for those parts of 2 Corinthains to Hebrews that have become illegible because of fire damage- the scholarly tradition, including the first volume, has up to this point depended exclusively on Troyes, BM, 96, a manuscript of the middle of the ninth century from Saint-Oyen (Saint-Claude, Jura). This manuscript, henceforth $T$, is a complete, contemporary copy of $L$ in its final state, containing (almost) all interlinear and marginal additions and alterations that were made in $L$ during the process of creating and finalising the Expositio. ${ }^{17}$ Produced by Mannon of Saint-Oyen, one of Florus' closest disciples, this manuscript is a very satisfactory alternative to the incomplete archetype. The copy exhibits large dimensions, careful handwriting and corrections, and was apparently designed to become a reference work or a copie de préservation. Historically, also, the emphasis placed on $T$ was not unfounded. Saint-Oyen, where the manuscript travelled shortly after its creation, was an important centre and Mannon of Saint-Oyen played a significant role in the distribution of Florus' works and the transfer of texts from the region of Lyons to Reims and other parts of Northern France. ${ }^{18}$

In an article preceding the publication of CCCM 220B, Luc De Coninck showed that $T$ is indeed a very important manuscript, but that it cannot be the basis for the entire further transmission of Florus' commentary. De Coninck did this through two approaches: (1) comparison of the text of the section on 2 Corinthians in the archetype $L$ on the one hand and, on the other, $T, O$ (Orléans, BM, 83; Rom. \& 1/2 Cor.) and $G$ (St Gall, Stiftsbibliothek, 281; $1 / 2$ Cor.); (2) comparison of the annotated text

17 See A.-M. Turcan-Verkerk, 'Mannon de Saint-Oyen dans l'histoire de la transmission des textes', Revue d'Histoire des Textes 29 (1999) 169-243 (172).

18 Turcan-Verkerk, 'Mannon de Saint-Oyen' discusses in detail Mannon's role in the transmission of texts and includes a discussion of our manuscript $T$ as well. 
of the surviving source manuscripts from which Florus had borrowed fragments for his section on Romans (for which $L$ is lacking) and that of the corresponding fragments in T, O, G and Laon, BM, 105 (Rom. \& 1 Cor.). ${ }^{19}$

In what follows, we will take De Coninck's results further by both broadening the range of manuscripts-taking into account all of the commentary's pre-twelfth-century witnesses-and by specifying their mutual relationships as far as possible. ${ }^{20}$ Our conclusions will be based on a collation of these manuscripts with the edition of De Coninck. The eventual aim of this research is to continue the project of the edition of the Expositio.

\section{Catalogue of the Pre-Twelfth-Century Manuscripts}

The Expositio has been preserved in more than seventy-five witnesses, many of which transmit only half or one-third of this extensive work. ${ }^{21}$ Only twelve of these witnesses were produced in the ninth to eleventh century. The transmission preceding the explosion of manuscripts in the twelfth century can thus be considered relatively narrow. The following list presents the pre-twelfth-century manuscripts, first by century, then alphabetically. ${ }^{22}$

19 De Coninck, 'Pour une nouvelle édition', 331-4 (first approach); 334-5 (second approach).

20 Though it remains possible that a valuable witness can still be found among the vast group of post-eleventh-century manuscripts, the stemmatical conclusions we reach below justify the elimination of this group of manuscripts from the investigation for the sake of economy.

21 'La distribution Rom.-1 Cor., 2 Cor.-Hebr. est fort répandue; mais cette autre n'est point rare: Rom. 1-2 Cor., Gal.-Hebr' (Wilmart, 'Sommaire de l'Exposition de Florus', 206, with notes on some manuscripts and their divisions). Fransen, 'Le florilège augustinien', 317 offers a further option in three parts: Romans, 1 Corinthians, and 2 Cor.-Hebrews. This, however, is most likely to be based on the description of St Gall, Stiftsbibliothek, 279-281 in Charlier, 'La compilation augustinienne', $136 \mathrm{n}$. 1, which is misleading in that it does not clarify that the original division was in four volumes of which one, containing Gal.-Col., was lost early on. See Fransen, De Coninck et al., Flori Lugdunensis Expositio, xxvii n. 88. We would like to thank Luc De Coninck for bringing this to our attention.

22 The list was based on Heil, Kompilation oder Konstruktion?, 403-5, but with the addition of bibliographical information and our own corrections from further research. Heil wrongly adds Orléans, BM, 84 to his list of witnesses of the Expositio: this manuscript in fact contains Bede's Collectio. We have also included the twelfth- 
Note: 'attribution' refers to the attribution to a compiler who differs from the author of the fragments, viz. Augustine; 'title' refers to a general title which applies to the entire work, not to the title which normally follows the prologue and applies only to the first section of the work, viz. In nomine Domini nostri Iesu Christi incipit expositio epistulae ad Romanos sancti Augustini episcopi. References are to the bibliography at the end of this chapter.

The general prologue reads as follows: In nomine Domini et Saluatoris nostri Iesu Christi. In hoc nolumine continetur expositio epistolarum beati Pauli apostoli collecta et in ordinem digesta ex libris sancti Augustini episcopi doctoris eximii et fidelissimi, sicut singuli suis locis adscripti sunt. In qua expositione, licet nonnulla ex uerbis Apostoli omissa videantur, tamen Deo auxiliante et per doctorem mirabilem mirabiliter agente quaecumque difficiliora, profundiora uel excellentiora ibi inueniuntur, tam diligenter paene omnia et praeclare tractata sunt, ut diuina gratia adspirante pio et prudenti ac studioso lectori sufficere possint ad instructionem doctrinae, ad exercitationem ingenii et ad ea quae intermissa sunt, facilius inuestiganda atque, in quantum Dominus adiunerit, penetranda. Cui profecto nec prolixitas nec multiplicitas expositionis debet esse onerosa. Quae ob hoc praecipue procurata est, ut sensus studentium magis magisque exerceatur legendo et intellegendo uinacius atque uberius instruatur. (Transcription on the basis of Troyes, BM, 96, fol. 1v).

\section{Ninth-Century Witnesses}

\section{$R \quad$ Brescia, Biblioteca Queriniana, G.III.2}

Origin: $\mathrm{IX}^{3 / 3}$, Northern Italy, possibly Milan (Bischoff); IX ${ }^{3 / 3}$, Brescia (Villa; Gavinelli); IX ${ }^{4 / 4}$ (Giovè Marchioli \& Pantarotto).

Provenance: Chapter Library of Brescia.

Attribution, title, prologue: anonymous; the space that was left free for a title on fol. $1 \mathrm{r}$ has never been filled; the ms. starts with the first fragment; the general prologue is absent.

Content: Rom.-Hebr. (fol. 1r-405v).

Bibliography: Villa (1969) 16-20; Bischoff (1998) 145-6 (no. 683); Gavinelli (2007) 270-1, 278-80 (with further bibliography); Giovè Marchioli \& Pantarotto (2008) 43 (no. 61; with further bibliography).

century witness Brussels, Bibliothèque Royale, 1059 (9358), since it seems to be a counterpart of Brussels, Bibliothèque Royale, 283 (9369-70); the latter is not included in our collations as it does not contain the sections on 2 Cor. and Phil. 


\section{- Laon, Bibliothèque Municipale, $105^{23}$}

Origin: IX ${ }^{2 / 2}$, Orléans or Auxerre (Contreni); IX ${ }^{2 / 3}$, French Cathedral school (Bischoff: 'Nähe zum Original des Florus (Lyon, BM, Ms. 484 (414)) durch die Art der mg. Angaben biblischer Bücher').

Provenance: Chapter Library of Laon.

Attribution, title, prologue: anonymous; no general title; the commentary starts with the general prologue.

Content. Rom.-1 Cor. (fol. 1r-184v).

Bibliography: Catalogue général (1849) 92-3; Contreni (1978) 35-6, 44-5; Bischoff (2004) 25-6 (no. 2073).

\section{Lyons, Bibliothèque Municipale, 484 (414) + Paris, Bibliothèque Nationale, Baluze 270 (fol. $72^{\text {bis }}-73$ )}

Origin: ca. 850, Lyons (partial autograph: Holtz).

Provenance: Chapter Library of Lyons.

Attribution, title, prologue: anonymous; no general title; no general prologue (the sections on Rom. and 1 Cor. have been lost).

Content: 2 Cor.-Hebr. (fol. 1r-203v + 72 ${ }^{\text {bis }}$ - $-73 v$; detailed description: Fransen, De Coninck et al., Flori Lugdunensis Expositio, vii-x.

Bibliography: Bischoff (2004) 141-2 (no. 2565); Holtz (2009); Fransen, De Coninck et al., Flori Lugdunensis Expositio, passim (with further bibliography). See also the bibliography on http://florus.bm-lyon.fr.

\section{O Orléans, Bibliothèque Municipale, 83 (80)}

Origin: IX ${ }^{2 / 2}$, Fleury, Saint-Benoît (Samaran \& Marichal); IX ${ }^{\text {med. }}$, Tours (Bischoff: 'Mgg. z.T. von der Vorlage, Lyon, Bm, Ms. 484 (414) kopiert'). Provenance: Fleury, Saint-Benoît.

Attribution, title, prologue: anonymous; no general title; commentary starts with the general prologue.

Content: Rom.-2 Cor. (p. 1-529).

Bibliography: Samaran \& Marichal (1984) 213; Bischoff (2004) 335-6 (no. 3683); Pellegrin \& Bouhot (2010) 97-8 (with further bibliography).

\section{G St Gall, Stiftsbibliothek, 279-281}

Origin: St Gall, during the abbacy of Hartmut (872-883).

${ }^{23}$ This manuscript is not included in our analysis because it does not contain the sections on 2 Cor. and Phil. 
Attribution, title, prologue: These are the only ninth-century witnesses that ascribe the anthology to Florus of Lyons. Titles: In nomine Domini incipit Collectaneum Flori presbyteri ex libris sancti Augustini episcopi super epistolam beati Pauli apostoli ad Romanos (ms. 279, p. 3), In nomine Domini incipit Collectaneum uolumen Flori presbyteri ex libris sancti Augustini episcopi in epistolam beati Pauli apostoli ad Corinthios priorem (ms. 281 [sic], p. 4). The general prologue is missing from ms. 279 (compare the situation in ms. R); no title is given in ms. 280 (see, however, p. 61: Explicit explanatio epistolae ad Thessalonicenses industria Flori presbyteri Lugdunensis ex libris sancti Augustini collecta).

Content: Rom. (ms. 279, p. 2-694); 1 Cor.-2 Cor. (ms. 281 [sic], p. 4-560); Thess.-Hebr (ms. 280 [sic], p. 3-430). The original division was in four volumes of which one, containing Gal.-Col., was lost early on (cf. Fransen, De Coninck et al., Flori Lugdunensis Expositio, xxvii n. 88).

Bibliography: Scherrer (1875) 106; Villa (1969) 16-17; Bergmann \& Stricker (2005) 521-2 (no. 217); Bischoff (2014) 321 (nos 5720-2). See also the bibliography on www.e-codices.unifr.ch.

\section{T Troyes, Bibliothèque Municipale, 96}

Origin: written by Mannon of Saint-Oyen, disciple of Florus; c. 850 (Wilmart); before 880 (Samaran \& Marichal); near the end of Florus' lifetime (Turcan-Verkerk 1999).

Provenance: Saint-Oyen (Saint-Claude, Jura) (cf. fol. 1r: Voto bonae memoriae Mannonis liber ad sepulchrum sancti Augendi oblatus [see De Coninck et al. (2009) 328-9 n. 18; Turcan-Verkerk (1999) 198, n. 91-3]); Dijon; Bouhier.

Attribution, title, prologue: anonymous; no general title; commentary starts with the general prologue.

Content: Rom.-Hebr. (fol. 1v-300r).

Bibliography: Wilmart (1926) 207; Charlier (1947) 168-86; Samaran \& Marichal (1965) 455; Étaix \& de Vrégille (1970) 27 n. 3; Fransen (1994) 85 n. 6; Holtz (1994) 156 n. 24; A.-M. Turcan-Verkerk (1999) 171-4, 178, 1867, 198 (no. LXXXIIII); De Coninck et al. (2009) 328-35.

\section{Eleventh-Century Witnesses}

\section{A Angers, Bibliothèque Municipale, 65/66}

Origin: XI, Angers, Saint-Aubin.

Provenance: Angers, Saint-Aubin.

Attribution, title, prologue: anonymous; no general title; commentary in ms. 65 starts with the general prologue. 
Content: Rom.-1 Cor. (ms. 65, fol. 1r-190r); 2 Cor.-Hebr. (ms. 66, fol. 1r171r).

Bibliography: Catalogue général (1898) 210; Vezin (1974) 261-3 and passim. See also the bibliography at http://initiale.irht.cnrs.fr.

\section{B Bamberg, Staatsbibliothek, 126}

Origin: XIinc, Cluny (dedication verses by Odilo of Cluny on fol. 1v). Provenance: Part of a gift by Odilo of Cluny (abbot of Cluny in the years 994-1049) to Emperor Heinrich II (973-1023; hence the dedication verses on $\mathrm{f} .1 \mathrm{v})$; Chapter Library of Bamberg.

Attribution and title: There is no general title; the commentary starts with the general prologue. The latter begins on fol. $2 \mathrm{v}$ (right column) and is preceded by a quotation of Cassiodorus' Institutiones 1.8 (fol. $2 \mathrm{r}-2 \mathrm{v}$ ), the chapter in which Cassiodorus mentions the Pauline commentary that was composed by Peter of Tripoli on the basis of Augustinian fragments. In the margin next to Cassiodorus' reference to Peter of Tripoli, a later hand has written: Hic facundissimi Cassiodori narrat sententia cuius subsequens liber ex operibus beati Augustini sit collectus industria (fol. 2r). In later times the dedication verses on $\mathrm{f} .1 \mathrm{v}$ prompted the attribution of the commentary to Odilo himself ('Vorsatzblatt': S. Odilonis abbatis Cluniacensis Commentaria in epistolas S. Pauli Apostoli).

Content: Rom.-Hebr. (fol. 5r-278v).

Bibliography: Wilmart (1926) 28-9; Leitschuh (1966) 106; Suckale-Redlefsen (2004) 70-1. See also the bibliography at:

http://bsbsbb.bsb.lrz-muenchen.de/ db/ausgaben.

\section{- Brussels, Bibliothèque Royale, 283 (9369-70) 24}

Origin: XI.

Provenance: Liège, Saint-Laurent.

Attribution, title, prologue: no general title; commentary starts with the general prologue, in which an attribution to Florus has been inserted: [...] in hoc uolumine continetur expositio epistolarum beati Pauli apostoli a quodam Floro collecta et in ordine digesta ex libris sancti Augustini episcopi [...]. This insertion is absent from all other manuscripts listed in the present article.

Content: Rom.-1 Cor. (fol. 6v-286v).

Bibliography: Van den Gheyn (1901) 152.

24 This manuscript is not included in our analysis because it does not contain the sections on 2 Cor. and Phil. 


\section{Brussels, Bibliothèque Royale, 1059 (9358)}

Origin: XII.

Provenance: Liège, Saint-Laurent.

Attribution, title, prologue: anonymous, no general title/prologue (the ms. starts with 2 Cor.).

Content: 2 Cor.-Hebr. (fol. 1v-171v).

Bibliography: Van den Gheyn (1902) 113.

\section{Montecassino, Biblioteca della Badia, 39 C}

Origin: $\mathrm{XI}^{2 / 2}$, Montecassino (Newton: 'It appears that a northern scribe brought his highly developed skills to the abbey and produced this volume here').

Attribution, title, prologue: anonymous; no general title; no prologue.

Content. Rom.-Hebr (p. 1-587).

Bibliography: Codicum Casinensium [...] catalogus (1915) 55-6; Newton (1999) 353.

\section{Nîmes, Bibliothèque Municipale, 36}

Origin: ca. 1100, written by Robertus, Abbot of the Abbey of Lagrasse (from 1086 until 1108).

Provenance: Abbey of Lagrasse; Geor. Paviot; François Massip; JeanFrançois Séguier.

Attribution, title, prologue: anonymous (on f. $2 \mathrm{r}$ a later hand [?] ascribes the commentary to Peter of Pavia [not to Peter of Tripoli]: Petrus abbas Papie bunc librum excerpsit ex libris sancti Augustini, monasterii Celi aurei); no general title; commentary starts with the general prologue.

Content: Rom.-Hebr. (fol. 2r-207v).

Bibliography: Catalogue général (1885) 545-7; Samaran \& Marichal (1968) 339. See also the bibliography at http://initiale.irht.cnrs.fr as well as www.e-corpus.org (reference: B301896101_MS0036).

\section{Città del Vaticano, Biblioteca Apostolica Vaticana, Vat. Lat. 4950}

Origin: ca. 1100, Nonantola, San Silvestro.

Provenance: Pietro Damiani; Fonteavellana; Cardinal Sirleto.

Attribution, title, prologue: originally no attribution; later additions on fol. $1 \mathrm{r}$ and $234 \mathrm{v}$ attribute the commentary to Peter of Tripoli (for the erroneous attribution of this specific manuscript, which is still defended by some scholars today, see Partoens (2012) 202-4 [with further literature]); no general title; no prologue (the ms. starts with 1 Cor.).

Content: 1 Cor.-Hebr. (fol. 1r-232r). 
Bibliography: Branchi (2011) 249-50 (with further bibliography).

Most of the above witnesses do not identify Florus as the compiler of the work: in most cases, no author or creator is mentioned at all, not even in $T$, whose copyist was a personal acquaintance of the deacon of Lyons. This initial anonymity probably explains why tradition has often ascribed the work to Peter of Tripoli or the Venerable Bede.

The attribution to Peter of 'Tripoli is based on Cassiodorus' reference to the latter's Pauline commentary in the Institutiones. ${ }^{25}$ This attribution is found in manuscripts $B$, where the commentary is preceded by the relevant chapter from Cassiodorus, and $V$, where the attribution was clearly introduced at a later date. The attribution to Peter of Pavia from the famous monastery of San Pietro in Ciel d'Oro, which was introduced probably by a later hand in $N$, seems to be a further development of the attribution to the Italian's north-African namesake. Since Cassiodorus' Institutiones were well read during the Middle Ages and the attributions in $N$ and $V$ seem to have been introduced by later hands, the references to Peter of Tripoli/Pavia in $B, N$ and $V$ do not constitute an argument in favour of some special relationship between these manuscripts. ${ }^{26}$

It is noteworthy that the attribution to the Venerable Bede is completely absent from the oldest manuscripts, but occurs frequently from the twelfth century onwards. This phenomenon, which goes hand in hand with the explosion of the witnesses to the Expositio in the twelfth century, can probably be explained by the fact that the transmission of Bede's Pauline commentary, which had known some popularity in the Carolingian period, had almost come to a standstill from the tenth century onwards. ${ }^{27}$

25 Quoted in note 3 above.

${ }^{26}$ For the wide dissemination of the Institutiones, see L.W. Jones, 'The Influence of Cassiodorus on Mediaeval Culture', Speculum 20 (1945) 433-42 and the list of witnesses in Mynors, Cassiodori Senatoris Institutiones, $\mathrm{x}-\mathrm{xlix}$. The earliest preserved manuscripts date from the eighth century.

27 Six or seven of the twelve extant direct witnesses to the Collectio can be dated to the Carolingian period. These are: Cologne, Dombibliothek, $104\left(\mathrm{IX}^{1-2 / 4}\right)$; Orléans, BM, 81 (78) (IX $\left.{ }^{1 / 3}\right)$; Orléans, BM, 84 (81) (IX $\left.{ }^{2 / 4}\right)$; Rouen, BM, 147 (A 437) (IX); Saint-Omer, BM, 91 (IX $\left.{ }^{1}\right)$; Würzburg, Universitätsbibl., Mp. th. f. 63 (IX $\left.{ }^{2 / 3}\right)$; Florence, BML, San Marco 648 (IX-XI). Four witnesses date from the eleventh and twelfth century: one is an abbreviation (Boulogne, BM, 64 (71) [XII inc.]); two were written in the monastery of Allerheiligen at Schaffhausen (Schaffhausen, Ministerialbibl., 64 [XII $\left.{ }^{1 / 2}\right]$ and 65 [XII); the fourth is Monte Cassino 178 (1075-80). 
This was possibly due to competition from more extensive Carolingian commentaries, some of which had incorporated large parts of Bede's compilation: these include Florus' Expositio, the anonymous commentary on Romans in Paris, BnF, lat. 11574, and Hraban Maur's commentary on the Pauline Epistles. ${ }^{28}$ Bede's Augustinian commentary on Paul was well known because of its description in the Historia Ecclesiastica. ${ }^{29}$ However, since it had almost stopped circulating, it may easily have been identified with Florus' Expositio, which formally corresponded to the description in the Historica Ecclesiastica and had started circulating widely. ${ }^{30}$

\section{New STEMmatical Results}

\section{A comparison of the section on 2 Cor. in $L$ with all other pre-twelfth- century witnesses}

As noted above, Luc De Coninck has shown—against a common assumption that had never really been proven-that $T$ is not the hyparchetype on which the Expositio's entire transmission depends (with the exception of $L$ ). Part of his argumentation consisted of a careful

One direct witness from the fifteenth century is of no importance for present purposes: Città del Vaticano, BAV, Urb. lat. 102 (between 1474 and 1482). See Partoens, 'The manuscript transmission', 216-24.

28 In addition, Lupus of Ferrières and Hincmar of Reims mention Bede's commentary with admiration. See Partoens, 'The manuscript transmission', 207-9 (Florus' Expositio); 207 n. 22 (Paris, BnF, lat. 11574; on this compilation, see also P.-I Fransen, 'Traces de Victor de Capoue dans la chaine exégétique d'Hélisachar', RevBén 106 (1996) 53-60; P.-I. Fransen, 'Le dossier patristique d'Hélisachar: le manuscrit Paris, BNF lat.11574 et l'une de ses sources', RevBén 111 (2001) 464-82; M. Gorman, 'Paris Lat. 12124 (Origen on Romans) and the Carolingian commentary on Romans in Paris Lat. 11574', RevBén 117 (2007) 64-128); 207 n. 23 (Hraban Maur); 207 n. 25 (Lupus of Ferrières, ep. 76 ad Hincmarum); 207 n. 26 (Hincmar of Reims, De praedestinatione dei et libero arbitrio posterior dissertatio 1).

${ }^{29}$ Hist. eccl. 5.24.2: In Apostolum quaecumque in opusculis sancti Augustini exposita inneni, cuncta per ordinem transcribere curaui (M. Lapidge, P. Monat, P. Robin, Beda Venerabilis, Histoire ecclésiastique du peuple anglais = Historia ecclesiastica gentis Anglorum. SC 489-91. Paris: Les Belles Lettres, 2005, 491).

30 According to the overview in Heil, Kompilation oder Konstruktion?, 403-5, the attribution to Bede is found in the following twelfth-century witnesses: Cambridge, Trinity College, 119; Munich, BSB, Clm 4516; Oxford, Balliol College, 178; Oxford, Bodl. Libr., Bodl. 317; Paris, BnF, lat. 17452; Reims, BM, 122; Saint-Omer, BM, 51; Valenciennes, BM, 87. 
comparison of the text of the section on 2 Cor. in $L, T, O$ and $G$, which proved that the latter two witnesses cannot possibly depend on $T$. De Coninck found 24 loci in the section on 2 Cor. in which $T$ differed from $L$, and investigated the more significant cases. The following apparatus, which presents all the variants explicitly discussed by De Coninck, shows that the same conclusion can be drawn for all other pre-twelfth-century witnesses: ${ }^{31}$

2 Cor. 40.6 ad R L O GAB MN V in TX (Vulg.); 70.13-14 qua aequabimur $\mathrm{R} L O A B M N$ V qua aequabitur $G^{\text {p.c. al. manu }} T X$, quaequabitur $G^{a . c} ; \mathbf{1 2 2 . 4}$ a parte $L O G A B X M$ V aperte $\mathrm{R} T($ def. $N)$; 137.25 autem $R L O G A B X M N$ V om. T; 180.3 quanto $\mathrm{R}^{\text {p.c }} L O G$ p.c. al manu $A B X M N$ V quando $\mathrm{R}^{\text {a.c. }} G^{\text {a.c. }} \mathrm{T} ; \mathbf{1 9 1 . 3}$ enim $\left.L O B\right]$ etenim $\mathrm{R}$ $G T A X M N V(V u l g) ;$.193.2 agit $\mathrm{R} L O G^{\text {p.c. al. manu }} A B X N$ V ait $G$ a.c. $T M$; 197.59-60 mundicordes $\left.L^{\text {a.c. }} O G^{\text {a.c. }} T N\right]$ mundicorde $L^{\text {p.c. }} G^{\text {p.c. }}$ $M$, mundo corde $\mathrm{R} A B X V$ (Vulg.)

\section{A full collation of fifty fragments in all pre-twelfth century witnesses}

Moreover, a collation of the available pre-twelfth-century witnesses for fragments 1-25 of the section on 2 Cor. (CCCM 220B, 5-24) and fragments $83-111$ of the section on Phil. (528-549), has enabled us to draw some further conclusions:

(1) Our collations yielded the immediate observation that in its early stage-i.e., the second half of the ninth century-the Expositio's transmission is very faithful and meticulous, with few variants. In the sections we have collated, every fragment that has been added in the margins of $L$ is found in all our witnesses; no fragments were purposely or accidentally omitted. Several witnesses testify to careful correction, showing that the copyist or a close contemporary reread the text, filtering out small mistakes. The dearth of common errors in the early stages of the transmission makes it harder to position the eleventh-century witnesses in the stemma.

(2) A few minor variants in Phil. 83-111 confirm, again, that $T$ was not the basis of the entire manuscript tradition (with the exception of $L$ ): ${ }^{32}$

31 De Coninck, 'Pour une nouvelle édition', 330-4. One additional variant he also discussed, but which is not relevant for the purpose of our apparatus above is 2 Cor. 4.15 sine $O G T$ ] om. per homoearchon L. De Coninck concluded that this obvious error in $L$ was easily corrected independently and thus did not constitute any indication of kinship ('Pour une nouvelle édition', 331).

32 For Montecassino, Biblioteca della Badia, $39 \mathrm{C}$ we only had access to 
Phil. (def. $O G) 83.30$ separemini $R L^{\text {p.c. }} A B N$ V separamini $L^{\text {a.c. }} T$, def. X; 92.4 unde $R L A B X N$ V inde $T$; 95.1 fraudari $R L A B X N$ V fraudare $T ; \mathbf{1 0 4 . 1 3}$ sibi $R L A B X$ V si $T N$; 106.29 gaudes...gaudes R L A B XN V gaudens...gaudens $T ; 107.9$ congruas $R L A B X N$ V congrues $T ; \mathbf{1 0 8 . 2 1}$ hominem $R L A B X N$ V homine $T ; \mathbf{1 0 8 . 2 3}$ posset R L A B XN V possit T

(3) The close relationship between $R$ and $G$ has been identified in the past on the basis of the overall composition of these witnesses and explained with reference to the close links that existed in the second half of the ninth century between the bishops of Brescia and the abbeys of Reichenau and St Gall. ${ }^{33}$ This is now confirmed in three ways: (a) two variants, shared with the north Italian manuscript $V$, and one, which can be found also in $V$ and $X$ :

2 Cor. 7.4 humani] humanam $R G V ; 16.18-19$ responderet mihi] inu. $\mathrm{R}$ $G V ; 25.3$ enim] om. R GXV.

(b) a compositional feature which will be dealt with in detail below, namely the inversion of the order of fragments 35 and 36 in the section on 2 Corinthians. This phenomenon is uniquely encountered in $\mathrm{R}, G$ and $V$; (c) the title of 2 Cor. 60.1. $R$ and $G$ both repeat the title of the previous fragment (ex libro de gratia et libero arbitrio) instead of the correct title (ex libro de natura et gratia). This caused $V$ to use the formula item ex eodem as the title for fragment 60 . Of these three witnesses, the text of $R$ is closest to that of $L$, while $G$ and $V$ have more individual mistakes. With regard to manuscript $X$, it should be said that it shares a few errors with $V$ in our sample from the section on 2 Cor., but none for the fragments collated of Phil. ${ }^{34}$ In our stemma below, we have added $V$ to the Carolingian pair $R G$, but preferred to not include $X$ in this group because its position remains more obscure.

reproductions of the section on 2 Cor., so it is not included in this apparatus.

33 Cf. C. Villa, 'La tradizione delle «Ad Lucilium» e la cultura di Brescia dall'età carolingia ad Albertano', Italia medioevale e umanistica 12 (1969) 9-51 (14-17, 51); S. Gavinelli, 'Tradizioni testuali carolinge fra Brescia, Vercelli e San Gallo: il De civitate dei di s. Agostino', in L'antiche et le moderne carte. Studi in memoria di Giuseppe Billanovich, ed. A. Manfredi \& C. M. Monti. Medioevo e Umanesimo 112. RomaPadova: Antenore, 2006, 263-84. See the summary in De Coninck, 'Pour une nouvelle édition', 331 n. 24.

342 Cor. 4.10 esse] om. $X V$; 13.6 sumus] deo add. $X V$; 14.7 fraglat] flagrat $X$ $V ; \mathbf{1 5 . 1 4}$ periebant] peribant $X V$. 
(4) We can posit with certainty a hyparchetype for $M$ and $N$, which regularly share exclusive errors. The most telling of these are:

2 Cor. 9.5 sobria ebrietate] sobri\&tate $M$, sobrietate $N ; 16.9$ alios $\left.^{1}\right]$ om.

$M N ; 19.14$ et resurrectione] om. $M N ; 20.18$ beatus] bonus $M N ; 25.11$ uolumine] lumine $M N$.

The hyparchetype of $M$ and $N$ had source identifications, but manythough not all-are absent from $N$ while in $M$ they are often illegible in our images. Both manuscripts contain a relatively large number of individual variants. For example, $M$ contains one extended saut du même au même, where the beginning of a fragment has disappeared (2 Cor. 13.1-11 ex-idoneus). $N$ shares a saut du même au même with $G$ (2 Cor. 23.18-19 sed-nobismetipsis) which, given the fact that the connection between $M$ and $N$ has been amply proven and $M$ does have the full text, must have been made independently in $N$ and $G$. This is not unlikely: $N$ shares another saut (2 Cor. 2.2-3 humilis-placere) with Oa.c.

(5) $O$ has a text that is definitely not far removed from that of the archetype $L$. The manuscript from Fleury shares the transposition of the title (ex libro suprascripto) of fragment 9 on 2 Cor. to fragment 8, which originally had no title, with codex $A$, of which it is a possible ancestor. ${ }^{35}$ However, as $O$ has a few errors in the titles that are not present in $A$, it is likely that somewhere between $O$ and $A$, the titles were corrected using a different model. The only variants present in $O$ that are not found in $A$ do not pose a problem for this hypothesis:

2 Cor. 13.26 ibi] sibi $O ; 20.7$ spiritu] spiritus $O$.

(6) Manuscript $B$, from Cluny, contains a great number of errors and is of no use for the edition. The manuscript shares a few variants with other witnesses without any evident pattern.

\section{Three independent branches represented by $R, O$ and $T$}

In addition to $T$, two excellent witnesses with very few deviations from $L$ have emerged from our analysis: $R$ and $O$. In this section, we will offer evidence that suggests that these three manuscripts are representatives of three branches that rely on $L$ independently from one another:

(1) The transmission of fragments $34-36$ on 2 Cor. proves that $R, G$ and $V$ constitute an independent branch that depends on $L$ without the

${ }^{35} \mathrm{~B}, \mathrm{X}$, and $N$ have eliminated the title of fragment 9 , but only $O$ and $A$ have repositioned it. 
mediation of a hyparchetype shared with any of the manuscripts $O T A B X$ $M N$. In the archetype $L$, the order of fragments $33-37$ is as follows:

$\begin{array}{lll}\text { fol. 7v } & \begin{array}{l}\text { expl. fragment 33 } \\ \text { lemma for 36 }\end{array} & \text { 2 Cor. 3:7b } \\ & \text { fragment 36 } \\ & \begin{array}{l}\text { lemma for 34 and 35 } \\ \text { inc. fragment 34 } \\ \text { fol. 8r }\end{array} & \text { 2 Cor. 3:7a } \\ & \begin{array}{l}\text { expl. fragment 34 } \\ \text { fragment 35 } \\ \text { lemma for 37 } \\ \text { inc. fragment 37 }\end{array} & \\ \text { 2 Cor. 3:14 }\end{array}$

This overview shows that the order of the fragments in $L$ was originally erroneous. For this reason, a corrector-probably Florus himself-marked the beginning of both fragments 36 and 34 with a capital letter ' $M$ '. The end of the passage that had to be replaced before fragment 36 was marked with a cross between the explicit of fragment 35 and the lemma for fragment 37 . Due to these instructions, fragments 34-36 follow each other in the right order in $O T A B X M N .{ }^{36}$ This is not the case, however, in the branch represented by $R G$ and $V$, where the erroneous order $(36,34,35)$ has been changed into an equally mistaken series $(34,36,35) .{ }^{37}$ This new order was clearly caused by a misinterpretation of the signs introduced by the corrector of $L$, resulting in the transposition only of the fragments marked by a capital ' $\mathrm{M}$ ' without noticing that the second element comprised not one but two fragments. This explanation presupposes a dependence of the group $\mathrm{R} G V$ on $L$, without an intermediate hyparchetype in common with any of the witnesses $O T A B X M N$.

(2) The critical apparatus offered in the Appendix to the present contribution is based on a full collation of $L, R, O$ and $T$ for the first 75 fragments on 2 Cor. (CCCM 220B, 5-69). This apparatus, which is complete with the exception of insignificant orthographical differences, shows that there are no significant common errors that link $R$ either with $O$ or $T$. This therefore confirms our hypothesis that $R$ depends on $L$ without the mediation of a hyparchetype shared with $O$ and/or $T$.

36 The passages are found respectively in $O$, p. 469-70; T, fol. 165r-165v; $A$ (ms. 66), fol. 6r-6v; B, fol. 156v; $X$, fol. 7r-7v; $M$, p. 340; $N$, fol. $115 \mathrm{v}$.

37 The passages are found in $R$, fol. $215 \mathrm{r}-215 \mathrm{v} ; G$ (ms. 281), p. 449-51; $V$, fol. 90r-90v. 
(3) The same critical apparatus proves that there is no reason to posit $O$ and $T$ as part of the same branch of the stemma. Both manuscripts contain their own specific errors and have each preserved marginal annotations copied from $L$ that are lacking in the other. This excludes a dependence of $O$ on $T$ or vice versa. Moreover, there are no significant common errors that suggest that the dependence of both manuscripts on the archetype $L$ is mediated by a common hyparchetype. It is thus highly likely that $O$ and $T$ each go back to $L$ independently. ${ }^{38}$

(4) A final illustration of the outstanding quality of these three witnesses and the proximity of their text to that of $L$ is found in their preservation of a number of marginal notes which are identical in shape and style to those present in L. Marginal annotations would be among the first elements to disappear in the course of transmission, and Bischoff has already remarked on this as an indication of the closeness of Laon, BM, 105 to $L .39$ The following examples of marginal annotations in $R, O$, and $T$ provide additional proof that none of the three is directly dependent on one of the other two:

2 Cor. 180 approx. 1.20 ' $\mathrm{M}$ ' is found in $R L T$, not in $O$; 2 Cor. 186 approx. 1.5 a capital ' $\mathrm{N}$ ' topped with ${ }^{\circ}{ }^{\circ}$ ' and bisected by a vertical line (=nota-sign) is found in $\mathrm{R} L$, not in $T$ O; 2 Cor. 187 approx. 11.87 and 102 capital letters in vertical order 'SNM' are found in $R L O$, not in T; 2 Cor. 197 approx. 1.14 'cōr I' is found in R L T, not $O$; Eph. 17 approx. 1. 11 ' $\mathrm{M}$ ' is found in $R L$, not in $T$ (def. O); Eph. 46 approx. 1.46 'cōr II' is found in $R L$, not in $T$ (def. $O$ ).

\section{CONCLUSION}

Our investigation has not so far provided an unambiguous and definitive stemmatical position for each pre-twelfth-century witness. We have demonstrated the close relationship between $M$ and $N$, but cannot yet situate this group clearly within the global transmission. The latter is also true of manuscripts $B$ and $X$. We have been able, however, to establish a clear stemma for the remaining witnesses:

38 See the descriptions of the manuscripts on 261 and 262 above for suggestions in past research that they were copied directly from $L$ without intermediaries.

39 See the description of this manuscript on 261 above. 


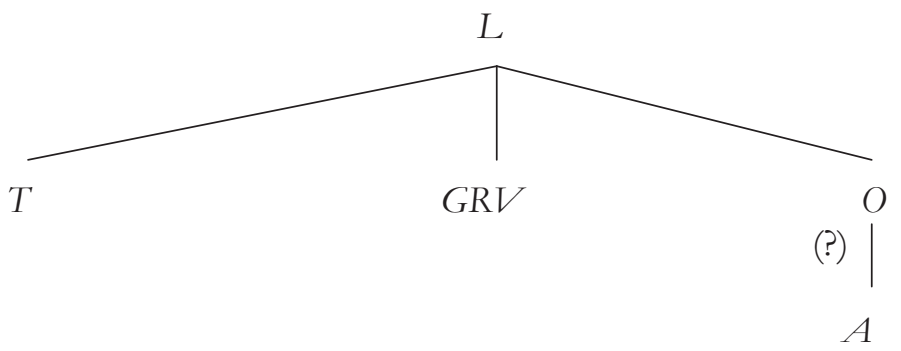

Moreover, we have shown that $\mathrm{R}$ and $O$ are two excellent witnesses in addition to T.40 All three of these manuscripts are faithful, meticulous copies that exhibit no indication of kinship other than their common dependence on $L$. It is likely that they are all three direct copies of the archetype (as has been suggested in the past for $T$ and $O$ ). ${ }^{41}$ For the critical edition of the sections of the Expositio that have not been preserved in $L$ (Rom. and 1 Cor.) a comparison between $R, O$, and $T$ is thus virtually guaranteed to produce an accurate reconstruction of $L .{ }^{42}$ Since earlier palaeographical research has suggested that Laon, BM, 105-the only ninth-century manuscript that has not been studied in this paper, because it does not contain the sections on 2 Cor. and Phil.-might also be a direct copy of $L,{ }^{43}$ an additional collation of this manuscript might be considered for the reconstruction of the archetype's lost sections on the first two Pauline Letters.

\section{APPENDIX: VARIANTS IN $O, T$ AND $R$ FOR FRAGMENTS $1-75$ ON 2 CORINTHIANS}

1.13 fluxum] fluxu* R 15 est] om. R || 2.1 XVIII] XLVIII $O 2-3$ humilis-placere] om. $O$ a.c. || 4.13 gloriandi] gloria dei $O$ a.c. 15 sine] ita $\mathrm{R} O \mathrm{~T}$, om. per homoearchon L || $\mathbf{5 . 1}$ sermone] sermo $\mathrm{R}||$ euangelii] LII add. $\mathrm{R}$ (e dittographia) 7 confingit] confingit* $\mathrm{R}^{\text {a.c. }}$

${ }^{40}$ Instead of $R, G$ could technically also be used. Both witnesses are dated to the same period, the final quarter of the ninth century, but $G$ contains more individual errors, making its testimony slightly less valuable.

${ }^{41}$ Cf. their respective detailed descriptions on 261 and 262 above

42 For titles and marginal identifications we must rely primarily on $R$ and $T$, because $O$ has a few mistakes here.

43 B. Bischoff, Katalog der festländischen Handschriften des neunten Jahrbunderts (mit Ausnabme der wisigotischen). Vol. 2. Wiesbaden: Harrassowitz, 2004, 335-6 (no. 3683). 


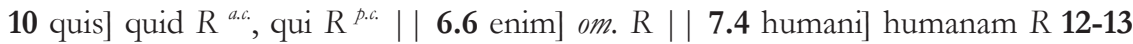

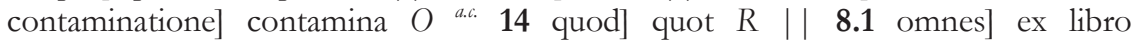
suprascripto praem. $O$ (cfr inscriptionem fragmenti IX) || 9.1. ex-suprascripto] om. $O$ (cfr l. 1 fragmenti VIII) || 10.1 sermone] sermo $R$ 10 spiritu] spiritum $R$ || 12.5 iudicio]

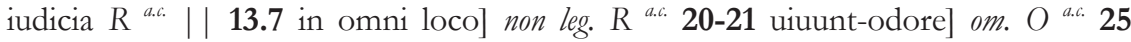
quomodo-dignatur] om. $O^{\text {a.c. }} 26$ ibi] sibi $O \|$ qui a] quia $O 40$ illum odorem] illu|modo rem $R|| 15.1$ XLIIII] XLII $O 14$ periebant] per*ant $O 20$ odorem] odore $R$ || 16.9 odor] odr $R{ }^{\text {a.c. }} 10$ bonos] bonus $R^{\text {a.c. }}$ 18-19 responderet mihi] mihi responderet $R$ || 18.5 corde] cor $R \mathbf{1 0}$ nobilitate] nobilate $R \mathbf{1 3}$ adhuc] ad $R^{\text {a.c. }}||$ 20.3 adimplere] implere $\mathrm{R} 7 \mathrm{spiritu}$ spiritus $O 13$ digiti] digito $O|| 21.4$ ait] dicit $O$ 10 uoluntatem] uoluntem $O^{\text {a.c. }}|| \mathbf{2 2 . 1}$ libro] ita $T$, II add. $\mathrm{R} O$ (fortasse recte), def. $L$ (in quo margo maxime laesa est) || 23.9 celerrime] scelerrime $O^{\text {a.c. }} 10$ anteuolent] ante uolunt $\mathrm{R}$, anteuolant $O^{\text {p.c. }}||$ moxque] mox quae $R|| 24.3$ pietatis uiam et] pietati sui amet $O^{\text {a.c. }}|| 25.2$ figuratam] figura| tam $O^{\text {a.c. }} 3$ enim] om. $\left.\mathrm{R} 6 \mathrm{cum}\right]$ om. $\mathrm{R} 29$ quil] quia $R^{\text {a.c. }}|| 26.4$ enim$^{2}$ ] om. $T^{\text {a.c. }} 6$ ita] uita $R^{\text {a.c. }} 11$ cui] clll $O^{\text {a.c. }} \mathbf{1 4 - 1 5}$ quis ea] qui se $O^{\text {a.c. }} 20$ liberet] liber et $R \mathbf{2 4}$ quia apponit] ita $L$ T, qui apponit $R O 26$ non] n $O 30$ quae] qua $R^{\text {a.c. }} 33$ nouitate] nouitatem $R O 34$ homine] hominem $R^{\text {a.c }} 40$ decalogo] decalago $T^{\text {a.c. }} 43 \mathrm{ob}$ omni] a boni $O^{\text {a.c. }} \mathbf{5 3}$ aberret] aberet $T^{\text {a.c. }} \mathbf{5 7}$ adest] ad est $O|| 27.1$ tit.] om. $R \mathbf{5}$ sic uidet] si cuidet $R \mathbf{~} 7$ scientia $\left.^{1}\right]$ om. $R \mathbf{1 5}$ seueram] se ueram $T 17$ multa] multi $R$ || 28.9 gratia] grata $O{ }^{a . c .}$ || 29.2 uoluntatem] uolunntatem $O^{\text {a.c. }} 8 \mathrm{hac}$ ac $\mathrm{R} \mathbf{1 8}$ recteque] necteque $O^{\text {a.c. }} \mathbf{2 1}$ absurda] absurdum $\mathrm{R}$ 24 sapere] sapare $R^{\text {a.c }} \mathbf{2 9}$ eoque] eo que $O \| \mathbf{3 0 . 6}$ uincientibus] uincentibus $R^{\text {a.c }} \mathbf{7}$ addictus] additus $\mathrm{R}$ 7-8 si uos] suos $O^{\text {a.c. }} \mathbf{9}$ docendo] ita $\mathrm{R} T^{\text {p.c. }}$, def. $L$, dicendo $O \mathrm{~T}$ a.c. (fortasse recte) 10-11 ut-saluatorem] om. $\mathrm{R} 17$ occidat] occidit $\mathrm{R} 18$ dei] om. $\mathrm{R}||$ $\left.\mathbf{3 1 . 1 0} \mathrm{est}^{1}\right]$ om. $T^{\text {a.c. }}|| \mathbf{3 2 . 4}$ adiuuat] adiuua $\mathrm{R}^{\text {a.c. }} \mathbf{6}$ adest] ad est $O \mathbf{9}$ ad] a $O^{\text {a.c. }} \mathbf{2 2}$ ministratio] litteris add. $\mathrm{R}^{\text {a.c. }} 25$ spiritus] non leg. $O^{\text {a.c. }}|| 33.7$ gloria] gloriam $\mathrm{R} 11$ dicta] data $O 14$ ignorans] a supra o $\mathrm{R}^{\text {p.c. }} 15$ dictam] datam $O 19$ superbis] superbus $O^{\text {a.c. }} 20$ impliciti] impliati $O^{\text {a.c. }} 22$ hinc] $*_{\text {nc }} O^{\text {a.c. }} 23$ malam] male $O 31$ et nimis] animis $O^{a . c .} \mathbf{3 8}$ nec qui] nequi $R^{a . c .}||$ ut] uel $R \mathbf{5 0}$ sententia] scientia $R \mathbf{5 3}$ moxque] mox quae $R 58$ aliquando] om. $R \mathbf{7 6}$ est] esse $T \mathbf{8 0}$ quod $\left.^{1}\right]$ quid $R{ }^{a . c} \mathbf{9 4}$ bonum] est add. $\mathrm{R}^{\text {a.c. }} 95$ dicit] def. $L$, dixit $\mathrm{R} O \mathrm{~T}$ (recte) 100 aut] ait $\mathrm{R}^{\text {a.c. }} 106$ deformata] deforta $O$ a.c. || 34.4 dictum] est add. $R 7$ est] om. $T^{\text {a.c. }} 10$ nam] om. $O$ || $36.1 \mathrm{II}$ om. R 3-4 intellecturi] intellectum $R^{a . c}$, intellectui $R^{\text {p.c. }} 6$ sed] om. $R^{\text {a.c. }}$ 11-12 itaque illa omnia] illa omnia itaque $O 11$ itaque] ita quę $T \mathbf{1 3}$ quod eos] quo $O 20$ uetere] ueteri $O \|$ in] im $T 27$ habentes] habemtes $R{ }^{a . c .}$ || 37.3 accipere sanguinem] sanguinem accipere $O 8 \mathrm{os}$ ] om. $R$ 9-10 persecutoris] peccatoris $R 10 \mathrm{sed}$ ] om. $O 14$ tu a terra] tuaterra $R 17$ operari] operare $T^{\text {a.c. }} 29$ absconditam] abscondit* $R^{\text {a.c. }} 30$ quo] quod $O$ 32 eius] ei $R$ 32-33 sanguinem-transeuntibus] om. $R$ || 38.9 dei] def. $L$, domini $R O$

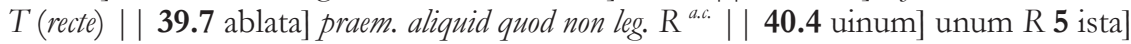
asta $\mathrm{R}^{\text {a.c. }} \mathbf{6}$ ad] in $T \mathbf{9}$ auferretur] aufetur $\mathrm{R}||$ adoperationem] ad operationem $O \mathbf{1 2}$ omnes] omne $O^{\text {a.c. }}|| \mathbf{4 1 . 6}$ mutatur] mittatur $T^{\text {a.c. }} \mathbf{7}$ uetere] uertere $\mathrm{R}^{\text {a.c. }}$ 8-9 qua expectabatur] qua*pectabatur $R{ }^{\text {a.c. }} 10$ expectatur] expectaretur $O||$ 42.2-3 autem] om. $R 6$ in ${ }^{2}$ ] ut $R 9$ dixit] dicit $R 10$ quae] ei add. $T$ || euacuantur] euacuatur $R 14$ imaginibus] inmaginibus $R 19$ non uident] inuident $R|| 43.3$ esse] esset $R 4$ auferretur] auferetur $R \mathbf{8}$ eis] eius $T$ a.c.

44.2 personam] persona* $R{ }^{\text {a.c. }}||$ 
ponebat] ponat $T \mathbf{5}$ faciem] facies $R|| 45.1 \mathrm{I}] \mathrm{om}$. $\mathrm{R} \mathbf{5}$ dominus] deus $O|| \mathbf{4 6 . 9} \mathrm{ad}$ dexteram] adexteram $R 11$ ideo] adeo $R{ }^{\text {a.c. }} 13$ domini $^{2}$ ] et add. $O|| 47.2$ non] om. $R$ 4 reuelata] reuelat* $O^{\text {a.c. }} 5$ transformamur] transformemur $\left.O|| \mathbf{4 8 . 1 1} \mathrm{ab}\right]$ a $R$ 13-14 dicens] dicentes $R^{\text {a.c. }} 15$ imago] dei add. $O 19$ gloria] gloriam $R^{\text {a.c. }} 28$ speciei] a $R^{\text {s.l. }}$

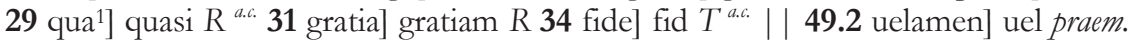
$\mathrm{R}^{\text {a.c. }} \mathbf{5}$ dicit] dixit $\mathrm{R} \mathbf{6}$ reuelata] reuela $T^{\text {a.c. }} \mathbf{9}$ deficimus] deficiamus $\left.O \| \mathbf{5 0 . 3} \mathrm{dicit}\right]$ dixit $O$ || hanc] haec $\mathrm{R}^{\text {a.c. }} \mathbf{6}$ astutiam] astitiam $\mathrm{R}^{\text {a.c. }} \mathbf{1 3}$ nosmetipsos] nonmetipsos $\mathrm{R}$ | 51.7 arbitrabitur] arbitrabimur $R 10$ putabit] putauit $R 13$ facientem] scientem $R$

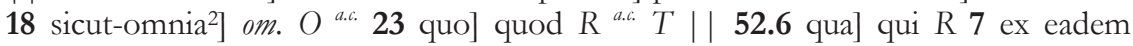
massa] eandem massam $R^{a . c}$, eandem massa $R^{\text {p.c. }} \mathbf{9}$ re cognoscit] recognoscit $O \| \mid$ 53.13 uenter] uent $O{ }^{\text {a.c. }} 16$ saeculum] secundum $\mathrm{R}$ a.c. 17 unde dicit] undicit $T$ || praesenti] prae* $T^{\text {a.c. }} 22$ excaecauit] et praem. $R^{\text {a.c. }}||$ ita] ite $R 33$ enim] om. $O 36$ et] om. $\mathrm{R} 37$ aedificatis] aedificantis $O^{\text {a.c }} \mathbf{3 8 - 3 9}$ temporis] temporibus $\mathrm{R}$ || $\mathbf{5 4 . 1}$ libris] libro $R$ 8-9 operatio] exoperatio $O \quad 9$ quendam] quen $T$ a.c. 15 praemisisset] praemisset $R 16$ et] ita $L^{p . c .} R O T$, e $L^{a . c .} 19$ et] om. $T^{\text {a.c. }} 26$ contumeliis] contumelias $\mathrm{R}^{\text {a.c. }}$, contumelia $\mathrm{R}^{\text {p.c. }} \mathbf{2 8}$ deus] om. $\mathrm{R} 29$ non] iterat $\mathrm{R} 30$ excaecat] excaecauit $\mathrm{R} 34$ uident ${ }^{2}$ ] non praem. $\mathrm{R}$ a.c. 38 uerissime] curissime $\mathrm{R} 40$ admiratus] anmiratus $O^{\text {a.c. }}$ | | 55.11 interuallum] inter uallum $R 21$ syllabae] syllaebe $R||$ praecedat] praecedet $T$ a.c. || $\mathbf{5 6 . 5}$ scriptum sit] scripsit $T \mathbf{7}$ ergo] om. T $\mathbf{1 4}$ isdem] hisdem $O$ || $\mathbf{5 7 . 8}$

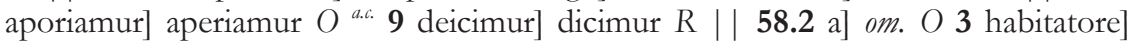
habitore $R^{\text {a.c. }} \mathbf{6}$ credimus] credidimus $R|| \mathbf{6 0 . 1}$ ex-gratia] ex libro de gratia et libero arbitrio $\mathrm{R}$ (cfr inscriptionem fragmenti $L I X$ ) || $\mathbf{6 1 . 2}$ quo] quod $O T^{\text {a.c. }} 4$ nos] om. $\mathrm{R}||$

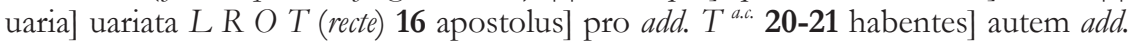
$\mathrm{R}^{\text {a.c }}|| \mathbf{6 2 . 1}$ ex-hilari] om. $\mathrm{R} \mathbf{3}$ credidimus] ita $L$, credimus $\mathrm{R} O \mathrm{~T}$ (cfr. credimus in

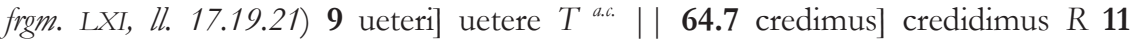
domini iesu] dnihu $R||$ domini] nostri add. $T$ 14 libris] libri $R^{\text {a.c. }} 19$ dei] deus $T^{\text {a.c. }}$ || 65.6 est] om. $R 7$ quia $\left.{ }^{1}\right]$ qui $T^{\text {a.c. }}||$ quia ${ }^{2}$ qui $T^{\text {a.c. }}$ 7-9 atque-credidit $\left.{ }^{1}\right]$ om. $T^{\text {a.c. }}||$ 66.1 sermone] sermo $R 10$ creditur] enim praem. $R 13$ is] his $R$ || 67.3 praeditum] praedictum $R^{\text {a.c. }}||$ ipse] ipsa $O \mathbf{6}$ dicat] ait $O \mathbf{7}$ noster] nrt $T|| \mathbf{6 8 . 2}$ quoddam] quodam $\mathrm{R}{ }^{\text {a.c. }} 18$ spiritalibus] piritalibus $O^{\text {a.c. }} 25$ huiusmodi] in praem. $\mathrm{R} 26$ agantur] aguntur $O 27$ uersentur] uersantur $O \|$ expertium] expertia $R 31$ non] om. $O{ }^{\text {a.c. }}||$ 69.5 eius] eis $T^{a . c} 6$ interius est] interi $O^{\text {a.c. }} 8$ non] om. $T^{\text {a.c. }} \mathbf{9}$ imaginem] imagnem $O$ a.c $12-13$ corpus-habet] om. $O^{\text {a.c. }} 13 \mathrm{sed}$ o om. $\mathrm{R} 22$ renouatur] re* $O^{\text {a.c. }}||$ autem] om. $\mathrm{R}$ 24 ueterem] nouum $O^{\text {a.c. }} \mathbf{2 4 - 2 5}$ et-hominem] om. $\mathrm{R}^{\text {a.c. }} \mathrm{O}^{\text {a.c. }} 25$ resurget] surget $\mathrm{R} 27$ dignitatem] dignitate $T|| \mathbf{7 0 . 5}$ quanto] quanta $T \mathbf{7}$ afflictionibus] afflictationibus $O$ 13-14 aequabimur] aequabitur $T|| 71.2$ sicut] sic $R^{\text {a.c }} 3$ renouatio] renouata $O 11$ proficiendo] proiciendo $\mathrm{R} \mathbf{1 2}$ fit] sit $\mathrm{R} 20$ transfert] transfer $\left.O \| \mathrm{a}^{2}\right]$ ad $\mathrm{R}^{\text {a.c. }} \mathbf{2 2}$ caritate] caritatem $R^{\text {a.c. }} \mathbf{2 6}$ ab eo] habeo $R^{\text {a.c. }} \mathbf{2 8}$ hac] ac $R \mathbf{3 0}$ de] da $T$ 36-37 apparuerit] paruit $R|| \mathbf{7 2 . 3}$ hominis] nominis $O$, homines $T^{a . c} \mathbf{6}$ fine] finea $R^{a . c .} \mathbf{9}$ noster] nrt $R$ 10-11 nondum-renouatus] iterat $O{ }^{\text {a.c. }} 12$ adhuc] ad hunc $O 17$

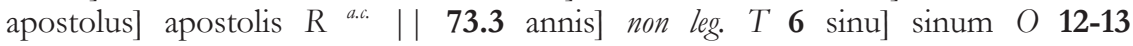
ordinatiusque] ordinatusque T 13 in uirum perfectum] iterat L R O T (recte) 16 omni ex] ex omni R 33 gerentium] gentium $R 35$ hominis] homi|hominis $O$ || 74.4 illud] illum R 8-9 nobis ${ }^{1}$-operatur] om. $O 14$ habebis] habebs $T^{a . c} 15$ quanto] quanti $L R O$ $T$ (recte) 22 perpetuo] pertuo $T^{\text {a.c. }}|| \mathbf{7 5 . 4}$ ut] et $O||$ uia] uiam $R$ 


\section{BibliograPHY FOR THE CATAlOgUE OF MANUSCRIPTS}

R. Bergmann \& S. Stricker, Katalog der althochdeutschen und altsächsischen Glossenhandschriften. Vol. 2. Berlin: de Gruyter, 2005.

B. Bischoff, Katalog der festländischen Handschriften des neunten Jabrhunderts (mit Ausnabme der wisigotischen). Vols 1-3. Wiesbaden: Harrassowitz, 1998, 2004, 2014.

M. Branchi, Lo scriptorium e la biblioteca di Nonantola. Modena: Artestampa, 2011.

Catalogue général des manuscrits des bibliothèques publiques des départements, vol. 1. Paris: Impr. nationale, 1849.

Catalogue général des manuscrits des bibliothèques publiques des départements, vol. 7. Paris: Impr. nationale, 1885.

Catalogue général des manuscrits des bibliothèques publiques de France, vol. 31. Paris: Impr. nationale, 1898.

C. Charlier, 'La compilation augustinienne de Florus sur l'Apôtre. Sources et authenticité', RevBén 57 (1947) 132-86.

Codicum Casinensium manuscriptorum catalogus. Cura et studio monachorum archicoenobii Montis Casini, vol. 1. Monte Cassino: s.n., 1915.

J. Contreni, The Cathedral school of Laon from 850 to 930. Its manuscripts and masters. Münchener Beiträge zur Mediävistik und Renaissance-Forschung, 29. Munich: Arbeo-Gesellschaft, 1978.

L. De Coninck, B. Coppieters 't Wallant \& R. Demeulenaere, 'Pour une nouvelle édition de la compilation augustinienne de Florus sur l'apôtre', RevBén 119 (2009) 316-35.

R. Étaix \& B. de Vrégille, 'Les manuscrits de Besançon, Pierre-François Chifflet et la bibliothèque Bouhier', Scriptorium 24 (1970) 27-39.

P.-I. Fransen, 'Le sermon 68 de saint Augustin chez Florus de Lyon. Identification d'un nouveau fragment', RevBén 104 (1994) 84-7.

P.-I. Fransen, L. De Coninck, B. Coppieters 't Wallant, R. Demeulenaere, ed., Flori Lugdunensis Expositio in epistolas beati Pauli ex operibus S. Augustini. Pars III. In epistolam secundam ad Corinthios. In epistolas ad Galatas, Ephesios et Philippenses. CCCM 220B. Turnhout: Brepols, 2011.

S. Gavinelli, 'Tradizioni testuali carolinge fra Brescia, Vercelli e San Gallo: il De civitate dei di s. Agostino', in L'antiche et le moderne carte. Studi in memoria di Giuseppe Billanovich, ed. A. Manfredi \& C. M. Monti. Medioevo e Umanesimo 112. Roma-Padova: Antenore, 2006, 263-84.

N. Giovè Marchioli \& M. Pantarotto, I manoscritti datati della Biblioteca Queriniana di Brescia. Florence: Sismel, 2008.

L. Holtz, 'La minuscule marginale et interlinéaire de Florus de Lyon', in Gli autografi medievali. Problemi paleografici e filologici. Atti del convegno di studio della Fondazione Eqio Franceschini (Erice, 25 settembre - 2 ottobre 1990), ed. P. Chiesa \& L. Pinelli. Quaderni di cultura mediolatina 5. Spoleto: Centro italiano di studi sull'alto Medioevo, 1994, 149-66. 
F. Leitschuh, Katalog der Handschriften der königlichen Bibliothek zu Bamberg, v. 1.1: Bibelhandschriften. Wiesbaden: Harrassowitz, 1966 (revised reprint of 1895 edition).

F. Newton, The Scriptorium and Library at Monte Cassino, 1058-1105. Cambridge Studies in Palaeography and Codicology 7. Cambridge: CUP, 1999.

G. Partoens, 'The manuscript transmission of Bede's Augustinian commentary on the Letters of Saint Paul', in La trasmissione dei testi patristici latini: problemi e prospettive, ed. E. Colombi. Instrumenta Patristica et Mediaevalia 60. Turnhout: Brepols, 2012, 201-51.

E. Pellegrin \& J.-P. Bouhot, Catalogue des manuscrits médiévaux de la bibliothèque municipale d'Orléans. Documents, études et répertoires publiés par l'IRHT, 78. Paris: CNRS, 2010.

C. Samaran \& R. Marichal, Catalogue des manuscrits en écriture latine portant des indications de date, de lien ou de copiste, v. 5: Est de la France. Paris: CNRS, 1965.

C. Samaran \& R. Marichal, Catalogue des manuscrits en écriture latine portant des indications de date, de lieu ou de copiste, v. 6: Bourgogne, Centre, Sud-Est et Sud-Ouest de la France. Paris: CNRS, 1968.

C. Samaran \& R. Marichal, Catalogue des manuscrits en écriture latine portant des indications de date, de lieu ou de copiste, v. 7: Onest de la France et pays de Loire. Paris: CNRS, 1984.

G. Scherrer, Verzeichniss der Handscbriften der Stiftsbibliothek von St. Gallen. Halle: Waisenhaus, 1875.

G. Suckale-Redlefsen, Die Handschriften des 8. bis 11. Jabrbunderts der Staatsbibliotheke Bamberg, v. 1: Texte. Katalog der illuminierten Handschriften der Staatsbibliothek Bamberg 1.1. Wiesbaden: Harrassowitz, 2004.

A.-M. Turcan-Verkerk, 'Mannon de Saint-Oyen dans l'histoire de la transmission des textes', Revue d'Histoire des Textes 29 (1999) 169-243.

J. Van den Gheyn, Catalogue des manuscrits de la Bibliothèque Royale de Belgique, v. 1: Écriture sainte et Liturgie, Brussels: Lamertin, 1901; v. 2: Patrologie. Brussels: Lamertin, 1902.

J. Vezin, Les scriptoria d'Angers an xi siècle. Bibliothèque de l'EPHE. ive section. Sciences Historiques et Philologiques 322. Paris: Champion, 1974.

C. Villa, 'La tradizione delle «Ad Lucilium» e la cultura di Brescia dall'età carolingia ad Albertano', Italia medioevale e umanistica 12 (1969) 9-51.

A. Wilmart, 'Sommaire de l'Exposition de Florus sur les Épîtres', RevBén 8 (1926) 205-14. 


\section{BIBLICAL QUOTATIONS IN THE GOTHIC COMMENTARY ON THE GOSPEL OF JOHN (SKEIREINS)}

\section{CARLA FALLUOMINI}

Eight folios divided between the Ambrosian Library and the Vatican Library transmit parts of a Gothic commentary on the Gospel according to John known as Skeireins, 'Explanation'. ${ }^{1}$ The text is anonymous and written in Gothic script. The exact period and place of its composition is unknown; it was written between the mid-fourth century, when Wulfila translated the Bible and devised an alphabet for the Goths, and the first third or first half of the sixth century, when the manuscript was copied. ${ }^{2}$ It appears very

1 The folios were originally part of a single manuscript, separated in 1606: Milan, Biblioteca Ambrosiana, E 147 sup., fol. 113-4, 77-8, 79-80, 309-10, 111-2 + Vatican City, BAV, Vat. Lat. 5770, fol. 59-60, 61-2, 57-8; with the exception of page 310, all were overwritten with Latin texts in the first half of the seventh century (see A. Zironi, Il monastero longobardo di Bobbio. Crocevia di uomini, manoscritti e culture. Istituzioni e società 3. Spoleto: Centro Italiano di Studi sull'Alto Medioevo 2004, 61, 67). The most recent critical edition is W.H. Bennett, The Gothic Commentary on the Gospel of John: Skeireins aiwaggeljons pairh Johannen. A Decipherment, Edition, Translation. New York: Modern Language Association of America, 1960 (from which the following citations of the Skeireins, with some corrections and adjustments, are taken). The name Skereins was given to the text by its first editor: Hans Ferdinand Maßmann, Skeireins aiwaggeljons pairh Iobannen. Auslegung des Evangelii Johannis in gothischer Sprache. Aus römischen und mayländischen Handschriften nebst lateinischer Uebersetzung, belegenden Anmerkungen, geschichtlicher Untersuchung, gothischlateinischen Wörterbüche und Scbriftproben. Munich: Jaquet, 1834.

${ }^{2}$ On the Gothic Bible see Carla Falluomini, The Gotbic Version of the Gospels and Pauline Epistles: Cultural Background, Transmission and Character. ANTF 46. Berlin \& New York: de Gruyter, 2015, and the literature cited there. 
probable that this manuscript was produced in a North Italian scriptorium, possibly Verona. ${ }^{3}$

Some scholars, among them Knut Schäferdiek, claim that the text is a translation of a partially lost commentary by Theodore of Heraclea, because seven lines of the Skeireins match a surviving part of Theodore's commentary remarkably well. ${ }^{4}$ However, the question is still open. The style and syntax of this Gothic text diverge from those of the Gothic version of the Bible. Traces of Greek influence seem to be undeniable but, at the same time, a back translation of the Skeireins does not offer incontrovertible evidence that the entire text is a version from a Classical language. ${ }^{5}$ In any case, the Skeireins attests to the participation of Gothic clergy in the Trinitarian debates. ${ }^{6}$ It is also worth nothing that this text, produced in a Homoean context, still circulated in sixth-century Italy. ${ }^{7}$ The corrections to the text, through glosses in the manuscript, demonstrate that active use was made of it at this time. ${ }^{8}$

The Skeireins contains several biblical citations, constituting about $27 \%$ of the text, which are inserted into the text and expounded. ${ }^{9}$ Taking account of brief quotations (juxtaposed in one case) and repetitions, the commentary transmits thirty-seven partial or entire biblical verses, sometimes adapted to the text, and one allusion. ${ }^{10}$ Apart from one citation

3 The particular form of $s$ used in the writing of the Skeireins connects it with Gothic manuscripts copied in Italy. See Carla Falluomini, 'Kodikologische Bemerkungen über die Handschriften der Goten’ Scriptorium 60 (2006) 3-37, esp. 10-11 and 35.

${ }^{4}$ K. Schäferdiek, 'Die Fragmente der Skeireins und der Johanneskommentar des Theodor von Herakleia.' Zeitschrift für deutsches Altertum und deutsche Literatur 110 (1981) 175-93.

5 See G.H. McKnight, 'The Language of the Skeireins.' Modern Language Notes 12 (1897) 205-9; G.W.S. Friedrichsen, 'The Gothic Skeireins in the Greek Original.' NTS 8 (1961) 43-56.

6 The commentary explicitly mentions Sabellius and Marcellus of Ancyra (Skeireins IVd, 11. 19-21).

${ }^{7}$ On the Goths and the Homoean belief see, among others, the papers of H.C. Brennecke, R.W. Mathisen and B. Wolfe in G.M. Berndt \& R. Steinacher, ed., Arianism: Roman Heresy and Barbarian Creed. Farnham: Ashgate, 2014.

8 See the critical edition of Bennett, The Gothic Commentary.

${ }^{9}$ R. Del Pezzo, 'Le citazioni bibliche nella Skeireins.' Annali dell'Istituto Orientale di Napoli (Filologia Germanica) 16 (1973) 7-15.

10 Juxtaposition: Skeireins IIId, 13-24: Appan ik in watin iqwis daupja (Luke 3:16) 
from a Psalm, the extant literal quotations derive from the New Testament, mainly—as expected—from the Gospel according to John. ${ }^{11}$ They are listed in the Appendix to the present chapter.

Quotations are marked throughout the text in the left margin: the beginning of each quotation is indicated by a horizontal sign (properly, a paragraph mark), the rest by a corrupted form of diple. They are often introduced by 'he said' or 'saying'. Only fourteen of these New Testament verses are also known from direct tradition, since a great part of the Wulfilian translation is lost. ${ }^{12}$ The citation from the Psalm may be compared with a citation transmitted in a Gothic sermon or liturgical prayer discovered a few years ago in Bologna, probably dating from the first quarter or first half of the sixth century. ${ }^{13}$

The question is whether the Skeireins citations derive directly from Wulfila's version or not. In other words, are the Skeireins citations reliable witnesses to Wulfila's translation?

ip sa afar mis gagganda swinpoza mis ist (Matt. 3:11) pizei ik ni im wairps ei anahne $<i>$ wands andbindau skaudaraip skobis is: sab pan izwis daupeip in abmin weibamma (Mark 1:7-8). ('I indeed baptize you in water (Luke 3:16), but he who is to come after me is mightier than I (Matt. 3:11), of whom I am not worthy that I should stoop and unbind the latchet of his sandal. He will baptize you then in the Holy Spirit (Mark 1:7-8)'). Allusion: Skeireins VIIc, 11. 2-7: John 6:13. Some divergences from the direct transmission exist. All translations of the Skeireins are from Bennett, The Gothic Commentary, with some adjustments.

11 On the Psalm quotation, see Carla Falluomini, 'A proposito di una controversa citazione biblica attestata nella Skeireins' in Studi in onore di Vittoria Dolcetti Corazza ed. C. Falluomini \& R. Rosselli Del Turco, Alessandria: Edizioni dell'Orso, 77-82, against Bennett, The Gothic Commentary, 51, 84-85, who claimed that the quotation derives from Romans 3:11-12 (on the basis of an alleged

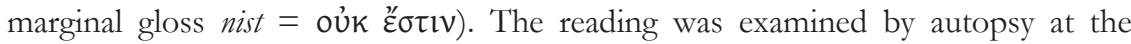
Ambrosian Library in January 2015 and the gloss nist is not present. It follows that the citation derives from Psalm 13(14):2-3 or 52(53):3-4.

12 See W. Streitberg \& P. Scardigli, ed., Die gotische Bibel. I. Der gotische Text und seine griechische Vorlage. Mit Einleitung, Lesarten und Quellennachweisen sowie den kleineren Denkmälern als Anhang. Germanistische Bibliothek 3. $7^{\text {th }}$ edn. Heidelberg: Winter 2000.

${ }^{13}$ See Carla Falluomini, 'Zum gotischen Fragment aus Bologna.' Zeitschrift für deutsches Altertum und deutsche Literatur 143 (2014) 281-305. 


\section{Verses Not Preserved in the Direct Tradition}

Twenty-three of the thirty-seven verses quoted in the Skeireins are not preserved in the direct tradition of the Gothic New Testament. They belong to the third and fifth chapter of the Gospel according to Matthew and to the first five chapters of the Gospel according to John. It is not possible to say anything about their textual relationship with the Wulfilian version, since the Vorlage of Wulfila's text is unknown. However, the lexical choice and the style of these citations are close to those of Wulfila's translation, which is highly literal and transmits an early form of Byzantine text with several non-Byzantine readings.

There are also some deviations from the Byzantine text in the Skeireins: ${ }^{14}$

\section{John 1:29}

Sai, sa ist wiprus gudis, saei afnimip frawaurbt pizos manasedais (Skeireins Ib.3-

6)

'Behold, this is the lamb of God, who takes away the sin of the world'

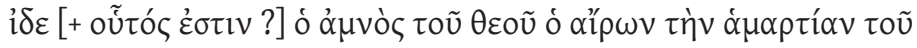
кóøuov

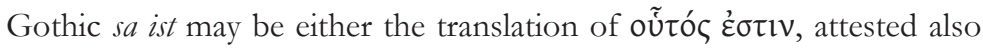
in Origen, or the result of a dittography, due to the preceding sai with the intrusion of the verb ist. ${ }^{15}$

\section{John 3:4}

Haiwa mabts ist manna gabairan alpeis wisands? ibai mag in wamba aipeins seinaizos aftra galeipan jag gabairaidau? (Skeireins IIb.11-17)

14 The Gothic New Testament (= Wulfilian text) is cited according to Streitberg \& Scardigli, Die gotische Bibel. The Greek New Testament is cited according to NA28; variants in the Greek and Latin New Testament texts are drawn from: NA28; The Gospel According to St. Luke, ed. by the American and British Committees of the International Greek New Testament Project. 2 vols. Oxford: Clarendon, 1984-7; Reuben J. Swanson, New Testament Greek Manuscripts: Variant Readings Arranged in Horizontal Lines against Codex Vaticanus. Matthew-John. 4 vols. Sheffield: Sheffield Academic Press, 1995; www.iohannes.com (last visited October 2015); the Psalms according to A. Rahlfs, ed., Septuaginta. Vetus Testamentum Graecum. X. Psalmi cum Odis. 2nd edn. Göttingen: Vandenhoeck \& Ruprecht 1967. Readings treated in the apparatus, as well as divergences and agreements between the Skeireins, the Wulfilian version and the Greek text, are underlined.

15 See Streitberg \& Scardigli, Die gotische Bibel, ad loc. 
'How is it possible for a man to be born when he is old? Can he go a second time into his mother's womb and be born?'

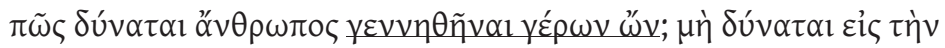

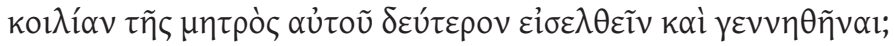

Some lines below (Skeireins IIb.25-IIc.1-7) part of the same verse is quoted differently: alpeis wisands gabairan. The word order gabairan alpeis wisands seems better to correspond to Gothic syntax, and agrees with the

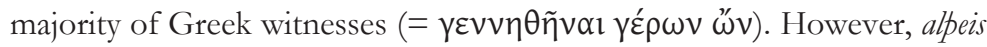

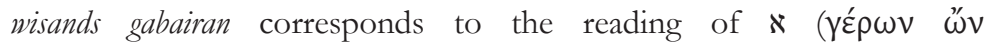

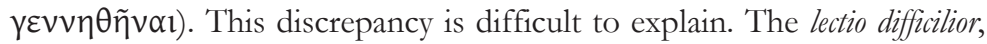
alpeis wisands gabairan, could be the original reading of the Skeireins and gabairan alpeis wisands a later change.

\section{John 3:25}

Dan warp sokeins us siponjam Iohannes mip Iudaium bi swiknein (Skeireins IIIa.24-5; IIIb.1-3)

'A question then arose between some of John's disciples and the Jews concerning purification'

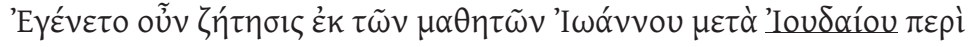

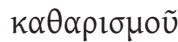

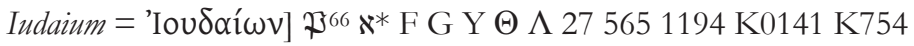

K994 L1073 L1075 L1091 f $\mathrm{f}^{13}$ latt syc samss bo Or | 'Ioudoíou $\mathfrak{P}^{75} \aleph^{2}$

A B N L Wsupp $\Psi \mathfrak{M}$ sy s.p.h sa $^{\text {mss }}$ Chrys

Possible explanations of the non-Byzantine reading Iudaium: (1) it may derive from a genuine Wulfilian reading - in this case one of the several non-Byzantine readings; (2) it follows another Greek tradition (Theodore's text?). Finally, it is not entirely possible to exclude the suggestion that the Skeireins citation has been influenced by Latin tradition (the manuscript was copied in Italy), even if no other evidence supports this idea.

No clear picture of the relationship with Wulfila's version emerges from the biblical citations transmitted only by the Skeireins.

\section{Verses Preserved in the Direct Tradition}

The fourteen citations also attested in the direct tradition were investigated by Karl Marold in 1890 and Raffaella Del Pezzo in 1973, in order to 
highlight their relationship with the Wulfilian version. ${ }^{16}$ Only six citations match the Wulfilian text perfectly or display insignificant differences. The other eight citations present different kinds of divergences, consisting of differences in word order and the addition of some particles and small portions of text. According to Marold, the different readings of the Skeireins derive from a corrupt manuscript of the Wulfilian translation. Del Pezzo argues, on the basis of the agreement in the lexical choice, that the text of the citations derives directly from Wulfila's Bible. Both scholars claim that some divergences may be explained as owing to the need to connect the citations with the proper commentary.

The following examples display textual divergences from the Wulfilian text:

\section{Luke 3:16}

Appan ik in watin irwis daupja (Skeireins IIId.13-14)

Ik allis izwis watin daupja (Wulfilian text)

'I indeed baptise you in water'

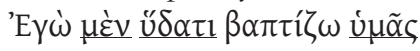

$\left.a p p a n^{\text {Skeirining }}\right]$ vs. allis, different rendering of $\mu \varepsilon v^{2}$, both are correct;

$\left.+i n^{\text {Seeiring }}\right]$ more idiomatic in Gothic? Influence of the parallel passage at

Matthew 3:11? Different model?

in watin izwis daupja Skeiring $^{\text {. }}$ the word order of the Skeireins diverges from

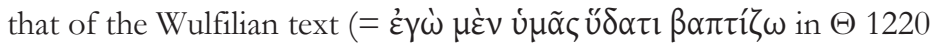

$\left.i^{b . c . f f 2}\right)$ and of the majority of the Greek witnesses. It agrees with ú $\delta \alpha \tau l$

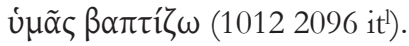

\section{John 6:11}

samaleikob pan jah andnemun pize fiske, swa filu swe wildedun (Skeireins VIIc.710)

samaleiko jah pize fiske, swa filu swe wildedun (Wulfilian text)

[ $\left[+\right.$ and then $\left.{ }^{\text {Skeiring }}\right]$ likewise [they $\left.{ }^{\text {Skeirining }}\right]$ also [received of $\left.{ }^{\text {Seirining }}\right]$ the fish as

much as they wished'

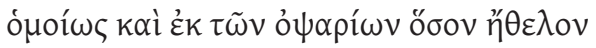

$\left.+-h^{\text {Skeirinin }}\right]$ enclitic particle ( $=$ '-que'); not relevant from the point of view

of textual criticism, very often added in the Gothic text;

+ pan $\left.^{\text {Skerriniss }}=\delta \varepsilon \dot{]}\right] \mathrm{D} 02191203$ L704 Basa;

${ }^{16}$ K. Marold, Die Schriftcitate der Skeireins und ibre Bedeutung für die Textgeschichte der gotischen Bibel. Königsberg: Hartung, 1890; Del Pezzo, 'Le citazioni bibliche nella Skeireins'. 
+ andnemun $^{\text {Skeirinin }}$ interlinear gloss, perhaps added for syntactic reasons; no parallels in the Greek or Latin tradition.

Since andnemun has been added secondarily, the divergence regards only the addition of pan.

\section{John 6:13}

Danuh galesun jah gafullidedun ib tainjons gabruko us paim $\cdot e \cdot$ hlaibam

barizeinam jab $\cdot b \cdot$ fiskam, patei aflifnoda at paim.... (Skeireins VIId.18-25)

Danuh galesun jah gafullidedun · ib t tainjons gabruko us fimf hlaibam paim barizeinam, patei aflifnoda paim (Wulfilian text)

'And then they gathered up and filled twelve baskets with bits of the five barley loaves [+ and two fish $\left.{ }^{\text {Skeirinin }}\right]$ that had been left over by those who...'

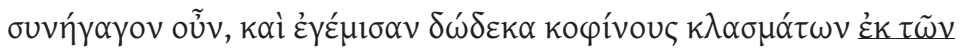

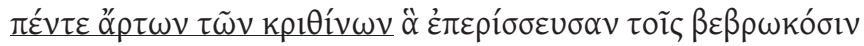

$+\operatorname{paim}(1)^{\text {Skeirinin }}$ definite article; its addition is not relevant from the point of view of textual criticism; different syntactic construction with blaibam barizeinam.

$e^{\text {Skeirining }}$ ' 5 ', number instead of the word 'five' (fimf); not relevant from the point of view of textual criticism;

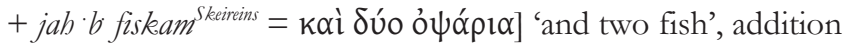
according to John 6:9 (cited some lines before)?; no parallels found in the Greek and Latin traditions;

$\left.+a t^{\text {Seciring }}\right]$ preposition; not relevant from the point of view of textual criticism.

It is not possible to determine whether the addition of jab $b$ fiskam is due to a different Greek model (Theodore's biblical quotation?) or to a free insertion of the author.

It is worth noting that, besides divergences, there are also peculiar agreements between the Skeireins citations and the Wulfilian text, sometimes in the same citation:

\section{John 7:45-6}

Galipun pan pai andbabtos du paim aubumistam gudjam jab Fareisaium. Darub qepun du im Jjailjainai: "duhve ni attaubup ina?" Andhofun pan pai andbabtos qipandans patei "ni huanbun aiw rodida manna swaswe sa manna" (Skeireins VIIIa.11-25)

Galipun pan pai andbabtos du paim aubumistam gudjam jah Fareisaium. Darub

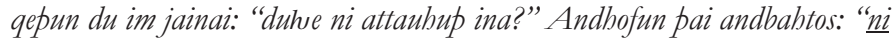
hanbun aiw rodida manna, swaswe sa manna" (Wulfilian text) 
'Then the officers went to the chief priests and Pharisees. And there they said to them, "Why have you not brought him?" [+ Then $\left.{ }^{\text {Skerrinins }}\right]$ the officers answered [+ saying that ${ }^{\text {Skeirining }}$ "Never did any man speak like this man".'

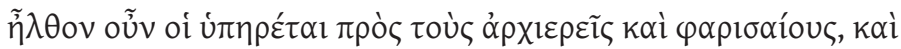

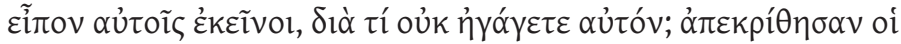

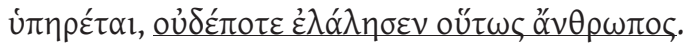

pan (1) ${ }^{\text {Skeirining }}$ interlinear gloss;

$\left.+\operatorname{pan}(2)^{\text {Skeerinin }}\right]=\delta \varepsilon \dot{\varepsilon} \mathrm{D}$ it $^{\mathrm{d}}\left(\mathrm{it}^{\mathrm{r}} \mathrm{l}\right) /$ oũv Chrys;

+ qipandans patei $\left.{ }^{\text {Seireinins }}\right] \mathrm{cf}$. + dicentes it it.e; + et dixerunt illis itc; it may be an insertion for syntactic reasons by the author of the Skeireins;

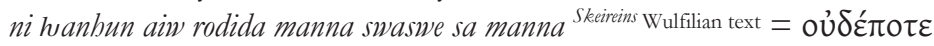

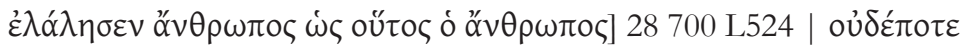

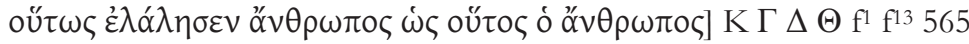

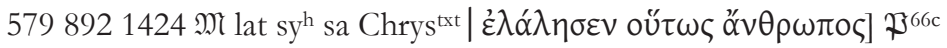
$7^{75} \mathrm{~K}^{2} \mathrm{~B} \mathrm{~L} \mathrm{~T} \mathrm{~W}$ vg gis bo Or Chrys ${ }^{\mathrm{mom}}$ | variae lectiones.

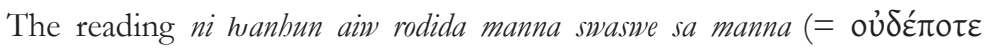

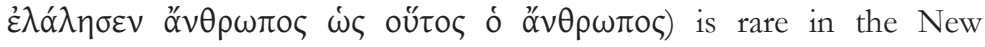
Testament tradition and the agreement between the Skeireins and the Wulfilian text does not seem to be a coincidence.

The following offers another example of a peculiar agreement:

John 7:48-9

Sai, jau ainshun pize reike galaubidedi imma aippau pize Fareisaie? Alja so managei, paiei ni kunnun witop, fraqipanai sind (Skeireins VIIIb.25-VIIIc.1-9)

Sai, jau ainshun pize reike galaubidedi imma aippau Fareisaie? Alja so managei, paiei ni kunnun witop, fraqipanai sind (Wulfilian text)

'[+ Behold,] has any one of the rulers or of the Pharisees believed in him? But this multitude, who do not know the law, are accursed'

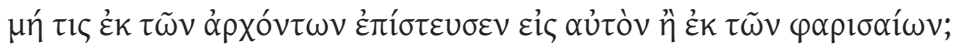

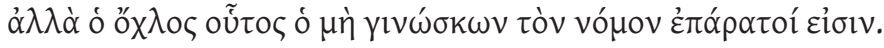

+ sai $\left.^{\text {Skeireins } \text { Wulfilian text }}=\imath^{\prime} \delta \varepsilon\right]$; no parallels found in the Greek or Latin traditions;

+ pize $\left.^{\text {Skeirinin }}\right]$ definite article; not relevant from the point of view of textual criticism.

However, the recently-discovered fragment of a sermon in Gothic may offer a possible linguistic hint that the text of the Skeireins citations does not derive directly from Wulfila's version. The beginning of the Skeireins (11. 15) contains the following citation, which is very likely to derive from Psalm 


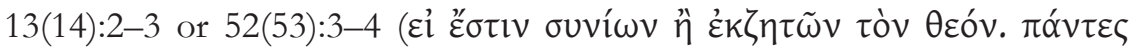

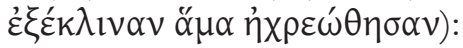

saei frapjai aippau sokjai gup; allai uswandidedun, samana unbrukjai waurpun.

The second part of this citation is also present in the Bologna fragment, in the form allai ushniwnn samana unbrukjai waurpun. Without the first part of the citation, it is not possible to verify whether the Bologna citation derives from the Psalms or from Paul, who quotes the Psalms. However, in this context it is not really important because the Greek verb દ̇kk $\lambda$ ív $\omega$ ("to turn away', 'to bend outwards') is always the same in the Psalms and in Paul. As a rendering of this, the Skeireins offers the verb uswandjan, formed by us-, the Gothic rendering of $\varepsilon k$-, and wandjan 'to turn'. Uswandjan translates

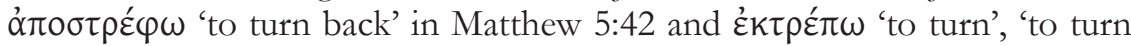
aside' in 1 Timothy 1:6. The Bologna fragment transmits the verb ushneiwan as a rendering of '̇k $k \lambda i ́ v \omega$, formed by $u$ s- and hneiwan 'to lean', 'to recline'; this latter form renders $k \lambda$ ív $\omega$ 'to lean', 'to recline' (in Luke 9:12). The form us-bneiwan is therefore a perfect loan translation of the Greek verb غ̇k- $k \lambda$ ív $\omega$ and there is no doubt that it is the original Wulfilian form. Wulfila, indeed, usually translates Greek words that derive from the same root with Gothic words that also derive from the same root, in order to be as close as possible to the Greek text. ${ }^{17}$ It follows that this citation of the Skeireins does not transmit the Wulfilian text. It would be too complicated to postulate that the Wulfilian version had an inaccurate form (uswandjan), which entered into the Skeireins but was corrected later in the course of the tradition to ushneiwan and thus entered into the text of Bologna.

In conclusion, the analysis of the Skeireins citations highlights several divergences together with some important agreements. It is, in my opinion, likely that the citations of the Skeireins were not taken directly from Wulfila's version; they were either translated from a Greek text (Theodore's biblical citations?) or quoted from memory from Wulfila's translation. In the former scenario, however, it is necessary to postulate-at some point of the tradition - a voluntary or involuntary influence of the Gothic biblical text on the Skeireins citations, comparable to harmonisations typical of the manuscript tradition. This would explain some peculiar agreements between the Skeireins and the Wulfilian text. Either way, the Skeireins does not seem to be a reliable witness to the reconstruction of the Wulfilian text, even

${ }^{17}$ See, for example, maitan 'to cut' (= кó $\left.\pi \tau \omega\right)$ and us-maitan 'to amputate' (= ع̇kкó $\tau \tau \omega)$. 
though it is an important witness to the use and transmission of biblical material among the Goths.

\section{APPENDiX: BibliCAL CitATIONS IN THE SKEIREINS}

\section{a). Verses not preserved in the direct tradition}

\section{Psalm 13(14):2-3 or 52(53):3-4}

.... saei frapjai aippau sokjai gup; allai uswandidedun, samana unbrukjai waurpun (Skeireins Ia.1-5)

'who understands or seeks God. All have turned aside, together they have become useless'

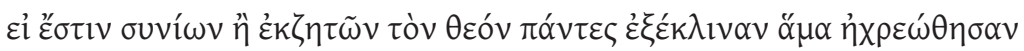

\section{John 1:29}

Sai, sa ist witrus gudis, saei afnimip frawaurht pizos manasedais (Skeireins Ib.3-6)

'Behold, this is the lamb of God, who takes away the sin of the world'

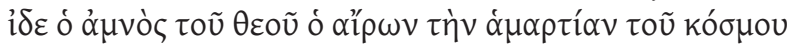

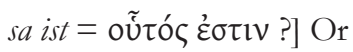

\section{John 3:3}

Amen amen, qipa pus, niba saei gabairada iupapro, ni mag gasaihuan piudangardja gudis (Skeireins IIa.20-5)

'Amen, amen, I say to you, unless a man be born from above, he cannot behold the kingdom of God'

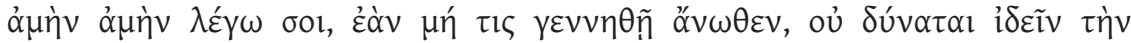

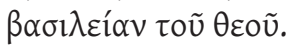

\section{John 3:4}

Haiwa mabts ist manna gabairan alpeis wisands? Ibai mag in wamba aipeins seinaizos aftra galeipan jag gabairaidau? (Skeireins IIb.11-17)

'How is it possible for a man to be born when he is old? Can he go a second time into his mother's womb and be born?'

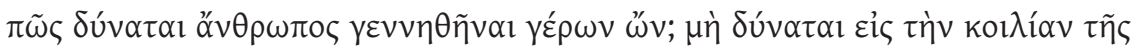

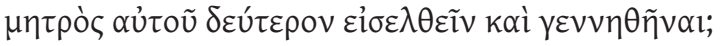

\section{John 3:4}

Haiwa mahts ist manna alpeis wisands gabairan? Ibai mag in wamba aipeins seinaizos aftra galeipan jah gabairaidau? (Skeireins IIb.25-IIc.1-7) 
'How is it possible for a man to be born when he is old? Can he go a second time into his mother's womb and be born?'

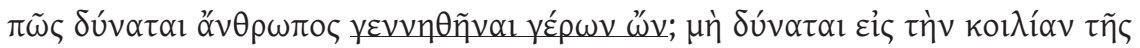

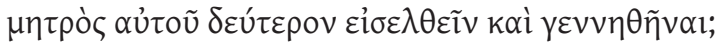

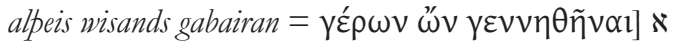

\section{John 3:5}

Amen amen, qipa pus, niba saei gabairada us watin jab ahmin, ni mag inngaleipan in piudangardja gudis (Skeireins IIc.16-22)

'Amen, amen, I say to you, unless a man be born of water and the Spirit, he cannot enter into the kingdom of God'

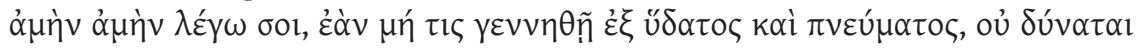

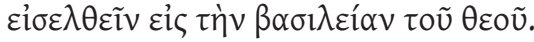

\section{John 3:23-4}

$<m a>n a g a$ wesun jainar; paruh qemun jah daupidai wesun. Ni nauhpanuh galagips was in kearkarai Iobannes (Skeireins IIIa.1-7)

'there was much < water $>$ there, and there they came and were baptized. John was not yet cast into prison'

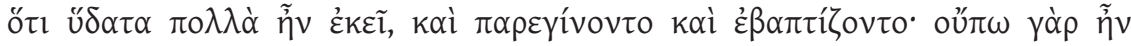

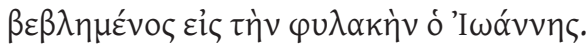

\section{John 3:25}

Dan warp sokeins us siponjam Iohannes mip Iudaium bi swiknein (Skeireins IIIa.24-5, IIIb.1-3)

'A question then arose between some of John's disciples and the Jews concerning purification'

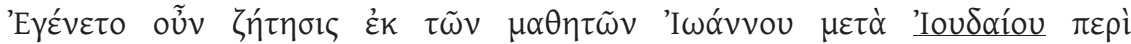

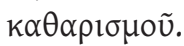

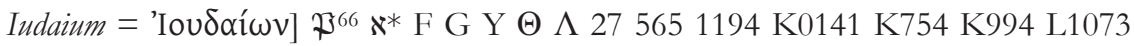

L1075 L1091 f $\mathrm{f}^{13}$ latt syc $\mathrm{sa}^{\mathrm{mss}}$ bo Or

\section{Matthew 3:11}

ip sa afar mis gagganda swinpoza mis ist (Skeireins IIId.14-17)

'but he who is to come after me is mightier than I'

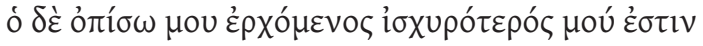

10. John 3:29-30

So nu faheps meina usfullnoda; jains skal wahsjan, ip ik minznan (Skeireins IVa.1-4) 
'This my joy is therefore fulfilled; he must increase, but I must decrease'

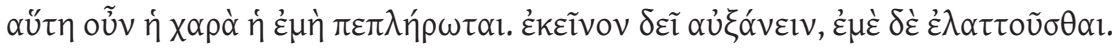

\section{John 3:26}

Rabbei, saei was mip pus bindar Jaurdanau, pammei pu weitwodides, sai sa daupeip, jah allai gaggand du imma (Skeireins IVa.10-17)

'Rabbi, he who was with you beyond the Jordan, to whom you gave testimony, behold, he is baptizing, and all are going to him'

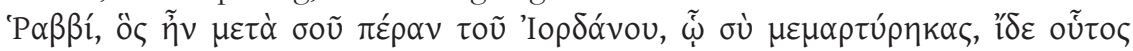

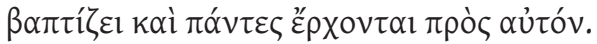

\section{John 3:30}

Jains skal wahsjan, ip ik miñnan (Skeireins IVa.22-3)

'he must increase, but I must decrease'

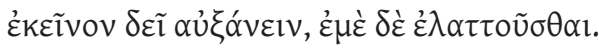

\section{John $3: 31$}

Sa iupapro qimands ufaro allaim ist (Skeireins IVb.20-1)

'He who comes from above is above all'

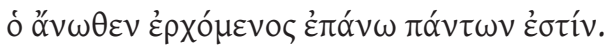

\section{John 3:31-2}

Ip sa us himina qumana [...] ufaro allaim ist, jah patei gasah jag gahausida pata weitwodeip, jah po weitwodida is ni ainshun nimip (Skeireins IVc.16-17, 19-24)

'He who has come from heaven is above all, and what he has seen and heard, that he testifies, and no-one receives his testimony'

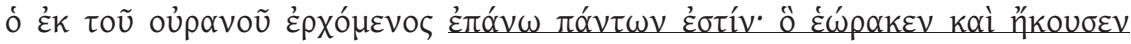

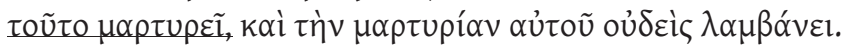

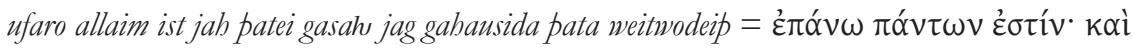

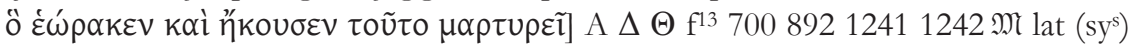
(syp) sy ${ }^{\mathrm{h}}\left(\mathrm{Chrys}^{\mathrm{b}}\right)$

\section{John 5:21}

Swaswe auk atta urraiseip daupans jah liban gataujïh, swa jah sunus panzei wili liban gataujip (Skeireins Vb.2-7)

'For as the Father raises the dead and quickens them, so also the Son quickens those whom he will'

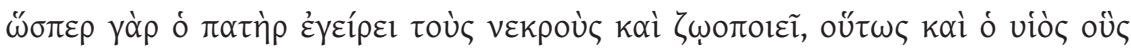

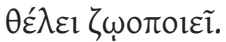




\section{John 5:22}

nib pan atta ni stoj̈p ain $<n>$ obun, ak stana alla atgaf sunau (Skeireins Vb.16-19)

'neither does the Father judge anyone but has committed all judgment to the Son'

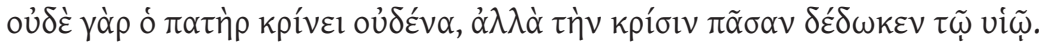

\section{John 5:23}

Ei allai sweraina sunu, swaswe swerand attan (Skeireins Vc.18-20)

'that all may honour the Son, even as they honour the Father'

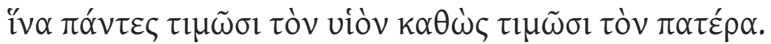

\section{John 5:23}

Ei allai sweraina sunu, swaswe swerand attan (Skeireins Vd.9-11)

'that all may honour the Son, even as they honour the Father'

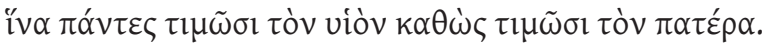

\section{John 3:30}

jains skal wabsjan, ip ik minznan (Skeireins VIa.5-7)

'he must increase, but I must decrease'

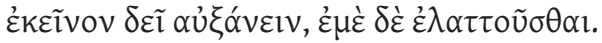

\section{John 5:35-6}

Jains was lukarn brinnando jah liubtjando, ip jus wildedup swignjan du heilai in liuhada is. Appan ik haba weitwodipa maizein pamma Iohanne; po auk waurstwa poei atgaf mis atta, ei ik taujau po, po waurstwa poei ik tauja, weitwodjand bi mik, patei atta mik insandida (Skeireins VIa.17-25, VIb.1-8)

'He was a burning and a shining light, and for a while you were willing to rejoice in his light. But I have a greater testimony than that of John, for the deeds that the Father has committed to me that I should perform them, these deeds that I do, testify of me that the Father has sent me'

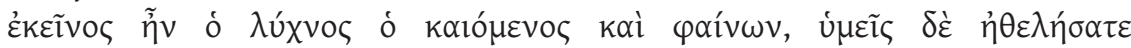

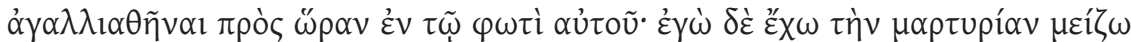

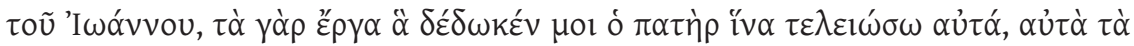

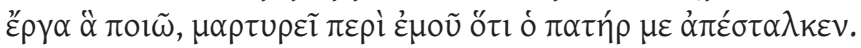

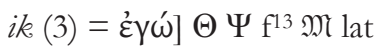

\section{John 5:37}

jah saei sandida mike atta, sah weitwodeip bi mik (Skeireins VIc.9-12) 'and the Father himself, who has sent me, gives testimony concerning me'

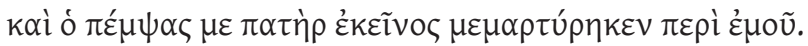




\section{John 5:37-38}

Nib stibna is huanbun gabausidedup nih siun is gasehup, jah waurd is ni habaip wisando in izwis, pande panei insandida jains, pammuh jus ni galaubeip (Skeireins VId.4-12)

'Neither have you ever heard his voice, nor have you seen his form, and you have not his word abiding in you, for him whom he has sent, in him you do not believe'

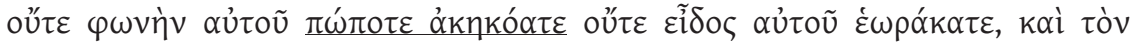

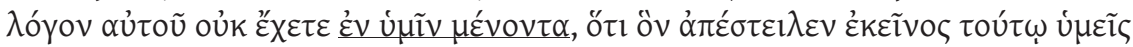
oủ $\pi l \sigma \tau \varepsilon u ́ \varepsilon \tau \varepsilon$.

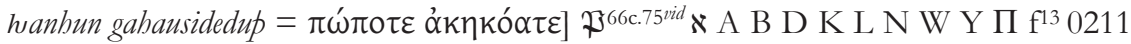
33579 K994 CyrJ lat

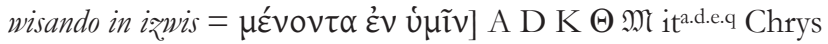

\section{Matthew 5:8}

Audagai [..] pai hrainjabairtans, unte pai gup gasaihsand (Skeireins VId.20-4)

'Blessed are the clean of heart, for they shall see God'

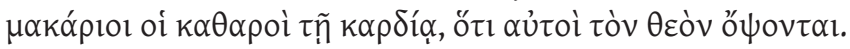

\section{b). Verses preserved in the direct tradition}

\section{i. Skeireins citations which diverge from the Wulfilian text}

\section{Luke 3:16}

Appan ik in watin izwis daupja (Skeireins IIId.13-14)

Ik allis izwis watin daupja (Wulfilian text)

'I indeed baptize you in water'

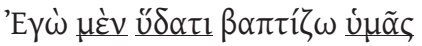

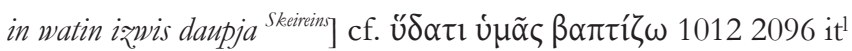

\section{Mark 1:7-8}

pizei ik ni im wairps ei anahne $<i>$ wands andbindau skaudaraip skobis is: sah pan izwis daupeip in ahmin weihamma (Skeireins IIId.17-24)

pizei ik ni im wairps anabneiwands andbindan skaudaraip skobe is. [...] ip is daupeip izwis in abmin weibamma (Wulfilian text)

'of whom I am not worthy that I should stoop and unbind the latchet of his sandals (sandal $^{\text {Skeirinin }}$. He will baptize you then in the Holy Spirit'

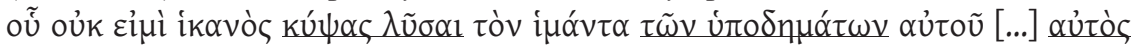

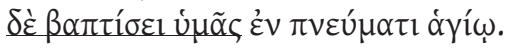

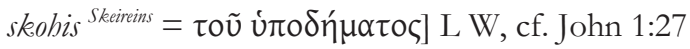




\section{John 17:23}

frijos ins, swaswe frijos mike (Skeireins Vd.18-20)

frijodes ins, swaswe mike frijodes (Wulfilian text)

'you love them, even as you love me' (Skeireins); 'you have loved them, even as you have loved me' (Wulfilas)

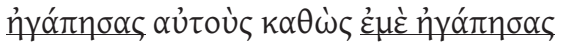

\section{John 6:10}

"waurkeip pans mans anakumbjan", ip eis at hauja managamma wisandin in pamma stada, po filusna anakumbjan gatawidedun (Skeireins VIIb.1-8)

"waurkeip pans mans anakumbjan", wasuh pan hawi manag ana pamma stada, parub anakumbidedun wairos (Wulfilian text)

"'make the people sit down." And there being much grass in the place, they made the crowd sit down'

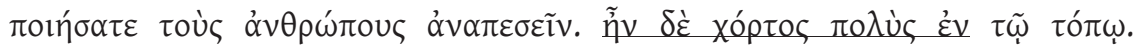

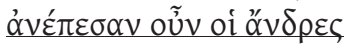

\section{John 6:11}

samaleikoh pan jah andnemun pize fiske, swa filu swe wildedun (Skeireins VIIc.7-10) samaleiko jah pize fiske, swa filu swe wildedun (Wulfilian text)

' $\left[+\right.$ and then $\left.{ }^{\text {Skeireins }}\right]$ likewise [they $\left.{ }^{\text {Skeireins }}\right]$ also [received of Skeireins] the fish as much as they wished'

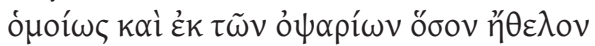

+ pan $\left.^{\text {Skeireins }}=\delta \dot{\varepsilon}\right]$ D 02191203 L704 Bas ${ }^{\mathrm{a}}$

\section{John 6:12-13}

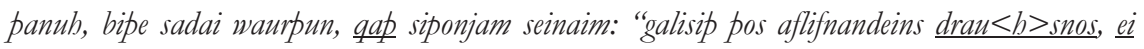
waibtai ni fraqistnai". Danuh galesun jah gafullidedun · ib tainjons gabruko us paim $\cdot e$. blaibam barizeinam jab $\cdot b \cdot$ fiskam, patei aflifnoda at paim.... (Skeireins VIId.10-25)

panuh, bipe sadai waurpun, qap du siponjam seinaim: "galisip pos aflifnandeins draubsnos, pei waibtai ni fraqistnai". Danuh galesun jah gafullidedun · ib - tainjons gabruko us fimf hlaibam paim barizeinam, patei aflifnoda paim (Wulfilian text)

'and then when they were filled, he said to his disciples, "Gather up the remaining fragments that nothing may be lost." And then they gathered up and filled twelve baskets with bits of the five barley loaves [ + and two fish $\left.{ }^{\text {Skeirein }}\right]$ that had been left over by those who...'

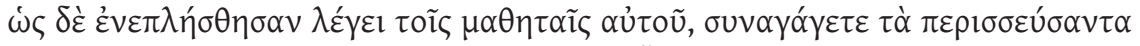

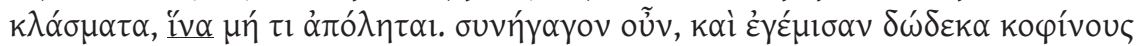

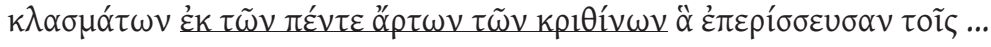




\section{John 7:45-6}

Galipun pan pai andbabtos du paim aubumistam gudjam jah Fareisaium. Daruh qepun du im [jaijjainai: "duhve ni attaubup ina?" Andhofun pan pai andbabtos qipandans patei "ni hanbun aiw rodida manna swaswe sa manna" (Skeireins VIIIa.11-25)

Galipun pan pai andbabtos du paim aubumistam gudjam jah Fareisaium. Darub qepun du im jainai: "duhve ni attaubup ina?" Andhofun pai andbabtos: "ni huanbun aiw rodida manna swaswe sa manna" (Wulfilian text)

"Then the officers went to the chief priests and Pharisees. And there they said to them, "Why have you not brought him?" [+ Then $\left.{ }^{\text {Skeirinin }}\right]$ the officers answered $[+$

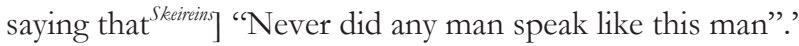

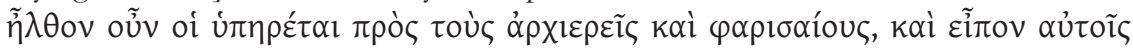

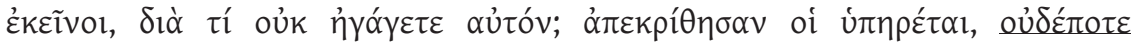

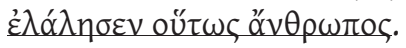

$\left.+\operatorname{pan}(2)^{\text {Skeirinin }}\right]=\delta \varepsilon \dot{\varepsilon} \mathrm{D} \mathrm{it}^{\mathrm{d}}\left(\mathrm{it}^{\mathrm{r}} \mathrm{l}\right) /$ oũv Chrys

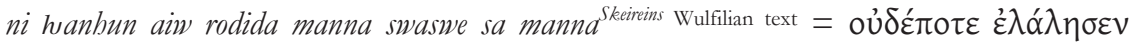

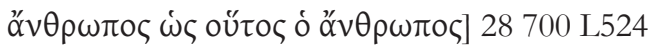

\section{John 7:48}

ni ainshun pize reike jah Fareisaiei galaubida (Skeireins VIIId.2-5)

jau ainshun pize reike galaubidedi imma aippan Fareisaie? (Wulfilian text)

'has any one of the authorities or of the Pharisees believed in him?'

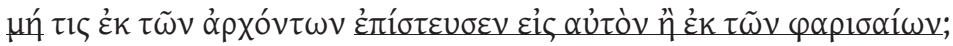

\section{ii. Skeireins citations which agree with the Wulfilian text}

\section{John 6:9}

Ist magula ains her, saei babaip $\cdot e \cdot$ blaibans barizeinans jah twans fiskans [...] akei pata ha ist du swa managaim? (Skeireins VIIa.8-12, 21-3)

Ist magula ains her, saei habaip $\cdot e \cdot$ blaibans barizeinans jah $\cdot \underline{b} \cdot$ fiskans; akei pata ha ist $d u$ swa managaim? (Wulfilian text)

'There is a certain boy here who has five barley loaves and two fish. [...] But what is that for so many??

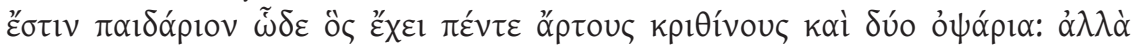

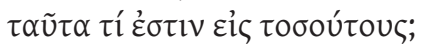

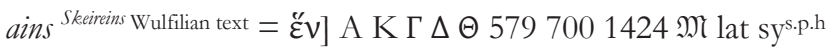




\section{John 7:44}

... <ni ains > bun uslagida ana ina handuns (Skeireins VIIIa.1-2)

ni ainshun uslagida ana ina handuns (Wulfilian text)

'no-one laid hands upon him'

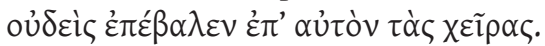

\section{John 7:47-9}

ibai jah jus afairzidai siup? Sai, jau ainshun pize reike galaubidedi imma aippan pize Fareisaie? Alja so managei, paiei ni kunnun witop, fraqipanai sind (Skeireins VIIIb.25-VIIIc.1-9)

ibai jah jus afairzidai sijup? Sai, jau ainshun pize reike galaubidedi imma aippau Fareisaie? Alja so managei, paiei ni kunnun witop, fraqipanai sind (Wulfilian text)

'Are you also seduced? [+ Behold,] has any one of the rulers or of the Pharisees believed in him? But this multitude, who do not know the law, are accursed'

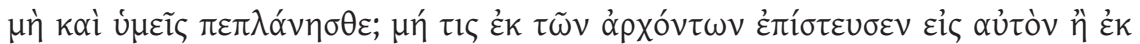

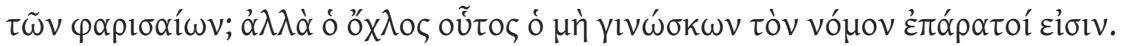

\section{John 7:51}

ibai witop unsar stojip mannan? (Skeireins VIIIc.24-5)

ibai witop unsar stojïp mannan? (Wulfilian text)

'does our law judge a man?'

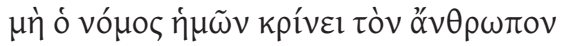

\section{John 7:52}

$i b a<i>$ jah pu us Galeilaia is? Ussoke $<i>$ jah saih patei ... (Skeireins VIIId.22-5)

ibai jah pu us Galeilaia is? Ussokei jah saih patei ... (Wulfilian text)

'are you also from Galilee? Search and see that ...'

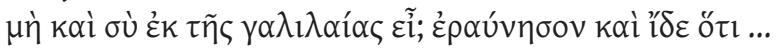

\section{Ephesians 5:2}

bunsl jas saup guda (Skeireins Ia.18-19)

bunsl jah saup guda (Wulfilian text)

'offering and sacrifice to God'

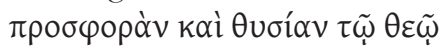





\title{
14. AN OVERVIEW OF RESEARCH ON BOHAIRIC CATENA MANUSCRIPTS ON THE GOSPELS WITH A GROUPING OF ARABIC AND ETHIOPIC (Gə‘วZ) SOURCES AND A CHECKLIST OF MANUSCRIPTS
}

\author{
MATTHIAS H.O. SCHULZ
}

\section{INTRODUCTION}

Commentaries compiled from various patristic sources and successively explaining the text of the gospels (or other biblical scriptures) are a rare phenomenon in Coptic, and a much neglected one in the Arabic and Ethiopic traditions. Only a few Coptic manuscripts contain catena-like commentaries, and these are limited to the Gospels. In fact, they are better described as dogmatic florilegia, because they do not comment on the complete text of the Gospels but on an extensive selection of verses which follow the order of the biblical text. The gospel text itself is often represented by the $\kappa \varepsilon \varphi \alpha ́ \lambda \varepsilon 1 \alpha$ titles or, at most, short extracts from individual verses. ${ }^{1}$ Besides the fact of their existence, Arabic and Ethiopic catenae have only been the subject of sporadic attention. Although there are many codices described as catenae in short notes, their relation to one another and their exact contents for the most part remain unknown. The

1 See P. de Lagarde, Catenae in evangelia Aegyptiacae quae supersunt. Göttingen: Hoyer, 1886, passim; F.J. Caubet Iturbe, La Cadena árabe del evangelio de san Matheo. 1: texto. Studi e Testi 254. Vatican City: BAV, 1969, li; G. Dorival, 'Aperçu sur l'histoire des chaînes exégétiques grecques sur le psautier (V-XIV siècles).' in Studia Patristica XV, ed. E.A. Livingstone. TU 128. Berlin: Akademie, 1984, 146-69, esp. 166-7; G. Dorival, 'Nouveaux fragments grecs de Sévère d'Antioche', in ANTI $\triangle P O N$. Hulde aan Dr. Maurits Geerard bij de voltooïng van de Clavis Patrum Graecorum, ed. J. Noret. Wetteren: Cultura, 101-21, esp. 117-21. I use the term catena in the current chapter for the sake of convenience. 
aim of this chapter is to provide sufficient information on surviving manuscripts to foster the awareness of early biblical commentary traditions which resemble the form of catenae in Bohairic, Arabic and Ethiopic.

\section{BoHairic CATENA MANUSCRIPTS ON THE GOSPELS}

All research on catenae in Coptic studies starts with Paul de Lagarde's edition of London, British Library, Or. 8812, published in 1886.2 The colophon of this parchment codex in Bohairic states that it was finished in AM 605, i.e. 888/9 CE, by the scribe Theodore, monk of the Lavra of Macarius the Great. ${ }^{3}$ The date is of interest in as much as the Bohairic text ranks among the oldest surviving catenae. ${ }^{4}$ According to Bentley Layton,

2 de Lagarde, Catenae in evangelia Aegyptiacae. The text is listed as CPG C 117, cf. C. Guignard, La lettre de Julius Africanus à Aristide sur la généalogie du Christ. Analyse de la tradition textuelle, édition, traduction et étude critique. TU 167. Berlin: de Gruyter, 2011, 153.

3 de Lagarde, Catenae in evangelia Aegyptiacae, iv. J.B. Lightfoot's account of the manuscript, *Parham 102, was given in de Lagarde's introduction and reprinted verbatim in subsequent editions: see F.H.A. Scrivener, A Plain Introduction to the Criticism of the New Testament. Vol. 2. $4^{\text {th }}$ edn. London \& New York: Bell, 1894, 115 note 1.

${ }^{4}$ Only nine manuscripts that predate the tenth century are listed in C. Zamagni, 'New Perspectives on Eusebius' Questions and Answers on the Gospels: The Manuscripts', in Eusebius of Caesarea: Tradition and Innovations, ed. A. Johnson \& J. Schott. Hellenic Studies Series 60. Washington DC \& Cambridge MA: Center for Hellenic Studies, 2013, 239-61 (on 250-7):

III. 47. Patmos, Monastery of St John, 59 ( $9^{\text {th }}-10^{\text {th }}$ century).

III. 52. St Petersburg, NLR, Gr. 216 (A.D. 862/3).

IV. 5. Città del Vaticano, BAV, Ms. Vat.sir. 103 (9 $9^{\text {th }} / 10^{\text {th }}$ century).

IV. 6. Città del Vaticano, BAV, Ms. Vat.sir. 154 ( $8^{\text {th }} / 9^{\text {th }}$ century).

VIII. 13. Besançon, Bibliothèque d'Etude, Fond géneral Ms 186 (9th century).

VIII. 15. Brescia, Biblioteca Civica Queriniana, F II 1 (9th century).

VIII. 77. Moscow, Russian State Library, Ms. 82 (9 $9^{\text {th }}$ century).

VIII. 109. Paris, BnF, lat. 1568 (fol. 40-67: $9^{\text {th }}$ century).

VIII. 141. Würzburg, Universitätsbibliothek, M.p.th.f. 61 ( $8^{\text {th }} / 9^{\text {th }}$ century). Interestingly, Codex Zacynthius (GA 040, $\Xi$ ) is missing from Zamagni's list even though the scriptio inferior of this palimpsest codex contains scholia by Eusebius (cf. J.H. Greenlee, 'The Catena of Codex Zacynthius' Biblica 40 (1959) 992-1001). This codex is believed to be the oldest surviving catena manuscript, dated to the sixth century in the Liste and to the seventh century in D.C. Parker and J.N. Birdsall, 
Robert Huntington might have seen the manuscript in Dēr Abū Maqār in $1682 / 3$, and it was transferred to the Syrian Monastery by G.S. Assemani in 1715. In 1838 it was obtained from this monastery by Robert Curzon, who gave de Lagarde permission to edit the text, when the manuscript's common appellation as the Curzon Catena or Lagarde Catena. ${ }^{5}$

It is commonly assumed that the Bohairic text is a translation of a lost Greek catena, probably not created in Egypt. ${ }^{6}$ Horner is quite cautious regarding the gospel extracts, suggesting that the passages might be taken from the Bohairic textual tradition or translated from Greek along with the citation. ${ }^{7}$ Achelis observes that the catena could have been compiled in the sixth century, following the death of Severus in 538, while Youssef assumes that it is a compilation between the seventh and eighth centuries. ${ }^{8}$ At any rate, it must be dated between 538 and $888 / 9$, the date mentioned in the colophon.

The rubricated word most commonly employed to introduce the

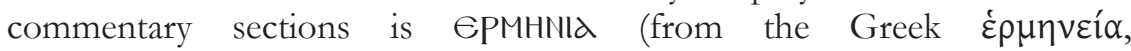
'interpretation, explanation'). This term is used in Coptic in a wide range of contexts, including the hermeneiai on the Gospel of John which also occur in Greek and have most recently been described as liturgical comments in bilingual environments'. ${ }^{9}$ In agreement with Metzger, Quecke, Porter and

'The date of Codex Zacynthius ( $\boldsymbol{\Xi})$ : A new proposal' JTS ns 55.1:117-31.

${ }^{5}$ It is called the Curzon Catena (Horner), Lagarde Catena (Pearse, Downer), Catena Patrum (Evelyn White), Exegetical Catena (Layton), or Dogmatic Florilegium (Dorival). See further B. Layton, Catalogue of the Coptic Manuscripts in the British Library acquired since the year 1906. London: British Library, 1987, 393-4.

6 'Les chaînes sont un genre palestinien puis constantinopolitain, mais aucune chaîne ne parait avoir été fabriqué en Égypte' (Dorival, 'Nouveaux fragments', 120; see also Dorival, 'Aperçu sur l'histoire des chaînes', 165-7).

7 G. Horner, The Coptic Version of the New Testament in the Northern Dialect Otherwise Called Memphitic and Bohairic with Introduction, Critical Apparatus, and Literal English Translation. Vol. 1. The Gospels of S. Matthew and S. Mark. Oxford: Clarendon, 1898, xxxvii-xxxviii.

8 H. Achelis, Hippolytstudien. TU 16.4. Leipzig: Hinrichs, 1897, 168; Y.N. Youssef, "The Coptic Catena on the Four Gospels According to Severus of Antioch. I. The Gospel of Matthew' Bulletin de la Societé d'archéologie copte 43 (2004) 95-120.

9 W.V. Cirafesi, 'The Bilingual Character and Liturgical Function of 'Hermeneia' in Johannine Papyrus Manuscripts. A New Proposal.' NovT 56 (2014) 45-67, including discussion of earlier studies and a list of witnesses. To the latter may be added a Fayyumic Coptic papyrus in Berlin, the first folio of a $\dot{\rho} \rho \eta \eta \varepsilon i ́ \alpha-$ codex: Berlin, Staatliche Museen Preußischer Kulturbesitz, P. 7818, cf. W. Beltz, 
Stegmüller, Cirafesi rejects the suggestion that hermeneia was used to indicate a biblical commentary drawn from patristic authors. ${ }^{10}$ In the Sahidic dialect of Upper Egypt the term designates psalm verses used as hymns during Christian liturgy: no catena-like commentary manuscripts are known in this dialect or in Fayyumic. ${ }^{11}$

De Lagarde's edition of Or. 8812 is the main source for all subsequent articles and chapters, supplemented by the edition by Hebbelynck of the $\kappa \varepsilon \varphi \alpha$ á $\varepsilon 1 \alpha$ for the Gospel of Matthew from several Bohairic manuscripts, including London, British Library, MS Add. 14740A fol. 9 (see below). ${ }^{12}$ De Lagarde's edition is very reliable, but his presentation of the text is rather puzzling since he has avoided blank space between headings and texts and omitted all headings introducing the gospel text. The excerpts from patristic writers have not been studied in their entirety: scholars have thus far concentrated on those attributed to individual authors (Hippolytus of Rome, Irenaeus of Lyons, Evagrius Ponticus, Titus of Bostra, Isaiah of Scetis, Eusebius and, in part, Severus of Antioch), which are considered in the following paragraphs. It is surprising that hardly any attention has so far been paid to several rather unexpected references in the text: some extracts are attributed to Arius, Nestorius, or others simply marked as 'heretical'. There is even a short quote indicated as coming 'from the Manichaeans'. ${ }^{13}$

'Katalog der koptischen Handschriften der Papyrussammlung der Staatlichen Museen zu Berlin (Teil I).' Archiv für Papyrusforschung 26 (1978) 57-119, 95: I 580.

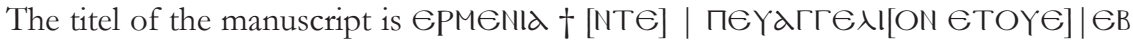
NKATd IO[LANNHC].

${ }^{10}$ Cirafesi, 'The Bilingual Character', 49-52.

${ }^{11}$ The most comprehensive article on $\dot{\varepsilon} \rho \mu \eta \nu \varepsilon \tilde{\alpha} \alpha$ in Upper Egypt/Sahidic is H. Quecke, 'Psalmverse als »Hymnen« in der koptischen Liturgie?' in Christianisme d'Égypte. Hommages à René-Georges Coquin, ed. J.-M. Rosenstiehl. Cahiers de la Bibliothèque Copte 9. Paris/Louvain: Peeters, 1991. For a brief note, see Y.N. Youssef and U. Zanetti, ed., La consécration du Myron par Gabriel IV 86e Patriarche d'Alexandrie en 1374 A.D. Jerusalemer Theologisches Forum 20. Münster: Aschendorff, 2014, where the relevant passage of Šams ar-Riyāsa Abì-al-Barakāt's Lamp of darkness is quoted in French on 41.

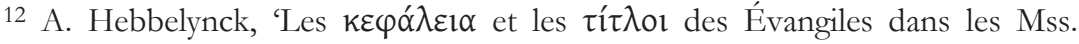
bohaïriques Paris Bibl. Nation. copte 16, Vat. copte 8 et le fragm. bohaïrique Brit. Mus. Add. 14740a fol. 9. La Lettre d'Eusèbe à Carpianus d'après le Ms. bohaïrique Vat. copte 9. 'Textes inédits et traduction.' Le Muséon 41 (1928) 81-120: edition and French translation of London, British Library, Add. 14740, esp. 85-8 and 111-4.

${ }^{13}$ See de Lagarde, Catenae in evangelia Aegyptiacae, vi. 
The first study of the patristic material is Achelis' 1897 examination of the scholia on Matthew ascribed to Hippolytus of Rome. This includes a German translation not only of the Bohairic but also of the Arabic and Ethiopic texts, provided by F. Schultheis. ${ }^{14}$ Achelis assumed that these were the only extant fragments of Hippolytus' commentary on Matthew from eastern catenae. ${ }^{15}$ Following the lead of de Lagarde and Adolf Erman, he is certain of the Bohairic text's Greek origin and supposes a common ancestor for all three versions. ${ }^{16}$ Mannucci published a one-page article on a scholion attributed to Irenaeus of Lyons in 1909.17 This immediately prompted further discussion, particularly with reference to the wording 'water and blood' in John 19:34.18 The most recent study accepts

${ }^{14}$ H. Achelis, ed., Hippolytus Werke. Vol. 1: Exegetische und homiletische Schriften. II. Hippolyts kleinere exegetische und homiletische Schriften. GCS 1. Leipzig: Hinrichs, 1897, 195-208.

15 'sind erhalten bestenfalls nur die in meiner Ausgabe übersetzen Fragmente der orientalischen Katenen'. (Achelis, Hippolytstudien, 163-4).

16 Achelis, Hippolytstudien, 163-9. Achelis does not refer to any specific article of Erman.

17 U. Mannucci, 'Ein unbeachtetes Irenäusfragment.' Theologie und Glaube 1 (1909) 291. He translated the excerpt into Latin, on which Bellet observes: 'The translation of Mannucci is faulty only at the beginning. The words: 'verbo eius non credidit sane Thomas ...' cannot be defended in Coptic grammar, and they cancel out the rubric of the scholion.' (P. Bellet, 'Analecta Coptica: 3. A Coptic Scholion of Irenaeus to John 20:24-29 and the 'Text of John 19:34' Catholic Biblical Quarterly 40.1 (1978) 47-9).

18 In Mannucci's translation this quotation reads: et quando dixerunt ei discipuli quod dederunt ictum lanceae in latus eius et exivit aqua et sanguis (Mannucci, 'Ein unbeachtetes Irenäusfragment', 291). J. Denk, 'Das „unbeachtete' Irenäusfragment Mannuccis und die Itala.' Theologie und Glaube 1 (1909) 648-9 noted that this wording is also attested in Latin by Codex Palatinus (VL 2, e), in Greek by Eusebius and Codex Macedoniensis (GA 034 or Y), and in Sahidic by Codex Askewianus. He concludes that the text has an 'unforeseen importance' and the scholion is indeed a fragment from Irenaeus’s writings. Vogels lists the Coptic text among the examples of the wording 'water and blood', adding Ambrose and Epiphanius as further witnesses (H.J. Vogels, 'Der Lanzenstich vor dem Tode Jesu.' Biblische Zeitschrift 10 (1912) 396-405). B. Kraft, 'Das Koptische Irenäus-Fragment De Lagardes zu Jo 19,34.’ Biblische Zeitschrift 13 (1915) 354-5 gives further examples, but states that the wording is of little significance and does not permit any conclusion. 
Mannucci's conclusion that the Coptic excerpt is likely to derive from a lost sermon of Irenaeus. ${ }^{19}$

The excerpts from Titus of Bostra were investigated by Bellet in 1955. ${ }^{20}$ His argument is based on the assumption that the Coptic translator had indeed used a Greek Vorlage of Titus' works, although the original authorship is concealed due to 'omissions, additions or mistakes' that are a normal factor in the transmission of scholia in catenae. Bellet demonstrates similarities in the structure of the argument and Titus' preference for specific words and phrases attested in both Greek and Bohairic examples which go beyond simple coincidence.

The chapter on the Lord's Prayer of Evagrius of Pontus' De oratione is only extant in the Bohairic catena and in Arabic. Even though it was previously attributed to Nilus of Ancyra, Hausherr has shown that the authorship is certain, even if the text in Bohairic reads more like an abstract of Evagrius' thoughts. ${ }^{21}$ Youssef, who identified Sahidic parallels for quotations from the Apophthegmata patrum and Isaiah of Scetis in the Bohairic catena, paid special attention to the extracts from Severus of Antioch. In 2004, he published Severus' scholia on Matthew with an introduction and English translation, identifying the Greek originals for certain passages: most are taken from the corpus of Severus' Homilia Cathedralis. ${ }^{22}$ Extracts from Severus preserved in the Arabic catena on Mark were noted several decades earlier by Caubet Iturbe. ${ }^{23}$

${ }^{19}$ Bellet, 'A Coptic Scholion', 48-9, with an English translation on 48.

20 P. Bellet, 'Excerpts of Titus of Bostra in the Coptic Catena on the Gospels', in Studia Patristica 1, ed. K. Aland and F.L. Cross. TU 63. Berlin: Akademie, 1957, 10-14. Bellet planed a translation and study of the Bohairic catena but it never appeared.

21 'Le texte qu'ils donnent semble n'être qu'un résumé, où transparaissent quelques idées caractéristique d'Evagre' (I. Hausherr, 'Le Traité de l'Oraison d'Evagre le Pontique (Pseudo-Nil).' Revue d'Ascétique et de Mystique 15 (1934) 34-93, 113-170; quotation from 88). See also G. Bunge, Das Geistgebet: Studien zum Traktat De oratione des Evagrios Pontikos. Koinonia Oriens 25. Cologne: Luthe, 1987, 59-61; an English translation with short introduction is offered in A.M. Casiday, Evagrius Ponticus. London: Routledge, 2006, 150-3.

22 Y.N. Youssef, 'The Coptic Catena on the Four Gospels According to Severus of Antioch. I. The Gospel of Matthew.' Bulletin de la Société d'archéologie copte 43 (2004) 95-120. The title of Youssef's article is inaccurate: the Bohairic catena is not a work 'according to Severus of Antioch'. For Youssef's earlier work, see Y.N. Youssef, 'Apophtegme Copte Méconnu de la collection Anonyme.' Göttinger 
Carol Downer and the Coptic Reading Group at University College London contributed the text and an English translation of the extracts ascribed to Eusebius of Caesarea to Pearse's Eusebius of Caesarea, Gospel Problems and Solutions. ${ }^{24}$ Downer subsequently devoted three articles to this subject, discussing the historical, theological, and literary background for Eusebius' extracts in the Bohairic text and its possible Greek ancestors and parallels. ${ }^{25}$ One passage ascribed to Eusebius has been identified as an extract from Julius Africanus' Epistula ad Aristidem on the genealogy of Christ. ${ }^{26}$ Nonetheless, the Bohairic text is technically correct in ascribing

Miszellen 175 (2000) 105-7; Y.N. Youssef, 'Un complément de l'asceticon Copte de l'Abbé Isaie.' VC 55.2 (2001) 187-90; Y.N. Youssef, 'Some Patristic Quotations of Severus of Antioch in Coptic and Arabic texts.' Ancient Near Eastern Studies 40 (2003) 235-44. The last of these includes the Bohairic text of a scholion on John 19:23 ascribed to Severus, with an English translation.

${ }^{23}$ F.J. Caubet Iturbe, 'La Cadena copto-arabe de los Evangelios y Severo de Antioquia' in Homenaje a Juan Prado. Miscelánea de estudios biblicos y hebraicos, ed. L. Álvarez Verdes \& E.J. Alonso Hernández. Madrid: CSIC, 1975, 421-32.

${ }^{24}$ C. Downer, 'The Coptic Fragments', in Eusebius of Caesarea, Gospel Problems and Solutions. Quaestiones ad Stephanum et Marinum (CPG 3470), ed. R. Pearse. Ipswich: Chieftain, 2010, 351-83. Zamagni, 'New Perspectives', 246 n. 42, overlooks Downer's clear statement in the introduction to this chapter that it is uncertain whether all quotations in the catena really derive from this work.

25 C. Downer, 'The Contribution of the Coptic Fragments from de Lagarde's Catenae in evangelia Aegyptiacae quae supersunt to our Understanding and Interpretation of Certain of Eusebius of Caesarea's Quaestiones ad Stephanum et ad Marinum', in A Good Scribe and an Exceedingly Wise Man: Studies in Honour of WJ Tait, ed. M. Dodson, J.J. Johnston, and W. Monkhouse. London: Golden House, 2014, 89-98; C. Downer, 'The role of Coptic translators in the transmission of Patristic Biblical Comment in the First Millennium CE' in Studies in Coptic Culture: Transmission and Interaction, ed. M. Ayad, Cairo, 2016; C. Downer, 'Some unparalleled fragments of de Lagarde's Catenae in evangelia Aegyptiacae quae supersunt (Göttingen 1886) which may contribute to our knowledge of Eusebius of Caesarea's Quaestiones ad Stephanum et ad Marinum' in Proceedings of the Tenth International Congress of Coptic Studies, Rome, September 17-22, 2012 ed. P. Buzi, A. Camplani \& T. Orlandi. Orientalia Lovaniensia Analecta. Leuven, Paris, Walpole MA: Peeters, forthcoming. Downer also included translations of other patristic authorities e.g. John Chrysostom, with identification of the origin, cf. Downer, 'The Contribution', 95.

26 Guignard, La lettre de Julius Africanus, 153. The identification is made independently by Pearse, cf. Downer, 'The Contribution', 93. 
the excerpt to Eusebius, because the letter is cited in the Historia ecclesiastica. ${ }^{27}$

While London, British Library, Or. 8812 is the most complete catena known in Bohairic, and the only one so far to be published, fragments of two other Bohairic Coptic catenae also survive. ${ }^{28}$ Their core leaves are gathered under the following classmarks:

Cairo, Coptic Museum, CM 2624

Leipzig, University Library, Nr. 1090

The script of all witnesses, unimodular but sometimes angular, is so close that it is impossible to assign fragments to a specific manuscript with certainty. Confirmation that we are dealing with at least three separate manuscripts is provided by the contents: the exegetical comment on Matthew 21:6-46 (edited in de Lagarde, Catena, 57-8) is attested three times:

London: fol. 195v-196r=pag. 152-3; de Lagarde, 57-8

Cairo [G324]: recto: de Lagarde 57.39-58.13; verso: 58.22-35

Leipzig [Bl. E 9]: recto: de Lagarde, 57.35-58.11; verso: 58.15-28

The ornamentation and the smaller rubricated script of the titles are of particular significance for distinguishing the fragments. All folios attached to Leipzig 1090 have every initial ornamented with dotted diplai written in red. Initials are only slightly enlarged. Each title is indented, some centred in the middle of the line, and are prefixed by an obelus or a small cross formed out of four triangles, one edge of each pointing to the center. None of the leaves of the Cairo codex shows these features. The titles are more italicised, not ornamented except for lines attached to the final character of a line, and their script is nearly as large as the script of the main text. However, some of the Cairo fragments seem to derive from the same manuscript as the Leipzig fragments, while others correspond to a couple of leaves in London, British Library, Add. 14740A (see the Checklist

27 Downer, 'The Coptic Fragments', 354-5, Fr.Copt.1; cf. PG 20, cols $93-4$ (= Eusebius, Hist. Ecc. i. 7 \21).

${ }^{28}$ See also H.G. Evelyn White, The Monasteries of the Wadi N Natrîn. Part 1: New Coptic Texts from the Monastery of Saint Macarius. New York: Metropolitan Museum of Art, 1926, 198 n. 3. The information given by Evelyn White depends on personal references by W.E. Crum, although the basis for Crum's statement remains unclear: it may be based on ornamentation and titles, as discussed below. 
below). There are no additional folios that can be connected with Or. 8812, our main witness.

Leipoldt described two further leaves in Leipzig as part of a catena manuscript, but these are dubious. ${ }^{29}$ Both are written in a less careful hand than the other fragments and, unlike all other leaves classed under this shelfmark, they show no indication of gospel or commentary sections. The script suggests that they may both belong to the same manuscript, but further investigation is required. ${ }^{30}$

The contents of Leipzig Nr. 1090 Bl. E14 are unidentified. On the recto, a heading with an enlarged initial is written in red: 'The fasting

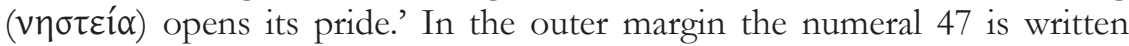
next to the title. On the verso a second heading in red, again with an enlarged initial which this time is ornamented, reads: 'In the way of the world whenever (ö $\tau \alpha \nu \mu \dot{\varepsilon} v$ ) it is saturated with water in joy.' Under the initial of this title is the numeral 48.

The recto of Leipzig Nr. 1090 Bl. E15 is nearly illegible; drawings and Arabic glosses by a later hand cover large parts of the original, faded script. On its verso, page 196, the text is a paraphrase of the story of David wishing to built a house for the ark of the covenant (2 Samuel 7:1-16), including a verbatim quotation of 2 Samuel 7:2.

\section{GROUPING OF ARABIC AND ETHIOPIC SOURCES}

The situation is better for Arabic catenae because complete codices are available, but is also more complex. Beside manuscripts that are translated from and dependent on the Bohairic catena, we find at least two catena-like commentaries handed down under the names of their compilers, 'Abdallāh ibn aț-Taiyib and Sim‘ān ibn Kalīl ibn Maqārah. ${ }^{31}$ In Ethiopic, catenae are entitled Tergüamè wangèl ('interpretation of the Gospel(s)'), but this is used

29 J. Leipoldt, 'II 3. Koptische Handschriften' in Katalog der islamischen, christlichorientalischen, jüdischen und samaritanischen Handschriften, ed. K. Vollers. Katalog der Handschriften der Universitätsbibliothek Leipzig 2. Leipzig: Harrassowitz, 1906, 383-427, here 419-20.

30 On the script, see H. Hyvernat, Album de paléographie copte pour servir à l'introduction paléographique des actes des martyrs de l'Egypte. Paris: Leroux, 1888, 14 (no. 20 with plate 20) and 17 (no. 42.2 with plate 42).

31 G. Graf, Geschichte der christlich-arabischen Literatur. Vol. 1. Studi e testi 118. Vatican City: BAV, 1944, 481-3; G. Graf, Geschichte der christlich-arabischen Literatur. Vol. 2. Studi e testi 133. Vatican City: BAV, 1947, 160-9, 336-8. See also the literature mentioned in the checklist entries for Arabic and Ethiopic catenae. 
for two different works. The first is a translation made from an Arabic text of the Bohairic catena, the second is the Ethiopic version of the catena by 'Abdallāh ibn aț-Taiyib. ${ }^{32}$ In grouping these manuscripts, it must be borne in mind that not all catalogues provide enough information to assign a codex to a specific manuscript group.

The first group comprises codices believed to be translated from the Bohairic catena. 33 F.J. Caubet Iturbe prepared a critical edition of the Gospel of Matthew in 1969-70 with a detailed introduction and Spanish translation. ${ }^{34}$ This is based on the oldest witness, Vatican City, BAV, Vat. ar. 452 (in two parts), with variant readings added from other Arabic manuscripts and references to de Lagarde's Bohairic text. The parts of the catena on Mark, Luke and John are still unpublished. The codices Paris, BnF, Arab. 55 and Vatican City, BAV, Vat. ar. 410 and Vat. sir. 531 belong to a slightly different textual family, which is a branch of this first group. ${ }^{35}$ The authors quoted most frequently are Cyril of Alexandria and John Chrysostom, followed by Severus of Antioch. Twenty manuscripts are known so far (the initial identifiers refer to the Checklist below):

Arabic 8. Cairo, Coptic Patriarchate, Theol. 26 (Ms. 41) (Iturbe D)

Arabic 9. Cairo, Coptic Patriarchate, Theol. 27 (Ms. 567) (Iturbe C)

Arabic 21. Dēr Abū Maqāar, Theol. 6 (= Comm. 6)

Arabic 25. Göttingen, Universitätsbibliothek, Arab. 103 (Iturbe G)

32 See R.W. Cowley, Ethiopian Biblical Interpretation: A Study in Exegetical Tradition and Hermeneutics. University of Cambridge Oriental Publications 38. Cambridge: CUP, 1988, 47-53 with a stemma for the manuscript tradition of 'Abdallāh ibn ațTaiyib's catena on 53 .

33 Valuable accounts of the Ethiopic translation of the 'Coptic-Arabic Catena' are included in M.C. Conti Rossini, 'Manoscritti e opere abissine in Europa' Rendiconti della Reale Accademia dei Lincei. Classe di scienze morali, storiche e filologiche, ser. 5a. 8 (1899) 606-37, esp. 633; R.W. Cowley, 'Review: E. Hammerschmidt and V. Six (eds), Äthiopische Handschriften 1: Die Handschriften der Staatsbibliothek preußischer Kulturbesitz:' Journal of the Royal Asiatic Society of Great Britain \& Ireland ns 116.2 (1984) 266-9, esp. 268; O. Löfgren, Katalog über die äthiopischen Handschriften in der Universitätsbibliothek Uppsala. Acta Bibliothecae Universitatis Upsaliensis 18. Uppsala: Almqvist \& Wiksell, 1974, 127-8; Cowley, Ethiopian Biblical Interpretation, 47-53.

34 F.J. Caubet Iturbe, La Cadena árabe del evangelio de san Matheo. 1. Texto; 2. Versión. Studi e Testi 254-5. Vatican City: BAV, 1969-70.

35 Cf. the description of the manuscripts in Caubet Iturbe, La Cadena árabe, I.xxvii-xxix, xxxviii-xli, xlvii, and the additional literature in the Checklist below. 
Arabic 29. Oxford, Bodleian Library, Ms. Huntington 262 (Iturbe O)

Arabic 30. Paris, BnF, Ms. Arab. 55 (Iturbe P)

Arabic 34. Strasbourg, BNU, Or. 4315 (Iturbe S)

Arabic 37. Vatican City, BAV, Ms. Vat. ar. 410 (Iturbe M)

Arabic 38. Vatican City, BAV, Ms. Vat. ar. 452 (in two parts) (Iturbe B)

Arabic 39. Vatican City, BAV, Ms. Vat.sir. 531

Arabic 40. Vatican City, BAV, Ms. Vat.sir. 541 (Iturbe K)

Ethiopic 2. Addis Ababa, Library of the Patriarchate, s.n.

Ethiopic 4. Ambasel, Private Library, s.n.

Ethiopic 5. Ambasel, Private Library, s.n.

Ethiopic 6. Ambasel, Private Library, s.n.

Ethiopic 7. Berlin, SBPK, Peterm. II. Nachtrag 52

Ethiopic 10. Lake Tānā 30 (= Kebrān 30)

Ethiopic 12. London, BL, Add. 16220 (Ms. Aeth. 11)

Ethiopic 19. Moğāa and Warānā, Parish Church, s.n.

Ethiopic 20. Paris, BnF, Eth. 65 (olim Eth. 34)

The second manuscript family, and the most interesting one after the first group, includes all known manuscripts of a catena ascribed to 'Abdallāh ibn at-Taiyib (d. October 1043). Aț-Ṭaiyib, who was a trained physician, philosopher and theologian, was a priest of the East Syrian Church sometimes described as Nestorian. Among his most notable writings are an Arabic translation of Tatian's Diatessaron, The Paradise of Christendom, and a commentary on the Eisagoge by the Neo-Platonist Porphyry. ${ }^{36}$ Despite the statement in some Ethiopic manuscripts that the Arabic text is translated from Syriac, 'Abdallāh ibn aț-Taiyib himself notes in the introduction to his commentary that he wrote in Arabic using the works of authorities of the East and the West, including Ephrem Syrus, Išō'dād of Merv and, most prominently, John Chrysostom. ${ }^{37}$ Twenty-nine manuscripts of aț-Ṭaiyib's catena have so far been identified, some of single Gospels and some with all four:

36 Graf, Geschichte Vol. 2, 160-77, especially 166-9.

37 Graf, Geschichte Vol. 2, 167-8, which notes editions of parts of the work, its introduction, and a complete (but uncritical) edition with extensive alterations. As Löfgren, Katalog, 126-9 states, there are ambiguities in the Ethiopic translation: in the introductions of some codices, John Chrysostom is named as the compiler who also translated from Syriac to Hebrew! For an extensive list of authors, see E. Sachau, Verzeichniss der syrischen Handschriften der Königlichen Bibliothek zu Berlin 1. Berlin: Asher, 1899, 375-6. 
Arabic 1. Aleppo ? (no collection named)

Arabic 2. Baghdad, Chaldean Catholic Patriarchate, Ms. 130

Arabic 3. Baghdad, Chaldean Catholic Patriarchate, Ms. 131

Arabic 4. Berlin, SBPK, Ms. sy 109 (= Ms. ar. 10178 according to Graf)

Arabic 5. Cairo, Coptic Museum, CM 1245 (Theol. 195, Getty 1337)

Arabic 6. Cairo, Coptic Museum, CM 1264 (Theol. 214, Getty 1204)

Arabic 10. Cairo, Coptic Patriarchate, Theol. 28

Arabic 15. Cairo, Coptic Patriarchate, Theol. 39

Arabic 17. Cairo, Coptic Patriarchate, Theol. 50

Arabic 18. Cairo, Coptic Patriarchate, Theol. 53

Arabic 19. Cairo, Coptic Patriarchate, Graf No. 602 (Theol. ?)

Arabic 20. Dēr Abū Maqār, Theol. 5

Arabic 22. Dēr Abū Maqār, number unknown

Arabic 23. Dēr el-Šarfeh (Lebanon), Patriarchal Library, syr. 9/18

Arabic 26. Leiden, University Library, Or. 2375

Arabic 27. London, British Library, Or. 3201 (= ar. Suppl. 15)

Arabic 31. Paris, BnF, Ms. Arab. 85

Arabic 32. Paris, BnF, Ms. Arab. 86

Arabic 35. Vatican City, BAV, Ms. Borg. ar. 231

Arabic 36. Vatican City, BAV, Ms. Borg. sir. 405

Ethiopic 1. Addis Ababa, Holy Trinity Cathedral, Ms. 63

Ethiopic 3. Addis Ababa, St. Gabriel Church (when photographed)

Ethiopic 14. London, British Library, Or. 731

Ethiopic 15. London, British Library, Or. 732

Ethiopic 16. London, British Library, Or. 734

Ethiopic 17. London, British Library, Or. 735

Ethiopic 18. London, British Library, Or. 736

Ethiopic 21. Paris, BnF, d'Abbadie Eth. 24

Ethiopic 22. Uppsala, University Library, O Etiop. 41

A third family, of catenae on the Gospel of Matthew by a known compiler, is attested only in a few instances. Sim 'ān ibn Kalīl ibn Maqārah was a highranking bureaucrat as secretary of the army with sultan Șalăh ad-Dīn before becoming a monk in the Monastery of St John Kolobos in Scetes. He died after 1206 CE. ${ }^{38}$ Sim'ān's commentary was written in Arabic. It is not known if he made use of sources in other languages; no authors are

\footnotetext{
38 Graf, Geschichte Vol. 2, 336-7.
} 
mentioned in the literature as being quoted in this work even though it is described as a catena. ${ }^{39}$ Five codices are known:

Arabic 12. Cairo, Coptic Patriarchate, Theol. 31 (Ms. 595)

Arabic 13. Cairo, Coptic Patriarchate, Theol. 36

Arabic 14. Cairo, Coptic Patriarchate, Theol. 37

Arabic 16. Cairo, Coptic Patriarchate, Theol. 42 (Ms. 599)

Arabic 24. Escorial, Escorial Library, Ms. III. ב. 5 (= Ms. ar. 446)

The exact contents of eight codices remains unclear. Most of these will probably belong to one of the three groups mentioned before, but the catalogue entries are insufficient to draw any conclusion. One of the first tasks is to examine their introductions and text. If introductions are lacking, lists of the gospel verses expounded and the patristic sources quoted will normally offer assistance with their identification:

Arabic 7. Cairo, Coptic Museum, CM 1393 (Theol. 346, Getty 1210)

Arabic 11. Cairo, Coptic Patriarchate, Theol. 30

Arabic 28. Los Angeles, St Shenouda Coptic Society, ML.MS.32

Arabic 33. Paris, BnF, Ms. Arab. 93

Ethiopic 8. Berlin, SBPK, Ms. or. 2283

Ethiopic 9. Bulga (Ethiopia)

Ethiopic 11. Lake Ṭānā 145 (= Dāgā Esțifānos 34)

Ethiopic 13. London, British Library, Add. 16248 (Ms. Aeth. 12)

Taking into account the fact that these different groups only include a limited number of manuscripts, it is of interest to note that the major part of Arabic commentaries in the form of catenae are not translations of the Bohairic text but the product of a 'Nestorian', even though they circulated in Egypt. However, the Egyptian tradition, albeit originally written in Greek and later translated into Bohairic, was in use at least in some Syriac communities since the text is also extant in Garšuni. The Arabic translation of the Bohairic text must therefore somehow have found its way to a Syriac-speaking monastery. The most probable candidate would be Dèr elSurian in the Wādī an-Națrūn, although this is no more than speculation.

39 Cf. Graf, Geschichte Vol. 2, 336-7; W.F. Macomber, Final Inventory of the Microfilmed Manuscripts of the Coptic Orthodox Patriarchate, al-Azbakizyah, Cairo. Vol. 2. Provo UT: Brigham Young University, 1997: 188-9, 200-1, 202-3, 211-2. The text is unpublished. 


\section{OUTLINE FOR FUTURE RESEARCH}

The major task for future studies of catenae in Bohairic, Arabic and Ethiopic is to catalogue the manuscripts as completely as possible and to group them into families, as a basis for a more refined grouping according to their texts. Only once this is done will it be possible to produce critical editions of the complete contents.

Since the Arabic manuscripts are copies made by different denominations in Eastern Christianity and were used in a variety of theological environments, comparison of these in order to identify changes related to theological differences might help to highlight how the churches of the East interacted with one another. The catena by 'Abdallāh ibn atTaiyib would be a particularly interesting subject for research, not only because of the context of its author but also because it was used by the Coptic Orthodox Church as well and transmitted as far as Ethiopia. ${ }^{40}$

In the case of the Bohairic text, de Lagarde's edition of London, British Library, Or. 8812 is no longer sufficient. A new edition is needed which better represents the manuscript, including improvements to the layout, the inclusion of all titles and, if possible, a detailed index to make the text more easily accessible. In addition, the two other Bohairic witnesses still have to be edited and are particularly significant in passages absent from de Lagarde's edition. Insofar as previous studies have shown that there are at least some reliable patristic excerpts in the Bohairic translation, more detailed analysis of the catenae might unearth portions of text not extant in Greek. The same is true of the Arabic and Ethiopic translations, which are more complete. Again, the provision of detailed indices and synoptic tables of the gospel verses commented on and the authors quoted in the catena, as well as the titles or designations of sources (so far as they are provided in the manuscripts), would be the most effective way to present the material for the scientific community.

40 U. Zanetti, Les manuscrits de Dair Abû Maqâr. Inventaire. Cahiers d'orientalisme 11. Geneva: Cramer, 1986, notes of Dēr Abū Maqār Theol. 5 that paragraphs are crossed out or marked: 'de nombreux passages sont raturés et munis de notes marginales très anciennes, réprouvant la caractère «nestorien» de certains paragraphes' (43). 


\section{Checklist of CATENa MANUSCRipts ON THE Gospels in BoHAIRIC, ARABIC, AND ETHIOPIC (Gə`วZ)}

The following list is meant as a starting point for further research and is far from being complete; every time I searched for specific classmarks, I came across new manuscripts in Ethiopic and Arabic. ${ }^{41} \mathrm{I}$ suspect that unidentified codices in Ethiopic will far outnumber the manuscripts listed below. ${ }^{42}$ In the case of the Bohairic manuscripts, the list appears to be reasonably complete although there remains a small chance that additional fragments may be discovered, as such material is still uncatalogued in many collections. ${ }^{43}$

41 For Arabic sources I depend mainly on the catalogues and lists of Graf, Caubet Iturbe, and Macomber, cf. the entries and the bibliography. According to Graf, Geschichte Vol. 2, 168 there are two Arabic manuscripts in the Patriarchal Residence at Diyarbakir mentioned in C.J. David, Recueil de documents et de prewves contre la prétendue Orthodoxie perpétuelle des Maronites: D’après deux manuscrits originaux écrits en 1873, Cairo, 1908: 347-8 (in Arabic). Most probably these are the two catena manuscripts mentioned by A. Scher, Notice sur les manuscrits syriaques et arabes conservés à l'archevêché chaldéen de Diarbékir.' Journal asiatique 10 (1907) 331-62, 385-431 (Baghdad Ms. 130 and Ms. 131 on 413-4). For Ethiopic codices, I have no principal source of information; according to Löfgren, Katalog, 127-8 manuscripts of the Terg" ämé wangèl are very rare. Zamagni, 'New Perspectives', 254 lists only two Ethiopic codices, and Conti Rossini, 'Manoscritti e opere abissine', 633 has included only four. I had only access to a limited number of catalogues, however, they revealed that there are in fact many codices that include works entitled Terg"ämé wangèl. For a very complete inventory of catalogues, see A. Bausi, 'La catalogazione come base della ricerca. Il caso dell'Etiopia' in Zenit e Nadir II. I manoscritti dell'area del Mediterraneo: la catalogazione come base della ricerca, ed. B. Cenni, C.M.F. Lalli and L. Magionami. Montepulciano: Thesan \& Turan, 2007, 87-108. Bausi's article shows how much is to be done before it is possible to give a reliable account of how much material is preserved.

42 The descriptions provided by catalogues are often too limited to determine whether or not a commentary is in the form of a catena. Since there are examples of catenae in Ethiopic that are identified in their headings as commentaries by John Chrysostom, it is likely that there are many more witnesses of this type (some, perhaps, included in older catalogues) still to be identified.

43 Among the libraries with fragmentary Bohairic material are Cambridge University Library, the Bodleian Library in Oxford, the Österreichische Nationalbibliothek and the Coptic Museum in Cairo, not to mention l'abîme béant of private collections. 
A recent article by Claudio Zamagni offers a list of manuscripts, mainly in Greek and Latin, which might contain extracts from Eusebius' Gospel Problems and Solutions. ${ }^{44}$ This includes copies of Nicetas of Heraclea's Catena on Luke as well as manuscripts with other portions of Eusebius' works and unidentified questions on the Gospels. Despite the length of Zamagni's list, it is inadequate for the languages discussed in this paper and the information provided for the Bohairic manuscripts is inaccurate. An asterisk in the Checklist denotes a manuscript mentioned by Zamagni.

The Checklist is divided into three sections according to language (Bohairic, Arabic and Ethiopic). A fourth section adds three further Ethiopic manuscripts whose catalogue entries are not sufficiently detailed to determine whether or not they are catenae. Abbreviated references in the Checklist are given in full in the Bibliography afterwards. To indicate the contents of the fragmentary Bohairic manuscripts, I follow Evelyn White's example and give the corresponding passages as pages and lines in de Lagarde's edition.

\section{Bohairic}

1. *A: London, British Library, Add. 14740 f. $9=$ pp.1-2 of the $\operatorname{codex}^{45}$ *B: London, British Library, Or. 8812 (cf. de Lagarde 1886) 888/889 CE (colophon) | Dēr Abū Maqār | Catena on the Gospels | parchment, $256+1$ fol. $|36.0 \times 27.5 \mathrm{~cm}| 1$ col. | 35-37 ll. | scribe: Theod(orus) of Abū Șīr | London Or. 8812 was formerly Ms. Parham 102 in the collection of Robert Curzon. De Lagarde and Layton give detailed accounts of the modern history of the manuscript as well as tables with the correct sequence of the leaves, which are currently bound out of order: de Lagarde (1886) v; Layton (1987) 389-90. For the Gospel of Matthew, Horner used the codex to include variant readings in the critical apparatus of his edition of the New Testament; for the other Gospels he used the edition by de Lagarde. | de Lagarde (1886); Horner (1898) xxxvii-xxxviii, siglum ж; Crum (1905) 325, No. 740; Hebbelynck (1928) 85-88, 111-4 (ed. and translation of Add. 14740 fol. 9); Layton (1987) 389-94, No. 249.

2. A: Cairo, Coptic Museum, CM 2624 [G 324] Evelyn White Frag. 146

44 Zamagni, 'New Perspectives'; list of manuscripts on 250-7.

45 Zamagni, 'New Perspectives', 254 lists this leaf as a separate manuscript. 
recto: de Lagarde 49.17-33; verso: 49.33-50.13

B: Leipzig, University Library, Nr. 1090 Bl. E 8 recto: de Lagarde 57.2-16; ${ }^{47}$ verso: $57.20-31$

C: Leipzig, University Library, Nr. 1090 Bl. E 9 recto: de Lagarde 57.35-58.11; verso: 58.15-28

D: Cairo, Coptic Museum, CM 2513 (29) [G 130] Evelyn White Frag. $3^{48}$ recto: de Lagarde 60.18-36; verso: 60.36-61.14

E: Leipzig, University Library, Nr. 1090 Bl. E 12 recto: de Lagarde 63.36-64.13; verso: 64.13-31

F: Leipzig, University Library, Nr. 1090 Bl. E 13 recto: de Lagarde 65.10-26; verso: 64.31- 65.9

G: Cairo, Coptic Museum, CM 2624 [G 324] Evelyn White Frag. 4 recto: de Lagarde 67.2, fills lacuna; verso: fills lacuna

H: Leipzig, University Library, Nr. 1090 Bl. E 10 recto: de Lagarde 72.13-22; verso: 72.30-39

I: Cairo, Coptic Museum, CM 2624 (93) [G 28], Evelyn White Frag. 5 recto: de Lagarde 109.18-28; verso: 109.35-110.6

J: $\quad$ Cairo, Coptic Museum, CM 2624 (92) [G 27] Evelyn White Frag. 6 recto: de Lagarde 119.15-21; verso: 119.34-39

K: Leipzig, University Library, Nr. 1090 Bl. E 11 recto: de Lagarde 168.7-26; verso: 168.26-p. 169 1. 4

L: Cairo, Coptic Museum, CM 2624 (93) [G 28] Evelyn White Frag. 749 recto: partly fills lacuna after Lagarde 174.19; 174.20-1; verso: 174.29-39 (om. 36-8)

M: Cairo, Coptic Museum, CM 2624 [G 324]

Evelyn White Frag. 8 recto/verso: unidentified

$9^{\text {th }} / 10^{\text {th }}$ century (Schulz) $\mid$ Dēr Abū Maqār (?) | Catena on the Gospels | parchment, 13 fol. (fragmentary) | ${ }^{*}$ c. $34.5-36.0 \times 27.0-28.0 \mathrm{~cm} \mid 1$

46 The leaf is paginated on the verso: pag. 148.

47 Leipoldt, 'Koptische Handschriften', 419 gives the contents as Mark 10:45.

48 The leaf is paginated on the verso: pag. 174.

49 The leaf is paginated on verso: pag. 152; see also Evelyn White, Monasteries, 199 note 2 . 
col. | *36-38 11. | The contents of the Leipzig folios, the grouping of the fragments from different collections, as well as the sequence of leaves are given here for the first time. | Leipoldt (1906) 419-420, Nr. 1090 Codex Tischendorfianus XXVIII, Bl. E 8 bis E 15; Evelyn White (1926) 198-9 E. Catena Patrum.

3. A: Cairo, Coptic Museum, CM 2624 (92) [G 27]

Evelyn White Frag. $9^{50}$

recto: de Lagarde 6.1-9; scholion by [Bas]ilios, not in de Lagarde; verso: unidentified (continuation of the text?)

B: London, British Library, Add. 14740A, fol. $10+$ fol. 11 recto: de Lagarde 21.37, 22.7; verso: 22.25-33

C: Cairo, Coptic Museum, CM 2624 [G 324] Evelyn White Frag. 2 recto: de Lagarde 57.39-58.13; verso: 58.22-35

D: London, British Library, Add. 14740A, fol. 24 recto/verso: unidentified

$9^{\text {th }} / 10^{\text {th }}$ century (Schulz) $\mid$ Dēr Abū Maqār (?) | Catena on the Gospel of Matthew | parchment, 4 fol. (fragmentary) | *ca. 34.5-36.0 × 27.0$28.0 \mathrm{~cm} \mathrm{|} 1$ col. |*36-38 ll. | The grouping of the fragments from different collections and the sequence of leaves are given here for the first time. It is not possible to say whether the manuscript contained commentaries on the other Gospels as well. | Crum (1905) 378-9, No. 914; Evelyn White (1926) 198-9 E. Catena Patrum.

\section{Arabic $^{51}$}

1. Aleppo ? (no collection named)

Date unknown | provenance unknown | Catena on the Gospels, compiled by 'Abdallāh ibn aț-Ṭaiyib | Information according to Graf (1947) 168 who depends on Sbath (1939) 145-8 [non vidi].

2. Baghdad, Chaldean Catholic Patriarchate, Ms. 130 (olim Diyarbakır 130)

50 Contents not identified by Evelyn White.

51 Zamagni, 'New Perspectives', 253 (VI.5) also lists Vatican City, BAV, Vat. ar. 411, which is an Arabic translation of 'La guía de pecadoros' by Fray L. de Granada written in 1679: Graf, Geschichte vol. 4, 196-7. Graf, Geschichte vol. 2, 168, gives the manuscripts Coptic Patriarchate 226 and 231 by mistake, since they contain parts of the Old Testament: see Macomber, Final Inventory (Patriarchate), 160-2 (Graf 231) and 185-6 (Graf 226). 
Before 1554 CE (date of donation) | Gift to the Church of Mar Petyun in Amid (Church of St Anthony in Diyarbakır) | Catena on the Gospel of Matthew, compiled by 'Abdallāh ibn aț-Ṭaiyib | paper, 492 fol. | $28.0 \times 22.0 \mathrm{~cm} \mid 1$ col. $\mid 6-14 \mathrm{ll}$. | For the history of the manuscripts formerly kept in the library of the Chaldean Archbishopric of Diyarbakır, see the next entry. I Scher (1909) 64-5, No. 130; Graf (1947) 168.

3. *Baghdad, Chaldean Catholic Patriarchate, Ms. 131 (olim Diyarbakır 131)

Finished $13^{\text {th }}$ of Hazìrān, year 1809 of the Greeks (13 $3^{\text {th }}$ June 1498) | Monastery of St John the Baptist, called Tiphyyin (in Turkey?) | Catena on the Four Gospels, compiled by 'Abdallāh ibn aț-Taiyib | paper, 364 fol. | $22.0 \times 16.0 \mathrm{~cm} \mathrm{|} 1$ col. | 18 ll. | scribe: Safar | Beginning and end of the codex are lacking. The manuscripts that once belonged to the Chaldean Archbishopric of Diyarbakır were transfered to the Chaldean Catholic Patriarchate some time between 1908 and 1937, when its library was situated in Mosul, cf. Vosté (1937) 348. According to Caubet Iturbe (1969) xlvi, the manuscripts were later transferred to Baghdad. The present whereabouts are unknown. I Sher (1909) 65, No. 131; Vosté (1937) 348; Graf (1947) 168; Caubet Iturbe (1969) xlvi-xlvii (manuscript not available, excluded).

4. Berlin, SBPK, Ms. sy 109 (= Ms. ar. 10178 according to Graf)

$14^{\text {th }}$ century (Sachau) | provenance unknown | Catena on the Gospel of Matthew, compiled by 'Abdallāh ibn aț-Taiyib | paper, 96 fol. | $18.0 \times$ $13.0 \mathrm{~cm}$ | 1 col. | 19 1l. per page, Garšūni | Sachau (1899) 375-6 gives an overview of the patristic sources of the catena. | Sachau (1899) 3756, No. sy 109; Graf (1947) 168.

5. Cairo, Coptic Museum, CM 1245 (Theol. 195, Getty 1337)

$17^{\text {th }}$ century (Graf), 17 th $/ 18^{\text {th }}$ century (Macomber) | provenance unknown (Egypt) | Catena on the Gospel of Matthew, compiled by 'Abdallāh ibn aț-Ṭaiyib | paper, 251 fol. | $29.0 \times 20.0 \mathrm{~cm} \mid 1$ col. | 2122 ll. per page | The manuscript was microfilmed by the Brigham Young University Center for the Preservation of Ancient Religious Texts. | Graf (1934) 42 No. 110; Simaika (1939) 30, No. 56; Graf (1947) 167; Macomber (1995) 449-50, CMA 15-6.

6. Cairo, Coptic Museum, CM 1264 (Theol. 214, Getty 1204)

1232 CE (colophon) | Egypt, Monastery of St Antony | Catena on the Gospels of Luke and John, compiled by 'Abdallāh ibn aț-Ṭiyib | paper, 
414 fol. | $21.0 \times 14.0 \mathrm{~cm} \mid 1$ col. | 14-16 1l. per page | According to Macomber (1995) 173 the codex has only 402 leaves. The manuscript was microfilmed by the Brigham Young University Center for the Preservation of Ancient Religious Texts. | Graf (1934) 50, No. 128; Simaika (1939) 25, No. 44; Graf (1947) 167; Macomber (1995) 172-3, CMA 3-4.

7. *Cairo, Coptic Museum, CM 1393 (Theol. 346, Getty 1210)

$14^{\text {th }} / 15^{\text {th }}$ century (Graf) $\mid$ provenance unknown (Egypt) $\mid$ Catena on the Gospels of Luke and John | paper, 285 fol. (Cairo, Coptic Museum, inventory book: 284 fol.) | $22.0 \times 15.0 \mathrm{~cm} \mid 1 \mathrm{col}$. | 13-14 1l. per page | According to Graf this manuscript is No. 1157. The manuscript was microfilmed by the Brigham Young University Center for the Preservation of Ancient Religious Texts. | Graf (1934) 71-2, No. 166; Simaika (1939) 28, No. 51; Macomber (1995) 201-2, CMA 6-4.

8. *Cairo, Coptic Patriarchate, Theol. 26 (Ms. 41)

$1735 \mathrm{CE}$ | provenance unknown (Egypt) | Catena on the Four Gospels | paper, 469 fol. | $29.0 \times 20.0 \mathrm{~cm} \mathrm{|} 1$ col. | 16 1l. per page | scribe: Sakundus | Each Gospel is introduced by a biography of the corresponding evangelist. The manuscript was microfilmed by the Brigham Young University Center for the Preservation of Ancient Religious Texts. | Graf (1934) 85, No. 195; Simaika (1942) 156, No. 351; Caubet Iturbe (1969) xli-xliii siglum D; Macomber (1997) 178-80, PAT 19-13.

9. *Cairo, Coptic Patriarchate, Theol. 27 (Ms. 567)

$14^{\text {th }}$ century (Graf) | provenance unknown (Egypt) | Catena on the Four Gospels | paper, 321 fol. | $25.0 \times 17.0 \mathrm{~cm}$ | 1 col. | 17 1l. per page | The beginning of the manuscript is lacking and 30 leaves at the end have been supplemented. The manuscript was microfilmed by the Brigham Young University Center for the Preservation of Ancient Religious Texts. | Graf (1934) 151, No. 411; Simaika (1942) 94, No. 225; Caubet Iturbe (1969) xxix-xxx siglum C; Macomber (1997) 181-3, PAT 20-1.

10. Cairo, Coptic Patriarchate, Theol. 28

1874 CE | provenance unknown (Egypt) | Catena on the Gospel of Matthew, compiled by 'Abdallāh ibn aț-Ṭaiyib | paper, 326 fol. | $30.0 \times$ $22.0 \mathrm{~cm} \mid 1 \mathrm{col}$. | 18-23 1l. per page | The manuscript was microfilmed by the Brigham Young University Center for the Preservation of Ancient Religious Texts. | Graf (1934) 213, No. 571; Simaika (1942) 233, No. 525; Macomber (1997) 184-5, PAT 20-2. 
11. Cairo, Coptic Patriarchate, Theol. 30

$16^{\text {th }} / 17^{\text {th }}$ century (Macomber) $\mid$ Egypt, Monastery of St Antony $\mid$ Catena on the Four Gospels | paper, 246 fol. $|21.0 \times 15.0 \mathrm{~cm}| 1 \mathrm{col}$. | 15 ll. per page | The biblical text has been omitted. The manuscript was microfilmed by the Brigham Young University Center for the Preservation of Ancient Religious Texts. I Simaika (1942) 95, No. 227; Macomber (1997) 190-1, PAT 20-5.

12. Cairo, Coptic Patriarchate, Theol. 31 (Ms. 595)

1502 CE | provenance unknown (Egypt) | Catena on the Gospel of Matthew, compiled by Sim ān ibn Kalīl ibn Maqārah | paper, 364 fol. | $26.0 \times 18.0 \mathrm{~cm} \mid 1$ col. | 20-21 ll. per page | scribe: Ya'qūb, son of Ishāq | The manuscript was microfilmed by the Brigham Young University Center for the Preservation of Ancient Religious Texts. | Graf (1934) 156, No. 427; Simaika (1942) 109, No. 263; Macomber (1997) 188-9, PAT 20-4.

13. Cairo, Coptic Patriarchate, Theol. 36

19th century [fol. 4-250] and 20 th century [fol. 251-275] (Macomber) | provenance unknown (Egypt) | Catena on the Gospel of Matthew, compiled by Simāan ibn Kalīl ibn Maqārah | paper, 272 fol. | 35.0 × $24.0 \mathrm{~cm} \mathrm{|} 1$ col. | 24-25 (fol. 4-250) and 14-15 (fol. 251-275) 1l. per page | The manuscript was microfilmed by the Brigham Young University Center for the Preservation of Ancient Religious Texts. | Graf (1934) 221, No. 605; Simaika (1942) 95-6, No. 230; Macomber (1997) 200-1, PAT 20-10.

14. Cairo, Coptic Patriarchate, Theol. 37

$10^{\text {th }}$ October 1828 (Graf) $\mid$ provenance unknown (Egypt), dedicated to the Patriarchal library in 1902/3 | Catena on the Gospel of Matthew, compiled by Simcān ibn Kalīl ibn Maqārah | paper, 417 fol. | $26.0 \times$ $22.0 \mathrm{~cm} \mathrm{|} 1 \mathrm{col}$. | 15-8 11. | The manuscript was microfilmed by the Brigham Young University Center for the Preservation of Ancient Religious Texts. | Graf (1934) 215, No. 576; Graf (1947) 337; Simaika (1942) 220, No. 492; Macomber (1997) 202-3, PAT 21-1.

15. Cairo, Coptic Patriarchate, Theol. 39

$1^{\text {th }}$ century (Macomber), 16 $6^{\text {th }}$ century (Graf) $\mid$ provenance unknown (Egypt) | Catena on the Gospel of Matthew, compiled by 'Abdallāh ibn aț-Taiyib | paper, 287 fol. | $24.0 \times 17.0 \mathrm{~cm} \mid 1 \mathrm{col}$. | 15-17 1l. per page | The manuscript was microfilmed by the Brigham Young University 
Center for the Preservation of Ancient Religious Texts. | Graf (1934) 220, No. 603; Simaika (1942) 96, No. 232; Macomber (1997) 206-7, PAT 21-3.

16. Cairo, Coptic Patriarchate, Theol. 42 (Ms. 599)

1831 CE (gloss) | provenance unknown (Egypt) | Catena on the Gospel of Matthew, compiled by Sim ān ibn Kalīl ibn Maqārah | paper, 228 fol. $\mid 17.0 \times 12.0 \mathrm{~cm} \mathrm{|} 1$ col. | 9-10 ll. per page | The manuscript was microfilmed by the Brigham Young University Center for the Preservation of Ancient Religious Texts. | Graf (1934) 156, No. 429; Simaika (1942) 221, No. 495; Macomber (1997) 211-2, PAT 21-6.

17. Cairo, Coptic Patriarchate, Theol. 50

29th September 1787 (colophon) | provenance unknown (Egypt) | Catena on the Gospels of Mark, Luke, and John, compiled by 'Abdallāh ibn aț-Taiyib | paper, 204 fol. | $31.0 \times 21.0 \mathrm{~cm} \mathrm{|} 1$ col. | 24-26 1l. per page | Same hand as Cairo, Coptic Patriarchate, Theol. 53 (the first part of the same codex). The manuscript was microfilmed by the Brigham Young University Center for the Preservation of Ancient Religious Texts. | Graf (1934) 220, No. 601; Simaika (1942) 180, No. 409; Macomber (1997) 225-6, PAT 22-4.

18. Cairo, Coptic Patriarchate, Theol. 53

1787 CE | provenance unknown (Egypt) | Catena on the Gospel of Matthew, compiled by 'Abdallāh ibn aț-Ṭaiyib | paper, 166 fol. | $31.0 \times$ $21.0 \mathrm{~cm} \mathrm{|} 1$ col. | 27 ll. per page | Same hand as Cairo, Coptic Patriarchat, Theol. 50 (the second part of this codex). According to Graf (1934) 220 the manuscript has 169 leaves. The manuscript was microfilmed by the Brigham Young University Center for the Preservation of Ancient Religious Texts. I Graf (1934) 220, No. 600; Simaika (1942) 180, No. 408; Macomber (1997) 230-1, PAT 22-7.

19. Cairo, Coptic Patriarchate, Graf 602 (Theol. ?)

$14^{\text {th }}$ century (Graf) | provenance unknown (Egypt) | Catena on the Gospel of Matthew, compiled by 'Abdallāh ibn aț-Țaiyib | paper, 555 fol. $\mid$ in $8^{\circ} \mid$ col. not specified | lines per page not specified | Information according to Graf (1934) 220, who does not mention the inventory number in the Coptic Patriarchate. Graf's catalogue number is not included in Macomber's catalogues. | Graf (1934) 220, No. 602. 
20. Dēr Abū Maqāar, Theol. 5 (= Comm. 5)

$14^{\text {th }}$ century? (Zanetti) | Egypt, Dēr Abū Maqār | Catena on the Gospel of Matthew, compiled by 'Abdallāh ibn aț-Ṭaiyib | paper, 269 fol. | Fol. 1-11 and 281 ff., are lacking. Some paragraphs are crossed out. There are marginal notes contradicting the opinions of the compiler. No further data. | Graf (1947) 168; Zanetti (1986) 43, No. 300.

21. Dēr Abū Maqār, Theol. 6 (= Comm. 6)

$14^{\text {th }}$ century ? (Zanetti) | Egypt, Dēr Abū Maqār | Catena on the Gospels of Matthew and Mark | paper, 146 fol. | Fol. 1-8, 62-73 and $164 \mathrm{ff}$. are lacking. The text is the 'Coptic-Arabic' family according to Zanetti (1986) 43, with reference to Graf (1944) 481. | Zanetti (1986) 43, No. 301.

22. Dēr Abū Maqāar, Theol. 13 (= Comm. 13)

$16^{\text {th }}$ century ? (Zanetti) | Egypt, Dēr Abū Maqār | Catena on the Gospel of John, compiled by 'Abdallāh ibn at-T Taiyib | paper, 216 fol. | in $4^{\circ}$ | No further data. | Graf (1947) 169; Zanetti (1986) 44, No. 308.

23. Dēr el-Šarfeh (Lebanon), Patriarchal Library, syr. 9/18

Date unknown | provenance unknown (Lebanon) | Catena on the Gospel of Matthew, compiled by 'Abdallāh ibn aț-Taiyib | Garšūni | Information according to Graf (1947) 168.

24. Escorial (San Lorenzo), Escorial Library, Ms. III. ב. 5 (= Ms. ar. 446) 1470/1 CE (Anno hegirae 875 according to Morata) | provenance unknown | Catena on the Gospel (of Matthew), compiled by Sim ān ibn Kalī ibn Maqārah | No further data available. The name given by Morata is rather strange: 'Semaan hijo de quelil el llamado Muleuen' | Morata (1934) 144, 181, No. 446; Graf (1947) 337.

25. *Göttingen, Universitätsbib., Arab. 103 (orient. 125.3)

$13^{\text {th }} / 14^{\text {th }}$ century (Caubet Iturbe), restored $18^{\text {th }}$ July 1811 (gloss) Egypt, Dēr Anba Bishoi | Catena on the Four Gospels | Oriental paper with watermark [sic], 363 fol. | $24.5 \times 15.5 \mathrm{~cm} \mathrm{|} 17$ ll. per page | Some folios of the original manuscripts are lacking and have been supplemented: Meyer indicates the folios written in a different hand. According to Meyer, the introductions to each gospel agree, in part verbatim, with the introductions of the gospel codex Oxford, Bodleian Library, Ms. 265 reproduced in Nicoll (1821) 16-19, No. 14. | Meyer (1894) 359-61, Arab. 103; Caubet Iturbe (1969) xxx-xxxii siglum G. 
26. Leiden, University Library, Or. 2375

1768/9 CE | provenance unknown | Catena on the Gospel of Matthew, compiled by 'Abdallāh ibn aț-Taiyib | paper, 116 fol. | No further data. | Graf (1947) 168; Witkam (2006-8) 123, No. Or. 2375.

27. London, British Library, Or. 3201 (= ar. Suppl. 15)

1805 CE (colophon: $2^{\text {nd }}$ of Mesore Anno martyrum 1521) | Egypt, Asyūt | Catena on the Gospels, compiled by 'Abdallāh ibn aț-Ṭaiyib | paper, 372 fol. | 30.0 × $20.5 \mathrm{~cm} \mid 1$ col. | 25 1l. per page Garšūni | Rieu (1894) 12-13; Graf (1947) 168.

28. Los Angeles, St Shenouda the Archimandrite Coptic Society, ML.MS.32 1790/1 CE (Anno martyrum 1507) | provenance unknown | Catena on the Four Gospels | paper | no further information | According to the St Shenuda the Archimandrite Coptic Society's online catalogue this is a 'nearly complete bound codex':

http://www.copticmanuscripts.org/Index-Listing.htm [27.8.2015].

29. *Oxford, Bodleian Library, Ms. Huntington 262

Before 1575 CE (Zamagni), 16 ${ }^{\text {th }}$ century ? (Caubet Iturbe) | Egypt, Dēr el-Baramūs | Catena on the Four Gospels | paper, 252 fol. | $26.0 \times$ $19.0 \mathrm{~cm} \mid 1$ col. | 20 1l. per page | Graf (1947) 168; Caubet Iturbe (1969) xxxiii-xxxvi siglum $O$.

30. *Paris, Bibliothèque Nationale, Ms. Arab. 55

1619 CE | provenance unknown (Egypt) | Catena on the Four Gospels | European paper (bombycin), 208 fol. | $21.0 \times 15.0 \mathrm{~cm} \mid$ col. not specified | 14-18 1l. per page | The manuscript was brought from Cairo to Paris by J.M. Wansleben. In the catalogue of 1731 it is stated that Isaac ibn al-Assāl was the compiler of the catena. According to a scribal note it was copied from a manuscript dated 1288 CE. I Anonymous (1731) 102, No. 28; Slane (1883-95) 12, No. 55; Caubet Iturbe (1969) xxxviii-xli siglum $P$.

31. Paris, Bibliothèque Nationale, Ms. Arab. 85

$11^{\text {th }}$ century (Slane) | provenance unknown | Catena on the Gospels of Luke and John, compiled by 'Abdallāh ibn aț-Taiyib | paper, 164 fol. | $26.0 \times 17.0 \mathrm{~cm} \mid$ col. not specified | 18-19 11. per page | The manuscript once contained the catena on all four Gospels, but now the beginning is lacking. | Slane (1883-95) 21, No. 85; Graf (1947) 167. 
32. Paris, Bibliothèque Nationale, Ms. Arab. 86

1248 CE (Slane) | provenance unknown | Catena on the Gospels, compiled by 'Abdallāh ibn aț-Taiyib | paper, 303 fol. | $25.0 \times 17.0 \mathrm{~cm}$ | col. not specified | $18 \mathrm{ll}$. per page | According to Graf the codex is a copy of Paris, BnF, Ms. Arab. 85. | Slane (1883-95) 21, No. 86; Graf (1947) 168.

33. *Paris, Bibliothèque Nationale, Ms. Arab. 93

$1^{\text {th }}$ century (Slane) $\mid$ provenance unknown $\mid$ Catena on the Gospel of John | European paper (bombycin), 108 fol. $|26.0 \times 18.0 \mathrm{~cm}|$ col. not specified | 14-16 ll. per page | The manuscript was brought from the East to Paris by J.M. Wansleben. On f. 1r is a prayer in Garšunni. In the catalogue of 1731 it is stated that Isaac ibn al-Assāl was the compiler of the catena. According to Slane the manuscript suffered from humidity. I Anonymous (1731) 102, No. 30; Slane (1883-95) 22, No. 93; Caubet Iturbe (1969) xlvii.

34. *Strasbourg, Bibliothèque Nationale et Universitaire, Or. 4315

$16^{\text {th }}$ century (Wickersheimer) $\mid$ provenance unknown (Egypt) $\mid$ Catena on the Gospel of Matthew | paper, 380 fol. | $29.0 \times 20.0 \mathrm{~cm} \mathrm{|} 1$ col. | 20 1l. per page | Wickersheimer (1923) 764, No. 4315; Caubet Iturbe (1969) xxxvi-xxxviiii siglum $S$.

35. Vatican City, Biblioteca Apostolica Vaticana, Ms. Borg. ar. 231

$16^{\text {th }}$ century (Graf) | provenance unknown | Catena on the Gospel of Matthew, compiled by 'Abdallāh ibn aț-Ṭaiyib | 247 fol. | Garšūni | Information according to Graf (1947) 168.

36. Vatican City, Biblioteca Apostolica Vaticana, Ms. Borg. sir. 405

Date unknown | provenance unknown | Catena on the Gospel of Matthew, compiled by 'Abdallāh ibn at-Taiyib | 247 fol. | Garšūni | Information according to Graf (1947) 168.

37. *Vatican City, Biblioteca Apostolica Vaticana, Ms. Vat. ar. 410

$13^{\text {th }}$ century (Graf), $13^{\text {th }} / 14^{\text {th }}$ century (Caubet Iturbe), $14^{\text {th }}$ century (Mai) | provenance unknown (Egypt) | Catena on the Four Gospels | European paper (bombycin), 263 fol. | $24.0 \times 16.5 \mathrm{~cm} \mathrm{|} 1$ col. | 15-17 11. per page | Mai (1831) 504; Graf (1947) 482; Caubet Iturbe (1969) xxvii-xxix siglum $M$. 
38. *Vatican City, Biblioteca Apostolica Vat., Ms. Vat. ar. 452 (in two parts)

Written c. 1204-14 CE (scribal notes) | Egypt, Wādī an-Națūn | Catena on the Four Gospels and index of lessons for the first half of the Coptic church year (fol. 369v-376v) | European paper (bombycin), 376 fol. | $25.0 \times 16.5 \mathrm{~cm} \mid 1$ col. | 17-18 1l. per page | scribe: John Besrob | Mai (1831) 519-20; Caubet Iturbe (1969) xv-xxvi sighm B.

39. *Vatican City, Biblioteca Apostolica Vaticana, Ms. Vat. sir. 531

$1486 \mathrm{CE}$ and $15^{\text {th }}$ century (van Lantschoot) | provenance unknown | Commentary on the Gospel lections of some feasts and Sundays, end of a Catena on the Gospel of Mark, Catena on the Gospel of Matthew, Prayers | paper, 265 fol. | $26.5 \times 18.0 \mathrm{~cm} \mid 1 \mathrm{col}$. | 22-23 1l. per page, Garšuni | scribe: Moyses | The end of the catena on the Gospel of Mark comprises fol. 144-145r, the catena on the Gospel of Matthew fol. $145 \mathrm{v}-263$. Based on the authors mentioned by van Lantschoot (1965) 57 , this codex is related to translations of the Bohairic text. I van Lantschoot (1965) 56-7, No. 531; Caubet Iturbe (1969) xlvii.

40. *Vatican City, Biblioteca Apostolica Vaticana, Ms. Vat.sir. 541

$1555 \mathrm{CE} \mid$ provenance unknown | Catena on the Four Gospels | paper, 283 fol. $|31.7 \times 21.5 \mathrm{~cm}|$ mostly 2 col. | 25-26 ll. per page, Garšūni | scribe: Manșūr | There are numerous glosses, prayers, etc. by the scribe and other people in the codex, cf. van Lantschoot (1965) 63. In this manuscript all references to the Coptic Orthodox Church and its liturgy are omitted although the text is nearly identical to Vatican City Ms. Vat. ar. 452; this leads Caubet Iturbe to assume that the present manuscript may be a copy of Ms. Vat. ar. 452. | van Lantschoot (1965) 63, No. 541; Caubet Iturbe (1969) xliii-xlvi siglum K.

\section{Ethiopic (Gə`əz)}

1. Addis Ababa, Holy Trinity Cathedral, Ms. 63

Early $17^{\text {th }}$ century (Haile) $\mid$ provenance unknown $\mid$ Catena on the Gospel of Matthew, compiled by 'Abdallāh ibn aț-Ṭaiyib, and Commentary on the Gospel of John | parchment, $215+2$ fol. | $23.5 \times$ $22.0 \mathrm{~cm} \mathrm{|} 3$ col. | 22-30 ll. per page | Two manuscripts bound together. The catena comprises fol. 2-164. According to the online catalogue it is similar to London, BL, Or. 736. For the commentary on John no further information is provided. The manuscript was microfilmed as part of the Ethiopic Manuscript Microfilm Library. | Haile (1979), EMML 1114 [non vidi]; 
http://www.vhmml.us/research2014/catalog/detail.asp?MSID=104906 (17.11.2015).

2. Addis Ababa, Library of the Patriarchate, s.n.

Early $18^{\text {th }}$ century (Macomber) $\mid$ provenance unknown $\mid$ Catena on the Gospel of Matthew | parchment, 125 fol. | $17.0 \times 16.5 \mathrm{~cm} \mid$ col. not specified | lines per page not specified | The catena comprises fol. 9121 and is a translation of the 'Coptic-Arabic catena', judging from the authors mentioned in the online catalogue. The manuscript was microfilmed as part of the Ethiopic Manuscript Microfilm Library. | Macomber (1976) EMML 630 [non vidi];

http://www.vhmml.us/research2014/catalog/detail.asp?MSID=104369 (17.11.2015).

3. Addis Ababa, St. Gabriel Church, s.n.

$17^{\text {th }} / 18^{\text {th }}$ century (Macomber) | provenance unknown | Catena on the Four Gospels, compiled by John Chrysostom [sic] | parchment, $237+$ 1 fol. (partially fragmentary) | $28.4 \times 24.0 \mathrm{~cm} \mid 2$ col. | 32-35 11. per page | For the attribution to John Chrysostom cf. Uppsala O Etiop. 41. The catena comprises fol. 3-237. The manuscript was microfilmed as part of the Ethiopic Manuscript Microfilm Library. Sample images are available on the website below. | Macomber (1976) 138, EMML 368 [non vidi];

http://www.vhmml.us/research2014/catalog/detail.asp?MSID=104087 (17.11.2015).

4. Ambasel, Private Library, s.n.

$18^{\text {th }}$ century (Haile/Macomber) $\mid$ provenance unknown | Catena on the Gospel of Matthew and varia | parchment, 152 fol. (partially fragmentary) | $24.0 \times 22.5 \mathrm{~cm} \mid$ columns not specified | lines per page not specified | The catena comprises fol. 1-136. The manuscript was microfilmed at the Monastery of Hayq Esțifānos as part of the Ethiopic Manuscript Microfilm Library. | Haile/ Macomber (1982) 138, EMML 2068 [non vidi];

http://www.vhmml.us/research2014/catalog/detail.asp?MSID=105881 (17.11.2015).

5. Ambasel, Private Library, s.n.

$18^{\text {th }}$ century (Haile/ Macomber) | provenance unknown | Catena on the the Gospel of Matthew and introductions to the Pauline Epistles | parchment, 141 fol. $|17.5 \times 13.5 \mathrm{~cm}|$ columns not specified | lines 
per page not specified | The catena comprises fol. 2-133. The manuscript was microfilmed at the Monastery of Hayq Esțiānos as part of the Ethiopic Manuscript Microfilm Library. | Haile/ Macomber (1982) 159, EMML 2088 [non vidi];

http://www.vhmml.us/research2014/catalog/detail.asp?MSID=105901 (17.11.2015).

6. Ambasel, Private Library, s.n.

$17^{\text {th }} / 18^{\text {th }}$ century (Haile/ Macomber) $\mid$ provenance unknown | Catena on the Gospel of Matthew | parchment, 141 fol. | size not specified | columns not specified | lines per page not specified | The manuscript was microfilmed at the library of Mamher Hāyla Māryām as part of the Ethiopic Manuscript Microfilm Library. | Haile/ Macomber (1983) 140, EMML 2797 [non vidi];

http://www.vhmml.us/research2014/catalog/detail.asp?MSID=106611 (17/11/2015).

7. Berlin, Staatsbibliothek Preußischer Kulturbesitz, Peterm. II. Nachtrag 52 $19^{\text {th }}$ century | provenance unknown $\mid$ Catena on the Four Gospels | parchment, 125 fol. | $18.5 \times 14.5 \mathrm{~cm} \mathrm{|} 2$ col. | 17 ll. per page | According to Dillmann only parts of the Gospels are discussed and the text is partly in disorder. | Dillmann (1878) 19-20, No. 26.

8. Berlin, Staatsbibliothek Preußischer Kulturbesitz, Ms. or. 2283

$17^{\text {th }} / 18^{\text {th }}$ century (Hammerschmidt \& Six) $\mid$ provenance unknown $\mid$ Catena on the Gospel of Matthew, short tracts ascribed to Evagrius Ponticus, and varia in Amharic | parchment, 135 fol. | $18.0 \times 17.5 \mathrm{~cm}$ | 2 col. | 28-31 ll. per page | The catena comprises fol. 4-129. | Hammerschmidt \& Six (1983) 310-1, No. 166.

9. Bulga (Ethiopia)

This manuscript is mentioned as the Vorlage for London, BL, Add. 16248 (Ms. Aeth. 12): see entry 13 below. No further data is available.

10. Lake Țānā 30 (= Kebrān 30; microfilm at Berlin, SBPK)

$16^{\text {th }}$ century ? (Hammerschmidt) | Ethiopia, Kebrān Island, Monastery of St Gabriel | Catena on the Four Gospels, Penitential Canons, and beginning of the Book of Job | parchment, 185 fol. | $39.0 \times 27.0 \mathrm{~cm}$ | 2 col. | 32-35 11. per page | The catena comprises fol. 2-180 and f. 183. The codex has suffered from humidity and the first 40 fol. are mutilated. | Hammerschmidt (1973) 152-4, No. 30. 
11. Lake Ṭānā 145 (= Dāgā Esțifānos 34; microfilm at Berlin, SBPK) $17^{\text {th }} / 18^{\text {th }}$ century (Six) | Ethiopia, Dāgā Island, St Michael's of Dāgā | Catena on the Gospels of Matthew and Mark | parchment, 170 fol. | $24.0 \times 21.5 \mathrm{~cm} \mathrm{|} 3 \mathrm{col}$. | 33-35 ll. per page | The codex is written by two or more scribes. The microfilm is nearly illegible: Six is unsure whether the codex also contains commentaries on the other Gospels. Hammerschmidt's notebook reads: 'Tergāmē wangēl (Johannes, Matthäus ?)'. | Six (1999) 167-8, No. 34.

12. *London, British Library, Add. 16220 (Ms. Aeth. 11)

1658/9 CE (scribal note) | provenance unknown | Catena on the Gospel of Matthew and Tabula for the Calculation of the Date of Easter | parchment, 46 fol. | 'formae 4ae' | 2 col. | lines per page not specified | The catena comprises fol. 9-46. | Dillmann (1847) 10-11, No. 11.

13. London, British Library, Add. 16248 (Ms. Aeth. 12)

1839-42 (Schulz) | provenance unknown | Catena on the Gospel of Matthew and varia | paper, $232+24$ fol. | 'formae 4ae' | 1 col. | lines per page not specified | The manuscript was copied from a manuscript in the city of Bulga (Ethiopia) for J.L. Krapf (1810-81), who stayed there from 1839 to $1842 .{ }^{52}$ The catena comprises fol. 1-232. The additional 24 folios contain short prolegomena to the New Testament Epistles and the Book of Revelation. | Dillmann (1847) 11-12, No. 12.

14. London, British Library, Or. 731

$17^{\text {th }}$ century (Wright) | provenance unknown | Catena on the Four Gospels and varia | parchment, 311 fol. | $36.0 \times 30.5 \mathrm{~cm} \mid 3 \mathrm{col}$. | 3233 1l. per page | The catena comprises fol. 12-260. It is preceded by an introduction, mainly derived from writings of Ephrem Syrus. The remaining folios contain a list of the patristic authorities of the Coptic, Syriac, Armenian, Greek, and 'Nestorian' churches, published along the with the introduction in Wright (1877) 199-200, No. 308.

52 See K.F. Ledderhose, 'Krapf, Johann Ludwig' Allgemeine Deutsche Biographie 17 (1883) 49-55 (esp. 50). 
15. London, British Library, Or. 732

1612-13 CE (note) | provenance unknown | Catena on the Four Gospels, compiled by 'Abdallāh ibn aț-Ṭaiyib | parchment, 371 fol. | $34.0-34.5 \times 30.5 \mathrm{~cm} \mid 3$ col. | 26-28 ll. per page | The catena comprises fol. 15-366. It is preceded by the same introduction as in London, BL, Or. 731. On fol. 206 and fol. 366 are notes identical to the information provided by d'Abbadie and Conti Rossini for Paris d'Abbadie Eth. 24; see no. 21 below. | Wright (1877) 200-1, No. 309.

16. London, British Library, Or. 734

$19^{\text {th }}$ century (Wright) $\mid$ provenance unknown $\mid$ Catena on the Gospel of Matthew and varia | parchment, 286 fol. | $33.0 \times 26.0 \mathrm{~cm} \mid 2$ col. | 28 11. per page | The beginning of the manuscript is lacking. Fol. 282-6 contain notes on the calendar, short tracts on heretical opinions and on the nature of Christ as human being, as well as extracts from Gregory and Theodotus. | Wright (1877) 203, No. 312.

17. London, British Library, Or. 735

$18^{\text {th }}$ century (Wright) $\mid$ provenance unknown $\mid$ Catena on the Gospel of Matthew and varia | parchment, 241 fol. | $30.0 \times 26.0 \mathrm{~cm} \mid 3$ col. | 33 11. per page | The catena comprises fol. 21-230. Beside the introduction mentioned for London, BL, Or. 731 above, there are short tracts on the Nature of God and of the Soul, extracts from the 'Lives of the Egyptian Fathers', etc., at the beginning and end of the manuscript. | Wright (1877) 202-3, No. 311.

18. London, British Library, Or. 736

$17^{\text {th }}$ century (Wright) | provenance unknown | Catena on the Gospel of Matthew, compiled by 'Abdallāh ibn aț-Taiyib | parchment, 163 fol. | $25.0 \times 23.0 \mathrm{~cm} \mid 3$ col. | 25-26 1l. per page | The note on fol. 163 is nearly identical to the information provided by d'Abbadie and Conti Rossini for the Arabic Vorlage of Paris d'Abbadie Eth. 24; see no. 21 below. | Wright (1877) 201-2, No. 310.

19. Moğā and Warānā, Parish Church, s.n.

$20^{\text {th }}$ century (Haile) $\mid$ provenance unknown $\mid$ Catena on the Gospel of Matthew and varia $\mid$ parchment, 128 fol. | size not specified | col. not specified | lines per page not specified | The catena comprises fol. 3128. According to the Hill Museum \& Manuscript Library's online catalogue the manuscript belongs to the textual family represented by 
Ambasel, Private Library, s.n. (EMML 2068). Beside the catena the codex contains prayers and poems. The manuscript was microfilmed at the Church of Denğud Abbo as part of the Ethiopic Manuscript Microfilm Library (EMML 5238; not yet included in the printed inventories). I http://www.vhmml.us/research2014/catalog/detail.asp?MSID=109188 (17.11.2015).

20. *Paris, Bibliothèque Nationale, Eth. 65 (olim Eth. 34)

$17^{\text {th }}$ century (Zotenberg) $\mid$ provenance unknown $\mid$ Catena on the Gospel of Matthew and Commentary on the Passion narrative by Buțrus as-Sadamantī | parchment, 132 fol. | $31.0 \times 28.5 \mathrm{~cm} \mathrm{|} 2$ col. | 31 1l. per page | Zotenberg (1877) 72-3, No. 65.

21. Paris, Bibliothèque Nationale, d'Abbadie Eth. 24

$17^{\text {th }}-18^{\text {th }}$ century (Chaîne), $18^{\text {th }}$ century (Conti Rossini) $\mid$ provenance unknown | Catena on the Four Gospels, compiled by 'Abdallāh ibn aṭTaiyib | parchment, 291 fol. | $20.0 \times 23.0 \mathrm{~cm} \mid 2$ col. | 27-31 1l. per page | scribe or owner: Amhā Giyorgis | According to d'Abbadie (1859) 31 and Conti Rossini (1912) 458, the catena is attributed to Denis, bishop of the Orient, and was translated from Arabic into Ethiopic in the $15^{\text {th }}$ year of Lebna Dengel (King from 1508-40). It is stated that the Arabic Vorlage was translated from a Syriac commentary by 'Abdallāh ibn aț-Ṭayyib in 1018 CE. | d'Abbadie (1859) 31-2, No. 24; Caîne (1912) 16, No. 24; Conti Rossini (1912) 458-9, No. 66; Löfgren (1974) 127-8.

22. Uppsala, University Library, O Etiop. 41

1605 or 1705 CE (Löfgren) | Egypt | Catena on the Gospels of Matthew and John, compiled by John Chrysostom [sic], and short anonymous tract on Nature and the Characteristics of the Maker | parchment, 219 fol. | $24.5 \times 23.0 \mathrm{~cm} \mid 3$ col. | 31-34 1l. per page | The catena comprises fol. 6-218. Its colophon is identical to that in London, BL, Or. 732, except that it states the catena was compiled and translated from Syriac into Hebrew [sic] by John Chrysostom [sic]. According to Löfgren, the authors cited in the catena on the Gospel of John are John Chrysostom, Ephrem Syrus, and Išō dād of Merv. | Löfgren (1974) 126-9 No. 37. 


\section{Further Possible Manuscripts in Ethiopic (Gə`əz and Amharic)}

1. Addis Ababa, Private Library of Alaqā Yamāna Berhān, s.n.

$20^{\text {th }}$ century (Macomber) $\mid$ provenance unknown $\mid$ Commentary on the Gospels and varia (Amharic and Gə`əz) | paper, 191 fol. | $17.5 \times 13.5$ $\mathrm{cm} \mid$ col. not specified | lines per page not specified | scribe: Takla Maryam | The commentary on the Gospels comprises fol. 50-135; it is written in Amharic and entitled Terg"amè wangël. It is not clear whether this is an Amharic catena or a commentary by a single author. If it is a catena it will be of special interest, because all other examples are in Gə`əz. Furthermore there are inter alia Amharic commentaries on Acts, the Epistles of Peter and Revelation; in Gə'əz there is an introduction to the Gospels and the Eusebian Canons, as well as Eusebius' Letter to Carpianus. The manuscript was microfilmed as part of the Ethiopic Manuscript Microfilm Library. | Macomber (1978); EMML 832 [non vidi]; http://www.vhmml.us/research2014/catalog/detail.asp?MSID=104612 (17.11.2015).

2. Ankober, Parish Church, s.n.

$16^{\text {th }}$ century (Haile/Macomber) | provenance unknown | Commentary on the Gospels of Luke and John (Gə`əz), Tract on the Council of Chalcedon (Gəcəz), World Chronology from the Birth of Christ to Emeror Suseneyos (Gə`əz), and Fragment of a Treatise (Old Amharic) | parchment, 152 fol. | $20.0 \times 18.0 \mathrm{~cm} \mathrm{|} \mathrm{col.}$ not specified | lines per page not specified | It is not clear whether this manuscript contains a catena or a commentary by a single author, but a catena seems likely. The manuscript was filmed in the Church of Mitāq Takla Hāymānot as part of the Ethiopic Manuscript Microfilm Library. | Haile/Macomber (1982) 264, EMML 2158 [non vidi]; http://www.vhmml.us/research2014/catalog/detail.asp?MSID=105971 (17.11.2015).

3. Moğāa and Warānā, Parish Church, s.n.

$19^{\text {th }}$ century (Haile) $\mid$ provenance unknown $\mid$ Commentary on the Gospel of Matthew (Gə⿳亠口冋z) and varia (Gə`əz) | parchment, 125 fol. $17.0 \times 16.5 \mathrm{~cm} \mid$ col. not specified | lines per page not specified | The commentary comprises fol. 93-155. It is entitled Tergäame wangèl and is most probably a catena. Among the other texts are the Acts of Adam and Eve, the Hexameron of Pseudo-Epiphanius, and a homily on the Transfiguration. The manuscript was microfilmed at the Church of Nač Gadal Ba'atā as part of the Ethiopic Manuscript Microfilm Library, project 
number EMML 5109; it is not yet included in the printed inventories. | http://www.vhmml.us/research2014/catalog/detail.asp?MSID=109058 (17.11.2015).

\section{BIBLIOGRAPHY FOR THE CHECKLIST OF MANUSCRIPTS}

A. d'Abbadie, Catalogue raisonné de manuscripts éthiopiens. Paris: Imprimerie impériale, 1859.

Anonymous, Catalogus codicum manuscriptorum Bibliothecae Regiae. Tomus primus. Paris: Typographia Regia, 1731. [Catalogue of the BnF].

M. Chaîne, Catalogue des manuscripts éthiopiens de la collection d'Abbadie. Paris: Imprimerie nationale, 1912.

F.J. Caubet Iturbe, La Cadena árabe del evangelio de san Matheo. 1: Texto; 2: Versión. Studi e Testi 254-5. Vatican City: BAV, 1969-70.

M.C. Conti Rossini, 'Manoscritti e opere abissine in Europa.' Rendiconti della Reale Accademia dei Lincei. Classe di scienze morali, storiche e filologiche, ser. 5 a 8 (1899) 606-37.

M.C. Conti Rossini, Notice sur les manuscripts éthiopiens de la collection d'Abbadie (suite).' Journal asiatique ser. 1020 (1912) 449-94.

W.E. Crum, Catalogue of the Coptic Manuscripts in the British Museum. London: British Museum, 1905.

A. Dillmann, Catalogus codicum manuscriptorum orientalium qui in Museo Britannico asservatur. Pars tertia, codices Aethiopicos amplectens. London: British Museum, 1847. [Published anonymously.]

A. Dillmann, Verzeichnis der abessinischen Handschriften. Die HandschriftenVerzeichnisse der königlichen Bibliothek zu Berlin 3. Berlin: Vogt, 1878.

H.G. Evelyn White, The Monasteries of the Wadi N Natrûn. Part 1: New Coptic Texts from the Monastery of Saint Macarius, with an appendix on a Copto-Arabic ms. by G.P.G. Sobby. New York: Metropolitan Museum of Art, 1926.

G. Graf, Catalogue de manuscrits arabes chrétiens conservés au Caire. Studi e testi 63. Vatican City: BAV, 1934.

G. Graf, Geschichte der christlich-arabischen Literatur. Vol. 1. Studi e testi 118. Vatican City: BAV, 1944.

G. Graf, Geschichte der christlich-arabischen Literatur. Vol. 2. Studi e testi 133. Vatican City: BAV, 1947.

G. Graf, Geschichte der christlich-arabischen Literatur. Vol. 4. Studi e testi 146. Vatican City: BAV, 1953.

G. Haile and W.F. Macomber, A Catalogue of Ethiopian Manuscripts Microfilmed for the Hill Monastic Manuscript Library. Vol. VI: Project Numbers 2001-2500. Collegeville: HMML, 1982. [non vidi] 
G. Haile and W.F. Macomber, A Catalogue of Ethiopian Manuscripts Microfilmed for the Hill Monastic Manuscript Library. Vol. VII: Project Numbers 2501-3000. Collegeville: HMML, 1983. [non vidi]

E. Hammerschmidt, Äthiopische Handschriften vom Tänäsee 1. Reisebericht und Bescbreibung der Handscbriften in dem Kloster des heiligen Gabriel auf der Insel Kebrän. Verzeichnis der orientalischen Handschriften in Deutschland 20.1. Wiesbaden: Steiner, 1973.

E. Hammerschmidt and V. Six, Äthiopische Handschriften 1: Die Handscbriften der Staatsbibliothek preußischer Kulturbesit: Verzeichnis der orientalischen Handschriften in Deutschland 20.4. Wiesbaden: Steiner, 1983.

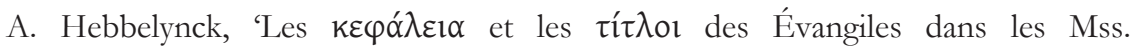
bohaïriques Paris Bibl. Nation. copte 16, Vat. copte 8 et le fragm. bohaïrique Brit.Mus. Add. 14740a fol. 9. La Lettre d'Eusèbe à Carpianus d'après le Ms. bohaïrique Vat. copte 9. 'Textes inédits et traduction.' Le Muséon 41 (1928) 81120.

G. Horner, The Coptic Version of the New Testament in the Northern Dialect Otherwise Called Memphitic and Bohairic with Introduction, Critical Apparatus, and Literal English Translation. Vol. 1 The Gospels of S. Matthew and S. Mark. Oxford: Clarendon, 1898.

P. de Lagarde, Catenae in evangelia Aegyptiacae quae supersunt. Göttingen: Hoyer, 1886.

A. van Lantschoot, Inventaire des manuscrits syriaques des Fonds Vatican (490-631) Barberini oriental et Neofiti. Studi e testi 243. Vatican City: BAV, 1965.

B. Layton, Catalogue of the Coptic Manuscripts in the British Library acquired since the year 1906. London: British Library, 1987.

J. Leipoldt, 'II 3. Koptische Handschriften' in Katalog der islamischen, cbristlichorientalischen, jüdischen und samaritanischen Handschriften, mit einem Beitrag von J. Leipoldt, ed. K. Vollers. Katalog der Handschriften der Universitätsbibliothek Leipzig 2. Leipzig: Harrassowitz, 1906, 383-427.

O. Löfgren, Katalog über die äthiopischen Handschriften in der Universitätsbibliothek Uppsala. Sowie Anhang über ätbiopische Handschriften in anderen Bibliotheken und in Privatbesitz in Schweden. Acta Bibliothecae Universitatis Upsaliensis 18. Uppsala: Almqvist \& Wiksell, 1974.

W.F. Macomber, A Catalogue of Ethiopian Manuscripts Microfilmed for the Hill Monastic Manuscript Library. Vol. II: Project Numbers 301-700. Collegeville: HMML, 1976. [non vidi]

W.F. Macomber, A Catalogue of Ethiopian Manuscripts Microfilmed for the Hill Monastic Manuscript Library. Vol. III: Project Numbers 701-1100. Collegeville: HMML, 1978. [non vidi]

W.F. Macomber, Final Inventory of the Microfilmed Manuscripts of the Coptic Museum Old Cairo, Egypt, Rolls A1-20. Provo UT: Brigham Young University, 1995. (published online: 
https://archive.org/details/MacomberCopticMuseum.I.BYURollsA120).

W.F. Macomber, Final Inventory of the Microfilmed Manuscripts of the Coptic Orthodox Patriarchate, al-Azbakiyah, Cairo, volume 2. Provo UT: Brigham Young University, 1997. (published online:

https://archive.org/details/MacomberCopticOrthodoxPatriarchate.IIBYUMi crofilms).

A. Mai, Scriptorum veterum nova collectio e Vaticanis codicibus edita, tomus $I V$. Rome: BAV, 1831.

W. Meyer, Die Handschriften in Göttingen. 3. Universitätsbibliothek. Nachlässe von Gelehrten, Orientalische Handschriften. Handschriften im Besitz von Instituten und Behörden. Verzeichniss der Handschriften im Preussischen Staate 1.3. Berlin: Bath, 1894.

N. Morata, 'Un catálogo de los fondos árabes primitivos de El Escorial.' AlAndalus: revista de las Escuelas de Estudios Árabes de Madrid y Granada 2.1 (1934) 87-181.

A. Nicoll, Bibliothecae Bodleianae codicum manuscriptorum orientalium catalogi partis secundae volumen primum. Oxford: Clarendon, 1821.

C. Rieu, Supplement to the Catalogue of the Arabic Manuscripts in the British Museum. London: British Museum, 1894.

E. Sachau, Verzeichniss der syrischen Handschriften der Königlichen Bibliothek zu Berlin 1. Die Handschriften-Verzeichnisse der Königlichen Bibliothek zu Berlin 23. Berlin: Rieu, 1899.

B. Sbath, Al-Fibris (Catalogue de manuscrits arabes), $1^{\text {re }}$ partie: Ouvrages des auteurs antérieurs au XVII ìme siècle. Cairo: Al-Sharq, 1939. [non vidi]

A. Scher, 'Notice sur les manuscrits syriaques et arabes conservés à l'archevêché chaldéen de Diarbékir.' Journal asiatique 10 (1907) 331-62, 385-431.

M.H. Simaika Pasha, Catalogue of the Coptic and Arabic Manuscripts in the Coptic Museum, the Patriarchate, the Principal Churches of Cairo and Alexandria and the Monasteries of Egypt. 2 vols. Cairo: Bulaq, 1939-42.

V. Six, Äthiopische Handschriften vom Tānāsee 3. Nebst einem Nachtrag zum Katalog äthiopischer Handschriften deutscher Bibliotheken und Museen. Verzeichnis der orientalischen Handschriften in Deutschland 20.3. Wiesbaden: Steiner, 1999.

W.M. Baron de Slane, Catalogue des manuscrits arabes de la Bibliothèque nationale. Paris: Imprimerie nationale, 1883-95.

J. Vosté, 'Notes sur les manuscrits syriaques de Diarbékir et autres locales d'orient.' Le Muséon 50 (1937) 345-51.

E. Wickersheimer, Catalogue général des manuscrits des bibliothèques publiques de France. Département - Strasbourg, tome 47. Paris: Plon-Nourrit, 1923.

J.J. Witkam, Inventory of the Oriental manuscripts in Leiden University Library, vol. 3 (Or. 2001-Or. 3000). Leiden, 2006-8. Available online: 
http://www.islamicmanuscripts.info/inventories/leiden/or03000.pdf (21.10.2015)

W. Wright, Catalogue of the Ethiopic Manuscripts in the British Museum Acquired Since the Year 1847. London: British Museum, 1877.

C. Zamagni, 'New Perspectives on Eusebius' Questions and Answers on the Gospels: The Manuscripts' in Eusebius of Caesarea: Tradition and Innovations, ed. A. Johnson and J. Schott. Hellenic Studies Series 60. Washington DC; Cambridge MA: Center for Hellenic Studies, 2013, 239-61.

U. Zanetti, Les manuscrits de Dair Abûu Maqâr. Inventaire. Cahiers d'orientalisme 11. Geneva: Cramer, 1986.

H. Zotenberg, Manuscrits orientaux. Catalogue des manuscrits éthiopiens (gheę et ambarique) de la Bibliothèque nationale. Paris: Imprimerie nationale, 1877. 


\section{INDEX OF MANUSCRIPTS}

\section{Greek New Testament manuscripts by Gregory-Aland number}

\begin{tabular}{|c|c|c|c|c|c|}
\hline P5 & 185 & 0142 & $31,11,114$ & 101 & 31 \\
\hline P30 & 101 & & $119,121-2$ & 103 & $31,102,112-$ \\
\hline P34 & 101 & 0150 & $34,119,120$ & & 3,114 \\
\hline $\mathfrak{P 4 6}$ & 100 & & 121 & 104 & 239 \\
\hline P59 & 185 & 0151 & $34,101,109$ & 108 & 32 \\
\hline P 61 & 100 & & 119,122 & 127 & 32 \\
\hline P92 & 100 & 0319 & 101 & 129 & 32 \\
\hline P99 & 100 & 12 & 32 & 131 & 30 \\
\hline 01 & 158 & 19 & 32 & 136 & 33 \\
\hline 02 & 17,158 & 20 & 32 & $137-8$ & 32 \\
\hline 03 & 101, 103-6 & $24-5$ & 32 & 139 & 33 \\
\hline 04 & 17,239 & 34 & 32 & 143 & 32 \\
\hline 06 & 6,101 & $36-7$ & 32 & 146 & 33 \\
\hline 010 & 101,248 & 39 & 21,32 & 148 & 32 \\
\hline \multirow[t]{2}{*}{012} & 101, 103-6, & 40 & 32 & 151 & 32 \\
\hline & 248 & 41 & 33 & 154 & 32 \\
\hline 015 & 103 & 48 & 32 & 168 & 32 \\
\hline 018 & $31,119,122$ & 50 & 21,32 & 177 & $103-6$ \\
\hline 025 & 101 & 63 & 32 & 186 & 32 \\
\hline 033 & 32 & 77 & 32 & $194-6$ & 32 \\
\hline 034 & 299 & 81 & 239 & 197 & 30 \\
\hline \multirow[t]{2}{*}{040} & $11,17,25,33$ & 82 & $31,119,127$ & 210 & 32 \\
\hline & 75,296 & 87 & 33 & 215 & 32 \\
\hline 050 & 8,33 & 91 & 31, 110-1, & 222 & 32 \\
\hline 055 & 32 & & $119,121,134$ & 233 & 32 \\
\hline 056 & $31,119,121-2$ & 93 & $103-6$ & $237-8$ & 32 \\
\hline 075 & 34,101 & 94 & 31,111 & 239 & 33 \\
\hline 098 & 35 & 95 & 33 & 240 & 32 \\
\hline \multirow[t]{2}{*}{0141} & $11,20,33$ & 97 & 114 & 243 & 33 \\
\hline & & 100 & 32 & 244 & 32 \\
\hline
\end{tabular}


$249 \quad 33$

$25021,31,114$, 119

$253 \quad 32$

254 31, 112-3, $114,119,120$

$259 \quad 32$

299-301 32

$303 \quad 32$

$304 \quad 33$

$305 \quad 32$

$306 \quad 33$

$307 \quad 21,31$

$310-1 \quad 33$

$313 \quad 33$

$314 \quad 31,21,119$

315-8 33

$320 \quad 33$

$327 \quad 31,114$

$329 \quad 32$

$332 \quad 32$

333-4 33

$353 \quad 32$

$354 \quad 33$

$357 \quad 33$

$362 \quad 33$

$366 \quad 33$

$370 \quad 32$

373-4 32

$377 \quad 32$

$379 \quad 32$

$381 \quad 33$

391-2 32

$397 \quad 33$

$423 \quad 33$

$424 \quad 31,114$

$426 \quad 33$

$427 \quad 33$

$428 \quad 32$

$430 \quad 33$ $\begin{array}{ll}434 & 33\end{array}$

$437 \quad 34$

441-2 31, 114

$453 \quad 31$

$454 \quad 31,110-1$,

119,127

$455 \quad 31,102,112-$

3,114

$457 \quad 13,103-6,119$

$463 \quad 31$

$468 \quad 31$

$549 \quad 32$

$556 \quad 32$

$569 \quad 32$

589-90 33

$591 \quad 32$

$596 \quad 33$

$\mathbf{5 9 8} 33$

$\mathbf{5 9 9} \quad 32$

$600 \quad 32$

$605 \quad 31,119$

$60631,102,108$, 119

$607 \quad 31,110-1$

$60831,112-3,114$

$610 \quad 31$

$617 \quad 31,114,119$

$61931,110-1$,

119, 127

$621 \quad 31,114,119$

$622 \quad 31,110-1$

$623 \quad 23,31$

$\mathbf{6 2 7} 31,119$

$640 \quad 34$

$641 \quad 31,110-1,119$

$649 \quad 32$

$684 \quad 32$

$709 \quad 21$

$719 \quad 32$
$720 \quad 102,112-3$,

114

$\begin{array}{ll}721 & 33\end{array}$

722-3 32

727-34 32

735-9 33

740-1 32

$742 \quad 33$

$743 \quad 30$

$744 \quad 32$

746-7 32

$749 \quad 32$

$751 \quad 33$

$754 \quad 32$

$\begin{array}{ll}770 & 33\end{array}$

771-3 32

$800 \quad 32$

$807 \quad 32$

$809 \quad 32$

$814 \quad 32$

817-8 32

$819 \quad 33$

$820 \quad 32$

821-2 33

$832 \quad 30$

833-6 32

840-2 33

846-8 33

849-50 2, 33

$853 \quad 33$

854-6 32

$857 \quad 33$

858 31, 112-3, 114, 119, 120

$859 \quad 33$

$861 \quad 32$

$862 \quad 33$

$863 \quad 32$

$865 \quad 33$

868-9 $\quad 33$ 


\begin{tabular}{|c|c|c|c|c|c|}
\hline 874 & 33 & 1182 & 32 & 1524 & $31,112-3,114$ \\
\hline 878 & 32 & 1184 & 33 & 1527 & 32 \\
\hline 879 & 33 & 1230 & 32 & $1533-6$ & 32 \\
\hline 881 & 32 & 1241 & 114 & 1537 & 33 \\
\hline 882 & 2,33 & $1252-3$ & 32 & 1570 & 32 \\
\hline $883-4$ & 33 & 1254-6 & 33 & 1613 & 33 \\
\hline 885 & 32 & $1261-3$ & 32 & 1616 & 32 \\
\hline 886 & $30,113,114$ & 1264 & 33 & 1631 & 33 \\
\hline 887 & 33 & 1265-6 & 32 & 1677 & 32 \\
\hline 888-90 & 32 & 1267 & $31,112-3,114$ & 1678 & $30,102,108$ \\
\hline \multirow[t]{2}{*}{891} & $31,112-3$ & 1268 & 32 & & 109 \\
\hline & 114,119 & 1271 & 33 & 1684 & 32 \\
\hline 892 & 185 & 1277 & 31,119 & 1707 & 33 \\
\hline $893-4$ & 33 & 1293 & 32 & 1720 & $103-6$ \\
\hline 911 & $31,110-1$ & $1302-4$ & 32 & 1739 & $13,165,229$ \\
\hline 918 & 31,114 & $1312-3$ & 32 & 1764 & 34 \\
\hline 949 & 32 & 1327 & 32 & 1769 & 31 \\
\hline 951 & 32 & 1330 & 31 & 1772 & 34 \\
\hline 964 & 32 & 1332 & 33 & 1780 & 114 \\
\hline 970 & 33 & 1336 & 32 & 1798 & $34,112-3,114$ \\
\hline 978 & 32 & 1337 & 33 & 1814 & 32 \\
\hline 989 & 32 & 1360 & $31,110-1$ & 1817 & 34 \\
\hline $993-4$ & 33 & 1366 & 33 & 1818 & 35 \\
\hline 1016 & 33 & 1370 & 33 & 1819-20 & 2,33 \\
\hline 1021 & 32 & 1371 & 30 & $1821-2$ & 33 \\
\hline $1027-8$ & 33 & 1373 & 32 & 1840 & $31,102,109$ \\
\hline 1029 & 32 & 1374 & 33 & 1842 & 31 \\
\hline 1043 & 33 & 1387 & 32 & 1844 & 34 \\
\hline 1066 & 31 & 1392 & 32 & 1845 & 31 \\
\hline 1078 & 32 & $1411-2$ & 33 & 1859 & 31 \\
\hline 1080 & 32 & 1419 & 32 & 1862 & $31,110,114$ \\
\hline 1112 & 33 & $1422-3$ & 32 & & 119 \\
\hline 1130 & 32 & 1424 & $20,30,114-5$ & 1871 & 31,119 \\
\hline 1137 & 32 & & 119 & 1878 & $34,110-1,119$ \\
\hline 1156 & 33 & 1437 & 33 & 1879 & 34 \\
\hline 1160 & 32 & 1480 & 119 & 1888 & $31,119,127$ \\
\hline 1162 & 31,119 & 1506 & 31,109 & 1895 & 31 \\
\hline 1164 & 32 & 1507 & 25,32 & 1900 & $11,23,26,34$ \\
\hline 1177 & 33 & 1516 & 33 & & $114-5,119$ \\
\hline 1178 & 32 & 1523 & $31,112-3$ & & \\
\hline
\end{tabular}




\begin{tabular}{|c|c|c|c|c|c|}
\hline 1905 & $\begin{array}{l}34,110-1, \\
119,127\end{array}$ & $\begin{array}{l}1942 \\
1943\end{array}$ & $\begin{array}{l}25,34,119 \\
34,112-3\end{array}$ & 1992 & $\begin{array}{l}34,102,112- \\
3,114,120\end{array}$ \\
\hline 1906 & $34,110-1$ & & 114,119 & 1993 & 34,120 \\
\hline 1907 & $34,110-1$ & 1945 & $34,108,166-7$ & 1994 & 34 \\
\hline \multirow[t]{2}{*}{1908} & $21,34,110-1$ & 1946 & 34 & 1995 & $34,113,114$ \\
\hline & 119 & 1947 & 34,102 & 1996 & 34,108 \\
\hline 1909 & $21,23,34$ & 1949 & 34 & 1997 & $34,110-1$, \\
\hline 1910 & $21,23,24,34$ & 1950 & $34,112-3$ & & 120,127 \\
\hline 1911 & 34 & 1951 & 34 & 1998 & $34,110-1,120$ \\
\hline 1913 & $34,112-3,114$ & 1952 & 34 & 1999 & 34,108 \\
\hline 1914 & 34 & 1953 & $34,111,229$ & 2000 & $34,102,112-$ \\
\hline \multirow[t]{3}{*}{1915} & $22,23,34$ & 1956 & 109,114 & & $3,114,120$ \\
\hline & $114-5,119$ & 1961 & $34,102,112-$ & 2001 & $34,110-1$ \\
\hline & $123-34,229$ & & 3,114 & 2002 & 34 \\
\hline \multirow[t]{2}{*}{1916} & $34,119,121$ & 1962 & $34,109,119$ & 2006 & 34 \\
\hline & 127 & & 120 & 2007 & $34,110-1$, \\
\hline 1917 & $34,10-1$ & 1963 & 34 & & 115,118 \\
\hline 1919 & $34,110-1$ & 1964 & 21,34 & 2008 & $34,102,107$ \\
\hline \multirow[t]{2}{*}{1920} & $34,110-1$, & 1965 & 35 & & 120 \\
\hline & 119,127 & $1967-8$ & 34 & 2011 & 34,114 \\
\hline 1921 & $34,110-1$ & 1969 & $34,109,119$ & 2012 & 34,108 \\
\hline 1922 & 34,111 & & 120,121 & 2013 & 34 \\
\hline 1923 & $34,119,127$ & 1970-4 & 34 & 2038 & 34 \\
\hline 1924-5 & 34 & 1976 & 34 & 2090 & 35 \\
\hline 1926 & 35 & 1977 & $34,102,112-$ & 2092 & 34 \\
\hline \multirow[t]{2}{*}{1927} & $34,110-1$, & & 3,114 & 2097 & 32 \\
\hline & 119,127 & 1978 & $34,102,113$ & $2100-1$ & 32 \\
\hline 1928 & 34 & & 114 & 2102 & $34,113,114$ \\
\hline 1929 & $34,112-3$ & 1979 & $34,03,113$ & 2103 & 33 \\
\hline \multirow[t]{2}{*}{1930} & $34,102,113$ & & 114 & 2104 & $34,112-3,114$ \\
\hline & $114,119,120$ & 1980 & 30,120 & 2105 & $34,102,112-$ \\
\hline 1932 & 9,34 & 1981 & 34 & & 3,114 \\
\hline 1933 & $34,110-1$ & 1982 & $34,110-1,120$ & 2106 & 33 \\
\hline 1934 & 34,114 & 1983 & 35 & 2107 & 32 \\
\hline 1935 & 34 & 1984 & $34,112-3,114$ & 2109 & 32 \\
\hline 1936 & 23,34 & 1985 & 34,113 & 2110 & $34,109,120$ \\
\hline 1937 & 21,35 & 1986 & 34 & & 121 \\
\hline 1938 & $12,21,35$ & 1987 & $34,112-3,114$ & 2111 & 33 \\
\hline 1939 & 34,108 & 1988 & $34,112-3,120$ & 2114 & 2 \\
\hline 1941 & 34 & 1991 & $34,112-3,114$ & 2125 & $31,114,120$ \\
\hline
\end{tabular}




\begin{tabular}{|c|c|c|c|c|c|}
\hline 2128 & 34 & 2381 & 32 & 2646 & 32 \\
\hline 2129 & 2,33 & 2395 & 32 & 2659 & $34,113,114$ \\
\hline 2130 & 34 & 2402 & 2 & 2668 & 34 \\
\hline 2148 & 32 & 2414 & 32 & 2690 & $34,102,109$ \\
\hline \multirow[t]{2}{*}{2183} & $34,110-1$, & 2431 & 31 & 2698 & 34 \\
\hline & 120,127 & 2450 & 33 & 2720 & 32 \\
\hline $2184-5$ & 33 & $2452-3$ & 32 & 2733 & 31 \\
\hline 2186 & 31 & 2458 & 32 & 2735 & 32 \\
\hline 2187 & 33 & 2470 & 32 & 2738 & 33 \\
\hline 2188 & 32 & 2480 & 34 & 2739 & $39,102,109$ \\
\hline 2189 & $34,110-1$ & 2481 & 33 & 2741 & 34 \\
\hline 2190 & 33 & 2482 & $31,102,112-3$ & 2755 & 33 \\
\hline 2192 & 33 & 2490 & 33 & 2763 & 34 \\
\hline 2197 & $31,112-3$ & 2517 & 32 & 2764 & 35 \\
\hline $2202-3$ & 32 & 2538 & 33 & 2768 & 32 \\
\hline 2205 & 34 & 2539 & 32 & 2770 & 33 \\
\hline 2206 & 32 & $2572-3$ & 34 & 2776 & 31 \\
\hline 2207 & 33 & 2574 & 35,103 & 2812 & 32 \\
\hline 2211 & 32 & 2575 & 34 & 2814 & 1 \\
\hline 2214 & 32 & 2576 & $31,102,112-$ & 2817 & 34,120 \\
\hline 2239 & 31 & & 3,114 & 2818 & 21,31 \\
\hline 2240 & 34 & 2577 & 33 & 2820 & 35 \\
\hline \multirow[t]{2}{*}{2242} & $31,108,166$ & 2578 & 32 & 2838 & 33 \\
\hline & 175 & 2579 & 33 & 2879 & 3 \\
\hline 2248 & $34,102,112-3$ & 2581 & 33 & 2887 & 32 \\
\hline \multirow[t]{2}{*}{2257} & $34,103,112-$ & 2583 & 32 & 2888 & 34 \\
\hline & 3,114 & 2593 & 33 & 2889 & $34,113,120$ \\
\hline 2285 & 32 & 2596 & 35 & 2890 & 35 \\
\hline 2317 & 32 & 2597 & 33 & 2899 & 34 \\
\hline 2318 & 31 & 2604 & 32 & & \\
\hline 2329 & $145-6$ & 2607 & 32 & \multirow[t]{3}{*}{ Family 1} & 13 \\
\hline 2346 & 32 & 2637 & 32 & & \\
\hline 2351 & $11,141-63$ & 2639 & 35 & & \\
\hline
\end{tabular}


Papyri (not of the Greek New Testament)

$\begin{array}{llll}\text { P.Berol. inv.7818 } & 297-8 & \text { P.Oxy.III 405 } & 5 \\ \text { P.Berol. inv.9780 } & 42-3 & \text { P.Oxy.VIII 1086 } & 41 \\ \text { P.Lille. inv.83 etc. } & 41 & \text { P.Stras. inv.84 } & 43-4 \\ \text { P.Mich. inv.3688 } & 41 & \text { P.Wash.Univ. II 63 } 41 \\ \text { P.Oxy.II 221 } & 41 & & \end{array}$

\section{Other manuscripts are given by library}

Addis Ababa, Holy Trinity Cathedral

63306,320

Addis Ababa, Patriarchate

s.n. $\quad 305,321$

Addis Ababa, private library

s.n. $\quad 325$

Addis Ababa, St Gabriel Church

s.n. $\quad 306,321$

Ambasel, private library

s.n. $\quad 305,321$

Angers, BM

65/66 262-3

$275 \quad 183-4,187$

Ankober, Parish Church

s.n. $\quad 326$

Athos, Dionysiou

$377 \quad 29$
Athos, Koutloumoussiou

1072

Athos, Vatopedi

1235

$38 \quad 35$

$457 \quad 29$

Baghdad, Chaldean Catholic Patriarchate

130 306, 312-3

131306,313

Bamberg, Staatsbibliothek

126263

Berlin, Staatsbibliothek

PK, or. 2283 307, 322

PK. Peterm. II. Nachtrag 52 305, 322

PK. sy. 109 306, 313

Phillipps 141933 
Besançon, Bibliothèque d'étude

186296

Boulogne, BM

$64(71) \quad 265$

Brescia, Biblioteca Civica Queriniana

$$
\begin{aligned}
& \text { F.II.1 } 296 \\
& \text { G.III.2 260, 267-74 }
\end{aligned}
$$

Brussels, Bibliothèque Royale

$$
\begin{aligned}
& \text { I I.8232-33 } 33 \\
& 283(9369-70) \quad 263 \\
& 1059(9358) \quad 264
\end{aligned}
$$

Budapest, University Library

VIIIc 32

Bulga (Ethiopia)

s.n. $\quad 307,322$

\section{Cairo, Coptic Museum \\ CM 1245 306, 313 \\ CM 1264 306, 313-4 \\ CM 1393 307, 314 \\ CM 2513 311-2 \\ CM 2624 302, 310-2}

Cairo, Coptic Patriarchate

Theol. 26 (Ms. 41) 304, 314

Theol. 27 (Ms. 567) 304, 314

Theol. 28 306, 314

Theol. 30 307, 315

Theol. 31 (Ms. 595) 307, 315

Theol. 36 307, 315

Theol. 37 307, 315

Theol. 39 306, 315-6

Theol. 42 (Ms. 599) 307, 316

Theol. 50 306, 316

Theol. 53 306, 316

(Graf 602) 306, 316
Cologne, Dombibliothek

$17 \quad 183-4$

$104 \quad 265$

Copenhagen, Det Kongelige Bibliotek GKS 1338 4ㅇ 237, 242-3

Dēr Abū Maqār

Theol. 5 306, 317

Theol. 6 304, 317

Theol. $13 \quad 317$

Dēr el-Šarfeh, Patriarchal Library syr. $9 / 18 \quad 306,317$

El Escorial, Escorial Library

$\Psi 1273$

$$
\text { III. ב. } 5 \text { 307, } 317
$$

Florence, BML

Gr. VIII.24 33

Gr. VIII.29 33

Plut. VIII.19 31, 127

Plut. LXXIV.7 53

Florence, Biblioteca Nazionale

Panciat. 15734

Göttingen, Universitätsbibliothek Arab. 103 304, 317

Kiev, National Library

$\Phi .1,137 \quad 34$

Lake Ṭānā

30305,322

$145307,322-3$

Laon, BM

105 261, 271-2 
Leiden, University Library

Or. 2375306,318

Leipzig, Universitätsbibliothek

Nr. 1090 302, 311-2

London, British Library

Add. 14740A 298, 302, 310, 312

Add. $16220 \quad 305,323$

Add. $16248 \quad 307,322,323$

Or. 731306,323

Or. 732 306, 323-4

Or. 734306,324

Or. 735306,324

Or. 736306,320

Or. $3201 \quad 306,318$

Or. 8812 296-8, 302, 308, 310

London, Lambeth Palace

$763 \quad 33$

Los Angeles, St Shenouda Coptic

Society

ML.MS.32 307, 318

L’viv, Bibl.

ZN $827 \quad 34$

Lyons, BM

484 257-9, 261, 266-72

Milan, Biblioteca Ambrosiana

$538 \quad 32$

A.282 inf 34

C. 255 inf 34

D. 25 inf 20, 33

E.147 sup 277-93

F.104 sup 31

O.245 sup 33
Moğāa and Warānā, Parish Church

s.n. $305,324,326$

Montecassino, Biblioteca della Badia

39 C 264, 267-71

$178 \quad 265$

Moscow, Russian State Library

$82 \quad 296$

Munich, BSB

Gr. 3333

Gr. 9933

Gr. 14629

Gr. 191 179-80, 186

Gr. 35872

Gr. 57135

Nîmes, BM

36 264, 267-71

Orléans, BM

$81(78) \quad 265$

83 (80) 258, 261, 267, 269-74

84 (81) 265,

87 237-8, 242

Oxford, Bodleian Library

Auct. E.2.2 33

Auct. E.2.20 21, 34

Auct. T.1.4 32

Auct. T.1.7 21, 34

Barocci 156 19, 33

Barocci 21133

Canon. gr. 6273

Grabe $22 \quad 34$

Huntington $262 \quad 305,318$

Ms. (Bodley?) 265317

Rawlinson G.157 21, 34 


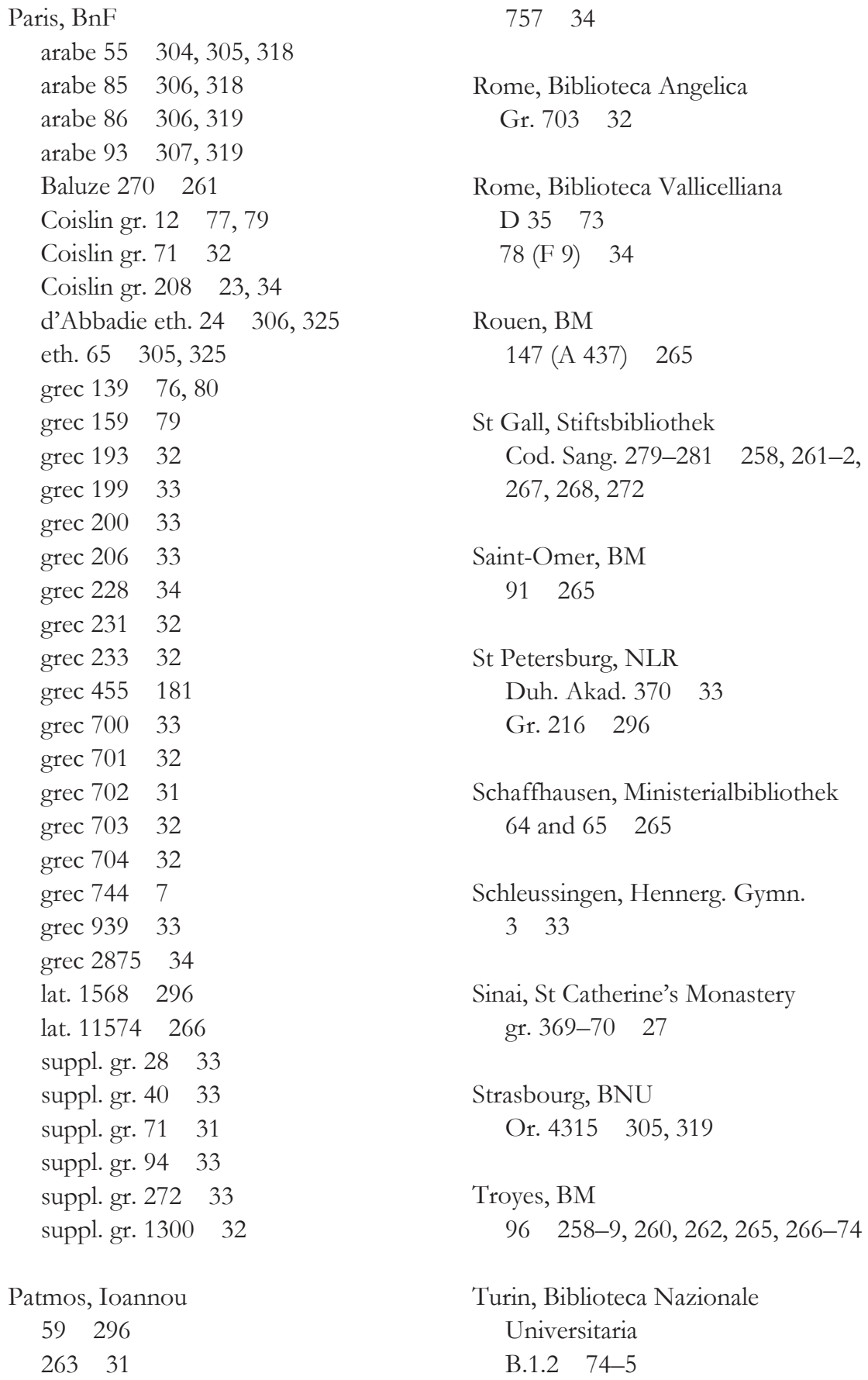


Uppsala, University Library

O Etiop. $41 \quad 306,325$

Vatican, BAV

Archivio di S. Pietro B 59

33

Barb. gr. 54634

Barb. gr. $444 \quad 33$

Barb. gr. 56233

Borg. ar. $231 \quad 306,319$

Borg. sir. $405 \quad 306,319$

Chig. R.VIII.54 79

Ottob. gr. 11333

Ottob. gr. 23733

Pal. gr. 27333

Pal. gr. $363 \quad 32$

Urb. lat. $102 \quad 265$

Vat. ar. $410 \quad 304,305,319$

Vat. ar. 452 304, 305, 320

Vat. gr. 934

Vat. gr. 38433

Vat. gr. $547 \quad 33$

Vat. gr. 66532

Vat. gr. 72433

Vat. gr. $757 \quad 32$

Vat. gr. $763 \quad 34$

Vat. gr. $764 \quad 34$

Vat. gr. $873 \quad 34$

Vat. gr. 87531

Vat. gr. $1153 \quad 79$

Vat. gr. 119033

Vat. gr. 143733
Vat. gr. 161033

Vat. gr. 169232

Vat. gr. 174132

Vat. gr. 175333

Vat. gr. $1767 \quad 30$

Vat. gr. 180434

Vat. gr. 1915 33,

Vat. lat. $4950 \quad 264-5,267-8,272$

Vat. lat. $5770 \quad 277-93$

Vat. sir. 103296

Vat. sir. $154 \quad 296$

Vat. sir. 531 304, 305, 320

Vat. sir. $541 \quad 305,320$

Venice, BNM

Gr I.34 32

Gr. Z.155 34

Gr. 43180

Gr. $687 \quad 33$

Vienna, ÖNB

Theol. Gr. $8 \quad 71,73$

Theol. Gr. 11732

Theol. Gr. 20933

Theol. Gr. 25133

Theol. Gr. 30130

Theol. Gr. 32430

Würzburg, Universitätsbibliothek

M.p.th.f. 61296

M.p.th.f. 63265 


\section{INDEX OF BIBLICAL PASSAgES}

\begin{tabular}{|c|c|c|c|}
\hline \multicolumn{2}{|l|}{2 Samuel } & $12: 39$ & $193-4$ \\
\hline \multirow[t]{2}{*}{$7: 2$} & 303 & 21:1-11 & $194-7$ \\
\hline & & $21: 6-46$ & 302 \\
\hline \multicolumn{2}{|l|}{ Psalms } & $25: 28$ & 188 \\
\hline $13: 2-3$ & $279,285,286$ & $26: 6-13$ & $219-23$ \\
\hline $52: 3-4$ & $279,285,286$ & & \\
\hline $56: 5$ & 149 & Mark & \\
\hline $103: 32$ & 153,155 & $1: 7-8$ & 279,290 \\
\hline \multirow[t]{2}{*}{$143: 2$} & $244-5$ & $6: 47$ & 158 \\
\hline & & $13: 32$ & 193 \\
\hline \multicolumn{2}{|l|}{ Proverbs } & $14: 17-18$ & 90 \\
\hline $12: 18$ & $151-2$ & $14: 22-4$ & 89-94 \\
\hline \multicolumn{2}{|c|}{ Song of Songs } & Luke & \\
\hline $2: 5$ & $151-2$ & $1: 1$ & 209-18 \\
\hline \multirow[t]{2}{*}{$5: 8$} & $151-2$ & $3: 16$ & 278-9, 282, 290 \\
\hline & & $7: 37-50$ & $218-23$ \\
\hline \multicolumn{2}{|l|}{ Isaiah } & $7: 38$ & 187 \\
\hline \multirow[t]{2}{*}{$7: 14$} & 189 & $9: 12$ & 285 \\
\hline & & $10: 39$ & $187-8$ \\
\hline \multicolumn{2}{|l|}{ Zechariah } & $10: 42$ & 187 \\
\hline \multirow[t]{2}{*}{$4: 10$} & 159 & $22: 3$ & 90 \\
\hline & & $22: 55$ & 158 \\
\hline \multicolumn{2}{|l|}{ Matthew } & $24: 32$ & 157 \\
\hline $2: 11$ & 154 & & \\
\hline $3: 11$ & $279,282,287$ & John & \\
\hline $3: 15-16$ & 5 & $1: 3$ & $192-3$ \\
\hline $5: 8$ & 290 & $1: 28$ & 177-90 \\
\hline $5: 42$ & 285 & $1: 29$ & 280,286 \\
\hline $8: 28-34$ & 189 & $3: 3$ & 286 \\
\hline $10: 34$ & $150-2$ & $3: 4$ & $280-1,286-7$ \\
\hline $11: 11$ & 188 & $3: 5$ & 287 \\
\hline
\end{tabular}




$\begin{array}{ll}3: 23-4 & 287 \\ 3: 25 & 281,287 \\ 3: 26 & 288 \\ 3: 29 & 287-8 \\ 3: 30 & 287-8,289 \\ 3: 31 & 288 \\ 3: 32 & 288 \\ 4: 10-14 & 193 \\ 5: 21 & 288 \\ 5: 22 & 289 \\ 5: 23 & 289 \\ 5: 35-6 & 289 \\ 5: 37 & 289,290 \\ 5: 38 & 290 \\ 6: 9 & 292 \\ 6: 10 & 291 \\ 6: 11 & 282-3,291 \\ 6: 12 & 291, \\ 6: 13 & 279,283,291 \\ 7: 44 & 292-3 \\ 7: 45-6 & 283-4,292 \\ 7: 47 & 293 \\ 7: 48 & 284,292,293 \\ 7: 49 & 284,293 \\ 7: 51 & 293 \\ 7: 52 & 293 \\ 8: 44 & 193-4 \\ 12: 3 & 187 \\ 13: 23 & 191-2 \\ 13: 27-30 & 90 \\ 17: 23 & 291 \\ 19: 34 & 299-300 \\ & \end{array}$

Acts

$$
\text { 17:28 } 52
$$

Romans

$\begin{array}{ll}1: 4 & 247 \\ 1: 16 & 174 \\ 1: 29 & 175 \\ 3: 5 & 247\end{array}$

\begin{tabular}{ll}
$3: 11-12$ & 279 \\
$3: 19$ & 247 \\
$3: 20$ & $244-5$ \\
$3: 22$ & $172-3$ \\
$3: 25$ & 247 \\
$3: 28$ & $235-6$ \\
$3: 31$ & $249-50$ \\
$4: 11$ & 168 \\
$4: 19$ & $174-5$ \\
$5: 1$ & 172 \\
$5: 14$ & 247 \\
$6: 6-7$ & $238-9$ \\
$6: 9$ & $241-3$ \\
$6: 14$ & 243 \\
$7: 25$ & $168-71$ \\
$8: 1$ & 174 \\
$8: 13$ & 170 \\
$8: 15$ & 173 \\
$8: 16$ & $237-8$ \\
$8: 22$ & 247 \\
$8: 23$ & 173,174 \\
$8: 38-9$ & $239-40$ \\
$9: 4$ & 173 \\
$9: 32-3$ & 175 \\
$10: 2$ & 248 \\
$11: 32$ & 173,174 \\
12 & $104-6$ \\
$12: 2$ & $170,245-6$ \\
$12: 3-5$ & 114 \\
$12: 3$ & 247 \\
$12: 8$ & $248-9$ \\
$12: 11$ & $173,174,247$ \\
$12: 13$ & $246-7$ \\
$12: 20$ & $107,109,116$ \\
$14: 10$ & 173 \\
$14: 20$ & 249 \\
$14: 23$ & 172,173 \\
$15: 27$ & 170 \\
$16: 3$ & $167-8$ \\
$16: 12$ & $240-1$ \\
$16: 25-7$ & 172,173 \\
& \\
\hline
\end{tabular}




$\begin{array}{clcl}16: 27 & 249 & \begin{array}{c}\text { Colossians } \\ 1: 23\end{array} & 217 \\ & & & \\ 1 \text { Corinthians } & & 1 \text { Timothy } & \\ 3: 12 & 155 & 1: 6 & 285 \\ 11: 3 & 221 & & \\ 15: 3 & 124 & \text { Hebrews } & \\ 15: 4 & 120,122,124 & 1: 7 & 153 \\ 15: 5 & 121-2,123-8 & 4: 12 & 150-2 \\ 15: 6 & 120,122,128-30 & & \\ 15: 7 & 130-2 & \text { Revelation } & \\ 15: 8 & 132-4 & 1: 15 & 153 \\ & & 1: 16-17 & 148-52 \\ \text { Galatians } & & 2: 18-20 & 153-5 \\ 1: 19 & 131 & 4: 1 & 158 \\ & & 4: 3 & 158 \\ \text { Ephesians } & & 5: 5 & 157 \\ 3: 17 & 216-7 & 5: 6-8 & 156-60 \\ 5: 2 & 293 & 22: 2 & 158\end{array}$





\section{INDEX OF SUBJECTS}

abbreviation $43,53,67,72,76,95$, $122,187,229-30$

of biblical text 25,230

symbols 10-1, 122, 113, 127, 147

Acacius of Caesarea 16, 23

Acts of the Apostles 15, 19, 21-2

adaptation 39, 43, 44, 95, 97, 117, $227,230,234,243,250$

of biblical text $4,25,26-7,150$, 233, 278, 285

see also abbreviation, paraphrase

affiliation of biblical text $3,20,26$, 114, 120-3, 172-5, 280-5

Aland, Kurt 30, 172

Alexander of Aphrodisias 48-50, 58

Alexandria 5, 40, 42, 54, 69, 80, 85, $89,204,228$

alternating catena $10,20,25-6$, 107-14, 120

Ambrose of Milan 14, 199-202, 223-5, 232

Commentary on Luke 203-25

Ambrosiaster 234, 239, 244

Amharic 325-6

Ammonius of Alexandria 23

Andreas of Caesarea 1, 17, 19, 152, 154, 158-9

Andreas the Presbyter 19, 22, 67, 79, 102, 107, 108,

anthology $\quad 65,78-9,83-4,87,89$, 96-8, 228, 253-4, 256, 262, 295

Antioch 16, 69, 85, 89, 91

Apollinarius of Laodicea 16, 23, 76, 85, 89-90
Apollonius of Citium 53

Apringius of Beja 154

Aquinas, Thomas 88-9, 96

Arabic 48, 295-6, 300, 303-10, 312-20, 325

Aratus 51-2

Archimedes Palimpsest 49, 59

Arethas of Caesarea 16, 17, 19, 23

Aristotle 8, 47-51, 58, 59

Arius 298

Armenian 150, 323

Asconius 44-5

Athanasius 73, 77, 80

Augustine of Hippo xiii, 17, 199, $208,216,225,244,253-5$

Aussedat, Mathilde 79-81

author lemmata see source identifications

Auwers, Jean-Marie $\quad 68,74$

Baghdad 88, 312-3

bark 62

Basil the Great $16,73,75,76,77$, 80, 84, 207-8, 228, 229, 232

Bede 254-6, 265-6

Bohairic 295-304, 307, 308-12, 320

Bologna fragment in Gothic 279, 284-5

Brooke, Alan England 181

Browning, Robert 85, 96-7

Caesarea 76, 203-4

Carruthers, Mary 87, 88-9, 94

Cassian the Sabaite 142, 145-6

Cassiodorus 254, 263, 265

Catena aurea 88-9, 96 
Catholic Epistles 14, 15, 19, 21-2, 26, 29, 30-1, 34-5, 67,

Caubet Iturbe, F.J. 304

Chadwick, Henry 91,93

Charlier, Célestin 256

Chenu, Marie-Dominique 89, 93-4

Chrysostom see John Chrysostom

Cicero 40, 44-6, 52, 207

classroom see lectures

Clement of Alexandria 15, 143, 208

Cohn, Leopold 21

colophon 75, 145-6, 296, 297

Constantinople $18,75,77,78,80$, $86,96,232,297$

contamination 120

Coptic see Bohairic and Fayyumic and Sahidic

Cramer, John Anthony 20-2, 67, 123

Curzon, Robert 297

Cyril of Alexandria 2, 14-5, 23, 75, 76, 80-1, 84, 89, 91-3, 145-6, 304

Cyril of Jerusalem 16

De Coninck, Luc 257-9, 266-7

de Lagarde, Paul 296-8, 308

Del Pezzo, Raffaella 281-2

Demosthenes 42-4

Devreesse, Robert 69-71, 77, 95

Dexippus 51

dialogue 40, 51, 146

Dickey, Eleanor 38

Didymus of Alexandria $14,23,76$, $85,142,148,152,156,174,201$, $224,228,232$

Didymus Chalcentrus 42

Diodore of Tarsus 16, 23, 77

diple $5,6,7,12,24,40,41,42,147$, $161,167,279,302$

doctrine 85, 89-94, 151, 230-2, 246-7, 278

Donatus, Aelius 44

Donatus, Bernardus 119, 134-5

doublets 247-50
Dorival, Gilles 2, 70-2, 297

Downer, Carol 301

Droungarios, John 79-80

Editio Critica Maior xiii, 28, 99, 165, 176, 185

eisthesis $5,42,148,153,156,161-$ 3, 302

ekthesis 5, 40, 147-8, 305

Ephrem Syrus 305, 323, 325

Epiphanius of Salamis 16, 185-6, 232

epitome $50,57-8,72-4$

Erasmus 1,26

Ethiopic 295-6, 303-10, 320-6

etymology 154-5, 160, 180-1, 184-5, 187

Eugippius of Lucullanum 254

Eusebian apparatus 20,326

Eusebius of Caesarea 16, 75, 76, 185-6, 206, 232, 296, 298, 299, 301-2, 310

Eusebius of Emesa 16, 23

Euthalian apparatus 20,103

Euthymius Zigabenus 18, 19, 23, 73, 74, 77, 107, 117-8, 123-34, 136

Evagrius of Pontus 232, 298, 300 exegesis 27, 148-60, 166, 168-71, 176, 186-90, 191-7, 214-7

Expositio Iohannis iuxta Hieronimum 183-4, 187

Faulhaber, Michael 69, 73, 74

Fayyumic 297

Ferrari, Ambrogio 180-1

flattening 5

florilegium see anthology

Florus of Lyons 253-76

Fortunatianus of Aquileia 177, 182-97

format see layout

frame catena $8-11,13,20,25,26$, 76, 108-14, 115, 120, 127, 147

Galen of Pergamum 54-63

Gennadius of Constantinople 16, 23 
genre 5, 38, 84-5, 253

Gibbon, Edward 86, 95

Glossa ordinaria $\mathrm{xx}, 96,97$

glosses 40-1, 218, 278, 279, 283-4, 303

Gospels 3, 21-3, 28-9, 30-4, 90, 124, 182, 189, 203, 206, 216, 218, 295-308

Gothic 277-93

Gregory of Nazianzus $16,73,75$, 228, 232

Gregory of Nyssa $16,69,73,74$, 84, 156, 232

hanging line see ekthesis

Hammond Bammel, Caroline P. 227-8, 233-4

Harl, Marguerite $\quad 67,70-2$

Heine, Ronald xx, 206

Heinrici, G. 22

Heracleon 13, 188

hermeneiai 297-8

Hesychius 69, 73, 76, 80

Hilary of Poitiers 204, 206-7, 21923, 232

Hipparchus 51-2

Hippocratic Corpus 53-4, 55-6, 61

Hippolytus of Rome 145, 195, 298-9

Homer 5-6, 40-1, 79, 207

homilies 15, 116, 206, 223

see also John Chrysostom, Origen

Horace 202

Hraban Maur 266

Huet, Pierre Daniel 180-1

humanism 74, 86-7

bypomnema $43,59,60,62,76$

illustrations 53

ibn al-Assāl, Isaac 318, 319

ibn aṭ-Ṭaiyib, 'Abdallāh 303-6,

308, 312-20, 323-4

ibn Kalīl ibn Maqārah, Sim`ān 303 ,

306-7, 315-6

IGNTP 99, 280

indent see eisthesis
Irenaeus of Lyons $\quad 5,145,298$, 299-300

Isaiah of Scetis $\quad 298,300$

Isidore of Pelusium 75

Isidore of Seville 5

Išō dād of Merv 305, 325

Jerome 14, 44, 185-6, 200-6, 20919,224

Jerusalem 24-5, 160, 228, 234

John Chrysostom xiii, 7, 10, 13, 15, $18,19,20-1,73,75,76,77,79$ 81, 84, 89, 90, 95, 102, 108, 109, 116, 119-20, 123-34, 136, 170, 301, 304, 305, 309, 321, 325

Homilies on John 2, 27, 185-6

Homilies on Romans 171, 174-5

John of Damascus 2, 19, 119, 122

Julius Africanus 301

Justinian 46-7

Karo, Georg 21, 29-30, 68

Katene see alternating catena

Kraus, Christina 38

Lamb, William 25

layout $\quad 4-8,76-7,103-15,121-2$,

$144,147,157,160-3,254,302$

Layton, Bentley 296-7, 310

Layton, Richard 202, 224

lectionary 3, 20, 103-13, 115-6, 225,320

lectures $\mathrm{xx}, 6,48,54,87,96,97$

legal commentaries $40,46-7$

lemma 4, 7, 15, 26-7, 40, 41, 45, 49, 62-3, 157, 166-7, 175, 190, 233-50, 254, 295

lexica 38, 41, 84, 135

Lietzmann, Hans 21-2, 29-30, 67, 68

Liste 2-4, 11, 25, 28-9, 35, 121

liturgy $15,20,115,205-6,224-5$, 279, 297-8

Macarius Chrysocephalus 19, 23

Mai, Angelo 67

majuscule see script

Manichaeans 298

Marcion 173 
margins $5,6,8,10,11,13,26,40$, $75,76,79,83,107-15,147,161-$ 3, 229, 256, 258, 267, 271, 279, $303,308,317$ see also layout

Marold, Karl 281-2

Maximus of the Peloponnese 2

Maximus the Confessor 73

McGuckin, John 92

medical commentaries $53-4,55-8$, 60

memory 5, 27, 88-9, 96-8, 208, $217,227,234,242,247-51,285$

mental text see memory

Mesarites, John 79

Metzger, Bruce 166

minuscule see script

Monophysite catena 80-1

Morgan, Teresa 84

Most, Glenn 38

Nautin, Pierre 73, 206

Nerses of Lambron 150, 159

Nestorius $90-1,298,307,323$

Nicetas of Heraclea 2, 18, 19, 22, 23, 25, 29, 67, 69, 77, 79, 96, 118-9, 310

Nilus of Ancyra 69, 73, 74, 300

NTVMR 2, 99-100, 117-8, 146

Nünlist, René 94

numerals 9-10, 108, 111, 121-2, $127,136,147,161-3,303$

Oecumenius $16,19,67,79,109$, 127,154

Oecumenian catenae $9,10,23$, 102, 110-1, 116, 118, 119, 121, 123-34, 136, 152

Olympiodorus 79

Origen 10, 13-4, 20, 67, 70-1, 75, $76,84,131-2,141-2$

Commentary on John 177-82, 184-96

Commentary on Matthew 195-7

Commentary on Romans 13, 167, 171, 176, 227-51, 266
Homilies on Luke 201, 203-6, 209-24

Scholia on Revelation 20, 141-63

Palestinian catena $67,70-1,75-7$, $78,80,297$

Pamphilus 229, 232

papyri 5, 39-40, 42-3, 62-3, 100, 103, 297

see also Tura

paraphrase $5,41,43,50,129,172$, 183, 208, 214-5, 229-31, 303

see also adaptation

Parker, David 75

Pauline Epistles 10, 13-6, 18-20, 21-3, 29, 96, 99-103, 107, 11723, 136, 165-6, 253-9, 265-6, 321

Peter of Laodicea 18, 20, 22, 67, 78,79

Peter of Pavia 264, 265

Peter of Tripoli 254, 263, 264, 265

Petit, Françoise $\quad 67,84$

Philo of Alexandria 84

Philocalia 228

philosophical commentaries $\quad 6,58-$ 60

see also Aristotle

Photius 16, 23, 77-8, 79, 87-8, 97

Phrynichus 135

Physiologus 189

Pinakes 29, 121

polemic 52, 57, 62, 92, 208, 224

Polychronios 79

prefaces $49,53,60-3,103,191$, 201, 218, 231-2, 255, 260

Preuschen, Erwin 181

Procopius of Gaza 17-8, 67-9, 72-9, 85, 87

Prosper of Aquitaine 254

punctuation 11, 40, 42, 59, 103-6,

$115,147,153,156,257$

Rahlfs, Alfred 68

Rabmenketene see frame catena

Randkatene see frame catena 
reconstruction

of biblical source $27,155,157$, 165-76, 217-8, 233, 280-5

of lost works $22,95,308$

repetition $8,26,87,122,248,278$

replacement of biblical text 120 , 233-4

Reuss, Joseph 3, 16, 24-5, 28-9, $68,75,91,95$

Revelation (Apocalypse) 1,2,13, $16-7,19,21,141-63,323,326$

Richard, Marcel 70, 75-6, 80

Rome 42, 58, 228, 234

Rouse, Richard and Mary 86, 96, 97

rubrication 6, 297, 302

Rufinus of Aquileia 14, 168, 202, 227-51, 266

running text $4,26-7,103$

Sahidic 185, 298, 299

Schäferdiek, Knut 278

scholia $6,8,13,38,39,42,45,71$,

$72,76-9,83,87,89,94-5,141-$

63, 296, 299, 300

script $\quad 6-7,11,25,121-2,147,302$

sequential citations $\quad 4,235-50$

Severian of Gabbala 16, 23

Severus of Antioch 75, 80-1, 84-5, 297, 298, 300, 304

Sickenberger, Joseph 23, 29, 75

Simon, Richard 65-6

Simonetti, Manlio 84, 85

Skeireins 277-93

Smith, Lesley 97

source identifications $2,10,67,72$,

73, 78, 114-5, 122, 127, 208, 269, 272

Staab, Karl 3, 16, 22-3, 29, 68, 121

stenographers 204, 206

stichometry 103

Stobaeus, John 78

substitution see replacement

suggramma 43

symbols see abbreviation symbols

Syriac 16, 185, 305, 307, 325
Talmud 8

Tatian 305

Terence 201

ter Haar Romeny, Bas 85

Tertullian 239

Textus Receptus 114

Text und Textwert 121, 166

Themistius 50-1

Theodore of Heraclea 23, 278, 281, 283, 285

Theodore of Mopsuestia 16, 23-4, $73,77,85,89,91$

Theodoret of Cyr 16, 23, 69, 73, 74, 76, 77, 85, 102, 108-9, 119, 148, 165-76

Theophilus of Alexandria 23, 81 Theophylact $18,19,23,67,102$, 112-3, 114, 116, 118, 120-1, 123-34, 136

Thesaurus Linguae Graecae 16, 135

Titus of Bostra 18, 20, 21, 22, 75, 298, 300

Tura 6, 14, 229, 235

Turner, C.H. 118

Typus Monacensis see Index of

Manuscripts GA 1909

Typus Parisinus see Index of Manuscripts

GA 1910

Typus Vaticanus see Index of Manuscripts GA 1915

Tzamalikos, Panayiotis 142-3, 146, $148,152,156-7$

variant readings $2,20,21,45-6,50$, 63, 114, 120-2, 155, 157, 166-75, 185, 189, 238-50, 267-9, 280-6, 304

Vianès, Laurence 80

Victor of Antioch 18, 20, 22, 75

Victorinus of Poetovio 152, 189, 195

Virgil 44-6, 207

Virtual Manuscript Room see NTVMR

von Soden, Hermann 3, 29, 108, 121,244 
Wendland, Paul 21

Wilson, Nigel 88,94

Wulfila 277-86, 290-3

Young, Frances 84

Zacynthius, Codex see Index of Manuscripts GA 040
Zamagni, Claudio 29, 296, 310

Zigabenus see Euthymius Zigabenus

Zonaras (Pseudo-) 135

Zuntz, Günther 74 